Neuber Fernandes Nascimento

\title{
A CIDADE LEMBRADA: um estudo sobre a memória subjetiva e social
}

Universidade de São Paulo - USP

Instituto de Psicologia

São Paulo - 2011 


\section{Neuber Fernandes Nascimento}

\section{A CIDADE LEMBRADA: um estudo sobre a memória subjetiva e social}

Tese de doutorado apresentada ao Programa de Pós-Graduação em Psicologia, do Instituto de Psicologia da Universidade de São Paulo, como parte dos requisitos necessários à obtenção do grau de doutor em Psicologia.

Orientadora: Profa. Dra. Sueli Damergian

Área de concentração: Psicologia Social e do Trabalho

Universidade de São Paulo - USP

Instituto de Psicologia

São Paulo - 2011 


\section{AGRADECIMENTOS}

Aos memorialistas: Sr. Antônio, Sr. José, D. Geralda e D. Maria Stella, que me forneceram conteúdo para compreender o mundo da alma e da cidade de Paraopeba-MG.

A Profa. Sueli Damergian pela orientação, sem a qual esta pesquisa não teria se realizado.

Foi de grande ajuda o aprendizado nos cursos oferecidos pelos professores: Profa. Dra. Ecléa Bosi, Profa. Dra. Eda Tassara, Profa. Dra. Sueli Damergian (orientadora) e Prof. Dr. Geraldo Paiva.

Ao programa de pós-graduação do Instituto de Psicologia da Universidade de São Paulo (IPUSP). Ao departamento de Psicologia Social e do Trabalho (PST); e, pela atenção, às funcionárias Maria Cecília e Nalva.

Às irmãs Cirleide e Marilurdes, grandes incentivadoras. Ao Fabrício, bibliotecário, pela eficiente ajuda técnica. Aos amigos Ronaldo, Eduardo e Nádia. A todos, a minha gratidão e carinho,

Sou muito agradecido pelo material iconográfico, presente nesta tese, das coleções particulares: profa. Maria Terezinha Mascarenhas, profa. Regina Horta Duarte, Maria Stella Rates, José Geraldo Edmundo Rocha, Geralda Maria Araújo, Júnia Mascarenhas e Sandra Fóscolo, Haroldo Edmundo, Mário Pires, Mary Gomes, Therezinha M. J. Edmundo. Também aos familiares do padre Sebastião Ribeiro Vianna, de Cachoeira da Prata-MG, que gentilmente me cederam as fotos de família.

Agradeço às instituições que me abriram as portas: Biblioteca Municipal Aguinaldo Edmundo, Paraopeba-MG; Biblioteca da Escola Estadual Padre Augusto Horta, ParaopebaMG; Biblioteca Nacional, Rio de Janeiro-RJ; Museu Têxtil Décio Magalhães Mascarenhas, Caetanópolis-MG. Por fim, ao Arquivo Diocesano, Diamantina-MG, e ao Arquivo Público Mineiro, Belo Horizonte-MG. 


\section{RESUMO}

Esta tese se propõe a estudar a memória subjetiva e social da cidade de Paraopeba-MG. Para tanto, valeu-se das entrevistas e conhecimentos orais dos idosos Sr. Antônio, Sr. José, D. Geralda e D. Maria Stella. As lembranças deflagradas pelos idosos pesquisados permitiram que a cidade fosse revelada em novas perspectivas, subjetivas e sociais. Através do diálogo estabelecido entre pesquisador e pesquisados, as lembranças foram gradativamente trazendo à luz os conhecimentos e a história de gerações passadas. Procurou-se demonstrar que a memória subjetiva está relacionada à memória social. Neste percurso, as lembranças dos idosos estariam ligadas aos conhecimentos históricos e eventos ocorridos na região, na comunidade, na cidade. Isto se deve ao fato de que a memória dos idosos pesquisados se apresenta como um rico manancial de conhecimentos: anímicos, históricos, urbanísticos, sociais, dentre outros. Constatou-se que estas lembranças se expressaram como trabalho, caracterizado através: dos silêncios, das idas e vindas, repetições, dentre os aspectos subjetivos; e quanto aos aspectos sociais, o trabalho da memória se revelou através das associações dos eventos, festas e a história da cidade. Através da escuta das lembranças dos idosos e com a finalidade de compreender e fazer as relações com a cidade, tais lembranças puderam ser agrupadas no espaço da família, da escola, do trabalho, entre outras, focalizando também os lugares de memória presentes nas lembranças dos idosos sobre o espaço urbano. Isso possibilitou recuperar, através da expressão oral, o tempo e as experiências dos idosos, o conhecimento de eventos da cidade para as gerações futuras. Adotou-se como proposta metodológica a história oral, aliada às perspectivas teóricas da psicologia social, psicanálise, literatura e filosofia, demonstrando, assim, com este arcabouço teórico, as interfaces da memória subjetiva e social. Deste modo, a presente pesquisa resultou do esforço em compreender a memória subjetiva e social dos idosos em relação à cidade.

Palavras-chave: memória subjetiva; memória social; tempo e narrativa; oralidade; cidade. 


\begin{abstract}
This thesis intends to study the subjective and social memory of the city Paraopeba-MG. With this purpose, interviews with the elderly Mr. Antônio, Mr. José, Ms. Geralda and Ms. Maria Stella were used. The memories brougt by them let the city be revealed in new subjective and social perspectives. Through dialogs established between researcher and the elderly, the knowledge and history of past generations were gradually emerging. This study tries to show that the subjective memory is related to the social memory. In this course, the memories of the elderly would be connected with the historical knowledge and events in that region, in the community, in the city. This is because the memory of the elderly researched presents rich knowledge: related to the soul, historical, urban, social between others. It was verified that those memories were expressed as work, characterized through: silence, comes and goes, repetition, between subjective aspects: as social aspects, the work of the memory was revealed through associations of the events, parties and the city history. Listening to the elderly memories and aiming to comprehend and relate them to the city, those memories could be grouped in spaces like family, school, work and others, focusing the places in the elderly memories about urban spaces. This made possible to recover, through verbal expression, time and experiences from the elderly, the knowledge from events of the city for future generations. It was adopted as methodological proposal the oral history, with theoretical perspectives from the social psychology, psychoanalysis, literature and philosophy, showing, with this theoretical skeleton, the subjective and social memory interfaces. In this way, the present research is a result of the effort in comprehending the subjective and social memory of the elderly towards the city.
\end{abstract}

Key-words: subjective memory; social memory; time and narrative; orality; city. 


\section{RÉSUMÉ}

Le but de cette thèse est celui d'étudier la memoire subjective et sociale de la ville de Paraopeba-MG. On s'est servi donc des interwies et des connaissances orales des messieurs Antônio et José, des dames Geralda et Maria Stella, qui sont tous du troisième âge. Les souvenirs évoqués par ces personnes âgés ont permis le flash de la ville dans de nouvelles perspectives, subjectives et sociales. Par le biais du dialogue établi entre intervieweurs et interviewé, le souvenirs ont, au fur et à mesure apporté à la lumière les connaissnces et l'histoire de générations passées. On a essayé de demontrer que la mémoire subjective est en rapport avec la mémoire sociale. Dans ce parcours, les souvenirs des plus âgés seraient liés aux connaissances historiques et aux évenements arrivés dans la région, dans la communauté, dans la ville. Il est dû au fait que leur mémoire se présente comme une riche source de connaissances: anímiques, historiques, urbanistiques, sociales et encore plus. On a constaté que se ces souvenirs s'expriment comme travail caracterisé à traves: des silences, des allés et retours, des répetitions, entre les aspect subjectifs et, en ce qui concerne les aspects socials, le travail de la mémoires s'est révélé a travers des associations des évenements, des fêtes et de l'histoire de la ville. Les tels souvenirs ont pu être groupés dans l'espace de la famille, de l'école, du travail, au délà d'autres, en faisant ressortir des lieux de mémoires présents dans les souvenirs des ces personnes âgés sur l'espace urbain par le biais de l'écoute de ses souvenirs en cherchant de les comprendre, et de les mettre en rapport avec la ville. On a pu, donc, récupérer par l'expression orale, leurs temps et leurs experiences, la connaissance des évenements de la ville pour les génerations futures. On a adopté l'histoire orale comme proposition méthodologique liée aux perspectives théoriques de la psychologie sociale, la psychanalyse, la littérature et la phylosophie, en démontrant alors, avec cette structure théorique, les interfaces de la mémoire subjective et sociale. Ainsi, cette recherche est le résultat de l'effort de comprendre la mémoire subjective et sociale des gens âgés en rapport avec la ville.

Mots-clé: mémoire subjective; mémoire sociale; temps et récit; oralité; ville. 


\section{RÉSUMEN}

Esta tesis se propone a estudiar la memoria subjetiva y social de la ciudad de Paraopeba-MG. Así pues se valió de las entrevistas y conocimientos orales de los mayores: señor Antônio, señor José, doña Geralda y doña Maria Stella. Los recuerdos deflagrados por ellos permitieron que la ciudad fuera revelada en nuevas perspectivas, subjetivas y sociales. A través del diálogo establecido entre pesquisidor y pesquisados, los recuerdos fueron gradualmente arrojando la luz sobre los conocimientos y la historia de generaciones pasadas. Se buscó demonstrar que la memoria subjetiva está relacionada a la memoria social. En este recorrido, los recuerdos de los mayores estarían encadenados a los conocimientos históricos y eventos sucedidos en la region, en la comunidad, en la ciudad. Esto ocurre porque la memoria de estos mayores encuestados se presenta como un rico manantial de conocimentos: anímicos, históricos, urbanísticos además de otros. Fue comprobado que estos recuerdos se expresaron como trabajo caracterizado a través de los silencios, de las idas y venidas y de las repeticiones, en los aspectos subjetivos. Por lo de los aspectos sociales, el trabajo de la memoria se manifesta a través de las asociaciones con eventos, fiestas e histórias de la ciudad. A través de la escucha de recuerdos de los encuestados y con fines de comprender y hacer relaciones con la edad, dichos recuerdos pudieron ser congregados en el espacio de la familia, de la escuela, del trabajo, y también de otros, enfocando pues lugares de memoria presentes en los recuerdos de los mayores sobre el espacio urbano. Eso posibilitó recobrar el tiempo y las experiencias de estos mayores, aun el conocimiento de hechos de la ciudad de ParaopebaMG para las geraciones futuras. Se ahijó como propuesta metodológica la historia oral, vinculada a las perspectivas teóricas de la sicologia social, sicoanális literatura y filosofia, demosntrando, con esta estructura teórica, las interfaces de la memoria subjetiva y social. Asimismo la presente pesquisa resultó del esfuerzo en comprender la memoria subjetiva y social de estos mayores con relación a la ciudad.

Palabras-llave: memoria subjetiva; memoria social; tiempo y narrativa, oralidad; ciudad. 


\section{SUMÁRIO}

2. Capítulo I - 25

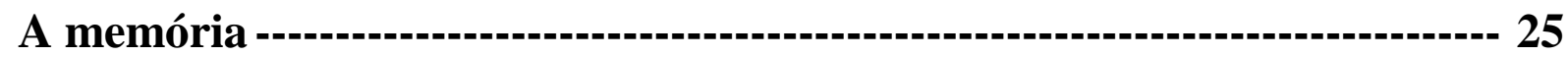

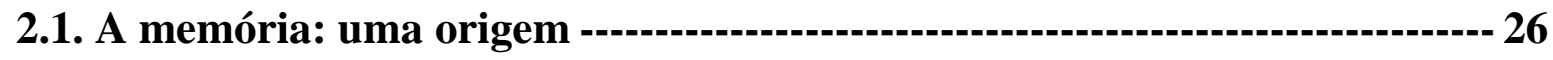

2.2. Agostinho: indagações sobre o tempo e a memória--------- 28

2.2.1. O tempo------on 29

2.2.2. O palácio da memória------------------- 31

2.3. A história e o narrador ---------- 34

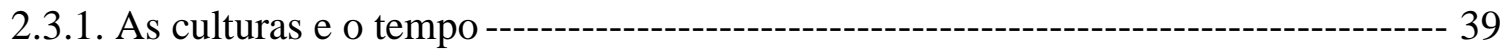

2.3.2. A memória e a voz --- 41

2.3.3. Memória e comunidade------------ 44

2.4. Tempo e narrativa--- 46

2.4.1. A narrativa e o texto escrito------ 47

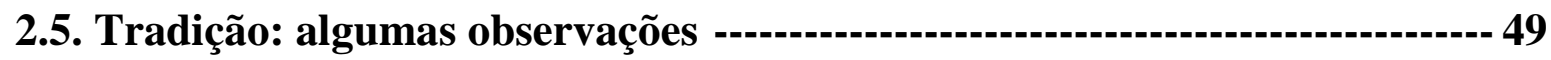

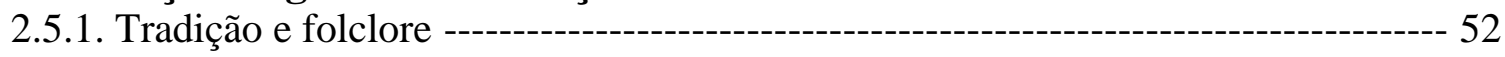

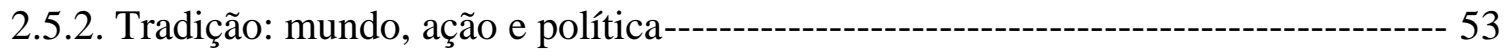

2.5.3. O enraizamento ---------- 57

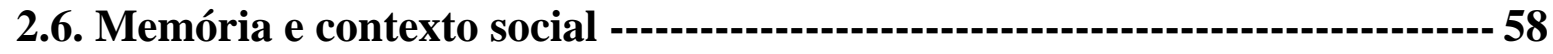

2.6.1. Fenomenologia e campos de sentido --- 64

2.6.2. Diálogo e percepção --

2.6.3. Memória e subjetividade ---o--o- 69

2.6.4. A memória dos idosos ---

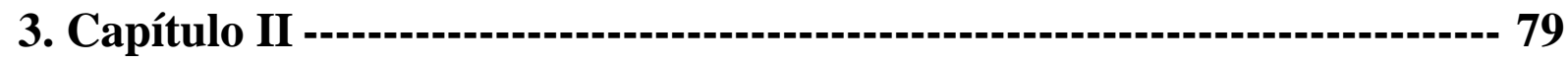

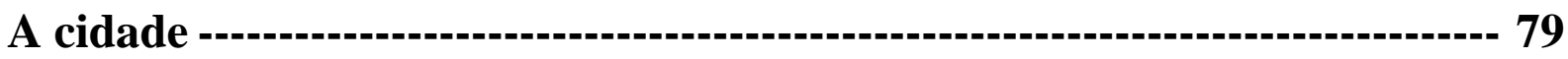

3.1. Percepções sobre a cidade e os modos de habitar ------------------------- 80

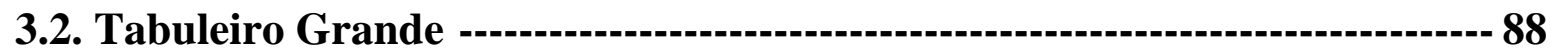

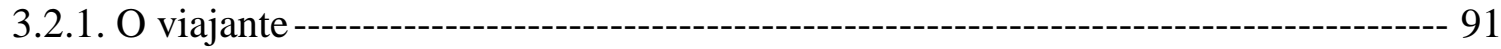

3.2.2. Avelino Fóscolo: criador da imprensa, escritor e anarquista---------------------- 99

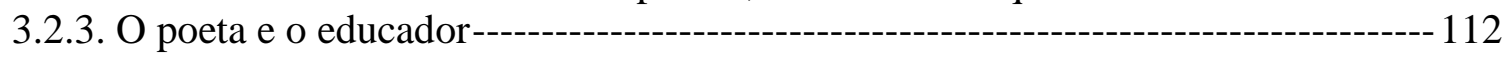

3.2.4. O esboço de uma memória ---------- 121

3.3. A cidade e a memória ---

3.4. Anexo 01 - Imagens --- 


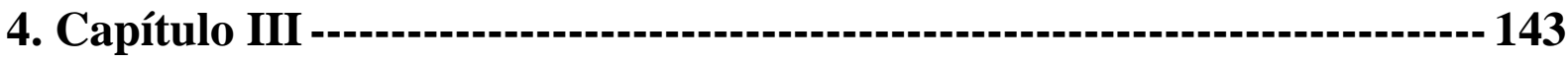

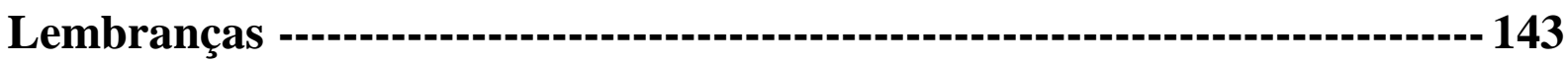

4.1. Sr. Antônio ---

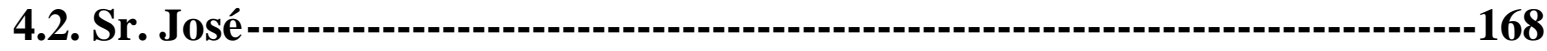

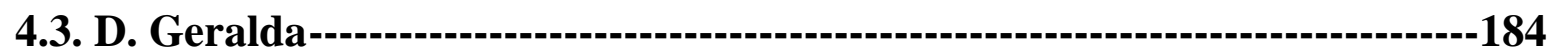

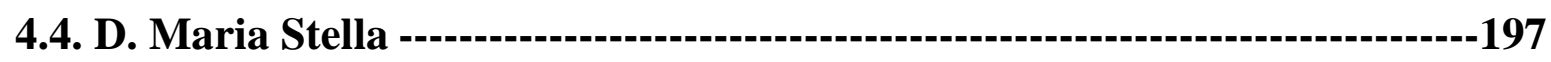

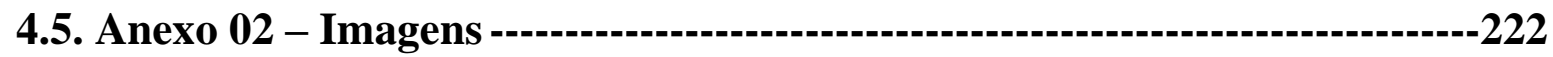

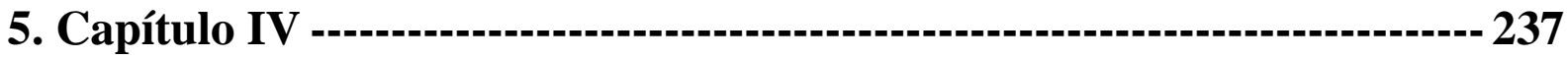

A cidade lembrada ---.--- 237

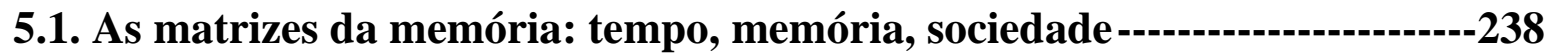

5.1.1. A importância social da memória ------ 239

5.2. $O$ tempo das lembranças: $o$ tempo vivido e a experiência -----------240

5.2.1. O tempo social ---

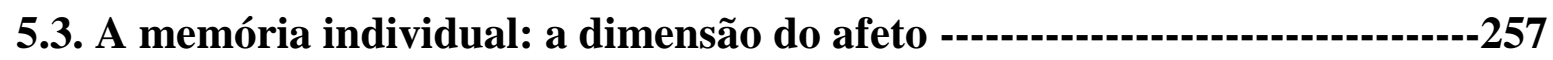

5.4. Lembranças da família ---

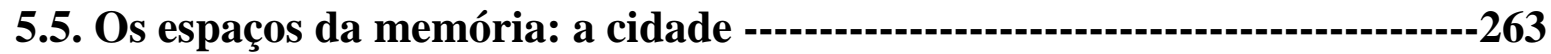

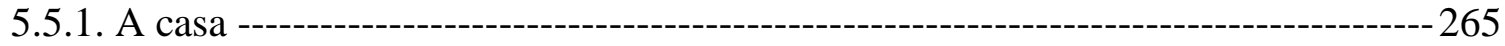

5.5.2. A rua---------o--- 270

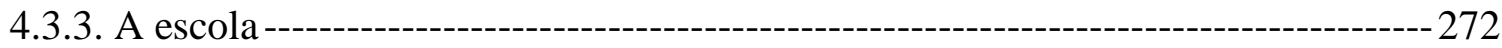

5.5.4. O teatro------------------------------------------------------------------275

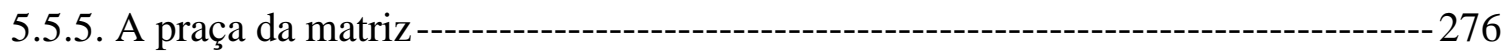

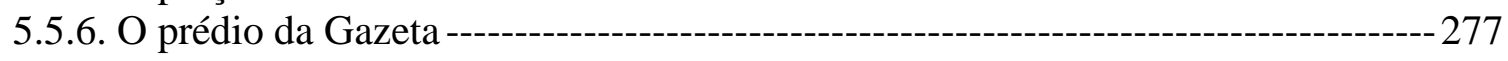

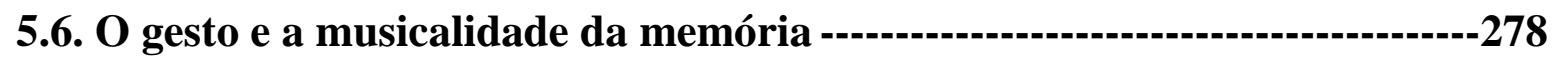

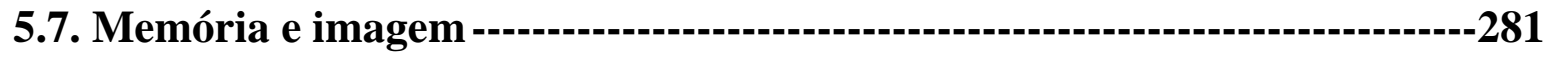

5.8. A lembrança da religião e do folclore -------------------------------285

5.9. A memória oral e a escrita ------290

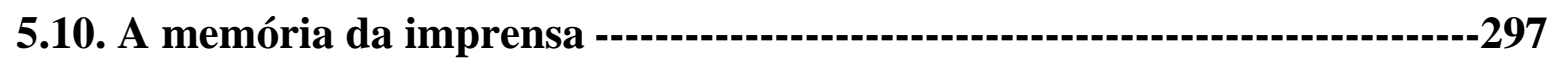

5.11. A história de uma conversão----301

5.12. A memória política------------------------------------------------------------309

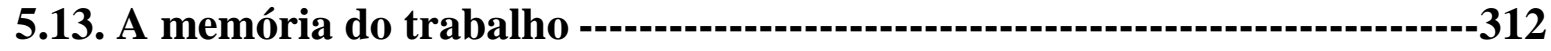

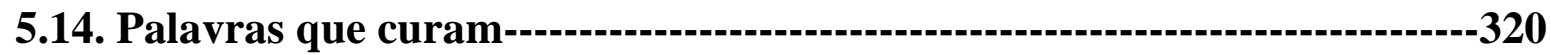

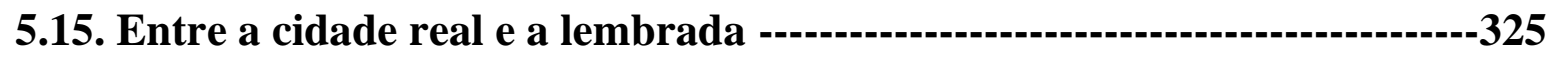

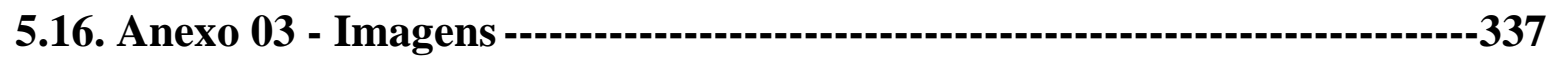


7. Referências bibliográficas ---------------------------------------------------- 375

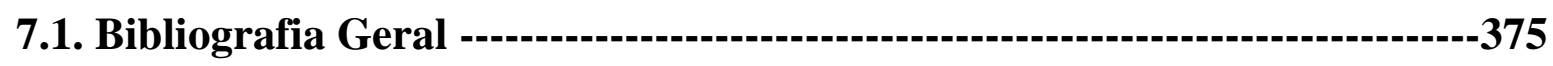

7.2. Bibliografia de periódicos consultados em Paraopeba---------------395

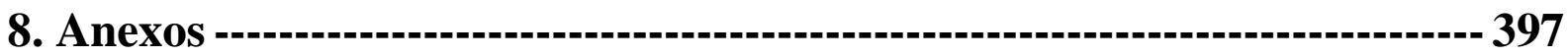

8.1. ANEXO 04: Roteiro da entrevista semi-estruturada ------------------397

8.2. ANEXO 05: Termos de consentimento livre e esclarecido ------------399

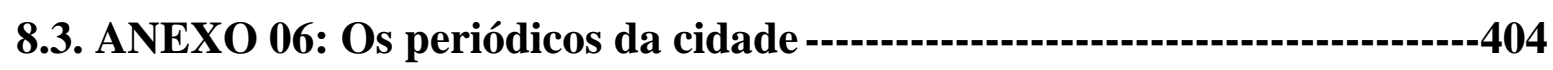




\section{Introdução}

"A cidade, como a história de vida, é sempre a possibilidade desses trajetos que são nossos percursos, destinos, trajetória da alma".

(BOSI, 2003, p. 15) 
Esta pesquisa nasceu de um fragmento de memória. Retornava à cidade natal, Paraopeba-MG, quando, passeando pela praça da matriz, me veio naquele momento a lembrança da cidade de minha infância e, ao mesmo tempo, a constatação de como a cidade mudara. As imagens das lembranças se apossaram de mim: a terra vermelha da praça, as casas desbotadas pelo tempo, as ruas e prédios, as pessoas, as festas e os eventos da comunidade. Dei-me conta de que o tempo engolira tudo, ou quase tudo. A memória era a única possibilidade de resgatar as coisas que o tempo ia levando em seu curso. E, pelas lembranças, compreender o tempo vivido, as flutuações das coisas e dos acontecimentos.

Ao examinar minhas lembranças, espantou-me percebê-las sem forma definida. A existência de um fato aqui, um evento ocorrido em outra época, fazia-me tentar, de forma muitas vezes vã, dar um sentido às lembranças. De uma lembrança informe, saltavam-me à consciência outras mais nítidas e de cores vivas. E isso fazia surgir uma questão: de onde vieram essas lembranças? Seu conteúdo é verídico? As imagens percebidas da cidade correspondiam a algum evento? Todas essas perguntas me impulsionavam a procurar as respostas. Entretanto, ao perceber o mar de impressões a minha volta, resignava-me. Pois sabia que, como as grandes questões da vida, as relativas à memória guardam contradições. Exigia-me olhá-las de modo minucioso a fim de retirar das evocações uma nova forma de compreender o mundo.

Assim, decidi compreender essas lembranças. Procurar um elo entre elas e os eventos da cidade. Pois as lembranças e os afetos com os quais elas se relacionam podem ter uma relação com os acontecimentos sociais. Diante das lacunas existentes entre o narrador das lembranças e seus atos havia algo de indefinível. Mas não era impossível resgatá-las. Daí a constatação de que o ato de lembrar pode ser recuperado e interpelado com novas significações. Este caminho acarreta um deslumbramento: a possibilidade de compreender o presente através dos lampejos vindos do passado.

A memória compõe-se de muitos fragmentos construídos no tempo. Ao juntar as partes, aos poucos ia surgindo um afresco de contornos inesperados. Os desejos, medos e sonhos se misturam aos incidentes que, ao longo dos anos, se sobrepõem a outros.

Juntando-se às minhas lembranças, vinham à mente as fotografias da cidade que conhecera ainda criança. As imagens traziam a marca do tempo: a cor amarela se contrapunha ao cinza e negro das fotos. Era uma cidade diferente! E, no entanto, era a mesma. O largo da matriz, 
onde o lugarejo fora se formando, possuía poucas casas. O prédio da prefeitura, as vendas, as pessoas caminhando pelas ruas poeirentas, pacientemente seguindo a rotina. Naquele momento, a cidade se revestia de abrigo, de aconchego.

Nesta praça, onde se ergueu a igreja havia primitivamente a capela. Este lugar guarda silenciosamente a história da cidade. De forma centrípeta, a igreja atraía para si as casas, as ruas, as pessoas. E com ela as histórias que eu ouvia quando menino. Através das palavras das pessoas da cidade, chegavam a mim o passado longínquo e aquelas vozes plenas de histórias. Pois a cidade, sabida ou intuída desde criança, era feita da realidade das casas e ruas, mas também do que era dito sobre ela.

Por que a cidade chegava-me dessa forma? Se quando criança percebia as múltiplas histórias contadas pelos moradores, quando adulto aquela curiosidade se transformou em trabalho. $\mathrm{O}$ trabalho através das palavras! Abraçava a profissão de psicólogo. Mas a palavra, intuíra desde antes, é o universo do prazer e do conhecimento. Encantavam-me as várias possibilidades que as palavras podiam suscitar-me: o lúdico, o conhecimento. Mas também a intervenção social. Pois é através das palavras, e no intercâmbio com as pessoas, que nós podemos compreender a dinâmica social. E é através das palavras e ações que podemos transformar o mundo. Ao menos em parte. Acreditamos, todavia, que a transformação do mundo tem uma dose de utopia e esperança. Já que estar aberto ao mundo é percebê-lo como inacabado, aberto às transformações.

Daí a memória, a meu ver, presentificar as imagens e palavras esquecidas. Descortinando para mim um mundo que não existiu e ao mesmo tempo existia. Explicarei melhor. Os fragmentos da memória potencializados pelas fotos da cidade e pelas palavras das pessoas da comunidade faziam-me conhecer uma época passada da cidade que não conhecera, mas que estava viva e presente. A ambigüidade da memória encantava-me! Ela era o presente-ausente ou a presença de algo que não existe literalmente. A cidade se abria diante de mim. E as lembranças da minha infância se acoplavam às lembranças dos idosos que presenciaram outra época que eu não conheci.

Desta forma, as imagens das minhas lembranças, das fotos antigas, das casas e ruas que sabia que existiram mas desapareceram; tudo isso me intrigava. Aliadas às minhas lembranças, juntavam-se as dos memorialistas que me chamavam a atenção para o passado da cidade. As 
lembranças e percepções flutuavam no tempo... Decidi compreender este mundo, que era minha origem e, ao mesmo tempo, desconhecido. Às minhas lembranças juntavam-se as dos outros habitantes da cidade. A paisagem da memória estava composta.

Além disso, desejava dar um corpo social a essas lembranças. E por este caminho, retirar as lembranças da escuridão do passado e lançar luzes do presente sobre elas. Com esta proposta, ainda que parcialmente, tornar as lembranças compreensíveis aos outros, já que, ao narrar as lembranças, cada memorialista lhes imprimia um sentido próprio. Entretanto, ia constatando que as lembranças se ancoram em grupos sociais e fazem parte de uma geração, uma época, da cidade. Sendo assim, além das particularidades, elas criam um laço espacial, possuem uma atmosfera comunitária. Desta forma, percebi a importância de recuperar as lembranças das pessoas idosas e fazê-las dialogar com a história da cidade.

Trabalhando como psicólogo social na cidade de Paraopeba-MG, tive a oportunidade de observar os vários problemas subjetivos e sociais de que esta comunidade é acometida. Resgatar a história da cidade, conhecer a dinâmica do passado, tentar recuperar o que foi perdido, tudo isso poderia ser uma alternativa para compreendê-la melhor. A reflexão sobre o tempo e a memória me acompanhava de longa data. A partir do fluxo da memória e do esquecimento constatava a passagem das coisas, com as transformações das pessoas e do mundo ao seu redor, o que contribuiu para acentuar a importância dos fragmentos da minha memória.

Mas a memória sem trabalho, sem reconstrução se dissipa e perde os laços sociais. Percebi que, através da voz, da expressão oral das pessoas, cada fragmento de lembrança ganha cores vivas e vibrantes. Ao enfrentar o efeito corrosivo do tempo, a memória revive e recria as coisas e eventos. O lastro frio do tempo se transformava em tempo pleno de vida nas lembranças das pessoas. O tempo, relatado pelas histórias de vida, apresenta-se como fonte de conhecimento, pleno de significado. Diante da caducidade das coisas, surgem momentos capazes de resgatar e dar sentido ao presente.

Quando desejei compreender a memória das pessoas idosas da comunidade de Paraopeba, percebi que elas estão ligadas à existência e à história da cidade. Fui me certificando de que havia relevância nas lembranças dos idosos, pois, ao reviver as lembranças de suas vidas, reviviam também a memória da cidade. Também ressurgiam, com intensidade renovada, as 
lembranças da infância, das casas, das ruas e praças, da escola e do trabalho, dentre tantas outras coisas, plenas de força e sentido. A memória subjetiva dialogava com a história da cidade. Embora cada lembrança dos narradores seja única, surgia ao mesmo tempo uma incrível unicidade das lembranças transfigurada em uma cidade lembrada.

Sendo assim, a partir das lembranças dos idosos entrevistados, o plano geral desta pesquisa consistirá em explicitar os níveis da memória subjetiva e social na construção da história da cidade de Paraopeba. Esse propósito enfatizará a peculiaridade das lembranças evocadas na recriação dos eventos subjetivos e sociais referentes ao imaginário cultural desta comunidade.

Através da própria forma de compreender as lembranças dos idosos, espera-se poder conectálas aos eventos sociais, de forma a possibilitar aos leitores compreender certas formações internas que as comuniquem com o contexto social, procurando ampliar as múltiplas relações entre lembranças pessoais e comunitárias. E assim poder utilizar campos de saber diversos, como psicologia social e psicanálise, filosofia, história, literatura, folclore, com o intuito de compreender, de forma ampla e múltipla, a memória social, expressa através da história oral.

Tendo em vista as peculiaridades das lembranças dos idosos e as especificidades das evocações em relação à cidade, este trabalho se ocupará em: a) identificar em que níveis os idosos pesquisados (Sr. José, Sr. Antônio, D. Maria Stella, D. Geralda) utilizam os recursos da memória para recriarem a história da cidade de Paraopeba; b) explorar as potencialidades evocativas das lembranças para a construção da identidade local: as relações de trabalho, as praças, retratos, festas serão explorados para se tentar identificar os processos em torno da construção dos elementos constitutivos da identidade individual e social; c) explorar aspectos da memória subjetiva e intersubjetiva; d) demonstrar como o ato de rememorar pode auxiliar na reconstrução do passado, compreendendo o presente e lançando luzes sobre o futuro; e) elucidar, finalmente, de que forma a cidade emerge da alma e dos afetos dos idosos entrevistados, com o propósito de entender o contexto sociocultural que os constitui.

A abordagem da pesquisa que norteará nosso trabalho se amparará em algumas justificativas básicas. A primeira justificativa se baseia na premissa de que, através das entrevistas dos idosos, aliadas às perspectivas teóricas acima mencionadas, é possível compreender a 
memória subjetiva e social expressa nas lembranças. Pois tais lembranças se revelam como narrativas que expressam conhecimentos peculiares da comunidade pesquisada.

O exercício da narrativa sempre esteve presente na humanidade. A importância de contar ou relatar os episódios da comunidade ou sociedade está presente até hoje. O filósofo Walter Benjamin confirma a importância do narrador para a sobrevivência dos conhecimentos do passado. Através das histórias, o narrador transmitiria o legado da tradição às gerações futuras. O narrador, para esse filósofo, seria preferencialmente um homem simples, artesão ou camponês, que, através do ensino oral, conta "histórias" plenas de ensinamentos. Pois esse movimento interrogaria o ser das coisas, indo ao fundo de si mesmo. Por isso, o narrador, ao lembrar os acontecimentos, ligaria os eventos presentes ao passado e, com isso, ampliaria o arco de compreensão do mundo.

A segunda justificativa se sustenta em minha experiência profissional. Trabalho como psicólogo na cidade, que se localiza na região central de Minas Gerais. Esta experiência profissional tem sido muito rica e me fez refletir sobre os conflitos individuais e sociais da comunidade. Pude, ao longo dos anos de exercício profissional, relacionar a memória com a tradição, o enraizamento das pessoas no espaço urbano e a possibilidade de compreender as relações entre a memória individual e social em relação com a cidade.

Diante disso, a pesquisa se deterá também na memória oral, porque ela tem a capacidade de transmitir as experiências vividas pelas pessoas idosas e as relações sociais em que elas estão inseridas. Através desta memória dos idosos, podemos esclarecer os episódios obscurecidos e turvos da consciência, já que "os vivos têm que responder pelas promessas dos mortos" (BOSI, 2004, p. 16). Deste modo, a psicologia poderá estabelecer zonas de transições entre história, filosofia, literatura, dentre outras, para melhor captar a memória individual e social.

A obra da psicóloga Ecléa Bosi se configura em importante auxílio para nossa pesquisa. Esta autora realizou uma pesquisa de memória oral com oito idosos da cidade de São Paulo. Retratando pessoas simples, a pesquisadora confirmou o modo como esses idosos, cada um à sua maneira, habitava plenamente o mundo. As experiências individuais e sociais traçadas pelos idosos revelam a vida da cidade que não existe mais. A não ser nas memórias evocadas, cujos conteúdos nos ensinam vivências internas e comunitárias. Ao escutar os idosos, a psicóloga resgata um campo infinito de lembranças. Assim os fragmentos de memória vão, 
aos poucos, compondo a paisagem da cidade. Entretanto, a tarefa de compreender e reconstruir a vida dessas pessoas e devolver-lhes dignidade é um exercício constante. Dessa forma, a psicóloga social pode afirmar que "o velho não tem armas. Nós é que temos de lutar por ele" (BOSI, 2006, p. 18).

Para melhor compreender os objetivos desta tese procurar-se-á apurar os conceitos de memória social e subjetividade com os quais trabalharemos. Pensamos que o conceito de memória social, diferentemente da noção de memória coletiva, cumpre melhor o papel conceitual com o qual abordaremos nossa pesquisa. Embora alguns autores tomem coletivo como sendo sinônimo (ver cap. I). Portanto, a perspectiva que adotaremos será a de Ecléa Bosi. A propósito, a psicóloga social afirma:

A memória opera com grande liberdade escolhendo acontecimentos no espaço e no tempo, não arbitrariamente mas porque se relacionam através de índices comuns. São configurações mais intensas quando sobre elas incide o brilho de um significado coletivo. (BOSI, 2003, p. 31)

Desta forma, tentaremos conceituar a memória social neste sentido. A substância social da memória se comporia das memórias individuais em seus pequenos comportamentos, como desejos e sonhos, que, por sua vez, se relacionam com a sociedade. Se a memória coletiva, para Halbwachs, se ancorava, ou mesmo se fixava, em grupo determinado, a memória social, em nossa perspectiva, se assentará na possibilidade de negociações entre tempos e grupos. Portanto, a memória social, em nossa proposta, deixa de ter o lastro positivista apresentado por Halbwachs. Tais críticas se atrelavam aos condicionamentos sociais a que o sociólogo fez referência, pois a memória sobre a qual trabalharemos não estará presa aos grupos. Embora presente nestes grupos, terá a possibilidade de se movimentar e interagir com outros aspectos da sociedade.

Para tanto, a nossa pesquisa com os idosos se pautará, dentre outros aspectos, pelos testemunhos e depoimentos biográficos. Esta proposta visa resgatar e conhecer o passado e, ao mesmo tempo, apresentar às gerações futuras aspectos individuais e sociais da cidade de Paraopeba, criando, desta maneira, uma rede de significações entre os fenômenos e eventos que estão distanciados no tempo. 
Podemos afirmar que estamos chamando de memória social a capacidade de construção e reconstrução dela, pois a constituição da memória, neste sentido, é individual e social simultaneamente. Nesse ínterim, a memória social levará em conta, também, a linguagem, os pensamentos e a vida afetiva das pessoas em interface com a interação social, para, através dessa dinâmica, apreender aspectos dos indivíduos pesquisados no contexto social. De modo que as lembranças dos idosos possibilitem a sua atualização no momento presente. Levaremos em conta os aspectos da subjetividade inaugurada pela psicanálise. Esta subjetividade diz respeito a um sujeito cindido, não fixo, atravessado pelos desejos, pela falta e a fantasia. $\mathrm{Ou}$ seja, um sujeito em construção, que dialoga consigo mesmo e com o meio social. Enfim, em nossa pesquisa, a memória é concebida como sendo psicossocial.

Observa-se, portanto, que as experiências de vida dos idosos, traduzidas em palavras, são muito importantes para o psicólogo, pois essas histórias de vida nos dão acesso a gerações e eventos muitas vezes já esquecidos. Daí, o valor dessas experiências, tantas vezes esquecidas pela história oficial, que nos auxiliam na compreensão de uma época, dos comportamentos de um grupo e da cidade.

A tradição, acredita Hannah Arendt, deve ser um veículo de transmissão da herança que liga o presente ao passado. Recusando a posição nostálgica do passado, esta pensadora assegura que a preservação da tradição seria um meio pelo qual os homens imprimiriam sentido aos seus atos. Por isso, nessa perspectiva, a tradição não seria repetição dos eventos passados, mas a percepção do elo entre o passado e o presente. Possibilitando aos cidadãos uma ação política pertinente dos indivíduos e da comunidade. Visto que a ação política é o espaço pelo qual os seres humanos podem viver a pluralidade de desejos, comportamentos e modos de atuação social. Portanto, a perda da tradição, segundo a pensadora, impediria uma ação adequada aos eventos sociais. (ARENDT, 2005)

A vida em comunidade pode ser afetada pela perda do enraizamento. Conceito difundido pela filósofa Simone Weill, nos chama a atenção para a compreensão de como as pessoas se relacionam com o mundo. Através do enraizamento, os indivíduos participam dos grupos e se interagem, recebendo e passando a herança para as gerações futuras. Essa atitude, além de ser uma ação ética, também é prática, pois, através do enraizamento, os conhecimentos são adquiridos e transmitidos para as gerações futuras. Deste modo, o enraizamento possibilita 
aos cidadãos a condição de conceber as relações sociais como parte integrante de suas vidas. A alma humana lança raízes e se integra às práticas coletivas. (WEIL, 2001).

Através das histórias de vida das pessoas idosas entrevistadas, pretende-se lançar luz sobre o espaço da cidade. As casas, praças, retratos amarelados pelo tempo, documentos, muros, escolas e igrejas poderão nos fornecer a fisionomia dos espaços que se entrelaçariam com os anseios dos afetos de cada pessoa. Reencontrar um tempo e um espaço que, longe de estar apenas preso no indivíduo, também está na memória social que se torna presente nas lembranças dos idosos.

Podemos então atestar a contribuição do sociólogo francês Maurice Halbwachs para a compreensão do fenômeno da memória coletiva. À primeira vista, a memória pareceria um fenômeno apenas individual, algo próprio da intimidade e da interioridade de cada um. Halbwachs contesta essa pressuposição.

Para este sociólogo, a memória, além de individual, é também coletiva. Sublinha a importância do aspecto coletivo da memória. A memória deverá ser percebida como um fenômeno coletivo e social que será construído coletivamente, sendo submetida a transformações, flutuações e mudanças constantes. Por isso, a memória não é uma simples identificação, mas um jogo de interações e negociações com o meio. Assim, o indivíduo se reconhece em contato com muitos grupos sociais. Daí podermos pensar, seguindo o caminho deste pensador, que a memória individual se estabeleceria no cruzamento das memórias coletivas. Halbwachs, ao estudar a memória dos grupos, chega a afirmar a característica da memória coletiva e diz que ela se espacializa (estudaremos mais detalhadamente no capítulo I). Assim, o legado de Halbwachs contribui para compreendermos os elementos da memória do grupo e individuais. (HALBWACHS, 2006)

Por fim, a última justificativa trata da opção por trabalhar com o tema aqui proposto. Deve-se ao fato de ser a memória um conceito extremamente relevante para se buscar compreender o processo de construção das múltiplas esferas sociais de atuação humana. Isso porque meu ofício de psicólogo acentuaria a hipótese psicossocial de que a memória pode ser resgatada a partir do estudo das lembranças das pessoas idosas da comunidade de Paraopeba. Pois, através dos relatos dos idosos, poderíamos verificar uma trama de acontecimentos da história subjetiva e social da cidade. 
A proposição deste trabalho de tese requer um procedimento metodológico capaz de captar as várias nuances da memória individual e social. Por isso, a pesquisa será de cunho qualitativo, implementada pelos procedimentos da história oral.

Constatamos que a história oral desempenha uma contribuição fundamental para a compreensão e o desenvolvimento da pesquisa. Acreditamos que ela proporciona uma forma privilegiada para a compreensão e o desvelamento do modo de vida das pessoas idosas. Isto se daria na medida em que, ao narrar suas lembranças, os idosos elaboram os conteúdos interiores e também dão testemunho da vida social.

Diante disso, caberão algumas observações. Utilizaremos a perspectiva da história de vida, pois nesta prática as questões de ordem subjetiva se mostram essenciais. Mas não só, pois há também a inclusão do âmbito da vida social captada através da fantasia, do sonho, do silêncio, entre outros aspectos. A memória subjetiva se entrelaça à social. O fato coletivo é apreendido por outros caminhos além do suporte da escrita. A natureza desse tipo de pesquisa deflagrado pela narrativa não se revela unilateral, já que inclui elementos do desejo, sentimentos, emoções e, ainda, pela dimensão racional. Todos esses aspectos contribuirão para a compreensão dos relatos dos idosos. Sempre atentando para a relação entre o individual e o social. Portanto, os procedimentos da história oral podem auxiliar para maior compreensão dos processos psicossociais relativos à memória individual e social.

Devemos fazer uma observação importante. Quando falamos de metodologia em ciências humanas, há sempre o risco da perda da "objetividade". Cumpre-nos demarcar os territórios. Através desta pesquisa, constatamos a inviabilidade de se separar, como se fossem formas estanques, sujeito e objeto. Percebemos ainda que quando nos posicionávamos, enquanto pesquisador, nossa presença se apresentava como fonte a despertar lembranças nos idosos pesquisados. Portanto, neste trabalho, visando potencializar a evocação e a transmissão das lembranças, a relação entre pesquisador e pesquisado se mostrou, em muitos momentos, uma relação de descobertas mútuas. Isso se deve ao caráter da nossa pesquisa: seu aspecto qualitativo. Utilizamos a história oral de vida, pois esta proposta, construindo e empreendendo uma visão mais subjetiva das experiências dos idosos pesquisados, supera a mera aquisição de dados. Esta perspectiva nos conduziu para lugares onde o limite entre o individual e o coletivo nos propunha um maior desafio teórico. Por intermédio da escuta às experiências dos idosos pesquisados, foi registrado um amplo panorama das vidas subjetivas e 
da cidade. Assim, recorremos a uma estratégia que contemplasse um campo interdisciplinar em que ao mesmo tempo pudéssemos ser ouvinte e participante destas vidas. Podemos, desta forma, fundamentar e certificar o grande mérito (houve outros) da pesquisa: a aprendizagem da escuta.

Acreditamos que, quando entrevistamos uma pessoa, ela é ao mesmo tempo produto e produtora de tudo que está ao redor dela. Em uma pessoa há singularidade, mas também relações com a sociedade. Isso legitima a história de vida como ferramenta importante de compreensão e intervenção metodológica. Através das histórias de vida, conseguimos chegar ao nosso objetivo maior: compreender a memória subjetiva o social e assim superar as barreiras metodológicas concebidas pelas ciências positivistas, a saber, o sujeito separado do objeto. Descobrimos que esta estratégia metodológica possibilitou criar novas formas de entendimento e solidariedade.

A psicologia social e a história oral estabelecem uma parceria profícua. O idoso, ao lembrar, elabora e transforma conteúdos da subjetividade e da socialização. Sendo assim, esta estratégia possibilitará conhecer a conjuntura social, política, econômica e cultural de um período histórico, revelando aspectos que a história oficial deixou de lado. Acreditamos que a metodologia da história oral possibilita outra forma de reconstruir e registrar a memória do grupo. Como, por exemplo, pessoas excluídas e sem representatividade social. Constituindo, dessa forma, um esforço de resistência contra o esquecimento da tradição e o desenraizamento dos indivíduos.

Na pesquisa, foram entrevistados quatro idosos: dois homens e duas mulheres. Todos com mais de 60 anos, nascidos na cidade e conhecedores de sua história. Os instrumentos utilizados foram entrevistas semi-estruturadas (vide anexo), gravadas em fitas. Além das entrevistas, foram consultadas instituições públicas, como museu e bibliotecas, dentre outras fontes, com o intuito de alargar a compreensão dos temas pesquisados e dos dados obtidos nas entrevistas.

O cuidado ético relativo às entrevistas e à pesquisa como um todo foi fundamental. Desde o consentimento para as entrevistas até o tratamento dos resultados nelas obtidos. Daí a participação ativa e relevante dos entrevistados na composição das narrativas, pois entendemos que as palavras empregadas nos diálogos são de grande valor individual e social. 
O trabalho está dividido em quatro capítulos. Como a investigação irá privilegiar os aspectos subjetivos e sociais da memória e sua relação com a cidade, não se ocupou de uma única perspectiva teórica. A recorrência dos lugares da cidade como espaço vital para repousar as lembranças dos narradores desta pesquisa exigiu uma mobilidade teórica e percepções variadas acerca da memória subjetiva e social dos idosos entrevistados.

O primeiro capítulo, "A memória", discorrerá sobre três eixos principais. O primeiro será "Tempo e narrativa: a escrita e a voz". Será abordada a importância da narrativa oral na compreensão da memória individual e social. A especificidade do narrador na transmissão e compreensão do conhecimento de uma comunidade. A escrita não será entendida como exclusão da oralidade, mas como outra forma de narrar. Essa atitude esclarecerá os elementos orais na escrita e sua relação como estratégia de preservação e transformação do legado do passado. A voz, noção desenvolvida por Paul Zumthor, nos ajudará a compreender a voz em sua conexão com o corpo, numa tentativa de alargar as concepções oralizantes das transmissões do conhecimento da comunidade, apontando, assim, outras redes de significações.

O segundo eixo, “Tradição e enraizamento", versará sobre as noções de tradição em algumas perspectivas, acentuando o caráter da tradição como forma de preservação e transmissão de significados aos grupos e à comunidade. Em outro ponto de vista, a tradição poderá ser vista pelo ângulo da etnologia, acentuando-se aspectos populares e folclóricos. O conceito de enraizamento nos ajudará na compreensão da dimensão biográfica das narrativas, demonstrando, assim, as raízes psicossociais das lembranças dos idosos. No ultimo eixo, “A memória e o contexto social", abordaremos a memória em interface ao conjunto de comportamentos, ações dos idosos entrevistados no meio social. Dentre os autores, estarão as contribuições de Ecléa Bosi, Maurice Halbwachs e Merleau-Ponty. Cada um destes autores contribuirá para a ampliação dos horizontes de compreensão acerca das lembranças expressas socialmente.

No segundo capítulo, intitulado “A cidade”, busca-se conceituar algumas percepções e noções acerca do que é uma cidade: o desenvolvimento da cidade na história, a contraposição com o campo, os elementos socioeconômicos presentes no espaço urbano. Para tanto, este capítulo constará de quatro subitens. O primeiro, eixo reflexivo verserá sobre "A cidade: percepções e sentidos do habitar", dará algumas características conceituais sobre a cidade. Utilizaremos 
autores que estudaram a cidade em seus aspectos historiográficos, urbanísticos, antropológicos e socioeconômicos. O segundo item deste capítulo, "Tabuleiro Grande", procurará esclarecer o surgimento da pequena comunidade no sertão de Minas, tendo em vista informar a peculiaridade do vilarejo no contexto das cidades mineiras. Ainda neste segmento, apresentaremos três narrativas de pessoas que conheceram a viveram na antiga Paraopeba, com intuito de mostrar as múltiplas percepções da cidade e seu legado aos cidadãos. O primeiro narrador foi o engenheiro inglês James Wells; o segundo, o escritor e fundador da imprensa local, Avelino Fóscolo; e o terceiro, o poeta e educador Sabino de Paula Freitas. Acreditamos que estas narrativas contribuirão para a compreensão da memória da cidade, visto que os memorialistas entrevistados citam dois desses narradores com frequiência. Por fim, haverá o item que reflete a inter-relação entre a memória e a cidade.

No terceiro capítulo, "Lembranças", apresentamos as transcrições, ou melhor, as "transcriações" dos entrevistados. (MEHY \& HOLANDA, 2008). Essa parte da pesquisa, ultrapassando a simples noção de entrevistas, consegue, através da memória oral, apresentar as lembranças subjetivas e sociais dos idosos. Através do diálogo, conseguimos explorar as várias facetas da memória: familiar, escolar, política, do trabalho, entre outras. Desta forma, o espaço da cidade vai surgindo em detalhes, cores e sons, ampliando a noção de memória e ao mesmo tempo demonstrando que ela não é simples reconstituição do passado, mas trabalho pessoal e social. Perceberemos, com essas narrativas, o afeto que sustenta as lembranças. Podendo ser percebidos os vários espaços e momentos da história da cidade, partilhados pelos idosos pesquisados.

No quarto capítulo, "A cidade lembrada", pretende-se analisar os dados obtidos nas entrevistas, procurando aliar os resultados com as teorias desenvolvidas nos capítulos precedentes. Neste capítulo, quer-se demonstrar, em face das entrevistas e conceitos desenvolvidos, os aspectos subjetivos e sociais da memória, tais como a memória subjetiva e social, e o diálogo da memória escrita e oral. Serão apresentados e refletidos os espaços urbanos da memória: a casa, a rua, a praça, o teatro, a escola, as festas, a imprensa, a igreja. $\mathrm{O}$ surgimento da cidade, narrado pelas crenças e pelo folclore dos cidadãos, procurando estabelecer relações entre os memorialistas e a cidade. Ainda neste capítulo, verifica-se a riqueza de detalhes das lembranças povoadas de nomes e lugares. Atentando para o caráter social das lembranças, também se poderá perceber como as memórias dos idosos ajudam as gerações futuras a compreender e fomentar as transformações da comunidade e da cidade. 
Demonstraremos também como a memória se relaciona com os lugares da cidade. Ao revelar, através das narrativas dos idosos a importância da casa, a rua, a escola, eventos, festas, igrejas, dentre outras, como lugares de memória da cidade pesquisada. Assim o historiador esclarece:

\begin{abstract}
Os lugares de memória nascem e vivem do sentimento que não há memória espontânea, que é preciso criar arquivos, que é preciso manter aniversários, organizar celebrações, pronunciar elogios fúnebres, notariar atas, porque essas operações não são naturais. É por isso que a defesa, pelas minorias, de uma memória refugiada sobre focos privilegiados e enciumadamente guardados nada mais faz do que levar à incandescência a verdade de todos os lugares de memória. (NORA, 1993, p. 13)
\end{abstract}

Com a tentativa de limitar o esquecimento, os lugares de memória procuram fixar na materialidade dos objetos e eventos uma rede de significação. Portanto, a sociedade, os cidadãos enlaçam os lugares da memória através da hibridez e as metamorfoses. Já que os lugares de memória temporalizam e também espacializam aquilo a que a comunidade der sentido. Desta forma, reiteram de tempos em tempos a multiplicidade de eventos. Assim, estarão imbricados nos lugares de memória os sentidos "de vida e de morte, de tempo e de eternidade, numa espiral do coletivo e do individual, do prosaico e do sagrado, do imóvel e do móvel”. (NORA, 1993, p. 22)

Em linhas mais amplas, este trabalho se coloca frente ao desafio de compreender as particularidades da memória social. Também pode lançar luzes e trazer subsídios ao psicólogo social nos enfrentamentos constantes de seu ofício. A conjunção da memória subjetiva e social, a partir da história de vida e ancorada na perspectiva da história oral, servirá para preservação do legado advindo do passado. Para a criação de estratégias de intervenção eficaz na cidade, aprendendo e transformando o conhecimento que nos chega através dos idosos, numa tentativa de superação de modelos segregadores e alienantes de condutas sociais, que visem ao desenraizamento. A tradição e o enraizamento nos colocam a dimensão ética como forma insubstituível para a compreensão das relações humanas. Essa grande rede que a memória traduz, aliando o oral e o escrito, o individual e o social, numa ação transformadora do mundo. 


\section{Capítulo I}

\section{A memória}

A memória é manhosa, tenho de negacear. Primeiro reproduzo o painel, assim vem à mente; depois, investigo pormenores, procuro restituir a pintura primitiva, removendo as finas pinceladas com que, sobre ela, o tempo compôs outros quadros. (ANJOS, 1979, p. 13) 
Neste capítulo, pretendemos abordar a temática da memória, com o propósito de discorrer sobre as relações estabelecidas entre memória e narrativa, memória e tradição e memória e contexto social. Para tanto, abordaremos a reflexão sobre o tempo e a memória feita por Santo Agostinho e as conexões entre narrativa e história desenvolvidas pelo filósofo Walter Benjamin. Também iremos tratar das noções de tradição e de enraizamento desenvolvidas pelas pensadoras Hannah Arendt e Simone Weill, respectivamente. Tal procedimento refletirá nossa intenção de explorar o conceito de memória em relação a diferentes perspectivas.

Também refletiremos sobre a memória no contexto social. Para isso utilizaremos o estudo do sociólogo Maurice Halbwachs que trata da memória coletiva. Em Merleau-Ponty, os estudos sobre a percepção e o diálogo marcarão de forma importante o desenvolvimento de nossa pesquisa. Haverá alusão à teoria de campo como espaço privilegiado para compreensão da atuação das ciências sociais. No contexto da psicologia, apresentaremos os estudos de Bartlett, que tematizou a memória através da psicologia social e experimental. Por fim, o estudo da psicóloga social Ecléa Bosi sobre as lembranças dos idosos como perspectiva de conhecer aspectos subjetivos e sociais da memória, alargando a compreensão dos eventos individuais e sociais apresentados pelos idosos e os inter-relacionando com os eventos da cidade.

Com isso, pretendemos compreender as relações da memória com a sociedade. Esses autores, diferentes em épocas e formações profissionais, nos auxiliarão no entendimento do fenômeno da memória no mundo contemporâneo, de modo a tencionar e interrogar os conceitos propostos nesta pesquisa.

\subsection{A memória: uma origem}

A mitologia grega é pródiga em criar imagens e narrativas. A narrativa mítica, ao longo dos tempos, foi usada nas artes e também nos discursos filosóficos. Platão é um exemplo paradigmático. Mnemosine é a divindade grega que representa a memória. É filha de Urano e Geia, e depois de sua união com Zeus deu à luz nove filhas: as musas. As filhas de Mnemosine eram sensíveis aos encantos da música, entoando hinos e, ao expandir sua belíssima voz, subiram ao Olimpo. Além de divinas cantoras, as musas eram responsáveis 
pela regulação do pensamento, expresso em forma do discurso da história e também através da eloqüência e da persuasão.

Deste modo, na Grécia arcaica, a deusa Mnemosine revelava aos poetas os segredos do passado, introduzindo-os nos mistérios do além. Assim, a memória se mostrava como dons para os iniciados, só revelados aos poetas, pois estes eram possuidores de poderes adquiridos através das palavras encantatórias. Em contrapartida, a reminiscência era a capacidade de rememorar os eventos e seres que a tradição elaborava. Isso se dava porque os poetas possuíam técnicas ascéticas por meio das quais entravam em contato com os mistérios do mundo e dos deuses. Entretanto, além da capacidade de rememorar, há o esquecimento. Este pode subjugar a memória. Para tanto, Lete, o rio cujas águas mágicas fazem ruir os duros e nítidos contornos das lembranças, contrabalançava o jogo entre a rememoração e o esquecimento. Por isso Weinrich declara:

Nos gregos, Letos é uma divindade feminina que forma um par contrastante com Mnemosine, deusa da memória e mãe das musas. Segundo a genealogia e a teogonia, Lete vem da linhagem da noite (em grego, nyx; nox em latim), mas não posso deixar de mencionar o nome de sua mãe. É a Discórdia (em grego, eris; em latim, discórdia), o ponto escuro nesse parentesco. (WEINRICH, 2000, p. 24)

Nessa perspectiva, haveria outra forma de perceber os poderes da memória. Sem a noção de esquecimento (aqui retratado positivamente) não haveria a possibilidade da reminiscência. Os poetas antigos, ao beber as águas do Lete, tinham a possibilidade de esquecer sua existência anterior e ficavam livres para renascer. Ao narrar as façanhas dos deuses, os poetas faziam renascer as glórias e infortúnios da herança dos antepassados.

A tradição nos legou uma fábula sobre o inventor da arte da memória. Em um banquete, um nobre da Tessália chamado Escopas comemorava uma vitória. Esse nobre contratou o poeta Simônides de Ceos (556-468 a.C.) para cantar em versos sua conquista. O poema lírico cantado por Simônides incluiu alguns versos elogiando Castor e Polux. Quando terminou a apresentação, Escopas dirigiu-se ao poeta dizendo que só pagaria a metade do valor combinado e que ele cobrasse o restante aos gêmeos a quem ele oferecera os versos. Algum tempo depois, Simônides é avisado de que dois jovens queriam lhe falar. Esperavam-no do lado de fora da casa. O poeta saiu e não encontrou ninguém. Durante sua ausência, a parte da casa onde se encontravam Escopas e seus convidados desmoronou e matou todos que lá 
estavam. Os cadáveres ficaram irreconhecíveis, sendo impossível realizar os funerais. Simônides foi chamado e conseguiu se lembrar do lugar onde cada pessoa estava à mesa. Puderam então enterrar seus mortos. Foi essa façanha que deu ao poeta Simônides o título de inventor da mnemotécnica ${ }^{1}$, a arte da memória. (YATES, 2007).

\subsection{Agostinho: indagações sobre o tempo e a memória}

Agostinho foi herdeiro da tradição filosófica antiga. Elementos do platonismo e neoplatonismo, pensadores cristãos e a literatura pagã possuem ressonância em sua obra. Abordaremos alguns pontos relevantes para nossa pesquisa: a memória, o tempo, a alma. E no caso particular deste pensador há o aspecto da fé cristã.

Concentraremos nossa atenção na obra As confissões. Livro de beleza e perspicácia enormes que irá refletir em muitos trabalhos subseqüentes. Pensemos, por exemplo, nos aspectos autobiográficos e as reflexões sobre o tempo e a memória que têm esta obra como referência e sua influência na tradição ocidental. Escrito por volta de 398 ou 399, Confissões presenciou um momento histórico de muita controvérsia. Para o leitor contemporâneo, é importante ressaltar que o autor estava questionando a exegese maniqueísta do Antigo Testamento, segundo a qual havia um dualismo religioso. Essa doutrina consistia basicamente na afirmação da existência de um conflito de origem cósmica cuja relação entre o Bem e o Mal impunha ao homem práticas ascéticas para livrá-lo do mundo das sombras.

Por outro lado, a doutrina de Platão afirmava que as "formas ideais" forneciam um padrão, um universal abstrato, onde as coisas do mundo se espelhariam. No mundo das Idéias, estariam localizadas as "Formas", estas eram apresentadas como unidades constantes e perfeitas. É, portanto, sob o paradigma metafísico e sob os princípios do cristianismo que se encontravam as premissas de Agostinho. Servo da verdade divina, Agostinho, sente-se livre para escrever e meditar sobre as coisas que atormentavam sua alma. Para ele, as coisas

\footnotetext{
${ }^{1}$ Remetemos à obra clássica $A$ arte da memória, de Frances Yates, na qual a estudiosa trata do aprendizado da memória antes do advento da página impressa. Uma das fontes para a memorização estaria na obra Retórica a Herênio. Há também The Book of Memory, de Mary Carruthers, que ilustra a função da memória na sociedade medieval, destacando seu desdobramento até a modernidade. Por fim, há dois ensaios: The art of memory receonceived: from rhetoric to psychoanalysis, de Patrick Hutton; e The art of memory and its relation to the unconscious de Jean-Phillipe Antoine. Os ensaios, cada um à sua maneira, retratam "a arte da memória" e suas repercussões na teoria psicanalítica. (Ver referências completas dos textos acima citados nas fontes bibliográficas deste trabalho).
} 
discorridas como verdade são realizadas a partir da rememoração. Assim, esse ato da memória imprime na alma as palavras concebidas a partir das imagens daquelas coisas medida pela sensibilidade do pensador.

\subsubsection{O tempo}

Agostinho, no livro XI das Confissões, expõe de forma lapidar as inquietações sobre o tempo. O autor procura demonstrar sua ignorância e dúvidas a respeito das demarcações temporais. Buscando referências em seu passado, numa tentativa de elaborar os enganos sobre as próprias vivências. Assim, descreve:

Que é, pois, o tempo? Quem poderá explicá-lo clara e brevemente? Quem poderá apreendê-lo, mesmo só com o pensamento, para depois nos traduzir por palavras o seu conceito? E que assunto mais familiar e mais batido nas nossas conversas do que o tempo? Quando dele falamos, compreendemos o que dizemos, compreendemos também o que nos dizem quando dele nos falam. O que é, por conseguinte, o tempo? Se ninguém me perguntar, eu sei; se quiser explicá-lo a quem me fizer a pergunta, já não sei. (AGOSTINHO, 1988, p. 278).

Apesar da dificuldade apresentada pelo bispo de Hipona, não significa que não possamos esclarecê-la, haja vista as inúmeras formas de abordar o tempo, como, por exemplo, através da astrofísica, da psicologia, entre outras. Essas tentativas em esclarecer as dúvidas sobre o tempo permanecem até hoje. Entretanto, para Agostinho, este questionamento se inscreve no âmbito de um universo de que participa o Ser em sentido pleno, ou seja, de Deus. O caminho, tal qual o autor o concebe em seu desenrolar no mundo, está em direção a Deus, através da inteligência e da fé cristã. É importante demarcar que é nessa perspectiva e sobre essa base que Agostinho refletirá sobre a problemática do tempo.

No mundo contemporâneo, convivemos e aprendemos a compreender o tempo separando-o em presente, passado e futuro. Já esse pensador, ao tratar da temática do tempo, diz que "é impróprio afirmar que os tempos são três: pretérito, presente e futuro. Mas talvez fosse próprio dizer que os tempos são três: presente das coisas passadas, presente das presentes, presente das futuras” (AGOSTINHO, 1988, p. 284). Sendo assim, onde estarão estas modalidades do tempo? Ele próprio responde: "Estes três tempos estão na minha mente que não vejo em outra parte: lembrança presente das coisas passadas, visão presente das coisas presentes e esperança presente das coisas futuras" (AGOSTINHO, 1988, p. 278). Desta 
forma, a alma seria o lugar onde se refletem as questões temporais. A alma como palco, lugar, vivenciados e não apenas algo intocado. Nesse contexto, compreendemos que o tempo e as vinculações apresentadas acima, realizadas pelo pensador cristão, estavam sendo observadas a partir da memória. Assim afirma um de seus estudiosos:

Aquelas coisas que são narradas como verdade o são a partir da memória, não são, pois, as próprias coisas das imagens daquelas coisas que na alma, sob a forma humana, o animus, fazem delas às vezes por mediação sensível, constituindo o substrato que tem a narrativa possível. (NETTO, 2002, p. 22)

Diante dessas questões e posições, chegamos a um ponto crucial nas interrogações agostinianas em relação ao tempo. O tempo seria o movimento dos corpos celestes? Seria a seqüência das estações onde a natureza no inverno se recolhesse e na primavera as plantas desabrochassem? Ou seria o tempo a duração do trabalho do oleiro a modelar no barro os vasos? O que nos parece importante frisar aqui é a reflexão sobre a natureza do tempo. Neste caso, seria a possibilidade de medirmos o tempo através dos movimentos de um lugar a outro como vetor para nossa compreensão acerca do tempo.

Agostinho, de outra forma, concebe o tempo como distentio animi. Ao medirmos os movimentos de dois corpos, não os medimos exatamente. Assim, o tempo não pode ser considerado, em si mesmo, como passado, presente ou futuro; é a partir da alma que o medimos, pois, segundo o autor, "o tempo não é outra coisa senão distensão" (AGOSTINHO, 1988, p. 290). Daí podemos pensar que é na alma, lugar cósmico do tempo, que se imprimem os desalentos e esperanças. Também é na alma que os eventos são captados e retidos na memória. Com a carga de seu testemunho, imbuído de sua fé, imprimiria aspectos "psicológicos" sobre a temática do tempo. Assim, o pensador cristão pôde demarcar:

Em ti, ó espírito, meço os tempos! Não queira atormentar-me, pois assim é. Não te perturbes com os tumultos das tuas emoções. Em ti, repito, meço os tempos. Meço a impressão que as coisas gravam em ti à sua passagem, impressão que permanece, ainda depois de elas terem passado. (AGOSTINHO, 1988, p. 292)

Portanto, entendendo o tempo através da distentio da alma que percebe, é que Agostinho, lembra e espera a flutuação das coisas, dos seres. Isto posto, poderíamos afirmar que o ardil demonstrado por Agostinho tem como consequiência uma espécie de continuum do tempo. Os três tempos, portanto, seriam percebidos então como: presente das coisas passadas pelo 
rememorar das lembranças, presente captado pela atenção e presente dos eventos futuros alentados pela esperança. Essa compreensão do tempo, feita por Agostinho, é que chamamos de temporalização. Nesta perspectiva, aboliria a concepção vulgar do tempo, na qual os eventos, os seres se sucederiam numa disposição cronológica, semelhante à do relógio. Há os desdobramentos dos eventos da existência de cada indivíduo vivente, mas não existe a sucessão do tempo que obedeça a um sentido linear. O agora, traduzido no presente, seria uma espécie de tempo dos tempos. O futuro e o passado são traduzidos em êxtases de um mesmo movimento. Prolongados pela alma e sob o olhar onipresente de Deus.

\subsubsection{O palácio da memória}

As indagações de Agostinho sobre a memória, como tempo, também repercutem na tradição ocidental. O aspecto confessional de Confissões fará seguidores na tradição ocidental. Além disso, o diálogo entre a filosofia neoplatônica e o cristianismo deste pensador, como aludimos anteriormente, foi fecundo. Mas é nas reflexões sobre a memória que nos deteremos agora.

Agostinho compara a memória a um palácio. Possivelmente uma referência à "arte da memória" (YATES, 2007). Com essa alegoria, vislumbrou em seu périplo "campos e vastos palácios da memória onde estão tesouros de inumeráveis imagens trazidas por percepções de toda espécie" (AGOSTINHO, 1988, p. 224). Tentou conhecer seu íntimo através de exercícios da memória. Essa prática de memorização apregoava atribuir lugares a imagens mentais. Fazendo o que hoje se diz, aproximadamente, sobre as associações na psicologia. Na Antiguidade, essa prática se aprendia, através de uma das fontes, a obra Retórica a Herênio. Este pensador enumera em Confissões as sensações e sentimentos: sons, sabores, cheiros. Numa tentativa de relacionar as imagens sensoriais a lugares da memória. Assim é descrito: "O grande receptáculo da memória - sinuosidades secretas e inefáveis, onde tudo entra pelas portas respectivas e se aloja sem confusão - recebo todas essas impressões para recordar e revisitar quando for necessário" (AGOSTINHO, 1988, p. 225).

Deste modo, Agostinho indica que o ato de rememorar potencializava as imagens e os pensamentos. Assim, um grande número de atividades sinestésicas se presentificariam na memória: o perfume das flores, a melodia dos sons, o sabor das frutas, as texturas. Isso se 
deve à capacidade de, nesse palácio, se fazerem presentes “o céu, a terra, o mar com todos os pormenores que neles pude perceber pelos sentidos" (AGOSTINHO, 1988, p. 255).

Diante desse quadro de imagens e sensações, podemos perguntar: onde se origina o memorialista? No capítulo VIII das Confissões, Agostinho revela a presença de um "eu", um lugar onde estaria o palco da memória. É um espaço de combate de forças estranhas, opostas. Guardadas as devidas proporções e o momento histórico, a comparação a Freud é pertinente. Afirmava: "Era eu o que queria e era eu o que não queria, era eu mesmo" (AGOSTINHO, 1988, p. 182). O sujeito da memória é sempre confrontado por forças antagônicas. Assim, declara: "Duas vontades que combatem num só homem, nem por isso afirmem que contenham duas almas contrárias, uma boa e outra má, formadas de duas substâncias e dois princípios também contrários" (AGOSTINHO, 1988, p. 228).

Além de princípios contrários na alma, Agostinho revela dois tipos de memória. Uma sensível, outra intelectual. A primeira se refere aos cinco sentidos do corpo humano, onde se imprime a sensação da memória. O pensador afirmava que os objetos, através das sensações que provocam, conectavam-se com o corpo. As sensações geram imagens que, por sua vez, são guardadas na memória. As imagens entram, assim, pelos sentidos:

Os olhos dizem: "se eram coloridos, fomos nós que anunciamos". Replicam os ouvidos: "se ressoaram, foram por nós comunicados". Declara o olfato: "se tinham cheiro, passaram por mim". Afirma ainda o sentido do gosto: "se não tinha sabor, nada me perguntes". E o tato: "se não eram sensíveis, não as apalpei, e se não as apalpei, não as pude indicar". (AGOSTINHO, 1988, p. 228)

A memória intelectual, por sua vez, é adquirida através das artes visuais. Através do aprendizado, a memória, vai sendo exercitada e os conteúdos guardados. Dessa forma, a voz dos cantos, os exercícios da gramática e da memorização constituem-se no cerne da preservação das lembranças. Todavia, a memória intelectual não tem o mesmo caminho da memória sinestésica. Agostinho faz a separação e afirma que "as noções de literatura, de dialética, as diferentes espécies de questões e todos os conhecimentos que tenho a este respeito existem também na minha memória, mas de tal modo que, se não retivesse a imagem, deixaria fora o objeto" (AGOSTINHO, 1988, p. 227). Naquela época, ele já fazia relação da memória com a imagem. Possivelmente fora influenciado por Aristóteles em seu tratado $\mathrm{Da}$ lembrança e da reminiscência. 
Então, percebemos com Agostinho que os lugares da memória requerem aprendizado. Eles estão no fundo da memória para serem evocados. Além disso, é preciso também salientar o fator afetivo contido na memória. O pensador afirmava que, mediante a lembrança, conseguese recordar as emoções escondidas. Dessa forma, Agostinho enumera quatro paixões da alma: o desejo, a alegria, a tristeza e o medo. Com base nesta afirmação, ele pôde afirmar que "não há dúvida de que a memória é como o ventre da alma. A alegria, porém, e a tristeza são o seu alimento, doce ou amargo” (AGOSTINHO, 1988, p. 237).

Em Confissões, há outro aspecto da memória. Trata-se do esquecimento. E acreditamos que o esquecimento nos parece importante na medida em que este conceito aparecerá em muitas teorias sobre memória - antigas e recentes. Para Agostinho, o fato de lembrarmos do esquecimento implica perceber a sua relação com a memória. $\mathrm{O}$ ato de esquecer em si revela sua ausência. Neste caminho, o esquecimento seria a privação da memória. Portanto, afirma o doutor da Igreja: "Se nós retemos na memória aquilo de que nos lembramos, e se nos é impossivel, ao ouvir a palavra "esquecimento", compreender o que ela significa, a não ser que dele nos lembremos, conclui-se que a memória retém o esquecimento" (AGOSTINHO, 1988, p. 233).

Dessa forma, para Agostinho, o esquecimento se enraíza na memória. O procedimento de esquecer, ou de lembrar do esquecimento, realiza-se a despeito de recordar. Acha inexplicável e incompreensível esta operação. Isso se revelaria como um paradoxo, pois estaria "certo de me lembrar do esquecimento” (AGOSTINHO, 1988, p. 284).

Enfim, o que parece estar em jogo em Confissões é a luta existencial entre os prazeres e as dificuldades de narrar sua autobiografia. Agostinho apresentou as belezas e imperfeições da vida humana, tendo a alma como lugar privilegiado para desvelar experiências pessoais e de fé. Entretanto, ao narrar sua vida, nos conduz aos desígnios da própria conversão. Aos leitores contemporâneos, muitas vezes sem o conforto de Deus, ele ensina também a narrar e lembrar a própria história. 


\subsection{A história e o narrador}

Walter Benjamin, em Sobre o conceito da história, nos auxilia a compreender o processo histórico. Na tese VI, ele esclarece como o historiador deveria apreender o passado. O filósofo rejeita a posição do historiador positivista. Em sua perspectiva, afirma que seria preciso articular o passado historicamente, o que não significa conhecê-lo "tal como ele de fato foi" (BENJAMIN, 1994, p. 224). O historiador, que está preocupado com o sujeito histórico, não acessa diretamente os fatos "reais", já que ele não vê a História como um progresso contínuo e ininterrupto. Ao contrário, procura "apropriar-se de uma reminiscência, tal como ela relampeja no momento de perigo" (BENJAMIN, 1994, p. 224).

Desta forma, para Benjamin, a história não deverá se prender apenas aos aspectos das classes dominantes. Antes, deter-se-á nos momentos nos quais os oprimidos ou os desprivilegiados e vencidos terão voz. Aprimorar o olhar e a audição a singularidades dessas pessoas que muitas vezes estão à margem da história oficial. Os lampejos das lembranças a luzir aqui e acolá deverão ser apreendidos pelo pesquisador que desejar decodificar as imagens desse passado. Numa posição dialética, o historiador, marcado pela atenta presença de espírito, poderá captar os momentos únicos que a ciência positivista não consagrou. Momentos fugazes, mas reveladores. Este posicionamento do historiador, discutido pelo filósofo, interpela a todos. Talvez porque concebamos a história, num primeiro momento, como a narração de algo fixo e/ou documental do passado.

Na rememoração histórica, Benjamin enfatiza a importância do "futuro do pretérito" para compor o conhecimento do passado. A significação do passado está na possibilidade de encontrar fragmentos que se perderam, mas que anseiam por ser encontrados. Talvez aí resida a dificuldade do historiador e mesmo do memorialista. Já que os dois, cada um à sua maneira, precisam perseguir os sonhos e os movimentos da alma. Assim, perceber, com alguma objetividade, os desejos que não chegaram a ser expressos de forma satisfatória.

Com esta perspectiva, podemos constatar que a história jamais pode ser neutra, visto que, qualquer que seja o posicionamento diante do fato histórico, terá conseqüências. Portanto, a relação com o passado se torna plena de significado na medida em que nos toca e, por conseqüência, nos coloca diante de uma escolha. Com esta posição é que o passado chega até nós. Através de nossa posição no presente. Essa operação nos faz abrir os olhos para segredos 
preciosos e indagações pertinentes. Através de nossa posição no presente, fazendo com que constatemos, ou não, o laço que une uma comunidade, uma nação, uma cidade. $\mathrm{O}$ "tempo perdido" não poderá ser recuperado literalmente, Benjamin já o sabia, mas o historiador poderá indagar o que poderia ter acontecido. De acordo com o diálogo estabelecido com o passado. Instaurando, assim, a estratégia de um continuum porvir.

Como poderíamos apreender o passado? Para Benjamin, o passado não nos mostra total e claramente. Ele nos manda sinais que necessitam ser interpretados. Desta forma, cada geração, cada comunidade, terá a tarefa de decifrar as emanações do passado. Com esta posição, o historiador descobre que cada recordação cintila e, embora desprezível para alguns, poderá ser compreendida. Há uma imensidão no passado, onde o historiador "materialista", segundo Benjamin, deverá perceber o perigo. O historiador poderá, pois, apreender a imagem fugaz e cambiante do passado. Esta posição, incomum para o historiador convencional, tem como missão lançar luz ao conformismo e à apatia. Diante desta concepção de história, Benjamin nos ajuda a construir uma história contada pelos vencidos ou por aqueles que oficialmente não têm voz.

Portanto, o passado manda dicas, "cacos", fragmentos, por onde podemos perceber o que havia sido esquecido. Daí, a importância de estarmos, no presente, imbuídos de uma paixão libertadora. Diante disso, o historiador não deverá se relacionar com o passado de forma saudosista, pois ao tomar esta posição ele terá que procurar meios de intervir e mudar o que porventura estiver errado ou adormecido. Assim, o historiador terá o passado como lugar de mudanças e descobertas. O passado, será um lugar de resistência e evocação de novas formas de compreensão do presente. Embora difícil, essa atitude desencadeará novas estratégias de se perceber o fluxo da história. A história, para Benjamin, será o lugar ou movimento de transformação e utopia. Com esta posição diante da história, Benjamin alude a outra forma de compreender e narrar o passado

Benjamin, através do ensaio $O$ narrador: considerações sobre a obra de Nikolai Leskov, faz uma distinção importante acerca do modo de operar a memória. A arte de narrar, para este filósofo, estaria em extinção. A narrativa, constataremos junto com Benjamin e através dos testemunhos dos idosos pesquisados, está presente na cultura popular, possui elementos vivos e cheios de sabedoria. Isso se deve ao fato de que a narrativa oral apresenta um discurso vivo e que transmite os conhecimentos e as experiências do grupo. Desse modo, o narrador, 
mobilizaria, através da plasticidade da narrativa oral, várias dimensões do tempo no qual se desenrolam os acontecimentos.

Mas quem é Nikolai Leskov? É um escritor russo, mas que não se alia aos grandes escritores russos consagrados, como Tolstói ou Dostoiévski. A escolha de Benjamin por esse escritor resulta da capacidade de Leskov, em suas narrativas, de descrever as pessoas simples do interior russo: artesãos, curandeiros, religiosos, homens do povo. Para o ensaísta, a narrativa de Leskov representaria a narrativa em seu curso natural. Os personagens do escritor são membros de uma tradição anterior à sociedade de massa criticada por Benjamin.

É preciso constatar, junto com Benjamin, que o enfraquecimento da narrativa se deve à ascensão da cultura de massa no mundo contemporâneo, cujo legado, de grande prejuízo, foi impedir a experiência advinda da capacidade de narrar. Tal experiência, expressa pela memória dos membros do grupo, permitiria que a palavra fosse compartilhada. A narrativa de Leskov, constatou o ensaísta, expressava-se na intensidade de seus diálogos, que, em Lady Macbeth do Distrito de Mtzenski, por exemplo, manifestam-se em linguagem rica e às vezes alucinante. O escritor demonstrava um grande conhecimento das regiões longínquas da Rússia do século XIX. Ele próprio viajou muito pelo interior do país, aprimorando assim o conhecimento da realidade de sua terra natal. Desfilam em suas narrativas: santos, mendigos, homens do povo e da igreja. Através dos contos, o autor revela, ora as particularidades linguiísticas e populares, ora a opressão a que eram submetidos os cidadãos. Por meio de sua biografia, sabemos que Leskov é um escritor com raízes na tradição popular, e isso será útil para escolha de Benjamin, pois o filósofo condenou a sociedade de massa porque ela recusaria o tradicional ao negar as raízes e a herança da tradição. Assim, devido a essa intimidade com as pessoas simples do povo, o escritor apresenta ao leitor, através das narrativas, a naturalidade de um diálogo.

Talvez por isso, Benjamin soube apontar com muita acuidade as virtudes narrativas do escritor russo. Leskov assegurava que "conhecia a vida do povo nos mínimos detalhes e a compreendia nos mais ínfimos matizes" e também afirmava: "Precisamos simplesmente conhecer o povo como a própria vida” (LESKOV, apud BEZERRA, 2009, p. 84). Em uma de suas narrativas, Nikolai Leskov, a exemplo dos contos de fadas, descreve assim o final: 
E aqui se encerra a nossa triste história. Ela não contém idéia de especial valor. Narrei-a apenas pelo que apresenta de curioso e interessante. Naquele tempo, tudo era diferente... As menores coisas, uma vez começadas, iam crescendo e se desenvolvendo. Hoje, os objetivos são muito mais importantes, mas o tempo se encarrega de deslizar por cima, e tudo vai diminuindo e diminuindo, até finalmente desaparecer... (LESKOV, 1986, p. 81)

O conhecimento de Leskov sobre a alma popular russa e sua vivência pessoal de escritor andarilho contribuíram para apreender aquilo que Benjamin deseja refletir: a extinção da narrativa oral. Tais efeitos são importantes para nossa pesquisa, na medida em que um dos focos de nosso trabalho são as pessoas do povo e, a exemplo de Leskov, a narrativa tem um peso grande para a compreensão das relações comunitárias e a história da cidade. Portanto, nesta perspectiva, Benjamin nos ajudará a compreender a narrativa em conexão com a memória.

Para compreendermos melhor, em seu Narrador, Benjamin diferenciou reminiscência e rememoração. A primeira, segundo o filósofo, "funda a cadeia da tradição que transmite os acontecimentos de geração em geração” (BENJAMIN, 1994, p. 211). Essa forma de operar a memória seria encarnada na figura do narrador, que mobilizaria as forças da tradição e, através da oralidade, transmitiria os conhecimentos sobre o tempo, sobre as plantas, o trabalho, dentre outros. A segunda, a rememoração, seria própria do romancista. Para esse pensador, o leitor do romance é solitário e não tem necessidade de transmitir o conhecimento adquirido a seus semelhantes. Já o narrador está imerso na tradição e, ao narrá-la, não se apodera dela como objeto próprio, distinto do todo. O romancista, por sua vez, quer transformar aquilo que narra em sua própria criação, separando-a do resto da comunidade. Dessa forma, "seduzir o leitor no romance é a esperança de aquecer sua vida gelada com a morte descrita no livro" (BENJAMIN, 1994, p. 214).

O narrador, ao contrário, seria aquele que "assimila à sua substância mais íntima aquilo que sabe por ouvir dizer" (BENJAMIN, 1994, p. 221). Pois sabe dar conselhos; o conhecimento pulsa em suas veias através da sabedoria que o sustenta. A dignidade de contar histórias, sustenta o narrador, está no fato de a narrativa ser sua e ao mesmo tempo do grupo. Não tem a assimetria do "eu" do romancista. O que é próprio do narrador é a memória herdada de sua comunidade. O trabalho, as mãos do artesão, as ervas do curandeiro, a prece para afastar as 
forças das trevas. É uma voz que possui a cadência de um coro ao mesmo tempo singular e plural.

A tarefa do narrador e a do historiador se irmanam na proposta de transmitir a tradição, pois a ação de ambos consistiria em perceber aquilo que a história oficial não recorda. Narrar o cotidiano e os eventos daqueles que não possuem voz, que estão misturados na massa dos acontecimentos e dar-lhes sentido e significação. Nesta posição, o historiador e o narrador se encontram, pois ambos ambicionam, a partir de fragmentos, narrá-los de outra forma.

Diante disso, o ato de recordar de Walter Benjamin se assemelha à escavação. A exploração do passado, como numa atividade arqueológica, não deverá ter o receio de voltar muitas vezes ao mesmo lugar; e assim comparar detidamente os achados. Pois aquilo que se recorda, do mesmo modo que os tesouros do arqueólogo, estão sob várias camadas que se sobrepõem. Daí podermos pensar que as coisas e os fatos estudados pelo historiador e pelo narrador, e os objetos e utensílios estudados pelo arqueólogo são como imagens que se inter-relacionam em um amplo painel histórico. Já que neste caminho "os fatos” concebidos a partir da ótica deste narrador e historiador "nada são além de camadas que apenas à exploração mais cuidadosa entregam aquilo que recompensa a escavação” (BENJAMIN, 1987, p. 239). Assim, as coisas evocadas num inventário também se equiparam às camadas sobrepostas que, aos olhos do pesquisador ou historiador, se atravessam e se sobrepõem.

Podemos fazer uma outra leitura do ensaio $O$ Narrador. Trata-se de entendê-lo em relação a outras formas de composição social. Nas sociedades artesanais, a temporalidade é vivenciada de maneira diferente daquela vivenciada nas sociedades capitalistas. Na primeira, há uma continuidade; na segunda, o tempo é entrecortado. Por isso as histórias relatadas pelo narrador das sociedades artesanais são ouvidas e seguidas, dando uma espécie de formação subjetiva e social para a coletividade. Entretanto, nas sociedades capitalistas, a história não se alicerça nos ensinamentos que passam de geração em geração. Para Benjamin, as sociedades capitalistas perderam a capacidade de ouvir e seguir os conselhos dos mais velhos, transmitidos pela tradição. (Exemplificaremos melhor esta argumentação no item "tempo vivido e experiência", no capítulo "A cidade lembrada").

Curiosamente, este ensaio nos aproxima da experiência da finitude. No parágrafo $X$, Benjamin explicita isso. Aproxima a experiência da narração com a morte. $\mathrm{O}$ sentido disso 
reside no fato de que o narrador, ao narrar, possuiria a autoridade de demonstrar a agonia da passagem do tempo e das coisas. Isso se deve à capacidade do narrador em apontar a morte como tendo relação com o mundo dos vivos: "Morrer era antes um episódio público na vida do individuo" (BENJAMIN, 1994, p. 207). Dessa forma, o narrador "abre e fecha atrás de nós a porta de verdadeiro desconhecido" (GAGNEBIN, 2007, p. 65). As sociedades capitalistas, para Benjamin, não saberiam mais contar porque têm dificuldades de olhar para a própria morte, já que estão obcecadas nas produções em série dos objetos e artefatos. $\mathrm{O}$ cidadão é visto como consumidor insaciável e se eternizaria nos objetos que o cercam. A crescente necessidade de consumir implica uma atitude aversiva diante da morte. Narrar, nesse sentido, permitiria aos indivíduos o contato com as coisas que escapam à compreensão imediata. A narrativa dá margem também à compreensão da sociedade a partir do lúdico e da imaginação. Hannah Arendt se aproxima da concepção de Benjamin sobre a tarefa da história e da narrativa:

É tarefa do historiador detectar esse novo inesperado com todas as suas implicações, em qualquer período, e trazer à luz a força total de sua significação. Deve saber que, embora sua estória tenha um começo e um fim, ela ocorre dentro de um quadro maior, a própria história. E a história é uma estória que tem muitos começos, mas nenhum fim. (ARENDT, 2002, p. 50)

Nesta perspectiva, é sempre na teia das relações humanas que o narrador pode retirar a ação necessária para a compreensão do mundo. A revelação do "quem" através da fala é a possibilidade de um novo começo , a natalidade; assim o narrador pode reatualizar, numa rede de experiência, a ação necessária para afetar o mundo que o cerca.

\subsubsection{As culturas e o tempo}

Cada sociedade vivencia o tempo de uma forma. A diversidade cultural, em um sentido amplo, revelaria também a diversidade das línguas. A expressão de cada cultura perpassaria pela lógica interna e semântica dos idiomas. Assim, a sintaxe, os vocábulos, a estilística, entre outros, estariam na base da concepção do tempo. Pois o tempo precisaria do código cultural e, por conseguinte, da língua para a compreensão das várias noções da expressão temporal. (RICOUER, 1979) 
Para melhor entendermos essa proposta, a literatura é um bom exemplo. Há várias formas de discursos. E estes, por sua vez, implicariam uma determinada modalidade de tempo. O hino, a epopéia, a tragédia, dentre outras, demarcam cada expressão temporal. Além disso, as expressões orais também possuem uma forma peculiar de demonstrar o tempo, na medida em que remetem a um tipo de grupo social específico. Tais práticas, ao longo dos anos, se enraízam na coletividade, dando identidade ao grupo através das Formas Simples, expressas nos contos populares, adivinhas, ditados, que estão enraizados nas práticas verbais dessas comunidades. Tais formas apontam para percepções próprias do tempo e através delas ensinam aos homens a resolverem os dilemas da vida (JOLLES, 1986). Este aspecto da temporalidade, exemplificado acima, nos remete à modalidade pela qual cada narrador expressa o tempo. E deste modo imprime na narrativa o tempo pelo qual se expressa.

Seguindo este raciocínio, as culturas percebem o ritmo do tempo de um jeito próprio. As atividades desenvolvidas pelas sociedades, durante épocas, vão formando a herança dos antigos, o legado da tradição. Por consequiência, os grupos, as comunidades produzem maneiras próprias de enfrentar o desenrolar das coisas e as maneiras de ver o mundo. Por isso, as concepções de tempo estão próximas das práticas sociais e, ao mesmo tempo, são condicionadas pelas percepções de tempo. Tempo e práticas sociais, aqui, se intercambiam, necessitam uma da outra para compreender a duração e a permanência dos fatos de cada grupo humano.

Se o tempo e o espaço, no primeiro momento, parecem abstrações, em um segundo momento podem ser compreendidos pelas atividades dos indivíduos junto à sociedade, estabelecendo relações entre tempo vivido e práticas sociais. Para tanto, os ritos, as cerimônias, as festas marcam o ritmo pelo qual as pessoas vivenciam o tempo. Deste modo é que cada momento histórico, pela perspectiva em que estamos falando, implica uma forma de conceber o tempo. O tempo vivido, diferentemente do tempo matemático, é demonstrado nos atos humanos. Junto à comunidade a que pertence.

O que daria a singularidade da percepção do tempo em cada cultura? Cada sociedade estabelece, a partir da história, características próprias sobre o tempo. Os bens de produção, as trocas, a ciência e a religião marcam a vida social dos grupos. Dando expressão própria em relação ao tempo. No cristianismo, por exemplo, o tempo é marcado pelo antes e o depois do nascimento de Cristo. Desta forma, ao contrário da noção bíblica, por exemplo, do antigo 
testamento, o tempo cristão será marcado pela futura salvação do Cristo. O caráter dramático expresso nos ritos demonstra a modalidade de tempo presente no cristianismo e além dele. “Cristo não destrói o tempo: orienta o passado e o futuro” (RICOUER, 1979, p. 20) [tradução livre]. ${ }^{2}$

Este elemento particular do tempo, referido pelo filósofo Ricouer, nos apresenta uma forma de perceber o tempo pelo caminho da historicidade de Cristo. No sentido em que a figura de Cristo ordena não só a fé cristã mas toda a comunidade em redor dele. Por outro lado, quando falamos da relação do tempo com a cultura, apontamos, em menor escala mas não menos importante, a possibilidade de se perceber o tempo numa comunidade pequena de uma cidade do interior. Indicamos as formas pelas quais os idosos, nesta pesquisa, revelarão o tempo e as conexões com a cidade. Revelados através das narrativas em seu "vaivém" no tempo pessoal, expresso pela modalidade da linguagem coloquial e entonação vocal, ou através do tempo, percebidos pelos ritos sociais e religiosos.

\subsubsection{A memória e a voz}

Procuraremos verificar a noção de voz apresentada pelo medievalista e poeta Paul Zumthor, pois acreditamos que os estudos feitos por ele são valiosos para nossa pesquisa, na medida em que podemos explorar as várias dimensões da voz expressas pelos narradores pesquisados. Ao trabalhar o conceito de voz, a partir desse autor, pretendemos demonstrar outras formas de apreender a memória. A obra de Zumthor focalizada no tempo medieval não se restringe a ele. Isso se deve ao caráter abrangente de seus estudos, pois os conceitos trabalhados por ele nos dão subsídios para compreender os aspectos da memória e da oralidade no mundo contemporâneo.

Utilizaremos alguns conceitos desenvolvidos por Zumthor, tais como movência, corpo e performance, para compreendermos a expressão da memória na tradição. Reconhecemos elementos desses estudos até nossos dias, como, por exemplo: os contadores de histórias, o cordel do Nordeste brasileiro, os poetas populares e os narradores anônimos que, de alguma forma, utilizam a voz como elemento para a transmissão das experiências.

\footnotetext{
${ }^{2}$ Trata-se da frase em espanhol: Cristo no destruye el tiempo: orienta el pasado y el futuro.
} 
Ao teorizar a poética da voz, Zumthor afirma que uma tradição, para existir e permanecer, tem necessidade de ser rememorada e esquecida. Esse movimento de esquecer e rememorar torna possível aos membros do grupo social a compreensão de suas vivências cotidianas assim que elas surgem na experiência. Assim, o estudioso afirma:

(...) voz quer dizer vontade de existência, lugar de uma ausência que, nela, se transforma em presença; ela modula os influxos cósmicos que nos atravessam e capta seus sinais: ressonância infinita que faz cantar toda a matéria... como o atestam tantas lendas sobre plantas e pedras enfeitiçadas que um dia foram dóceis. (ZUMTHOR, 1997, p. 11)

Diante disso, cumpre-nos apresentar a evidência da relação entre a memória e a voz no processo das lembranças. Para isso, esclareceremos os conceitos de corpo, movência e perfomance e intervocalidade para o entendimento da dinâmica da rememoração. Em seu livro A letra e a voz, Paul Zumthor diz que a memória é "um espelho mágico de onde a imagem não se apaga, mesmo depois de passada” (ZUMTHOR, 1997, p. 155). Assim sendo, perceber a palavra viva como gesto cultural e reconhecer as tradições arcaicas, ou mesmo a cultura popular, como lócus desta voz poética e transmissão de conhecimento. Ao contrário daqueles que pensam na voz dos antepassados como algo morto e inútil, Zumthor acaba revivendo, no mundo contemporâneo, a possibilidade de ser a voz humana reintroduzida como elemento importante para a transmissão de conhecimento.

A poesia, para Zumthor, não se restringe à métrica ou à cultura erudita, mas a várias expressões das palavras carregadas de sentido. Para melhor compreensão dessa dimensão da palavra, Zumthor cunhou o termo movência para compreender a mobilidade da poesia no tempo e nas culturas. A movência seria a capacidade da poesia em mobilizar a memória da tradição, reatualizando-a. É importante ressaltar que a poesia aqui referida está na boca dos contadores de histórias, dos oradores, entre outros. A história da tradição não é linear, atesta o medievalista. Principalmente no que se refere à voz e sua relação com a memória. A voz teria a função de coesão do grupo social. Interpretada - em vários espaços e tempos - a voz integrava as pessoas comuns aos conhecimentos do mundo que as rodeava. Através da voz, a tradição permanecia e se propagava. Assim, pensa o estudioso: “A perfeita voz da memória forma-se na garganta, na boca, no sopro de um poeta ou de um padre - tem como fim último, sem dúvida, evitar rupturas irremissíveis, o despedaçamento de uma unidade tão frágil" (ZUMTHOR, 1997, p. 142). 
Nas margens do tempo, muitos homens se ancoravam nas expectativas da comunidade cuja realidade, tantas vezes inóspita, lhes eram impostas. Possuindo, então, duas estratégias: as integrativas e as evasivas. Para estes homens, tantas vezes anônimos, a voz da memória e da poesia conseguiam captar as intermitências do coração e as mazelas do mundo. A tradição, tendo a voz como veículo, comenta o ensaísta, possuía a variabilidade como nota. Por isso, a voz, segundo Zumthor, atingia regiões distantes que outro veículo não conseguia alcançar. Assim, revela que "ouvindo-a como uma rede vocal imensamente extensa e coesa; como, à distância, literalmente o murmúrio desse século - quando não, por vezes, isoladamente, como a própria voz dum interprete” (ZUMTHOR, 1997, p. 144).

Há outro ponto a destacar: a voz como rede de intervocalidade. Este termo serviria para demonstrar a flexibilidade e a liberdade com a qual opera a tradição, potencializada pela voz. Assim, a intervocalidade seria a "troca de palavras e de convivência sonora, polifonia percebida pelos destinatários de uma poesia que lhes é comunicada - quaisquer que sejam as modalidades e o estilo de performance - exclusivamente pela voz" (ZUMTHOR, 1997, p. 145). Acentua dessa forma os movimentos dos textos lidos pelos oradores, na medida em que faz fluírem os ritmos e sons emitidos pelos falantes e cantadores. A variabilidade dos intérpretes em épocas e regiões distintas apresentaria jogos vocais onde se renova e amplifica a tradição. Curiosamente, mesmo com o advento da imprensa, a noção de voz estudada por Zumthor não se extinguiu; haveria ressonância entre voz e escrita. Isso se daria através da veiculação dos códigos culturais, tais como os rituais políticos, morais, mobilizados no imaginário da comunidade. Até os efeitos da voz impressos em jornais e livros confirmam essa relação entre voz e escritura. Percebemos que os efeitos da linguagem e da voz estão presentes nos periódicos de Paraopeba (exemplificaremos adiante, em "memória da imprensa", capítulo "A cidade lembrada").

Para o nosso estudo, seguindo Zumthor, é importante apontar a relação entre o corpo e a performance. Esse estudioso afirma que sem o corpo não há voz. Embora óbvia, essa afirmação terá consequiências importantes, porque a voz não será compreendida sem o intérprete que a carrega e veicula. Sendo assim, a transmissão da memória oral necessitaria de corpo e do gesto para existir, portanto do indivíduo que a transmite e a reordena no momento em que a emite. Ao elaborar a performance, o indivíduo, por sua vez, reflete o texto em situação dinâmica e viva. Cujos cantadores e oradores, por exemplo, ressignificavam a tradição da comunidade, potencializados pelo gesto e pelo corpo. Neste contexto, os atores 
sociais, através da "cena" criada, conjugavam a voz e o gesto. Deste modo, estes cantadores e narradores criavam um espetáculo livre de sanções. Os atores sociais a que nos referimos acima podiam afastar o horror que os eventos da realidade representavam aos indivíduos da comunidade. Sendo assim, a voz da memória, reinterpretada ao longo das épocas, proporcionava não só os efeitos lúdicos, mas também a transmissão de conhecimentos. Há uma ligação importante na dinâmica da performance. A partir disso, Zumthor declara:

Um laço funcional liga de fato a voz e o gesto: com a voz, ele projeta o corpo no espaço da performance e visa a conquistá-lo, saturá-lo de seu movimento. A palavra pronunciada não existe (como o faz a palavra escrita) num contexto puramente verbal: ela participa necessariamente de um processo mais amplo, operando sobre uma situação existencial que altera de algum modo e cuja totalidade engaja os corpos dos participantes. (ZUMTHOR, 1993, p. 244)

Daí podermos afirmar, seguindo Zumthor, que os cantadores e declamadores da Idade Média, graças à dimensão do corpo, alcançaram outros níveis de status. É sabido que durante a era medieval a Igreja Católica tentou, através do jejum e de práticas ascéticas, controlar os gestos, os movimentos da carne. Em vão. As gesticulações, os ritmos das danças lançam o corpo além das fronteiras do exercício físico. A verdade é que o corpo estaria no centro da sociedade (o filósofo Merleau-Ponty afirma, em outro contexto, a importância do corpo - aludiremos adiante). E o corpo está participando, através dos gestos e da performance, da comunicação do indivíduo e da coletividade. Esta constatação será importante para nossa pesquisa, na medida em que os idosos, como narradores e memorialistas, utilizarão o corpo e o gesto para reavivar as lembranças próprias e da cidade. Embora Zumthor tenha começado suas pesquisas na Idade Média, elas não terminam nela. Ao contrário, este estudioso contribuiu de forma pertinente para a compreensão do corpo e da voz no mundo contemporâneo, instigando-nos, desta forma, a pensar a voz e a memória como elementos formadores e cruciais para pensar a tradição e as relações sociais.

\subsubsection{Memória e comunidade}

Quando a voz é enunciada, desfecham-se vários outros fatores, dentre eles: o tom da melodia, a modulação com o corpo, as conexões do espaço e do tempo. Consciente dessa variedade de elementos, Zumthor nos instiga a pensar um destes elementos que nos parece relevante. Tratase da relação da voz e a memória. Abordamos parcialmente acima essa relação, contudo 
acreditamos ser necessário retornar mais detidamente a este tema. A memória seria fonte coletiva do conhecimento, e também individualmente, afirma o autor (ZUMTHOR, 1993). Nesta relação entre memória e voz, uma enriquece a outra. A voz poética (num sentido amplo) é a memória. Procuraremos esclarecer um pouco mais.

A voz poética, em suas diversas expressões na história, guardaria, segundo Zumthor, a tarefa de dar "coesão" frente à dispersão da pluralidade das coisas. É importante lembrar, entretanto, que a voz poética não se resumiria na expressão métrica e erudita. Antes, a voz poética é palavra no tempo, na comunidade. Por isso, gostaríamos de destacar que a voz expressa pelos oradores, padres, narradores populares, dentre outros, tem como objetivo a procura da unidade em face às frequientes rupturas do tempo. Zumthor elaborou essa noção face à tendência em se pensar a transmissão dos conhecimentos e da poesia a partir do suporte documental. E assim, segundo o ensaísta, restringia-se a compreensão da voz em relação ao momento, o lugar, o contexto social no qual era veiculada. Assim, os aspectos da voz e da memória, apresentados por Zumthor, contribuiriam e de certa forma contribuem para proteção dos grupos e dos ritos, pois, ao narrar os eventos no tempo, os indivíduos transformam a herança do passado e asseguram sua continuidade.

Portanto, no jogo da memória e da voz, confirma o autor, existe uma função dupla: "coletividade, fonte de saber e, para o indivíduo, aptidão de esgotá-la e enriquecê-la" (ZUMTHOR, 1993, p. 139). Assim, Zumthor remove as barreiras de entendimento sobre a memória e a voz e nos permite vislumbrar um campo amplo entre texto, corpo e imagem. Isso ocorreria, na medida em que a voz, como veículo da memória, potencializaria a relação entre a escrita passada e presente e as relações sociais onde ela surgiu. Acreditamos que nesta perspectiva vários campos de saber podem dialogar: a poesia, os oradores e narradores e psicólogos sociais, dentre outros. De certa forma, nossa pesquisa esbarrou nesta proposta quando os memorialistas recitavam alguma cantiga da infância, orações, e mesmo a narrativa como um todo; a voz dos narradores recuperava os gestos, as imagens da cidade, as percepções das lembranças. Todos esses elementos enriqueciam a compreensão das lembranças dos idosos pesquisados, permitindo-nos, assim, uma compreensão maior do mundo pessoal dos idosos e da história da cidade em movimento. 


\subsection{Tempo e narrativa}

Acreditamos que deve ser apurado o entendimento entre narrativa e tempo, visto que nossa pesquisa tematiza os efeitos da narrativa e a relação com o tempo nas lembranças dos idosos pesquisados. O que é narrar? Poderíamos afirmar, sucintamente, que narrar implica perceber a sucessão dos fatos, a dimensão dos episódios e acontecimentos que se desenrolam no tempo. Seguindo este raciocínio, Benedito Nunes declara que os enredos das histórias necessitam dos eventos que se configuram numa "totalidade temporal" (NUNES, 2000). Pelo menos os textos narrados a partir da escrita (os textos orais necessariamente não obedecem a essa lógica). A unidade dos textos opera-se por meio do discurso - seqüência de enunciados que se interligam na narrativa textual - e se expressam no ato de narrar. Assim, a voz do narrador, segundo o crítico, diferentemente do que enuncia o autor real se dirige aos leitores que potencializam o sentido do texto contado. Portanto, tudo que se narra torna-se um texto escrito ou oral. Este elemento é importante para a compreensão das lembranças dos narradores, porque, embora sejam lembranças orais, foram depois transformadas em texto escrito.

Há várias dimensões do tempo que poderíamos mencionar, dentre elas o tempo físico e o tempo psicológico. O tempo físico ou natural, por exemplo, no qual o cientista mede o movimento dos corpos celestes; está presente na tradição ocidental desde os gregos. Aristóteles, em sua Física, expressava em grandezas os processos "objetivos" do movimento dos objetos que observava. Toda dinâmica, na filosofia aristotélica, implicava um processo que não dependia da consciência do sujeito. Diferentemente de hoje, quando é impossível ou desaconselhável falar do tempo sem levar em consideração o sujeito. A despeito das evoluções teóricas que a ciência obteve (houve várias ao longo da tradição ocidental), é importante refletir sobre o tempo também a partir dos aspectos afetivos ligados a ele.

O tempo psicológico, ao contrário do tempo matemático, possui outra maneira de existir. O tempo psicológico se expressa pelos afetos e sentimentos. Dando outra cadência à narrativa. Sendo assim, o tempo vivido imprime na consciência do sujeito a dissonância entre a cronologia dos relógios e a apreensão interna do tempo. Uma hora ou um minuto pode parecer uma eternidade. Minutos podem se revestir de júbilo ou de tédio. Pois o tempo subjetivo e qualitativo, por oposição a um tempo "objetivo", transcorre numa dimensão carregada de experiência, moldando a consciência temporal com as experiências dos indivíduos no mundo. 
Isso fica claro na temporalidade contida nas narrativas dos livros de ficção contemporânea, como, por exemplo, Em busca do tempo perdido, de Marcel Proust, ou Grande sertão: veredas, de Guimarães Rosa. Estas obras apresentam um rico manacial de eventos narrados, tencionando assim, dentre outros, várias dimensões do tempo. A obra de Guimarães Rosa, por exemplo, expressam na peculiaridade do tempo psicológico e expressões orais contidas na narrativa. Isso ocorre a partir das lembranças do Riobaldo, personagem do romance, que se coloca a investigar sua vida subjetiva e social. Dando a narrativa um amplo painel da vida do sertão e a dinâmica cultural na qual ele viveu; entrecruzando tempos subjetivos e sociais.

A pluralidade do tempo, presente nas obras de ficção contemporâneas, poderá perturbar os desavisados. Na complexidade em que o cidadão contemporâneo vive seria impossível apreender o tempo apenas por uma perspectiva. Esta posição temporal da ficção atual corrobora, de certa forma, a relação da narrativa com a sociedade. Uma sociedade complexa e diversa como a contemporânea exige também uma complexidade na elaboração e na leitura das obras artísticas. Entretanto, devemos observar que a complexidade de uma obra artística não está vinculada diretamente à sociedade. Arte é contrução. Apenas gostaríamos de exemplificar com os exemplos acima, o grau de sofisticação e elaboração que estas obras apresentam a respeito do tempo e da narrativa na ficção atual. Portanto na narrativa contemporânea, os tempos se misturam e se refratam: o histórico, o subjetivo, o cósmico, o lingüístico. Desta forma, a duração (entendida como a permanência do tempo) e a ordem (percebida pela sucessão dos eventos) exigem dos leitores sagacidade e interação maior com o texto escrito Assim, a noção de permanência em oposição à mudança está implícita para se entender o tempo na narrativa (NUNES, 2000). Como havíamos afirmado anteriormente, o tempo estaria ligado à narrativa; de certa forma, também, tempo e narrativa, estariam ligados à memória. Isso se confirma porque, ao narrar, potencializamos os elementos da memória subjetiva e social.

\subsubsection{A narrativa e o texto escrito}

Outra modalidade da narrativa é o texto escrito. Embora esteja no suporte físico, a narrativa escrita também passa por mudanças. Ou melhor, o texto escrito está fortemente relacionado com a sociedade e com os atores sociais que lhe deram origem. Portanto, para melhor entendimento da relação entre narrativa e texto escrito, necessitamos demarcar a história e a 
maneira pela qual os atores sociais se situam nela. As narrativas, por exemplo, se dão através das práticas sociais e subjetivas, que, por sua vez, estão presentes nos códigos lingüísticos e sociais. Neste caminho, podemos afirmar que as regras da linguagem darão suporte material ao texto escrito, dando-lhe uma forma peculiar. Desta forma, a obra escrita aponta para tempo e espaços determinados, já que o texto escrito, nesta perspectiva, também e sobretudo, se endereça à comunidade onde foi escrito. Assim, uma obra escrita não relata apenas uma época e um grupo social, mas, também, em sua estratégia discursiva, alude a uma forma de compreendê-los. É como se, a grosso modo, o próprio texto escrito oferecesse pistas para melhor compreendê-lo.

O historiador da leitura, Roger Chartier, revela que haveria um elemento fundamental para compreensão da relação entre o texto escrito e a oralidade. Trata-se da suposição de que as formas orais poderiam ser lidas como o texto escrito. Alerta o historiador que cumpre-nos, pois "historicizar a definição e a taxonomia dos gêneros, das práticas de leitura, das modalidades de circulação e dos diferentes públicos visados pelos textos (...)” (CHARTIER, 2002, p. 14). Para Chartier, o texto escrito e o oral não estão absolutamente separados e distintos, porque a modalidade escrita de um texto seria apenas uma das formas de veiculação. Aqui, o "texto" é entendido de forma ampla, não só o texto clássico de autores consagrados pela tradição, mas também os anônimos. Dessa forma, para melhor compreendermos estas modalidades do texto, teremos que saber como se organiza a textualidade e as relações com o meio social onde foi veiculado, pensando, assim, em várias vertentes do texto, como invenção, imitação, por exemplo. E também como se expressa a transmissão deste mesmo texto: a recitação, a leitura em voz alta, a declamação, a teatralização dos gestos e falas. Até mesmo a formação das pessoas às quais o texto foi dirigido: letrados, eruditos, proletários, dentre outros.

Isto posto, fica mais claro o motivo da estranheza de alguns textos lidos ou ouvidos em épocas e meios diferentes de sua origem. Muitos textos têm origem oral num primeiro momento e, depois, num segundo momento, são transmitidos e passados para a escrita. Por isso a confusão, muitas vezes, de a escrita ser incompreensível. Isso se deve ao fato de alguns textos escritos reproduzirem elementos orais de sua origem. Talvez pelo motivo de o texto oral apresentar um frescor de recitação e de leitura oral que escapa ao texto escrito. Por um lado, o fato é que a memória escrita apresenta algumas reservas, na medida em que ela não conseguiria revelar as sutilezas do texto de origem oral. Por outro lado, nossa sociedade, 
através da influência da imprensa, não conseguiu extinguir as expressões da oralidade na nossa cultura. Ela sobrevive em expressões e ditados populares, nas rezas das benzedeiras, nos rituais do casamento, e se transformam ao longo da história. As observações feitas por Chartier acerca do texto oral e escrito nos mobilizaram para a compreensão da escrita das memórias narradas dos idosos e da memória presente na imprensa local. O texto escrito e o texto oral ora se convergem, ora se afastam, mas ambos revelam, cada um a seu modo, a dinâmica da narrativa.

\subsection{Tradição: algumas observações}

O conceito de tradição possui vários sentidos. Elaboraremos algumas noções de tradição que achamos importantes para a reflexão de nossa pesquisa. A tradição, em uma perspectiva, se quer perene. Nesta acepção, a tradição se traduz como uma linha permanente que perdura e avança no tempo. Todavia, as culturas imprimem sua marca no tempo; umas sucumbem, outras não. Entretanto, o que fica ou o que passa depende de cada sociedade. Cada geração marcará sua especificidade e criará formas de se constituir, delineando deste modo a tradição. O fato é que a tradição, ao permanecer e criar raízes, promove formas de interagir com o mundo que lhe são próprias e, por sua vez, demarcam a própria identidade.

Do ponto de vista semântico, podemos observar que a palavra tradição vem do latim traditio. Nessa acepção, pode significar, a partir do verbo tradire, "algo que passa para outra pessoa ou que pode passar de geração a geração" (BORNHEIM, 1978, p. 20). Tal concepção já esboça uma condição imprescindível para a compreensão da tradição. Trata-se da continuidade e certa uniformidade em sua transmissão. Mas, como toda cultura é viva e múltipla, acreditamos que há elementos da tradição que caem no esquecimento, fazendo com que percebamos mudanças na uniformidade da transmissão, como, por exemplo, nos vestuários, nas palavras e expressões peculiares de uma região que desaparecem. Depois, estes elementos podem surgir em diferentes lugares, frutos de novas associações simbólicas. A continuidade, a partir desse sentido, é característica importante de uma tradição.

Todavia, a tradição, ao afirmar a continuidade, aponta também para seu contraponto: a ruptura. Pois a tradição se espelha naquilo que é seu oposto ou deficiência. A ruptura por um lado aponta para a inquietude de quem não se acomoda com os estados estabelecidos nas 
relações sociais. Mas, também, apontaria para a superação das relações sociais estagnadas. Por isso, a ruptura é fator importante para sua permanência, na medida em que, sendo viva a tradição, cria movimentos de conflito com os quais se depara e os supera. Através da dialética, vivenciados pacificamente ou não, os grupos humanos se movimentam e se transformam. Com isso, permanecem alguns elementos da sociedade e outros não. A tradição também neste sentido, alimenta-se dos conflitos e superações.

Outra forma de compreender a tradição é colocá-la em outro nível interpretativo, deixando de pensá-la apenas como legado do passado. Estabelecer outros caminhos de entendimento da humanidade e seu meio. É assim que percebe o ensaísta Hobsbawn: a tradição como invenção. As tradições inventadas, discutidas por Hobsbawn, significam "um conjunto de práticas normalmente reguladas por regras tácitas ou abertamente aceitas" (HOBSBAWN, 1997, p. 9). Por isso, nesta acepção, a tradição não diz de uma uniformidade, mas em processos nos quais estão envolvidas práticas e rituais simbólicos que ditam normas de comportamento a um determinado grupo.

O processo da invenção das tradições, acredita Hobsbawn, é desconhecido pelos pesquisadores. Precisamos conhecer como seria a formalização dos complexos, dos rituais e como seriam criados, já que, ao entendermos a "tradição inventada", abriríamos novas formas de percepção da formalização e ritualização das práticas com o passado. Sabemos que novas tradições são reinventadas constantemente. Desta forma, a tradição não é vivenciada como algo abstrato e perdido no passado, mas como estratégias criadas para reinventar e esclarecer a própria tradição.

$\mathrm{Na}$ perspectiva da ficção literária trabalhada por Ricardo Piglia, a tradição também se aproxima ou, mesmo, é sinônimo da memória. Para o escritor, ao lidar com inúmeras lembranças estamos evocando a tradição. As recordações das pessoas, as casas e ruas, os monumentos e a cidade, todos os objetos que são criados pelas mãos das pessoas ou pela imaginação constituem a tradição. É assim que as imagens da memória, para o narrador/escritor, às vezes se confundem com seu próprio devaneio, criando à sua maneira a tradição. Por isso a tradição e a memória, para Piglia, têm a marca do sonho, na medida em que o escritor introduz os elementos da imaginaçrão ao criar a ficção. Tradição e memória, 
pois, têm "a estrutura de um sonho: restos perdidos que reaparecem, máscaras incertas que encerram rostos queridos". ${ }^{3}$ (PIGLIA, 1991, p. 60) [tradução livre]

Por isso, o estilo do escritor (também podemos estender aos narradores orais) possui uma relação peculiar com a linguagem. Usando as metáforas e figuras de linguagem, transformam os "conteúdos" da tradição, que são coletivos, em objetos pessoais; e os devolvem com novas roupagens. As palavras, gestos, lembranças se tornam propriedades desse narrador, na medida em que o legado coletivo passa a sofrer a influência desse indivíduo. Contando e recontando, apropria-se e transforma o que recebeu da tradição.

Ao pensarmos a tradição como memória, estamos procurando uma compreensão maior do tema proposto. A ficção, por exemplo, sempre foi um arcabouço privilegiado dos memorialistas. Isso se deve ao fato de a narrativa ficcional potencializar as figuras de linguagem em qualquer meio cultural. As metáforas e símbolos estão presentes em sociedades que possuem escrita e naquelas que não a possuem.

A narrativa ficcional, através das figuras de linguagem, aprofunda as relações entre a tradição, a memória e os costumes da comunidade. Como se fosse uma rede imemorial, onde há um confronto entre o legado cultural, a sociedade e a narrativa. Dessa forma, a ficção, por exemplo, constrói pequenas ilhas de resistência entre as ideologias vigentes e as novas propostas. Desta forma, o escritor, embora muitas vezes de forma inconsciente, posiciona-se eticamente ao criticar e demonstrar em sua ficção aquilo que está sendo segregado ou ignorado. Por exemplo, algumas narrativas ficcionais revelam características da linguagem oral presente em bairros e guetos da cidade, construindo, assim, núcleos de resistência em relação à repetição massificada.

O confronto entre memória e tradição alimenta possibilidades de transformações da cultura. Notamos esse efeito através da imaginação narrativa; de maneira que o superficial, presente em alguma sociedade, sofra interferência da imaginação do escritor. Embora em pequena escala, a luta entre a memória e a tradição vigente recria, através da imaginação do narrador, espaço de indagação e crítica, fazendo com que a realidade tome outra aparência. Assim, o escritor e o narrador oral, por exemplo, podem servir como depositários da memória da

\footnotetext{
${ }^{3}$ Trata-se da frase em espanhol: “(...) la estructura de um sueño: restos perdidos que reaparecem, mascaras incertas que encierram rostros queridos".
} 
comunidade, estabelecendo elos entre o que fora perdido e a atualidade. A razão pela qual apresentamos algumas acepções da tradição se assenta na premissa de que para melhor compreender é necessário que haja diversidade de pontos vista. A seguir, com o intuito de apreender melhor vários aspectos abordados em nossa pesquisa, desenvolveremos mais detidamente algumas relações entre a tradição e outros conteúdos sociais.

\subsubsection{Tradição e folclore}

Do ponto de vista da etnografia, a tradição ganha contornos importantes para compreendermos a memória coletiva. Para Câmara Cascudo, "a memória é a imaginação do povo, mantida e comunicável pela tradição, movimentando as culturas convergidas para o uso, através do tempo" (CASCUDO, 1971, p. 9). Assim, as normas, hábitos, gestos, rituais fixados pelos costumes formam a mentalidade ou a "alma" popular. A "ciência popular", preservada pela memória coletiva, transmite um rico legado às culturas posteriores. A partir deste aprendizado, os conhecimentos populares são transmitidos: uma meteorologia na forma de entender as estações das chuvas, a direção dos ventos, a aspereza e fertilidade da terra. Há também, para a tradição popular, uma botânica que, além de curar os males do corpo, redireciona o espírito. As plantas possuem poderes sobrenaturais, dizem os conhecimentos populares. Existem algumas plantas que emitem vozes, relata Cascudo, e também atraem raios, como, por exemplo, as gameleiras. Todos estes elementos são formados pelas populações ditas “incultas," que constroem um vasto conhecimento de práticas que têm como objetivo enfrentar as forças incompreensíveis da natureza.

Para a cultura popular, a tradição alia-se à superstição e dela tira seu substrato. Ao conservar e perpetuar práticas, gestos e rituais, a tradição também modela a identidade popular. Por um lado, a cultura popular, com a tradição, presta homenagem aos antepassados e, por outro, veicula um modus muito peculiar de compreender e interagir com as forças naturais incompreensíveis. Nesse caminho, a tradição se mantém através dos ritos e conhecimentos populares, onde se assenta e se propaga.

O folclore é uma manifestação popular universal. Quando falamos em manifestação popular, nos vêm à mente o folclore. Podemos afirmar, todavia, que o folclore retrata o cotidiano de uma cultura. É ele, o folclore, que estabelece raízes profundas na mentalidade de um povo. As 
manifestações folclóricas estão presentes nos anseios, sentimentos e indagações das comunidades. Antiqüíssimo, o folclore tem sua origem no passado remoto. E se faz presente nas representações da comunidade, através de contos e histórias, adivinhações, danças e músicas, entre outras manifestações culturais.

Entretanto, nem tudo que é popular significa que seja folclórico. É preciso demarcar algumas características que traduzem melhor o folclore. Há características que são peculiares ao folclore, como a antiguidade, o anonimato, a divulgação e a persistência. Além disso, o folclore deverá estar na memória da comunidade. Mesmo anônimo, o folclore deve divulgar o conhecimento e através da oralidade tornar-se hábito. Dessa forma, as datas específicas servem como fixadoras dos ritos e eventos comunitários que, porventura, venham a se perder no tempo (CASCUDO, 1971).

Mesmo numa sociedade tecnológica, as características do folclore permanecem presentes. A da cultura contemporânea massificada, apesar disso, convive com o folclore. Isso se dá pelo fato de que o folclore estaria na formação interior de cada um de nós, pois é estabelecido pela relação afetiva da herança cultural e permanece nas práticas sociais. Percebemos isso em nossa pesquisa porque os memorialistas narram muitos elementos do folclore que ainda subsistem na sociedade. Estes memorialistas descrevem os ritos das festas, das crenças que se perpetuam na comunidade.

\subsubsection{Tradição: mundo, ação e política}

A pensadora Hannah Arendt não acredita que o passado e a tradição sejam a mesma coisa. A tradição, para ela, seria um veículo de transmissão de uma herança que liga o presente com o passado. Sendo preservada, a tradição tem como um de seus objetivos conservar no presente seu potencial de transformação. Já o passado, para Arendt, é aquele tempo no qual os eventos marcaram seus traços. O passado, diferentemente da tradição, é constituído pelos acontecimentos que se sucedem no tempo, deixando sua marca. Mas, no mundo atual, o que aconteceu com a tradição? Arendt, responde: "Com a perda da tradição, perdemos o fio que nos guiou com segurança através dos vastos domínios do passado: esse fio, porém, foi também a cadeia que aguilhoou cada sucessiva geração a um aspecto predeterminado do passado" (ARENDT, 2005, p. 130). 
Tradição, para Arendt, seria o veículo de transmissão de uma herança que ligaria o presente com o passado. O reconhecimento, por parte dessa pensadora, do rompimento da tradição não seria um desejo nostálgico do passado, uma tentativa de voltar a uma origem imaculada. Ao contrário, é permitir que o passado esquecido possa surgir de forma nova, e assim resgatar os fatores transformadores do passado para o momento atual. Por isso, a importância de se perceberem as ameaças do esquecimento para o momento presente. Aqui, o esquecimento é entendido como uma espécie de "amnésia coletiva" na qual a sociedade perderia a referência que a sustentava. Deixando, dessa forma, a sociedade sem referências e direção. Daí, as denúncias de Arendt ao apontar e demonstrar os aspectos negativos do esquecimento na esfera política.

Há, neste esquecimento, um perigo para as sociedades contemporâneas. Tal perigo se revela de várias formas e, para Arendt, uma deles se apresenta nas sociedades de massas com o desaparecimento da esfera pública. Tem como conseqüência o predomínio de um modelo de sociedade que impõe conformidade e isolamento. A sociedade contemporânea, acusa Arendt, apresenta excesso de normas, estabelecendo assim um governo baseado na burocracia. $\mathrm{O}$ excesso da burocracia tem consequiências nefastas para a cidadania. Arendt, inclusive, relaciona este modo de vida ao favorecimento do surgimento de regimes opressores.

Nas sociedades burocráticas, afirma Arendt, constata-se que "o fio da tradição foi rompido" (ARENDT, 2005, p. 131). O exemplo marcante desse fato são os regimes totalitários, cujo programa de governo efetua bruscamente a ruptura com a tradição. Neles, a perda brutal dos direitos civis e da liberdade resulta em consequiências avassaladoras para a sociedade. Daí a importância do espaço político, na vigilância constante aos sistemas de governos nos quais as esferas públicas começam a diluir. Quando os cidadãos não conseguem apreender o legado da tradição, a barbárie cresce; e com ela a diminuição ou o término dos direitos civis.

Para Arendt, pertencemos a um mundo comum. E a característica fundamental do mundo é se apresentar aberto à pluralidade humana. Segundo ela, os homens podem viver sem muitas coisas: sem o trabalho formal, com a escassez de recursos naturais, mas não podem viver sem a vida em ação. O que é o mundo? Responde a pensadora:

(...) o mundo comum é aquilo que adentramos ao nascer e que deixamos para trás quando morremos. Transcende a duração de nossa 
vida tanto no passado quanto no futuro: preexistia à nossa chegada e sobreviverá à nossa breve permanência. É isto o que temos em comum não só com aqueles que vivem conosco, mas também com aqueles que aqui estiveram antes e aqueles que virão depois de nós. Mas esse mundo comum só pode sobreviver ao advento e à partida das gerações na medida em que tem uma presença pública. (ARENDT, 1991, p. 65)

Portanto, o espaço público só se daria num mundo que estivesse aberto à diversidade. $\mathrm{O}$ mundo humano, ao contrário do mundo animal, necessita do outro e da diferença para se constituir. Desta forma, Arendt nos convida a pensar o mundo além das fronteiras do particular. O mundo é o lugar da política, pois é através da política que se dá a pluralidade humana. É o lugar no qual o homem se mostra ao outro. Define Arendt: "A política baseia-se na pluralidade dos homens. (...) A política trata da convivência entre diferentes" (ARENDT, 2007, p. 21). Mas, como se mostram os homens no mundo? Os homens se revelam ao falarem e agirem no espaço público. Aliás, a fala e a ação se dão no mundo partilhado, onde cada identidade é revelada ao outro. "É com palavras e atos que nos inserimos no mundo humano; e esta inserção é como um segundo nascimento, no qual confirmamos e assumimos o fato original e singular do nosso aparecimento físico original” (ARENDT, 1991, p. 189). Aí está a diferença fundamental do mundo humano com o mundo da natureza: a natalidade. Assim, para os homens, ao contrário dos animais, sempre se engendra um novo começo no mundo.

Mas o mundo é também feito da herança que nos antecede e o que virá depois de nós. O mundo, pois, é sempre uma criação dos homens que nos antecederam. Como entraríamos no mundo humano? É através das palavras e da ação que entramos no mundo. A ação e a palavra correspondem, por excelência, à condição humana da pluralidade. Sendo que, para Arendt, a palavra e a ação seriam formas humanas de se distinguir e de se revelar. Hannah Arendt comenta: "Agir, no sentido mais geral do termo, significa tomar iniciativa, iniciar (como o indica a palavra grega archein, "começar", "ser o primeiro", e, em alguns casos, “governar”), imprimir movimentos a alguma coisa (...)” (ARENDT, 1991, p. 190). Agir, portanto, é começo, natalidade, início marcado pela inserção do homem no mundo.

Ao entrarmos no mundo, devemos levar em conta aqueles que nos antecederam. A herança e as realizações dos antepassados são importantes para nós, na medida em que seus atos nos norteiam e auxiliam. Por isso, a memória é tão importante para Arendt. É através da memória que os homens são capazes de lembrar os feitos grandes e belos. Daí a importância dos narradores. São eles que transmitem para as gerações futuras o legado da tradição. Como o 
poeta que transforma a memória em artefato vivo, o narrador deverá se munir dos bens da cultura e dar-lhes sentido e substância. Afirma Arendt:

(...) os homens, que agem e falam, precisam da ajuda do homo faber para sua mais alta capacidade, isto é, a ajuda do artista, dos poetas e historiógrafos, de escritores e construtores de monumentos, pois, sem eles, o único produto de sua atividade, a história que eles vivem e encenam, não poderia sobreviver. (ARENDT, 1991, p. 187)

Curiosamente, os idosos participantes desta pesquisa, à maneira deles, nos transmitem o legado da comunidade. Estes memorialistas, através das lembranças, nos colocam em contato com os eventos passados da comunidade. Nos fazem reconhecer que somos membros de um fio da tradição que nos liga e nos interroga. Posição importante, na medida em que nos faz compreender fatos e eventos de outras épocas e revitaliza o presente.

O fato de nos referirmos à tradição implica encará-la como algo que reverbera em nós e na comunidade. Fator de sobrevivência para o mundo, a tradição, uma vez rompida, causa enormes estragos à sociedade. Por outro lado, a ação teria uma relação íntima com os aspectos públicos do mundo. O espaço público é o lugar onde os homens se reúnem para falar e agir. É neste espaço, de fala e ação, que aparece a liberdade, fim último da ação plural do homem. Assim, é por isso que a razão de ser da política é garantir a ação e a fala dos homens em sua diversidade. Se não fosse assim, o mundo não seria humano, mas apenas um amontoado de coisas sem sentido e significação. A própria capacidade de ação e fala pressupõe a existência do mundo enquanto pluralidade humana.

Como os cidadãos poderiam se relacionar com a tradição? Para Arendt, o humanismo é uma boa resposta ao esquecimento da tradição. Pois este humanismo "é o resultado da cultura animi, de uma atitude que sabe como preservar, admirar e cuidar das coisas do mundo" (ARENDT, 2005, p. 280). Esta conduta implicaria uma forma de vida que se ergueria acima das especializações burocráticas. No entendimento de Arendt, o pensamento humanista é herdeiro dos gregos e depois dos romanos, que têm como substrato a liberdade. Assim, os cidadãos, agindo em liberdade, têm a capacidade de escolher "entre coisas e entre pensamentos, tanto no presente como no passado" (ARENDT, 2005, p. 280).

Para esta pensadora, o conceito de mundo é muito importante para se concretizar a liberdade. Diferentemente dos animais, regidos pelas forças da natureza, apenas os homens são capazes 
de construir o mundo. É neste mundo que se realiza a pluralidade humana. O mundo é o estar em relação, é o lugar adequado à diversidade humana. É abrigo contra as adversidades da natureza, e também a realização dos projetos individuais e coletivos. Diante disso, o mundo é sempre um lugar comum e público, embora cheio de diferenças políticas, históricas etc. Enfim, o mundo é o lugar essencialmente da partilha. A expressão “amor mundi" revela para Arendt a capacidade dos homens em criar um mundo onde a ação e a palavra promovam a pluralidade. Entretanto, é o exercício da compreensão que daria forma a esse projeto, já que a “compreensão é interminável, portanto, não pode produzir resultados finais; é a maneira especificamente humana de estar vivo, porque toda pessoa permanecerá sempre um estranho, em sua inconfundivel singularidade. A compreensão começa com o nascimento e termina com a morte" (ARENDT, 1993, p. 40).

Sendo assim, Arendt nos convida ao exame constante e apurado do mundo no qual vivemos. Posicionando-nos, com os diferentes de nós, no espaço público que fazemos e refazemos junto daqueles que herdamos e para os que virão depois de nós.

\subsubsection{O enraizamento}

O diálogo com o passado faz com que a comunidade não perca suas raízes. As atividades da comunidade, como os ritos, o trabalho, por exemplo, proporcionam estabilidade e sentido às pessoas. Portanto, a sociedade que perdeu o vínculo e a comunicação com o passado corre o risco do desenraizamento. Simone Weil nos alertou para este risco:

O ser humano tem uma raiz por sua participação real, ativa e natural na existência de uma coletividade que conserva vivos certos tesouros do passado e certos pressentimentos do futuro. Participação natural, isto é, que vem automaticamente do lugar, do nascimento, da profissão, do ambiente. (WEIL, 2001, p. 347)

As pessoas idosas pesquisadas da comunidade possuem essa virtude: a de deixar seu legado às gerações futuras. Os conhecimentos dos idosos são capazes de transmitir valores morais, o ensino do trabalho, as lembranças da cidade que não existe mais. Os vínculos possibilitam aos cidadãos imprimir sua marca ao grupo, já que "cada ser humano precisa ter múltiplas raízes" (WEIL, 2001, p. 347). Esta atitude impede a desagregação dos cidadãos e a paralisia do conhecimento. A comunidade se alimenta destas raízes que herdou. 
Esta forma de estar no mundo não é reacionária. Ao contrário, a partir da tradição e do enraizamento, novas formas de inserção no mundo são constituídas. Através de estratégias que visem dar sentido às práticas da comunidade, as raízes serão lançadas, fazendo com que os indivíduos se interajam com o meio em que vivem. Desta maneira, o passado que Weil relata são propostas transformadoras da sociedade. Não é inércia nem saudosismo, mas ações que visam à participação entre os indivíduos.

O enraizamento procura recriar o mundo através de práticas sociais transformadoras. $\mathrm{O}$ trabalho, por exemplo, é uma atividade que proporciona o enraizamento dos indivíduos. Isso ocorre porque o trabalho se transforma em substância viva integrativa dos indivíduos na sociedade. Desta forma, para Weil, as ações humanas não podem estar desenraizadas. O desenraizamento não conduz a nada, porque não possibilita aos indivíduos imprimir em suas tarefas o sentido de pertencimento. Ao contrário, o enraizamento cria campos intersubjetivos e preserva vínculos criativos com o passado. O homem, "pela ciência, recria o universo por meio de símbolos; pela arte, recria a aliança entre seu corpo e sua alma” (WEIL, 1979, p. 391). Através destes meios, ter a compreensão de que cada vida precisa levar em conta os aspectos moral, intelectual e espiritual da vida. Desta forma, o indivíduo e a coletividade humana se enraízam na ordem do mundo.

\subsection{Memória e contexto social}

O sociólogo Maurice Halbwachs teve o mérito de estudar a memória do ponto de vista coletivo quando estudava a memória subjetiva e individual. Sua teoria da memória coletiva está relacionada com os aspectos do estudo da estrutura material das populações e dos grupos.

Colaborador do sociólogo Émile Durkheim, no início do século XX, consolidou sua carreira acadêmica com estudos sobre estatística, morfologia social e economia política.

Halbwachs defendeu o estudo da memória através do confronto em várias esferas de atuação, procurando tratar dessa forma a dinâmica apresentada nos quadros sociais da memória. Estudou a memória coletiva e afirmou que ela está presente em um sistema de signos que se fixam ao longo do tempo no espaço social, possibilitando identificar o que é peculiar em cada grupo. Foi assim que ao estudar as lembranças dos músicos identificou os sons e suas conexões presentes na memória coletiva. Sua obra póstuma, A memória coletiva, publicada 
em 1950, após sua morte num campo de concentração, reúne vários estudos acerca da memória coletiva e individual, tempo, história, espaço. Afirma nesta obra que a memória forjada coletivamente "tira sua força e sua duração do fato de ter por suporte um conjunto de homens, não obstante eles serem indivíduos que se lembram, enquanto membros do grupo" (HALBWACHS, 1990, p. 51).

A memória, nessa perspectiva, é construída pelos membros de um grupo social determinado. Sendo assim, os indivíduos utilizarão convenções, regras disponíveis nestes grupos. Nesse caminho, os indivíduos não poderiam lembrar "sozinhos", mas a partir das lembranças pertencentes ao grupo. Estas lembranças se ancorariam nos espaços físicos, como praças, prédios, casas e monumentos, dentre outros. Portanto, as lembranças são resultados das relações das pessoas entre si, não podendo ser apenas uma aptidão pessoal.

Para Halbwachs, de onde viria a memória? Certamente ela nunca vem do vazio. As lembranças das pessoas são adquiridas na medida em que cada sujeito da memória toma suas lembranças como pertencentes ao grupo com o qual se relaciona. A constituição do sujeito da memória se daria no confronto das imagens pessoais com o "outro", num processo contínuo de transformações e mudanças. Dessa forma, o sociólogo contribui para o entendimento da tradição presente na coletividade. Já que a tradição presente nos quadros coletivos antecede as decisões e pontos de vistas individuais. Assim, as relações entre os indivíduos e os quadros sociais procuram, através das interações, manter as estruturas sociais vigentes.

Em Les cadres sociaux de la mémoire, poderíamos considerar alguns tópicos sobre a memória. Primeiro refletir a memória através das convenções sociais, depois pensar a memória a partir do mundo prático, observável, e não sob o ângulo da intuição dos indivíduos. Também conceber o passado, que, em suas lembranças, só poderá ser evocado e reconstruído no presente. Por isso, acreditamos que haveria algo de fundamental para compreendermos a memória. Trata-se da afirmativa de que os indivíduos, mesmo sozinhos, teriam suas recordações não apenas através das lembranças pessoais, mas da memória dos “outros”, ou seja, da memória coletiva. Dessa forma, a memória é construída, elaborada, entre as interações das rememorações dos indivíduos. Daí, Halbwachs desacreditar em uma memória estritamente individual. Enfatiza, todavia, o caráter social do ser humano e as interações com o meio ambiente. Nesta perspectiva, o sociólogo constata a memória e sua relação com o espaço: 
Assim, não há memória coletiva que não aconteça em um contexto espacial. Ora, o espaço é uma realidade que dura: nossas impressões sucedem uma às outras, nada permanece em nosso espírito e não apreenderíamos que seja possível retornar ao passado se ele não estivesse conservado no ambiente material que nos circunda. É no espaço, ao nosso espaço - o que ocupamos, por onde passamos muitas vezes, a que sempre temos acesso e que, de qualquer maneira, nossa imaginação ou nosso pensamento a cada instante é capaz de reconstruir - que devemos voltar nossa atenção, é nele que nosso pensamento tem de se fixar, para que essa ou aquela categoria de lembranças reapareça. (HALBWACHS, 2006, p. 170)

Diante disso, os indivíduos estarão em contínuo processo de apropriações das representações coletivas. Portanto, durante esse processo, cada indivíduo, em suas várias experiências de vida, poderá dar sentido a sua história pessoal. Sempre levando em conta a dinâmica social. A memória, portanto, não é exclusivamente individual, mas contém as lembranças anteriores do grupo. O legado de Maurice Halbwachs também aponta para a reconstrução da relação entre tempo e memória. Pois o passado é sempre reconstruído na tensão entre normas e situações e os eventos do presente. Assim, a afirmação de que a memória é coletiva está baseada no pressuposto de que as percepções individuais do passado estão relacionadas com as representações coletivas.

Outro modo de estudar a memória foi desenvolvido pelo psicólogo inglês Frederic Bartlett. Ele construiu uma teoria da memória a partir do ângulo psicossocial. Sua obra de 1932, A study in experimantal and social psychology, criou experimentos nos quais tentava demonstrar as relações entre estímulos físicos e suas conseqüentes reações. Concluiu que a memória não era apenas biológica e nem exclusivamente mental. A memória seria então um ato individual inserido em grupo social, por onde se associava à imaginação, à linguagem, às construções do pensamento e à percepção. Enfim, a memória, para Bartlett, possuiria aspectos adaptativos e também envolveria uma busca de sentido. Por isso, os experimentos, conclui o psicólogo, que enfatizava estritamente aspectos acumulativos e estatísticos da memória, eram deficitários.

A partir de seus estudos, Bartlett constatou que cada percepção envolveria algum tipo de julgamento. Por isso, só poderíamos perceber algo que fosse significativo para nós mesmos. Tendo a memória como constituinte de todas as etapas do pensamento humano, Bartlett, em seus estudos, romperia com um sistema mecânico que subjaz à percepção e compreensão das 
imagens. Para o psicólogo inglês, o que poderíamos chamar de percepção seria, na verdade, uma rememoração. Porque, quando um indivíduo percebe alguma coisa a sua volta, estaria utilizando experiências passadas para apreender algo de novo. Embora, muitas vezes, as pessoas não percebam esta operação. Sendo assim, para se lembrar, o indivíduo tem que ter percebido antes os objetos, e depois estabelecer as relações entre percepção e memória.

É importante enfatizar que Bartlett, diferentemente de Halbwachs, não refletiu sobre as representações coletivas. Tampouco em grupos sociais que sustentassem a memória individual. Seus estudos se voltavam para os comportamentos individuais e suas relações em condições sociais determinadas. Bartlett enfatizava que ao construirmos o passado estaríamos nos colocando em várias experiências. As percepções, por exemplo, são as imagens do passado organizadas por nossa vida mental. Por isso, para o psicólogo, a memória só existiria no contexto do grupo, e não como "pertencente" ao grupo.

Para tanto, este pesquisador utilizou o conceito de schema para compreender este processo da memória. Tal conceito significa um padrão adquirido pelo indivíduo com o qual permitiria a percepção de novas experiências. O schema mediaria, portanto, a realidade e a percepção. Então, constata Bartlett, o complexo ato de recordar repousaria na capacidade dos indivíduos em utilizar e reutilizar imagens, a partir dos schemas que foram aprendidos ao longo da história de cada um.

Bartlett estudou em sua obra a reconstrução da memória através do processo psicossocial. Recusou, em seu célebre livro Remembering, que houvesse "estruturas imanentes" no processo de memorização. Para esse psicólogo, o que importa é o estudo de apropriação dos códigos sociais inerentes a suas construções. Dessa forma, Bartlett enfatiza o conceito de schemas como códigos sociais da memória que são internalizadas pelos indivíduos. Daí a importância dos gestos, dos objetos pessoais, dentre outros fatores que sustentam o ato de lembrar. Pois a memória, mesmo sendo individual, não poderia ser desvinculada dos fatos, das histórias, do grupo social. Todos estes elementos comporiam as lembranças e servem como base da compreensão. Deste modo, o "schema se refere à organização ativa das reações do passado, ou das experiências passadas, as quais têm sempre de ser imaginadas e 
estar operando em alguma bem adaptada resposta orgânica” (BARTLETT, 1932, p. 20) [tradução livre]. ${ }^{4}$

Diante disso, acreditamos que Bartlett trouxe uma nova perspectiva de abordar a memória. Trata-se de não pensar a memória como estritamente subjetiva. Mas compreendendo a memória em relação a um passado entendido como essência. Talvez seja necessário refletir e associar a memória a fenômenos e práticas sociais. Dando atenção às relações intersubjetivas ocorridas no presente para a compreensão da memória (SANTOS, 2003).

É importante fazermos algumas observações acerca destes dois ícones do pensamento social da memória. Bartlett se assemelha com Halbwachs no que diz respeito a suas experiências com a memória. Como apontamos anteriormente, Bartlett também buscou fixar a memória em "quadros sociais"; chegou a conclusões semelhantes às de Halbwachs, mas partindo de outro lugar. Bartlett estudou a linguagem advinda das tribos swazi no contexto diferente de sua origem. Este psicólogo conseguiu demonstrar, através dos experimentos, que as recordações não surgiriam em estado puro e isolado, mas em conexão com o grupo onde os sujeitos estão ideológica e culturalmente inseridos.

O estudo de Bartlett coloca em questão as modalidades do ato de lembrar. As lembranças não estão literalmente ligadas nos fatos percebidos. Quando lembramos, alerta o psicólogo, não recordamos da "mesma forma", como o fato narrado. Esta afirmativa foi inovadora no sentido de que os estudos sobre a memória eram entendidos como um arcabouço "fixo", sem relação com outros componentes. Continuando as comparações, Bartlett acreditava na possibilidade de análise das formas narrativas em relação aos sujeitos das lembranças. Já Halbwachs ficou atado às lembranças em relação aos quadros sociais da memória, como a família, a escola, o trabalho, entre outros. O sociólogo acreditava poder articular as lembranças evocadas pelos indivíduos em relação a estes "quadros".

Mas o que nos chama atenção é o caráter de "construção" da memória, ou melhor da reconstrução do passado através das narrativas dos sujeitos da memória. Halbwachs e Bartlett, cada um a seu modo, revelaria aspectos da memória como processo de reconstrução. $\mathrm{O}$ primeiro revela isso se referindo aos quadros da memória; o segundo através dos esquemas

\footnotetext{
${ }^{4}$ Trata-se do texto em inglês: "schema" refers to an active organisation of past reactions, or of past experiences, which must always be supposed to be operating in any well-adapted organic response.
} 
das imagens e narrativas evocadas. A aproximação destes dois estudiosos, todavia, nos auxiliam a repensar a memória e os desenvolvimentos teóricos posteriores. Durante muito tempo, a memória era apenas pensada pela perspectiva individual e mental. A memória era uma faculdade cerebral e não se detinha nos aspectos exteriores que a acompanhavam. Por exemplo, o grupo, a linguagem e as particularidades culturais não eram tematizados nos estudos sobre a memória. Estes dois pensadores abriram caminhos para compreendermos a dinâmica da memória. Sendo assim, a memória, depois destes estudos não poderá mais ser compreendida simplesmente como essência pura afastada do contexto social.

A psicanálise parte por outra via na compreensão das lembranças evocadas. A partir de Freud, as lembranças serão entendidas a partir do inconsciente. Quando o sujeito lembra, sofre a interferência de conteúdos subjacentes advindos do inconsciente. É importante lembrar que Freud não cria uma teoria, propriamente dita, sobre a memória; entretanto, a psicanálise abre caminhos importantes para a compreensão do ato de lembrar. Lembrar e esquecer, para Freud, estão intimamente ligados. Isso ocorre na medida em que o sujeito ao lembrar põe em jogo os desejos e fantasias de sua história subjetiva. Desta forma, as lembranças do sujeito são "alteradas" por estarem ligadas aos conteúdos inconscientes

Entretanto, gostaríamos de apresentar o eixo importante na reflexão de nossa pesquisa. Reconhecemos o valor destes pensadores, mas não ficaremos atrelados somente a eles. A idéia da memória como construção será muito importante para nossa reflexão. Todavia, não nos restringiremos somente a eles para a sustentação teórica. Embora não nos prendêssemos aos "quadros" de Halbwachs e nem aos esquemas de imagens de Bartlett ou apenas aos efeitos dos conteúdos inconscientes da psicanálise. Todos eles, cada um à sua maneira, serão marcadores para compreensão das narrativas apresentadas nesta pesquisa.

A psicóloga social Ecléa Bosi, por exemplo, nos convida a pensar a memória em relação à sociedade (discorreremos em detalhes adiante). A obra de Bosi conseguiu avançar na compreensão da memória e sua relação ao meio social. Apontou as relações da memória com os conteúdos simbólicos e a história da cidade. Ao apresentar a memória como algo ativo e transformador, Ecléa Bosi lançou luz sobre a cidade e sua dinâmica social e isto foi de muita valia para nossa reflexão. Acreditamos que, ao seguir estes estudiosos, estaremos compreendendo a memória em várias nuances: seja subjetiva ou social. Assim, poderemos, ao estudar a memória em vários aspectos, demonstrar os acontecimentos da vida dos idosos 
como elementos de compreensão da história individual e social. E com esta proposta, encontrar saída para os entraves do presente e libertar-se para o futuro. Enfim, a noção de memória que nos norteará, será aquela que contemple os elementos de construção do conhecimento e transformação.

\subsubsection{Fenomenologia e campos de sentido}

Do ponto de vista etimológico, a fenomenologia seria a ciência que estuda os fenômenos. Mas, se atentarmos para as aplicações da fenomenologia, elas são ilimitadas. Da abordagem filosófica às práticas psicológicas, esta ciência contribui para novos horizontes do conhecimento. De fato, a partir de Husserl, o campo de estudo da fenomenologia se amplia, marca novos sentidos de aplicação. (DARTIGUES, 1973)

Diante das várias vertentes abertas à compreensão do mundo, cumpre-nos perguntar: o que seria a compreensão? É o ato pelo qual o sujeito procura conhecer o mundo. Apontando para a intencionalidade que é inerente ao sujeito no ato de conhecer. Por isso o conhecimento não se revela de forma unívoca. Ao contrário, compreender abarca um movimento incessante entre o sujeito e o campo onde se encontra.

O ato de compreender, na perspectiva filosófica, exige que se faça a redução fenomenológica. Trata-se de uma operação que coloca entre parênteses a realidade, diferenciando-a do senso comum. De forma a indagar e questionar aquilo que aparece à percepção do sujeito. Assim, essa atitude obrigará o sujeito a conceber a relação entre consciência e objeto de forma diferente, porque a consciência e o objeto que aparece diante do observador não estão separados, já que a consciência é sempre consciência de alguma coisa. Nesta operação, existe sempre uma correlação entre a consciência e o objeto observado. Nesse ínterim, a concepção de consciência isolada do objeto é improvável.

Para melhor compreensão desta estratégia, a noção de campo é fundamental. O campo comporta a dinâmica entre o sujeito e o mundo. $\mathrm{O}$ "campo fenomenológico corresponde às correlações estabelecidas entre a consciência e o mundo a sua volta. É um espaço primordial no qual aparecem os pólos nos quais se configuram o eи e o não-eu” (DARTIGUES, 1973, p. 
43). Podendo, assim, determinar os comportamentos dos grupos e estabelecer conexão com o meio ambiente.

Por outro caminho, mas não excluindo este, a teoria da Gestalt é um modelo exemplar para o conhecimento psicológico e a noção de campo. Trata-se do ensino no qual se entrelaçam estruturalmente as formas de comportamento e o complexo de significação. A obra de Koffka e Wertheimer endossa essa afirmativa ao estudar a percepção dos objetos (KOFFKA, 1985). O princípio fundamental dessa teoria afirma que há campos de sentido nos quais os indivíduos se interagem.

Kurt Lewin, psicólogo e matemático, aprimorou o ensino da Teoria da Gestalt, que se converteu em referência fundamental para a psicologia social. Seus estudos enfatizam a experiência do espaço social topológico. Podemos entender a topologia como a área da matemática que não é quantitativa e que trata das relações no espaço, estabelecendo relação entre o todo e suas partes. Desta forma, as pessoas e os objetos passam a ser compreendidos não apenas em sua individualidade, mas também através do campo onde estão inseridas. Os acontecimentos são percebidos em espaços "maiores" do que eles, pois os eventos estão relacionados com o todo à sua volta. Daí a importância de percebermos a relação das pessoas com o grupo para formação das identidades e das relações sociais. Essas idéias foram desenvolvidas por DAMERGIAN (1991 e 2009).

Com esta orientação, podemos compreender o substrato presente nas lembranças dos idosos pesquisados, uma vez que o processo de rememoração aqui apreendido se desenrola no espaço social, condição que o adequa aos pressupostos da teoria de Lewin. A fluidez do tempo das lembranças individuais também se relaciona a um significado coletivo. Sendo assim, o campo social onde se espacializam as lembranças, a mobilidade subjetiva, os comportamentos que se configuraram, tudo isso foi levado em consideração. Desta forma, a noção de campo desenvolvida por Lewin nos aponta para o local onde o meio geográfico e comportamental se unem em um espaço psicofísico, daí podermos perceber a dinâmica do que está "dentro" e "fora" nas lembranças dos idosos e, neste movimento, apreender a dimensão da rede interpessoal e as configurações do espaço urbano mencionadas por nossos entrevistados. 
A noção de "espaço de vida" é muito importante na teoria de Lewin. Este conceito se refere à totalidade dos fatos que, em dado momento, podem determinar o comportamento das pessoas. Para isso, deve-se levar em conta a pessoa e o meio numa mesma operação, pois estes representariam a totalidade dos eventos e acontecimentos possíveis naquele tempo. Isso implicaria, para o pesquisador, excluir aqueles fatos que não têm importância para o indivíduo ou para o grupo no momento específico. Desta forma, a inovação de Kurt Lewin para a psicologia e a nossa pesquisa reside na constatação de ele não perceber os fatos, as lembranças e eventos separados do campo onde estão inseridas. O campo não é apenas individual, mas socialmente construído. O psicólogo afirma:

De acordo com a teoria de campo, o comportamento não depende do passado e nem do futuro, mas do campo presente. (Este campo presente tem uma determinada dimensão tempo. Inclui o "passado psicológico", o "presente psicológico" e o "futuro psicológico", que constituem uma das dimensões do espaço de vida existindo num determinado momento). (LEWIN, 1965, p. 32)

Portanto, podemos perceber que há uma inovação em perceber os fenômenos não apenas no aspecto psicológico, mas através do campo social, instaurando não apenas a noção de classe do grupo, mas a interdependência dinâmica entre seus membros. E assim constituir um todo dinâmico.

\subsubsection{Diálogo e percepção}

Diante da relação com o outro, estabeleceríamos uma dinâmica diferente da corriqueira. Ou melhor, o diálogo não é simplesmente uma posição unívoca na qual o sujeito está diante do objeto exterior a ele. Poderíamos pensar que, através do diálogo, há um descentramento do sujeito que observa. A relação estabelecida no diálogo, segundo o filósofo, "produz a estranha articulação com o outro" (MERLEAU-PONTY, 2002, p. 169). Isso se dá porque o diálogo tem a capacidade de criar laços com o que é diferente de nós mesmos.

Neste caminho, a memória dos idosos, potencializada pelo diálogo, revelaria a existência como sendo heterogênea. A presença nos diálogos daquilo que é diferente de nós possibilitaria e resgataria histórias imprevistas, cheias de pequenos acidentes e realizações. $\mathrm{O}$ diálogo estabelecido entre o pesquisador e os idosos faz emergir universos únicos através das surpresas com o desconhecido, com o novo. Porque o tempo da memória dos idosos é, dentre 
outras coisas, empreendimento e busca de compreensão das gerações passadas. O espaço criado pelo diálogo nos possibilita reconhecer efeitos sutis presentes na comunicação: o desejo, o silêncio e sonho. Todos fazem parte deste empreendimento. As lembranças dos idosos, suscitadas pelo diálogo, propiciam desse modo o reencontro com certos desvios ou mesmo pontos obscuros da existência. Assim, as lembranças são também: percepção, olhar atento, escuta, trabalho. A partir desta perspectiva, podemos instituir, junto ao outro, novas compreensões aos eventos do passado, bem como confrontá-las com o presente. Isto porque o trabalho da memória dos idosos, num jogo contínuo, articula vínculos consigo mesmo e com a socialização, resultando, com isso, numa busca contínua de compreensão da alteridade.

A reflexão ontológica merleupontiana nos convida a pensar no diálogo como possuindo um "eu" diferente de nós mesmos. Essa é uma verdade aparentemente óbvia, mas que desencadeia outras posições para a compreensão do diálogo que desejamos apresentar aqui. Primeiramente, o filósofo quer mudar a lógica de expectador entre o observador e a coisa observada. Depois, entre sujeito, objeto e a percepção. Quando observamos o mundo a nossa volta, alerta Merleau-Ponty, freqüentemente percebemos várias coisas. E nem sempre captamos realmente as coisas de forma intensa. Entretanto, há uma modalidade de observação na qual estabelecemos uma compreensão e nela um encontro com o outro. É neste momento que saímos de meros expectadores para estabelecermos um diálogo verdadeiro. Diante desse fato, o diálogo muda a qualidade do encontro. As palavras do outro, os sons, a fala ganham outros contornos. Neste momento, nasce outro observador do mundo e no mundo. É estabelecida, através do diálogo, uma espécie de comunicação "íntima” na qual observamos o outro e nós mesmos. Acreditamos que na perspectiva do diálogo poderemos perceber os pontos obscuros do outro e assim também reconhecer os nossos paradoxos e os do outro. É que, no diálogo, a comunicação se estabelece porque o outro entra no nosso campo de sentido e afeto.

Portanto, a percepção e a compreensão não podem ocorrer fora desse campo. Pelo contrário, este campo é o lugar onde percebemos o mundo e nós mesmos. Por isso, não podemos falar de interior ou exterior dos objetos percebidos; ou um mundo de "fora" e outro de "dentro". Mas, sobretudo no diálogo, estabelecemos uma constante de nós mesmos com o mundo. $\mathrm{O}$ impacto constante de nossa percepção com o que está sob nossos olhos. Nesse sentido, o diálogo não ocorre numa linha reta onde podemos enxergar o ponto final. Ao contrário, o diálogo está obliquamente em virtualidade: sempre a recomeçar. Portanto, o campo 
estabelecido pelo diálogo se reveste como o espaço de possibilidades por onde se encontram a escuta, os sentimentos, os movimentos, a reflexão. Diante disso, não é de se estranhar a ambigüidade que envolve o eu, o outro e o mundo. É neste solo, de ambigüidade e potencialidades, que o diálogo se dá.

Seguindo o pensamento do filósofo, esbarramos num conceito importante para nossa reflexão. Trata-se da reflexão em outrem, sugerida por Merleau-Ponty. À primeira vista, pode nos parecer sem propósito, visto que a reflexão, costumeiramente, é um ato solitário. A noção recorrente de reflexão se assenta no sujeito que dialoga consigo mesmo e exclui a alteridade. Como pode haver a reflexão em outrem? Com essa proposta, Merleau-Ponty pretende resgatar o sentido originário da reflexão e assim eliminar a noção cartesiana entre objeto separado do sujeito. Para Merleu-Ponty, a reflexão possuiria uma íntima relação com o outro. Sendo assim, através dessa proposta, a reflexão, antes isolada em apenas um lado, passa a reconhecer o outro como pertencente ao campo de compreensão.

Quando se estabelece o diálogo, estabelece-se um jogo no qual podemos falar de nós mesmos e, ao mesmo tempo, o outro nos ajuda a compreender nossas próprias palavras. As palavras do outro nos ensinam a respeito das nossas; a presença do outro nos ensina sobre o nosso próprio ser. Por isso, quando o outrem é visível em alguma parte, é quando ele nos arrasta para seu campo. E, com ele, a nossa subjetividade e o nosso corpo têm de estar presentes neste processo. Por isso, o filósofo afirma: "O corpo de outrem não é um objeto para mim, nem o meu para ele, se eles são comportamentos, a posição de outrem não me reduz à condição de objeto em seu campo, minha percepção de outrem não o reduz à condição de objeto em meu campo" (MERLEAU-PONTY, 2002, p. 472).

Desta forma, a reflexão estabelecida no diálogo é um movimento rumo à descentralização. Caso contrário, seria um monólogo. Daí podermos pensar que neste processo haveria uma reversibilidade constante que passa da unidade à diferenciação, pois o diálogo não é uma unidade das partes envolvidas estabelecida numa adequação. Se assim fosse, poderia se passar por uma forma de narcisismo ou de isolamento, sem a possibilidade de encontro com o outro. Mas, ao contrário, o diálogo é a possibilidade de os participantes poderem desligar-se um do outro, sem a tirania da verdade única, abrindo-se, dessa forma, ao encontro com o que é diferente. É através do diálogo que se inauguram a compreensão e a abertura para o mundo. 
Mas o diálogo não está isento de conflitos. Não poderia ser diferente, porque no diálogo é criada uma atmosfera em que não existe apenas o "eu" isolado do que é diferente, pois diante de nós há um corpo que está próximo e distante ao mesmo tempo. Em uma palavra: a alteridade. E neste encontro, seguindo a rota do filósofo, é que nos deparamos com uma verdade óbvia: duas existências que se manifestam reciprocamente. A experiência com o mundo, neste encontro, faz nascer em nós perguntas e indagações incessantes. Perguntas íntimas, e respostas difíceis de conclusão. Isso se deve ao fato de que, no diálogo, percebemos o outro e daí constatarmos o mistério que há em nós mesmos e nos outros. Assim, constatarmos, junto com o filósofo, o paradoxo das relações humanas:

Pois o milagre da percepção do outro reside primeiro no fato de que tudo o que pode valer como ser a meus olhos só ocorre tendo acesso, diretamente ou não, a meu campo, aparecendo no balanço de minha experiência, entrando em meu mundo, o que quer dizer que tudo o que é verdadeiro é meu, mas também que tudo o que é meu é verdadeiro e reivindica como sua testemunha não apenas eu mesmo no que tenho de limitado, mas também um outro $\mathrm{x}$, e no limite um espectador absoluto - se um outro, se um espectador absoluto fossem concebíveis. (MERLEAU-PONTY, 2002, p. 170)

Tudo que percebemos está imerso no campo. Todas as coisas que nos interpelam, nos perguntam, para as quais procuramos respostas, estão nesta relação, nesta percepção estabelecida na relação com o outro. Neste percurso, não podemos falar em "exterioridade" dos objetos percebidos. O mundo é o que está intimamente ligado ao outro; e se estabelece num jogo de proximidade e diferença constantes. É assim que, através do diálogo, percebemos os ruídos e silêncios, imersos que estamos no campo que nos impulsiona a compreender o mundo.

\subsubsection{Memória e subjetividade}

De forma ampla, poderíamos afirmar que a memória está relacionada à subjetividade. Isso se deve ao fato de que o sujeito, ao lembrar, imprime sua marca às lembranças. Daí afirmamos que os conteúdos das lembranças estão diretamente ligados ao indivíduo: as histórias, os afetos, o desejo. Ao lembrar, o indivíduo dá uma conotação pessoal e íntima às lembranças.

Há várias formas de pensarmos a subjetividade. Quando falamos de sujeito, à primeira vista nos vem à mente aquilo que é próprio do sujeito pensante, o que pertence ao indivíduo ou a 
seu íntimo. Também, a subjetividade se caracterizaria como um conjunto de atos pertencentes à vida psíquica, emocional e cognitiva do ser humano.

Para Marilena Chauí, a subjetividade no mundo contemporâneo se apresentaria em três instâncias: o Ego, o Sujeito e a Pessoa. Entretanto, uma grande ruptura na história do conhecimento operou para o entendimento da subjetividade. Segundo Chauí, a partir de Descartes, o pressuposto cartesiano "cogito ergo sum", "penso logo existo" - nortearia a compreensão da subjetividade na modernidade. O sujeito da consciência, para Descartes, seria a capacidade de reconhecer-se a si mesmo. Portanto, o sujeito, nesta perspectiva, se apresentaria como uma unidade coesa na qual não ocorreria nenhuma mudança através do tempo e do espaço. O sujeito adquiria uma unidade e uma consistência no pensamento deste filósofo. E como conseqüência desta proposta, o sujeito adquiriria o estatuto da "certeza" e a consciência como o palco da subjetividade. Portanto, a subjetividade se revestiria na capacidade da consciência em compreender, indagar sobre as coisas, os fatos e seres. A consciência, neste contexto, reinaria absoluta.

Mas o que significa as três instâncias referidas por Chauí? O Ego, conceito trabalhado pela psicologia, seria a capacidade que unificaria a experiência com o intuito de manter a identidade do sujeito. A outra instância, o Sujeito, é "uma atividade que reconhece ou produz, a partir de si mesma, o sentido do real, pela produção de idéias ou conceito dos objetos e dos estados interiores", define a filósofa (CHAUÍ, 1976, p. 30). Por fim, a Pessoa é um conceito ligado à moral e indicaria a capacidade da consciência em decidir e deliberar.

Seguindo outro caminho, a psicanálise inaugura outra forma de compreender a subjetividade. Ao contrário da filosofia cartesiana, que afirma a "certeza" do sujeito, Freud apresenta uma nova forma de entender os processos mentais do ser humano e, por conseguinte, sua relação com o meio social. Se para Descartes o sujeito tem certezas, para a psicanálise o sujeito é "cindido", de "falta" e permeado por dúvidas. Portanto, neste contexto, podemos atestar que para a psicanálise, o sujeito está em construção. Assim, a partir da psicanálise, a certeza da consciência cartesiana será invadida pela dúvida. A indubitabilidade da expressão "eu penso", do cogito cartesiano, traz a marca da continuidade e da certeza. Poderíamos, a partir desse pressuposto cartesiano, pensar em uma subjetividade unificada. Já para a psicanálise, ao contrário, o sujeito se apresenta dividido e descontínuo. Isso se deve à clivagem da subjetividade em instâncias psíquicas: consciente e inconsciente. Por isso, desde Freud, a 
subjetividade deverá levar em conta o inconsciente para compreensão dos fatos psíquicos. Em A Interpretação dos sonhos, Freud afirma que:

O inconsciente é a verdadeira realidade psíquica, em sua natureza mais íntima, ele nos é tão desconhecido quanto a realidade do mundo externo, e é apresentado de forma tão incompleta pelos dados da consciência quanto o mundo externo pelas comunicações de nossos órgãos sensoriais. (FREUD, 2001, p. 584)

A radicalidade da psicanálise em pensar a subjetividade reside em pensá-la descontínua e não unificada, como Descartes. Portanto, Freud, ao pensar na realidade psíquica a partir do inconsciente, implicaria concebê-la a partir do Outro, da incompletude, do desconhecido. A constituição da subjetividade depois de Freud, portanto, deverá levar em conta a alteridade, na medida em que o sujeito se constrói em relação ao outro, ao diferente.

Nossa pesquisa terá a subjetividade concebida por Freud como um dos articuladores conceituais para a compreensão dos indivíduos pesquisados no que diz respeito aos conteúdos internos e também no contexto social. Assim, também poder relacionar, quando possível, a subjetividade aos conceitos caros para psicologia social, tais como grupo, comunidade, aos quadros socioculturais. Em nossa pesquisa, a ordem histórico-social permitirá o entendimento das subjetividades dos idosos em relação à comunidade e à cidade. Portanto, como aponta Freud, a subjetividade está em construção, interagindo com o meio social. Desta forma, a perspectiva conceitual da nossa pesquisa é psicossocial.

O que a psicanálise nos ajudará na compreensão da memória? Para a psicanálise, as fantasias inconscientes, com as quais o sujeito da memória lida, nunca será encontrado de forma pura. Pois, ao lembrar, o sujeito perceberá que as lembranças foram, ao longo da história, acrescidas de outros elementos. Portanto, a primeira lembrança se perdeu para sempre. Vemos, todavia, que as lembranças, da quais trata a psicanálise, não são factuais, mas representações destas lembranças no psiquismo do sujeito. Assim, a subjetividade, marcada pela falta, dará ao sujeito razões para que busque obter sentido para essa ausência, essa falta. Portanto, lembrar e esquecer são inseparáveis para a psicanálise; já que o esquecimento é constitutivo da memória. Fruto da operação do recalque, o esquecimento imprime no sujeito as marcas do sintoma e, conseqüentemente, comportamentos. Desta forma, o esquecimento, para a psicanálise, apontaria para um sintoma que deverá ser decifrado. É nesse jogo entre 
lembrar e esquecer que o sujeito busca o sentido daquilo que o atormenta. Esquecer, para a psicanálise, é um vetor de "verdade" para o sujeito, mas a "verdade" do inconsciente.

Essa operação deve ser entendida à luz da reconstrução do processo psicanalítico. Paradoxalmente, para se lembrar da "sua verdade", o indivíduo deverá ter se esquecido. O objeto esquecido na consciência do sujeito é anúncio da verdade de sua história subjetiva. Daí, para a psicanálise, as operações de linguagem, a metáfora, a condensação, metonímias e deslocamentos servirem de via necessária para a compreensão da dramaturgia do sujeito. A busca da história subjetiva, no enquadramento do processo analítico, se estabelece, pois, como um jogo contínuo entre lembrar e esquecer.

Portanto, se pudéssemos falar de uma contribuição psicanalítica no estudo da memória, não seria de um esforço sobre os fatores intrínsecos da memória, como fatos observáveis e mensurados. Mas a importância da psicanálise residiria em investigar os fatores afetivos e emocionais na atuação e organização da memória, já que, ao lembrar ou esquecer, o indivíduo estaria marcado pelos conteúdos inconscientes. Sendo assim, buscar para eles significados únicos e particulares. Exemplo paradigmático para a psicanálise, Psicopatologia da vida cotidiana introduz na cena científica aspectos negligenciados para a compreensão da vida psíquica. $\mathrm{O}$ esquecimento de nomes próprios, palavras estrangeiras, entre outros, revelaria as imbricações sexuais e afetivas nas operações da memória. Os esquecimentos, aludidos por Freud, demonstravam conflito entre as instâncias psíquicas: o consciente e o inconsciente.

Desta forma, deveremos, com a psicanálise, refletir sobre as correlações entre a memória e a subjetividade e fazer algumas demarcações. Primeiro, o sujeito, ao lembrar, não traz as lembranças exatamente como elas eram. Segundo, lembrar implica mobilizar as forças afetivas que subjazem nas lembranças. Depois, atestar que o esquecimento está no processo das lembranças, sempre refazendo e transformando a memória. Esta afirmativa nos posiciona sobre os limites e implicações das reflexões sobre a memória a partir da psicanálise.

Por outro lado, para a fenomenologia de Merleau-Ponty, memória e subjetividade deverão ser refletidas através da noção de campo. Não pretendemos opor a teoria da psicanálise à fenomenologia, mas oferecer outra forma de pensar a subjetividade em relação à memória. Estas duas teorias não possuem uma conceituação stricto sensu sobre a memória, entretanto ambas oferecem boas perspectivas de compreensão da subjetividade e da memória. 
Estabelecendo relação entre a memória, a imagem e o sujeito que vê, este filósofo traz relevantes contribuições. Retornemos ao filósofo. Diferentemente dos outros sentidos, a visão, revela Merleau-Ponty, possui a especificidade da dimensão subjetiva, estabelecendo a relação entre a visão e o sujeito que vê. A premissa do filósofo seria colocar em reflexão a relação entre o processo de ver, da percepção, do vidente com o Ser. Portanto, sigamos os passos do filósofo.

Percebemos que a visão, o olhar e o ver não se esgotam nos órgãos sensoriais; o ato de ver não se limita àquilo que a visão apreende. Merleau-Ponty, nas obras $O$ olho e o espírito e $O$ visível e o invisível, por exemplo, afirma que a visão é indissociável do corpo. Para o filósofo, a visão é uma experiência estabelecida daquele que vê com o que vê. Quando o corpo surge no campo, sendo ao mesmo tempo visto e visível, o sujeito que vê não se apropria do que vê como objeto de posse simplesmente. O vidente não se apropria do que vê, apenas aproxima pelo olhar: o vidente se abre ao mundo. Afirma o filósofo:

\begin{abstract}
Meu corpo móvel conta no mundo visível, faz parte dele, e é por isto que eu posso dirigi-lo no visível. (...) Tudo o que vejo por princípio está ao meu alcance, pelo menos ao alcance do meu olhar, assinalado no mapa do "eu posso". Cada um dos dois mapas é completo. O mundo visível e o mundo dos meus projetos - motores são parte totais do mesmo Ser. (MERLEAUPONTY, 1969, p. 33-34)
\end{abstract}

Todo o esforço do filósofo consiste na tentativa de superar o dualismo e buscar a unidade perceptiva. Esse processo, explica Merleau-Ponty, não estaria na consciência, como resolveu a tradição cartesiana, mas na experiência perceptiva (Descartes separou dicotomicamente o sujeito e o objeto). Dessa forma, é o corpo o mediador da experiência, pois entre os corpos dispostos no campo se estabeleceria uma relação reflexiva. E como conseqüência nasceria uma nova modalidade de comunicação com o outro. Isso ocorreria na medida em que este movimento dos corpos no campo está indissociável da percepção.

Qual será, neste contexto, o lugar da visão? Para Merleau-Ponty, nesta nova ontologia, a visão não é o centro da percepção, mas um meio. Assim, a visão, é transferida para o exterior do sujeito que vê. Nesta operação, nos mostra o filósofo, não somos nós que fazemos a visão, mas é ela (a visão) que se realiza em nós. Por isso, o corpo, seria a "carne" do mundo: é o sujeito-objeto e, ao mesmo tempo, a experiência como signo de possibilidades. Este "olhar" fenomenológico é mais abrangente do que se pensa à primeira vista. Ele inaugura uma nova 
maneira de perceber o outro, na medida em que o outro que vemos é também e ao mesmo tempo aquele que nos vê. Desta forma, "meu corpo é ao mesmo tempo vidente e visível. Ele, que olha todas as coisas, também pode olhar a si e reconhecer no que está vendo então o "outro lado" do seu poder vidente. Ele se vê vidente, toca-se tateante, é visível e sensível por si mesmo" (MERLEAU-PONTY, 1969, p. 35).

Portanto, há uma observação importante acerca dessa operação. Ver, nessa acepção, não é apoderar-se do objeto percebido, mas aproximar-se dele; não é possuir, mas abrir-se para o mundo. Neste caminho, a visão percebe mais do que está à sua frente. Coloca-se aí a dimensão da "invisibilidade" no campo da visão. Quando Merleau-Ponty afirma que ver é uma aproximação, uma abertura, convida-nos a pensar que há necessariamente naquilo que vemos algo que escapa à visão, que a ultrapassa. Daí concluirmos que no processo da visão existe alguma coisa que não pode ser reduzido na representação. Essa invisibilidade, indica o filósofo, significa que na própria visão há algo de uma não-visão, já que a visão não é apropriação mas aproximação dos objetos percebidos. Neste processo, a não-visão que está presente na visão não é uma pura negação da visão, mas a promessa de visões futuras. Por isso, o que é visível estaria imbricado no invisível, pois a visão é relação com a realidade e não conhecimento acabado.

A visão, neste sentido, é um caso particular e importante de percepção. O que seria a percepção? Uma possibilidade de descoberta e desvelamento do Ser. A percepção não é apenas um objeto físico visto pelos olhos do sujeito que vê. Antes é uma sutil relação entre os órgãos do corpo, o movimento das imagens da memória e da percepção. Mas perceber é conceber, porque só através do entendimento o vidente pode empreender as variações dos objetos que o cercam. Assim, para Merleau-Ponty, a percepção também poder circunscrever um campo de pensamento. Nesse jogo de percepção e de ser visto, o vidente e o sujeito em psicanálise se aproximam: ambos nos remetem ao inacabado. Embora as bases conceituais sejam diferentes, o objetivo final é próximo. As duas teorias, aqui, demonstram o caráter e a peculiaridade do sujeito que percebe: o aspecto inacabado das percepções.

De fato, visão e memória estabelecem um laço importante para compreendermos a percepção. A imagem que o vidente apreender existe porque está situada numa região onde se interconectam o presente, o passado e o futuro: os contornos vagos e moventes do tempo se escoam e se interpenetram na percepção. A memória é, pois, campo de presença e sentido 
amplo e abrangente. O tempo, nesse sentido, só existe para quem vê, porque está situado nele. "Porque um setor do ser é tão próximo que ele nem mesmo se expõe diante mim e não posso vê-lo, assim como não posso ver meu rosto” (MERLEAU-PONTY, 2006, p. 568).

Assim, a visão, privilegiada espécie de percepção, imprime na memória a capacidade infinita de perceber o mundo. Já que, quando vemos, "vemos mais" do que se acredita. O mundo de quem "vê" é aquele no qual cada imagem está no campo perceptivo, visto que neste ato de perceber, sempre há algo para se ver. Mas a memória é trabalho da percepção. Neste caminho, os indivíduos, no cotidiano, podem perceber o mundo com olhos "novos", já que perceber nunca é algo mecânico, fixo, mas o movimento entre o sujeito que vê dentro do seu campo. A memória não retém uma única imagem, mas, através do olhar do vidente, recria a percepção. O mundo, para Merleau-Ponty, é aquilo que vemos, e quem vê percebe através de sua subjetividade, que, por sua vez, situa-se no tempo singular e único. Assim, dá às imagens a potência ontológica (caminhos do ser) que reside no visível.

É instigante refletir as lembranças dos idosos nesta perspectiva, porque constatamos o campo criado a cada encontro das entrevistas. Através do espaço das lembranças dos idosos, em certos momentos, percebíamos a presença do olhar que apreende o "invisível". Isso ocorreria porque, a cada lembrança dos idosos, instaurada pelo campo de presença, podíamos apreender as coisas que não são palpáveis e mensuráveis de imediato. Pois as lembranças exprimiriam a condição do ser no mundo, fazendo surgir associações inesperadas. A visão, acoplada à dinâmica do campo, potencializava a comunicação de duas pessoas (pesquisador e pesquisado) a encontrar sentido para aquilo que surgia inesperadamente nas lembranças. Desta forma, o "invisível" se revelava: aquilo que estava presente no campo mas não era visto. O corpo mobilizando a visão e vendo através dele. A visão dos idosos se revelava, assim, abertura e aproximação, e não posse dos objetos lembrados, mas também revelava as fissuras e hiatos que os constituem. É neste sentido que aproximamos a memória, a percepção e a subjetividade. Para despertar as lembranças, necessitamos da subjetividade, ou melhor, as lembranças só ocorrem tendo em vista o sujeito que lembra; mas aqui não é uma subjetividade isolada, mas potencializada pelo campo de sentido. 


\subsubsection{A memória dos idosos}

Chegamos ao item para onde se convergem todos os conceitos elaborados anteriormente. Sabemos que o conceito de memória é amplo e complexo. Todavia, sentimos a necessidade de algumas colocações. Este capítulo percorreu alguns conceitos que nos ajudarão a esclarecer a memória dos idosos pesquisados. No início, abordamos a memória através de sua origem lendária apresentada pelos gregos. Em seguida, Agostinho nos deu reflexões importantes acerca das questões sobre o tempo e a memória. Estes temas, embora não sejam matéria crucial para a nossa pesquisa, serviram como ponto de partida para as reflexões posteriores, apresentando para nós como o tema da memória é antigo.

Em seguida, os outros eixos conceituais, tais como a história, o tempo e a narrativa, a relação da memória e a voz, tradição e enraizamento. Convergiram, cada um à sua maneira, para situarmos os depoimentos dos idosos pesquisados. E por fim o contexto social da memória que trata dos aspectos da fenomenologia, da psicanálise, do diálogo e percepção como elementos importantes para se chegar e apreender a memória dos idosos. Isso nos deu a possibilidade de reconhecer as interfaces conceituais da memória. Por fim, chegamos à psicologia social como o lugar por onde as relações entre memória subjetiva e social se darão. Acreditamos que, ao conjugarmos esses vetores conceituais, não os estamos tematizando aleatoriamente, mas potencializando o diálogo entre eles a fim de compreender o tema proposto.

Através das narrativas dos idosos, Ecléa Bosi explorou o campo de experiência deles. Os acontecimentos do dia-a-dia e as lembranças compõem o espaço interior e social dos memorialistas, fazendo surgir ricos ensinamentos. Ao contar, os idosos tecem uma trama de episódios e sentimentos que traduzem a história de uma época e da cidade de São Paulo. A psicóloga não se detém na história oficial, embora não a negue. Os objetos de seus estudos são aquelas histórias feitas no cotidiano, na rotina, construídas ao longo de toda uma vida. Histórias exemplares e cheias de vida.

Desta forma, o trabalho da memória é traduzir em palavras aquilo que a história oficial não constatou. As lembranças dos idosos transmitem as experiências de toda a vida. Ensinam aos ouvintes e acessam momentos que permanecem ao longo das décadas. A psicóloga nos convida a compreender a memória além das fronteiras da psicologia experimental. Por isso 
sua estratégia é da interdisciplinaridade. E para isso não recusa as outras ciências humanas; ao contrário, mantém com elas um diálogo fecundo.

Os relatos orais apontam para a dimensão subjetiva e social das lembranças. A partir disso as lembranças se apóiam no espaço urbano. O tempo e o espaço são compartilhados pelos idosos: as casas, ruas, escolas, o trabalho retratam também a memória da cidade. Neste movimento de compor as memórias, a cidade também vai sendo revelada. Assim, constata a psicóloga: "Cada geração tem, de sua cidade, a memória de acontecimentos que são pontos de amarração de sua história" (BOSI, 2003, p. 70).

Assim, quando a memória se converte em narrativa, ganha ações transformadoras. Então, a memória subjetiva dialoga com a coletividade. Mesmo sem ter consciência, os idosos estarão reproduzindo a interpretação dos eventos sociais. Ora esclarecendo, ora acentuando os estereótipos. Em cada evocação um mundo se abre. O presente, o passado e o futuro se mesclam nas lembranças, podendo surgir fatos reveladores para as novas gerações. Entretanto, a memória não é feita apenas de fatos, mas também de desejos e sonhos. E pode, desta forma, retratar a história coletiva da cidade.

Ao explorar as memórias dos idosos, Ecléa Bosi percebe as contribuições da teoria da Gestalt. Pois esta teoria preconiza a existência de campos de significações na vida subjetiva dos narradores. Isso lhe permitiu apreender as histórias de vida em vários ângulos. Gerando um campo entre o eu e o outro, de forma a irradiar momentos de percepções singulares. Daí, pensamentos, gestos, silêncios entrarem no campo de compreensão das lembranças dos idosos.

Por isso a afirmação da pesquisadora de que a psicologia é uma "fenomenologia dos atos expressivos" (BOSI, 2003, p. 48). Isso acentua a compreensão de sua obra, possibilitando a compreensão das lembranças dos idosos como campos de sentido e eliminando as fraturas entre sujeito e objeto. Diante desta estratégia, podemos vislumbrar a dinâmica fecunda entre o pesquisador e seu objeto de pesquisa.

É neste percurso que Ecléa Bosi pesquisa a memória dos idosos. Através do diálogo, eles vão desvelando a si mesmos e a cidade em que viveram. Todos os elementos se interagem na pesquisa: gestos, indagações, silêncios, aprendizados. A memória se apresenta como um 
labirinto de lembranças em que uma vai puxando a outra. Por isso o trabalho da memória exige inteligência dos narradores: "Não há evocação sem uma inteligência do presente, um homem não sabe o que ele é se não for capaz de sair das determinações atuais. Apurada reflexão pode preceder e acompanhar a evocação” (BOSI, 2006, p. 81).

Diante disso, ensina a psicóloga social, as lembranças não podem se perder em impressões abstratas. Precisam do contorno social como substrato. Aí está o compromisso ético. Os idosos são narradores natos e, através dos relatos orais, nos ensinam com as experiências e os dons do conselho e do testemunho. A vida se restitui pelas evocações. Através delas, tomamos conhecimento e usufruímos de um mundo que não existe mais, mas que revive nas lembranças.

Esta proposta nos faz chegar ao ponto crucial da memória subjetiva e social. A partir das referências conceituais discorridas ao longo deste capítulo, temos a memória individual e social como sendo um processo de construção. Não uma memória imanente ou fixa, mas aquela que nos permite uma fonte de conhecimento subjetivo e social. A memória, por essa via, se torna um manancial rico por onde a sociedade se assenta e dela tira meios para superar os impasses do presente. 


\title{
3. Capítulo II
}

\author{
A cidade
}

Mas a cidade enjambra cada limite que se lhe dá... (NAVA, 2000, p. 119).

Esta é a minha Cidade, saudade! A cidade que escolhi para vida, paixão e morte do mineiro despencado do seu Caminho Novo. A cidade onde todos se abraçam no mesmo bloco e seguem sob o mesmo estandarte rutilante. (NAVA, 2000, p. 234). 
A proposta deste capítulo é verificar, em várias narrativas, aspectos da história e da memória da cidade de Paraopeba-MG. Primeiramente abordaremos algumas noções e percepções sobre a cidade. Elencaremos os autores que, a nosso ver, conseguem abordar esta temática de forma a contribuir para a compreensão da cidade. Dentre os autores, o historiador Munford descreve o nascimento das cidades ao longo da história; Fustel de Coulanges reflete sobre a cidade através das perspectivas institucionais; Karl Max acentua as relações de trabalho e as mudanças socioeconômicas nas cidades. Outra perspectiva importante para a compreensão da cidade é pensá-la a partir das metáforas, como o escritor Italo Calvino desenvolve.

Também descreveremos o surgimento da cidade de Paraopeba, quando ela se chamava Tabuleiro Grande. Os dados históricos de seu surgimento e os avanços culturais e sociais ao longo dos anos. Procuramos alargar as visões sobre esta cidade através de escritos preservados de pessoas que a conheceram. Alguns contribuíram para o avanço social e cultural do lugar. Com o intuito memorialístico, exemplificaremos com quatro representantes: o viajante, o anarquista, o poeta, o jornalista. Estas pessoas, em sua maioria, viveram na comunidade e nos deixaram valiosos documentos para conhecimento da cidade em momentos e perspectivas diferentes. Por fim, no subitem "A cidade e a memória”, discutiremos, com base na contribuição de Walter Benjamin, a relação entre a memória e a cidade. Esse intérprete das metrópoles contemporâneas contribuiu de forma exemplar para compreensão das relações entre afeto, fatos históricos e a geografia da cidade. É importante frisar que as citações preservam a grafia da época. Tanto do romance quanto dos periódicos relatados.

\subsection{Percepções sobre a cidade e os modos de habitar}

A clássica obra de Lewis Munford, A cidade na história, traça a trajetória da cidade na história. $\mathrm{O}$ autor percorre os séculos na tentativa de compreender o surgimento e o desenvolvimento das cidades e localiza o momento histórico em que a cidade nasceu. Para ele, "a cidade surgiu como um emergente definido na comunidade paleoneolítica" (MUNFORD, 1982, p. 37). Nessa época, a organização humana tornara-se diversificada e complexa. Surgiram dessa nova modalidade de convivência o lenhador, o caçador, o pescador, o feiticeiro, entre outros. A partir dessas atividades, esses moradores desenvolveram novas formas de uso de instrumentos e trocas de conhecimentos. Essa "grande transformação 
urbana teve lugar no limiar da história escrita” (MUNFORD, 1982, p. 44), constata o historiador, propiciando novas formas de compreensão do mundo.

E com essa nova e revolucionária forma de inserção no mundo, a comunidade humana deu um grande passo. A aldeia se transformara. Agora a pequena cidade se alterava substancialmente. Os instrumentos de trabalho e guerra para enfrentar as adversidades da natureza se ampliaram. Outra transformação ocorrida na cidade foi a revolução advinda da escrita, que transformou para sempre o mundo simbólico. Os habitantes, dessa forma, puderam aperfeiçoar o poder temporal e o sagrado em suas cerimônias. A cidade se aparelha para controlar o ambiente, com as novas funções dos monarcas e dos sacerdotes imprimindo os poderes aos cidadãos, criando assim as hierarquias. Dessa forma, as cidades, marcos da civilização, sobreviveram na memória da humanidade: Ur, Tebas, Nínive, Babilônia, entre outras. Elas exemplificam um grande período de poder e glória e depois decadência.

Para Munford, a cidade sobrevive ainda por causa da sua complexidade e durabilidade. Pois, a "missão final da cidade é incentivar a participação consciente do homem no processo cósmico e no processo histórico" (MUNFORD, 1982, p. 621). Além das defesas das catástrofes naturais, a cidade exerceria a melhoria de todas as atividades humanas: o domínio tecnológico, as relações afetivas, o aprimoramento da linguagem, a criação artística. Os hábitos das cidades se alteraram historicamente, mas permaneceu a forma de coesão que traduz cada comunidade. Ao se expressar, cada cidade dialoga consigo mesma e com as outras cidades. Assim, nesse processo, a cidade permanece ajudando a comunidade a dar sentido à existência.

A cidade, por outro lado, pode ser compreendida através dos movimentos dos corpos. Esse é o argumento do historiador Richard Sennett defendido em Carne e pedra. A cidade é o lugar privilegiado do poder onde desponta a expressão e o comportamento próprios. Como, por exemplo, os poderes políticos, religiosos, econômicos. Entretanto, nesse espaço também os poderes se estilhaçam. Pois, segundo o historiador, a imagem humana, o movimento das pessoas não estão dissociados da cidade. Se pensarmos assim, veremos que a glória e a destruição de muitas cidades estavam ligadas às expressões do comportamento humano. Foi assim com Alexandria, foi assim com Roma e tantas outras 
Não é de se estranhar que a experiência urbana exiba vários aspectos dos valores humanos. A estranheza, a indiferença, a ostentação, a agressividade, a beleza, entre tantos outros, mostram os movimentos das pessoas no espaço da cidade. Dessa forma, a cidade e o corpo apresentam uma intimidade na qual um se espelha no outro. A vida na cidade é constituída, por excelência, pelas múltiplas conquistas e derrotas dos cidadãos. Constata Sennett: "Busquei mostrar como aqueles que foram banidos do Éden poderiam encontrar um abrigo na cidade" (SENNETT, 2008, p. 26). A civilização ocidental, onde se baseia o ensaio de Sennett, ilustra esta dinâmica. As regras dos corpos: das orgias à ascese, das virtudes à guerra. Todas vinculadas ao espaço da cidade e por conseqüência às questões sociais. Assim, o espaço da cidade apresentaria a possibilidade às pessoas de experiência e convívio com a alteridade. Nesse caminho, para o ensaísta, os sofrimentos dos corpos e sua superação são também os da cidade.

Fustel de Coulanges, em A cidade antiga, se preocupa em entender a dinâmica urbana através das instituições da cidade: a propriedade privada, a religião, a família. Fazendo o percurso desde a antiguidade até a modernidade; com intuito de compreender as instituições em relação a cidade; Coulanges realiza um estudo apurado sobre esse tema. Sendo historiador do século XIX, Coulanges contribuiu para chamar a atenção para o papel da instituição religiosa na construção da base de uma cidade. Segundo ele, a religião possibilitaria as relações de solidariedade entre os homens. Assim, a cidade se constituiria em torno das instituições sociais. A religião é uma delas; as outras instituições, declara Coulanges, seriam a propriedade privada e a família. Por isso, afirma:

Há três coisas que, desde a idade mais antiga, encontram-se solidamente fundadas e estabelecidas nas sociedades gregas e itálicas: a religião doméstica, a família e o direito à propriedade: três coisas que tiveram entre si, na origem, uma relação manifesta e parecem ter sido inseparáveis. (COULANGES, 1975, p. 65).

O fenômeno religioso sempre foi uma manifestação cultural ao longo dos séculos. Desde a sociedade mais remota, a religião é reconhecida como sendo preponderante na formação das sociedades e conseqüentemente para as cidades. Para Coulanges, a instituição religiosa é um elo importante para a construção de convivência entre os cidadãos. Dessa forma, afirma o ensaísta, “à medida que os homens sentem que existem para eles divindades comuns, vão se unindo em grupos cada vez mais extensos" (COULANGES, 1975, p. 166). A despeito das inúmeras críticas, percebemos, posterior a Coulanges, a relevância dessa abordagem na 
medida em que chamou a atenção para a instituição religiosa como fundamento para a compreensão do fenômeno urbano.

O contraste entre a cidade e o campo, em diferentes épocas, sempre marcou atitudes e comportamentos peculiares. A partir disso, ao longo dos tempos, essas atitudes foram sendo cristalizadas. A cidade foi sendo associada à idéia de realizações como trabalhos especializados, comunicações, enquanto o campo é associado a atitudes emocionais: paz, harmonia, virtudes e vida simples. Obviamente essas associações foram criadas e mudadas ao longo do tempo. Mesmo assim, sempre houve esse contraste e ele permanece criando o imaginário de várias sociedades.

Notamos, por outro lado, que elementos pertencentes à cidade se encontram no campo e viceversa. Trabalhos complexos e de alta tecnologia, por exemplo, hoje em dia, se encontram no campo. Os mercados de verdura e frutas estão espalhados pela cidade. Dessa forma, a cidade, historicamente vem se desenvolvendo devendo muito aos trabalhadores do campo. E do ponto de vista econômico, vemos isso historicamente, a exploração dos trabalhadores do campo pelos habitantes da cidade é evidente. As necessidades da cidade são supridas pelos trabalhadores do campo. Por outro lado, as cidades surgidas na era industrial se organizaram em torno do trabalho das fábricas, marcando, assim, acentuada dicotomia entre cidade e campo.

Entretanto, tanto a cidade como o campo necessitam de novos olhares e intervenções. A dinâmica social exige sempre outras posturas. Pois, constata o historiador, "o campo e a cidade são realidades históricas em transformações tanto em si próprias quanto em suas inter-relações" (WILLIAMS, 1989, p. 387). Essa perspectiva requer que olhemos para essas duas realidades como quem deseja descobrir as relações sociais e culturais e propor mudanças. O contraste não deveria ser objeto de exclusão, mas de entender que cada realidade - a cidade e o campo - exigirá uma política de intervenção apropriada. Essa perspectiva é aliciada por políticos e ideologias de diferentes vertentes. Tais elementos de contraste entre cidade e campo são vetores importantes para compreendermos a dinâmica social. Em nossa pesquisa, por exemplo, a cidade surgia pelas lembranças dos idosos, no início como um prolongamento do campo ou cerrado. O núcleo urbano, na origem de Paraopeba, era rudimentar, mas aos poucos notamos a complexidade sociocultural: o surgimento das indústrias, o comércio, a imprensa, dentre outros componentes. Do ponto de vista dos 
habitantes, o imaginário sobre a cidade permanecia oscilando entre o campo e as novidades da vida urbana.

A propósito das dinâmicas socioeconômicas, Karl Marx contribui para percebermos essa mudança, embora não tenha elaborado propriamente uma teoria sobre a cidade. No entanto, este pensador, a partir das reflexões dos aspectos sociais e econômicos, nos deixou uma compreensão do cotidiano das cidades em relação às forças econômicas e produtivas. Além do retrato dos comportamentos dos cidadãos em relação às instituições, a reflexão sobre as instituições parecem-nos uma tônica dos pensadores do século XIX. E Karl Marx se encontra também nessa proposta teórica.

Mas o fato é que Marx, ao estudar as cidades a partir da dinâmica dos trabalhadores e do capitalismo, deixou um estudo que nos auxilia até hoje. Através dos anos, constata o pensador, a cidade se desenvolveu além do espaço geográfico. Marx assinalava que a cidade medieval havia se desenvolvido em oposição ao campo; já na Idade Moderna, os lugarejos tenderiam a uma urbanização do campo. Definido, assim, outra forma de produção nas cidades. Dessa passagem do modo de produção feudal para o de produção capitalista, houve uma grande mudança nas comunidades. A cidade se tornou um lugar onde se dá a produção de manufaturas e o desenvolvimento do capitalismo comercial. Em Marx, através do materialismo histórico, não poderíamos compreender o fenômeno urbano sem perceber as condições socioeconômicas presentes na dinâmica das cidades. O filósofo nos chama a atenção para a divisão do trabalho, a imposição e a exploração e que os cidadãos eram submetidos. Em 1845, Marx afirmou que:

Com a cidade, aparece, simultaneamente, a necessidade de administração, de polícia, de impostos etc., em uma palavra, a necessidade de organização comunal e, portanto, da política em geral. Aqui, manifesta-se pela primeira vez a divisão da população em duas grandes classes, divisão que repousa diretamente na divisão do trabalho e nos instrumentos de produção. A cidade já é o fato de concentração da população, dos instrumentos de produção, ao passo que o campo evidencia exatamente o fato oposto: o isolamento e a separação. (MARX; ENGELS, 2000, p. 78)

Isso nos dá uma clareza muito grande das relações sociais numa cidade. Pois, para o entendimento da organização social de uma cidade, deveremos apreender, a partir dessas reflexões de Marx, como as pessoas, os grupos, as relações de trabalho, as instituições se inter-relacionam. Assim, através das relações socioeconômicas, percebemos como esses 
vários grupos se apresentam no espaço urbano e como cada um se especifica. Por isso, a cultura de uma cidade (aqui cultura entendida num sentido amplo) deverá se deter nas diversas formas de organizações, sejam religiosas, sociais, econômicas, já que nessa perspectiva todos esses fatores se interpenetram no contato de uma cidade.

Por outro lado, a cidade é um organismo vivo. Jane Jacobs compreende a dinâmica urbana constatando as leis implacáveis da natureza: a vida e a morte. Esta urbanista percebe essas leis, mas não esquece a possibilidade de "humanizar" a cidade, no sentido de pensá-la em função das pessoas que a habitam. Seguindo este caminho, analisa as funções dos espaços urbanos: a rua, os prédios antigos, o bairro, a praça. Assim, os perigos e a vitalidade das cidades estão ligados a estes detalhes, por isso é importante pensá-la em diversos ângulos e fazer as devidas intervenções.

Em Morte e vida das grandes cidades, Jacobs investiga, por exemplo, como as calçadas são importantes para os habitantes e a iluminação que as acompanha, fazendo a adequação às ruas. Percebe também a necessidade dos prédios antigos como forma de garantir a memória da cidade. Argumentando, ainda, que a preservação dos prédios antigos dificultaria a especulação imobiliária. Acreditamos também que os prédios antigos são lugares por onde a memória da cidade se preserva. Esses prédios conseguem dizer muito de uma época. A urbanista se detém nas grandes cidades, mas muito de suas observações podem ser úteis para uma pequena cidade. Na medida em que as cidades possuem uma organização semelhante: casas, prédios, ruas, praças, instituições. Por fim, a cidade e o campo podem manter uma relação saudável, onde os cidadãos valorizem a diferença e convivam com ela, já que as cidades vivas têm uma estupenda capacidade natural de compreender, comunicar, planejar e inventar o que for necessário para enfrentar as dificuldades. Esta preocupação em preservar os lugares de memória foi, ao longo de nossa pesquisa, uma constante. Os idosos, a partir das lembranças, evocavam os prédios antigos, as casas e ruas, como detentores da memória da cidade. Nas lembranças dos idosos, além do caráter afetivo que os lugares da cidade traziam, eles mesmos eram irradiadores dos eventos sociais e culturais da história da cidade.

Argan revela que a cidade não é feita apenas de pedras. É construída e idealizada pelo homem, para se proteger do mundo inóspito que o cerca. Assim, os homens necessitam do abrigo da cidade. Além da estratégia da proteção, a cidade possuía intrinsecamente a arte em sua concepção. Pois "sempre existe uma cidade ideal dentro ou sob a cidade real, distinta 
desta como o mundo do pensamento o é do mundo dos fatos" (ARGAN, 2005, p. 73). Assim, o historiador Argan reflete a cidade a partir da concepção artística. A cidade como obra de arte é uma construção de e para os homens. Esta construtibilidade não se refere apenas às técnicas de materiais ou composições de objetos; antes se revelam como construções estéticas. As cidades, pensadas através da lógica artística, apresentam as combinações entre claro e escuro, tempo e espaço, perspectivas, cores. Atributos caros e necessários às obras de arte.

A partir deste sentido, a cidade se opõe à natureza. Se antes as pessoas eram regidas pelas leis da natureza ou estavam submissas a elas, a cidade inaugurou regras de comportamento que regem a vida entre as pessoas. Com estas mudanças de concepção, foram sendo mudadas as percepções das pessoas sobre a natureza e sobre elas mesmas. Como o espaço urbano, a dimensão "interna" das pessoas também se transforma. A cidade redimensiona a noção de arte e também a cosmovisão das pessoas em relação ao mundo. Estabelecendo, dessa forma, a relação da cidade entre concepção estética e abrigo.

Por outro caminho, as cidades, para Italo Calvino, não são apenas construídas como relevo ou construções de prédios, casas e monumentos. Antes, são cidades “invisíveis", por onde desfilam monstros fabulosos e sonhos encantados. A geografia desta cidade é fantástica e com lugares encantados. Por isso, cada lugar desta cidade se multiplica em diversos nomes e simbologias; são memórias que refletem imagens oníricas.

Assim o viajante Marco Polo descreve para Kublai Khan as inúmeras cidades que os olhos não avistaram. Um vasto império que conquistou e cidades que visitou. Mas o herói sabe que as cidades conquistadas possuem segredos e mistérios. Ela é uma conquista real, embora as cidades também sejam imaginadas. Cada cidade possui uma chave e exige perícia para entrar nela. Além das ruas e pedras que revestem os caminhos da cidade, há um jogo de imagens labirínticas por onde cada viajante deverá passar, pois "as cidades, como os sonhos, são construídas por desejos e medos, ainda que o fio condutor de seu discurso seja secreto, que as suas regras sejam absurdas, as suas perspectivas enganosas, e que todas as coisas escondam uma outra coisa" (CALVINO, 1990, p. 44).

Deste modo, tantas vezes o viajante ao entrar na cidade não se depara apenas com o que vê, mas com aquilo que traz consigo. Dessa forma, as memórias que o acompanham se mesclam às imagens ao seu redor. Um mapa interno se acopla ao espaço por onde anda. Os lugares e 
objetos são infindáveis porque cada forma percebida, círculos, retângulos e retas, se amplificam aos contatos e encontros. As cidades surgem como os desejos humanos, são intermináveis. Assim a memória, como as cidades visitadas, reverberam em um Atlas que se refaz em espaços variados.

Todavia, os homens e mulheres, ao longo dos tempos, forjaram progressivas formas de habitar as cidades. Historicamente, como demonstrou Munford, a cidade surgiu para enfrentar as adversidades da natureza. Desde então, acreditamos, a cidade passa a abrigar a pluralidade de cidadãos e formas de morar. O espaço urbano, desde então, além de abrigo, aponta para modos de morar e de pensar.

De fato, o espaço urbano não é um ponto fixo e imutável. Embora a arquitetura ajude a fixar um tempo histórico, ela não suprime as ações dos cidadãos, sua organização e seu dinamismo. Os eixos organizadores do espaço urbano são variados: instituições religiosas e administrativas, casas, ruas, a cidade e o campo, dentre outras organizações espaciais e sociais. Dessa forma, podemos afirmar que a cidade é viva e dinâmica, se move de acordo com seus habitantes.

Mas o que são modos de habitar a cidade? Primeiro é uma forma de dar sentido, simbolizar as relações do espaço urbano. O cidadão, ao refletir sobre a interação entre a história individual e a comunidade, significa o espaço onde vive. Portanto, habitar a cidade não seria apenas estar numa geografia urbana, mas sobretudo interagir com a cidade. Dar ao espaço urbano onde se vive sentidos e significados múltiplos. Habitar a cidade, com efeito, é compreender que a cidade é algo vivo. E em conseqüência disso cuidar da cidade é estabelecer contatos saudáveis com a alteridade. Já que a cidade é a possibilidade da convivência e da pluralidade humana.

Constatamos, não obstante, que as percepções sobre a cidade são variadas (apresentadas acima). Para o historiador Richard Sennet, por exemplo, a cidade é vista em relação ao poder; Coulanges reflete a cidade a partir das instituições; Marx revela que nas cidades, a partir da Idade Moderna, a divisão do trabalho será importante para a compreensão da dinâmica urbana; Em Calvino, por outro lado, a imagem da cidade se faz pelas metáforas literárias. Embora a noção de cidades apresentadas aqui não esgote o tema, nossa pretensão é dialogar com estas referências conceituais. Isso se revelará, em maior ou menor grau, nas pessoas que serão elencadas e discutidas adiante - (James Wells: o viajante; Avelino Fóscolo: o 
anarquista; Sabino de Paula Freitas: o poeta; Aguinaldo Edmundo: o jornalista) - sobretudo nos memorialistas pesquisados, os quais apresentaremos no capítulo III.

Dessa forma, a cidade de Paraopeba revelará, a partir desta pesquisa, múltiplos aspectos culturais, podendo, assim, romper a idéia de uniformidade cultural da cidade. Sabemos, através do corpo teórico apresentado e juntamente às narrativas dos memorialistas, as transformações que o espaço urbano sofreu ao longo da história. Paraopeba será compreendida também pelos habitantes que vieram de outros lugares e pelos próprios habitantes. Ao fazermos essa afirmação, acentuaremos a argumentação segundo a qual habitar a cidade e interagir com ela é compreendê-la a partir da pluralidade dos habitantes e da história que a sustenta. Os diferentes modos de morar - urbano e rural - se configurariam numa experiência temporal e sociocultural singular. Portanto, perceber a cidade é interagir com as peculiaridades das identidades, subjetividades e as histórias próprias dos cidadãos. Procurando, com essa atitude, entender o espaço urbano pelas perspectivas da diversidade, da "mistura" de tempos, histórias e culturas. Assim:

Compreender o que seja morar nos diversos lugares de uma cultura e nas diversas culturas exige a busca por identificar nas construções, nos objetos da moradia e na sua disposição, criando os ambientes, uma inscrição ornamental. Tudo comporia e mobilizaria representações, valores, sistemas de significação que estão na base da constituição da identidade, seja de um sujeito, seja de um povo, de cultura, numa cidade (FERNANDES, 2005, p. $81)$.

Dessa forma, demonstraremos a seguir a cidade de Paraopeba, percebida por ângulos diferentes. Esta perspectiva corroborará a idéia sobre a qual acabamos de exemplificar. Ou seja, a cidade é composta por vários olhares e sentidos. Apresentaremos nesta pesquisa, através do trabalho, do olhar do estrangeiro, da atuação sociocultural, entre outros, a possibilidade de compreensão da cidade.

\subsection{Tabuleiro Grande}

O surgimento do arraial de Tabuleiro Grande nos chegou oralmente. De acordo com esta história oral, havia um donatário da sesmaria, Coronel Marques, que passava por essas terras. De repente fora atacado por uma onça. Muito católico e devoto de Nossa Senhora do Carmo, rogou à santa que o livrasse deste perigo. Diante de sua fé, a feroz onça não mais o atacou. 
Assim, por gratidão à santa, erguera uma capelinha. Ao redor da capela, solta no sertão de Minas, as pequenas casas foram surgindo... A cidade despontava no sertão.

Curiosamente, há uma declaração, obtida no Arquivo Público Mineiro, onde um morador da Comarca de Sabará-MG, Manoel de Araújo Morgado, reclama a posse de uma fazenda chamada Pagabem. Essa propriedade era para criar gado vacum, como o documento nos informa. A região ainda possui esse nome e se encontra nas mediações da cidade de Paraopeba. Isso ocorreu no início do século XVIII. A fazenda, segundo o documento, pertencia ao sogro do requerente, Miguel Fernandes de Siqueira, que por sua vez a havia comprado de Manoel da Silva Costa, em 1709. Certamente a posse dessas terras era em sistema de sesmaria. As descrições geográficas correspondem a lugares existentes na região da antiga Tabuleiro Grande, atual Paraopeba. Assim a declaração descreve a demarcação da região:

(...) pelo Riacho da Taboca abaixo emté a Barra do Riacho chamado o Cabouculo, e dahi cortando ao morro Preto com Manoel Pereira de Freitas, e pela Estrada com Felix Barboza Barros, emté as cabeceiras do Cedro, e pelo Cedro abaixo emté a Barra da Barra com Manoel Coelho Dias, e como o suplicante quer possui as ditas terras que poderão ocupar três legoas de comprido (...). (GONÇALVES, 2000, p. 1).

O sertão de Minas foi ocupado por essa gente. Essas pessoas desbravavam as terras e por lá criavam as vacas e porcos, plantações de subsistência, e depois veio o café. As fazendas, ou roças como eram chamadas as terras cultivadas, foram aos poucos ocupadas por famílias que, quase em sua totalidade, se auto-supriam. As necessidades básicas de subsistência eram poucas. Adultos e crianças desempenhavam todos as formas de trabalhos nesse núcleo de produção: a pastagem, cultura de mandioca e cana-de-açúcar, e serviços domésticos. Dessa forma, ao longo da imensidão de terras que se perdiam no horizonte, iam surgindo os lugarejos. A população aumentava e "os vilarejos estradeiros serviam de pouso para aos viajantes de um centro de pequenos comércios a outros" (RIBEIRO, 1995, p. 196).

Possivelmente foi dessa forma que surgiu a pequena Tabuleiro Grande. Com a capelinha erguida pelo tal Coronel Marques, era passagem obrigatória dos tropeiros que conduziam boiadas para o sertão da Bahia. Uma palhoça aqui, outra casinha ali, iam ornando a paisagem de lugar. A toponímia Tabuleiro Grande, dado ao lugarejo, era o nome que as pessoas davam 
às elevações que acompanhavam o sertão. Portanto, Tabuleiro indicaria planícies levemente onduladas. Para alguns sertanejos, Tabuleiro seria sinônimo de cerrado.

Com o passar dos anos, ao redor da pequena capelinha erguida em honra de Nossa Senhora do Carmo, o povoado foi crescendo a passos lentos. As casas, palhoças, mocambos e roças, fazendas da região foram tomando corpo. Até que Tabuleiro Grande foi elevado a freguesia, em 29 de março de 1840. Posteriormente, confirmada pela Lei Estadual $n^{\circ} 1.395$, de 24 de novembro, com a criação do município de Sete Lagoas, o arraial de Tabuleiro Grande passa a pertencer a Sete Lagoas. Assim, durante 45 anos, Tabuleiro Grande ficou sob a jurisdição do município de Sete Lagoas ${ }^{5}$.

A paróquia de Nossa Senhora de Carmo de Tabuleiro Grande teve seu primeiro vigário em 1846-1853, o padre Antonio Soares Diniz. Antes dessa época, a paróquia pertenceu à Diocese do arraial de Tejuco, atual cidade de Diamantina. Atualmente a paróquia de Paraopeba pertence a Sete Lagoas. O fato é que, como todo interior de Minas, a Igreja Católica desempenhou um papel fundamental. Através não só da fé cristã, mas também na organização cultural e social das pessoas. Postulando formas de comportamento aos indivíduos e também as regras sociais.

Temos um relato da antiga Tabuleiro Grande que também nos esclarece, ao menos em parte, as relações sociais estabelecidas naquela época. Trata-se de um caso de feitiçaria, obviamente feito por algum negro ou descendente dos negros. Esse episódio revela como o arraial de Tabuleiro Grande tinha barões latifundiários, embora fosse uma cidadezinha pobre. Estes possuíam o poder econômico e político. Ao menos é o que diz o relato ao qual tivemos acesso. O barão Antônio Cândido Mascarenhas, proprietário da fazenda do Rasgão cultivava café durante o século XIX. Também era comerciante e empresário. Antônio e os irmãos Bernardo e Caetano Mascarenhas se associaram para fundar, em 1872, a primeira fábrica de tecidos de Minas Gerais, na comunidade do Cedro, que pertencia a Tabuleiro Grande.

Além do poder econômico, Antonio Cândido Mascarenhas era uma espécie de delegado e juiz, pois julgava e absolvia as pessoas. O fato é que esse barão recebera a informação de que uma pessoa de nome Cândido Gomes ganhava a vida como "feiticeiro". Um dos feitos desse

\footnotetext{
${ }^{5}$ Fonte: www.ibge.org.br
} 
indivíduo era possuir o dom de "abrandar corações, dar e tirar fortuna, atrair e engendrar amores" (VAZ, 2005, p. 93). Mas, segundo o barão Antonio Cândido, embora ele não acreditasse, haveria muita gente crédula. Diante de tal façanha, e sendo subdelegado por 23 anos, o barão dá alguns conselhos ao feiticeiro por carta. Essa carta data de 2 abril de 1871 . A narrativa é a seguinte:

Contam até que vosmicê vai fazer as suas mágicas contra meu filho Jorge em negócios de amores e a favor do desgraçado Praxedes, que carrega com a imputação de crimes tão informantes dizendo que o porá fora do alcance da punição da lei. Se isto é verdade, previno-lhe que deixe de asneiras, de tolices que o podem comprometer. Eu não faço ainda um juízo fundado a tal respeito, mas me parece que vosmicê não se mete em tais bandalheiras [...] seria bom conversar com o vigário que lhe esclarecerá muitas coisas. (MASCARENHAS, apud VAZ, 2005, p. 93).

Essa correspondência nos exemplifica, ao menos em parte, as relações sociais vivenciadas na comunidade de Tabuleiro Grande. As crenças africanas, tantas vezes ligadas à criminalidade, eram condenadas. O poder da Igreja Católica era enorme, pois era a expressão religiosa permitida e oficial. A relação deste fazendeiro com a comunidade, ao que tudo indica, se pautava pelo poder do dinheiro. E ao mesmo tempo era ele quem fazia a justiça. Não temos informação sobre o desdobramento deste episódio, se o feiticeiro acatou ou não as recomendações do barão Antonio Cândido. O relato deste episódio tem como objetivo resgatar uma parcela da memória social e cultural do arraial no século XIX. Este relato está presente na biografia de Bernardo Mascarenhas, irmão de Antonio Cândido. Integra as correspondências estudadas pelo biógrafo de Bernardo Mascarenhas. Este relato ilustra aspectos das relações culturais, do poder e da economia local, ou seja, as formas de poder com as quais os cidadãos conviviam.

\subsubsection{O viajante}

O trânsito dos viajantes pelo mundo não é novo. Em todas as culturas, de alguma forma, existiram pessoas vindas de outro lugar que aos poucos iam desvelando uma cultura e organizações sociais diferentes. O próprio Brasil, em muitos aspectos, é fruto dessas pessoas que chegaram, ficaram e partiram. Trazendo conhecimentos e formas novas de interagir com o que existia por aqui. Criando, ao longo dos anos, uma cultura movente e misturada. 
Minas Gerais não foi diferente. Sendo um estado grande, com riquezas, tornou-se alvo constante desses artistas, cientistas, entre outros estrangeiros que passaram por aqui. $\mathrm{O}$ conhecimento que os viajantes deixaram por onde passaram é relevante como forma de depoimentos vividos por pessoas de cultura diferente da nossa. A despeito das críticas feitas a eles, os relatos dos viajantes nos fazem compreender a composição natural e humana da região. Ao passarem por Minas, os viajantes a descreviam, ora com preconceito, ora com exaltação. Às vezes, as duas posturas se misturavam. O olhar dos viajantes nos deixou uma forma de ver o mundo, a memória de uma época. E com essa postura ficaram representações das comunidades por onde passaram.

Durante a consolidação das comunidades mineiras, sobretudo durante o século XIX, muitos viajantes se aventuraram pelo estado. A notícia que chegava à Europa era a de que Minas era um lugar repleto de ouro e diamantes. Isso aguçava a cobiça de muitas pessoas. Mas, também, a terra mineira favorecia a visita de cientistas e artistas. Dentre eles, Saint-Hilaire, Spix e Martius estiveram no estado no início do século XIX. Com relatos de conteúdos variados, os viajantes deixaram uma memória importante de Minas Gerais daquela época.

James Wells ${ }^{6}$ foi um engenheiro que viajou por Minas entre 1873 a 1875 . Pertencia a uma equipe de engenheiros de Londres que trabalhava na Public Works Construction Company. Essa empresa fora contratada pelo governo imperial para construir a Estrada de Ferro Pedro II, na região do vale do rio Paraopeba. Entretanto o percurso de Wells não foi construído, pois foi adotada a rota do rio das Velhas. Todavia, seus escritos são um relato importante de sua passagem pelo Brasil. E mais especificamente do arraial de Tabuleiro Grande, hoje a cidade de Paraopeba-MG.

Diferentemente dos outros viajantes que documentaram Minas Gerais, Wells não era um cientista, naturalista ou artista plástico. Entretanto, descreveu o Brasil, especificamente Minas, com lirismo e clareza. Com destreza e senso estético, esse engenheiro desenhou cenas de muitos episódios e lugares que conheceu durante sua viagem. Isso dá ao seu relato um frescor imaginativo singular. E para nossa pesquisa um depoimento urbanístico e social importante.

\footnotetext{
${ }^{6}$ Encontramos um relato dessa obra na Gazeta de Paraopeba de 9 de agosto de 1931. O nome do engenheiro está grafado como J. V. Veles. Segundo consta neste periódico, Caetano Mascarenhas, um dos fundadores da fábrica de tecido Cedro e Cachoeira, conheceu o filho desse engenheiro no Rio de Janeiro e pediu a ele que traduzisse o trecho em que James Wells narra sua passagem pela praça da matriz de Tabuleiro Grande.
} 
Antes de James Wells chegar nessa localidade, existe um relato da presença de outro estrangeiro na região de Tabuleiro Grande. Trata-se do famoso paleontólogo Peter Lund. Em suas Memórias científicas, este cientista, estudando cerca de oitenta grutas no Brasil, descreve minuciosamente suas descobertas. Em meados do século XIX, Lund chega na gruta de Maquine, região de Tabuleiro Grande, e assim descreve a topografia:

Em minha primeira memória sobre a lapa do Maquine, fiz notar a diferença existente - quanto ao modo e ao tempo de formação - entre esta crosta e as concreções foliáceas ou em forma de colunas, que ora relevam-se do chão, constituindo enormes pirâmides. Destas ultimas produções calcáreas, as que apresentam maior depósito de camadas argilosas, uma vez que está no exterior, se encontra aglomerada ao sopé das montanhas as mais antigas. Uma parte incomparavelmente menor formou-se em tempo posterior, e continuou a produzir-se todos os dias, sob as vistas do observador atual. (LUND, 1935, p. 12)

A descrição minuciosa das memórias de Lund, sob o ângulo de cientista que era, consegue relatar os aspectos geológicos da região de Tabuleiro Grande. Voltemos ao outro estrangeiro. Todavia, há um aspecto que o engenheiro James Wells conseguiu documentar, que nos parece relevante. Trata-se dos aspectos das relações sociais e morais, bem como a linguagem popular veiculada naquela época e que reverbera até os dias de hoje.

As pessoas do interior de Minas, formadas pelas várias etnias, guardam ainda hoje uma expressão típica da linguagem oral. Trata-se do "uai!"7, que é uma expressão de surpresa muito comum em Minas e que Wells retratou, reiteradas vezes, em sua viagem. E até hoje está presente nas conversas no interior de Minas. Outro fator que chamou a atenção do engenheiro no interior de Minas é a imprecisão das pessoas quando iam informar a distância de um lugar a outro. A mente lógica e matemática do inglês contrastava com a mente imaginativa das pessoas do sertão mineiro. Perdidos no cerrado, livres na imensidão das montanhas e nos vales extensos daquela época, os sertanejos não poderiam conhecer a exatidão numérica tão apreciada pela cultura inglesa. Assim, Wells revela uma situação peculiar que ilustra bem isso. Pergunta a um negro que encontrou no caminho onde ficava uma localidade. "O negro tira o chapéu, estende a palma da mão e oferece o cumprimento usual dos negros a um branco, dizendo "S' Cris", ao que respondo "pra sempre” (WELLS, 1995, p. 114). O viajante continua seu relato:

\footnotetext{
${ }^{7}$ James Wells grafou assim: "o-o-o-whi”, segundo a representação fonética inglesa. Essa expressão, de acordo com a tradutora de Wells, está presente várias vezes em seu relato.
} 
É esta a estrada para Neotim? repito.

N'hor? (abreviação de "senhor").

É esta a estrada para Neotim?

N'hor sim.

A que distância fica?

$\mathrm{Oh}$ - hum - quatro léguas ou mais.

Quanto mais?

$\mathrm{Oh}$, um pedaço.

Quanto é o pedaço?

N'hor?

Quanto é o pedaço?

Oh, um tiquito.

Bem, meu caro, quanto é o tiquito?

N'hor, sim - ele me olha espantado, coçando a cabeça. (WELLS, 1995, p. 114)

Dessa forma, o viajante conseguiu demonstrar, embora seja um exemplo pontual, como as pessoas se comunicavam e interagiam com a comunidade. Wells, mesmo sendo estrangeiro e de uma classe econômica privilegiada, estava frequientemente em companhia de negros, sertanejos e caboclos. Essas pessoas faziam parte da comitiva e, ao que tudo indica, este viajante gostava dessas pessoas. Tanto é que, dos viajantes, foi o que mais permaneceu no Brasil: cerca de quinze anos. Assim, a sua viagem, além do exótico, está repleta de relatos orais dos fatos com os quais se deparou.

Encontramos uma descrição peculiar sobre a praça da matriz de Nossa Senhora do Carmo, em Tabuleiro Grande. Ocorreu, aproximadamente, em 19 de agosto de 1873. James Wells, em tom descritivo, relata sua percepção sobre a paisagem do arraial. Ocorreu num domingo de sol, quando as pessoas se encontravam para participar da missa. A impressão dele foi boa. Diante das pessoas - mulheres, homens, mulatos, fazendeiros, negros, sertanejos -, Wells teve oportunidade de constatar a diversidade do lugarejo. Pois era "uma manhã de domingo em uma vila mineira normalmente próspera!” (WELLS, 1995, p. 182, v. 1), afirma o engenheiro.

A vila, aos seus olhos, se erguia numa planície elevada, por onde se avistavam as serras que a contornavam. A população do arraial, afirmou o engenheiro, em seus primórdios, era de apenas 600 habitantes. As palmeiras de palmito serpenteavam ao redor da igreja que, naquela época, possuía duas torres. Num primeiro momento, as torres da igreja fizeram-no lembrar um teatro de fantoches. Mas logo em seguida percebeu os sinos que anunciavam o tempo e os compromissos litúrgicos. Essa curiosa impressão de teatro não se afastava da realidade da 
igreja de Minas, que utilizou, em sua catequese, as encenações para divulgar as doutrinas religiosas. Mas, sendo um inglês, de origem protestante, é compreensível esta observação.

Além da arquitetura da igreja, Wells descreve um circo que havia sido armado na praça da igreja. Os integrantes desse circo estavam na expectativa do público que freqüentava a missa dominical. Em meio à poeira vermelha que se levantava ao sopro do vento na pequena vila, o engenheiro observava as cores intensas que o cercavam. Com riqueza cromática, consegue descrever as vestimentas das mulheres presentes na praça. Assim observa:

\footnotetext{
Que cores elas trajam! É bastante para fazer os olhos lacrimejarem. Havia uma dama bem morena e robusta com um chapéu de palha amarelo adornado com papoulas artificiais, espigas de trigo e laços azul-celeste, um vestido cor-de-rosa de textura leve, entremeado de laço amarelo vivo e botões azuis; um xale verde, uma faixa escarlate na cintura; e finalmente, sapatos de couro de salto alto, evidentemente reservados com todo cuidado para estas ocasiões. (WELLS, 1995, p. 182, v. 1).
}

Diante de tantas cores dos vestuários femininos, não podemos deixar de notar, aos olhos do estrangeiro, a atração pelo exuberante. Não é improvável essa suposição, visto que os viajantes que chegavam ao Brasil no século XIX já chegavam aqui com o imaginário para o exótico e para o extravagante. Na antiga Tabuleiro Grande, não poderia ser o contrário. Entretanto, essa descrição da vida social da cidade nos ajuda a perceber e a compreender uma parcela da dinâmica da cidade que não existe mais.

Mas como não ficar atraído diante de tantas cores, formas e sons? Além dos sinos repicando, havia o barulho do circo, o estouro dos foguetes, o vozerio das pessoas na praça pública, já que o dono do circo fazia os convites a todos para o espetáculo. Havia também o relinchar dos cavalos com suas tralhas de gala, a algazarra das crianças enternecidas com os palhaços. Daí, a possibilidade do olhar do estrangeiro, estando fora dos costumes locais, poder descrever o que se lhe apresentava aos sentidos.

Tanto que, permanecendo à frente do armazém, junto à família Mascarenhas que o hospedara, podia perceber os detalhes da praça. A multidão que caminhava em frente à família Mascarenhas, sempre a cumprimentava. Segundo Wells, a linguagem mudava segundo a classe social à qual cada cidadão pertencia. Dessa forma, os fazendeiros se dirigiam aos outros com um aceno de mão e um como está? Como passou? Os proprietários menores, com 
um bom dia, senhor - e os chapéus acompanhavam os gestos. Além disso, havia os trabalhadores mulatos, caboclos e negros que estendiam as mãos para uma bênção, dizendo "S' Cris", com as cabeças sem os chapéus. Certamente, todos o cumprimentavam devido ao poder econômico e político da família que o hospedava.

Nos surpreende a mobilidade social das pessoas nessa descrição. Uma sociedade escravagista e patriarcal revela também uma certa "mistura" das pessoas de condições econômicas e sociais distintas. Muitas dessas pessoas, segundo Wells, vinham até a praça descalças e colocavam os sapatos e botas quando chegavam nas imediações da praça. O viajante notou o desconforto das pessoas com os calçados que quase nunca eram usados. Além disso, completavam "suas toiletes à beira de um riacho ao lado da estrada antes de se apresentarem ao 'povo'” (WELLS, 1995, p. 183, v. 1).

Isto posto, percebemos que o viajante conseguiu ilustrar várias coisas da pequena Tabuleiro Grande. A praça da matriz, a arquitetura, a fábrica de tecidos, a linguagem da época, a mobilidade social. Embora parcialmente, Wells nos apresenta uma cidade viva e cheia de detalhes. Além da igreja matriz, esse viajante descrevia as ruas, casas e vegetação, compondo assim um quadro exótico, como era o gosto dos viajantes de século XIX em Minas.

Um dia depois de passar pela praça de Tabuleiro Grande, James Wells se dirigiu para a fazenda da Picada. Lá encontrou o senhor José ${ }^{9}$ e se encantou com a sua generosidade. O engenheiro se identificara com as famílias do seu anfitrião devido à cor clara da pele das pessoas da Picada. Já que a maioria das pessoas que avistara na comunidade de Tabuleiro Grande era negra, mulata e mesmo parda. Essa fazenda ficava a poucos quilômetros da praça da matriz. O intuito do viajante era conhecer o terreno para a futura construção da ferrovia. Mas que nunca foi realizada por aquelas bandas.

Há outro aspecto importante na narrativa do viajante. Trata-se de sua descrição das árvores da região. Catalogou várias espécies que fazem parte da vegetação até hoje. Em sua lista, relata as seguintes árvores: pequi, pau-terra, angico vermelho, aroeira, pedregoso, angelim,

\footnotetext{
8 "S' Cris é uma saudação muito comum nas Minas do século XIX. Os negros e crianças se dirigiam aos senhores dessa forma. Trata-se da contração de "Jesus Cristo". Mas a expressão completa seria "Louvado seja Nosso Senhor Jesus Cristo", tendo como resposta "Pra sempre".

${ }^{9}$ Trata-se do Sr. José Lucas de Figueiredo, que até hoje possui inúmeros descendentes nesta comunidade. As pessoas da Picada o homenagearam colocando seu nome na escola local.
} 
barbatimão, capitão-dos-campos, patui, jacarandá-dos-campos, cedro do campo, mangabeira, e tingui. Descrições de relevo, do clima, do índice pluviométrico eram importantes para seu trabalho. Mas o engenheiro constata a dificuldade econômica dessas pessoas que habitavam a região. Além da fazenda, havia duas casinhas de pau-a-pique que eram vizinhas dessas terras. Assim, o viajante, relembra os detalhes da paisagem que o encantava.

O engenheiro permaneceu mais de dois meses nessa fazenda de Tabuleiro Grande. Assim, teve oportunidade de presenciar outros aspectos da vida social da comunidade. Participou de um casamento e da algazarra da festa. O batuque era o ritmo, embalado pela viola e os excessos ocasionados certamente pelo álcool. Notou que "os homens brigam como crianças" (WELLS, 1995, p. 192). Wells era acostumado com as formalidades e etiquetas de sua formação inglesa. Essa surpresa diante da descontração era esperada para um homem de educação tão diferente.

Nesse ambiente, esse viajante era capaz de perceber muitas coisas. Sendo estrangeiro, podia descrever, de outro ângulo, às manifestações dessas pessoas. Com a noite avançando, Wells ficava fazendo anotações em seu caderno e, de dentro seu aposento, ouvia atentamente as coisas ao redor. O viajante presenciou, por exemplo, um negro alto e forte, arrancando gargalhadas dos companheiros da fazenda. Devido a sua destreza com as palavras, constata o engenheiro, esse homem era "um grande contador de histórias" (WELLS, 1995, p. 192). Dessa forma, mesmo não sabendo as nuances das histórias, percebia a reação das pessoas: os risos, o prazer, a descontração.

A cidade, ao menos o esboço que se formava daquele arraial, já possuía um perfil, uma atmosfera própria, inúmeras formas de relações sociais, econômicas e culturais. Esse viajante conseguiu, a despeito do seu olhar de estrangeiro, traçar algumas referências da comunidade de Tabuleiro Grande do século XIX. Ainda que toda a percepção desse homem seja parcial e sujeita a ideologias, mesmo assim suas narrativas nos ajudam a conhecer as pessoas e as relações estabelecidas naquele espaço e tempo. É um documento precioso da cidade.

Os aspectos da cidade apontados por Wells demarcam algumas coisas. Do ponto de vista econômico, as relações de trabalho relatadas por ele demonstram claramente a ideologia capitalista em que se nutria. A “ordem” que o encantara, ao ver crianças, homens e mulheres bem organizados e adaptados às regras da fábrica do Cedro, retrata essa afirmativa. Também 
não comenta que essas pessoas eram, até pouco tempo, lavradores da cidade e que possuíam outra modalidade de desenvolver o trabalho. Obviamente, era realmente inusitado e inovador um arraial do sertão de Minas sediar uma fábrica de tecidos. Isso por volta de 1870 . Possivelmente via aquilo com naturalidade, já que na própria Inglaterra Industrial as pessoas foram também obrigadas a adotar outra relação com o trabalho. Sabemos, através da história, que os ingleses, no início da Revolução Industrial, também foram muito explorados, com horários de trabalhos estafantes e desumanos.

As relações culturais, aos olhos desse viajante, são exemplificadas pela visão do exótico. Compunham as percepções de Wells as roupas coloridas das mulheres ao sair da missa, o circo e o batuque que alegravam as pessoas. A Tabuleiro Grande descrita pelo viajante é uma pequenina comunidade, mas próspera. As relações sociais entre os fazendeiros brancos, detentores do poder econômico, e o restante da comunidade, através de suas observações, pareciam cordiais. Ao menos naquela manhã de domingo de céu azul.

Embora pacífica, segundo o engenheiro, a cidade já apresentava hierarquização da sociedade. Ou seja, os brancos latifundiários, os operários, negros, a comunidade pobre, todos no mesmo espaço. Possivelmente esta mistura favorecesse conflitos, embora o viajante não os tenha relatado. Os negros e pardos, por exemplo, e sua reverência aos senhores. As pessoas que saíam das casas de capim e adobe para as festas da igreja. Estes aspectos foram revelados por Wells. Ao apresentar o arraial de Tabuleiro Grande dessa forma, o viajante apresenta algumas características daquele tempo que até hoje permanecem na organização social e cultural da cidade. Este panorama, todavia, é um retrato do interior de Minas. As características apresentadas por Wells, como a igreja católica como expressão religiosa da maioria, a economia agrária, o início da industrialização e os embates com a sociedade de lavradores, em certa medida, permanecem no imaginário social do estado de Minas Gerais. A comunidade foi formada, retratou o viajante, por vários segmentos étnicos: negros, brancos, caboclos, que deram base à cidade. E que, de alguma forma, realiza uma espécie de mistura singular que nos acompanha até a contemporaneidade. 


\subsubsection{Avelino Fóscolo: criador da imprensa, escritor e anarquista}

A história pessoal de Avelino Fóscolo tem a intensidade de muitos dos seus livros. Nasceu em 1864, em Sabará-MG, e morreu em 1944, em Belo Horizonte. Órfão, foi criado pelo padrinho. Entretanto, insatisfeito com o tratamento que recebia nessa família, resolveu abandonar a casa, indo, depois, trabalhar com os negros numa mina na região de Nova Lima-MG. Desde cedo, aprendeu na carne o sentido da opressão.

Logo depois, quando passou um circo na região onde estava, Avelino decidiu acompanhá-lo. Era uma companhia norte-americana. Essa experiência parece ter deixado marcas indeléveis na sua alma. O gosto pela dramatização e pela versatilidade, o aprendizado das línguas. Sabemos que ele viajou até alguns países da América do Sul. Adquiriu o conhecimento das diferenças sociais e sentiu na pele a opressão advinda desse desnível social. Posteriormente esse fato desempenhará papel importante em sua vida literária e política. O encontro com várias culturas e comportamentos o ajudará a compreender melhor a dinâmica social e será objeto da ficção e das lutas políticas.

Retornando a Sabará, junto com amigos, empreendeu atividade jornalística. O jornal "A Folha Sabarense" foi o periódico no qual escreveu seus primeiros artigos. Mas, além dessa atividade que começava a esboçar e que o marcará por toda a vida, há outro fato: Avelino se apaixonara. Trata-se de uma moça chamada Maria, filha do boticário Manoel Pinto Ribeiro, nascida no arraial de Tabuleiro Grande. Ela estudava o curso Normal em Sabará-MG. Sabemos que Avelino escrevia poemas para a amada e também procurava influenciá-la a respeito da política, fazendo com que ela percebesse as injustiças do mundo no qual vivia. Consta que, através da sua influência, Maria escreveu a seus pais, em Tabuleiro Grande, para que libertasse os escravos domésticos. Isso ocorreu pouco tempo antes da abolição da escravatura (MALARD, 1987).

Ao final do ano letivo de 1888, Avelino resolveu acompanhar Maria até a casa dos pais, na pequena Tabuleiro Grande. Essa decisão marcará sua vida e mudará os rumos do pequeno arraial do sertão de Minas. Esse enredo romanesco será finalizado com casamento. Avelino Fóscolo, dotado de inteligência inquieta, não só aprendeu o ofício do sogro, mas acabou assumindo sua botica por vários anos. Até sua mudança para a capital, Belo Horizonte, 
assumiu muitas atividades na comunidade de Tabuleiro Grande e desempenhou grande papel na comunidade.

Ao chegar em Tabuleiro Grande, Avelino Fóscolo imprimirá sua marca na história da cidade. Além de boticário, criará a imprensa local. Com determinação e com poucos recursos, recrutou um habilíssimo marceneiro, Manuel Félix de Abreu, para construir uma máquina impressora. Esta máquina, segundo o relato do jornalista Manuel Antônio da Silva, foi feita com madeiras da região (GAZETA DE PARAOPEBA, 1945). Assim, no dia 6 de janeiro de 1893, apareceu o primeiro número do jornal da cidade: “A Vida”. E, logo depois, na medida em que este ofício foi se solidificando, Fóscolo, aos poucos, começou a veicular suas aspirações ideológicas e literárias.

A diferença visível entre Avelino Fóscolo e os habitantes da comunidade eram marcantes. Além da diferença cultural, era ateu e anarquista, e a comunidade com a qual convivia era de pessoas, em sua maioria, católicas. Além disso, as pessoas de Tabuleiro Grande, em grande parte, eram iletradas. Entretanto, os anos se passaram e cada vez mais a participação de Avelino na comunidade ia crescendo.. Nessa época, a igreja da praça da matriz já existia, mas a atividade da prefeitura eram incipiente, pois a emancipação do município só se deu no início do século XX. A farmácia de "Seu Avelino", começava a se esboçar como lugar de memória freqüentado pela comunidade. Foi um lugar de dimensão simbólica, importante para a cidade daqueles tempos. Era na farmácia de Avelino Fóscolo que buscavam sua atenção sobre os males do corpo e as dificuldades sociais da comunidade.

Na farmácia de "Seu Avelino", além da fabricação de remédios, funcionava também a Biblioteca Grande Taboleirense (DUARTE, 1991, p. 67), onde se podiam encontrar à venda várias obras de propaganda anarquista. Essas obras eram emprestadas para a comunidade. Também nesse espaço funcionava a tipografia para a impressão dos jornais. Nesse período, Avelino já editara o periódico "A Vida" e depois "O Industrial”. Já era o início do século XX, e o "O Industrial” foi editado, aproximadamente, até 1902. No começo do século, já havia outros jornais, como "O Taboleirense" e "O Ensaio". Naquela época, era muito comum os jornais durarem pouco tempo. Portanto, chama atenção o fato de, numa comunidade pequena, conviverem vários periódicos. 
Quando assumiu o posto de farmacêutico, Avelino pôde, além de outras coisas, escutar as queixas da comunidade, pois na farmácia passou a conhecer profundamente a sociedade do arraial de Tabuleiro Grande. Inteligente, culto e destemido, começou a agitar o lugarejo. Isso se dava pelo caminho da palavra escrita: escrevia romances em folhetim nos periódicos que editava e posteriormente criou "A Nova Era", um jornal declaradamente de conotação anarquista.

No fundo da farmácia havia uma biblioteca, fundada por Avelino e seus amigos. Nela podia se encontrar Zola, Flaubert, Balzac, Stendhal, André Gide e Anatole France. Os de língua portuguesa também tinham lugar de destaque: Camilo Castelo Branco, Eça de Queiroz, Machado de Assis. Quanto aos socialistas: Marx, Kropótkin. Avelino lia bem francês e assinava o "Le Journal" e o "Correio da Europa".

O jornalista Jair Silva, que o conheceu pessoalmente, dizia que quando alguém chegava em Tabuleiro Grande e se hospedava no Hotel Bilar, assim era o comentário: "Ali mora Seu Avelino, anarquista e ateu" (SILVA, 1958, p. 6). Havia no fundo da farmácia, digamos, uma espécie de transmutação pelos livros. Embora Avelino fosse culto e enérgico, tinha momentos de descontração e gracejos com a comunidade. Conta-se que, quando uma mãe aflita levava o filho doente para "Seu" Avelino (naquela época o farmacêutico exercia a tarefa de médico) avaliá-lo, a consulta se transcorria assim:

"Seu" Avelino, trouxe o meu filho para o senhor olhar.

Ele, devagarinho, de certo pensando no original do livro que escrevia lá dentro,

Considerava:

- Pois, minha senhora, eu estou olhando...

Meio assustada com a idéia de ter dito uma besteira, ou uma batata na frente de um homem tão culto, a mulher procurava corrigir:

Não, "Seu" Avelino, é para o senhor ver...

E ele gracejava ainda, falando pausadamente:

- Sim, minha senhora, estou vendo. (SILVA, 1944, s/p)

Curiosamente, esse diálogo despretensioso nos dá a idéia, ao menos inicial, de como um homem pode utilizar os eventos cotidianos para a criação. Dizemos isto para aludir à dinâmica desse lugar de memória que foi a farmácia de Avelino Fóscolo. Essa farmácia revela, através deste pequeno diálogo, a relação do anarquista com a comunidade. Escutava os males do corpo e da alma. Além de conhecer, através da escuta, os males sociais e econômicos. Pois os 
operários da fábrica do Cedro eram clientes de sua farmácia e certamente conheciam as mazelas dos operários e as injustiças cometidas contra os trabalhadores.

Posteriormente, em 1906, decidiu fundar um periódico de propaganda anarquista chamado "A Nova Era". Para Regina Horta Duarte, que pesquisou sua vida, esse jornal foi editado pela primeira vez em junho de 1906. Era irregular e em sua edição as cores vermelha e negra se sobressaíam. Com ideário libertário, baseava-se nas teorias de Jean Grave e Tolstói. Em seu editorial, reafirmava sua posição ideológica e procurava instigar o público para manifestações políticas. Consta que aceitava "qualquer artigo em defesa dos fracos, dos esbulhados, das vítimas da injustiça” (DUARTE, 1991, p. 70).

A Farmácia Fóscolo se localizava ao lado da capela do bispo D. Cirilo. Mas a intrepidez de Avelino era maior e não temia a opressão. Tanto que defendia publicamente qualquer excesso de autoridade cometida pela polícia local. Não era em vão. O jornal "A Nova Era" tinha a intenção de divulgar as idéias libertárias e "textos de Tolstói, E. Reclus, J. Grave, E. Malatesta, dentre outros teóricos libertários” (DUARTE, 1991, p. 70). Assim, nesse espaço, Avelino avaliava e escutava as queixas dos operários. Naquela época, crianças e adultos trabalhavam na fábrica sem nenhuma segurança. Havia até um delegado de nome Felão, que era chamado pela direção da fábrica para coibir qualquer manifestação e "desordem".

Assim, este espaço da cidade se tornava um espaço livre e de resistência. Avelino Fóscolo tinha o lema de combater as desigualdades e não economizava meios para divulgar seus ideais. Desta forma, o anarquista procurava movimentar e transformar a pequena Tabuleiro Grande. Através dos romances, jornais, os trabalhos de farmacêutico, os discursos e a atividade política ia divulgando sua visão de mundo. Sabemos que ele fez parte do grupo de pessoas que ajudou na emancipação política da cidade, em encontros na Câmara de Vereadores da cidade de Sete Lagoas-MG. Tanto é que se aliou a algumas pessoas para construir o primeiro teatro da cidade, inaugurado por volta de 1903. Além de entretenimento, o teatro divulgava seus ideais libertários e políticos. Avelino era também dramaturgo e, como falamos, teve longa experiência em circo. Assim, aliava vários meios para promover a formação cultural e social.

Avelino Fóscolo, apesar dessas atividades políticas, tinha muitos amigos e se reunia com o poeta Sabino de Paula Freitas e Manoel Antonio da Silva - "Seu Neném" - entre outros, para 
agitar a cena pública da cidade. Esse último aprendeu o ofício de jornalista com Avelino. Posteriormente, "Seu" Neném fundou a "Gazeta de Paraopeba", que circularia por mais de quarenta anos. O fato é que em 1903, nos finais de semana, no palco do teatro do arraial eram encenadas peças escritas ou traduzidas por Avelino Fóscolo.

O teatro fora construído por um mutirão organizado por Avelino. Encenavam-se comédias e tragédias. Consta que as apresentações eram realizadas aos sábados. Avelino participava como diretor, às vezes como ator, e também dramaturgo. Sabe-se que escreveu, por exemplo, as peças $O$ Diabo Moderno e $O$ Semeador. Tais peças refletiam atividades sociopolíticas e econômicas da comunidade (DUARTE, 1991).

Quando se casou, Avelino foi morar na casa do sogro, e herdou o casarão. Em 1915, quando decidiu mudar-se para Belo Horizonte com a família, vendeu o imóvel para o marido de D. Anésia, professora da cidade, cuja filha é a memorialista D. Maria Stella. Com o temperamento forte e fina ironia criticava as práticas sociais que despreza. Até seu sogro era alvo das críticas. Dizia que o sogro e seus amigos se enriqueceram à "custa do suor dos negros" (DUARTE, 1991, p. 32).

Com estas atitudes, criaria muitos conflitos. E o alvo foi a família Mascarenhas. Os irmãos Antônio, Bernardo e Caetano foram os fundadores da fábrica do Cedro. A fábrica Cedro e Cachoeira, em seu início, foi movida por escravos e lavradores. Além de empresários, a família Mascarenhas era constituída por fazendeiros latifundiários. Na região de Tabuleiro Grande, essa família possuía a fazenda do Rasgão, que se localizava a mais ou menos $1 \mathrm{~km}$ de sua casa. Já a fábrica do Cedro ficava a $2 \mathrm{~km}$. Portanto, conhecia bem essa realidade da cidade.

Há um livro de Avelino Fóscolo que exemplifica seu ideário libertário e literário. Possivelmente, há elementos existenciais dos quais comungava e estava presente na narrativa. Trata-se de $O$ Caboclo, romance naturalista, no qual traça a trajetória patriarcal de uma família mineira. $\mathrm{O}$ enredo do romance passa-se em uma fazenda nas redondezas da cidade de Sabará-MG. Os elementos que compõem esse romance marcam claramente o naturalismo como estilo de época. Uma família de latifundiários cujo perfil exibe todas as características detectadas nesse tipo de narrativa: a preservação dos valores de classe, o preconceito racial, a acumulação de riqueza, a influência do meio ambiente na descrição da narrativa. 
Assim, João, o caboclo, herói do romance, filho ilegítimo do fazendeiro, apaixona-se por Lená. Essa, por sua vez, é filha legítima e desde criança os dois conviveram pelos arredores da fazenda. Embora essa relação próxima e afetiva tenha se dado ao longo de anos, os direitos sociais de cada um eram diferentes. João não poderia aspirar casar-se com Lená. Sua condição de caboclo abria entre eles um abismo. Sendo assim, a paixão que o assolava não encontrava ressonância em Lená, muito menos junto à família dela.

Diante dessa impossibilidade, o caboclo lança mão de várias estratégias. Tenta seduzi-la, mas em vão. O ciúme apodera-se dele. Em meio aos sentimentos obscuros, arredios e incontroláveis como forças da natureza, o caboclo pensa em possuir Lená a todo custo. Mesmo que tenha de usar a força.

O próprio caboclo guarda em sua história a marca da violência. Ele é fruto da relação sexual entre Tiago, cunhado do fazendeiro Lima, e a negra Joana. Assim, da aventura sexual de Tiago e a escrava, nasce João. Dessa forma, o caboclo, não sendo branco como seu pai e nem negro como sua mãe, é assolado pela indefinição nas relações étnicas e familiares, já que sua condição social também é ambígua: filho de branco, mas sem posses.

Nem mesmo a amizade desde a infância entre o caboclo e Lená mudou sua condição. Assim, quando Lená conhece Meira, o médico, começaram a namorar. Adoentada, é tratada por Meira e a proximidade dos dois se acentua ao longo do tratamento. Acabam, Meira e Lená, ficando noivos. João, o caboclo, se exaspera com essa situação, exprimindo toda a sua rudeza e selvageria, segundo a narrativa romanesca, próprias da condição biológica do caboclo.

Acometido por forças incontroláveis da natureza humana, o caboclo violenta Lená na floresta. Desse ato insano, Lená se engravida. Desesperada e estando noiva do médico, decide contar tudo à tia Manuela. Essa senhora era a guardiã dos bons costumes da fazenda. Procurava manter a moral e os bons costumes a todo preço. Dessa forma, a tia Manuela ajuda Lená a encobrir a gravidez. Consegue, junto à família, marcar o casamento de Lená com Meira.

O desespero do caboclo é patente. Pensa nas maiores baixezas, até decidir relatar ao médico que Lená está grávida dele. Depois da dúvida, toma a decisão de contar tudo ao médico. Vai até o consultório do médico, que fica no arraial próximo à fazenda. Ao contar tudo ao médico, 
este não suporta o golpe. Absolutamente desesperado, o noivo suicida-se. Mas antes do suicídio, o médico escreve uma carta ao fazendeiro contando tudo o que acontecera.

Diante desse desfecho, o fazendeiro, pai de Lená, procura uma alternativa para manter a moral da filha e a dignidade da família. Propõe ao administrador da fazenda o casamento com Lená a fim de encobrir o "pecado". Além disso, planeja uma vingança contra o degenerado João. O administrador apóia, pois ele era sem fibra e um grande bajulador. Depois da decisão tomada, atrai o caboclo para uma cilada. Então, Cunha, o administrador, juntamente com o pai de Lená, atrai João para uma gruta nos arredores da fazenda. Em meio ao desespero, o caboclo é castrado e abandonado à própria sorte. Mas é salvo pelo cachorro de estimação, que, ao retornar à fazenda, consegue levar a mãe de João para a gruta. Dessa forma, sua mãe consegue libertá-lo e, mesmo ferido, ele consegue fugir. Finalmente, Lená, diante dos infortúnios, perde seu filho.

Tentaremos fazer algumas observações sobre este romance para podermos conhecer melhor o pensamento do escritor Avelino Fóscolo, embora a idéia aqui não seja fazer crítica literária, mas dialogar com o romance e fazer uma aproximação com os eventos e a atmosfera da comunidade. É visível a relação entre a sociedade e o meio físico, demonstrando, assim, a relação da natureza e os desvios das normas vigentes. Por isso, as descrições das personagens ganham relevo e contornos de uma paisagem, ora alegre, ora angustiada. A vegetação da fazenda se anima em sentimentos como as mudanças e dúvidas de Lená, como anuncia o narrador do romance:

Os campos reverdecidos atapetavam o solo de virente relvedo e nas árvores abotoavam-se as primeiras flores da primavera. Um aroma forte, quase embriagador, evolava-se no ar e a temperatura cálida, aborchonante, infundia adormentadora lassidez. (FÓSCOLO, 1902, p. 20)

As comunidades, simples ou complexas, se esforçam para estabelecer valores, cujas regras os indivíduos terão que seguir. Nessa escolha, os pares antitéticos - verdadeiros ou falsos, proibidos ou permitidos, claros ou escuros - entram em conflitos. Os esforços para superar os pólos antitéticos nem sempre dão certo. Identificar os conflitos e apontar saídas é uma tarefa árdua. Contudo, Avelino, o romancista, se utiliza do estilo naturalista para descrever as falhas e o desnível social. Esta proposta ia de encontro aos ideais políticos e econômicos que professava. Como anarquista, Avelino desejava a superação das desigualdades. O romance 
naturalista atendia o propósito, dentre outros, de retratar as diferenças de classe e a condição humana em seu embate com as forças da natureza.

Por isso, o enredo do romance se passa em uma cidade do interior de Minas. Esta atmosfera revela uma grande pressão social e econômica. Uma pequena cidade do século XIX estava submetida a estes padrões sociais e morais. Um destino implacável, onde os homens estão fechados em círculo, com ritmos perpétuos de repetição e reprodução do sistema social. Desta forma, os meios físicos, as regras sociais, as condições genéticas são retratadas por uma "lei" biológica que não deixa nenhuma margem de mudança e liberdade para a sociedade. Esta era a conduta científica que norteava os romances naturalistas, presente neste romance de Avelino Fóscolo.

Diante disso, podemos perceber que o naturalismo procura fazer uma transposição imediata da realidade. Quase como uma lei de causa e efeito. Talvez por isso, o escritor, imbuído dessa perspectiva, se colocasse diante da realidade e dessa forma narrá-la sem nenhuma influência. Era o sujeito em frente de um objeto puro, sem interferência. A narrativa seria, então, das impressões à sua volta na constituição do romance: "Já lhe conheço as manhas... se não são castigados, não há jeito de se obter trabalho de tal gente. O negro é de má raça!’” (FÓSCOLO, 1902, p. 49).

A animalidade, ou os aspectos grotescos das personagens, constitui um momento alto dessa narrativa. Os aspectos da animalidade, nesse tipo de romance, não estão retratados de maneira leve e harmoniosa. Como se os animais, à moda dos contos populares, revelassem ensinamentos, lições de vida. A narrativa aqui nivela o homem ao bicho, enquanto seres submetidos a uma lei inexorável. Isso decorre da operação na qual a "verdade" científica estivesse subjacente aos organismos da natureza como bichos e também homens. Está aí a concepção de homem que tenta apreender as mazelas dos homens a partir da animalidade subjacente à natureza dos seres vivos. $\mathrm{O}$ animalesco revela a crueza e a verdade humana. Assim, "a finalidade dessa operação parece apenas científica, mas na verdade é também ética, devido às conotações relativas a certa concepção de homem” (CANDIDO, 2004, p. 124).

Há, no romance de Avelino, alusão romântica das personagens quando traz uma certa 'vaguidade' que caracteriza a psicologia deles. Entretanto, o eixo narrativo se dirige ao 
homem comum, tantas vezes desfigurado e marginalizado pela sociedade. Isso se deve à herança da biologia, uma referência à teoria de Darwin. Apresenta conturbações afetivas e sexuais do grupo familiar, a condição social e do trabalho. Há ênfase das taras, desvios sexuais e a preferência da rotina e mediocridade dos costumes. Revelando, assim, através da narrativa ficcional, os impasses criados na alma dos personagens em detrimento da vida social. Assim o romancista descrevia o caboclo:

Sentia um prazer immenso em derribar com certeiro tiro as avesinhas voando descuidosas; comprazia-se com a agonia dos quadrúpedes, pequenas bestas que elle estirava a balas; fustigava os animaes que lhe incumbiam de amansar, sujizando-os ferozmente a rédea, vesgastando-os sem piedade, cravando-lhes brutalmente os acicates, quando os seus sonhos de esperança se evolavam a dura realidade da vida. (FÓSCOLO, 1902, p. 63)

A natureza vegetal, em $O$ Caboclo, é um cenário constante, onde se desenvolve a trama. Aqui, há a referência explícita ao ideário naturalista e romântico. Mas também podemos inferir a condição do escritor quando favorece a expressão de suas crenças. Avelino era, como já descrevemos, afeito às ciências naturais, com seu trabalho de boticário. Dessa forma, no romance, revela-se na sexualização da natureza. Isso se dá através da fecundação e preservação dos seres vivos, mas também nos aspectos ideológicos das interdições. Como esta passagem do romance:

Ao transporem o portão, a vida dos visitantes, em frente, surgiam jardinetes oitavadas, ovaes, quadrados, com roseiras diversas pejadas de flores rubras, róseas, amarellas e brancas, no vértice dos ângulos; em torno, numa gamma de tonalidade varia, ostentando a vitalidade do solo humano, dahlias, açucenas, bogaris e violetas ataviavam os canteiros deslumbrando pela variedade de cores. Um aroma forte, delicioso desprendia-se das corollas. (FÓSCOLO, 1902, p. 124)

Há também a natureza que se metamorfoseia em outros aspectos: uma espécie de natureza "barroca". Expressa pelos excessos das imagens: grutas, cerrados em tons fortes e profundos. A natureza "renascentista": jardins da casa-grande, hortas bem cuidadas dispostas em medidas e ângulos. E por fim uma natureza "realista" representada pelas plantações da fazenda: milho, arroz, café. O aspecto "realista" da natureza desempenha papel preponderante na narrativa, na medida que retrata o poder patriarcal. A escravidão, a ambição das pessoas, pois o caboclo era “um mestiço quase negro, dizia por vezes” (FÓSCOLO, 1902, p. 10). 
A dimensão da sexualidade é variada. A título de exemplo, podemos ilustrar algumas relações para podermos entender a dinâmica do romance. A sexualidade e os desvios, a relação ideológica fazem parte da estratégia do naturalismo, do qual Avelino Fóscolo parece que estava bem consciente. Vejamos um trecho. Meira, o médico, namora a prima Lená, onde há uma expressão recorrente: "quase incestuoso". Atestando as relações amorosas alicerçadas no parentesco, que de certa forma degrada o amor. Há também as relações de tensão entre João, o caboclo, e Meira, o médico. Em termos hierárquicos, um é superior ao outro.

Depois do ato monstruoso da castração do caboclo, há um suposto direcionamento da sexualidade. Com este ato, o desvio da sexualidade é punido. Em meio ao sangue e a escuridão da gruta, o caboclo agoniza e sofre pelo ato desmedido que cometera. Um misto de punição entre o ato pecaminoso do estupro e a rebeldia de tentar amar alguém de uma classe social superior. O próprio nascimento do caboclo, nessa lógica, era fruto de um erro. Ele era filho de branco com negra. Por isso, a reprodução, como reação em cadeia, reproduzia o ato anterior. Uma seqüência determinista. Então, o que resta ao caboclo senão a punição, perder a condição de ser sexual, a virilidade? O final do romance é esclarecedor: "Do rubro nascente ejaculava uma onda de luz sangrenta, enovelando nos seus raios aquele cavaleiro fantasma correndo sem norte através do desconhecido” (FÓSCOLO, 1902, p. 190).

Os temas desenvolvidos nesse romance e repetidos em outras obras são a vida e as relações nas fazendas mineiras, os costumes da pequena burguesia, o problema da mestiçagem, a aristocracia rural, o conflito interior dos personagens e o meio ambiente. Os subtítulos das obras de Avelino Fóscolo eram: "romance de costumes mineiros" ou "romance social", demonstrando a preocupação social do escritor. Os enredos revelam os aspectos psicológicos e biológicos dos quais os heróis são acometidos. As forças que movem os personagens em confronto com a natureza. Que por sua vez se traduzem em crise social e a sustentam.

Mas qual a importância do anarquista para a cidade? Como a cidade aparece para Avelino Fóscolo? Qual seu legado para a cidade? Estas questões talvez não tenham uma resposta única. Entretanto, as atividades política e artística, ao nosso ver, são marcantes para a futura cidade de Paraopeba. O homem de múltiplas atividades, como Fóscolo, não poderia ser delimitado ingenuamente. Mas, pelo romance que aludimos, as atividades editoriais e artísticas que referimos, podemos apontar alguns aspectos de sua permanência e o legado 
cultural desse homem na comunidade. E ao mesmo tempo são patentes nas narrativas dos idosos pesquisados.

Na capa, o romance $O$ Caboclo se apresenta como "de costumes mineiros" e, posteriormente, outros romances se apresentarão como "romance social". Dentre eles, aparecem em A Capital e $O$ Jubileu. Mas $O$ Caboclo, embora seu enredo fale da cidade de Sabará-MG, o romance retrata ficcionalmente a vida social existente em Tabuleiro Grande. Editado em 1902, ele foi escrito possivelmente nos fundos de sua farmácia, como indicou o jornalista Jair Silva sobre as atividades intelectuais do boticário.

As relações familiares, sexuais e afetivas, e também de trabalho, retratadas em $O$ Caboclo eram realidades vivenciadas pelo escritor na comunidade de Tabuleiro Grande. Trabalhadores, lavradores e operários são indivíduos da ficção e também das relações sociais que Avelino presenciava. Acreditamos, por exemplo, que as queixas afetivas, as violências ouvidas pelo escritor em sua farmácia serviam como argila para moldar a trama romanesca. As cores vivas e intensas da "realidade psicológica" dos personagens nos dão a dimensão de sua experiência cotidiana. Obviamente não queremos sugerir que a obra do escritor seja uma transposição do cotidiano para os livros. A obra de arte é criação, portanto construção. Não queremos sugerir um psicologismo ingênuo onde se sustenta a relação direta entre o narrador do romance e o escritor. Nosso intuito é fazer uma aproximação entre os elementos ficcionais e a comunidade onde a obra se passa como realidades que se comunicam. Para, se possível, conhecer um pouco melhor a dinâmica social da comunidade de Tabuleiro Grande.

É fato que a existência da imprensa até hoje na cidade testemunha o legado de Avelino Fóscolo. Já que, além do discípulo direto "Seu Neném", editor da "Gazeta de Paraopeba", houve outros periódicos editados na cidade (ver relação anexa - iconografia dos periódicos). Entendemos que, através da memória expressa nos jornais, retratavam também o desenvolvimento da cidade, com seus impasses e conquistas, obviamente. Digamos que a alma da comunidade é retratada através dos medos, anseios, relações políticas, ideais de liberdade, crenças, que podem ser documentadas nos periódicos produzidos na comunidade.

Podemos perceber a memória impressa da cidade em vários momentos. Criada por Avelino, a imprensa expressa também os ideais libertários e artísticos. Mas também as contradições do ser humano, embora os ideais socialistas de Avelino Fóscolo tenham sofrido mudanças. 
Sabemos que o socialista e anarquista depois se tornou empresário de sucesso. Ele criou um coalho chamado de "Coalho Halley", em homenagem ao cometa, e ficou rico. Consta que foi fazer negócios na Europa. E, por volta de 1910, durante a viagem a Europa, conheceu Jean Grave em Paris (DUARTE, 1991).

Entretanto, a luta contra a opressão e as conquistas sociais foi importante façanha empreendida junto à comunidade. Os lavradores, os operários, fazendeiros estão presentes como personagens em suas obras literárias. Dessa forma, a cidade descrita por Avelino pode ser retratada através da dinâmica política da qual participava e das atividades de escritor. Por exemplo, vivenciou o drama social da comunidade, que conhecia bem, pois tinha uma vida ativa junto à população. Mas, qual será o anarquismo de Avelino Fóscolo? O ensaísta, Eduardo Frieiro, que o conheceu pessoalmente e assumiu sua cadeira na Academia Mineira de Letras, afirmou:

O desígnio da obra escrita de Fóscolo, em último termo, era o de condenar a organização social vigente. Via remédio na reforma das instituições políticas? Nada disso. Adepto da doutrina anarquista de Kropótkin, considerava o Estado como inimigo que se devia aniquilar, e não, ao contrário dos socialistas e comunistas, como alguma coisa que se precisa conquistar. (FRIEIRO, 1979, p. 40)

No ano de 1891, Avelino Fóscolo escreveu um texto e o publicou no jornal "O Contemporâneo", em Sabará. Tratava-se de O Naturalismo, artigo no qual o autor descrevia as idéias sobre as diretrizes como escritor. Este artigo discorria sobre a utilidade do romance na sociedade. Indagava se as tramas dos romances não poderiam corromper os indivíduos através da imitação. Sua resposta foi um simples "não sei” (FÓSCOLO, 1891, p.2 apud DUARTE, 1991).

Entretanto, afirma a capacidade da arte romanesca na elevação do espírito e como um meio para a depuração e mudança na cultura. Segundo Avelino, o romance naturalista "é científico, artístico e não prejudica ninguém, por conseqüência é moral" (FÓSCOLO, 1891, p. 2, apud DUARTE, 1991). Era o que fazia na pequena Tabuleiro Grande. Descrevia o que via, posicionando-se através da ciência naturalista e descrevendo as mazelas individuais e sociais. Avelino se armava de tudo que conhecia: dos romances franceses e portugueses, dos anarquistas e da experiência própria de cidadão. Percebia o que estava à sua volta e afirmava: 
Descrever com todas as minuciosidades as ações humanas, os pendores naturais dos seres, servir nessa pintura de cores vivas dessa vivacidade artística, das gerações modernas; não recuar diante de obstáculo algum de ordem ética ou material, lutar!... lutar!.. lutar até implantar no seio da sociedade esse naturalismo moderno tão repleto de seiva, ardente de ciência e de arte - tal é incontestavelmente e fatalmente o fito daquele que transpuser as portas do grande templo, donde não se pode recuar, nem abaixar o rosto. (FÓSCOLO, 1891, p. 2, apud DUARTE, 1991)

Realmente, "Seu Avelino" nunca abaixou o rosto. Durante anos em Tabuleiro Grande lutou com todas as armas de que dispunha para defender a comunidade. Através dos jornais, romances, teatro, o ofício de farmacêutico e depois as atuações políticas na Câmara Municipal de Sete Lagoas. Nesta época, Tabuleiro Grande era da jurisdição de Sete Lagoas. Foi um dos articuladores para a emancipação do arraial em 1912, passando a se chamar Vila Paraopeba.

O lugarejo modesto do sertão de Minas tornou-se um lugar frutífero para colocar em prática os ideais políticos e culturais de Avelino Fóscolo. Certamente o que aparece nos romances são os dilemas percebidos pelo autor. Em sua prática como cidadão, realizou mudanças na comunidade. Em grande parte o conseguiu, ao plantar a semente da imprensa na cidade, divulgando os desejos das pessoas e também levando cultura a elas. Em 1915, mudou-se para Belo Horizonte, capital do estado de Minas Gerais que se iniciava. Mas sabemos que não perdeu o contato com os amigos de Paraopeba. O motivo da mudança foi a educação dos filhos. No início do século XX, publicou o primeiro romance, que tem como personagem a própria cidade de Belo Horizonte-MG, com o título de A Capital. Na capital mineira conheceu a glória da riqueza e, no final da vida, a pobreza.

Pouco antes de morrer, em 1944, escreveu um artigo na "Gazeta de Paraopeba" intitulado "Ave Maria". Não sem ironia, visto que seu ateísmo e ataques ao clero eram públicos. Nele, as imagens do badalar dos sinos revelam saudade, o crepúsculo da vida. Nessa época, convalescia de um câncer. Possivelmente, ao redigir o artigo, sua dor física se misturava à dor da alma. Era um tempo de sentimentos obscuros e avaliação da vida. Assim relata:

É a hora da saudade.... uma saudade indefinível! de que? de quem? Não o sabemos: talvez cansaço de prazeres efêmeros, de imagens mal gravadas no cérebro, de algo jamais existente, talvez... ânsias de um mundo sonhado evolando-se com a realidade enganadora dos sonhos esvaindo-se às sombras da noite. (FÓSCOLO, 1944, p. 1) 
Esse parece ser o destino de todos os homens, grandes e pequenos. Todos se depararão com a maior de todas as sombras: a morte. Mas quem teve uma trajetória tão múltipla e rica como Avelino Foscolo poderia se regozijar. Deixou seu trabalho na história da comunidade que, de alguma forma, conseguiu transformar. Os sonhos não se dissiparam na noite. Avelino Fóscolo deixou também um rastro de luminosidade, na memória das pessoas e da cidade.

\subsubsection{O poeta e o educador}

A família de Sabino de Paula Freitas é originária da cidade de Capelinha, Norte de Minas. O educador e poeta nasceu em 30 dezembro de 1876. Estudou na Escola Normal de ParacatuMG, onde teve oportunidade de encontrar mestres que o marcaram por toda a vida. Há uma informação, dada por sua família, de que pela linhagem materna Sabino é de origem de Diamantina-MG. Essa família, os Oliveira Rolim, seria a mesma do Padre José da Silva de Oliveira Rolim, integrante do grupo do movimento da Inconfidência Mineira.

O fato é que era muito ligado ao irmão, o padre Cirilo, que depois se tornaria bispo. Aos nove anos começou a acompanhar o irmão, em andanças missionárias, até quando fixou residência em Tabuleiro Grande, em 1901. Nessa época, Sabino tinha por volta de 20 anos.

Soubemos, pelo relato da família, que ele fez uma longa viagem com o irmão D. Cirilo (FREITAS, 1977). Este, já com o título de bispo. Essa viagem percorreu até o estado de Mato Grosso. Antes, fizeram o trajeto de Tabuleiro Grande ao Rio de Janeiro e, depois, por via marítima, até Buenos Aires, Argentina. Então, a partir da capital argentina, por via fluvial, chegaram até Mato Grosso. A viagem teria sido penosa para Sabino, que era fisicamente frágil. Quando retornou a Tabuleiro Grande, junto com o amigo Manoel Antonio da Silva "Seu Neném", desenvolveu atividades jornalísticas e como educador, durante toda a vida. Sabino Freitas permaneceu nesta cidade até sua morte, em 1937.

O jornalista Jair Silva, afilhado do poeta Sabino, afirmou que seu padrinho possuía uma inteligência rara, em meio a tanta ignorância do antigo arraial. Era chamado de "Seu" Sabino e morava num sobrado pelos lados da rua da Palha. Jair Silva afirmava que "Sabino de Paula Freitas era poeta, orador, professor, jurista e matemático - tudo isso sem diploma e sem 
ostentação” (SILVA, 1937, p. 1). Ninguém o tratava como professor ou doutor, mas com o singelo "Seu Sabino".

De índole poética, Sabino era vinculado à escola parnasiana, gostava de ouvir pássaros e o vento nas folhas da árvore casuarina que ficava no quintal do sobrado onde morava. Era "um moço triste e retraído que vivia escrevendo" (SILVA, 1937, p. 1). Mas o temperamento de poeta não o impedia de participar das atividades sociais da comunidade. Tanto que desempenhou várias funções. Foi professor do Grupo Escolar Afonso Pena e até prefeito da cidade, e depois ajudou a elaborar o estatuto da Câmara Municipal.

Todos admiravam sua competência. Nada se fazia em relação à palavra escrita sem consultar o "Seu Sabino". Quando menino, Jair Silva trabalhava como tipógrafo na "Gazeta de Paraopeba", cujo editor era seu pai, "Seu Neném”. Jair Silva conta que o pai não publicava nada sem passar pela aprovação do poeta. Em poucos minutos, o professor Sabino, identificava a frase sem sujeito ou sem concordância.

Gostaríamos de trazer do passado as lembranças desse homem que até hoje permanece na memória das pessoas da cidade. Uma das escolas da cidade de Paraopeba, em sua homenagem, possui seu nome. Desenvolveu principalmente as atividades de educador e poeta. Infelizmente, segundo nos informa a família, a maioria de seus textos em prosa se perdeu; suas poesias foram reunidas a partir de publicações no periódico "Gazeta de Paraopeba".

Em abril de 1927, o professor Sabino de Paula Freitas realizou uma conferência em Vila Paraopeba. Esta conferência, dirigida aos alunos, professores e à comunidade, nos dá a noção dos problemas e possíveis soluções na dinâmica do ensino-aprendizagem. Curiosamente, essa conferência, realizada há mais de oitenta anos, apresenta atualidade evidente: a metodologia empregada na época, o manejo do professor e a tentativa de superação, por parte dos professores, das dificuldades enfrentadas. O professor Sabino, em sua trajetória docente, aponta e demarca as perspectivas pedagógicas que enfrentava e também o perfil dos alunos da comunidade daquela época.

O ilustre professor reconhece a pouca participação dos pais dos alunos na prática do ensino. Ao reconhecer que os filhos não aprendem, Sabino revela que os pais se justificam dizendo 
que o professor é adulador dos filhos dos ricos, deixando de lado os menos favorecidos. Percebemos que esta justificativa por parte dos pais se apresenta bem atual. Entretanto, o professor Sabino afirma que para um bom ensino são necessários professores, alunos e responsáveis.

Em seguida, reconhece que a formação intelectual dos professores é fundamental. A capacidade física, intelectual e moral dos professores, segundo o professor Sabino, formaria o perfil ideal para que se possa obter um bom resultado no ensino. Para que isso ocorra, seria necessária uma estratégia bem montada pelo professor, pois "os bons professores têm sempre o cuidado de preparar previamente as lições” (FREITAS, 1927, p. 1).

Assim, o método é uma ferramenta indispensável para o professor. Mas o que é o método? Responde o professor: "Elle consiste na maneira natural e adquirida que se usa para transmitir a outrem o que se sabe” (FREITAS, 1927, p. 1). Por isso, constata Sabino, sua importância: o ensino não pode abdicar dessa ciência. Deverá, contudo, ser aperfeiçoada para servir melhor ao professor.

Mas, o professor Sabino confessa que em seu tempo de aluno as crianças e jovens tinham horror à escola. Naquela época, utilizava-se a palmatória: "No meu tempo, a verdadeira mestra e a única encarregada de resolver todas as dificuldades do ensino" (FREITAS, 1927, p. 1). Segundo Sabino, a palmatória estava sempre vigilante, sempre à espreita, pairando sobre o ensino e a aprendizagem. Era um recurso imprescindível à formação dos alunos. Entretanto, o professor afirma que esse tempo da palmatória já havia terminado e não teria utilidade para o professor que dominasse o método de ensino.

O professor Sabino dá recomendações e é taxativo: o professor deve dominar a língua portuguesa. Ela é o fundamento para a aprendizagem. Aqui, além do educador, o poeta Sabino entra em cena. A importância da palavra e o rigor da forma são requisitos substanciais para todo poeta. Quanto mais um poeta parnasiano, que prima pela forma estilística. Mas o professor Sabino apresenta sua metodologia para atingir os objetivos educacionais: "Ensinar a definir as cousas, dizer de que ellas se fazem e para que ellas servem, é ensinar ao alumno a analysar o assumpto, é dar-lhe a chave que abre a porta do grande campo, onde o escriptor convence, onde o orador arrebata” (FREITAS, 1927, p. 1). 
Logo em seguida, o educador afirma a necessidade da escola como um modelo moral. Incentivando as regras cívicas e o comportamento adequado. Dessa forma, para o professor Sabino, "a escola é ao mesmo tempo um noviciado e um templo". (FREITAS, 1927, p. 1). O educador remete a todos a entender a formação como algo maior do que apenas um letramento, ou atividade mecânica, como um adestramento. Pois o noviciado se revela no desenvolvimento das virtudes e o templo seria o lugar onde se cultua o que é grande, nobre. Para que o homem, na perspectiva desse educador, se eleve acima do que é rotineiro.

Além da referência à assiduidade, da atenção para o pleno desenvolvimento da aprendizagem, a conferência do educador Sabino nos revela uma concepção do estudo muito adequada aos dias de hoje. O professor afirmava, na década de 1920, no sertão de Minas, que "o estudo é que põe a inteligência em movimento, tornando-se prompta e clara para toda a compreensão" (FREITAS, 1927, p. 1). Daí a importância da educação, da escola. Ela propicia às pessoas uma compreensão do mundo e faz o aprimoramento do espírito.

Para o professor Sabino, haveria dois mestres com o quais se poderia basear a prática do ensino: Sócrates e Jesus. Segundo ele, Sócrates era o filósofo do Bem e afirmava que "não façaes a outrem o que não quereis que se vos faça. [e o outro mestre] E o lema de Jesus: ame ao próximo como a si mesmo" (FREITAS, 1927, p. 1). Estas recomendações são os pilares para a ciência do Bem. Obviamente, o educador instiga a comunidade para que estes pressupostos morais sejam atingidos. Portanto, o "Seu Sabino" concebia a educação a partir destas duas bases: racional e pela fé.

Por fim, o educador chama a atenção de todos para um assunto muito contemporâneo. Tratase da divisão de responsabilidade no que se refere aos objetivos da educação. Precisaria, para uma boa educação, os seguintes atores: alunos, pais, professores; cada um fazendo sua parte para atingir o propósito educacional.

Esse apanhado dos pontos centrais da conferência poderá nos ajudar a perceber a dinâmica da pequena Vila Paraopeba. Já naquela época, se pensava, nessa cidade, aspectos educacionais que até hoje são discutidos. Por exemplo: disciplina, responsabilidade, metodologia, processo ensino e aprendizagem, virtude. Parece-nos peculiar uma cidade de poucos mais de três mil habitantes (incluindo a zona rural) estar preocupada com todas estas questões. O educador 
procurava compreender os dilemas da comunidade e propunha algumas soluções para a vida educacional.

Há outra faceta do poeta: a de homem público. O prefeito Sabino deixou um relato da comunidade no início da década de 30, com os aspectos sociais e sanitários da cidade. Havia o impaludismo, devido à falta de higiene, e a lepra, que causava pavor na comunidade com casos presentes na região da vila. De acordo com o texto de Sabino, a higiene era notada "nas classes civilizadas". Já nas classes de menor poder aquisitivo, era precária a higiene tanto individual quanto domiciliar. Detecta, também, o vício do alcoolismo. Naquela época, este vício estava presente na comunidade e na observação do então prefeito.

Os aspectos culturais abordados pelo prefeito Sabino, através do recenseamento de 1920, identificam um grande número de analfabetos. A instrução primária é dada nas escolas rurais e do centro da Vila Paraopeba. Entretanto, a falta de recursos financeiros impede a população de investir na instrução das crianças. A educação não é transmitida como deveria, pois o dinheiro público dispensado ao ensino é parco. As necessidades da comunidade são insuficientes.

Entretanto existem, por iniciativa da comunidade, atividades culturais relevantes. Há no município o jornal "A Gazeta de Paraopeba", de propriedade de Manoel Antonio da Silva. Há, também, corporações musicais, clubes de futebol e dois cinemas, um na vila e outro na comunidade do Cedro. É importante ressaltar que o prefeito Sabino dá muita importância aos aspectos cultural da cidade, participando, ele mesmo, de muitos eventos culturais.

O texto do prefeito Sabino, escrito na década de 1930, aponta alguns pontos que julgamos importantes para revelar aspectos da memória social da cidade. O prefeito relata sobre a população seus problemas. São observações pessoais, sem compromisso em teorizar, apresentando um quadro social da comunidade daquela época. Percebemos que a sensibilidade de poeta acompanha o exercício do prefeito Sabino. Expõe a história da origem da cidade e seu desenvolvimento no tempo. Em seu relato, apresenta preconceitos e limites, mas também nos dá o sentido da aprendizagem. É um documento importante da cidade na medida em que apresenta um panorama da comunidade daquela época. 
As condições da população da Vila Paraopeba, segundo o prefeito Sabino, são semelhantes àquelas dos centros civilizados. Há uma variedade de costumes e atitudes. Habitantes polidos, educados e, nas fazendas, encontram-se "primitivos da palhoça do Jeca” (FREITAS, 1931, p. 1). O prefeito considera boa a situação da cidade e as pessoas têm índole ordeira e pacífica. $O$ trabalho é diversificado, distribuindo-se entre "o comércio, lavoura, a indústria têxtil e a pecuária, formando a classe pastoril, etc.” (FREITAS, 1931, p.1). Declara que as pessoas são formadas na religião católica, e contabiliza que naquela época a Vila de Paraopeba possuía por volta de 5.000 habitantes, contando com o Cedro, que nessa época era bairro dessa comunidade.

Há neste relato algumas informações que nos saltam aos olhos. O prefeito Sabino descreve alguns costumes da comunidade, mais especificamente dos cultos africanos que eram praticados na cidade. Dizia o prefeito que "a feitiçaria tem também os seus representantes nos descendentes da África e discípulos destes, mas operosamente na classe ignorante" (FREITAS, 1931, p. 2). Os curandeiros já faziam parte das práticas culturais daquela época na Vila de Paraopeba. Prática que parece se enraizar no imaginário da cidade desde muito tempo atrás. No século XIX, através da carta de Antônio Mascarenhas, já mencionamos relato de práticas da religiosidade africana na comunidade.

Também se encontra no texto do professor Sabino a referência do engenheiro inglês James Wells, dando conta de sua passagem pelo arraial de Tabuleiro Grande. Segundo o prefeito, "sabe-se que o inglês J. V. Vills, que em estudos de sua profissão, por aqui passou em 1873 em seu livro Three Thousand Miles Trough Brazil" (FREITAS, 1931, p. 2). O intuito do prefeito era mostrar, através do seu relato, um panorama daquela época. Os momentos históricos, sociais e culturais da Vila de Paraopeba. O tom do ensaio é ora exaltativo, ora pejorativo. É importante pensarmos, ao ler este relato, que naquela época a comunidade já refletia sobre os limites e impasses que repercutem até a atualidade. Enfim, este ensaio também revela a conjuntura socioeconômica e cultural da época, ao demonstrar as práticas religiosas, os tipos de trabalho, os eventos da cidade daquela época.

Voltemos ao poeta Sabino de Paula Freitas. Tal poeta possuía o ideal parnasiano. Sabemos que devemos ter cuidado ao falar sobre poetas. Eles são, tantas vezes, inclassificáveis. Isso não é defeito moral ou relacional, mas uma forma de se posicionar no mundo. Sempre há risco em se fazer afirmações sobre os poetas, pois corremos o risco de ser reducionistas. 
Assumiremos o risco com a ressalva de que nosso propósito é apenas dialogar com os versos do "Seu Sabino". As palavras dos poetas, algumas vezes, nascem de regiões obscuras do Ser e, portanto, são refratárias a afirmações superficiais.

Não faremos crítica literária, mas tentaremos compreender os versos como leitor e pesquisador da memória social da cidade na qual Sabino foi muito atuante. A poesia parnasiana apresenta, freqüentemente, um "eu" romântico e que se expressa através de conflitos insolúveis com a sociedade. Este "eu" do poeta lança-se muitas vezes à evasão, acreditando que a recusa à sociedade e refúgio na Natureza curariam os males da alma. Essa Natureza, segundo a teoria literária, se apresenta sempre exuberante e expressiva. Como se a Natureza pudesse apaziguar a dor que o poeta carrega dentro de si. $\mathrm{O}$ mais antigo poema que encontramos do poeta Sabino data do ano de 1899, intitulado "Na floresta" e corrobora nossa opinião:

Se há felicidade na mundana vida Não é nascida nos salões de festa É no silêncio, nas brumosas relvas Nas semi-trevas da vivaz floresta.

(...)

Lá no silêncio só a brisa fala;

Tudo mais cala pr'a gozar delícias

Do odor suave da florinha bela,

Que vai com ela a suspirar carícias (FREITAS, 1977, p. 2)

Os parnasianos tinham o gosto pela metrificação do verso e também o apreço pela rima e pelo ritmo. Era um "culto da forma" a partir do rigor da métrica. Do ponto de vista da crítica literária isso se deve a uma reação contra aos aspectos "vagos" adotados pelos românticos. Uma tentativa, pelos parnasianos, de mudar essa tônica para uma visão mais "real" das coisas. Daí o rigor da forma para se atingir uma "objetividade" em relação aos fatos que o poeta deseja retratar.

Poderíamos dizer, dentre outras coisas, que o poeta parnasiano teria uma percepção negativa do mundo. As descrições da dor: uma lista minuciosa das dores sentida pelo poeta, seus desenganos e frustrações. Talvez a crítica a essa escola seja às vezes severas ao dizer que a escola parnasiana habituou-se a ornamentos e gosto por padrões de linguagem consagrados. Redundando, assim, em aspectos realizados, pelos poetas, no gosto pela imitação. 
Não estranharemos o gosto de Sabino de Freitas pelo tom desencantado da vida. Os lamentos e descrições de suas dores. Tudo isso impresso em formas poéticas. E no que se refere ao ritmo e métricas, eram muito rigorosas. Não era, obviamente, uma língua falada no vilarejo de Tabuleiro Grande, mas versos medidos e pensados - cheios de ornamentos. Entretanto, são versos de beleza em que o poeta homenageia quem admira e gosta. Expressa também o apuro da língua portuguesa com a qual ajudou a imprensa local e seu ensino na comunidade.

Há na história pessoal desse poeta um episódio que o marcou muito. Querendo viver uma vida baseada no ideal virgiliano, entre idílios e éclogas, decide morar no sítio próximo ao rio Paraopeba (este episódio foi relatado por um de seus alunos, o memorialista Sr. Antônio - no capítulo "As lembranças"). Durante a permanência nesse lugar o poeta foi atacado por marimbondos, logo depois ficando cego de um olho. Sua tentativa evasiva foi em vão. Retornou depois para Tabuleiro Grande, onde exercerá, por longos anos, a profissão de professor. A sensibilidade poética aliada aos percalços econômicos o lançou na melancolia. Assim, compôs o poema "Descrença":

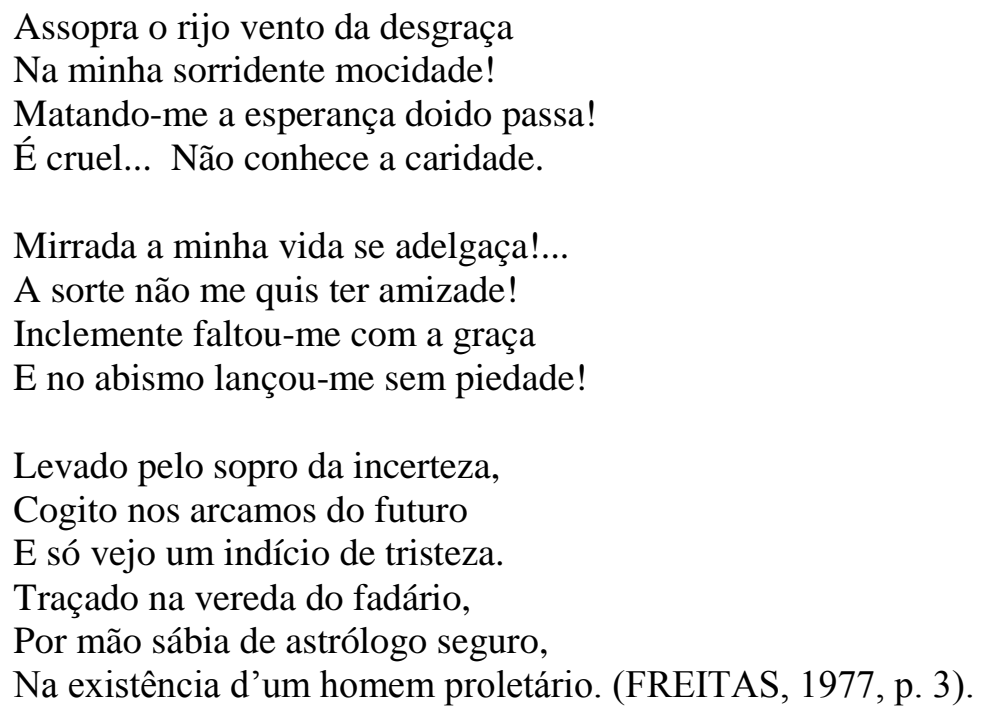

Diante dos infortúnios, o poeta passará pela vida sob o signo da descrença. E o rigor moral e da forma poética era seu chão. Logo após sua morte, seu amigo e criador da "Gazeta de Paraopeba", Manoel Antonio da Silva - escreveu um artigo, no qual evidencia sua conduta:

Modesto, esquecido e afastado da sociedade, Sabino passou uma longa parte da sua existência como um eterno descrente da vida, sem uma ilusão que o despertasse nessa quadra em que nos preocupamos tanto com o nosso bem estar e esse mytho que é a felicidade. (SILVA, 1937, p. 1). 
Há também na poesia de Sabino referência à religião católica, a cujo vínculo permaneceu fiel durante toda a vida (a memorialista D. Maria Stella lembra das idas do poeta, às tardes, ao cruzeiro da cidade fazer suas orações - capítulo “As lembranças”). Acompanhara o seu irmão, bispo D. Cirilo, em viagens e desfrutou da biblioteca dele. O amor à natureza e a fé constituíram elemento marcante na cosmovisão do poeta:

Amar, servir a Deus com abundância,

Eis o que sobretudo prevalece...

Neste afã é que o homem se engrandece;

Fora disso o saber é petulância! (FREITAS, 1977, p. 30)

A tristeza e gosto pelas imagens que se desvanecem fazem parte dos versos do poeta. Compôs um poema, "Numa Tarde", de 1902, em Tabuleiro Grande. Aludindo às imagens da melancolia da voz dos pássaros e dos sentimentos acres. Curiosamente, foi redator e fundador de um periódico nesse arraial por volta de 1904, chamado "O Crepúsculo". Nome apropriado para a índole do poeta. Assim descreve os versos:

Um dia, quando o sol já repousava, Fui, muito triste, passear sozinho:

A brisa vagamente suspirava, N'árvore seca trilava o canarinho. (FREITAS, 1977, p. 8)

Não acreditamos, num psicologismo ingênuo, que o "eu" do poeta e do seu criador seja o mesmo. A poesia é artefato, palavras em alta intensidade. Contudo, podemos dialogar com elementos sociais e subjetivos do poeta. Acreditamos, pois, que o trabalho do poeta é com as palavras. Por sua vez, as palavras carregam semanticamente o universo simbólico. Portanto, a linguagem é símbolo criado e criador da tradição. Assim, o mundo do poeta dialoga com o mundo subjetivo e social. Não poderia ser diferente, já que é a linguagem o lugar em que o ser humano habita e dá sentido às coisas que o cercam. Assim, o poeta esclarece o ofício de "Ser Poeta":

Ser poeta é saber com gentileza

A verdade em estrofe sublimar.

É saber dominar a natureza,

P'ra cantar, p'ra sorrir ou p'ra chorar...

Ser poeta é ter um dom de tal grandeza

Que o mundo nada tem p'ra comprar.

Não cultua o poeta a realeza.

Tem no belo o seu culto, o seu altar. 
O encanto juvenil que se envelhece,

O poder que corteja a tirania,

Bem assim tudo aquilo que apodrece,

Não lhe passa de tola vilania.

Mas aquilo que enleva, que enobrece,

Lhe é belo, para si tem poesia. (FREITAS, 1977, p. 24).

\subsubsection{O esboço de uma memória}

As reminiscências da cidade relatadas por Aguinaldo Edmundo ${ }^{10}$ nos surpreendem pela riqueza de detalhes. Pretendia escrever a história da antiga Tabuleiro Grande, mas morreu antes de publicá-la. Entretanto, em 1947, publicou na "Gazeta de Paraopeba" um artigo onde evoca saudosas imagens do arraial. Tudo indica que era um esboço do que seria o livro de memória da cidade. Nesta narrativa, Edmundo evoca uma profusão de nomes de pessoas, ruas, casas, comportamentos. Indicaremos alguns trechos, numa tentativa de apreender, através desse relato, às imagens que não encontramos mais da cidade.

O memorialista Edmundo lembra das casas daquela época e as descreve em detalhes. Afirmava que a arquitetura da cidade era outra, feita de outros materiais e traços. Na pequena cidade "casas velhas. Tipo colonial. Nenhuma de tijolos. Todas de madeira e adobe. Porque, muitas - muitas - de enchimento. De puro enchimento" (EDMUNDO, 1947, p. 1). Pelas descrições do narrador, não havia sofisticação. O que se via eram vielas e ruas sem esgoto e calçamento. A poeira da rua era um componente daqueles tempos. Pois a cidade surgia sem planejamento urbanístico. Como se a cidade fosse surgindo ao acaso.

A partir das lembranças do Edmundo, já em 1947, percebemos que muitos prédios da cidade não existem mais. A matriz Nossa Senhora do Carmo, surgida no lugar da capelinha, foi a única a testemunhar as tropas de bois que "vinham do Norte, dos antigos currais da Bahia" (EDMUNDO, 1947, p. 1). O lugarejo testemunhara as idas e vindas dos tropeiros. Lá, persistia no tempo a igreja, que possuía duas torres, que foi derrubada. As imagens vão surgindo com a propriedade de quem conhece a cidade em detalhes. $\mathrm{O}$ cruzeiro, que vigiava solene a cidade, também, aos poucos, foi sendo urbanizado. A paisagem foi mudando! Mas

${ }^{10} \mathrm{O}$ jornalista e poeta Aguinaldo Edmundo nasceu na localidade do Cedro, atual Caetanópolis, nesta época esta localidade pertencia a Paraopeba. Exercia também a função de rábula e orador. Escreveu poemas e peças de teatro. Em sua homenagem, a biblioteca pública da cidade foi batizada com o seu nome. 
naquele tempo "à pequena distância do velho Cruzeiro, uma grande cazuarina, em cujos ramos o vento gemia, gemia, gemia constantemente..." (EDMUNDO, 1947, p. 1). Curiosamente, esta era a mesma árvore evocada pelo poeta Sabino de Paula Freitas.

A paisagem da cidade e sua topografia surgem com nomes que se perderam no tempo. As vendas de secos e molhados, o comércio e os proprietários que trabalhavam na praça da matriz. O comércio do "Sô Virgilio Reis e seu irmão Sô Dino. Também a do Sô Mascarenhas e a padaria de D. Policeninha Mascarenhas" (EDMUNDO, 1947, p. 1). Segundo Edmundo, só havia essa padaria. E os pães eram colocados num baú de lata pelo preto Dominguinhos. Há também a região da capela do Rosário, que permanecia no ermo do cerrado da cidade. Sem casas e comércio. Com o nome bem peculiar de rua da Outra Banda. Esse nome ninguém sabe se existiu. Havia outra rua, do lado oposto da cidade. Também era oposto seu objetivo. Era a famosa e temida rua da Palha. Este lugar causava arrepios nas boas famílias da comunidade, pois ali era a "rua dos jogos, da cachaça, das mulheres, das brigas" (EDMUNDO, 1947, p. 2). Ruas que terminavam e começavam sem nenhuma numeração, mas cheias de "porcos, leitões, bois, vacas, bezerros, carneiros, cabritos" (EDMUNDO, 1947, p. 2). Com sua profusão de nomes associados a algum ofício, como "sô Manoel Pinto, sô Isaías Corrêa e sô Paulo Cecílio, Sá Viauí e de sô Toninho Nascimento” (EDMUNDO, 1947, p. 2). Todos eles faziam alguma coisa e as ruas recebiam o nome deles informalmente. Todos eles tinham um ofício: padeiros, açougueiros, marceneiros, doceiras etc.

Além destas pessoas, havia os mais "ilustres" do arraial. Havia o Manuel Cazuza, o sacristão e fundador da banda Lira do Espírito Santo, o "Seu Avelino" que, segundo as memórias de Edmundo, gostava de ficar assentado numa pedra no adro da igreja e subia de terno de linho branco ou casemira escura, fumando seu charuto. $O$ memorialista lembra que as correspondências do correio eram quase todas para ele. O jornalista lembrava detalhes da cidade, que infelizmente se perderam. Ele pretendia escrever muitas páginas e capítulos. Um testemunho da Tabuleiro Grande que se perdeu no tempo. E nós, seus leitores, ficamos mais distantes ainda. Ficaram duas páginas de detalhes da paisagem da cidade. Um panorama que não existe mais. Mas que pode ser prolongada pela nossa imaginação e pelos fragmentos da memória apresentados por Aguinaldo Edmundo. 


\subsection{A cidade e a memória}

A cidade é povoada de nomes e imagens. Mas também de lugares. É no espaço da cidade que os eventos se apresentam. As festas, os aprendizados, o trabalho e também desejos e sonhos. Os relatos dos narradores podem revelar lugares desconhecidos da cidade. Através, das lembranças dos narradores, conseguimos conhecer lugares e eventos que as gerações atuais desconhecem. A casa materna, a escola, lembrados como lugares de memória e de afeto, são revividos pelos memorialistas. E nos fazem descobrir a dinâmica da cidade antiga: os sons do sino da igreja, o apito da fábrica chamando para o trabalho, os animais domésticos, o espaço das brincadeiras de rua. A diversidade de sons e imagens nos instiga a conhecer a geometria da cidade.

Na obra A rua de mão única, Walter Benjamin convida o leitor a conhecer a metrópole. Um mosaico de lugares se apresenta neste livro, dentre eles o posto de gasolina, a casa mobiliada, a arquitetura, as viagens. O narrador também vagueia pelas imagens da infância em Berlim, pelos livros das bibliotecas e pelas ruas da cidade. O crítico propõe, através da narrativa, escavar os vários níveis de realidade. Esta operação visa "descobrir" no passado pequenas ilhas de conhecimento, fragmentos, para depois reutilizá-los no presente. Através dessa operação de redescobrir as vivências e experiências, a atitude do narrador assemelha-se ao arqueólogo que escava camadas do solo para compreender às civilizações desaparecidas. Embora saibamos, nos ensina o filósofo que aquilo que o esquecimento levou não poderá ser totalmente recuperado. Ainda assim, sabemos que os fatos e lugares existiram, através dos lugares evocados pela narrativa. Mas temos que saber que "os fatos nada são além de camadas que apenas à exploração mais cuidadosa entregam aquilo que recompensa a escavação" (BENJAMIN, 1987, p. 239). O fato, para Benjamin, não é correspondência exata entre as coisas, mas correlações e aproximações.

A cidade, por este caminho, pode ser escrita como um livro. Assim propõe Benjamin, pois " $a$ atuação literária significativa só pode instituir-se em rigorosas alternâncias de agir e escrever" (BENJAMIN, 1987, p. 11). Esse texto benjaminiano foi construído de fragmentos de lembranças, dando um panorama da cidade que o narrador visitou. Dessa forma, a construção da vida, assim como a escrita, exige que o cidadão saiba escavar os fragmentos das lembranças da cidade e da história subjetiva presentes nas lembranças. Dessa forma, recomenda o pensador cultivar as brochuras, jornais, folhas avulsas que melhor correspondam 
e retratem as comunidades. É como se pudéssemos conhecer a cidade com olhos de colecionador e assim apontar novas correlações que vão além do conhecimento oficial sobre a cidade. Todavia, escrever a cidade e lembrá-la, argumenta Benjamin, é a posição de quem deseja e sabe usar a língua como “médium e mensagem” (BOLLE, 1984, p. 275). A língua é instrumento de transformação e luta. Assim, escrever a memória da cidade é usar a língua que o narrador utilizará nas correlações das lembranças evocadas.

Entretanto, para se conhecer a cidade é preciso disposição e atitude de quem se aventura na empreitada. Para Benjamin, flâneur é o homem que vagueia só pela cidade a fim de conhecêla. Observando os detalhes, se entretém no espetáculo da cidade. A verdade é que o flâneur passeia, mas não se sente totalmente em casa na sua própria cidade; tenta desbravar a cidade como um olhar novo. Isso ocorre porque o flâneur desfruta da percepção de forma nova, escavando por camadas subterrâneas aquilo que as pessoas normalmente não vêem. Por outro lado, o flâneur pode significar um protesto da divisão do trabalho que o capitalismo impõe. Não se ligando àquela paisagem ele pode observar os meandros das esquinas, becos e ruas. A percepção da multidão anônima dos habitantes da cidade em seu frenesi, a competição das pessoas. Nisso haveria, alerta o crítico, o perigo da perda de identidade. Assim, "o flâneur é $o$ observador do mercado, seu saber está próximo da ciência oculta da conjuntura. Ele é o espião que o capitalismo envia ao reino do consumidor” (BENJAMIN, 2006, p. 471).

Diríamos que o flâneur é também aquele que caminha pela cidade sem destino e pretensão de esgotar o tempo. É aquele que ao vaguear pelas ruas da cidade se abandona às impressões e ao espetáculo do momento. Pois o flâneur "é o senhor da cidade" (ROUANET, 1988, p. 50). Este sabe rastrear os meandros dos becos e esquinas, faz correlações inesperadas. Com um olhar minucioso, o flâneur vasculha tudo e percebe o que a visão comumente ignora.

O trabalho das Passagens faz lembrar que o espaço da cidade faz parte da história do flâneur. Já que ele despreza a história positivista, mas imprime seu faro para desvelar a cidade. É impelido a buscar outras coisas. Sua imagem é a do labirinto. Uma imagem que é mítica e presente ao mesmo tempo. O flâneur detecta as curvas eretas que não terminam nunca; a monotonia não é o forte dele. O caminho que leva ao labirinto é imprevisível e cheio de riscos. Para este observador, "a cidade é a realização do antigo sonho humano do labirinto. O flâneur, sem o saber, persegue esta realidade" (BENJAMIN, 2006, p. 471). 
O mundo se transforma, ao olhar de Benjamin, nos detalhes do cotidiano. Ele dá importância dos restos, cacos, objetos à primeira vista desprezíveis. As coisas que nos rodeiam e que são demasiado próximas. Elas nos dão a impressão de familiares e se oferecem à percepção. Por isso, tantas vezes são rejeitadas. Daí a necessidade de o narrador ou o memorialista estar atento aos detalhes, aos fragmentos e se abrir às descobertas.

A salvação do passado através das rememorações evocadas não está em perceber as imagens do presente idênticas às do passado. Este está inevitavelmente perdido. Mas o passado pode, quando lembrado, ressurgir de forma nova. De forma que, através da dialética entre o passado e o presente, se revigore. Não como repetição de si mesmo. Ambos, passado e presente, continuam sendo o que são, mas ao mesmo tempo diferentes. Nesse choque temporal surge um "agora" capaz de transformar essa distância em proximidade. Dando um caráter novo a essa pequena fresta e fazendo surgir algo promissor.

Uma atividade importante está presente em Passagens. O flâneur "consegue lembrar-se de sua história individual e da história coletiva em que ela está imersa” (ROUANET, 2002, p. 66). Pois as lembranças, como as mônadas, estão presentes e em trânsito. A verdade é que o flâneur, em seu périplo, faz-nos lembrar do labirinto. Imagem mítica em que o movimento o remete às ruas em várias concepções; mas também abre caminho para outros sentidos. O meio físico das ruas em nomes que se transformam em imagens e lembranças em movimento. Neste caminho, a cidade potencializa as palavras dos narradores (como Aguinaldo Edmundo em seu esboço da memória da cidade e memorialistas pesquisados):

A cidade possibilitou a todas as palavras, ou pelo menos a um grande número delas, algo que só era acessível a pouquíssimas, a uma classe privilegiada de palavras: serem elevadas à nobreza do nome. Esta revolução da língua foi realizada pelo que há de mais comum: a rua. Através dos nomes de ruas, a cidade se torna um cosmos lingüístico. (BENJAMIN, 2006, p. 563)

O ensaísta Sérgio Paulo Rouanet faz uma indagação pertinente sobre as Passagens de Walter Benjamin. É a cidade que habita os homens ou são eles que moram nela? Obra inacabada, Passagens trabalha com as duas dimensões: o da realidade objetiva e a onírica. Assim, as pedras e ruas da cidade, sonhos e devaneios compõem os movimentos do flâneur. Há um diálogo entre a duas realidades. A cidade física e a onírica se comunicam. Talvez aí residam os elementos dissonantes quando nos deparamos com a cidade. A cidade física se transforma 
traz à consciência aspectos da imaginação e do sonho. Quando nos lembramos de uma cidade, as imagens dos objetos reais e dos lembrados se misturam. Percebemos e somos percebidos pelo ato de evocar as lembranças da cidade. Daí a cidade física se torna habitada, humana. Há uma relação entre os fatos reais e os objetos oníricos. É nesta perpectiva que Benjamin nos ensina a perceber a cidade - (exemplificaremos, através das lembranças dos memorialistas pesquisados, no capítulo "A cidade lembrada").

Mas em que estas reflexões sobre a cidade podem nos ajudar? Obviamente a pequena cidade no sertão de Minas não é a metrópole retratada pelo flâneur. A pessoa que vagueia por uma cidade pequena não encontrará grandes lojas e multidões, a exemplo do flâneur. Ao contrário, o tempo parece, em algum momento, parado. Pois, aparentemente nada acontece. Entretanto, podemos perceber a relação entre o "eu" e a cidade quando as lembranças da cidade fazem relações e estabelece ligações. Uma dialética constante de quem recorda e escava o passado. Delineia-se um mapa sonoro e afetivo, a partir da topografia dos memorialistas, pois as lembranças não são lineares ou nem estão no mesmo plano. O mapa da cidade se move de acordo com cada narrador. Dessa forma, Benjamin declara:

\begin{abstract}
Saber orientar-se numa cidade não significa muito. No entanto, perder-se numa cidade, como alguém se perde numa floresta, requer instrução. Nesse caso, o nome das ruas deve soar para aquele que se perde como o estalar do graveto seco ao ser pisado, e as vielas do centro da cidade devem refletir as horas do dia nitidamente quanto um desfiladeiro. Essa arte aprendi tardiamente; ela tornou real o sonho cujos labirintos nos mata-borrões de meus cadernos foram os primeiros vestígios. (BENJAMIN, 1987, p. 73).
\end{abstract}

Por isso, a memória topográfica não se pretende esgotar nos espaços urbanos. Descrever as ruas e praças nos moldes de um engenheiro não nos interessa. A memória procura e se detém além das referências físicas. Cumpre-nos perceber as associações espirituais, sociais, afetivas. A memória afetiva da cidade não se esgota em apenas uma referência. Os eventos lembrados são fisgados pelo narrador a partir dos desejos; não só pela realidade física concreta que se lembra da topografia da cidade. Há os lampejos, os fragmentos de histórias, que dialogam entre si e com a cidade; procurando, neste movimento, correspondências e conhecimentos.

Assim, o espaço físico da cidade não pode ser a única realidade dos memorialistas. Falar de si e da cidade (pequena ou grande) é saber fazer correspondência dos fragmentos das lembranças. E depois narrá-las como quem percorre um labirinto. Narrar e escrever são 
formas com as quais os memorialistas podem conhecer a vida subjetiva e social da cidade. Dessa forma, a atitude de quem deseja conhecer ou "passear" pela cidade não deverá está preso ao espaço físico, real e concreto. As imagens do pensamento deflagrados pela narrativa oral ou escrita dos narradores construirão a memória do espaço urbano. A cidade, assim, não é só física nem apenas imaginada, mas várias camadas superpostas. Enfim, para escrever a memória da cidade, tem-se que se levar em conta que os indivíduos habitam a cidade e são habitados por ela. 


\subsection{Anexo 01 - Imagens}

IMAGEM 01: Representação pictórica do surgimento da cidade realizada através das lembranças dos memorialistas

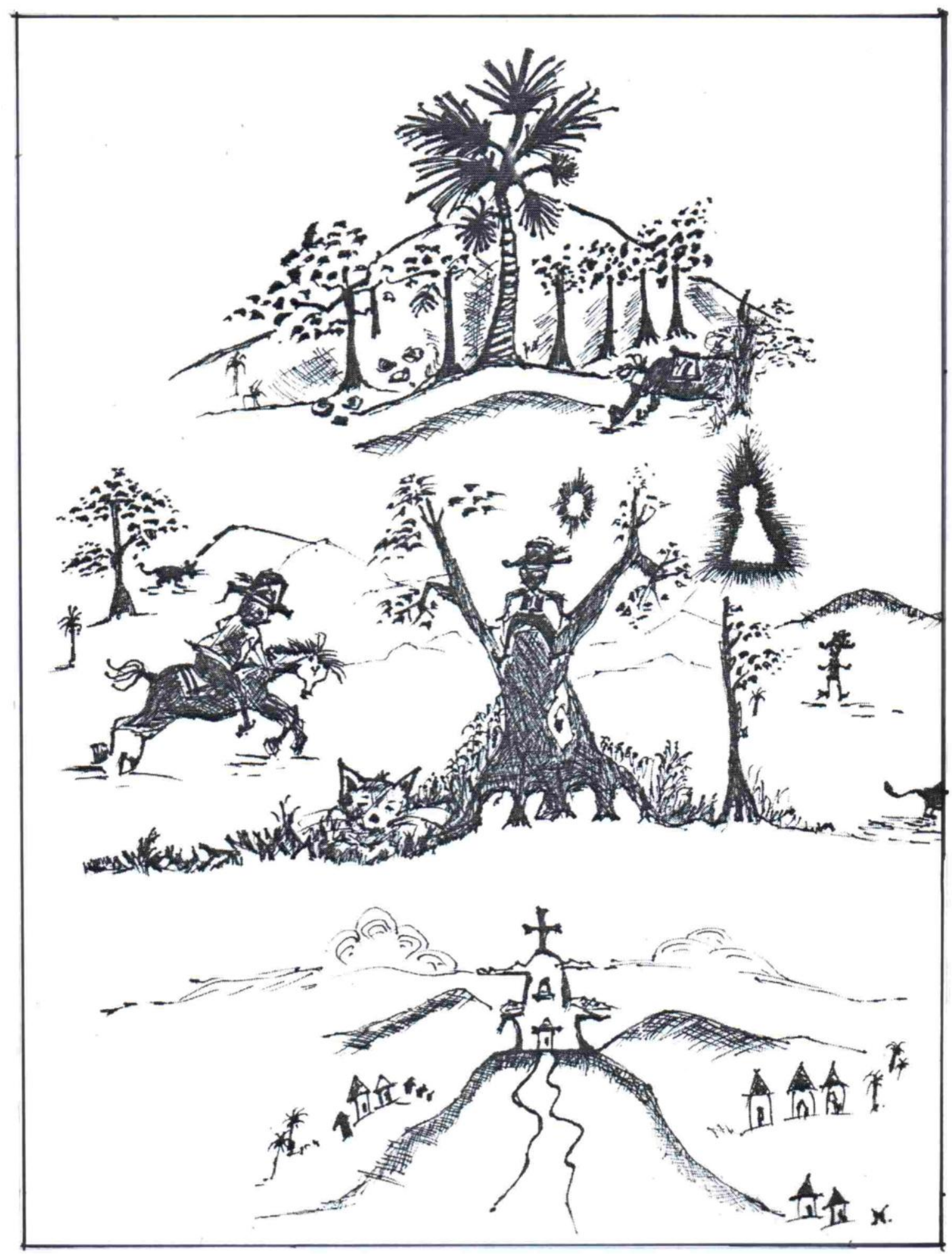

Fonte: Concepção do autor 
IMAGEM 02: O mapa do viajante e Tabuleiro Grande está em sua rota
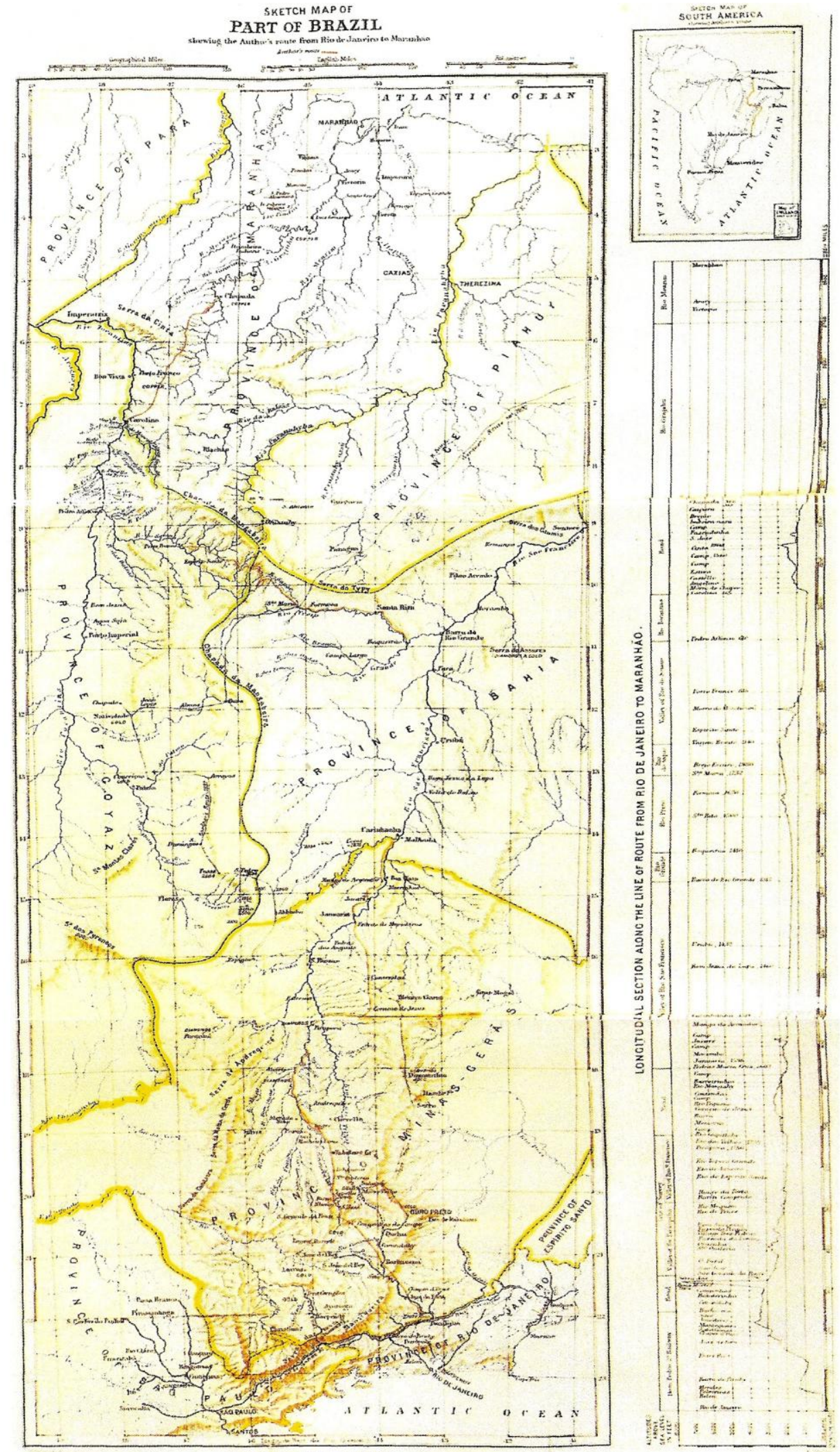

MAPA PARCIAL DO BRASIL

Fonte: WELLS, James W. Explorando e viajando três mil milhas através do Brasil: do Rio de Janeiro ao Maranhão. 
IMAGEM 03: A cidade vista da torre da igreja por volta de 1930

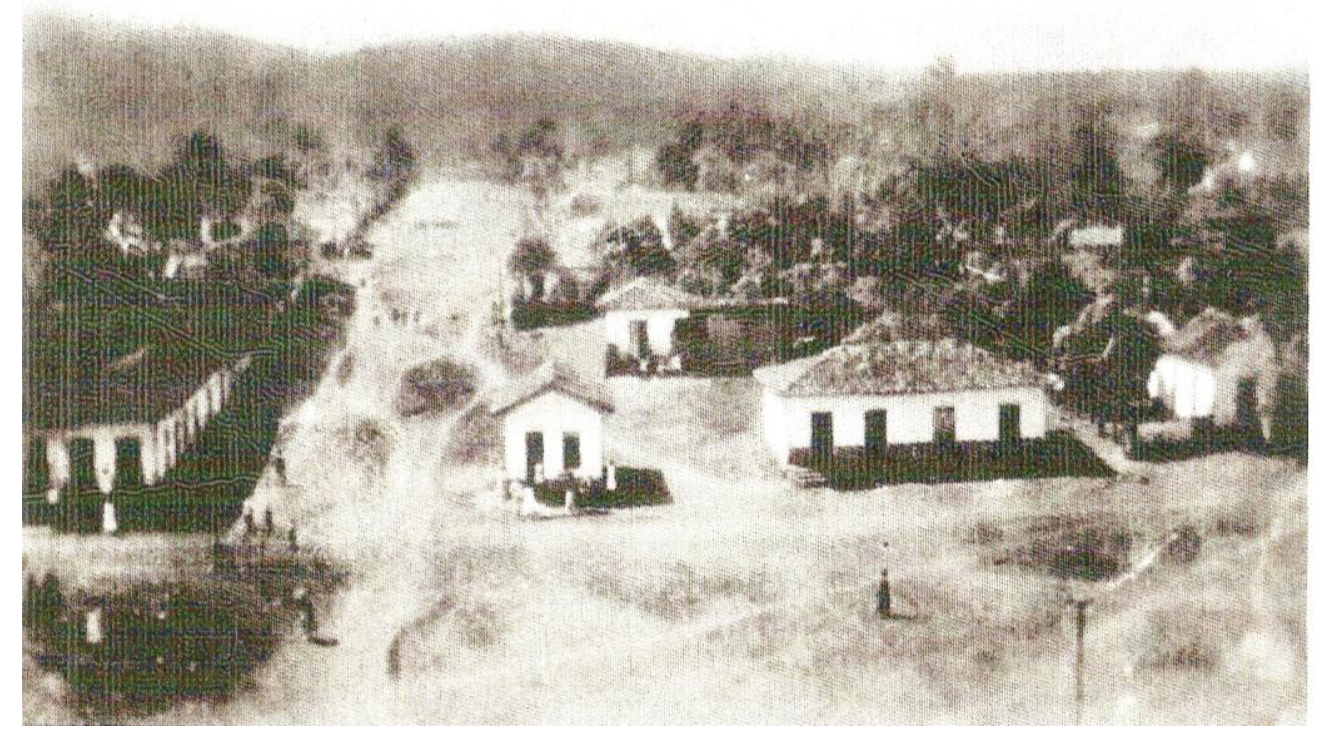

Fonte: Arquivo particular

IMAGEM 04: A cidade retratada por J. Lanza Netto por volta de 1960

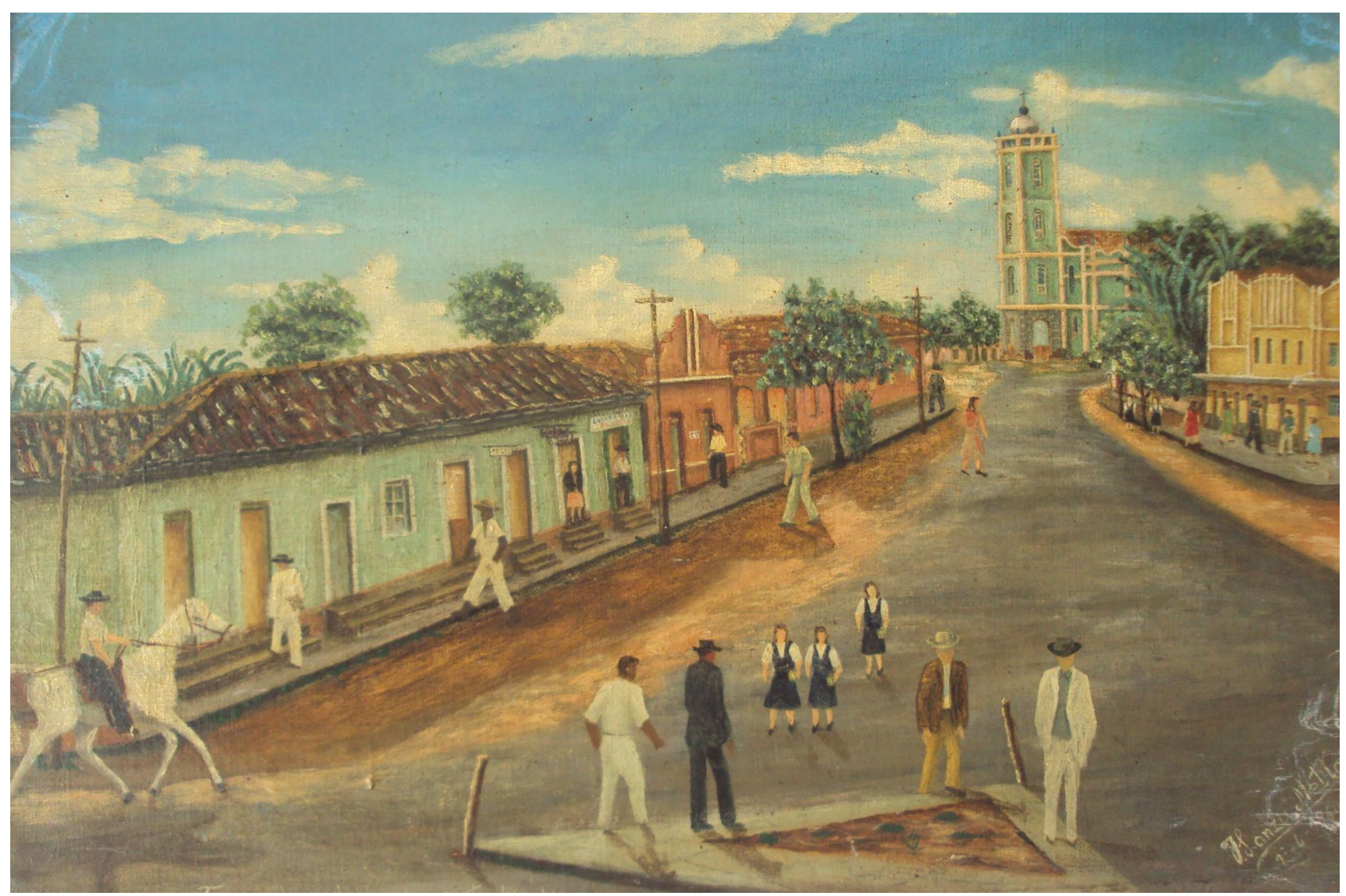

Fonte: Arquivo particular 
IMAGEM 05: A Fazenda do Rasgão

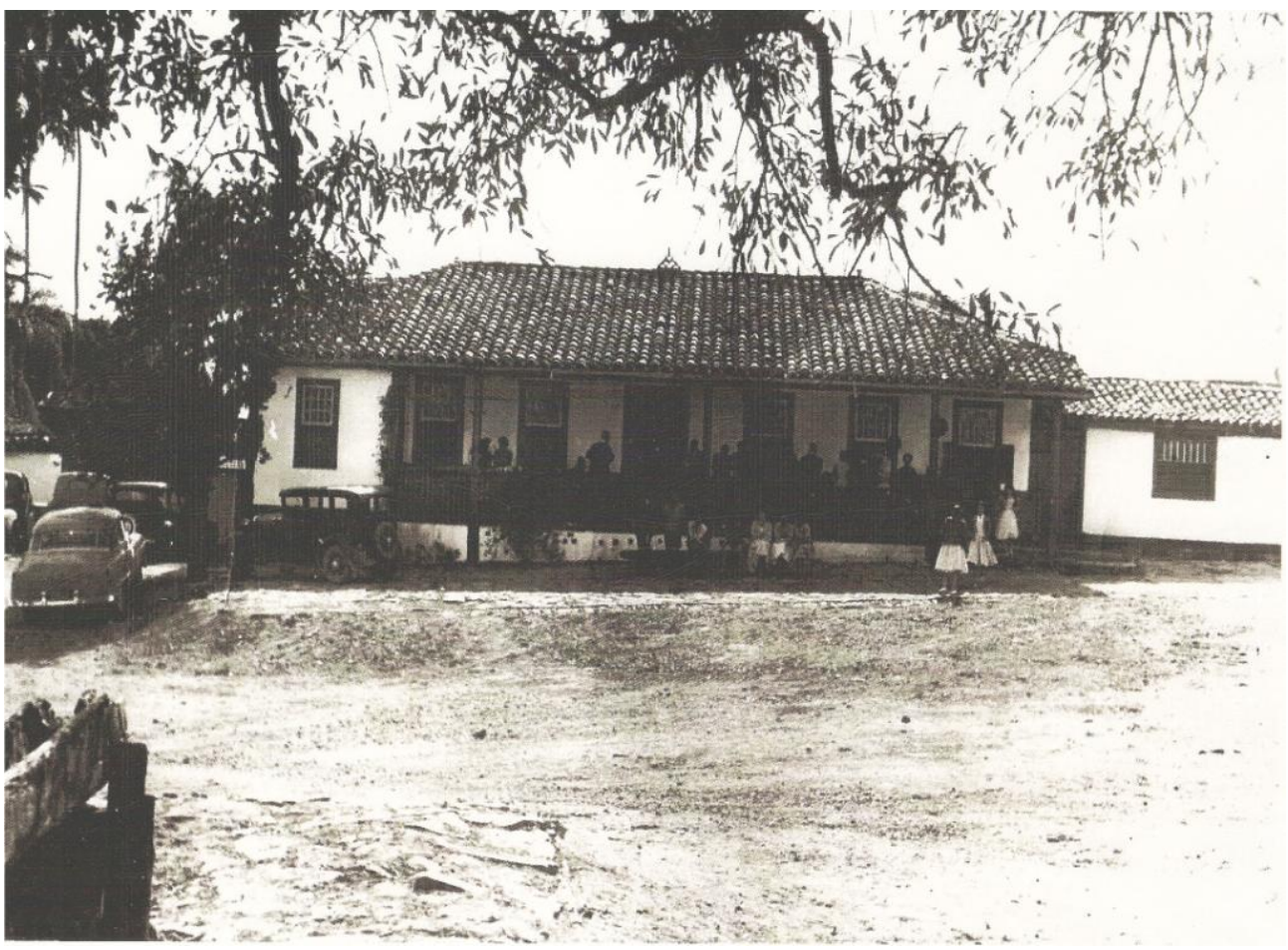

Fonte: Arquivo particular

\section{IMAGEM 06: Outro ângulo da Fazenda do Rasgão}

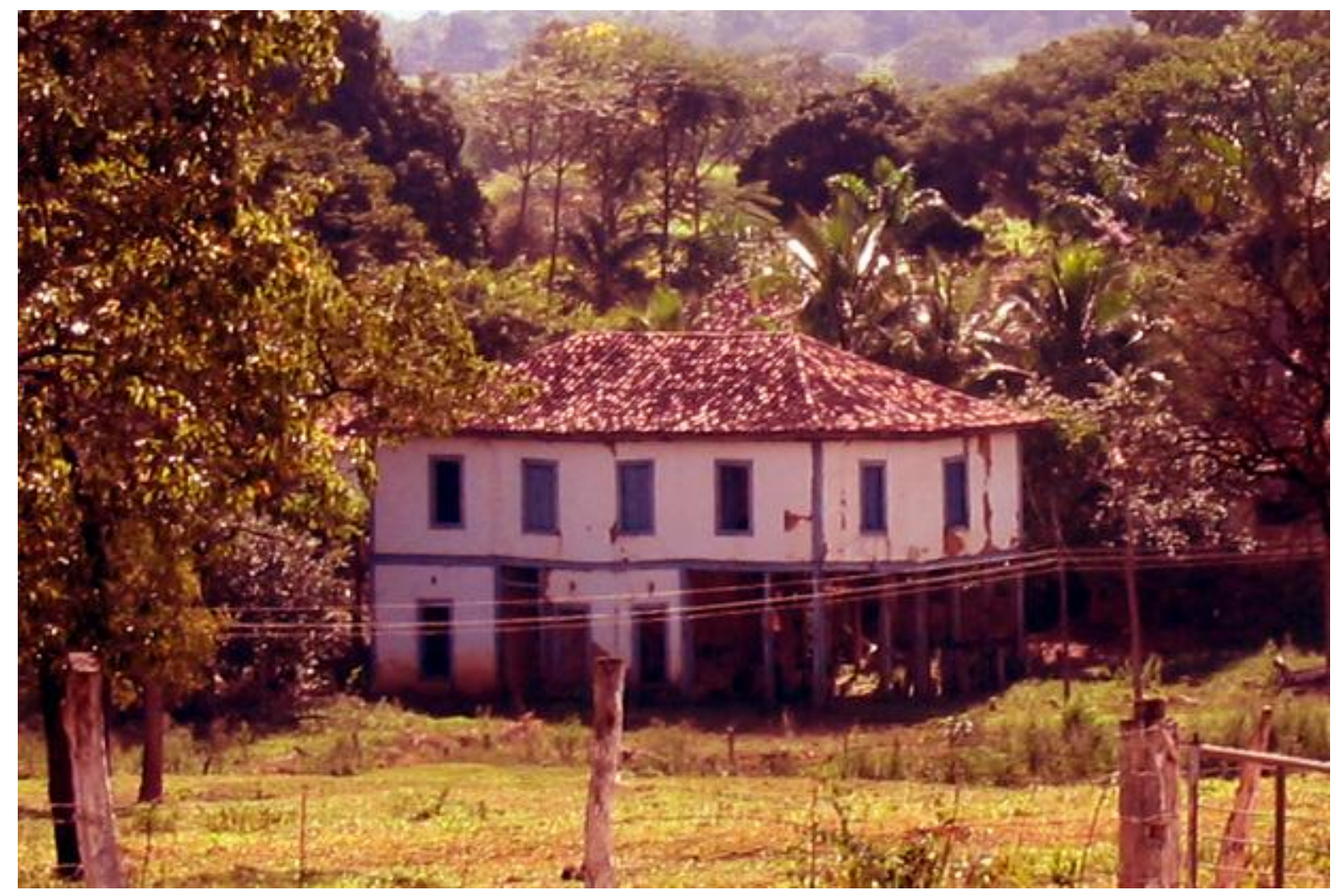

Fonte: Arquivo particular 
IMAGEM 07: Avelino Fóscolo - "Seu Avelino"

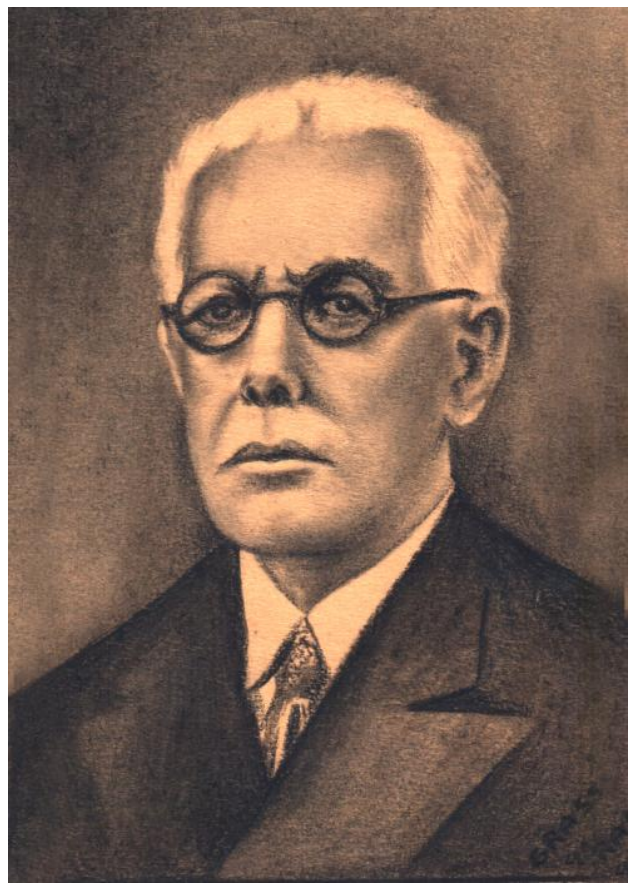

Fonte: Arquivo particular

IMAGEM 08: Capa do romance $O$ caboclo de Avelino Fóscolo

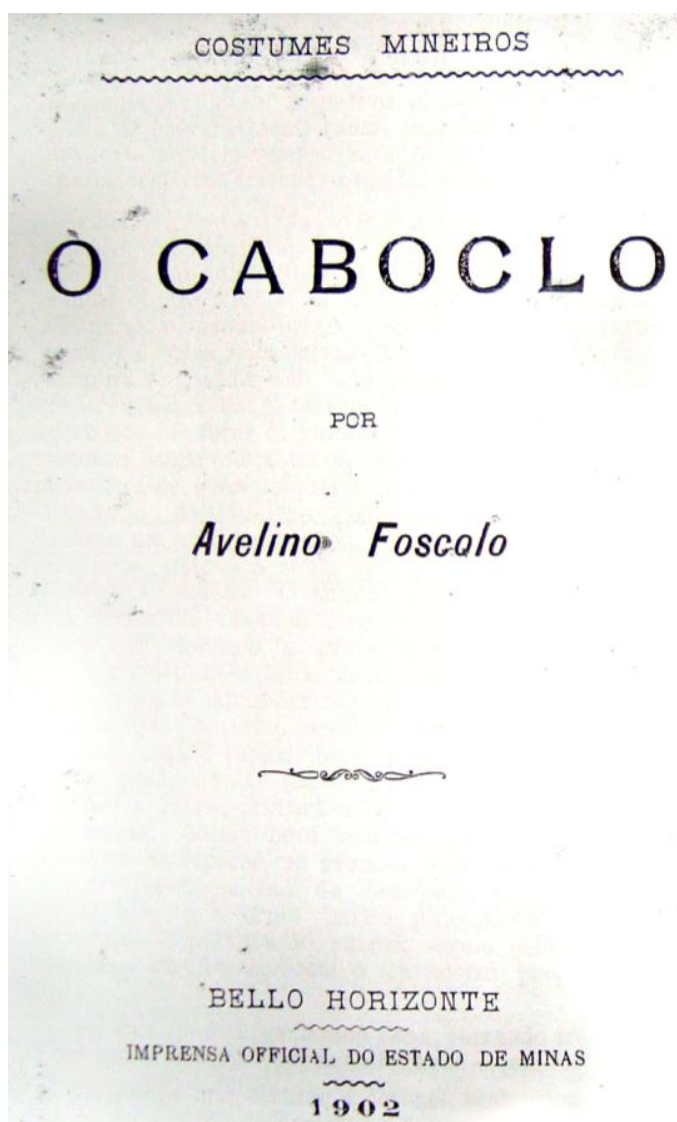

Fonte: Arquivo particular 
IMAGEM 09: O Coalho Halley, criado por Avelino Fóscolo

\section{COALHO HALLEY}

Li' o melhor o o mais barato. Nma colloerinha de conlho liquido on em pó basta para congular sem litros de leite. ב-Vemdas comdicionnes: nos nio for mellhor do gunes qualguer marea existento no moreado, neecitu-so o vidro mesIIIo violado.

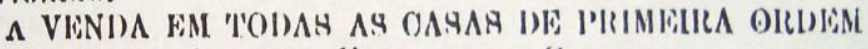

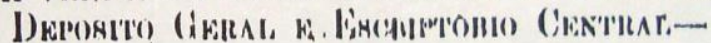

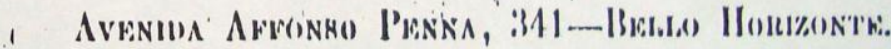

Fonte: Jornal "A folha do Cedro"

IMAGEM 10: Propaganda do vinho feito por Avelino Fóscolo

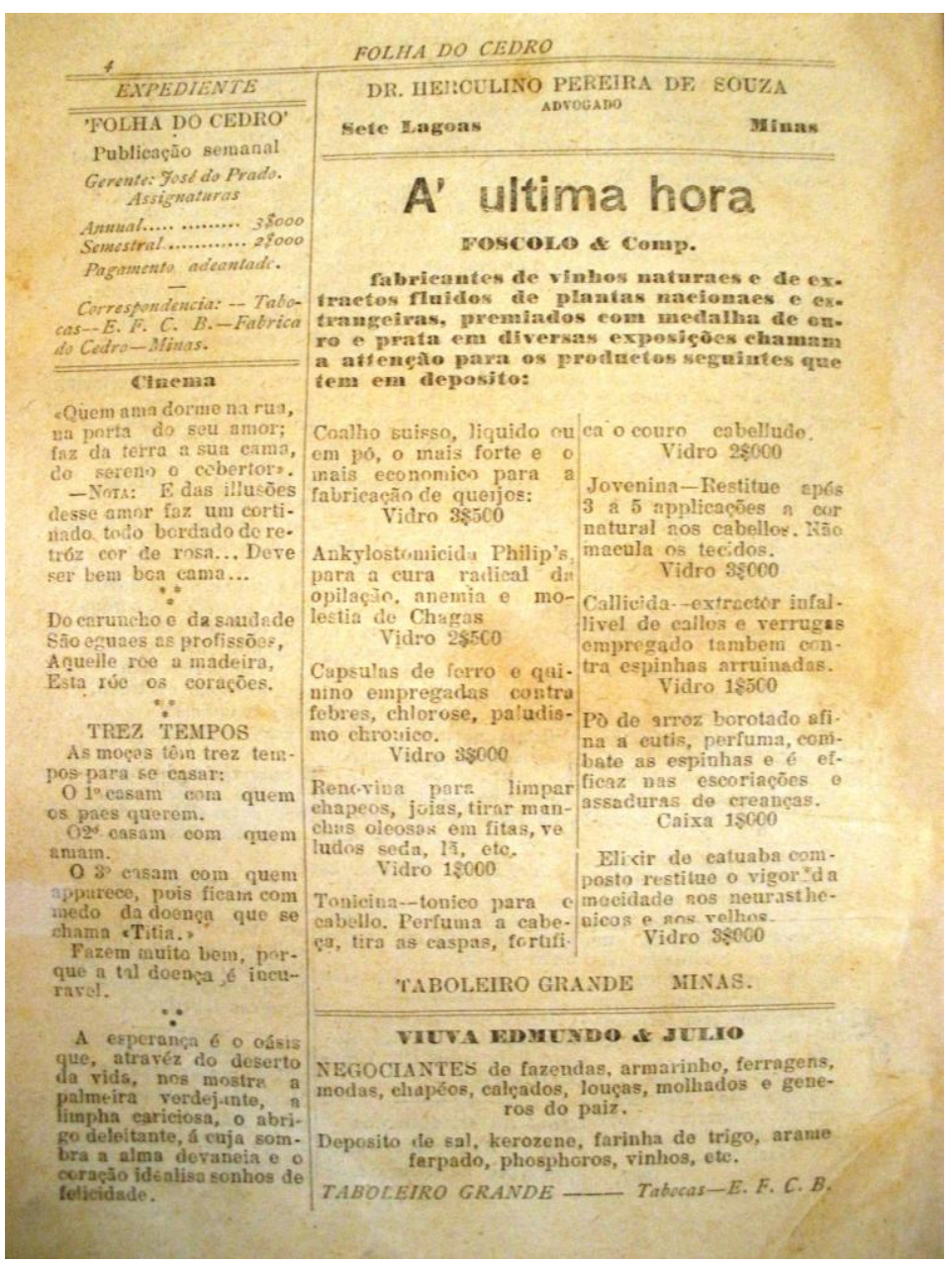

Fonte: Jornal “A folha do Cedro" - Biblioteca Agnaldo Edmundo - Paraopeba/MG 
IMAGEM 11: O primeiro jornal da cidade: “A vida" - 1893
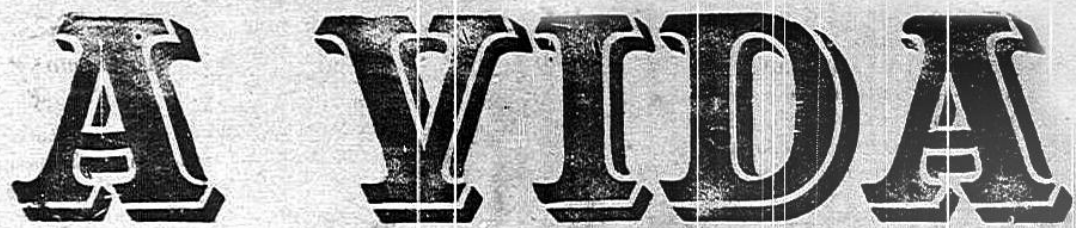

ORENRA LITTERNRIO

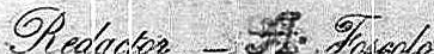

\section{EXPEDIENTE}

Assignatura por um enno 58000

Publicasües a pedidos a cem reis por linha c os annuncios por presos a contencienar.

Serão considerados arsignantes to des os que näo devolverem loqo 0 mimeiro nimern recelido.

seitio puóticados yratuitamente os artigo: de interesse geral.

A mportancra de assignatura podera ser renuttiut em carta registrada a redaçấo da "Vida." Ao ansignamte en atrazo rogamios o

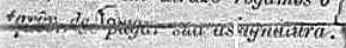

\section{Reflexies poititicas}

Dinutralos fictos, que, ha dois meges, se despmolio em nossi firita. cobrindo de lurto e d. indignacho a Famili : i maik ine en sinto,

\section{FOLHETIM 16 O DIVORCIO \\ por}

- Xio nhasinfia lles, poryus $t i c$ com dor de taieç. ceu faico compantia a

-Nio yrectsas por matis na carta. Totza tà $\$ \$ 000$ para t.

-Drasinho, eu naio fiz nada con tentalo degunhi. E E turanosente nossa conversit...

-D.isa mnosenncir exta n inferno calçado, grande veltiacu!

- Mal liz eu. Slas nà me compromete pelo amor do beos, sintó.

Fica diesciusindo. As 9 e meta 1

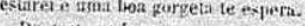

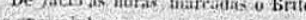
se enciuminhavit para a caka de Iquez. Prelexiato umacera onire amigos elle recusara lexar ciara ia missa. n arosa ticoudercontentecutm a neghuiva mas resignaita.

0 Brito saluo.

As ruas, orciuarnamente calmas e sj. frucioxas. estavam pejalas de povo. Grupos disseminasos pelas esquinas. etm palestra pornegraphica, ou em te- como republicano sincero e -omo patrota devotado, nue tenho o dever de to rns 1 ben patente o meu modo de ver sobrea nossa artualidade po-

Esse dever impóe-so-mo tanto mais, quante m. éimpossivel comprehe ader a nova theoria da netitraitidade politiea tão astuta, cavillosia e traicoeinamente defendida por todosilyu He:; que nầo querendo abs agal francamente a causil da r volta, (por duridarem des situ triumplio, prestio-lhe todavia o seu neutral cum niv, co mo :utores ou trims nissoes de brates prijuliciae Por da legalidade. Porisso, enibor affirma relacion a -revolta - pela votacrio do cestato le sitio e da moció - Bicayuva,bera romo pelo minifesto collertive da firaceâe constiturional dos Dejutados federates mitteiros, pelo mer nifesto que dirigi ag $50^{\circ}$ districto, declarand, $n$ й se candidacto thas futuras eleicoes,-eu aprovirite on fas

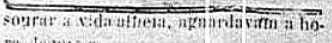
T.1 Alimsti.

Mugis, creancas, mniheres de capote, fieatis, gerolmente,durigıam- iea matrzz othle havia sighta e missti.

O noxilunto no seo crisce ife illtmmnava as ruas cum clardide c ubio.

Encohriñdo-se nn pen umbira das càsas o Bacharel chequa z tú junto a moraviz de d. Carolinn e. recos ando-se a um donoso ceitro, que foptirsin is sta sombra em um grance darui tro. esoorou ii ver si o into Cume homem impacinger.

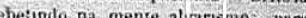
passar o tempo. Os otempo.

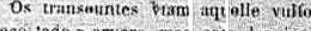
minas setritar im-

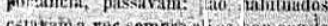
A

becorreram-se vute mintos, cunciderados trorax peia unpo iencai do Britw; mas, utinni, teas, da vetha beata abrio-so estahiratn deas pessoas: era d. Carotuna, muto refiçada, com um ituco. triangularmente dol rato, ua cabeca, e o classicorapote de 60; atras, tegura a Joanfia, envolia eia um chate de ulgolune da cubasi a trunfa conn que encobria a carapinla.

-Ja deviamos lîestar, Jianna; pordemoso fiymnu do menino Jorns. Ando d'abii, falou d, Carolins. to de me serem sentilman-

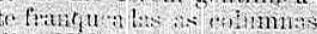
d'A Vida', - parial sncetar uma seri: fic artigos subre o tristr estalo actuial de cousis, tormandu bem arentuada a magia que elle inspira ato met coracio de B zileirso

Comecareit :xarninandosi algum facto poderia authorisal ou justifica a actual revelti, revolta que tem a singularidate de surgir menos de dois mezes antes do dia designado para is pleicócs gerace; revolta, quie apresenta a curinsidade de querer depor ten prezidente de repulica inenos de 6 mezes antr $x$ da epocha marrada pa\& I efricio de

Emphatiea e bombasticamente sè̃o annun iadas, co mo motivo que levilo Snr Custodio a revoltar-se, as Custodio a revoltar-se,
violacóes da constitucicon.

violacóes da constituceno.
Mas a que vislacóes da constituiçù) refere-se s chefe da revolta?

As deposicōes ie Governa dores

Nào; que nó tempo, em

-Inda é muto cedo: aía comeco igitha, thia nis; responden a negra.

-Anda. a disse. Pirteces mais ve tha ds que eu. Bulbeitn alongon os passos para nao gerder os hymnos si cros do natal.

-Qnando de sapparieceram 'no largo Buto sahio da somprumencaminnol se para tase de Irnet

O Antonio ta eataris a porto

-Entios. mierrogout deutar, esth 50 ?

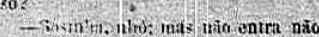
Ticnat no caupromes.e.

-0.4 deix te de histomis; tom 1i. Ho Brato iréonpantieu as palavers cont nemi cesula de cio on mil ress. -Vialhr-me deos coin ance, nho; cemte nie tein geito do negit.

Aindaño tersainara poraze quando a wast gunitos, chegaram doas assob os aquitos epritongudus, como um is

-Ti bìn, obè e tita socegalinn que ed wal ath arrumid un necocio.

E o Antenitr sahio tarrendo no enontro dos hoiben.

Ignez ticon completuniente a sus. Atrindo natadamente a ports efechando-a com a chayet, após st, o Brito panetron ma sala.

A morki, Rerneahenitian, nioc nond ster um crith de surpies.

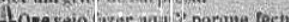

gue ellas se_delam. o snv. nostodio éra, pelo prestigto the adveio do glomioso 23 Nicrembro, a figuramais liente do Governo, e as deposicōes se fizeram, senão por sua iniciativa, pelo menos com o set apก!กษร์.

Alem disso é notorio que ma dis cauras da retiracte iv fici o désgosto com u marehin1. por nio ter este queridd ordemnar que as forcas federies depozessem a Dr. Barbusi Lima. Governador de Pernambaco.

Referiv se-hn o Sr. CustoTieferir an 10 de abml?

ram ar 10 de abrmerir vista 0 pareca, yisto gue, erseegcio Thav wosy pits. thos, todostodio no Aquidabein foram protogonistas d'aquell sediçio abortada, não pode ser. à esses actos que se rehra Chefe da revolta porque rio tempo en cueres se de ilos marnas do Governo tlos magras do Ge cule ho que deportou a gente que no je se occulta pur tiaz dacou

3 porra

- Para que ninguem nos ouca.

Pa deos' aue tuncura! S o vzcom excramou Ig rem rez, colm do fos con as matos rento Eta, antes gue al kuem o veja.

a, antes que alzaenc o vaj. -Nio voul reliro worrer a dense esie moniento la latiohor mina jido.

- Virgem sonta! quer entio desacro hitar-me por loives os meios.

B it moça. cahindo no sofi, pareil thorar.

elle cam ntonacao amorosit.collocante the do emante os braças sabre u homiro com o rosto quasi junto ao della; hailo hores, porque prefiro morrera ver-to taagoada.

-romo nio the nei de alligr, sio ae, haz e a peruicho e o crnme.

-Creance ratrmarou a britó con

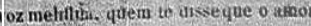
Ira bentigio? quens te disse que era

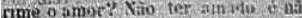
ler vivido: fer azas en nim vear, ier polthöes e nto respurar, ter cerchrn e aio centir. Que crune e gue norihratio ves

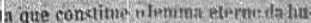

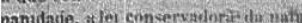

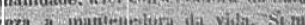

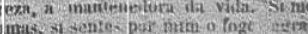


una cuitra cousa eã habitar da giorix: o- mundo somente tinha soffrimentos e yesares," esponcieo a. outri. - Reparassem, $d$ sse a te:ceira, o semblaute de Ctlina, que parecis imagem de santa; que sté porects estar viva, nác lunta se descorndo e tinha assim uns ares Fisonhor. St whis ñ̄o estiresse sem Trespirle, se dizia estar dormando tranquliamente". Na vedace Celima naoștinin semblanie codavericn: shat "Excoes foe nuatinhrom regin $-m \times n l e$, reveiando nåo iorem

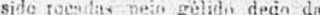
mort

A. hora in rasada partia daquelTa cusa o pr-slito funebre, tevado do o corno de Culina a ses nitumo jazigu. Thado-chopram. egritos ite vehmente dôr eram oucidos no cefatrc via casa:-eram os parentes, ératr as am:gas! Hora angustinsid é por certo a $e m$ oue vemo purtir. par: niv mais loltar, aquelfe ser gue da vida cue nossa vida

Suguia o prestito. frm u:n des ancrivios do cem ter:o testacin...e um jovem pailydi e micilento co. mo u propra morte: immove! co.

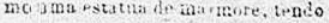
U. Inigguidos ghos fixos inconving

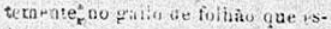
Lava nof tope in eruz de crimte.

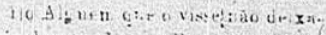
ria te reconhecter at: a inagem da dor. $12 \mathrm{~m}$, conjuncio of soffimen tost.

que naquelle logar aguard rehquias de eno unico umor: queriz abraçal-a pela uluma vez. A acerbal dôr enturpecera the os membros,

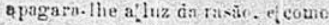
que em estupôr, macisnalmente, estupidamente, nada nuis vin e nem jercebia daque se fasidarm derrecior de si.

O corpo de Celna tei encerrado em uma cataciumba no parečá do cemiterio.

Maitu depoiz de terminatas as eeremonias reliziosas, jà alla noite. Josias despertando daquelie profundo torpốr em que o havia sıbInerğdo a dôr; recordando-se-como se houvera despertado dit sinis. Irc peordelo-do que la ria succecido; depois de certeficar-se de que Dão sorhava, mas que thó tristrmeute revitudad - correors is ao messa b-ijint in jazigo de sua ainavi e segur-ibe com o pranto. Prostatio ano: $\pi$ catacumba, Josias zolta um estricente gonto de tor,

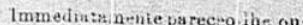
vir. atruvez tas prentes dapuelle sacrario, a voz de Cirlia, que gritave par socestew. Justus curro attomitu. confluso, e tolla cre um ariso yue alle rncont ou, ragem bercilea, forca que the ministrou $\mathrm{v}$ amor, desmorons $\mathrm{em}$ um momento as paredes do cercere de sua amada, tomaa-a aus braços es trextando-a contra si, oscuiando-i wa face frenticameute, delirantemente..

-Amon-se muito, Josias! disso
Cetina estretando-lhe: o rollo, e como vitima phrase nase:cin do a mor. agora exhals ella realmente a via. Jusias, estreitando a mois conin o perio. gritou sutfocado: -

- Ceiina!.. F nmbus tombaram em vidu, no chāo do ceutitetio. em reciproco amplexs.

Assiti como o thonolitho eticsnecente sepulredisi uni

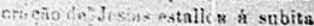
ransicuio que roffreo tis dòr ao pra-

Cilipal tinti sira victims de um Hotito catileptico, e si volthra it vio para celebrar aquolle consorsolumpe. Neatacnmias for o thalamo do ditoso par!.

SANTOS DE CARVALHO

\section{HOSPEDES EVIA JANTES}

Estevecutre noscom a ex. ${ }^{\mathrm{ma}}$ snr." d. Olga eseguio a tomar parte no congreso estadoal nosoo illustrado conterraneo e am. ${ }^{\circ} \mathrm{dr}$. Viriato Masrentias.

Estiveram ent re nos os sr.s Antonine Machato, mtelligente pharmaceutico em Prio Grosso. Vaientim des Reis, Antonio Avelino dia licelia, negociantes em Jequitiba, Vieter Camulio, uegeciante Cordisbm ge, F miscise andido Diniz m S. Quiterit. I div Now ra, viajante da inipritant casa de Cardeso Rang i\&. C. ni Olmpie Amsigocianto no (urvello, Joaquim Pereira de Araujo.

\section{MEFICADO}

PRECOS DOSGISNEROS ENPRIMEIR+ ฟÃOO

Toucinho com carne $15 \mathrm{ki}$ les ..............115000 Toucinho sem carne $15 \mathrm{ki}-$ los $12 \$ 1300$ Sabăo $15 \mathrm{k}$. $6 \$ 000$ Fumo superior $15 \mathrm{k}$. $38 \$ 000$ Assucar brarico " " $7 \$ 000$ assucar brarco " mascavido" $\quad 6 \$ 000$ Algodão herijaceo $15 \mathrm{k} .4 \$ 200$ andigo $15 \mathrm{k} .3 \$ 500$ Café $15 \mathrm{k} .16 \$ 000$ Arro 2 pilado $56 \mathrm{~L}$. $15 \$ 5000$ * com casca $56 \mathrm{~L}$. $6 \$ 000$ Feijao $56 \mathrm{~L}$. 45000 Farinha de rnilho 56 L. 55000 * manilioca 56 L. 6\$0oo Polvilho surerior $56 \mathrm{~L}$. $10 \$ 5000$ Fubá $\quad 56 \mathrm{~L}$. $\{: 000$ Batatinhas $\quad$ ", $12 \$ 000$ Amendoim $\quad " \quad 35000$ Mamons " " Gilho Azeite " 4 45000 litro i\$ooo Sal sacca : $\$ 800$ Aguardents litro \$30o Queijo duzia $3 \$$ a $15 \$$ Rapsdura targa 20\$000

Por falta de espaco ceixamos de publicar diversos artigos.

\section{Exames}

De acordo com o resula mento em vigor procederamse os exames nas escholas prmarias deste districto.

\section{BELLEZAS MUNICIPAES}

Veio ao nosso escrinturio o snr. Joaquim Ferrcicade f. Anna e mostrou-uos um cibo numero $149 \mathrm{~d}$, imfosto sobre afericio de pesos e medidas que a tivibuteco nio possue. Porem o mais original nio é it cobanca indebita $e$ illegal. mas

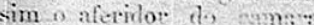
ter dito a victim: ris rollo pessoa que postue engenico e obrigada i ter nesos a modidas, sob pena de multu. $\mathrm{O}:$ gento exemtivo ortenon tal ou o aferidor o fez pos conta provia? +m qualoucr das hypotizeses despamos saber em que lei so fundamenta edilidade para cobras impostos de afericio de quem nio se serve de pesos e medidas para fins commerciass, do quem nio os tem sequer.

\section{APEDIDOS}

COMPANHIA VINICUI TQRA SETE L.AGOANA

Convido os Snr:s accionis tas desta Companhia para u ma assemblea geral extritor dmaria no dia 17 de Dezem. bro p.f., ao meio dia, em ea. bro p.f., ao meio dia, em ea.
sa de minha residencia, parase deliberar sobreaugmento da capital, ou contrahirsc emprestimo, ou entios li quidar-se a Companhia. E pero que nào faltem, a finudo evitar-se maiores despezas prejuisos

Sete Lagoas, 15 de Noventbro de 1 s93.

Conego Raminno Nosicito Vaz dE Mello.

\section{AOCOIIIERCIO}

A Companhi: Cedro \& Cachoeirachamseitroco, nomenor praso possivel, os seus cartóes de trocos meudis Pede ao commercio para $\mathrm{n}$ via-los sem demora a Eabricado Cedro ou da Cachoeira. 1893.

\section{Francisco Mascaren has}

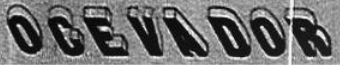

Por falta dievasilhame naio tenho attendido a todos os

pedidos vialus de tora; bre vemente, porera, espero pio encher tal lacuaa.

fios distinctas collegas de imprensa quefranquearnm as columnas ao annuncio do priducto. agrudes e peco quis disponhari do meo mo desto periodico para firo identicos.

A. FosCOLD

\section{minchis of SAPATEIRO E SELIEIRQ}

Belazmino Elivodoes

Grande sortimento de cellioes. stins, arreios, mantas, etc. dis todos os formatos, de todas as qualidades, du suparior cabedal e trabalha dos com capricho. Varizdo sortimento de calcados pura homens. sewhoras, creanca: Tondo samne em depo ito e:un su. aento de wrefisetos de sua profissio o com. jurador pode: ter a sertezy desersem. re ber servidor

por prfecis sem compes dores. As pessoas que se qut: cmeonvencer da verdade vi itemas officinas

Tabcleiro Grande-iinas

\section{OSEVADOR}

tcherse sempre a renda em caca dos senhores:

SimJes. Hocha e C Sete Lasoos. Jalles e Eraire. Hospiero, 2:. Fio. Modestino Rocha, S. Luzia do Ro, das Augusto Mare: Gma. S. Sebast:a Raymundo A. Gonçalves Solefade Joŭo Heariques de Frevias E en totas as casas te commienere de promeini ordem.

Grande degosito e talrica en Tsboleiro Grande.... Shinas.

Cendor dusin 18500 
Nito sando as depnsicies de Guviradions enem as aits de 20 at Abril a causa determuante da revolta, serí esta a yiostrio do Rio is ande do sul?

Tambern nio; porque, embrisa a ella so teitha iembraan de niferir o $\mathrm{Sr}$. Cusind n) sen 2. manifesto, isó no 2. $)$ e certo que iongo tempo sinccionoa, com a sua piesinea no froverno, a mtervencio dieste nos negocios daquelle istado, tomando gresmó parte bastante aztiva n nesmó parte bastante aztiva
zesa intervengào. Demais, r fesino it mais obsecada intelligeacia, não pode deixar ce ser ciaro a disposicio do rue legitima, ou antes inpoe ao Governo, o proced.poe as Governo, o procedi-
inento que teve com aquella jutervengio, nйо podendo por consegainte aer ella inrocada ecmo rolacic da constituigio.

Sera finalmente, como diz o Snr. Custodio, o véto à lei de incompatibilidades para a eleicio prezideneral, o motivo da revoita?

- Ninvé crivel, poryue tendo -ido rose aeto pubiticado no dia 5 de: Setembro, na inadrugadi de 6 comecou a revita, ergo evoluir tem demon-trablix jue ella se achava com grame ante-esdencia greparad.

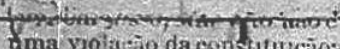
maita pelo contrario, i 0 execcicio die tim direito clara. mente expresso om linss. Estatuto fundamenital. -

Por conveguinte i illogica, inoportatia e injustifico. vel essa revolta, the, portadora do lusu, da jestacio, da morte e cia ruina, hastea, como mais un insulio \& $\mathrm{Pa}$ -

do aue me:ivivenic eduicitica nexisien

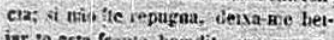
jar to esta fraule beandit: gue menncanta: deixa-nie escular teses labios de rosa que me faccman: deixa tre apertar de enco

C. apezarita reststencis de Isnez, elleacompanhava as patavras of $m$ nectio. escalando, cara fogo, as:era-amente. A fronte, os hbios, etseic. a cibeci ate dominal a cotupletamente petuexertaçä le rolnpia.

Depoisad mats deshsaram se niein extradamonte.?

OBas uto: mirmaron tgiez.

lar-se.

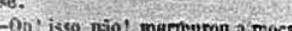
com roz desfaliocith

A lua penetrondo pin ian. . cerrada, lurmou um diadema ce lazem: torno da fromte des dois amantes.

$$
\text { v1 }
$$

Snaram dez horzs no veltho rologo ee parede da fazenda do Major Sila.

Igrez indolentamento recostada sobro a race atina, de quando em rez. abocez en signal de asfado, emgaanin foltheava, enojada da ieitura, um ro- tria, o busneo stim inio da paz?..

Para salvar a cuisutuirio. attenta-se contra tila? Fart extingnir o militarismo, un chefe militar revolta-se cuntra o thefe supremo to poiler legatmente corstilnido: Serat irrisorio, sentio fosse angustiosamente triste, e tristemente deprimente para os creditos de nossi jovem re. publica!.

Mas... ninguem se llly $\mathrm{O}$ que o St. fustodio that? é ser Prezidente da republi-

Deposio wimarechal Fla riano, oven 1.9 substituto legral, o Sr. Prudente de Momes, nico arreitata o poffer, porque, alem de nāo quere pactuar com o Sr. Custudio nà se ynerera incompatilylisar para a futura eleicio plesidential, como caududacto: que $e$.

O2. substituro, Sr. Joîo Lopes, tamben náo acceitarit o podier, apeiador, roms tem sido da politira du marerhal. e adverso, coma te tem mostrado, i revoli:

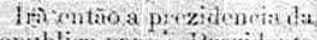
republica parass Prezidente do Suptemo Tribunal Fede al, e esto, ont acceital-i-ha, u tera procedimento igua o dos Priridentes do Senádo e da Camara. No 1. caso eri 6 Sr. Custrdio enton-

preparar sua el icio: nu entregsta o poder ao $\mathrm{Sr}$. Ruy, ou a qualquer outro. Ruy, ou a qua quer outro,
que acceite a fiste empreique acceite a tiste emprei-
tada de fazer cin. Chefe revoltoso de hoje o s zidenta da republica deste infeliz, Bra zil, amanha!!.

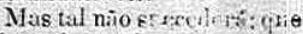
o impedem a hista 4 i dive nidade sios Brazileiros!

\section{mance de Slontepar a}

Tirava us ultus. as rezes. do tivro. para ding t-octem jrente, ao caminho targo. de carro, fita or hracea estenelda ate a povoacto, a ver se percebia algue ti que potesse aticiorar a juella nionotons.

Depors o entade. cheso nos cutros ditix, dommando-a ella ercueo-se, dehruccu-se sobre c alpendre da varinda.

considéerou. . .

Parecar impossivel, absurdo, raaciectavel o ter-se sujestado áquella vida. Que desnlaçao, que unsteza. que vi:sear impreticuo.

A fazenda era horrvel.

Úm cissrrabo enorme, achaparrido com a classica varinda na frente. A somelerra secular estendentio a somhra dos bracos per todo o terreno; sempre-totrosamvanavelmenlecober la de foles; usasamieiro. polypo pro ectande os tentocil os odoriterose dio reos.de:de da pytwira do curral, ont estavaro tronce, ate a varands; a hit cie cera. espiralada num arame, ernatares tandoa frente da cass: 0 aspecto ias perterra, da estracta larga, vermelta, ser penteando atravez do campo e hivivio sapparecer no horizonte; a terra inanuavel sempre a mesma, sempreomos

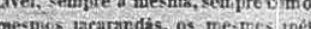
o soliretedo apuelie annuwariento da
Enem o eorvo da monarUitu, yue, sinistro e famin10. ju comeca a esvoagar por some a Patria, conseguir enpolgar a préza cubiçada! Aio, nada disso snccederiti,

Para iricilade + gloria do Bizzil ha de triumphar a canca da legaliciade, que $\dot{e} a$ da Patria e da Republica.

Sete Lagous, 7 de Nacembiro de 1893. 1. Aorllew

Mrjor Lisis Cifs stema

Victemacio por antigos so frimentos talfereo em Sabi-

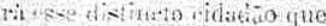
no seio d Hm viver homeste Senty rapar at rousirleraco esestialib los sos conterianeis:

Adiogady inteifigente e il

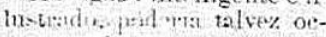

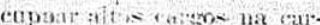

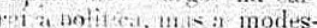

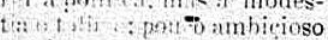

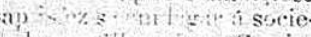
catce that ditho- Sar\% Cissiano, $j+12,1,-2$ thi fat olorias do jor corlomis mis eiro.

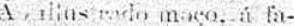
muia do firatios emviamos pezanes de confurdes e de migos.

15 de ช $20: m$ bro

Apezar d esiri. de luet a parra pola fraticida guer ra ateada pelo seniso. Cus folio, a mostimosa banda do musica desta lost não qu deisar $\mathrm{cm}$ silen -io a grand:osiz data do nosel patria 1 assim,com festiva's pecus de musien - fogrtetes, comme moro: o andversario da nossa republica

atmos phera doi montes, tornados qua si regros polo fir no das quermadas.. tudo o gue vai e tudo que o espirito phantasiava acerea da fazanda servia so nente pard angentar-fite o dissabor e (xasr dejejir. sens) dantes, co-
mo seimpre, a volta para a cilafe.

- Vào, a jailla nio podia contuna assim, nis polin..

else curcunstancias terrivais de ura passo loaco.

Apss aquella notts em it 12, inconect onto: se darson arrestar pelos arrophes da puxán. nute te reatura devolu.

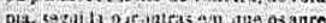

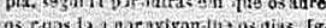
os res

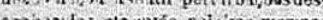
corpo.

Dasparteasi acinate de grave doence que a assaltars. lastiming as s9s estado se n purcaser contulo i gravidade da

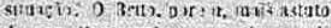

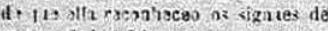
materatiade of fol-a scie ve.

Buerns o sentes actu ta i) - bres ei-

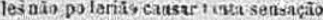
tanto terrot como a juell estado melta droso - feitara di paris. Ternião ascantula nagrezinie e faul, trazenda, conse janta azate, a perdicio de ambus daile, o honen cristo, a sopimatro politico gar vix por osts forma ratas plitico qus via por ost3 forma

Trovado do tumulo! Ao eximio litterato $A$ zevedo Junior

0 baaslar vin agente dos stnos no. companatio da aldsia annunciava a finados. Zerandio nas unil. saerias. a consterançáo, o tucto e $a$ do. pungentisstmu sas coraçoes dnftodos os habutantes da povcaçăo.

Ojadunco estylete da inexuravol. libitula havia cerfado mals ama precios do de ferniviat precoetneute, arrebatanduea do veio daquelia Eociedate, para condusii a ros paramos da uncognoscivel. Era geral a consternaçio. Aajo di: cundurajo belleza perigrina, de uma plastica indiscriplive:. Celina, rosa primaveril da aldera, érk amada nlii até à wieiatzis.

Aforavam-na, rendium cnito \& șa utmia bundade, á sua puichritaan serafic.t. a seos costumes, stugelos; e puriss? a suh inorte subita o inesperad, foi pura aquella gento um hor:ivel frueasso.... Suas ami gas e coispranheiras de diversão deploraviı perial e truts quabam depor is seos pós, a unolesto catafaico, sngelas. mu sint thichtives cordoss entre tr:cida-, Uu- - tit: sandadea r perpettuas, autian de govine sitanades, e to cas orvaliaud to de amarissinio tyrastb.

Si moditata habitacto dos progentrot na celina via-se nma pequean saht forrada de crépe o ar

taves ma: crua - an creumvist 'nharaca, acrercanio-se do cataver. vetavam as, ir.ciosus reatas camiraygtose acusinente)

-Qua éra ella um aujo do cếo e yü ja possone is? Dess fexere 


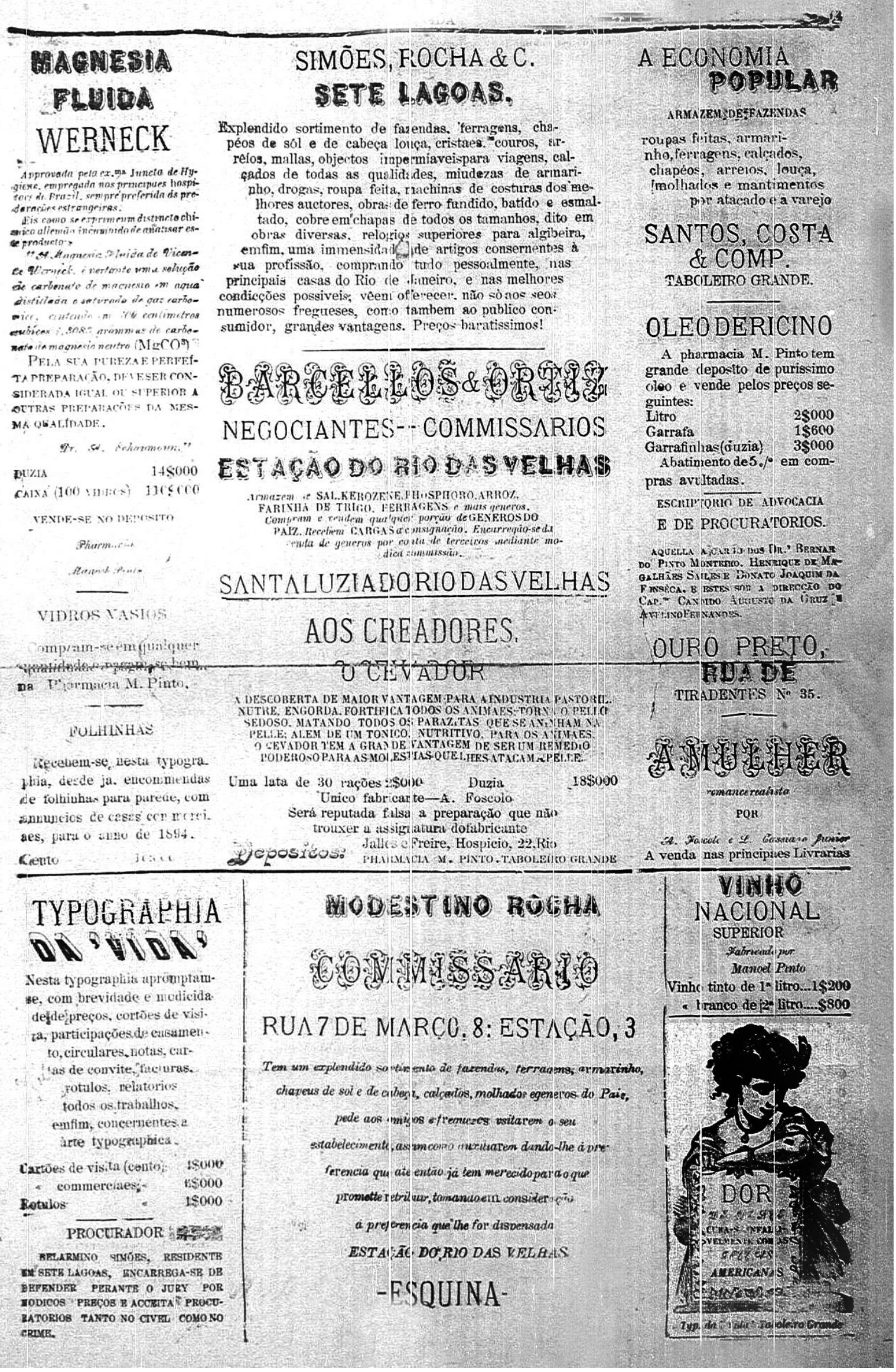

Fonte: Arquivo Público Mineiro 


\section{IMAGEM 12: O jornal anarquista "A Nova Era"}

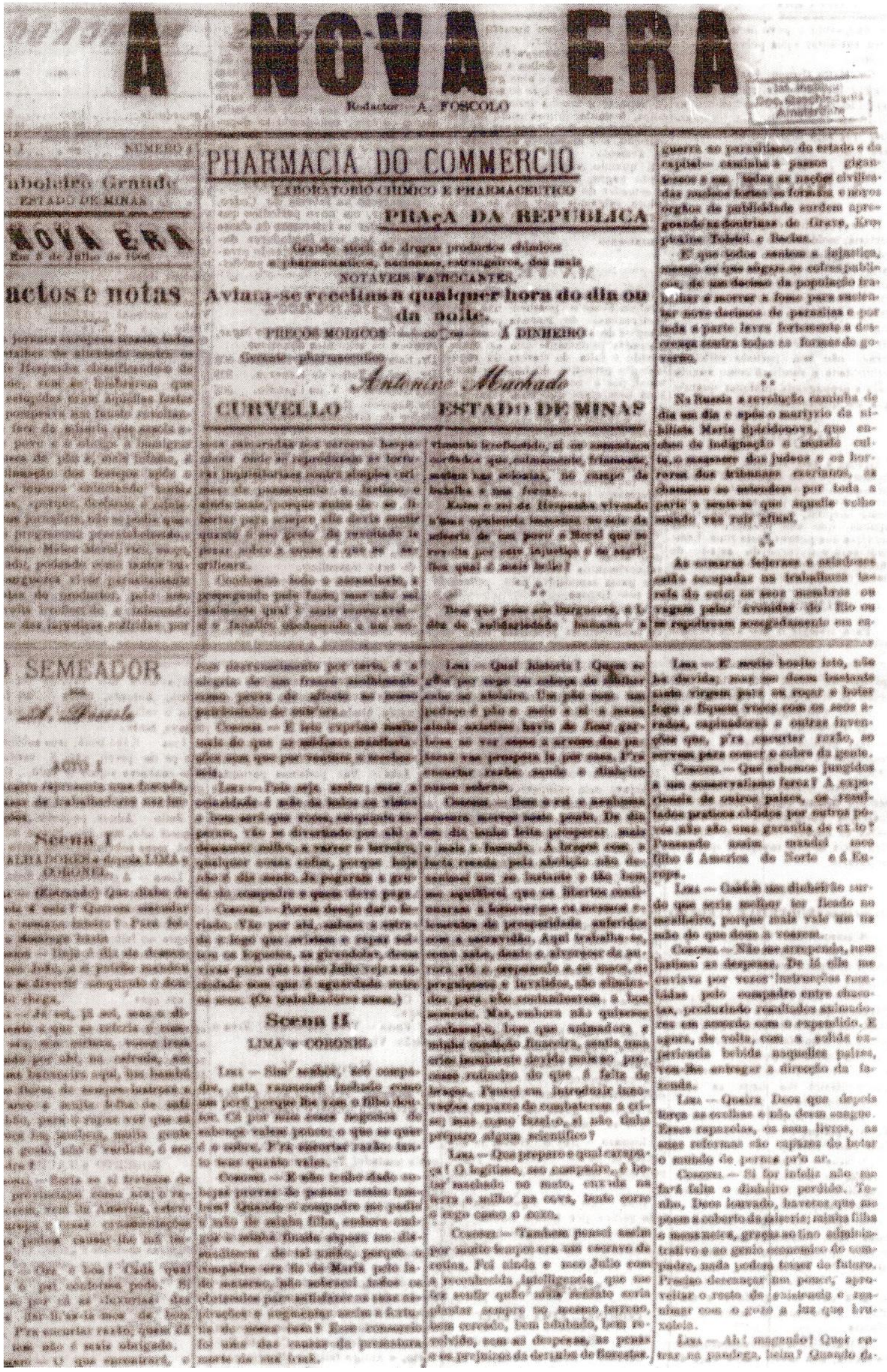

Fonte: Arquivo particular 
IMAGEM 13: O poeta e educador Sabino de Paula Freitas

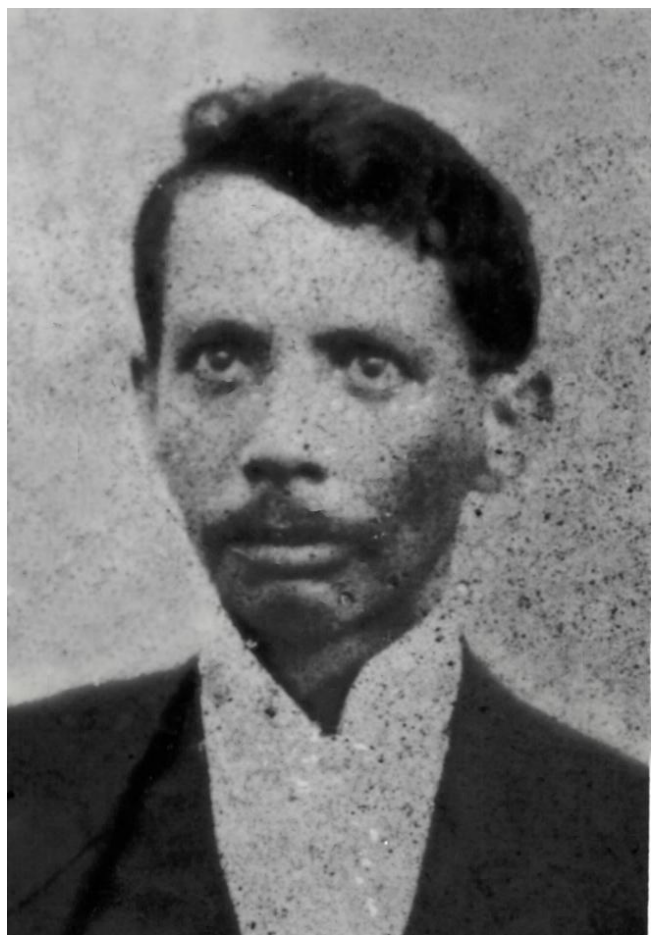

Fonte: Arquivo particular

\section{IMAGEM 14: O sobrado do poeta}

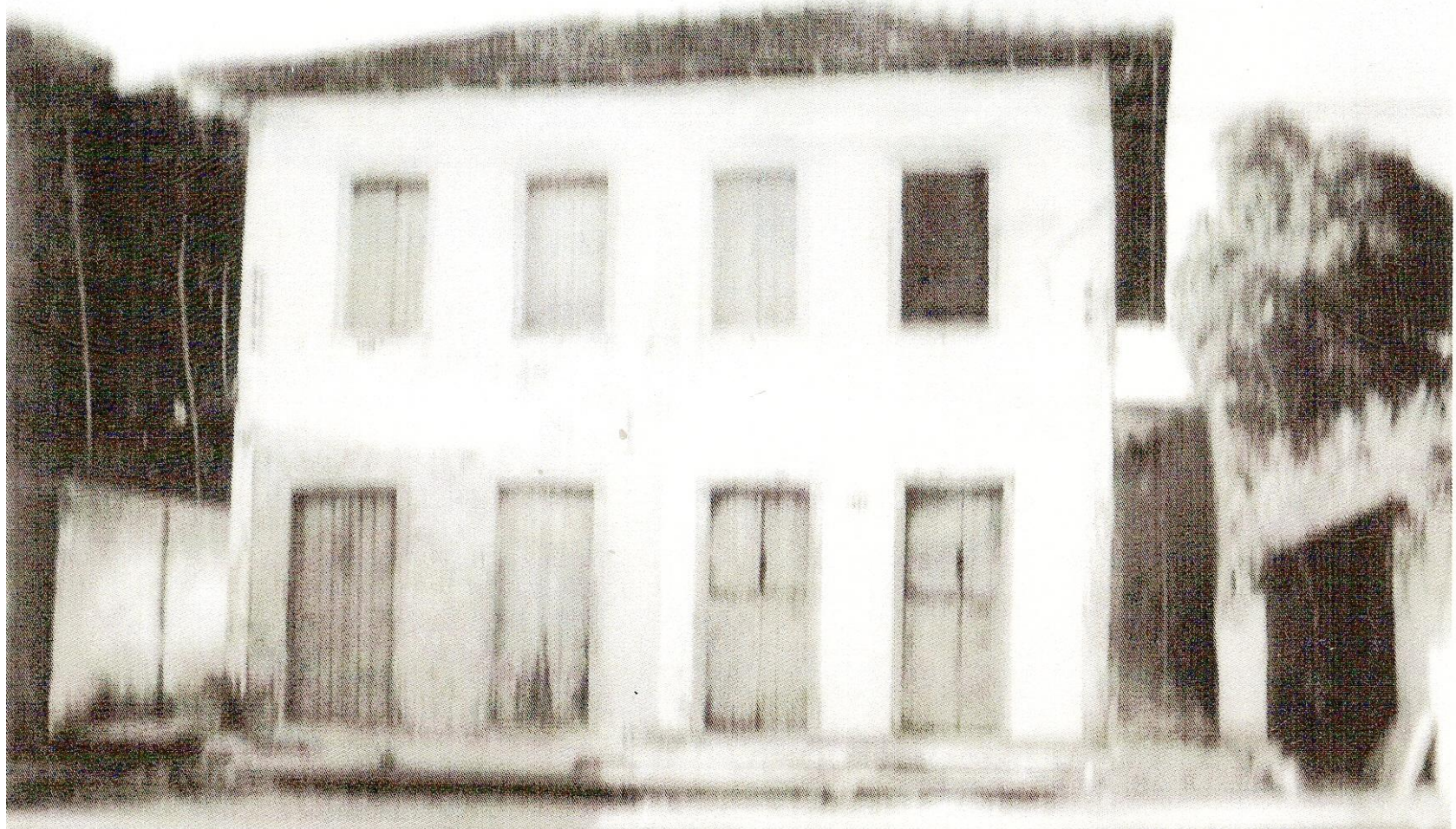

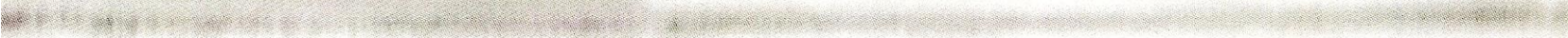

Fonte: Arquivo particular 


\section{IMAGEM 15: O jornalista Manuel Antônio da Silva: "Seu Neném"}

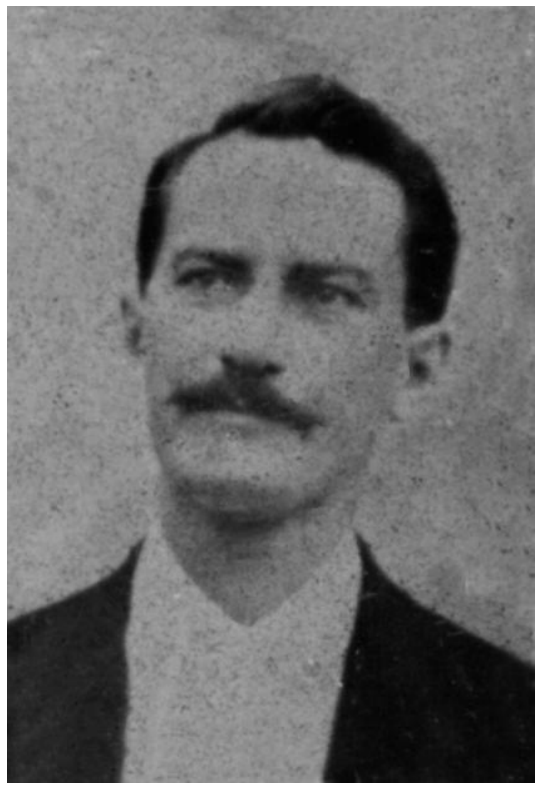

Fonte: Arquivo particular

IMAGEM 16: Crônica do dia da emancipação da cidade feita pelo farmacêutico

\section{Sebastião Ribeiro Vianna}

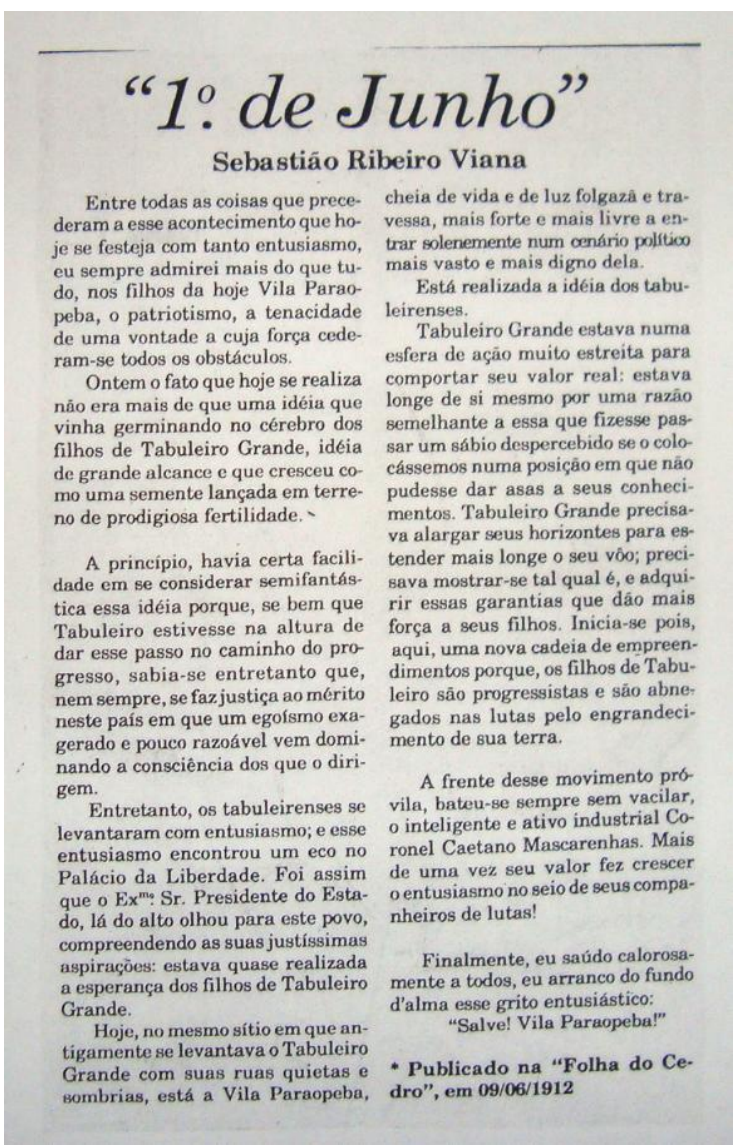

Fonte: Jornal "Folha do Cedro" - Biblioteca Municipal Agnaldo Edmundo - Paraopeba/MG 
IMAGEM 17: Três perspectivas da praça central vista a partir da torre da igreja
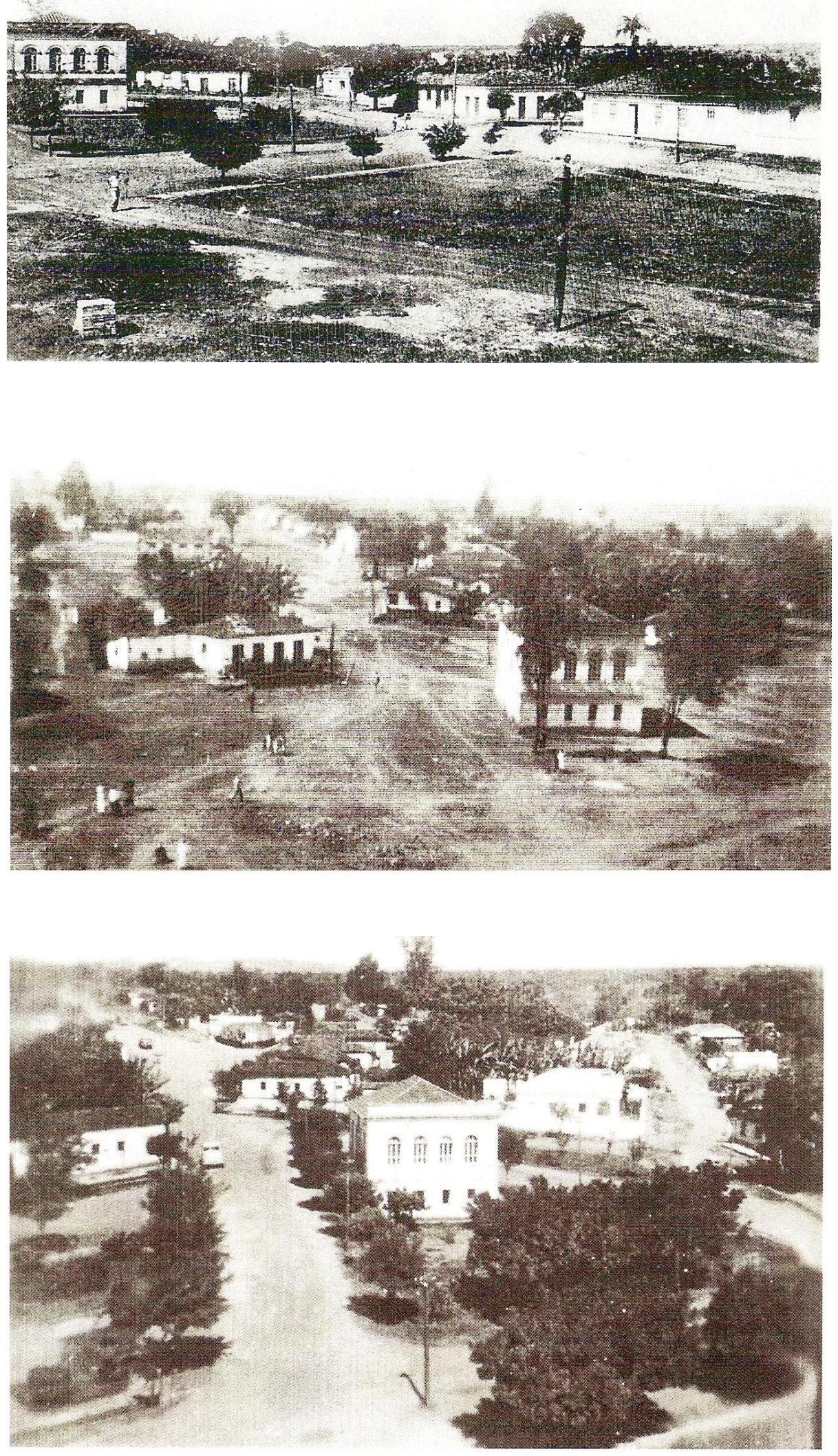

Fonte: Arquivo particular 
IMAGEM 18: A antiga rua direita

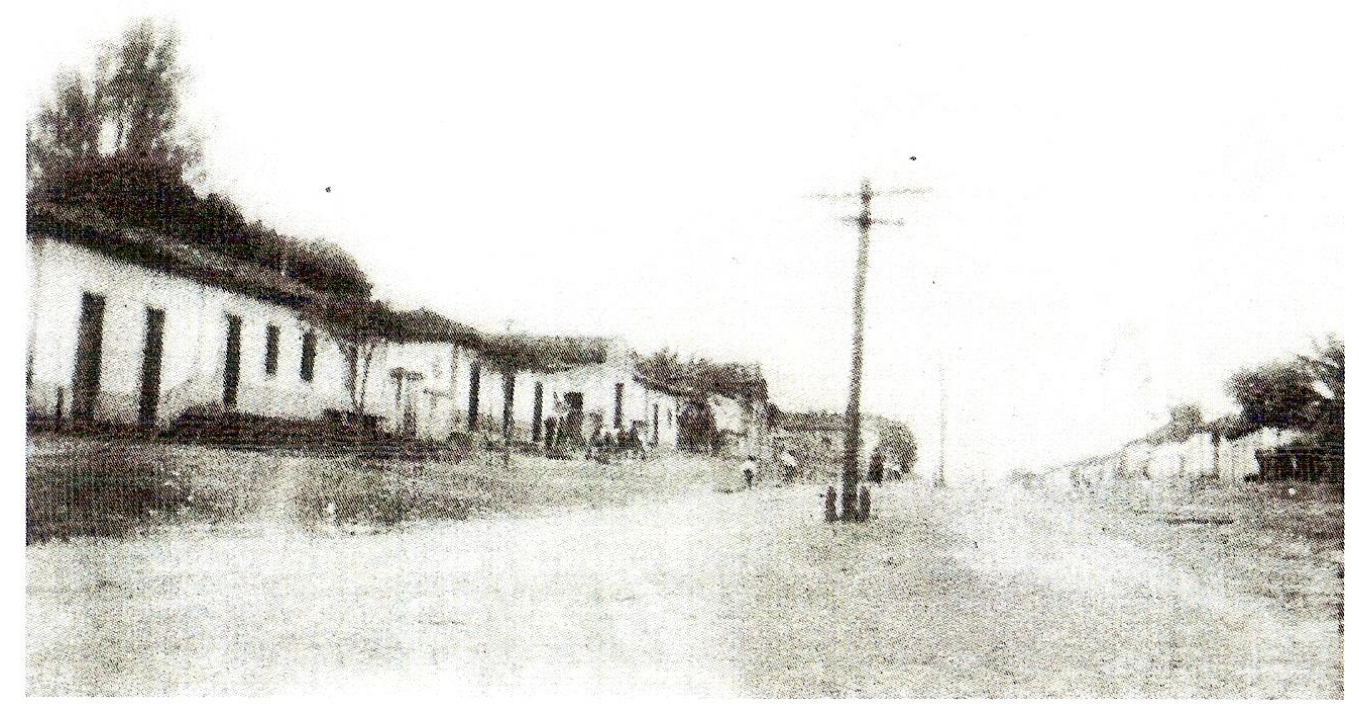

Fonte: Arquivo particular

IMAGEM 19: A praça com o grupo escolar à esquerda

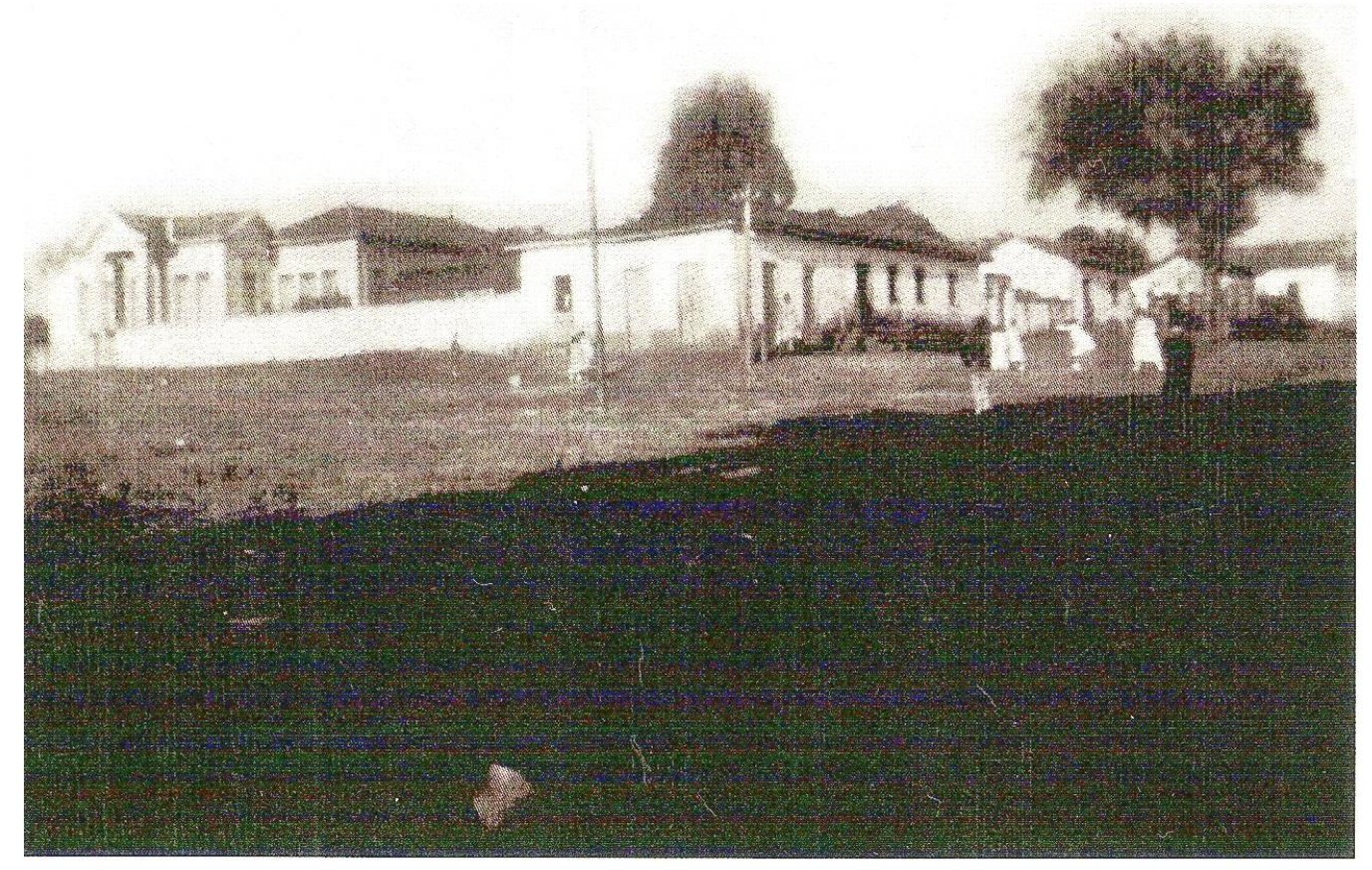

Fonte: Arquivo particular 


\section{Capítulo III}

\section{Lembranças}

De cacos de buracos de hiatos e de vácuos de elipses, psius faz-se, desfaz-se, faz-se uma incorpórea face, resumo de sentido.

Apura-se o retrato na mesma transparência: eliminando cada situação o trânsito subitamente vara o bloqueio da terra

E chega àquele ponto onde é tudo moído no almofariz do ouro: uma Europa, um museu, o projetado amar, o concluso silêncio. (ANDRADE, 1977, p. 365).

E o esquecimento ainda é memória, e lagoas de sono selem em seu negrume o que amamos e fomos um dia ou nunca fomos, e contudo arde em nós ... (ANDRADE, 1977, p. 265).

Pouco importa venha a velhice, que é a velhice? Teus ombros suportam o mundo. (ANDRADE, 1977, p. 111). 
Neste capítulo serão focalizadas as lembranças dos quatro idosos pesquisados. Têm como referências as modulações das memórias subjetivas e sociais dos narradores. Revelando-se agudos memorialistas, os idosos, em cada depoimento dado, nos revelam imagens, sentimentos, que traduzem o trabalho da memória. Estas evocações são confrontadas com lembranças individuais em relação ao espaço da cidade.

São dois memorialistas homens: Sr. Antônio e Sr. José; e duas memorialistas mulheres: D. Geralda e D.Maria Stella. Eles se abriram para o diálogo com naturalidade e empenho. Todos se apresentaram como conhecedores da história da cidade de Paraopeba. Através das histórias de vida, cada um à sua maneira passou a limpo os aprendizados: a vida de família, o tempo da escola, o trabalho, entre outras recordações. Além disso, a cidade surgia, em cada lembrança, com elementos íntimos, mas também conteúdos sociais comuns. Pois, como suspeitávamos, a memória individual também se ancora no grupo, na comunidade e na história da cidade.

Procuramos deixar que o diálogo fluísse. Entretanto, o "tom informal" da narrativa apresentada pelos narradores não excluía um procedimento estudado que favorecesse a condução das entrevistas. Por isso a utilização de entrevistas semi-estruturadas (vide anexo) que contemplassem a análise posterior. De modo que o resultado da elaboração do texto, a partir das entrevistas, desse coesão, clareza e naturalidade aos leitores. Por isso, as entrevistas, transformadas em texto escrito, têm algumas expressões regionais, alguns cacoetes de linguagem, as repetições, as indicações gestuais, e um "tom livre" para as associações. Demonstrando, assim, o vaivém das lembranças. Revelando, entre outras coisas, repetições que atestam o trabalho da memória dos idosos. Ainda que tais lembranças estejam agrupadas conforme o roteiro elaborado.

Estes dispositivos e estratégias textuais, todos conscientes, têm como objetivo apresentar ao leitor o frescor e a naturalidade dos diálogos. Obviamente tendo em mente a linguagem culta como norte e adequação. Assim, apontando para uma linguagem de forma híbrida: oral e escrita. Dessa forma, apresentar aos leitores a intensidade da comunicação, a energia multissensorial do diálogo. Que por sua vez levasse em conta o corpo, o gesto e as múltiplas expressões das palavras; com a finalidade de incorporar às entrevistas situações concretas das lembranças. Enfim, apresentaremos as histórias de vida, povoadas de nomes, eventos e imagens, que nos ajudam a conhecer as memórias individuais e sociais em relação ao espaço da cidade. 


\subsection{Sr. Antônio}

Nasci aqui em Paraopeba, mas na zona rural, completei 99 anos no dia 11 de outubro. Nasci no ano de 1910 em uma fazenda pertinho daqui. Mas a cidade, nessa época, era quase toda um cerrado aberto.

A lida diária era na roça. Mas nós transitávamos o tempo todo. Era um ir e vir para lá e para cá constantemente. A vida era partida, não é? Aqui e lá: comprávamos as coisas para casa, as trocas, a escola... De maneira que a vida era essa partida o tempo todo.

Vivi com meus pais na roça. Junto com doze irmãos. Meus pais eram uma maravilha! Eles eram muito bons com todos os filhos. Eu e meus irmãos combinávamos demais. Todos irmãos criados juntos e sem briga. Imagine só! Tão diferente de hoje em dia em que as famílias têm no máximo dois filhos...

\section{$* * *$}

Minha infância foi boa. Em meio aos bichos e plantas. Mas algo aconteceu que me marcou muito na infância. Recordo de um problema de saúde quando era menino. Eu tinha 3 anos quando fiz uma cirurgia na garganta. Eu quase morri! Estava muito mal, chegou um tio e disse para minha mãe: "tem que levar esse menino para Belo Horizonte". Como aqui não tinha recurso nenhum, meus pais decidiram me levar para lá. Me lembro como se fosse hoje. Chegamos em Belo Horizonte e fomos recebidos por um médico de origem alemã. Esse médico estava ensinando para os médicos de Belo Horizonte. Decidiram aplicar um Raio X. Sabe o que era o Raio $\mathrm{X}$ daquela época? Tinha um aparelho com uma luz na ponta, e com essa luz se fazia a radiografia. Ainda me lembro do trajeto da viagem! Lembro da irmã de caridade e do médico me cortando sem anestesia.

Antes da viagem para Belo Horizonte, fui atendido aqui na cidade por um médico. Parece que era da família dos Mascarenhas. Esse médico tentou resolver o problema na minha casa, sabe? Me cortou, e era sangue voando até o telhado! [Chuá, chuá - as mãos se dirigem ao pescoço]. Eu gritava e minha mãe também. Já a viagem para Belo Horizonte foi com minha mãe e com meu irmão mais velho. Daí esse médico, acho que era mesmo alemão, perguntou ao meu irmão: "Foi você quem fez a cirurgia?" Meu irmão respondeu: "Doutor, foi um médico da região". Indagando, o médico falou: "Não pode ser um formado que fez isso". Aí esse médico fez um curativo, me tratou e me salvou. 
Além desse lado de minha dor, me recordo com clareza das ruas de Belo Horizonte. As ruas eram de chão e só havia um hospital. Isso em 1913, mais ou menos. Eu estava com três anos, ou um pouco mais, acredito?

Lembro do meu pai lendo romances e jornais. Gostava do romance Iracema, de José de Alencar. Lia e fazia comentários. Aprendi a gostar também. Recordo de um livro que li quando era menino. Era o livro de Alexandre Dumas, $O$ Conde de Monte Cristo. Achei esse livro um "romançasso". Estava na roça ainda, mas ainda me lembro que o personagem mata uma dúzia de inimigos sem pôr as mãos neles.

Tenho agora uma lembrança. Uma irmã mais velha comprou alguns instrumentos musicais para nós: violão, viola cavaquinho, pandeiro, caixa, bandolim. Havia de quatro a seis rapazes tocando e cantando. Passávamos a noite cantando. Eu tocava violão, depois comprei um livro de partitura e aprendi as posições. Tinha um rapaz que tocava muito e aprendi a tocar de orelha. Ele tocava e a gente o acompanhava.

Meu pai não era culto. Ele aprendeu as coisas na roça. Ele era um homem que sabia tratar todo mundo bem. Tinha prosa boa, sabe? Ele se chamava Luis Antônio Moreira e a minha mãe se chamava Maria Pereira da Rocha. Ela também era alfabetizada. Sabia ler e fazer as quatro operações, mas nada além disso.

Recordo bem dela. Minha mãe era mais calada, mais dura. Ela era assim: se tomasse antipatia de alguém, aí acabou. Já o meu pai fazia aquele barulhão, mas no outro dia ele procurava a pessoa. Ele tinha um coração muito bom. Minha mãe não, era muito calada, mais fria. Quando meu pai mandava alguém que trabalhava com a gente na roça ir embora, no outro dia voltava atrás.

Agora, com os filhos era bem rígido. Mas quando algum dos filhos adoecia, ele ficava doido. Na hora de corrigir, sempre corrigia. Era bom demais, mas era severo. A gente obedecia a ele piamente, por bem ou por mal. A voz do pai era definitiva!

Não esqueço o fato de meu pai ter romances em casa. Ele lia muitos romances. Tinha sobrinhos dele que iam lá em casa e ele gostava e ler para eles. Lia uma parte e depois fazia comentários. Os sobrinhos dele diziam: "Ô tio, viemos escutar o senhor! Leia os romances para nós!” Era o José de Alencar que ele gostava muito! Havia outros, mas agora me lembro desse. Depois que eu aprendi a ler, gostava também dos romances.

Sabe de uma coisa? O meu pai comprava jornal de São Paulo e do Rio de Janeiro. Gostava de ler jornais também. Comprava e deixava os meninos mais velhos lerem. E depois começou a comprar a "Gazeta de Paraopeba", lá por volta de 1912 que ela começou. Sabe, ele conheceu o Sr. Avelino, que fundou os jornais em Paraopeba, na época do Tabuleiro Grande. 
A "Gazeta" foi do Sr. Neném, mas antes era do Sr. Avelino. Acho que foi lá pelos anos de 1890 e poucos... Meu pai e o Sr. Avelino eram amigos.

Havia uma professora na roça. Meu pai se preocupou em alfabetizar todo mundo, mas era na roça. Meu pai aprendeu a ler aqui na cidade. O vô morava ali onde hoje moram as irmãs de caridade, atrás do atual fórum e da igreja matriz. Era lá na rua da casa do Padre Augusto. Freqüentava escola numa casa, pois não havia grupo escolar. Era por volta de 1860 ou 1870, sabe? Ali morava uma professora. [Fica pensativo, em silêncio]. Ela dava aulas na casa dela. Era D. Virgínia, minha mãe me contou. As aulas eram particulares. Era mais ou menos assim: juntavam uns meninos, meia dúzia, aí ela ensinava.

Meus pais se preocuparam em estudar. Me lembro que havia uma vizinha da roça onde todos eram analfabetos. Havia seis rapazes e uma moça e todos eram analfabetos. Quando meu pai morreu, eu tinha uns trinta anos e ele morreu com uns oitenta e dois a oitenta e quatro anos. Essa escola, onde me pai aprendeu, funcionou por volta de 1860 a 1870. Ah! Minha mãe falava demais na professora, a D. Virgínia...

Recordo que teve gripe espanhola aqui na cidade. Foi por volta de 1930. Muita gente morreu por aqui! Eu era rapazinho novo! Era difícil o recurso para tratamento! Médico era só um - o Dr. Theóphilo Nascimento. Para toda a região: além daqui, Caetanópolis (antes Cedro), Araçaí, Cordisburgo. Fazia o seu trabalho montado a cavalo. Realmente era muito difícil!

Na minha casa na roça teve gripe espanhola também. Dois irmãos meus e um rapaz da roça ficaram muito doentes. Eles tiveram para morrer. Ficaram abatidos, de cama mesmo, com a gripe espanhola. Hoje, graças a Deus, tem prevenção. As pessoas caíam em febre, o corpo doendo e com dificuldade para se alimentar. Mas acabou, graças a Deus. Tenho uma lembrança do Dr. Theóphilo. Ele era especialista em observar os males da região abdominal. Não operava, mas examinava e acertava em cheio. Nem fazia exames. Sei que ele saiu daqui para estudar medicina no Rio de Janeiro. Era também farmacêutico. Tratou de muita gente na cidade.

\section{$* * *$}

Lá na roça tinha um vizinho que era sobrinho do meu pai. Meu tio morava pertinho. Era uma relação muito boa com os vizinhos. Um ajudava o outro. Se um sofria, todos sofriam. Qualquer aperto que um tinha, todos estavam juntos... Isso é até hoje! Tenho nove filhos: são 
nove "pais" que eu tenho. É tradição, não é? É a tradição da família. Me mudei para cá depois que me casei. O casamento ocorreu quando eu tinha 30 anos. Foi em 1945 que me mudei da roça para a cidade. Moro aqui até hoje!

\section{***}

Meu pai e minha mãe trabalhavam na fazenda. Os meus irmãos também. Depois cada um foi casando e saindo da casa. Todos trabalhavam em casa ou na roça. A mãe ficava em casa com as filhas: arrumavam a casa, lavavam as roupas, costuravam. Recordo do meu pai sempre trabalhando. Viajava a cavalo, batia enxada, de maneira que fazia o trabalho da fazenda toda. E era ocupação o dia todo. Já minha mãe criava as filhas na cozinha.

Aqui na cidade tinha pouca coisa. Olha, a gente trazia as coisas da fazenda e vendia na cidade: arroz, feijão, milho. Pois o serviço na fazenda que era duro, lá que pegava. Era o trabalho de lavoura e agricultura. Era nas fazendas que davam serviço para o povo. Havia a Fazenda do Rasgão e a Fazenda do Engenho. Na cidade tinha era o comércio, as pessoas da periferia, quero dizer eram as pessoas que moravam um pouco afastadas da Igreja Matriz.

Há uma história que aconteceu na roça. Quando eu nasci já não havia escravos, mas tem uma história que aconteceu com a minha família. Os escravos, sabe Neuber? Existiam muito na Fazenda do Engenho, sei que lá tinha um preto velho. Quando chegava um empregado, todos ficavam mudos... Era cheia de negros. Aqui, já era do Barão Antônio Cândido, que era dono da Fazenda do Rasgão.

Como lhe falava, meu avô, pai do meu pai, conheceu uma situação precária. Meu pai era o segundo filho, meu tio saiu logo de casa. Lá na roça havia um negro chamado Chico; ele era uma fera para trabalhar. Meu avô contou para meu pai que o Barão era doido com o Chico. O Barão falava com meu avô: "Vou comprar o Chico na sua mão". Meu velho avô ia vender o Chico, mas meu pai não estava dando conta do trabalho sozinho. Mas meu avô ainda tinha o Chico. Foi então que o Chico ficou sabendo do possível negócio... Daí o Chico falou: "Sinhozinho, eu não quero ir para a Fazenda do Rasgão de jeito nenhum".

Diante das dificuldades, meu avô estava com dúvidas. O Chico estava sem saída, pois meu avô falava com ele: "Olha Chico, eu estou devendo, doente e não estou agüentando". Foi aí que o Chico retrucou: "Vamos trabalhar". Meu avô fez a proposta para meu pai: "Oh, Luiz, você tem o Chico, quer enfrentar a lavoura com ele? Tem uma roça para lavrar".

Então os dois foram para o mato, roçaram e plantaram uma roça. O resultado foi bom: colheram muito milho e algodão e depois venderam. Com isso os dois puderam pagar tudo o 
que deviam! Isso tudo por causa do Chico. Ele provou que era bom mesmo no seu trabalho. Junto com meu pai, o Chico reverteu a situação. Então acabaram as dívidas.

$\mathrm{Na}$ época do meu avô, o Chico tinha sido escravo. Meu avô morreu e ele ficou com o meu pai. Ficou com minha família até se casar. O Chico era amigo do meu pai. Depois que acabou a escravidão, continuou na roça da minha família. Ele era mais velho que meu pai. Não o conheci, foi meu pai que me contou essa história. Eu ainda era solteiro quando meu pai morreu. Sei que o Chico não quis ir para a fazenda do Barão.

Aprendi o trabalho de carpinteiro com meu irmão mais velho. Trabalhava com ele na roça construindo engenho, casa, porteira. Ele tinha paciência em me ensinar: "risca assim a madeira, corta assim...” Eu estava longe de sua capacidade. Ele era um mestre! Quando não trabalhava com meu irmão, cuidava da roça. Ia moer cana e fazia açúcar e farinha.

Digo a você, acho que tem uma ciência nesse ofício. Para fazer uma porteira, de uma porta, precisa de uma régua para medir. Diferente do eletricista que seu trabalho é 8 ou 80, o carpinteiro pode consertar seus erros... Acredito que esse trabalho não deixa de ter "arte". Veja só aquele telhado [aponta para a casa vizinha], ele tem uma arte, porque é bem feito, certo? Precisou de tempo e conhecimento para ser realizado. Isso é arte! Quando o carpinteiro foi construir esse telhado ele já pensava. Assim, quando eu ia fazer um trabalho de carpinteiro, ele já estava na minha cabeça. Na minha mente eu já o via como bonito. Quero assim, tinha que ser assim! Na minha mente já via. Vou lhe dar um exemplo: quando aprendi a fazer um tear, foi muito bom. Isso foi quando comecei a trabalhar na fábrica. $\mathrm{O}$ tear tem arte: tem os movimentos da lançadeira - vai de um lado para o outro; para lá e para cá [faz os gestos com as mãos imitando o movimento do tear]. Mas na roça era mais simples. O serviço era mais grosseiro do que este. Mas, por exemplo, o moinho movido a água tem arte. A água batia no rodízio embaixo, em cima era preso por uma pedra, daí a pedra moía o milho, e depois ia virando fubá. De modo que a arte está em pensar e realizar o trabalho que saía das minhas mãos, entende?

Minhas lembranças trabalhando com meu irmão são muito boas. Ele era o mestre e eu o aprendiz. Eu era obediente e quando terminava as minhas tarefas chamava meu irmão para ver os resultados. Daí fui aprendendo aos poucos o trabalho de carpinteiro. Quando comparo o trabalho da roça com o da fábrica, vejo como eram diferentes! Na roça era o meu pai que mandava. Na fábrica era o gerente e aquele tanto de puxa-saco querendo mandar. É a lei do salário mínimo. Quando alguém ia pedir um aumento era essa a resposta do gerente. Adoecia, tinha que pegar atestado com o médico. Na roça não era assim: se alguém ficava doente, ia 
para a casa se cuidar. Na fábrica existiam muito ciúmes e disputa, até eu fui vítima dos ciúmes por parte dos superiores. Por que havia feito um bom serviço...

$\mathrm{Na}$ fábrica havia o cartão de ponto. Não podia se atrasar. $\mathrm{Na}$ roça não tinha hora. $\mathrm{O}$ relógio era o sol! O sol nascendo, a gente começava o trabalho, o sol se pondo, era chagada a hora de parar. Se precisasse, a gente fazia o trabalho até a noite. Era uma liberdade só! A gente trabalhava mais alegre. Já na fábrica, muitos companheiros não se adaptavam ao sistema. Eles não agüentavam. Me incomodava era ser vigiado, a pressão dos colegas, do chefe me olhando. Apesar da fábrica na minha época ter poucos recursos, acho que naquela havia poucas máquinas. Ah! Mesmo assim era uma mão-de-obra danada. Tão diferente do trabalho na roça...

\section{$* * *$}

A única escola da cidade era o Afonso Pena. Em todas as regiões, seja rural ou mesmo dentro da cidade. Todo mundo freqüentava essa escola: o Boqueirão, o Mocambo - todos estudavam nesta escola. Uns iam e voltavam, outros não. Meu pai comprou uma casa aqui. Freqüentei a escola até os 12 anos. Quatro anos no grupo e depois não voltei mais.

O grupo escolar, como falei para você, não tinha nem muro. Lembro que as aulas devem ter sido iniciadas, mais ou menos, em 1917, 1918. Depois veio o diretor, o José Augusto Rezende. Era mais ou menos essa data. O prédio era novo, de pouco tempo. Foi em 1920, pois eu estava com doze anos.

Gostei demais quando vim estudar aqui na cidade. Havia um salão com duas salas. Era menino, vinha aqui com meus pais, por volta de quatro horas da tarde. Lembro demais dessas aulas lá no salão. Você sabe! Era uma escola onde hoje é o posto de saúde. Lá foi escola antes do grupo Afonso Pena. Vinha gente do Cedro (hoje Caetanópolis-MG) e andando a pé. Lembro delas demais! Eram duas irmãs, as professoras dessa escola. Depois foi quartel de polícia, até ser posto de saúde.

Essa escola era mais antiga que a escola Afonso Pena. Ah, era por volta de 1900. Lá não havia nem diploma. Era assim: aprendeu, aprendeu; não aprendeu, não aprendeu. Agora, depois que passou para o grupo Afonso Pena, mudou, sabe? Era escola pública, passou a ter diploma. Ah! Como o tempo passa. Eu sou mais velho que a cidade uns dois anos. A cidade de Paraopeba tem uns 96 anos. Era vila, depois passou a ser cidade. Já era rapaz nessa mudança. 
Eu vinha segunda-feira de manhã para a escola. Saía cinco horas da manhã, sete da manhã começavam as aulas. Estudava segunda, terça, quarta e depois voltava na sexta e sábado. A folga hoje em dia é no sábado, mas na minha época era na quinta-feira. Portanto, quarta-feira depois da aula eu voltava para a roça e depois retornava na sexta-feira. Quando terminavam as aulas, no sábado, voltava outra vez para a roça. Domingo era a outra folga da escola. Só depois é que começou a guardar os sábados.

A vida era para lá e para cá. Isso tudo a pé! Lembro como se fosse hoje! Meu número de chamada era 360. A soma de todos os alunos era 360. Hoje só um salão dá mais de 360 alunos. Naquela época, acho que só tinha escola aqui e no Embiruçu. A comunidade da Picada e do Boqueirão não tinha escola. Havia dois turnos: de 7:00 às 11:00 horas e de 12:00 às 16:00 horas.

No começo da minha aprendizagem foi diferente. Tinha uma coisa muito engraçada, vou lhe contar um caso: naquele tempo meu pai pagava uma professora na fazenda. Juntava com os vizinhos lá na roça e fazia uma turma de 10 a 13 alunos. Eu tinha, nesse tempo, 7 a 8 anos. Além de mim, havia três irmãos mais novos do que eu. Só que na roça, Neuber, a professora ensinava era matemática, a ler e a escrever. Fazíamos ditado também. Não ensinava história, nada de geometria. Me lembro de dois professores lá no mato, na fazenda. Quando entrei na escola, meus irmãos tinham a idade de mais ou menos 10 anos; 8 anos; outro com 6 e o último com 4 anos. Meu irmão de 8 anos e eu viemos estudar aqui na cidade e os outros ficaram lá.

Daí fomos matriculados no grupo escolar Afonso Pena. A diretora foi aplicar um teste em nós dois. Em mim e no meu irmão Luís. Nós dois tivemos nota para ir para o terceiro ano. Mas a diretora disse: “É uma dó, sabe!” Meu pai perguntou: "Por que?”. Ela foi bem sincera: "Seus dois filhos não conhecem nada de história, nada de geografia, nada de geometria. Mas em matemática, ler e escrever, eles dão show".

Sendo assim, fomos matriculados no $2^{\circ}$ ano. Eu tinha 10 anos nessa época. Quando estávamos no meio do ano, eu e meu irmão, que conseguimos compreender. Estudávamos geografia e história. Havia contas, música - ah, os comentários sobre a história. Na roça não tinha nada disso.

A minha primeira professora era uma Mascarenhas chamada D. Corina e era muito boa. Quando fomos fazer a matrícula, era outra professora. Você se lembra do Olavo? Era parente dele, e também muito boa professora. A convivência entre os alunos e as professoras era muito boa. Entre as crianças também... Tinha muitas brincadeiras... Consigo lembrar de todas as professoras que tive: D. Corina, D. Anésia, D. Alvina e D. Mindita. 


\section{***}

Naquele tempo de escola eu tive outra experiência de aprendizado. O professor Sabino de Paula Freitas, que hoje é nome de escola, foi meu professor em seu sobrado. "Seu" Sabino, como era conhecido, chegou na cidade com seu irmão, o bispo D. Cirilo. Eles eram raça de gente brava do Norte de Minas. Acho que nasceram em Capelinha ou Paracatu. Adoravam esta cidade. O Sabino casou-se aqui e aqui foi professor durante muitos anos.

O professor Sabino era muito culto. Sabia inglês e francês. Me lembro dele dando aulas de francês em seu sobrado onde morava. Isso ocorria no início do século XX, lá pelos anos de 1920. Soube que uma época morou em um sítio na região da comunidade do Retiro, zona rural de Paraopeba. Lá foi picado por um maribondo no olho e ficou cego. Era magrelo, nervoso, fechado e, juntando tudo isso, dá para perceber que não era bonito. Mas era muito competente. Grande orador, sempre fazia discursos. Não sei por que foi morar na roça, ele não sabia fazer esse tipo de trabalho. Lá, infelizmente, foi atacado por marimbondo e foi marcado para sempre.

Mesmo fechado e bravo, tinha amigos. O "Seu" Neném foi um deles. "Seu” Neném fundou a Gazeta e era aprendiz do "Seu" Avelino. O professor Sabino era muito católico, sei que ele subia para o cruzeiro da cidade para fazer suas orações. Recordo também que, além de professor, foi prefeito da Vila Paraopeba. Como prefeito, foi honestíssimo e não deixou dívidas. O cofre público ficou cheio!

Mas como estava lhe contando, era um professor muito bom. Uma época, o meu pai me mandou fazer aula particular em sua casa. Ele dividia a turma em uma sala no andar térreo do sobrado antigo. Uns meninos como eu fazia as aulas do primário e um grupo de maior idade fazia aulas de francês, de modo que ele podia dar atenção aos dois grupos. Recordo também um incidente nessa época. Eu tinha um colega que era um capeta. Quando o professor Sabino foi dar atenção à turma de francês, ele pegou sua cadeira e a colocou em falso. Assim, quando foi assentar, virou de pernas para o ar. Ficou bravo demais... Mas como toda pessoa honesta é difícil ficar rica... Ele gostava era de ensinar, das palavras!

Há um episódio que aconteceu quando era rapazinho. Estava estudando na escola, acho que era na década de 1920, mais ou menos. Era o caso do farmacêutico chamado Sebastião Ribeiro Viana. Depois ele se tornou padre. Parece que ele vinha da Pontinha, uma localidade que tem muitos negros aqui da cidade. Avistou uma luz, amarrou o cavalo e foi dormir. Ao acordar, não havia nenhuma capela. Ficou atormentado e se converteu, e foi estudar para padre. Daí, já quando padre, foi celebrar na igrejinha do Rosário e lá foi 
provocado por uma prostituta. Ela o insultava, sem remediar a situação, acabou excomungando essa mulher. Eu era rapazinho e ouvi isso na escola...

O padre Sebastião era muito inteligente, tinha boa aparência. Mas antes era boêmio, ateu e escrevia na "Gazeta de Paraopeba" falando mal da igreja. Soube que depois da conversão dele, ele pediu perdão ao padre Augusto Horta. Chegou até a morar com ele. Não me esqueço dele! Porque, quando era farmacêutico, tinha uma farmácia no Cedro e assistia a toda região. Ele se formou para farmacêutico na cidade de Ouro Preto. Bom, mas estava dizendo, acho que já lhe disse isso, mas foi ele que ajudou na minha cirurgia na garganta quando eu tinha três anos de idade. Eu havia me engasgado com milho. Minha mãe me contou que foi o padre Sebastião junto com o médico que me salvou; ele ajudou a me dar os primeiros socorros. Assisti muito às missas dele: era virtuoso e cerimonioso. Depois saiu daqui da cidade. Não sei para onde foi. Recordo que as pessoas falavam assim: "Que padre se tornou o Sebastião, heim?" Ele tomou um chicotada lá de cima! [aponta para o céu]. Sei que passou a vida pedindo perdão ao padre Augusto, pois ele depois de ordenado foi morar na casa desse padre. Como lhe contei, o Sebastião quando era ateu, atacou muito o padre Augusto e a igreja... Sei que trabalhou na comunidade do Cedro. Sei também que ele seguiu seu destino.

\section{***}

As casas aqui, na cidade, em sua maioria eram muito simples. Todas meio perdidas no cerrado. Eram mocambos de palha no meio do mato. Com piso de chão batido e camas feitas, muitas vezes, de bambu. Paredes de adobe onde se podia ver os buracos quando o sol batia... Era uma pobreza! Acho que as pessoas nem percebiam isso. Apenas iam vivendo.

Havia a casa da D. Anésia, muito antiga e grande. Sei que antes da D. Anésia, ela pertenceu ao Manuel Pinto. Eu era bem criança, mas me lembro dele. Era alto, branco. Ele também foi, acredito, o primeiro farmacêutico dessa região. Ele exerceu esse trabalho no século XIX.

Outra casa que se destacava era o sobrado da família do professor Sabino. Ele ainda existe e foi transformado em uma gráfica. Meu pai me contava que antes da família do professor Sabino, que chegou aqui em Tabuleiro Grande no final do século XIX, início do século XX, esse sobrado pertenceu a um amigo do Barão Antônio Cândido Mascarenhas. O Barão era dono da Fazenda do Rasgão. Sei que o Barão deu a esse amigo as madeiras para concluir esse sobrado. Dizem que era só para amigo avistar a sua fazenda. Naquela época, era tudo cerrado e se podia avistar a fazenda. Deve ficar a mais ou menos $2 \mathrm{~km}$ de distância o 
sobrado da fazenda. Hoje esse sobrado está no centro de Paraopeba, sei que este sobrado era a casa da D. Anésia, deve ter quase duzentos anos.

Esse sobrado tem histórias! Quando o professor Sabino morava nele, cheguei a visitálo. Fui aluno dele também no Grupo Afonso Pena. O professor Sabino era cego de um olho, pois foi picado por um marimbondo. Sua mulher se chamava Maria. Mesmo cego de um olho e magro era bravo demais. Ele falava bem demais a língua francesa. Gosto de contar isso, eu já lhe contei? Nesse sobrado chegou a alfabetizar alguns alunos, mas também ensinava o francês. Lembro que aprendi algumas frases: "Bon jour, mon ami...”.

A paisagem da cidade se transformou. Mais abaixo desse sobrado, onde hoje era o prédio da rodoviária do Tolentino, que foi desativada, havia era árvores enormes. Era um coqueiro e um pé de barrigudo. Ao lado, era a casa e a capela do bispo D. Cirilo, que era irmão do professor Sabino. Eles vieram, eu acho, de Capelinha ou Paracatu. A mãe do D. Cirilo e do Sabino era uma mulata forte, quase preta. Esse bispo, em sua casa, plantava parreira e fazia vinhos. Veja só, hoje, nesse local são lojas e um banco. A própria farmácia do Avelino Fóscolo, a farmácia Fóscolo, era ao lado da casa do D. Cirilo. Até os nomes das ruas mudaram. A rua aqui de casa se chamava rua da Palha, hoje se chama rua Avelino Fóscolo em homenagem ao Sr. Avelino que fundou o jornalismo aqui na cidade. Até a rua do sobrado da família do Sabino, que chama hoje Av. Getúlio Vargas, já se chamou rua Direita. É, as coisas mudam mesmo!

As casas da cidade eram muito diferentes. Eram mais modestas. Lembro-me que naquela época, a maioria das casas era construída de adobe. Não havia tijolos como os de hoje. As telhas eram do tipo redondo, como aquelas que eram modeladas nas pernas. $\mathrm{O}$ barro era colocado na altura das coxas para se conseguir o formato de telhas. Mas também existiam telhados feitos de palha, capim. Na roça era muito comum esse tipo de telhado, feito com capim retirado do cerrado.

As paredes não eram pintadas, no máximo passava-se cal. As portas eram, algumas, de madeira rústica. O piso da casa era de chão batido. Quando as pessoas tinham uma condição econômica melhor colocava-se assoalho feito de tábuas corridas. Os móveis eram simples! Um fogão a lenha, cadeiras e bancos de madeira fabricados à mão. Guarda-roupa era raro! Havia uma caixa de madeira, parecendo com um baú, para colocar as roupas. Luz e água não existiam. A luz foi chegar aqui na cidade com regularidade depois da década de 1950. Tanto que as pessoas faziam cisternas ou buscavam água nos minadores. Havia uma mina d'água onde hoje existe uma avenida asfaltada. Também não havia banheiros, mas sim fossas no 
fundo do quintal. Nem se falava em rede de esgoto. A luz era de velas ou lamparinas a querosene.

Daí dá para perceber de como as casas eram pequenas! Quartos pequenos. Os bichos de estimação faziam parte da família: cachorros e gatos, galinhas e patos. As galinhas ciscavam no terreiro e não deixavam as cobras entrarem em casa. Criávamos porcos também. Eles davam a banha para cozinhar. A horta sempre verdinha! Havia alface, couve, taioba, tomates bem vermelhos. Além dos canteiros com plantas medicinais. Todos plantavam um pequeno canteiro no quintal para os chás medicinais: camomila, funcho, alecrim, boldo e tantos outros.

Quando era moço, estava quase todos os dias por aqui, onde hoje chamamos de centro da cidade. Tomávamos banho de bacia. Mas quando estava na roça passava um riacho perto de casa para tomar banho. Levava um sabão preto na capanga e antes de chegar em casa me banhava. Dormíamos bem cedo! Por volta de 8 horas da noite (20:00 horas) já estávamos na cama, pois no dia seguinte, antes do dia amanhecer, já estávamos nos preparando para o trabalho.

As casas da cidade eram simples. Havia as casas das pessoas que tinham mais dinheiro. O casarão da D. Anésia, o sobrado do poeta e professor Sr. Sabino, as casas da praça da Matriz. Tanto que não falávamos os nomes das ruas. Era assim: a rua do Sobrado, a rua de fulano ou beltrano. Nós identificávamos o nome da rua pelo nome da pessoa mais velha daquela rua. Sabe que quando eu era menino a cidade só tinha por volta de 3 mil habitantes?Agora, a cidade cresceu muito. Havia os mocambos, casas com telhados de capim, como já lhe disse, ao redor da região central da cidade. Mas a cidade era pequena! Acima daqui era só cerrado. A igreja do Rosário hoje faz parte da região central, mas antes era um cerrado cheio de poeira e árvores como o Jatobá e o pequizeiro. Assim se desenhava, ao redor da igreja matriz, pequenas casas...

\section{***}

A cidade daquela época era muito diferente! Aqui, tudo era cerrado! Aqui nessa casa era cerrado, não havia quase nada. O grupo não tinha muros. Era todo aberto. Nada além de cerrado. Isso era 1920, eu nasci em 1910, uai!

Eu sei mais ou menos como surgiu a cidade. Tinha um português, esqueci o nome dele, estava de passagem por aqui. Então encontrou uma onça e começou a fugir. E para se 
livrar do ataque dessa onça fez uma promessa para Nossa Senhora do Carmo. Estava em cima do pau e prometeu à santa que todo o horizonte à sua frente ele daria para ela. Então a onça foi embora. Sendo assim, construiu uma capela em homenagem à santa. A capela foi construída onde hoje é a Matriz de Nossa Senhora do Carmo. Depois, se fez uma casinha perto da capela, um boteco e assim foi... Daí foi que começou o Tabuleiro Grande, como era chamada a cidade naquela época, a comunidade ia surgindo em volta da capela.

Tenho algumas recordações da cidade antiga. A igreja da praça foi demolida, não é? Aliás, mais de uma vez. A praça era muito diferente do que é hoje! Havia ali, por baixo da igreja, um armazém. Naquele tempo a gente chamava de venda e também de armazém, não se chamava loja. Esse armazém tinha de tudo: de seda a toucinho. Era tudo misturado, a gente comprava muitas coisas. Olha só, me lembro de comprar: carne de boi, miudezas e armarinhos - secos e molhados, sabe? Também feijão, arroz, farinha, açúcar, rapadura. Roupas, casimira... Ficava perto da Matriz. O dono desse armazém era o Martins dos Reis. Foi o primeiro que conheci nesse negócio. O outro era o Galdino e também o Sr. Dino. Depois, indo descendo da praça, indo em direção à fabrica de tecidos, havia também um armazém que era do mesmo tipo. Existiam muitas mercadorias: de calçados a "trem" de comer. Mas era um armazém e não uma loja.

Uai! A praça da matriz era bem grande mesmo, sabe? Não tinha as palmeiras que tem hoje em dia. Não tinha o fórum. Ela era enorme! No meio da rua tinha um moinho de vento. Era um moinho d'água. Ficava na frente da casa do padre. No meio da praça.

Havia outra diferença na praça da matriz. Onde hoje é o Fórum fazia parte da praça. As ruas eu acho que são as mesmas. Não mudou. A diferença é que não existia luz elétrica e nem água encanada. A água que usávamos era lá de baixo. Havia um minador. Jorrava muita água. Agora fizeram uma avenida nesse local. Lá onde tem a ponte, sabe? Recordo das mulheres lavando roupas por lá. Buscávamos água para beber era lá! Depois veio a energia elétrica, os poços artesianos, e aí melhorou!

Você, Neuber, sabe o que é um moinho d'água? O povo chamava de moinho de vento [fica pensativo]. Ele puxa água, como cisterna. Sei bem disso porque quase todo domingo eu ia à missa. A primeira missa que eu participei foi quando eu vim estudar na cidade. Antes, como eu falei, o meu pai pagava uma professora na roça.

Foi em 1920 que o meu pai comprou uma casa aqui. E nessa época eu fui às primeiras missas. Na praça da matriz não existia o fórum nem muitos outros prédios. A praça era toda de terra, sem árvore, não havia nada! Jorrava até uma bica d'água muito boa para beber. E claro, não tinha luz elétrica. 
Eu recordo da gráfica da Gazeta de Paraopeba. Sei que o "Seu Neném", o fundador da Gazeta, começou a trabalhar em uma farmácia que era do Sr. Avelino Fóscolo. Esse era o apelido dele: o Sr. Neném se chamava Manuel Antônio da Silva. Não conheci o Sr. Avelino, mas conheci os filhos dele.

A gráfica do "Seu Neném" era muito simples. O Lauro, seu filho mais velho, trabalhava com ele. Tudo era feito à mão porque não tinha energia. Depois eles foram embora para Belo Horizonte. Mas era um bom jornal. A gráfica era na casa dele. E a farmácia funcionava onde hoje é o Banco do Brasil. Eu lia sempre a Gazeta! Comprava por 500 réis. O "Seu. Neném” era boníssimo, caridoso. Ele também trabalhava muito bem na farmácia.

Essa praça também me traz outras recordações... Lembro do mês de maio. Era todo de festa, de reza. Chegava gente de todo lado: Sete Lagoas, até de Belo Horizonte, para a festa. $\mathrm{Na}$ frente da igreja havia um pé de eucalipto. Era uma árvore enorme! Embaixo dessa árvore costumávamos brincar com o sacristão, chamado Sr. Mário. Era um negro velho que morava ali por perto. Tinha uns oitenta anos e era barrigudão... Sabe? Ele colocava os pés na parede na altura da cara dele. Os meninos não conseguiam fazer isso. Ele pegava a gente assim pelo braço e jogava para cima [demonstra com gestos]. Tínhamos de 10 a 15 anos. Era uma diversão! Também havia leilões e o sacristão era o leiloeiro.

Há uma boa lembrança dessa cidade: era o teatro! Eu fiz teatro aqui, o nome da peça era "Branca de Neve e os sete anões". Eu estava com 12 anos quando apresentei a peça. O teatro existia onde é o cinema de hoje. Só que ele acabou também, existe é uma loja, não é?

O prédio, ele era antigo. Era de madeira... Era teatro e cinema juntos. Isso foi por volta de 1924. Depois desmanchou e fez outro cinema. Mas não sei quem fundou o teatro. Sei que era o príncipe da peça...

Agora vou lhe contar o enredo do drama. O rei tinha uma filha e a mãe dela tinha morrido. A menina era bonita, sabe? A madrasta mandou destruir a menina... Essa madrasta tinha um espelho mágico e perguntava ao espelho assim: "Espelho, existe alguém mais bela do que eu?" Aí o espelho respondia: "Existe, é uma bela menina”. Daí queria destruir essa menina. E mandou o escravo consumir com ela. A madrasta falou com o escravo: "Mata essa menina e me traga o seu coração". Mas o escravo não teve coragem. Decidiu matar um cabrito e tirar-lhe o coração. Pegou o coração do cabrito e levou para a madrasta.

Mais uma vez a madrasta perguntou ao espelho: "Existe alguém mais bela do que eu?" O espelho respondeu: "Existe, pois Branca não morreu”. Nesse momento, Branca de Neve já morava com os anõezinhos. Esses amiguinhos de Branca a protegiam e pediu para que ela tivesse cuidado e não abrisse a porta para ninguém. No final, uma velha deu uma maçã 
envenenada para Branca de Neve e ela desmaiou. No final, ela foi salva pelo príncipe que a fez voltar aos sentidos. Daí o príncipe casou-se com Branca de Neve e a madrasta se suicidou. Eu sei que depois dessa peça comecei o namoro com a menina da peça. Depois ela se mudou para Sete Lagoas. Mais tarde, soube que ela se casou com outro.

Você sabe que aqui se chamava Tabuleiro Grande, não é? Quando se criou a Vila de Paraopeba eu estava com três anos. Minha mãe me deixou com minha irmã mais velha e veio para a festa. E só depois criou o município. Minha mãe ficou feliz quando aqui se tornou uma vila. Recordo disso pois ela me contou várias vezes durante a minha infância.

Quero the falar mais sobre a cidade. Acho que resolveram colocar o nome de Vila Paraopeba por causa do Rio Paraopeba. Conheci um dos políticos mais velhos, o coronel Caetano, ainda eu era menino. Era um dos três irmãos: o A, B, C. Eram o Antônio, o Bernardo e o Caetano Mascarenhas. Eles foram os fundadores da fábrica do Cedro no século XIX, por volta de 1860 ou 1870, sabe? Esta foi a primeira fábrica de tecidos de Minas. Só conheci o Caetano, estava velho, barrigudão. Ele não era bravo, os funcionários dele que eram meio complicados. Os operários se queixavam mais dos chefes do que dele.

Havia um lugar que não existe mais. É a estação ferroviária Carvalho Almeida, na fazenda Tabocas. Aqui, a chamávamos de estação Tabocas porque existia naquela região um riacho chamado Tabocas. Por isso o nome de Tabocas da fazenda e da estação. Acho que ainda existe este pequeno rio. Ah! Gostaria de lhe contar uma coisa. Soube pelos mais antigos que vieram alguns estrangeiros por aqui, acho que eram ingleses, para construir uma ferrovia. Os trens iriam passar pela comunidade da Picada. Mas acho que não deu certo. Mas isso é outra história...

Sei que agora as estações de trem foram desativadas. Que pena! Para mim é a melhor forma de transporte. A gente se assenta, as janelas são grandes e podemos ver uma paisagem muito bonita. Mas era uma dificuldade só viajar. Essa estação funcionava perto de Araçaí e Cordisburgo, cidades vizinhas daqui, ainda mais que naquela época a Vila de Paraopeba era uma referência para esses lugarejos, lá pelos idos de 1920, por aí.

As pessoas que desejavam viajar tinham que fazer um trajeto muito cansativo. Primeiro, saíamos daqui de Paraopeba, naquela época ainda Vila de Paraopeba, a cavalo ou de uma condução que chamávamos de "Curralinho". Esse "Curralinho" era puxado por um burro ou uma besta. Era uma espécie de charrete. Todo caminho era de terra, cheio de poeira e buracos. Parávamos em um lugar chamado "Muda" porque era o lugar onde os animais eram trocados, mudados; para seguir a viagem. A fazenda onde isso ocorria passou a se chamar de 
Fazenda da Muda. Esse percurso era feito por volta de uma hora. Depois, mais uma hora ou pouco mais até a Estação de Tabocas.

Nessa estação de Tabocas foi crescendo um povoado de pequenas casas, muito simples. Todos aproveitavam para fazer um pequeno comércio. Lembro que saíamos daqui de "Curralinho" ou a cavalo para Tabocas e negociávamos toucinho, café, feijão, farinha. O trem que passava por lá e ia para o Norte de Minas, mas também para as cidades de Sete Lagoas, Belo Horizonte e até para o Rio de Janeiro.

Depois desse "Curralinho" as viagens eram feitas de "Jardineira". Era um carro movido a gasolina, ou óleo diesel. O percurso era mais rápido que o feito a "Curralinho", mas a gente pegava muita poeira. E no tempo de chuva? Era aquele aguaceiro. A "Jardineira" atolava e tínhamos todos que descer para empurrá-la. Sei que pegávamos a condução que saía daqui com o dia nascendo, depois pegávamos na estação Tabocas às 10 horas da manhã e só chegávamos em Belo Horizonte lá pelas 5 horas da tarde.

Fiz uma viagem a Belo Horizonte lá pelos anos de 1930. Aquela viagem me deixou saudades! O trem tinha um bar, o barulho do apito, além de ser menos perigoso. Adorava a viagem de trem! Havia dois tipos de trem: um era o expresso, que só transportava pessoas; o outro, o misto, onde se transportavam pessoas, animais e cargas. Esse último demorava ainda mais. Quando cheguei a Belo Horizonte fui encontrar com meu irmão no bairro da Lagoinha. Não me esqueço! A revolução do Getúlio Vargas havia terminado. Quando chegamos à pensão avistamos vários buracos na parede e no portão feitos pelos soldados da revolução. Nunca esqueci disso.

\section{$* * *$}

A minha profissão era mista lá na roça. Eu era lavrador e carpinteiro. Fazia de tudo. Consertava moinho d'água - esse era serviço de carpinteiro. Depois que me mudei para a cidade fiquei meio à toa. Aí a fábrica de tecidos me chamou. Eu comecei a trabalhar na fábrica porque o carpinteiro estava de férias. O gerente da fábrica veio aqui em casa pois sabia que eu era carpinteiro. Daí me perguntou: "Você tá à toa?" Eu disse que estava. Ofereceu o serviço de carpinteiro para substituir o que estava de férias. Disse para mim: "Antônio, você é inteligente e aprende logo. Se você quiser, vá amanhã, segunda-feira, na fábrica”. Depois que o outro voltou de férias o patrão me perguntou: "Você quer o serviço?" Eu estava desempregado e aceitei. A fábrica começou a funcionar em 1950 mais ou menos. Eu estava na 
roça e mudei para a cidade. Comecei a trabalhar na fábrica em 1955. Os meus irmãos moravam aqui. Eu estava na fazenda, eu com um cunhado.

A fábrica de tecido se chamava PISA: Paraopeba Industrial Sociedade Anônima. Eu comecei a trabalhar nessa fábrica em 1955, mas ela foi fundada, mais ou menos, em 1950. Eram muitos funcionários, por volta de 1.000, acho que era essa quantidade. Trabalhei 24 anos nessa fábrica e me aposentei. Meus documentos são de carpinteiro da PISA. Antes eu era lavrador. A relação com os colegas era muito boa. E além do mais, os funcionários davam conta do recado, uai!

No trabalho da roça eu fazia de tudo: capinava, batia a foice, trabalhava de carpinteiro. Quando fui para a fábrica era diferente! Eu gostava muito da roça, lá eu fazia de tudo... A liberdade. Como já lhe disse, lá na roça não tinha nada fixo. Nós fazíamos de tudo!

Tem uma outra diferença, sabe? Na roça não era uma renda fixa. Um pouco vinha daqui, outro pingava dali. Mas não me faltava nada! [Afirmou com muita ênfase]. Não faltava comida, os "trem" de comida, havia fartura, não é? A gente só comprava sal e querosene. Naquela época não havia luz elétrica. Na roça não tinha falta nenhuma! Aqui, na cidade, eu tinha falta sim. Ganhava o ordenado, mas aqui a gente gastava muito. Aqui não havia uma (fica pensativo) normalidade na despesa de casa. Era assim: "eu ganho isso, tenho que gastar com isso"! e assim vai... Na roça não. A gente não gastava nada. Para quê? A gente tinha de tudo! Tinha saúde.

A forma de trabalhar também se modificou. Na fábrica era uma roda d'água, não é? Na roça não. Não fazia o trabalho agora, podia fazer depois - daqui a um ano! Amanhã... Fazia o serviço de acordo com a necessidade do serviço lá. O bom era isso! A gente não tinha de pensar em mais nada. Não era esse tipo de obrigação que havia na fábrica. Eu tinha de ficar bem atento com o tempo. Por isso eu tinha mais prazer na roça! Sabe, Neuber, o comportamento era outro. Na roça a gente precisava de quase nada. Eu ganhava menos, mas não precisava de nada.

Apesar disso tudo, o trabalho na fábrica não era sacrifício. Eu aprendi a profissão aqui na cidade, pois era mais adiantada do que na roça. Vou explicar para você: na fábrica o serviço era mais de marceneiro, sabe? Lá na roça era mais na base do serrote e martelo. Era um serviço mais grosseiro, a gente fazia o engenho d'água, os telhados... Aqui era de marceneiro e não de carpinteiro. Mas quando eu apanhei a rotina, aí sim, gostei do trabalho. Gosto de falar disso. Já lhe contei isso, não? Tem uma outra diferença: na fábrica tinha muita gente mandona. Primeiro o gerente e depois os fiscais. Na roça era o meu pai, não é? O pai que mandava e acabou. 
Recordo da construção da fábrica. Desde menino as pessoas falavam em ter uma fábrica aqui. Eu tinha uma professora, a D. Inhazinha, que falava demais sobre a necessidade da cidade progredir. Nessa época eu tinha mais ou menos uns doze anos.

Nesse tempo eu ouvia falar em construir uma indústria aqui. Não era a fábrica de tecido. Era uma indústria qualquer. Aí, depois da quarta série do grupo, eu voltei para a roça. Fui trabalhar. Depois de alguns anos, surgiu a idéia do Dr. Guilherme e do Olavo de construir uma fábrica. Eles falavam que era para dar serviço para a rapaziada. Daí combinaram em levantar o capital. Foram procurar as pessoas nas fazendas. Também foram lá em casa na roça. Pegaram todo mundo como acionistas. Todos os meus irmãos, sabe? Almoçaram conosco. Meu pai e minha mãe eram vivos. Recordo da conversa do Dr. Guilherme e do Olavo: "Precisamos dar serviço para esses moços". Aí meu pai achou a idéia muito boa! Disse assim: "Eu tô velho, mas os meus filhos podem trabalhar!". Decidimos, as pessoas lá de casa, a sermos acionistas da fábrica. Eles levantaram o capital e puseram no banco.

Isso tudo aconteceu no final da década de quarenta. Talvez cinqüenta ou cinqüenta e um. Pois eu fui trabalhar lá por volta de cinqüenta e quatro ou cinco. O dinheiro era réis ainda, não? Outra coisa... O Olavo, que era um dos cabeças, trabalhava era com fazenda. Ele arrendava as terras do Alcides Cunha. Ele falava assim: "Eu não sei mexer com fábrica, como é que eu vou fazer?”.

O Dr. Guilherme falava assim: "Eu também não sei mexer com fábrica, tenho o meu hospital para cuidar". Dizem que uma hora ia aparecer uma pessoa que ia saber como levar a fábrica para frente. Aí apareceu! Foi o Dr. Pedro, que era filho daqui, mas morava em Belo Horizonte. Na verdade era uma raposa, “um raposão..." Ficou sabendo do negócio e bateu por aqui. O Dr. Pedro disse: "Vocês estão com dinheiro no banco, não? Vocês não querem largar suas obrigações para mexer com a fábrica, não é?". Ai o Olavo falou outra vez: "Ele tem que aceitar, não?” [Entoa a voz com gravidade]. Por fim, o Dr. Pedro aceitou.

Naquele tempo não havia nada. Depois compraram o terreno. Havia a fábrica do Cedro desde o século XIX e que pertencia à cidade de Paraopeba. Na época da fundação da fábrica do Cedro aqui se chamava Tabuleiro Grande. As pessoas da fábrica do Cedro não acharam ruim porque o Dr. Guilherme era da família da fábrica do Cedro também, não é? Eles estavam mais ou menos de acordo. A PISA foi construída a mais ou menos $2 \mathrm{~km}$ da fábrica do Cedro. Lá foi a primeira fábrica de tecido de Minas Gerais, sabe? Mas no dia da inauguração da PISA eu estava na roça, depois cheguei aqui, na cidade. Eu participei, teve festa, lanche... Morava ainda na roça. Depois de uns quatro anos que comecei a trabalhar aqui, na fábrica. 
Sabe, Neuber, não me desagradou trabalhar na fábrica. Não tive muitas contrariedades. Achei ruim em mudar da roça. Mas depois foi normal. Os companheiros e os amigos eram muito bons. Não tinha o que queixar. Continuei lá até aposentar como carpinteiro. Desse modo posso falar que foi bom ter tido a fábrica aqui na cidade. Teve emprego, pois não tinha nada. As pessoas tinham que sair daqui para trabalhar. Assim foi trazendo outros trabalhos...

As pessoas daqui iam trabalhar na fábrica do Cedro a pé. Iam debaixo de chuva e de madrugada. Pensava: “agora aqui perto tem uma fábrica”. Na fábrica do Cedro eu não trabalhei. Como eu lhe falei, nessa época eu trabalhava na roça. Ia a Caetanópolis quando tinha algo para vender da roça. Mas tinha muita amizade por lá.

Recordo que as pessoas contavam que os escravos trabalhavam na fábrica do Cedro. Depois vieram os operários para trabalhar no lugar deles. Você sabe, não é? Naquele tempo não havia muitas coisas para trabalhar. Depois vieram as mudanças e com elas também vieram os chefes. Olha só, vou lhe contar uma coisa: mesmo depois das leis trabalhistas os operários não eram respeitados.

Há um caso que nunca esqueci. Eu tinha um amigo, colega de escola e pai de família que foi injustiçado. Eu tinha o hábito de marcar o cartão e ficar conversando com os colegas na portaria até a hora de fazer o serviço. Então tive a primeira decepção no serviço. Esse companheiro era da turma dos pedreiros da fábrica. Ele foi impedido de marcar o cartão porque chegou um minuto atrasado. O porteiro o impediu de marcar o cartão e ele teve que voltar para casa e perdeu o dia apenas por causa de um minuto. Daí eu reclamei: "pá, pá, pá" [encenou a situação nervosa que vivenciou]. Pois soube de um outro operário que chegou dois minutos atrasado e conseguiu entrar para trabalhar. Aí fiquei indignado!

O porteiro então falou: "Vou chamar o seu chefe". Eu próprio resolvi procurar o chefe, naquela época era o Lucas. Daí, falei para ele: "Por que um pai de família, bom funcionário, teve que perder um dia de trabalho por causa de 1 minuto? Que administração é essa?” O gerente disse assim: "Soube na portaria que o senhor havia falado em proteção da administração". Aí respondi: "É por isso, por isso, por isso... e sou contra esse tipo de proteção". Estava pronto para a demissão, mas o gerente disse: "Não, Sr. Antônio, o que é isso?". Retruquei: "Se isso é a lei, ela está errada”. Achei que iria ser demitido mas não fui.

Sabe uma coisa, é o tal chefe da seção! Às vezes os dirigentes e donos não sabiam de nada. Isso era muito comum na fábrica. Havia as leis, mas elas não eram cumpridas. Os chefes queriam ser os mandões! Sabe como? Na roça não tinha esse patrão, era outro sistema. Vou lhe contar outra situação que me desagradava. 
Quando fui trabalhar na fábrica daqui de Paraopeba existia uma forma de admissão muito injusta. As moças iam trabalhar na fiação, na tecelagem e ficavam sem receber durante uns quatro meses mais ou menos. Daí chegou um Juiz de Direito aqui e determinou que todo aprendiz teria que entrar ganhando um salário. Mas o Pedro Barbosa "negociou" com o governador... Soubemos depois que o Juiz foi retirado da cidade. Corria um boato na cidade que dizia assim: "Se você não retirar o Juiz desta cidade vai perder o amigo". As pessoas falavam que era uma afirmação do presidente da fábrica. Eram as regras daquela época, não é? Ainda bem que as coisas mudam...

Olha, rapaz, as coisas daquela época eram muito diferentes de hoje. Me lembro que eu e mais cinco irmão entramos como acionista. Vendemos vacas, sacos de mantimentos da última colheita para podermos ser acionistas. Ainda não era operário da fábrica. Só trabalhava na roça. Logo depois da visita do Dr. Guilherme em nossa casa na roça... Sei que no final da PISA não recebemos nenhum dinheiro pelas ações que havíamos comprado. Tenho 99 anos e até agora, nada! As coisas não eram boas para os operários. Onde nós podíamos reclamar, uai? Tínhamos que aceitar. Os patrões não tinham dó dos operários. Era assim: “o patrão passava a mão e depois dava as chicotadas". Hoje, graças à Deus, estou aqui na minha casa, com os filhos. Tenho a aposentadoria que é pouca, mas é com dignidade que ganhei esse dinheiro. Aprendi desde a infância. Na roça era desta forma! Nós dividíamos o que tínhamos, não é essa ganância que existe por aí.

Quando aposentei, eu gostei muito! É uma garantia, não é? Tenho nove filhos, mas na verdade tenho nove pais! Mas queria ter meu próprio dinheiro. A aposentadoria veio com o Vargas, o presidente. Foi ele que criou essa lei. Pois eu votei nele! O primeiro voto meu foi para ele! Ele foi o homem do povo, o homem do povão! Por isso ele morreu. Ele suicidou, não é? O Brasil é assim: o sujeito que é bom morre mesmo. Aquele que é bom para o povo não tem jeito, morre...

São os de gravata branca, uai! Esses sujeitos que acabam com eles, os homens do povo. São esses mesmos - "os políticos, os politicão". Esses oficiais... Você não lembra do Juscelino? Foi tudo tramado! Depois Ulisses Guimarães. Também o Tancredo Neves, morreu tramado. Inclusive na hora dele tomar posse o homem vai e morre. Ele falava para o Brasil inteiro. Ele foi eleito, não? Mas não deixaram ele tomar posse. Foi trama...

A política na cidade teve momentos de conflito. Neuber, começou uma guerra aqui! Era a família Mascarenhas contra um padre e um médico. O partido do padre e do Dr. Theóphilo e o partido dos Mascarenhas. O padre da época era o padre Augusto Horta. Eles queriam mandar, mas acabou que o povo... Ah! Você sabe! O povo, nem Deus segura! [risos] 
Eu era menino, ia para a escola e era aquela confusão. Aí veio a ditadura do Vargas, não é? E depois a guerra...

Naquela época havia um interventor do município. Na cidade, daqueles tempos, os companheiros de governo eram arranjados. Era assim: o governador escolhia algumas pessoas de confiança no município e o interventor, junto com essas pessoas, ficava de prontidão. Se precisasse de qualquer coisa, esse grupo agia. Por exemplo: quem mandava prender alguém, eram essas pessoas. E o povo tinha que aceitar. O governador mandava e pronto. Havia poucos políticos e poucas pessoas que entendiam de política. Nesse tempo, o povo aceitava melhor que hoje, não é?

O Padre Augusto não falava de política na igreja, mas fazia política nas ruas. E o Dr. Theóphilo fazia política também era na rua. O Dr. Theóphilo foi prefeito, você sabia? Daí os Mascarenhas mais velhos foram morrendo... Depois veio o mais novo e as coisas foram mudando... As inimizades foram também acabando. O Dr. Guilherme, o Seu Neném, dono da Gazeta de Paraopeba, foram apoiando as atividades políticas. O Dr. Guilherme também foi, mais tarde, prefeito, e ele também era da família dos Mascarenhas. De maneira que as coisas foram mudando. Aquelas brigas do passado já não existem. Havia a política, “pá, pá, pá,” [faz um gesto com as mãos], como até hoje.

\section{$* * *$}

As festas principais da cidade eram duas: a festa dos dançantes de congo - a festa de Nossa Senhora do Rosário e a do Divino. Eram três, quatro dias de festas. Chegava muita gente de fora da cidade. Havia comida, bancas de jogos... A festa do Rosário era em agosto e a do Divino em junho. Minha formação é católica. Foi a que eu aprendi. É tradição de família. Para mim, é essa que é boa. É a tradição. Procuro não discutir com as pessoas de outras religiões. Quando alguém quer discutir eu mudo.

Eu participava e participo até hoje da igreja. Sou confrade de São Vicente de Paulo desde a idade de 20 anos. Tenho mais de 75 anos de confrade. Ser confrade é atender os mais necessitados: alimentar, dar remédios, dar casa se precisar. Construir um barracão. Daí nós fazemos uma sindicância para constatar se a pessoa precisa realmente de alguma coisa. Levar na igreja os que são católicos. Os que não são, não levamos. É esse o trabalho dos vicentinos.

Lembro que a gente tocava e cantava até o sol raiar. Era a noite inteira de festa na roça! Meu pai tinha apelido de Nonô. Aí, quando alguém queria fazer uma diversão ou 
casamento, todos convidavam a orquestra dos meninos do Nonô. Eram cinco componentes: dois ou três empregados lá de casa, eu e meu irmão. A orquestra era composta de: dois violões, um cavaquinho, um cavaquinho dobrado e também a caixa. Eu já lhe disse isso, não?

Às vezes eram até sete componentes, variava sabe? Sei que era forró a noite inteira. Bebíamos cachaça e vinho. A gente também tomava leite da fazenda e fazíamos canjica. Era para divertir. Isso eu tenho saudade! Mas agora morreu tudo... Meus irmãos e... Tenho apenas uma irmã que mora em Curvelo, a caçula. Eram doze irmãos. Mas agora tem eu aqui e ela lá.

Na cidade existia uma banda de música. Ela se chamava, ainda chama, Banda Divino Espírito Santo e foi fundada em 1914. Portanto, sou quatro anos mais velho do que ela. O primeiro maestro era um negro e se chamava "Manuel Gazuza" ou "Mané Cazuza". Em sua banda tocava o "Seu Neném" [Manuel Antônio da Silva] que fundou a Gazeta de Paraopeba e também o Sr. Paulo - me lembro bem. Toda festa da igreja e missa cantada eles se apresentavam. O maestro, acho que tocava trombone, mas seu maior gosto era reger a banda.

\section{$* * *$}

Eu fui educado e formado na religião católica. Até hoje sou católico praticante. Participo da missa desde criança. A igreja e a prática eram diferentes. Antes a gente não sabia o conteúdo da missa. Era um "tum, tum, tum" e a gente não sabia. Era o latim. Depois sim, pudemos acompanhar a celebração.

A missa hoje é mais bonita, não é? O padre pára, a gente responde em português, canta e... É mais bonita! Achava aquilo de antes esquisito. Agora a gente pode acompanhar, sabe o que o padre está falando. Como prega o evangelho. De maneira que é muito melhor. O padre da época era muito santo. Era o padre Augusto Horta. Ele era enérgico, mas muito bom. A casa dele vivia cheia de pobre.

Quero lhe contar uma história sobre a fé. Era tempo do padre Herculano Pimenta. Este padre substituiu o padre Augusto. Recordo que ele era ainda jovem. O fato aconteceu na roça. Eu já era casado e não havia me mudado para aqui na cidade. Havia na cidade uma senhora de nome Porfíria que trabalhava na roça também e pegou amizade com minha esposa. Fazia algum serviço lá em casa: lavava roupas, ajudava nas tarefas da casa. Bom, algum tempo depois, começou a adoecer. Ficou isolada e nem quis saber de coisa nenhuma. Achei que precisava de um padre para fazer uma oração. Como era confrade de São Vicente de Paulo, conhecia o padre Chaves, que também trabalhava por aqui. 
Quando sugeri isso ela se recusou. Mas não fiz por satisfeito. Encontrei com seu filho, Zoroastro, e lhe contei. Ele falou que ela não queria. Fiquei com isso na cabeça. Se ela estiver morrendo? Precisa de um padre. Sei que ela foi aumentando a doença. Então decidi, por conta própria, ir buscar o padre. Arriei dois cavalos para que o padre voltasse em um deles. Cheguei na casa do irmão Luis aqui no centro da cidade e ele ficou preocupado. Achando que alguém da família estivesse doente. Logo o esclareci. Ele me disse: “O padre Herculano não está aqui, só tem o padre Chaves no Cedro." Montei no cavalo e fui até lá. Chegando na casa de padre Chaves, ele me disse: "Não posso pois vou fazer um velório à tarde". Depois me deu a idéia de permanecer na cidade e pela manhã iríamos para a roça. Voltei para casa do meu irmão. Ao chegar, encontrei o padre Herculano. Expliquei a situação e ele aceitou ir para roça comigo.

Escute e veja! Alguma coisa estava impedindo à ida do padre. Logo que chegamos a D. Porfíria estava com a cabeça encoberta. Aí eu lhe disse: "D. Porfíria aqui está o padre". Nesta hora houve uma transformação! Ela ficou transfigurada e nervosa. O padre Herculano pediu que eu saísse e começou a rezar. Logo que saí fui para o quintal. Depois o padre me chamou. Ele estava perplexo, e me disse assim: "Era o demônio que estava aqui. Eu consegui que ela se confessasse. Depois ela morreu.” O padre Herculano estava muito assustado. Você veja! O que tem nesse mundo... Nunca me esqueci desse acontecimento.

A cidade possui outros templos. Há aquela capela perto da padaria do Sr. Zé de Souza, indo para a praça da Matriz. Eu não sei como ela surgiu. Sei que a Matriz estava em reforma e o único lugar que tinha para celebrar era lá. As pessoas ficavam na rua pois a capela e pequenina. Eu estava com 20 anos nessa época. O primeiro batizado que eu participei foi naquela capela.

Não sei como ela surgiu, mas também nunca perguntei. Fiquei sabendo que era da família, pelo menos atualmente, do Zé Dimas, mas não tenho certeza. O primeiro batizado que vi foi em 1930, celebrado pelo padre Augusto Horta. Eu acho que o nome dessa capela é Nossa Senhora da Conceição, mas não tenho certeza. Não tenho consciência exata.

\section{$* * *$}

Percebo algumas mudanças na cidade. Aqui não tinha água e nem luz elétrica. Havia muita dificuldade! Tinha pouco comércio naquela época. De maneira que a cidade transformou muito. A cidade aumentou, cresceu. Melhorou o meio de vida. Agora tem água nas casas, tem um hospital... Acho que as coisas são mais fáceis. 
Sabe de uma coisa? Tem coisa que a gente não esquece. Tanto as boas quanto as ruins. Por exemplo, a lembrança da roça, da escola... As ruins de lembrar são aquelas que se referem à cirurgia que lhe contei. Porque eu estive quase morto! O resto era trabalhando e a vida passando... Precisava trabalhar na roça, mas eu gostava. Contar o que a gente lembra é assim mesmo: tem coisa que é fácil lembrar, outras são difíceis.

Quando penso na minha vida... Sabe? Aquela coisa em querer ser alguma coisa, ser uma coisa que a gente não é, sabe? Não podendo, a gente tem que se conformar. Queriam até que eu fosse vereador porque me dava bem com muita gente, fazia pequenos favores. Até apliquei injeção quando alguém precisava... Mas eu não quis ser vereador. Às vezes ficava sem dinheiro, mas a ganância, não. Não pensei em fazer coisa errada. É isso, estou satisfeito com a vida.

$* * *$ 


\subsection{Sr. José}

Nasci na cidade de Paraopeba em 8 de outubro de 1938. Não foi na zona rural. Meu pai se chamava Luiz e era da zona rural da cidade e minha mãe Lavínia era de Santana de Pirapama-MG, cidade vizinha que antes era conhecida como Traíras. Nos meus 72 anos de idade consigo me lembrar de algumas coisas. Por exemplo, não conheci meu avô materno, mas me lembro da minha avó materna.

\section{$* * *$}

Vivi com meus pais até a morte deles. Além de mim, havia mais sete irmãos. Ao todo eram: quatro homens e quatro mulheres. Era o caçula da família. Minha casa era muito simples e pobre. Foi construída com piso de tijolo, forrada com esteira e a cozinha era de chão batido, os móveis eram bem modestos. Quando estava deitado na cama, via o sol entrando pelo telhado, fazendo bolinhas luminosas na parede... Mas o ambiente da casa era saudável e eu me divertia muito. Meus pais tratavam a gente com muito carinho...

\section{$* * *$}

A vizinhança era boa e bem diferente de hoje. Não tinha essa bagunça de vizinho incomodar o outro. Não havia som alto, nada. Era raro uma casa ter um rádio. Não existiam tantos jornais e revistas como hoje! Eu me relacionava bem com os vizinhos. Brincava com a família dos Tolentino: Rubens, Wanderley, os filhos do Zé Barbeiro, os filhos do Raimundo Castelo. A rua era de chão, cascalho e... de um lado e de outro tinha muitas pedras. Era uma turminha que brincava na rua.

Sabe, Neuber, no nosso tempo as coisas eram muito mais simples! Hoje tem a invasão dos meios de comunicação. Que coisa estranha, ao invés de unir, isola... não é? Os brinquedos, nós mesmos é que criávamos. Fazíamos carrinhos de lata e brincávamos também de "finca". Sabe o que é? É um estilete que arremessávamos na terra. Havia outras brincadeiras como: bolinha de gude, o jogo do pião. À noite tinha o pegadô, que hoje se chama esconde-esconde. Corríamos o tempo todo. No pátio da escola, na hora do recreio, eram separados os homens das mulheres. 
A profissão do meu pai era de barbeiro e minha mãe era doméstica. Antes, o pai trabalhava na roça, mas acho que era muito pesado para ele e não agüentou. Saiu da zona rural da cidade e quando chegou aqui trabalhou no comércio e depois se casou. Também fazia serviços de escritura do comércio para o pessoal da cidade. Executava outras tarefas: consertava relógios, máquinas do comércio e construía gaiolas. Meu pai aprendeu sozinho, vendo. Foi um autodidata. Assim, foi fazendo estes serviços durante muito tempo. Mas o trabalho de barbeiro foi a vida toda.

Aqui na cidade o trabalho era muito restrito. Havia apenas um grupo escolar; coletoria federal e estadual. O trabalho que havia era ocupado por funcionários públicos e pelas pessoas que trabalhavam na Prefeitura. Não existiam fábricas, só a do Cedro e depois a PISA nos anos cinqüienta. De modo que havia pouca opção de trabalho. O pessoal trabalhava mesmo era na zona rural! Tudo que se gastava aqui era trazido da roça. Vinha de fora somente sal e querosene. Na década de 40 e 50 as professoras tinham um salário bom. Esse trabalho era bem pago; as professoras eram valorizadas. Recordo que nessa época não tinha estrada asfaltada. Tudo era chão! Não se passava nada por aqui. Os pioneiros do transporte coletivo foram os irmãos Tolentino. O Juvenal das Neves e o João Paulino possuíam caminhões. Esses eram os meios de transporte que passavam pela cidade... Para você ver, a cidade tinha apenas um grupo escolar que possuía quatro salas de aulas trabalhando em dois turnos e dava para toda a cidade e zona rural! Também ajudava meu pai na barbearia. E me lembro quando ia fazer a barba do "Seu Neném" em sua casa. Recordo dele com os óculos no nariz, era o “pince-nez". Ele gostava de ficar na oficina da Gazeta de Paraopeba lendo os jornais vindos de fora. Havia um jornal vindo de Portugal, me lembro disso. Eu fiz, ainda menino, muito a barba deste jornalista.

\section{$* * *$}

Lembro bem da minha primeira escola, chamada Afonso Pena. Era esse grupo escolar que eu lhe falei. Eu entrei para a escola com oito anos de idade. Minha mãe achou que eu era muito pequeno com a idade de sete anos. Naquele tempo não tinha jardim, nem pré-escola. Até sete ou oito anos a gente só brincava... Somente brincava, entendeu? Recordo das 
brincadeiras: pegadô, os adultos contavam histórias para as crianças. Acho que era para formar a base mental da gente. Aí contava aquelas histórias maravilhosas que ia traçando, aos poucos, a base da nossa psicologia. Agora... [pausa].

Minha primeira professora foi D. Anésia França Ribeiro. Na escola, eu era bom aluno. Tinha memória e inteligência muito boas. Todos os quatro anos do grupo escolar eu fui o primeiro aluno. Mas eu era levado... Me lembro de um caso que eu não esqueci. Uma dia a professora resolveu me testar. Estava conversando na hora da explicação dela. Achou que ia me "pegar"! Daí ela me perguntou o que ela estava ensinando: eu falei tudo que ela tinha ensinado. Então, a professora surpresa disse: "Você sabe mas vamos parar com essa conversa a'”. [risos].

Naquela época a gente aprendia pelo sistema da cartilha. Era assim: "a - a - a" e "o o - o”. Depois ia juntando as sílabas. Recordo de um acontecimento que marcou a minha vida. Foi quando peguei o apelido de Coró, que ficou até hoje! Aconteceu que minha professora nessa época era D. Maria de Lourdes Ribeiro, mulher do coletor federal. Quando ela ficou grávida, pediu minha irmã Lourdes para substituí-la. Na minha casa tinha o tratamento carinhoso em me chamar de "coró", "corozinho". Daí ela falou isso na escola, aí pegou. Era o segundo ano do grupo. Pegou o apelido e acabou! Até hoje as pessoas me chamam por este apelido.

Depois que eu terminei a quarta série, o Dr. Guilherme, pensou em fundar o ginásio na cidade. Assim que terminei o grupo escolar fui pegar o pau de arara e fazer exame em Curvelo-MG, até que o ginásio iniciasse. Primeiro o ginásio da cidade funcionou no grupo escolar e depois no prédio do antigo hospital da comunidade. Era um ginásio muito deficiente. Os professores trabalhavam de graça. Depois, comecei a fazer o $2^{\circ}$ grau em Diamantina-MG. Achei lá muito ruim e aí passei para Sete Lagoas-MG. Parei um tempo de estudar. Só depois fui fazer o curso de matemática na UFMG. Isso aconteceu em 1970. Eu tinha por volta de quarenta anos. Não, acho que tinha era 32 anos.

Naquele tempo, era bem diferente, a relação com os colegas de classe... Para mim, naquela época, tudo era novidade: a sala de aula, os colegas que chegavam de fora. Época mais bela da vida! Como havia lhe contado, a minha primeira professora foi D. Anésia França Ribeiro. Era uma ótima professora! Corrigia a gente e era muito exigente. Isso, me recordo bem. Eu aprendi a ler com três meses. Quando se formava a quarta série, a gente sabia juros, regra de três e muitas coisas... Mas hoje em dia se aprende esse conteúdo até a $8^{a}$ série. Lembro-me de outra professora: era a D. Margarida, essa foi no quarto ano do grupo escolar. 
A relação entre alunos e os professores eram bem diferentes. Por outro lado as coisas mudaram pouco... Antigamente os professores tinham mais autonomia para tratar o aluno. Os professores não admitiam falta de respeito! Levavam os alunos desrespeitosos para a secretaria e mandavam chamar o pai do menino. Naquele tempo os pais batiam nos filhos. Não é como hoje! Então, os professores tinham autoridade e os alunos respeito por eles. Lembro de uma atividade na infância que eu gostava muito. Trata-se da minha primeira leitura. Nesta época o autor que me marcou muito foi Monteiro Lobato. Ficava encantado com a forma com a qual este escritor contava suas histórias. Acho que Monteiro Lobato, através das leituras dos seus livros me ensinou sobre as fantasias, a imaginação, sabe? A partir destas leituras eu conseguia viajar para outros lugares, me transformava em outros seres. As levadezas da boneca Emília, o universo de encanto do Sítio do pica-pau amarelo. Tudo era alimento para minhas fantasias... Sei também que meu pai e minha mãe liam também, mas não me recordo quais eram suas leituras, talvez algum livro sobre religião, sobre a Igreja Católica. Talvez porque viviam ocupados com as tarefas domésticas não tivessem tempo para as leituras.

Entretanto as minhas leituras foram mudando. Sei que na minha juventude comecei a ler os romances clássicos. Dentre os autores preferidos estão: Emile Zola em Germinal; A Divina Comédia de Dante, o Paraíso Perdido de Milton, e um que eu gosto muito é o $D$. Quixote de Cervantes. Este último relata os sonhos do cavaleiro andante e seu fiel escudeiro. Ah! E os amores de Dante por Beatriz... O fato foi que estas obras me mostraram a natureza humana. Cada uma à sua maneira estava em busca da própria origem. Busca do sentido para a vida, sabe? Isso sempre foi e continua sendo importante para mim.

\section{$* * *$}

Recordo das casas da cidade... Eram casas do estilo feito em Portugal, não é? Como a casa da D. Anésia, a casa do Dr. Theóphilo, a casa do Sr. Leonel. As casas eram construídas com pátio interno e muitos cômodos. Naquele tempo não existiam casas feitas com laje. Eram apenas, casas feitas com telhados.

No restante da cidade as construções eram mais modestas. Como de adobe, o chão batido, móveis muito simples. As pessoas viviam sem muita exigência de conforto. 
A cidade surgiu, sabe como? Consta que essa região era uma sesmaria de um coronel chamado Marques. Ele era católico e devoto de Nossa Senhora do Carmo. A lenda conta que ele veio caçar por essas terras e foi pego de surpresa por uma onça. Então, na eminência de ser morto pela onça, ele ajoelhou e disse: "Se for salvo, toda a terra que avistasse no horizonte seria dado à santa”. Escute só: consta-se que havia na Paróquia de Sabará-MG doações para a paróquia daqui. Mas esse documento desapareceu. Talvez por interesses duvidosos. Mas o fato é que, o coronel Marques, salvo do ataque feroz da onça, mandou construir uma capela em promessa à Nossa Senhora do Carmo, santa que o salvara. Assim, ao redor da capela, foi surgindo um povoado. Dando origem ao arraial de Tabuleiro Grande, depois Paraopeba.

Ultimamente, recebi um e-mail curioso de um jornalista de Sete Lagoas chamado Márcio. Ele está querendo fazer um trabalho de pesquisa e a hipótese dele seria que a estrada real passaria por essa região daqui. Segundo ele, Tiradentes teria sido incumbido em fazer uma estrada daqui à Paracatu. Tiradentes foi um policial, além de mártir, mas esse jornalista tem pouca informação sobre a possível passagem dele por essas terras.

Como eu já havia contado, a única comunicação que tinha era quando chegava à cidade alguém de fora. Havia poucas casas que tinham rádio. Poucas pessoas assinavam jornais vindos de outras cidades. Me lembro quem recebia os jornais de fora da cidade: era o Sr. Neném, o Dr. Theóphilo. Acho que era o jornal Correio da Manhã. Para nós, as crianças, a vida era brincar! Às vezes comprava revistas em quadrinhos, os álbuns de figurinhas. A gente ficava doido com aquilo... Havia outra brincadeira que nos encantava: era construir uma espécie de câmara de cinema. Pegávamos algumas latas, desenhávamos no papel, improvisando uma câmera, sabe? E depois a gente projetava aquilo. Ah! Como era bom!

Havia também um teatro na cidade onde se encenava peças. Era uma alegria quando chegavam os parques de diversões e os circos. Adorava os circos que tinham cavalos: era o circo de touradas! E também os parques para conhecer as moças. Ah! E depois namorar...

A cidade era muito diferente. Havia alguns prédios que hoje não existem mais. Recordo do prédio da Prefeitura e a cadeia que funcionava no andar abaixo. Eles foram demolidos. Ficavam na praça da Matriz. Hoje fizeram um jardim no lugar. 
Minha profissão sempre foi de professor. Antes trabalhava com meu pai em sua barbearia. Eu o ajudava quando ele precisava... Agora estou aposentado. Mas escrevo no jornal há muitos anos. Aqui na cidade existe atividade jornalística há anos desde o século XIX. Lembro-me da "Gazeta de Paraopeba" do Manuel Antônio da Silva. Era conhecido como "Seu Neném", você já ouviu falar nele? Foi o "Seu Neném" que aprendeu o ofício com Avelino Fóscolo. Bom, o Martins, que havia sido jornalista prático, resolveu fundar o "Repórter de Paraopeba". Isso se deu na década de 80. Juntei uma turma interessada e passei a colaborar com esse jornal. Mas o Martins entrou em atrito com os colaboradores, então o jornal acabou. Logo depois houve a idéia de um outro jornal e as pessoas quiseram que eu fosse o presidente, mas eu não aceitei. Daí surgiu o "Jornal de Paraopeba", há dezoito anos que ele circula. Escrevi no "Repórter" e continuo a escrever no "Jornal de Paraopeba".

Durante a existência do jornal "O Repórter de Paraopeba" eu tinha uma coluna chamada: "O caminho do meio", era uma coluna de cunho espiritualista. Mas também era uma diversão. Agora, no "Jornal de Paraopeba" a coluna passou a se chamar "Histórias". Nessa coluna vou colocando subliminarmente as minhas crenças e introduzindo algumas visões de mundo da qual acredito.

Há algumas histórias que escrevi, que realmente aconteceram aqui na cidade. Elas vêm da tradição, do tempo dos antigos. Aí, aos poucos, fui catalogando estas histórias. Minha tia chamada D. Dometilde, ela era uma contadora de histórias nata. Ela morreu com 104 anos. Titia, é como eu a chamo na minha coluna do jornal, narrava muitas histórias da cidade. Algumas dessas histórias acontecidas nos idos século XIX. Funcionava assim: ela contava e eu as anotava.

A partir dessas histórias eu descobri os costumes daqui, aqueles ocorridos antigamente... "Titia" contava que a cidade era muito pequena. Não havia água encanada, apenas um chafariz na rua. Só depois que o Olimpio Moreira construiu uma caixa d'água para a comunidade. As pessoas buscavam água na bica. Havia cinema mudo, um teatro. Esse teatro existia onde foi construído o cinema do Wander Marota. Agora, tem apenas uma loja, que pena! Você sabia que o meu pai foi apreciador de cinema mudo? No Cedro também teve cinema mudo... Mas depois, teve cinema falado. Lá pela década de 50... A diretora do grupo Afonso Pena chamada D. Helena instalou uma câmara nesta escola. Isso tenho como lembrança fresca.

Então, voltemos ao jornal. O jornal de hoje tem um caráter diferente. Antigamente era mais penoso, era feito nas oficinas. Hoje não, é muito mais fácil. Por exemplo: o "Jornal de Paraopeba" é mais prestigiado pelas pessoas que moram fora. Querem saber o que acontece 
aqui na comunidade. As mudanças da cidade, as pessoas... Já o jornal do "Seu Neném", a "Gazeta de Paraopeba", era feito de forma diferente. Recordo que ia, ainda menino, nas oficinas da "Gazeta", via as máquinas rústicas e as pessoas trabalhando nelas. O jornal era feito durante a semana e aos sábados, trabalhava-se até altas horas, para sair no domingo. Trabalhava na "Gazeta" o Ponciano e outros amigos. Rodava até de madrugada... Era semanal o jornal. Às vezes minha coluna faz referência à "Gazeta" do "Seu Neném", sabe?

Há um outro ponto para demarcar: a minha temática é muito diferente da do jornal “Seu Neném”. Minha coluna é inocente, apenas conta histórias; ela é um divertimento, feita para distrair. Como já disse para você, ponho subliminarmente o que acho bom e acredito. Está nas entrelinhas o que desejo passar para os leitores.

Além do jornal do "Seu Neném" tenho notícias dos jornais do Sr. Avelino Fóscolo do qual o "Seu Neném” foi discípulo e aprendiz. Lá pelo final do século XIX é que teve o primeiro jornal feito em Paraopeba, era o jornal "A Vida". Depois vieram outros jornais como: "O Operário", “A Urucubaca" dentre outros. Os objetivos dos jornais eram variados ia do político a literatura e humor, retratando as pessoas e a cidade de várias formas... Mas acho que minhas histórias retratam um pouco da cidade que não existe mais. A inocência da cidade que se perdeu! A cidade esta se transformando, assim que percebo.

Quero falar com você da minha atividade nos jornais. A relação das histórias que escrevo e a cidade. $\mathrm{Na}$ verdade, existem muitas e muitas coisas para contar. Então vamos começar.

A cidade a partir da qual construo minhas histórias é real. É a cidade onde eu nasci. Era pequena e agora está crescendo... Essas histórias são inventadas e outras acontecidas realmente. O nome "sobrenatural”, que dá título às histórias, veio da época do jornal "O Repórter de Paraopeba", anterior ao "Jornal de Paraopeba". Refiro às coisas inusitadas, por isso que eu pus esse nome. A idéia do título pode significar: coisas que não acontecem no dia a dia, que vão além do natural, sabe?

A “Titia”, a qual me refiro nas histórias é uma senhora doce que nasceu na roça. Lá não tinha luz elétrica e nem comunicação. Ela viajava de carro de boi, daí me contava as coisas que aconteciam por lá... Então, era ela que me dava o relato e o enredo das histórias. Minha relação com ela era a seguinte: eu ia para o quarto dela e puxava conversa, então ela me soltava as histórias.

Decidi colocar a titia porque eu conversava com ela. Era um fato real, que acontecia mesmo. Não é que ela participava realmente, mas ela era minha informante dessas coisas. Ela dizia: "Isso aconteceu assim..., em tal época...”. Ela tinha mais de cem anos e possuía uma 
memória fabulosa! Contava detalhes de tudo que ocorria e até recitava versos de cor. Agora, para as histórias fazer sentido, eu dava o "enchimento" e escrevia à minha maneira.

Acho que ela não fazia esse "enchimento" do qual me refiro. Ela contava às coisas que tinha ouvido falar. Ela narrava as histórias contadas por sua avó e por todos à sua volta. Mas também coisas que aconteceram com ela no passado. Vou the dar um exemplo de fatos que ocorreram no "tempo da fumaça". Esse "tempo da fumaça" se refere à época de sua bisavó. Pelos idos anos do começo do século XIX. A titia conta que nessa época havia tanta fome que a avó dela dava fubá às pessoas para fazerem mingau. Havia muita fome! Quer dizer, essas coisas aconteceram naquela época. Aí eu usava esses fatos mas acrescentava coisas da minha cabeça.

Quando comecei retratar a cidade através das histórias, não tinha a intenção de engrandecê-la. As coisas que narro não acontecem apenas aqui em Paraopeba. Ocorrem em outras regiões. Na verdade, é o espírito de uma época! As histórias nascem do espírito daqueles tempos. Minha, tia que viveu naquele tempo antigo, nasceu no começo do século XX, em 1900. Com esse espírito ela sabia de tudo. Não pensei em nenhuma forma de patriotismo, nem em engrandecer. Apenas relatar aquilo que ocorria aqui, mas que também podia acontecer em outro lugar. Essas histórias se transmitiam de boca em boca. Minha tia contava sempre de memória. Ela contava os fatos que, de certa forma, presenciava, e aqueles que ouvia.

Há várias histórias acontecidas que conto no jornal. Uma delas é sobre assombração. Mas essa história de assombração, da qual eu conto, é uma piada. Essa história é uma lenda muito difundida. Além dessa figura que aterrorizava às noites, o que estava por trás era a traição. O camarada gostava da mulher do outro... Desse modo o sujeito saiu a cortar o outro no "coro", bater nele, sabe? Na minha narrativa o sujeito falava assim: "É eu compadre, sou eu...". O outro respondia: "Eu tô batendo é no lobisomem" [risos]. Escute, a titia me contou esse caso ocorrido por aqui, foi um fato.

Conto também, no "jornal", um costume muito difundido por aqui. É o hábito de "curar de cobra". Trata-se de fazer o seguinte: durante a sexta-feira da paixão algumas pessoas tomam cachaça misturada com jiló. As pessoas afirmam que aquele que bebe essa mistura em jejum, será curado do veneno das cobras durante o resto do ano. Se uma pessoa for picada por uma serpente o veneno não fará efeito.

Existem lugares de Paraopeba que aparecem nas histórias que eu conto. Um deles é a região da Serrinha. Este lugar fica ao lado da fazenda da minha tia, pelos lados do Caboclo, dos Mangues. A Serrinha era um povoado e por lá existia uma capela. Mas também era um 
lugar que reunia muitas mulheres e tinha muitas festas. Para as pessoas muito católicas a Serrinha não era um lugar bem visto. Era um lugar de farras, onde os homens iam procurar "as mulheres da vida". Sei que a capela ruiu e foi construída outra no lugar. Acredito que hoje em dia existem alguns sítios por lá.

Há tanta coisa que posso contar! Existe a história do homem que enganou o diabo. Mas o enredo... [deseja consultar o "jornal" para relembrar]. Eu lhe conto depois, Neuber. Mas existe a história da origem sobrenatural da cidade, em que há uma pessoa chamada Furriel. Escute só: tem essa história, mas é inventada. Mas o mestre Furriel, ah! Esse sim, existiu. Furriel era uma espécie de título. Como alferes, sabe? Lá na fazenda de titia teve um mestre Furriel. Os fazendeiros contratavam os mestres para ensinar. Não tinha escolas naquele tempo! Ninguém estudava. Lá as pessoas aprendiam a ler e a escrever.

A propósito de escrever e ler há uma coisa que gostaria de lhe dizer. Ao longo da minha vida, acredito que haja uma relação entre ler escrever. Sei que a leitura me dá munição, argumento para desenvolver a escrita. Acho que existe uma influência nesta relação: aproveitar a leitura como material para escrever. Essa relação me permitiu descobrir tipos de pessoas, comportamentos, sentimentos, momentos históricos; para compor qualquer coisa, que porventura desejo escrever. A leitura sempre acompanhou minha vida.

Escute, eu gosto de escrever! Há um impulso dentro de mim que me leva a escrever. As histórias que eu escrevo tem algo dos contos "sobrenaturais". Mas, não só. Há histórias com humor e outras têm uma preocupação com a ciência. Acho que não seria ciência propriamente mas ao menos alguma teoria que sirva no enredo das histórias que desenvolvo. Talvez, por isso tenha cultura popular e erudita misturadas, em minhas narrativas. Sei que há diferenças entre elas. Pelo menos graus de diferenças: ciência não é popular no sentido estrito. Minhas histórias, por exemplo, me detenho mais na cultura popular mas a cultura erudita vai atrás. É para fazer a "costura" dos assuntos, sabe?

Dentre todas as histórias contadas e inventadas existe uma que me marcou muito. Foi uma história que aconteceu realmente aqui na cidade. Trata-se de uma conversão. Esse fato abalou muito a nossa cidade: a conversão do padre Sebastião! A gente sabe que antes dele se tornar um padre ele era farmacêutico. Trabalhou aqui na época do padre Augusto. Lá pelo início do século XX. Tinha rivalidades políticas, sabe como é? Políticas contrárias. Naquele tempo a cidade era um ovo e tinha disputa política, sempre teve. Depois que caiu o Império, começou...

O fato é que, antes de se tornar padre, Sebastião era muito farrista! Gostava de música e tocava clarinete. Existe até uma valsa de sua autoria. Ele freqüentava a rua da Palha para 
farrear com as mulheres. Sendo um sujeito bem aparentado, fazia sucesso com as mulheres! Dentre essas mulheres da vida teve uma que se apaixonou por ele. Você sabe Neuber, que naquela época farmacêutico fazia papel de médico. Quando as pessoas adoeciam elas se tratavam com rezas e receitas caseira. Quando era uma enfermidade mais séria, chamavam o farmacêutico. Se não o encontrasse, as pessoas morriam. Me recordo que narrei esta história no "Repórter de Paraopeba", acho que foi nos anos oitenta.

Ainda como farmacêutico Sebastião foi chamado para fazer um atendimento na roça. O dia estava terminando quando ele, inesperadamente, se perdeu em uma tempestade. Ficou sem rumo, desnorteado. Diante dessa situação seu cavalo se agitara. Foi então que Sebastião avistou uma luz no meio da escuridão. A luz cambiante vinha de uma capela! Sem pestanejar saltou do cavalo e entrou na capela para se abrigar. Já exausto deitou e dormiu dentro da capelinha perdida no sertão. No outro dia, quando acordou, estava deitado ao chão e não havia nenhuma capela. Aquilo tudo abalou profundamente o Sebastião. Diante disso se converteu. Mesmo sendo boêmio, decidiu entrar para o seminário. Foi estudar teologia, ele que havia estudado Farmácia. Logo depois de ordenado, decidiu vir para Paraopeba.

O fato é que ele se tornou um padre devoto. Só que aquela mulher que foi apaixonada por ele não aceitou essa situação. Quando ele celebrava a missa essa mulher ia assisti-la. Dizem que um dia ela colocou a cadeira bem perto do altar. Sebastião ficou impedido de oficiar a missa. Tentando ignorá-la, procurou continuar a celebração. Então pediu que essa mulher afastasse a cadeira. Mas ela teimosamente insistia em afrontar o padre. De repente, num ato de completo desvario essa mulher se levantou e começo a esbravejar. Diante dos paroquianos presentes fez um escândalo! Relatando a todos a vida anterior do padre Sebastião. Sua boemia... Daí ele disse: "Tudo que ela falou é verdade. Eu fiz isso que ela contou! Agora não faço mais, eu mudei!"

Deu um reboliço muito grande. Os familiares da mulher e todos os presentes ficaram atônitos. Naquele tempo acontecia o seguinte: quando ocorria uma afronta às leis da igreja se interditava o local. Foi o que aconteceu. A capela foi abandonada. Era a antiga capela do Rosário. Esse padre Sebastião era parente da Maristela. Depois ela fez um movimento para reconstruir a capela. Até hoje a Maristela continua nos festejos da igrejinha do Rosário. Nessa festa de Nossa Senhora do Rosário há os grupos de congado e suas danças rituais...

Há um desdobramento dessa história. Depois de muitos anos desse episódio um homem estava para morrer. Era o irmão da mulher que afrontou o padre Sebastião. Durante o escândalo esse homem tentou matar o padre, mas não conseguiu. Sebastião já se encontrava doente, estava para morrer também. Esse homem quis se redimir do pecado e das afrontas ao 
padre. Pediu que um intermediário fosse ao hospital solicitar ao padre que ele o perdoasse e pudesse assim, partir desse mundo sem culpa e pecado. Esse intermediário era o Sr. Pito, o pai da minha sogra. Dessa forma o Sr. Pito procurou o padre para levar-lhe o pedido de perdão. Conseguiu. Assim, houve uma espécie de "transconfissão" [risos]. Esses dois homens se perdoaram mutuamente! Acredito que isso abalou tanto a cidade que entrou para sua história. "Uai!” Essa e outras histórias permanecem no inconsciente coletivo. Assim, para mim, essas histórias que narro não têm a intenção de ser uma peça literária. Servem para distrair. O ser humano é sempre o mesmo! Gosta de ouvir e contar histórias.

Quando comecei a escrever essas histórias tinha a intenção de preservar a tradição da cidade. Mas depois eu mudei. Uso essas história para falar do que acredito. Já lhe disse, não? Minhas histórias têm um fundo espiritualista que bebe também na tradição oriental: o budismo, o taoísmo, etc. Ás vezes as pessoas percebem esta relação com a religiosidade, mas não desejo converter ninguém.

Quero contar outras histórias para você, essa causou polêmica entre os leitores. Há um deboche nela! Trata-se da história da "casa do tempo". Havia um menino da tia Benedita. Alguém me disse: "Você arruma tanta tia, hein?" O outro respondeu: "Não, essa tia é emprestada"... [risos]

Conta-se que Tonico ganhou uma casinha do tempo. Essa casinha tem um homem que sai dela quando vai chover! [Saiu da sala e buscou um exemplar dessa casinha do tempo para me mostrar. É uma espécie de termômetro.] Quando vai chover [aponta para o boneco] o boneco sai daqui. De acordo com a temperatura ele faz o movimento. Então foi que o Tonico, absorvido pelo "mistério" daquele movimento do boneco não arredava pé de frente dessa “casa do tempo". Observava-a o ano inteiro.

Para o Tonico era um milagre! Ele ficava maravilhado com isso. Anunciava chuva e chovia... Era um menino da roça com a idade de 15 ou 16 anos. Ele estudou minuciosamente a casa. De tanta intimidade botou nome no boneco da casa: o homem era Crispim e a mulher era Jurema. Quando Crispim saia da casa era chuva que desabava, e quando Jurema saía o sol brilhava. De tanta ciência Tonico ficou conhecido como o menino do tempo. Ao passar os meses e diante das transformações das coisas, a região foi acometida por uma feroz seca.

As pessoas temerosas com a falta d'água começaram a fazer promessas. Ajuntavam baldes de água para jogar no pé do cruzeiro. Tonico olhava para sua casinha e só via Jurema do lado de fora. O sol castigava! Assim, Tonico que era muito observador pensou: "Tenho que arrumar uma solução!" Esperou que sua mãe saísse e decidiu o que ia fazer: "Se chover quando o Crispim está fora da casa do tempo, então tenho que dar um jeito". Foi então que 
tomou a iniciativa. Tonico pensou: "Vou amarrar o Crispim com um barbante e puxar o boneco para fora da casa". [risos]. Daí logo começou a chover. Só que da falta, a chuva se tornou um excesso. A tempestade não parou tudo estava encharcado de água. Era chuva demais! Um dilúvio. Diante de tamanha tormenta as pessoas foram procurar o menino do tempo. "Viemos ver a casa do tempo!", disseram à mãe de Tonico. Vendo a situação, uma mulher pegou a tesoura e cortou o barbante que havia amarrado Crispim. Daí a Jurema foi saindo e a chuva foi parando... Parece uma fábula, não é? Para ensinar e divertir.

Por isso um amigo meu, o Crioulo, me disse: “Zé, essa história sua é um abuso! Você tem que fazer outra história justificando essa”. Sabe. Neuber, tem uma porção de histórias: o jogo de truco; a fogueira de São João e muitas outras. Ah! As histórias se desenrolam assim, sem muita garantia de resultado. Há leitores e ouvinte diferentes. Eles acabem influenciando... Os leitores têm o poder sobre o que está escrito. Cada um é único, não é?

Gostaria de falar de outra história que ocorreu nessa cidade. Mas antes vou informar para você: o Antônio Moreira que você conhece tinha um padrinho chamado Fortunato, se o Moreira tem 99 anos, esse Fortunato viveu por aqui no final do século XIX. O Fortunato possuía uma botica no meio do mato. Ele também ia a Sete Lagoas resolver os problemas do povo. Receitava medicamentos, tinha um livro de medicina que ele deixou para o Moreira, mas o filho dele perdeu esse livro. Ah! Como gostaria de ver esse livro, suas receitas...

Mas a história que queria lhe contar é a seguinte: “O homem que ajudava a morrer”. É uma história que aconteceu por aqui e algumas pessoas mais velhas que eu me confidenciaram. Uma história impressionante! Não havia tratamento específico naqueles tempos, por exemplo: quando uma pessoa tinha derrame ficava tempos agonizando. Aquilo era uma tragédia! Daí chamavam esse homem para ajudar essa pessoa. Não havia recursos, não é? Ele ia lá na casa do moribundo, se fechava no quarto e rezava, rezava. Esse camarada se achava muito importante! Possuidor de poderes e conhecimentos.. Mas sabe o que ele realmente fazia? Sozinho com o enfermo e debulhando o rosário, botava o cotovelo em cima do pescoço da pessoa e o apertava intensamente. [Levanta para demonstrar a prática]. Assim a pessoa não podia respirar, morrendo asfixiada. Esse homem matava as pessoas, que horror! Mas falava com todos da casa que era o poder de suas rezas. Ajudava as pessoas a morrer? Não, matava a todos que recorriam a seus poderes! Essa história foi meu sogro quem me contou. É um fato dessa cidade mas acho que acontecia em outras cidades.

Olha, escute só Neuber, quero falar para você: o mundo é um mistério insondável! E a pessoa que diz que sabe, não sabe. Quem afirma isso é um tolo. A vida tem seus próprios desígnios que nós desconhecemos. 
Consta que nessa região há uma fazenda chamada Vargem do Paga-Bem. Esse nome foi dado porque o fazendeiro dessa terra pagava bem os funcionários. Soube, recentemente de que o Tiradentes passou por essa região, pelo menos para mim é uma novidade! Há também um outro dado sobre a região da fazenda do Zé Teófilo. São todos casos dessas bandas... O lado de Paraopeba que dá para a cidade de Cordisburgo tem uma gruta... E dizem que havia um tesouro enterrado por lá.

Reza a lenda que as pessoas iam procurar o tal tesouro desaparecido. E para não perder a viagem, os buscadores do tesouro, recorriam à sessão espírita para saber o lugar onde se encontrava o tesouro [risos]. Meu tio Gumercindo me contou que havia uma venda por aqui onde os meninos compravam várias coisas. Certo dia, chegou um menino com algumas moedas desconhecidas. Daí, um viajante que passara por aqui viu aquelas moedas e se surpreendeu. Logo desaparecendo daqui. Entretanto, tal viajante indagara sobre o achado do menino. O dono da venda não soube responder. Mas ouviu a afirmação desse homem misterioso que seria libras esterlinas. Mas o tesouro ninguém encontrou... Bom, mas você se lembra da origem da cidade? O caso do coronel e da onça.... Os antigos falam que é verdade. Faz parte da nossa tradição. Também teria um registro dessas terras feito no século XVIII, mas desapareceu.

Como a cidade se modificou! Sinto a passagem das coisas, sinto saudades! Todas as ruas eram de chão. A luz elétrica era muito deficiente e era cedida pela fábrica de tecido Cedro \& Cachoeira. No domingo, durante o dia, não tinha luz porque se fazia manutenção. Ah! Domingo era aquela paz. Também quando dava uma chuva a luz elétrica ia embora. Quando queimava um transformador ficávamos um mês, dois meses sem luz, e pronto. Hoje em dia isso parece impossível.

Mas há um paradoxo nessa história toda! A cidade daquele tempo não tinha tantos meios de comunicação como hoje. No entanto, as pessoas da comunidade sabiam tudo que acontecia com os outros. As pessoas iam às casas das outras para visitá-las e serviam o tradicional cafezinho. Quando adoecia alguém, a cidade inteira sabia! Naquela época não precisava de muros altos para cercar os quintais. Era uma paz! Havia união, entende? Outra curiosidade, mesmo a cidade sendo pequena existia dois clubes. Um dos operários da fábrica de tecidos, o outro para os restantes. As pessoas se reuniam para conversar, dançar... Nas tardes de domingo tinha as horas dançantes, pois havia uma vida social intensa. Havia um cinema, hoje não tem nada disso. O sofrimento do resto do mundo não chegava até aqui. As pessoas da cidade se preocupavam com os próprios problemas. Quando necessário, as pessoas se ajudavam. 
Agora acontece o seguinte: as pessoas vivem em função dos sofrimentos alheio. $\mathrm{O}$ sofrimento do mundo, que chega até nós pelos meios de comunicação, isso é um problema. Vejo o sofrimento das telenovelas. Tanta loucura nas telas. Naquele tempo não tinha nada disso. Sabe o que existia? A gente trabalhava, estudava, vivia apenas...

A juventude não engajava na política. Havia atividades políticas, mas não eram nem a décima parte que é hoje. As pessoas mais jovens se nutriam de outras idéias. Ser vereador não era nada em Paraopeba, pois não se ganhava nada, nenhum dinheiro. $\mathrm{O}$ vereador não ganhava um tostão. Só àqueles que estavam em uma posição estabelecida, que possuíam interesses próprios. Aí sim, entravam na política para se defender. Apenas o prefeito era remunerado. Era essa a forma de se fazer política por aqui. Geralmente a política era coisa dos ricos da cidade, apenas uma forma de coronelismo.

\section{$* * *$}

As festas na cidade eram um acontecimento. Todo mundo se preparava. Não tinha essa badalação que tem hoje em dia. Recordo de uma festa de Nossa Senhora do Rosário, durou uma semana inteira. Era a oportunidade para a gente encontrar gente nova. Apesar daquele poeirão! O povo comprava e vestia roupas novas para participarem da festa. Houve outra festa que eu nunca esqueci. Foi a festa de Nossa Senhora de Fátima. A maior que aconteceu aqui, sabe? No ano de 1954. Nessa festa a cidade ficou toda enfeitada de bandeirinhas coloridas. A comunidade recebeu gente de muitos lugares. Dentre tanta gente de fora daqui veio um camarada cantar. Era um tenor. Você sabe que gosto de música erudita: Mozart, Schubert e outros. E também de chorinho. Toco um pouco de cavaquinho e flauta. Mas aquele acontecimento foi mesmo uma beleza! São tantas as lembranças: as procissões e até mesmo um incêndio no andor que carregava o santo. Essas festas serviam para dar formação às pessoas, para socializar, sabe? Além dessas festas existiam os bailes no cerrado da cidade. Esses eram perigosos! A gente chegava nesses bailes e se não ficasse moleque, esperto, eles batiam na gente. Podia ganhar uma surra por lá [risos]. 
A minha formação religiosa era católica. Desde criança participava da igreja, meu pai e minha mãe eram católicos. Meu pai foi presidente da conferência dos vicentinos. Ele foi um dos fundadores dessa conferência. Ela já completou mais de cem anos! Ele vivia nisso, gostava de ajudar a comunidade. Também foi um dos fundadores do hospital São Vicente de Paula; ele, o Gumercindo e outros. Até hoje existe uma placa lá no saguão do hospital com o nome do meu pai.

Eu era um menino piedoso e muito medroso. Tinha medo do inferno, achava que lá a gente queimava no fogo. Isso mudou quando a minha mãe morreu. Foi um enorme sofrimento para mim. Desde então, passei a buscar outras coisas... Outras tradições religiosas. O espiritismo, por exemplo. Ficava procurando, procurando, procurando... Até que eu encontrei os ensinamentos do Krishnamurti. No início eu relutei muito. Eu não acreditava de jeito nenhum. Mas quando compreendi o que esse pensador dizia... Tudo mudou. Eu aceitei sua mensagem e a igreja caiu! Virou cacos.

Escute, como dizia para você, eu participava de tudo. A festa preferida era a de Nossa Senhora do Rosário. Era uma festa religiosa, mas tinha muita gandaia! Isso era década de 50 e 60. Existia a zona boêmia, os botequins e muitas mulheres chegavam das cidades vizinhas. Nessa época não havia o perigo das doenças, sendo assim, tudo era diversão. Depois me casei, tive minhas três filhas. As coisas vão tomando outro rumo...

Você sabe, Neuber, eu não tenho nenhuma bandeira! Não pertenço a grupo nenhum. Quero a liberdade! Todo tipo de autoridade a gente tem que evitar. Aprendi isso com Krishnamurti: a importância da liberdade interior; compreender a escravidão do ego. Enfim, a urgência da "plena atenção" na vida diária. Pois bem, "Histórias" são coisas que acontecem por aí. Tem histórias inventadas também. Olha, se não tem assunto a gente inventa. Se fosse apenas histórias "reais" ou documentadas, eu já teria parado. Todo mundo está “mentindo"... O que importa mais uma mentira? [Risos].

\section{$* * *$}

Escute, Neuber, contar essas histórias mexeu com meus arquivos, minha memória. Então tive que consultar meus arquivos. Mas tem muita coisa... De modo geral é uma recapitulação. Você lembra do Carlos Castañeda? Todos os feiticeiros têm que fazer a recapitulação de sua vida toda para poder ficar livre das coisas negativas. Mas no fundo, não tem coisas positivas nem negativas, apenas existem os acontecimentos, os fatos! O melhor é 
ficar sem nenhuma lembrança, sabe? Talvez, cada um possa estar num ponto onde exista uma plenitude da memória; lembranças de tudo, ou ausência de tudo, que dá no mesmo! Que pairasse sobre nossos julgamentos banais e egocêntricos. E assim ter apenas a experiência do "vazio". 


\subsection{Geralda}

Nasci aqui mesmo em Paraopeba. Foi em 24 de setembro de 1924, escute só já tenho 85 anos e a vida passa... Acho que ainda era Vila de Paraopeba. Meu nome completo é Geralda Maria Araújo, alguns me chamam de Geralda da Marcília por causa da minha mãe. Olha Neuber, naquela época aqui não havia ainda se tornado a cidade de Paraopeba. A cidade era bem diferente. Quando olho para trás, vejo as diferenças. As coisas vão mudando... A cidade se transformou junto com as pessoas, não é? A casa, o bairro, as ruas vão mudando... Acho que é isso mesmo!

\section{$* * *$}

Aqui em casa era uma família grande. Era muita gente, aí as pessoas foram se casando... A casa foi sendo mudada. Ficou aquele pedacinho. [Anda de um lado para o outro até se assentar].

Quando meu pai morreu, eu era pequena. Nem o conheci. Acho que eu tinha uns três anos. A família dele não era daqui. Não conheço ninguém da família do papai. Agora, minha mãe era daqui, nascida e criada nesta cidade. Ela se chamava Marcília e morreu com mais de 100 anos.

Recordo que minha mãe falava que meu pai trabalhava em fazendas dessa região. Em carros de boi, sabe? Na Fazenda do Rasgão ele também trabalhou. Ele morreu cedo demais, e a mãe trabalhava em casa. Nessa casinha aqui no quintal, olha [aponta para a janela]! Existia uma fornalha. Lá eu fiquei cozinhando até quando dei conta. Eu cozinhava toucinho. Mas agora faz mal, não é? E torresmo também! Será porque naquela época não fazia mal? Ah! mas agora...

Quando lembro da família, lembro também da cidade! A minha família me deixou numa boa condição, graças a Deus! Fiz o grupo e tirei o diploma de quarto ano. Fazia de tudo em casa. Depois aprendi a costurar. Desde menina tinha o dom para costurar. Até sem aprender direito eu já fazia algumas roupas.

A mãe era carinhosa. Tinha só eu de filha. Meu pai morreu num chalezinho ali [aponta para a vizinhança], onde hoje é a casa da Laíca [casa vizinha]. Ouvia a história de que quando estava passando o enterro do meu pai, com o caixão e tudo, eu estava brincando e cantando na 
rua. Tinha apenas três anos. Ele trabalhava na Fazenda do Rasgão, como eu lhe disse, com carros de boi. Morreu de meningite. Sei que ele morreu novo.

Dentro de uma casa sempre tem uma briguinha. Estando junto, alguma coisa acontece, não é? Mas a gente se gostava. Ninguém guardava raiva um do outro!

Naquele tempo, era assim, tudo era reunido! Em casa, Lauzico, gostava muito de tocar violão. A casa era cheia de gente durante à noite. Quando minha mãe ficou viúva, ela voltou para casa, todos ficaram juntos, outra vez!

Recordo que eu ficava com medo de mula sem cabeça. Hoje em dia o povo não faz medo nos meninos. Eles não têm medo de assombração, como na minha época. Agora as pessoas fazem as crianças terem medo de assalto. Antes, a gente não tinha medo de roubos. Os quintais eram abertos, sem muros. Era apenas um fio de arame farpado até os vizinhos. E ninguém entrava na casa dos outros para roubar.

A gente vivia apenas... Não havia emprego como agora. O povo comia o que plantava. As pessoas viviam de plantar roça. Era socando arroz no pilão. Tudo era assim! Deu na hora de fazer comida, não tinha esse negócio de ficar pensando. A gente ia até o muro e pegava o ora-pro-nobis ou couve e cozinhava. Comia de tudo que dava no quintal. Agora é só beterraba, cenoura, couve-flor [risos] e também pizzas, lasanha [risos].

Levantava da cama bem cedo, às 6 horas da manhã. Quando tinha, comia alguma coisa. A gente fazia um bolo assado na caçarola, sabe? O café não podia faltar, né? Torrava o café e o moía no pilão.

O almoço não tinha horário certo. As pessoas não eram empregadas como são no dia de hoje. Então a gente comia às dez ou onze horas. Quando era menina tinha que ir para a escola às 12 horas. $\mathrm{O}$ jantar era qualquer coisa, lembro da farinha de munho, fubá, sabe?

Zé Luiz e o Deusdete se juntavam com Lauzico para tocar violão. Era uma casa movimentada, com muita gente. De primeiro, o povo não tinha luxo! Lembro bem do "Seu Gui”, era o Agnaldo Edmundo. Pois ele não saia daqui de casa. Foi quando começou a namorar a Mindita. Vinham juntos. Ele tocava bem violão e fazia uma dupla com o Lauzico.

A casa era cheia! As pessoas assentavam nos caixotes. Não tínhamos sofá, nem nada. Eles cantavam muito. A Ester gostava muito de cantar... Também freqüentava aqui o Manuel Serrador, o pai da cantora Clara Nunes. O Lau tinha um boteco no cômodo da frente da casa. Recordo bem da música que o Mané Serrador gostava de cantar:

“Ei chuchu, chuchuzinho

Bem temperado, que bom será 
Minha Sinhá

Vai pra cozinha

Põe na panela pra temperá

Ainda ontem eu tive uma pega

Com a minha prima Zuzu

Ele pôs armoço na mesa

E esqueceu do meu chuchu

E. ê, ê chuchu, chuchuzinho

Bem temperado, que bom será

Minha sinhá vai pra cozinha

Põe na panela

Pra temperá."

Não me esqueço que ele cantava com o olhão arregalado. Ficava se "arremexendo" e os meninos rindo. Era aqui nessa casa velha, aqui na frente [aponta para fora]. Ali tinha o boteco do Lau. Depois foi se desmanchando, foi caindo... Aí construiu essa casa aqui que eu moro. Aquele pedaço lá fora é parte da casa velha. Lembro-me que a Clara Nunes não freqüentava aqui, apenas o pai dela.

O bar era do nosso avô. Era uma casa grande. Da sala da casa foi feito um bar. Era um boteco onde as pessoas se reuniam. O Lau era o meu avô. Sabe o Mané morava em Caetanópolis e vinha nos visitar. Como se diz por aqui: "vinha molhar o bico".

As tarefas da casa quem me ensinou foi minha mãe. Coitada, ficou viúva! Nem conheci meu pai direito. Ela saía para trabalhar nas casas e nas roças. A minha mãe morreu com 102 anos; e fizemos a festa do aniversário dela. Você vê como são as coisas! Hoje em dia você não pode nada. E ela viveu tanto, não é?

\section{$* * *$}

Sempre morei por aqui mesmo. Nessa rua havia poucas casas, os quintais eram grandes e não eram fechados com muros. A rua era de chão, poeira... 
Todo mundo era muito simples! Pobre mesmo, sabe? Não havia esse negócio de emprego não. A gente plantava roça para viver, aqui mesmo na região da cidade, pelos lados do Rasgão. Meu povo todo! Tinha o Lauzico, você se lembra dele? O Lau ia plantar roça, e depois... a gente ia socando arroz no pilão, sabe? Tinha de pilar o arroz porque nós comprávamos pouca coisa. Todo mundo tinha um chiqueirinho no quintal e assim a gente criava os porcos. Era assim: tirava um porco e punha outro. Mas era muita fartura!

Aqui era um terreno só. Vinha de lá da casa da Conceição. [aponta para a casa da vizinha]. Até a casa da Sônia [a casa abaixo], ali sabe? Tudo pertencia a uma pessoa só. Aí, quando o velho morreu,(não, acho que foi antes dele morrer) decidimos repartir o terreno, um lote para cada um. O pedacinho ali, onde a Deija morava, que era mãe do Walter. Aqui ficou para minha mãe. Na esquina, ficou para a Ester que foi casada com o João Gato. A Ester era minha tia, irmã do Lauzico do Gestal e da mãe do Walter. Sabe aquele lote ali perto da Sônia [vizinha que mora abaixo da casa]? Fixou o terreno para o Gestal. Era um lote enorme...

O povo dessa época não coava café com açúcar cristal. Era açúcar moreno, açúcar preto, ou rapadura. Eram poucas as pessoas que podiam comprar açúcar cristal. Eu até saia vendendo banana na rua. Sempre me recordo que tinha fartura, entende? Mas das coisas simples.

Era muito comum as pessoas pedirem alguma coisas para os vizinhos. Por exemplo, quando amanhecia sem o café, a gente pedia emprestado ao vizinho. Uma xícara de açúcar, sabe? Hoje em dia não se usa isso mais, não é? Mas antigamente era assim! Acho que não se usa mais porque tem mais venda perto das casas. Mas depois, as pessoas devolviam, no regime de troca. Um ajudava ao outro. Nós tínhamos poucas roupas. Fazíamos vestidos de chita para irmos à missa aos domingos.

Recordo das brincadeiras de roda. Havia uma brincadeira que se chamava Berlinda. Era assim: a pessoa que ia para a berlinda ficava sentada. Aí a outra pessoa perguntava: por que você foi para a berlinda? A resposta era: por isso ou por aquilo. Me lembro que havia um rapaz solteiro e mais velho por aqui. O coleguinha perguntava: por que o Ameriquinha não está na berlinda? Ah, porque não se casou. Aí seguiam as perguntas e as respostas.

Brincávamos de passar anel. A gente perguntava: “com quem está o anel”? Ia se passando o anel na mão de cada um. Também havia outra brincadeira, ela se chamava o tatuzinho. Era assim: “alguém perguntava se o tatuzinho passa por aqui”? Daí o outro respondia: "não passa não"! Isso era repetido várias vezes. "Aquele passa"? ou "O outro passa"? "Que pau é esse"? "É jacarandá". "Que pau é esse”? O outro respondia: "É aroeira”. Existia também a brincadeira da Pata-Choca, você já ouviu falar? No grupo a gente brincava 
muito de pata-choca. Era uma porção de meninas que faziam um círculo, aí uma delas corria em volta do círculo e deixava uma bolinha atrás de uma pessoa, se ela não visse as pessoas gritavam: "pata-choca"! Ah, eram brincadeiras assim, bem sadias!

De primeiro, o povo não tinha automóvel. Andavam a cavalo. E os cavalos ficavam soltos, balançando o sineiro. Eu ficava deitada e ficava ouvindo o sino batendo no pescoço do cavalo. Sentia muito medo. Era um sineiro, um sininho, sabe? Era para o dono localizar onde estava o cavalo.

As pessoas chegavam cansadas do trabalho na roça. Não havia televisão! As pessoas se assentavam na porta da casa junto com os vizinhos. Aí ficavam até 9 horas da noite conversando. A meninada brincava na rua. Eram brincadeiras simples: esconde-esconde; pegadô, brincavam de roda. Era desse modo que se "fazia hora", até a hora de dormir!

\section{$* * *$}

Às vezes fico lembrando... Como a vida era sofrida! Uai! Mas a gente não sentia, sabe? Era uma luta para sobreviver, menino. Ah! A gente vivia muito diferente de agora. Nos tempos de hoje o povo está rico, sabe? Antes tudo era buscado na cabeça: a lenha para cozinhar, as roupas para lavar. Não existia água encanada. Ontem mesmo estava lembrando dessas coisas... Estava conversando com um rapaz e falava para ele: "ali embaixo, na praça da Matriz, onde morava D. Lourdes Mascarenhas, eu tinha medo de ir lá sozinha. Era só mato!” Mas agora tem muitas casas por lá. Lembro-me de uma tia me pedindo para comprar couve de uma horta naquela região. Eu ia, mas morrendo de medo...

Nós vivíamos assim! Tudo era na cabeça, baldeando... Recordo do moinho de moer. Era movido com a força d'água. A gente vinha, trocar milho por fubá, entende? Era assim, a vida...

Nos anos quarenta, fomos morar em Pacu para extrair cristal. Era uma região perto daqui. Fui trabalhar lá, para dar pensão aos operários. A vida era simples, mas muito melhor. Ia lavar roupas na Lagoa do Tabuleiro Pequeno. Não existia água encanada. Outras vezes, lavávamos roupa no Beco. Hoje lá é uma avenida, não é? Havia bicas de água jorrando. Era uma beleza!

Trabalhávamos apanhando algodão na Fazenda do Engenho. O serviço era deste tipo e íamos levando... Não tinha isso de não pode comer isso, não pode comer aquilo. Veja, minha 
mãe com 102 anos, morreu lúcida! Já lhe disse isso, não? Só você vendo. Ela nasceu e morreu aqui.

Eu nunca tive um emprego como se tem hoje! Era assim [pausa], a gente lavava roupa para os outros. Mas eu cheguei a trabalhar na roça como muitos da minha família. Depois, trabalhei em casa. Quando já era adulta eu aprendi a costurar e fiquei costurando... Resolvi não me casar. Fiquei solteira! Naquela época era muito diferente de hoje.

O trabalho que existia... O fato é que não havia emprego. A fábrica de tecido custou a chegar. Eu me lembro quanto estavam construindo a fábrica de tecidos (PISA). Só existia em Caetanópolis, antigo Cedro. E muitas moças iam trabalhar lá de madrugada. Elas iam para fábrica do Cedro à pé.

O Lauzico mesmo era pedreiro. Quando não estava na roça, trabalhava de pedreiro. As casas eram feitas de adobe. O Lau fazia muito aquele barro! Era tanto que o quintal ficava todo "cavucado", assim cheio de buracos. Ele não colocava nada além de terra. Fazia para vender para a comunidade.

\section{$* * *$}

Estudei na escola Afonso Pena. Nessa época, havia quatro professoras. Tirei o diploma do grupo nessa escola [aponta para fora, sua casa fica na esquina dessa escola]. Sabe de uma coisa? Tudo foi mudando...

Eu não achava a escola difícil. Estudei durante quatro anos no grupo Afonso Pena. Minha professora era a D. Margarida Mascarenhas. Ela deu aula para mim a vida toda! Era mãe do Bereco e a esposa do Joaquim Nascimento, sabe quem?

Naquele tempo a gente levava pouquinha coisa de material escolar. Hoje em dia os meninos vão para a escola com aquelas mochilas... Aquele mundo de coisas! No meu tempo era um caderninho ralo assim [faz um gesto com a mão]. A gente usava pena e tinteiro, e todo mundo ficava pelejando... nós vendíamos algumas coisas para comprar o tinteiro nas vendas. A professora era brava, mas era legal, boa! E o diretor era o Sabino de Paula Freitas, aquele que era poeta e foi também prefeito da cidade.

A gente aprendia de forma diferente! As pessoas passavam na rua e ficavam escutando: $\mathrm{b}+\mathrm{a}=\mathrm{ba}$, sabe como? E depois é que nós formávamos as palavras. Havia lousa de pedra e lápis próprio. Era um quadrinho assim... Parecia com uma pedra [desenha com os dedos no ar]. 
Havia as músicas de roda. Recordo algumas delas, escute só:

"Olha a rolinha doce

Doce, doce, doce

Embaraçou, doce, doce.

Ponha aqui, ponha aqui

O seu pezinho

Ponha aqui, ponha aqui

Bem junto ao meu

Já ao tirar o seu pezinho

Um abraço dá-me eu

A rolinha doce, doce

Caiu no lago

Doce, doce

Coloca o nosso amor

Doce, doce (...)”.

Uma outra brincadeira era desse jeito, sabe? Cada um cantava e improvisava um verso. Era assim:

"Um, $a, b$ ou c

Um, c, b ou a

Um, $a, b$ ou $c$

Um, c, b ou a

Um, $a, b$ ou $c$

Eu não caso com você”!

Daí uma outra pessoa fala: [Tenta relembrar] Ah! É assim:

"Norta apanhou o cravo

E enfiou o espinho no pé

Amarrei com fita verde 
Cabelinho de José”.

Era alguma coisa assim, sabe? Uns "trens" assim, Uai!Vou lembrar, espere.

"Agacha, agacha serrania

Que eu quero ver a cidade

Meu amor está tão perto

E eu, morrendo de saudade”.

Cada um punha um verso assim, mais ou menos. É bobo assim mesmo, sabe? Ah! A gente contava muita história. Na hora que a gente quer lembrar, não lembra! [Fica pensativa].

\section{$* * *$}

Lá em cima, onde as pessoas até hoje chamam esse lugar de "Chora-cadela", era muito diferente de hoje. Hoje em dia, colocou o nome de bairro Dom Bosco. Mas lá as casinhas eram quase todas feitas de capim, sabe? Não existiam telhas. Passou dali, do açougue do Brandão, eram casas de capim. Hoje em dia existem muitos prédios! No bairro Champ's [aponta na direção], pertencia à Fazenda do Rasgão. Até onde você mora, Neuber, era também a Fazenda do Rasgão. Ali mesmo, onde existe a caixa d'água do Horto Florestal começava a Fazenda.

Me lembro que daqui de casa a gente escutava os burros berrando... Aquela região lá da serra, na Pedra Grande, também era a Fazenda do Rasgão. Eles venderam lá, não é? A Ester, daqui de casa, foi dona de um terreno chamado Borra e quando ficou viúva, o Lau ficou morando por lá, para ajudar tomar conta...

\section{$* * *$}

Quero lhe contar, Neuber. Aqui antigamente se chamava Tabuleiro Grande. O povo falava assim: “vamos lá no Tabuleiro". Depois veio a emancipação e passou para cidade. Era tão diferente que existia até um teatro! Era uma casa bem grande. Também tem aquela história da onça, sobre o surgimento da cidade, não é?... 
Quando eu era menina, fui ao teatro. O pessoal aqui de casa, o Lauzico, tocava no conjunto de música. Lembro das meninas cantando no bailado... Eu assistia, mas não participava. Depois desmanchou o teatro e fez o prédio do cinema. Naquele tempo a gente não conhecia nada. As pessoas daqui de casa contavam que o Vitinho, que era nosso amigo, fazia parte no teatro.

Também existia a Câmara e a Prefeitura, prédios que foram demolidos. Achava esses prédios bonitos. Havia a casa do Aristides Nascimento, ao lado da Prefeitura. Onde hoje é o supermercado da Vó Vina. Também tinha um bar lá. Agora, o teatro eu fui muito nele! Recordo lembro até de uma galeria em cima do palco... Sabe aquela poetisa daqui? A Mercês? Ela cantou, quando menina, nesse teatro.

Havia um posto de saúde perto do hotel de D. Maricota, mas já foi demolido. No boteco, que hoje é do Pedro Careta, tinha uma casa. O Silvio, meu tio, tinha uma sorveteria neste lugar. Isso fica na região da Praça da Matriz. Recordo de um acidente que houve por lá. Não sei quem, mas alguém esqueceu alguma coisa ligada e pegou fogo. Eu trabalhei lá, nessa sorveteria, para ajudar meu tio que era sócio.

Quase em frente, onde hoje é o hotel da D. Maricota, existia a farmácia do "Seu Neném". E o Otávio Silva, seu filho, gostava muito de passarinho. De frente da farmácia ficava cheia de gaiolas. Ficava ali, na praça da rodoviária, sabe? Havia também uma rua cheia de cascalho...

Na praça só existia um posto de saúde que foi demolido. Lembro da casa do "Seu Neném" - o jornalista da "Gazeta de Paraopeba". Os filhos dele trabalhando... Havia a farmácia. Mas o filho dele, o Zé do Neném era farmacêutico formado. Depois o Otávio, filho dele, também continuou com a farmácia. Ele gostava da banda de música, ele até tocava um instrumento, acho que flauta. Lembro da oficina da "Gazeta de Paraopeba" era no mesmo prédio da casa e da farmácia. Era boa pessoa, recordo dos meninos vendendo pequi em frente à sua casa. Sei que ele comprava os pequis só para ajudar as crianças. Era assim...

Quando era menina, não tinha luz elétrica. Era luz de lamparina. Ia sempre comprar querosene na venda do Sr. Bernardo Mascarenhas. O Lau tinha um botequim onde ele colocava uma outra iluminação. Era a luz de carbureto. Fazia uma luz bem clarinha. Quando a luz chegou o Neves, nosso vizinho, falou assim: “a luz aschendeu, a luz aschendeu"!... [risos] Não existia luz, meu filho... Era tudo gente do povão...

Havia uma lagoa chamada Lagoa do Tabuleiro Pequeno, do outro lado da cidade como lhe contei. Ali havia um terreno e um moinho. Nós moramos lá por uns tempos. Plantávamos horta e depois vendíamos as verduras na rua. Havia bananeira e dava muita banana. Lá da 
Borra, daquele terreno que eu lhe falei, nós trazíamos muitas frutas, frutas... [repete a palavra fruta várias vezes]. Nessa época tudo era feito à pé. Íamos para o Cedro à pé e depois voltávamos à pé. A estrada era de terra, sabe?

A cidade era outra coisa. Não existia a rodoviária, como até pouco tempo atrás, apenas a casa do Belo. Depois foi construída a rodoviária. Eles começaram com uma jardineira, sabe? Era um ônibus de madeira que fazia a linha de Curvelo para Belo Horizonte. O filho do Belo, o mais novo, que se chamava João e era conhecido como Zito, acho que trabalhava nessa empresa. Me lembro que em uma ocasião eu e minha avó viajamos de ônibus. Ela vinha de Curvelo e passava por aqui por volta de seis ou sete horas.

Mas a viagem era assim: ia num dia a voltava no outro. Minha avó foi para se consultar. Quando nós voltamos, viemos em um ônibus que saía de Venda Nova, em Belo Horizonte, até chegar em Sete Lagoas. Não Era direto como hoje. Lembro que nós sentamos no aterro da lagoa, no centro da cidade de Sete Lagoas, o dia inteirinho. Não havia condução para Paraopeba. O chauffeur era o Setembrino, não me esqueço. A jardineira daqui estava quebrada, mas conseguimos chegar até aqui. A vovó e eu viemos de carona na boleia do carro do Zé Gomes até o Cedro. Tudo era uma dificuldade danada!

Tenho muitas lembranças do hospital antigo. Não é o Hospital São Vicente que existe até hoje. Era o hospital que existia onde hoje é o colégio Padre Augusto Horta. Ia muito nesse hospital e me recordo de uma mulher meio doida que andava com a tampa do caixão na cabeça [risos]. Ela era interna, tinha a cabeça ruim, você compreende, não?

O médico que trabalhava lá era o Dr. Theóphilo Nascimento e depois foi o Dr. Guilherme, que era mais novo. Havia uma paciente chamada Marcela que foi operada por eles. Recordo do tumor que ficava dentro de um frasco... Sei que depois ela ficou boa.

\section{***}

Costurava desde menina. Mas era tudo "pros coco", sabe? Olhava minha vó costurando e fui fazendo. Depois de adulta aprendi o corte e costura com uma pessoa de nome Inhá. Não sabia o corte, era por medida. Quando era moça fui aprender em Sete Lagoas com a D. Esperança. Logo adiante aprendi com o Neves alfaiate a fazer calça para homem. Aí passei a costurar para homem e mulher.

Eu gostava de ensinar e ensinei para muitas moças. Não ganhei dinheiro como costureira, mas gostava do que fazia. Só que agora mudou demais! Agora o ombro pode cair, 
uma gola perfeita é raro. Hoje em dia costurar para gente gorda e magra é a mesma coisa. Primeiro aprendi o corte paulista, era bem simples e fácil de ensinar. Com a minha vó aprendia "de olho", observando ela costurar. Recordo que cheguei a trabalhar na rua dos Tupis em Belo Horizonte. Era um salão de pessoas chiques e muito exigentes. A dona desse salão aprendeu aqui comigo e depois fui tentar a vida na capital. Mas não pude ficar lá porque a mamãe só ficava reclamando. Sou filha única, é mais difícil não é?

Quando via meu trabalho, achava bonito. Era uma arte costurar, pois tinha que sair perfeito. As pessoas traziam os modelos, da loja Grande Gala de Belo Horizonte, para eu poder copiá-los. E procurava fazer igual, tentava até conseguir. Daí olhava para a roupa e pensava: “Olha que bonito!". Sei que trabalhei costurando mais de quarenta anos. Era um trabalho que fazia com gosto. E ainda mais que aqui na cidade, naquela época, não tinha muita opção de trabalho. Mas desde menina gostei de costurar...

Você vê! Nessa época não tinha recurso nenhum. O Dr. Guilherme era chamado! Era muito caridoso também. A riqueza dele não foi tirada da medicina. Ele era assim: quebrava um braço, ele cuidava. Parto, ele também fazia. Ele tratava de tudo, sabe? Agora não, se não tem ortopedista, não pode. Chegou uma criança, se não tem pediatra, não pode cuidar. Mas ele sabia cuidar de tudo!

A política da cidade era muito diferente. Era a época dos coronéis. Lembro que na fábrica os operários eram obrigados a votar nos candidatos dos patrões. Se alguém não votava, os patrões mandava embora. Os operários eram despedidos. Os candidatos eram Dr. Guilherme, Dr. Campolina, os Mascarenhas... Quando o Bernardo Cirilo ganhou foi uma mudança. Ele era simples, do povo. Igual ao Lula de agora.

Me recordo de uma briga na prefeitura. Havia um homem chamado Geraldo Carlos e ele não agradou as pessoas. Essas coisas que acontecem na política, sabe como? Então juntou um povão que foi à prefeitura e o tirou. Mas naquela época a prefeitura era muito pequena. Não tinha nem um caminhão, só as carroças puxadas por burro. Não esqueço dos homens capinando as ruas. Não tinha quase nada na cidade, agora cresceu muito. Tudo mudou...

\section{***}

Recordo das festas da cidade. As festas do Rosário eram uma beleza! Todos nós somos católicos, sabe? A Ester daqui [se refere à sua casa] foi a rainha e festeira. Era uma semana inteira de festa. Recordo que o padre era o Augusto. Tinha um tal jogo de bolinha que 
era um sucesso! O Lau, daqui de casa, toda vida gostou desse jogo. Era mais ou menos assim: havia uma banca de madeira, arredondada, e as pessoas jogavam as bolinhas até cair no buraquinho. Parecia uma sinuca. As pessoas faziam uma tolda, uma barraca enorme onde hoje é o açougue do Brandão. Era cercada de pita, bem verdinha. E coberta com folhas de bananeira.

A festa ocorria ali na região da igreja matriz. Não haviam desmanchado esta igreja ainda, para depois reconstruí-la. Era a noite inteira o povo gritando no jogo das bolinhas, nos botequins... Vendiam lingüiça, carnes e bebidas. Na hora da procissão da Santa, todos desciam. Onde hoje é a Praça da Fonte Luminosa se armava o circo de touradas. Não havia casas. O povo da roça vinha com os carros de boi. Ah, como eram boas essas festas! Muito diferente de agora.

\section{$* * *$}

Você conhece a história do padre Tião? Vou lhe contar. Sei que teve até profanação da igrejinha do Rosário. O motivo da excomunhão da mulher foi o seguinte: no tempo em que o padre Sebastião era rapazinho, ele teve envolvimento com ela. Depois se converteu e se regenerou. Quando ele se ordenou, e celebrava nessa igreja, essa mulher colocava a cadeira perto dele, era no cercadinho que existia nessa igreja, justamente ao lado dele. Foi então que ele brigou com ela e a excomungou.

As pessoas falavam que aconteceu um milagre com ele. Não sei se foi em Cachoeira ou em Lagoa da Prata quando aconteceu o tal milagre. Despencou um temporal, uma coisa horrorosa, sabe? Ele estava à cavalo. Não conseguindo andar, pediu à Nossa Senhora, a Deus que o ajudasse. Na mesma hora apareceu uma casinha e ele se abrigou. Nessa casinha existia uma dona que o hospedou. De repente, quando parou o temporal, ele desamarrou o cavalo e não viu mais casa nenhuma. Foi mais ou menos assim. Ocorreu uma transformação nele, sabe? Então decidiu estudar e se ordenar padre.

\section{$* * *$}

Quando me lembro dessa cidade, como ela era... Sinto saudades! Sinto saudades do teatro, da igreja do Rosário, que possuía um sino que eu escutava daqui. Hoje é impossível ouvir as badaladas do sino daqui de casa, veja só. Há muito barulho de carros, o movimento das pessoas... Ali no asilo era o cemitério antigo [aponta para a rua]. Pouco tempo atrás havia 
alguns homens trabalhando no terreno do asilo e encontraram tumbas por lá. Me lembro das pessoas indo visitar aqueles túmulos, logo aqui nesta rua. O pai do "Sô Guil" foi enterrado nesse cemitério. Lá existia uma igrejinha, catacumbas. Hoje é o asilo. Quanta mudança!

Existiam algumas coisas esquisitas. Por exemplo, a mulher mais poderosa da cidade era a D. Corina. Tudo na cidade era para ela. Até as melhores carnes do açougue eram reservadas para ela! Ela era rica, sabe? Não tem isso mais; Graças a Deus!

Há outra mudança. A igrejinha do Rosário era diferente! Depois acabou toda. Ela tinha um sino e quando morria alguém, a gente escutava daqui o sino bater. Não tinha barulho nenhum, aí dava para ouvir. Dessa forma, chamava o Zé Mutengo, que era o coveiro. Existia uma vizinha aqui, que tinha muito medo e que quando o coveiro passava na rua ela falava: "Cruz credo! Cruz credo"!

A igrejinha do Rosário acabou porque o padre Sebastião excomungou uma mulher. Depois desse episódio, a igreja foi lacrada. Aí ela foi ficando em ruínas até que a Maristela, depois de algum tempo, resolveu reconstruí-la. As pessoas falavam que quando uma igreja ficava nessa situação nada vai adiante. Engraçado, depois que reconstruiu essa igrejinha a cidade melhorou muito. Cem por cento! Veio a PISA, a fábrica de tecido. Não havia nenhum emprego por aqui.

Também veio o asfalto que atualmente passa aqui dentro da cidade. É a rodovia, sabe? Veio o IBAMA e melhorou muito! Fui muito nessa igrejinha, nas aulas de catecismo. Quem ensinava catecismo era da D. Zezé que se tornou freira. E o padre era o Tião. Sebastião que ele se chamava. Lembro que, quando mamãe ficou viúva, o padre Sebastião a ajudou. Naquela época havia o costume das mulheres usarem roupas pretas depois da viuvez, como não tínhamos recursos, o padre Tião deu a ela o dinheiro para comprar as roupas pretas para viver o luto.

Naquela época s pessoas se davam melhor. Todas as pessoas eram mais simples. Eram mais amigas. Recordo agora: no grupo não tinha nem banheiro, como existe hoje em dia. A água da escola era colocada numa talha, em um pote de barro. A D. Dulina enchia os potes de água buscada no Beco. Todo mundo era igual. Mas a gente não sentia as dificuldades! Em casa não havia nem sofá. Só tinha um banco de madeira para se assentar. Era uma vida difícil, mas divertida. Agora, é só apertar o botão e pronto.

A gente lembra, a saudade... Esquece também, não é? Eu me sentia bem. Era uma vida boa que a gente levava. Mas depois foi acabando tudo. Daqui de casa só restou eu. Mas é assim mesmo, é a vida! 


\subsection{Maria Stella}

Nasci nessa mesma casa, em 1927, ainda era Vila Paraopeba. Olha como o tempo passa! Já tenho 82 anos.... A casa está do mesmo jeito, tudo igualzinho, não mudou nada. Os mesmos móveis, nada mudou. Me lembro, tudo está igual! Meus pais se chamavam Américo Moreira e Anésia França Moreira. Tiveram seis filhos: Carlos, Rachel. Paulo Vicente (falecido ainda bebê), Vicente de Paulo, Wander e eu. Minha mãe cuidou dos filhos com a ajuda da vovó Sacena e minha tias, irmãs da mamãe.

Vivi aqui até os dezessete anos. Meu pai morreu quando eu tinha três anos de idade. E minha mãe cuidou dos filhos sozinha. Essa casa era igual a uma fazenda. Praticamente não havia vizinhos. De um lado havia um terreno da Prefeitura, que se chamava "Lagoa Seca". Deveria ter sido mesmo uma lagoa porque era cheio de minadouro. No tempo da chuva corria um riacho. Servia também de pastagem para os animais que viviam soltos. Logo ali acima, era cheio de minadouro e havia também muita formiga. Então a minha mãe pegava o remédio e a gente ia socando, socando para matar o formigueiro.

O quintal aqui era maravilhoso! Havia uma horta muito bonita, que nós cuidávamos. Ainda é essa casa, a mesma casa centenária no centro da cidade. Aqui na frente tinha uma horta e minha mãe sempre pedia: "vai lá, Maristela, pega alface na horta"! Todos sempre me chamaram de Maristela, assim com o som dos dois nomes juntos. Havia uma variedade de hortaliças. Graças a Deus! Essa saúde que eu tenho hoje com oitenta e dois anos de idade, posso dizer que nunca adoeci. Fui criada aqui e eu gostava muito de frutas. Olha só, rapaz, tinha no quintal: laranjeiras, mangueiras, jabuticabeiras, (hoje centenária). Como eu me deliciava com jabuticabas, tão negras que às vezes ficavam azuis. Ah! Que saudades.

O jardim de mamãe era muito bonito. Aqui à frente [aponta para a janela lateral] era cheio de lírios, minha mãe gostava muito de lírios. Eram brancos e também rosados. Depois que ela morreu eu tentei preservar o jardim, mas não consegui. É difícil cuidar dos lírios porque tem que retirar os bulbos dos lírios e deixar ao sol para secar. Para, só depois, eles florescerem. Recordo que minha mãe fez uma composição com o título "As flores" e nela dizia que dentre todas as flores a que mais apreciava era o lírio.

Existem várias lembranças, são tantas, não é? Oh! Olhe ali [aponta para a janela na qual se avista o jardim] havia três quartinhos: um para colocar a lenha; um para os arreios do cavalo e o outro para o depósito do milho. Ainda me lembro da bomba d'água e de um cômodo que usávamos para fazer manteiga. Hoje, ninguém imagina isso, pois essa casa está no centro da cidade, mas tínhamos vaca aqui. Eram duas vacas, elas ficavam no pastinho ali 
nos fundos. Sabe, Neuber, fomos criados com leite de vaca daqui mesmo de casa. A saúde que tenho até hoje, posso dizer que nunca tive doença grave, foi graças a Deus; e também agradeço às frutas e as verduras sem agrotóxico, e muito leite tirado na hora. À noite ficávamos todos em volta da mesa para saborearmos o leite com nata, farinha de milho e os delicados biscoitos feitos pela mamãe. Logo após rezávamos o terço e íamos dormir, mais ou menos às oito horas. A vovó passava de cama em cama para nos cobrir.

Há uma curiosidade acerca dessa casa: ela foi construída de forma diferente das casas antigas aqui da cidade. A casa da D. Dolores, por exemplo, que morava no início dessa rua. A casa dela era mais forte! Acho que esta casa e a da D. Inês do Cartório são as primeiras casas que teve em Paraopeba. Essa casa toda foi construída de taquara e adobe. Tanto é que houve um roubo aqui tempos atrás e os ladrões entram com facilidade... Essa casa não tem alicerce. O alicerce dela são toras de aroeiras bem largas. Quando minha mãe morreu e ela ficou fechada apareceram muitas goteiras. Olha para ali [aponta para a parede] existe um enchimento nas paredes. Essa casa é dos tempos da escravidão...

Essa casa guarda muitas histórias. Antes de meu pai comprá-la ela foi do Sr. Avelino Fóscolo que inaugurou a imprensa aqui na cidade. Acredito que foi lá pelo final do século XIX que ele criou o primeiro jornal. Ele também escreveu vários livros. Sabe, ele morou aqui muitos anos. Sei também que três filhas do Sr. Avelino se casaram aqui nessa casa, sendo que duas delas no mesmo dia. Nessa casa já teve muito casamento!

Mas antes do Sr. Avelino vir morar aqui, essa casa pertencia ao seu sogro, ele se chamava Manuel Pinto. Era pai da mulher do Seu Avelino, ela foi sua única filha. O "Seu Pinto", como era chamado, morreu em Sete Lagoas com a idade de cento e quatro anos. Ele era farmacêutico e ensinou esse ofício para o seu genro. O Sr. Manuel Pinto nasceu na primeira metade do século XIX, certamente teve escravos vivendo aqui. Ele viveu aqui nessa casa durante muito tempo. Acho que essa casa deve ter quase 200 (duzentos) anos. Meu pai a comprou por volta de 1923, eu acho...

\section{$* * *$}

Aqui nessa casa morávamos eu, minha mãe e meus irmãos. Como já disse, meu pai morreu quando eu tinha três anos de idade. Soube depois que ele morreu do mal de pneumonia, me contaram que ele foi emagrecendo. Naquela época não havia tratamento. Não teve jeito mesmo. 
Meu pai morava na fazenda, junto com minha avó, e acho que a empregada da casa adoeceu. E não teve aquela separação, não é? Não foi só o meu pai que adoeceu, outros também. Quando meu pai contraiu a doença, minha mãe separou tudo. Aqui em casa era tudo separadinho.

Naquela época, as pessoas não mudavam muito de ofício. Meu pai se chamava Américo e foi fazendeiro a vida toda. Meus avós, pais de meu pai, eram muito ricos. Olha só, rapaz, toda região do rio Paraopeba que passa por aqui era deles. Quando eles morreram a fazenda foi distribuída para os filhos. Eram uns onze ou doze filhos. Cada um ficou com um pedaço da terra. A herança do meu pai era assim: Alto Grande, Manga grande, Funil, Lagoa dourada, essa regiões rurais de Paraopeba eram terras dos meus avós. A minha mãe herdou parte delas, mas quando ficou viúva foi vendendo para cobrir as necessidades. Perdeu muito desses bens.

Quando minha mãe, Anésia, ficou viúva ela tinha trinta e cinco anos e meu pai tinha quarenta e cinco anos. Ficaram apenas dez anos casados. Meus pais tiveram seis filhos. O Paulo Vicente, meu irmão, morreu novinho. Foi então que, para cuidar de tantos filhos sozinha, minha mãe precisou vender as terras e os bens herdados.

Lembro-me de minha mãe comentando que ela teria nascido em uma casa perto do que hoje é a padaria do Zé de Souza. Minha avó materna morava por ali, acho que minha mãe nasceu ali. Tenho boas lembranças de minha mãe! Ela era uma pessoa assim: era muito inteligente. Vou lhe contar: por onde ando, não conheci nenhuma pessoa igual a minha mãe. Ela pensava para a frente... Dava muito valor aos estudos. Falava sempre "o saber ninguém tira", dizia.

Minha mãe se formou em 1915 na cidade de Barbacena-MG. Estudou um ano no colégio Imaculada Conceição. Foi educada pelos meus tios. A minha tia Maricota, irmã da minha mãe, casou-se com o meu tio Quintino Moreira, irmão do meu avô paterno. Como eles não tiveram filhos e criaram a minha mãe e a Esterzinha que se formou em psicologia. $\mathrm{O}$ nome dessa rua é Quintino Moreira em sua homenagem. Ele foi coletor federal e grande benfeitor de nossa cidade.

Sei também que mamãe era muito prendada, sabia fazer de tudo. Ela era musicista, sabia tocar vários instrumentos. Aliás, todos em minha família eram ligados à música. Mas tio Randolfo era músico, era pianista. Escute Neuber, você se lembra como ela tocava piano aqui nessa sala? Ah, você era muito criança quando ela morreu, não é? Todos a admirava! Minha avó era assim: você podia cantar para ela que rapidinho ela punha tudo na pauta. Mamãe dominava o piano, o órgão e a flauta. Ela gostava muito de tocar órgão na igreja! Este mundo 
é uma bola! A mamãe tocou o órgão na igreja até quase na véspera de Deus levá-la. Acho que você não se lembra dela tocando piano, ou você não era nascido. $\mathrm{O}$ piano está ótimo e tem muito mais de cem anos. É francês, sabe? Veja só, se ela chegasse em uma festa onde era preciso de alguém para tocar, ela tocava. Ah, sem contar a sua habilidade na cozinha. Ela fazia qualquer tipo de doce.

Essa casa tem muitas lembranças! Como eu estava lhe contando... Eu, o Vicente e o Wander meus irmãos nascemos nessa casa, mas os outros nasceram na casa onde morava o Sr. Chico Maurício. Essa casa ficava na praça da Matriz de Nossa Senhora do Carmo. Meu pai morava por ali. Depois ele decidiu comprar essa casa na mão do Sr. Avelino Fóscolo. Como já lhe disse, essa casa é secular. A rotina de nossa casa era assim: sete horas, escola; almoço, depois brincava um pouco, fazia o dever e escola. Duas horas da tarde, tomávamos café, não se usava lanche. Estudar, tomar banho de bacia, jantar as quatro horas da tarde, brincar na porta da casa. As brincadeiras eram variadas: pegador, esconde-esconde, passar anel, maré, que se chama hoje de amarelinha, cinco Maria, eram as que mais gostávamos. Os meninos homens jogavam malha, carrinho de rolimã e futebol.

Recordo-me das dificuldades também. Minha mãe teve momentos difíceis na vida, sabe? Uma vez eu a vi tirando um brinquinho lindo da orelha para vender aos mascates que passavam aqui nesta rua. Coitada! Ela passava muito aperto financeiro. Cinco filhos pequenos para criar. A renda da fazenda naquela época era mínima e ficava ainda mais reduzida por causa dos empregados. Meu irmão Carlos ajudava na fazenda, mas tinha só dez anos.

Há uma coisa da minha mãe que me marcou para o resto da vida. Trata-se da sua fé e de sua grande devoção. Ela tinha três devoções: Sagrado Coração de Jesus; Santíssimo Sacramento e Nossa Senhora do Rosário. Lembro sempre da imagem de Nossa Senhora do Rosário ao lado da sua cama e dos cadernos de oração do qual acabei herdando. Decidi ficar com a devoção de Nossa Senhora do Rosário que me marcou ao longo da vida. Até hoje essa devoção é muito forte na minha vida.

\section{$* * *$}

Parece estranho falar, mas essa casa era como uma fazenda. Embora hoje ela se encontre no centro da cidade. Aqui não havia tantos vizinhos como hoje. Quase nenhum vizinho. Recordo da loja da Maria Quinta, logo ali. Depois da casa do Tonico [aponta para a casa ao lado], não existia quase nada. Aqui ao lado havia um beco. O Sr. Alipinho e o Sr. 
Sabino de Paula Freitas, o educador e poeta, passavam por esse beco toda tarde. Os dois iam rezar lá na capela do cruzeiro. No outro lado dessa casa havia mesmo uma lagoa, você acredita? Se chamava Lagoa Seca e pertencia ao terreno da prefeitura, como já lhe disse.

Tenho um retrato desta casa com a rua sem asfalto, hoje a rua está asfaltada. Recordo da D. Chiquinha na rua acima e ela fazia a festa de São João. E depois a casa da Inês do Cartório, uma casa antiga como esta aqui. Tenho uma vaga lembrança de um casebre. Havia outras casas um pouco mais afastadas: a casa do Sr. Quincas, casado com a D. Duninha, irmã da D. Inhazinha. Ele ficou viúvo e sua casa ficou fechadinha durante muito tempo. Teve apenas um filho que foi criado pela D. Inhazinha. Esse filho foi para o Rio de Janeiro e em pouco tempo morreu por lá. Acho que se chamava Joaquim.

Tenho lembranças dessa região. Tive um tio que foi prefeito aqui na cidade. Ele decidiu arrumar quatro bicas. Ah! Menino, havia uma água muito cristalina. Era ali, logo abaixo dessa rua. Perto da casa do João Pio, hoje é uma avenida asfaltada. Como mudou, não é? A água era tão pura que a gente podia beber. As mulheres passavam por essa rua com as latas d'águas na cabeça ou com feixes de lenha. Vou lhe contar: queria fazer como essas mulheres. Um dia eu quis colocar na cabeça uma "rodia" de lenha. Fiquei assustada: como aquilo era pesado! Eu quase cai no chão. Elas buscavam lenha para suas cozinhas ali pelos lados da Fazenda do Rasgão, no cerrado, perto do cemitério. A lenha estava verde e pesava muito. Trouxe uns três paus, mas satisfiz minha vontade, era pequenina. Tudo era fogão à lenha! Então, como contava, as bicas d'água aqui na rua de baixo, ficavam cheias de lavadeiras lavando as roupas. Achava aquilo lindo. Quanta saudade sinto de tudo isto; minha infância foi divertida com coisas tão simples! Louvado seja Deus!

Quando lembro das ruas daquele tempo sinto muitas saudades. Sabe o por quê? Não tenho muito para onde ir aqui na cidade. As pessoas fecham as casas e vão assistir as telenovelas. Eu detesto as telenovelas. Naquele tempo a gente brincava na rua. A rotina era assim: nós jantávamos quatro horas da tarde e depois íamos para a rua brincar. Acho que eu já lhe contei... E não havia nenhum perigo! Juntavam algumas crianças e também as minhas primas. Há uma outra brincadeira que eu amava: era a coroação de Nossa Senhora. Colhíamos espinhos nas laranjeiras e fazíamos roupas compridas, com as folhas das mangueiras confeccionávamos a coroa, não havia asas para os anjos. A Santa era feita de sabugo de milho. Divertíamos também fazendo casinha, variamos o chão de alguma sombra, catávamos os cacos de louça quebrados, lavava-os, as mesas, camas e bancos de tijolos. Separávamos os cômodos com cacos de telhas. Era ótimo! E passávamos o dia no quintal. Ah, também 
fazíamos guisado: arroz e algum passarinho que os meninos pegavam. Hoje ninguém gosta de matar passarinho, não é? Ah! Éramos livres na rua...

No mês de maio, nós meninas coroávamos de verdade a Nossa Senhora e os meninos coroavam o Sagrado Coração de Jesus, no mês de junho. Colhia as flores no jardim. Sempre punha a coroa no dia trinta, aniversário da mamãe. A minha infância dos seis aos doze anos foi muito boa, simples e pura. Ia também para a Fazenda das Pindaíbas, dos saudosos tios Pedro e Maria América. Íamos a pé, brincando na poeira com os primos. Íamos também para a Fazenda do Brejo, dos parentes Maria Gertrudes e Quintino. O Augusto vinha nos buscar de carro de boi, era mais distante. Gostava muito de andar a cavalo, mesmo aqui na cidade. Carlos tinha um cavalo bonito, branco e bege, chamava-se Oiapoque. Para não ficar só brincando e estudando fui aprender trabalhos manuais com a prima América Moreira, professora de trabalho no Grupo Escolar: crochê, bordados, tricô, crivo, macramé.

\section{$* * *$}

O trabalho aqui na cidade era a mesma atividade quase toda a vida. As pessoas aprendiam um ofício e continuavam com ele. Meu pai, por exemplo, foi fazendeiro a vida toda. E minha mãe foi professora também a vida toda. Foi diretora do Grupo Escolar Conselheiro Afonso Pena. E depois, quando o ginásio da cidade estava começando, deu aulas de graça neste ginásio, durante algum tempo.

Além dessa atividade de professora, minha mãe realizou outras. Ela era muito dinâmica e dava conta de tudo. Depois que ficou viúva, mamãe, não se casou mais. Mas pretendentes não lhe faltaram. Ela era bonita, elegante, sábia e culta. Apaixonada pelo papai, só pensava na criação dos filhos. Depois, vieram minha avó e minhas tias morar aqui em casa. Mesmo assim, fazia algumas atividades da casa. Depois, me recordo, de duas empregadas que passaram a ajudar na casa, pois essa casa sempre foi muito grande. Uma se chamava Celinha e a outra Ana. Elas só saíram daqui para se casar. Mesmo assim, ensinaram a mim e a minha irmã Raquel as tarefas da casa.

Outra atividade que minha mãe fazia era escrever cartas. Ela recebia muitas cartas. Minha mãe era bonita e instruída. Me lembro dela respondendo muitas cartas. Certo dia ela estava escrevendo uma carta e estava nos visitando uma de nossas prima. Nós tínhamos visto a carta, era de um pretendente. Então a prima lhe perguntou: "tia Anésia, a senhora vai responder? Ela disse: “Toda carta tem respostas". Também muitas pessoas pediam para ela 
fazer discurso. Um deles era presidente de alguma entidade da cidade. Pois, seu português era correto é por isso que ela era solicitada.

Um pouco mais tarde, minha mãe e o Dr. Guilherme fundaram o lactário daqui. Funcionava onde era o posto de saúde antigo. Era um prédio muito bonito que foi demolido. Esse lactário ajudava muito o crescimento das crianças. Recordo também dos trabalhadores da roça pois só depois se fundou a fábrica de tecidos. Havia também o trabalho da igreja: as filhas de Maria; o apostolado de orações; as damas de caridade. Paraopeba era tão pequena! Acho que progrediu só depois da festa do Rosário.

O trabalho que realizei, fora o serviço doméstico, foi quando me mudei, aos dezessete anos, para Belo Horizonte. Trabalhei em uma livraria que existia na avenida Afonso Pena. Também trabalhei, durante quatro anos, na Companhia Nansen, aquela que fazia hidrômetro. Só depois, a convite do Olavo, que era gerente da fábrica de tecidos, resolvi voltar para cá e trabalhar na fábrica. Ela estava recém inaugurada.

Quero contar para você minha experiência na fábrica de tecido de Paraopeba Industrial Sociedade Anônima (PISA). Comecei a trabalhar nesta fábrica, na década de 1950, logo após o início dela, fui registrada dia 22-10-1952. No primeiro dia que eu entrei no escritório, entrou um beija-flor, deu uma volta e saiu. Para mim, foi um beijo de Deus. Passadas algumas horas uma borboleta e assentou na folhinha que estava sobre a minha escrivaninha. Novamente, enchi-me de alegria. A escrivaninha ficava perto da porta. Acho que foi um mandado de Deus para me alegrar com as belezas da natureza e para me dar força e sabedoria. Recordo que eu trabalhava oito horas por dia. Como não tinha despesas aqui na cidade, morava com minha mãe, compensava eu ter deixado meu trabalho em Belo Horizonte. Meu trabalho era no escritório. Dentre as minhas atribuições eu fazia os pagamentos dos operários. Naquela época, a fábrica estava começando e era tudo muito precário, sabe?

Mas havia uma situação que eu achava um absurdo. A admissão na fábrica se fazia da seguinte forma: as pessoas trabalhavam quatro meses até seis meses sem ganhar nada. Diziam que era para os operários terem experiência. Eu achava aquilo uma injustiça! Naquela época as pessoas eram ignorantes em leis trabalhistas, as pessoas não conheciam nem a carteira de trabalho. Tive muito trabalho para registrá-los. Não me lembro de acidentes de trabalho, mas sei que alguns operários vieram das cidades vizinhas para ensinar os aprendizes de operário. De São Roberto chegaram muitos. A pensão da cidade ficava cheia de operários! Alguns gostaram, se casaram, constituíram famílias e continuam aqui até hoje. O interessante era que as pessoas da fábrica do Cedro, que existia há mais de cem anos, não contribuíram, que eu saiba, para o aprendizado dos operários da PISA. Olha que a fábrica do Cedro fica a dois 
quilômetros da fábrica de Paraopeba. Parece que as dificuldades da primeira não serviram de exemplo para a segunda. Os operários, embora bem experientes, ainda trabalhavam sem remuneração durante uma boa temporada.

A relação patrão e empregado eram assim: o patrão era bravo e o operário tinha que obedecer (acho que não devo falar...). Eu tinha dó dos operários. Era um absurdo! Sei que operários ficavam num zum zum zum, entende? O fato é que não havia emprego. Os operários acabavam aceitando as injustiças por necessidade. Quem reclamava acabava sendo despedido.

Também existiam algumas coisas esquisitas. Contei para você que nossa família possuía um pequeno terreno atrás da fábrica, você se lembra? Nós o chamávamos de "pastinho". Um dia chegou algumas pessoas aqui em casa e falando para minha mãe que queria comprar este terreno. Diziam que era para aumentar o tamanho da fábrica. Se não vendêssemos a prefeitura iria desapropriá-lo. Então mamãe vendeu este terreno por uma ninharia. O "pastinho" e o terreno do Sr. Mingau, de tantos nos pressionarem, que foram vendidos por uma ninharia. O Sr. Chico Mingau ficou tão apaixonado que morreu logo depois. Fizeram um loteamento e hoje é o bairro Colina. Outra coisa estranha foram as ações da fábrica de Paraopeba. Ela foi construída com o dinheiro dos acionistas para dar empregos aos paraopebense. Eu quando saí, consegui vender minhas ações. Mas soube que muitas pessoas não receberam nenhum tostão. Venderam a fábrica mas muitos acionistas ficaram no prejuízo. Sei que apenas quem recebeu o dinheiro das ações, foi o Sr. Ribeiro, que era coletor federal daqui. Ele exigiu o seu dinheiro. Mas os outros.... Ah! Que pena. Não receberam nada, não sei dos detalhes por que não morava mais aqui. Sai da fábrica antes para me casar, assim consegui vender as minhas ações. Depois o presidente da fábrica negociou a PISA com os donos da fábrica do Cedro. Ela foi vendida para os acionistas da fábrica do Cedro há mais de vinte e cinco anos; agora sei que ela está no quarto dono.

\section{$* * *$}

O meu primeiro dia de aula era uma felicidade! "Era bom demais da conta"! Vestia o uniforme, achava a coisa melhor do mundo. A mamãe foi a minha primeira professora. Estudei no grupo escolar Afonso Pena. Fui aluna da minha mãe do $1^{\circ}$ ao $4^{\circ}$ ano. Eu era a primeira aluna. Alguns diziam que minha mãe era uma professora brava, mas ela era só enérgica. Quando ela olhava para a gente, vou contar para você... Nós tínhamos que saber como se comportar e entender o que mamãe queria dizer. 
Mas antigamente a educação era outra. Quando chegava visita os meninos não podiam ficar na sala com os adultos. Minha mãe só olhava assim, meio de lado e a gente obedecia, ia saindo de fininho. Ela pensava muita na educação de todos nós. O Carlos meu irmão não quis mais estudar. Daí ele teve que escrever um bilhetinho, explicando seus motivos por sua desistência dos estudos.

Como eu contava para você, a minha primeira escola era o Grupo Escolar Afonso Pena, a primeira escola oficial daqui. Acho que ela foi inaugurada por volta de 1918 ou 1920. Os alunos tinham a obrigação de estudar e a relação com os professores era de muito respeito! As professoras eram consideradas a segunda mãe. Hoje vejo que as crianças não têm muita educação não respeitam as professoras e nem os idosos. As crianças não têm muita educação e nem respeito com os mais velhos; é um erro, não é? Recordo quando estavam consertando a sala do grupo, para não ficarmos sem aula, mamãe trouxe a classe toda para estudar aqui em casa. Essa casa virou grupo escolar. Era nesse quarto ao lado [aponta]. Essa casa tem mais de quinze cômodos, sabe?

Não me esqueço de um acontecimento na escola. Foi quando fiquei de castigo, sabe por quê? Eu fui pega comendo merenda na hora da aula. Eu fazia assim [faz gesto demonstrando como esconder a merenda com a mão]. A merenda eram as frutas daqui do quintal: bananas, jabuticabas... Mas no dia o diretor escolar estava lá e me viu de castigo e me retirou dele. O diretor era o poeta Sabino de Paula Freitas. Hoje há uma escola aqui na cidade que tem o seu nome. Sinto muita saudade de tudo no Grupo: de cantar o Hino Nacional, Hino da Bandeira, das comemorações das datas festivas, dos brinquedos no recreio. Tudo passa e a saudade fica.

Os meus colegas eram pessoas humildes. Vinha muita gente da roça, pois este era o único grupo escolar da região. Chegavam alunos do Mocambo, da Picada... Me lembro da Augusta, filha do Otávio Clarim, era muito inteligente. A Zelina, a Elvira França, a Risoleta e também o Mauro. Todos foram meus colegas. A convivência entre os colegas era muito boa. Eu gostava muito deles. Até hoje visito as colegas que estão vivas quando venho aqui para a cidade. Lembro que quando eu tinha que podar as mangueiras eu chamava as colegas e era uma diversão! A mamãe não gostava que seus filhos fossem para a casa dos outros. Gostava que as minhas colegas viessem aqui para casa para que pudéssemos brincar.

Depois que eu estudei os quatro anos com a mamãe como professora, não havia, aqui em Paraopeba, como continuar os estudos. Teríamos que mudar da cidade. Daí fomos morar na casa da tia Iraci para estudar. A Raquel, minha irmã mais velha, se formou em normalista. 
Eu fiquei aqui dois anos esperando, depois do grupo escolar, para entrar na escola de comércio.

Essa escola ficava em Sete Lagoas e se chamava Escola Complementar de Comércio. Lá só podia entrar com doze anos e eu tinha apenas dez anos. Eu tirei o primeiro lugar no exame de admissão dessa escola. Porque eu fiquei aqui em casa estudando durante dois anos. Sabia o livro de admissão todo de cor! O Vicente se formou em dentista na UFMG, em Belo Horizonte. O Wander formou em jornalismo, mas só depois de muito tempo. Ele lia demais e estudava muito, sabe? Ele falava e conhecia várias línguas. Foi um jornalista respeitado do jornal O Estado de Minas e também escreveu algumas matérias na Gazeta de Paraopeba. Ele conheceu o mundo inteiro...

Minha mãe era especial! Quando o Silvério, meu marido, se formou em advocacia ela foi à formatura. Não me esqueço, ela disse assim: “o saber é o que é importante”! Ela dava muito valor à educação. Mamãe não mediu sacrifícios para nos estudar. Recordo-me claramente que havia uma mesa grande nessa casa que mamãe levou para Belo horizonte para o conforto dos filhos. Também montou uma casa na rua Guarani, em Belo Horizonte, para a gente estudar.

Essa rua fica na região central de Belo Horizonte. Olha, me lembro que o endereço completo era: Rua do Guarani, 280. Não me esqueço disso. Mamãe tomou essa decisão de ir para lá, porque o Vicente meu irmão, estava morando em uma pensão. Vicente reclamava do desconforto da pensão dizendo que na pensão só existia carne cozida para comer. Ele estava enjoado disso. Nesse meio tempo a Raquel já tinha se formado para normalista. Ela estava com pouco mais de quinze anos. Teve até banda de música para recepcioná-la aqui na cidade. Estudar naquele tempo era muito difícil. Eu me formei no grupo com dez anos. O Vicente formou com vinte e um anos. O Carlos não quis estudar. Quando o meu pai morreu, foi o Carlos que ficou tomando conta da fazenda. Nessa época ele já estava namorando com a Jandira e queria se casar. Então a mamãe vendeu a fazenda e deu uma parte do dinheiro para ele.

Até hoje encontro gente que elogia o ensino que mamãe deu para eles aqui no Grupo Afonso Pena. Eles dizem assim: "Maria Stella, o que eu sou hoje eu agradeço à sua mãe, a professora D. Anésia!” Ela era enérgica e só com seu porte físico e postura ela impunha respeito. Ela foi uma dama! A gente aprendia mesmo.

Vou lhe contar um fato. Quando fui para Goiânia, por uns tempos. Havia uma advogada que me pediu para datilografar um documento. Eu não conseguia entender o que estava escrito. O português era muito ruim. Eu não sabia se consertava ou não aquele texto. 
Decidi então sair corrigindo. As pessoas hoje escrevem muito mal! Naquele tempo a gente saia do grupo escolar sabendo escrever. Recordo da mamãe nos corrigindo assim: "mim não fala, mim não faz nada! O correto é para eu...".

\section{$* * *$}

Hoje em dia a cidade de Paraopeba cresceu muito; as casas, as ruas, as praças. Mas a lembrança que tenho das casas é que elas eram muito asseadas, limpas. Havia o capricho das donas de casas que decoravam as mesas com forros muito bonitos. Hoje, as casas, as mesas são de vidro e as pessoas não gostam de colocar os forros. Pois eu adoro! Lá em casa está cheio de forrinhos coloridos. Digo que minha casa é a minha cara. Gosto de flores... As pessoas todas por aqui plantavam um pequeno jardim.

$\mathrm{Na}$ Paraopeba de antigamente havia muita casa com telhado de capim. Naquela praça da fonte luminosa, logo ali em cima, só tinha casa de capim. As pessoas viviam na rua pedindo esmolas. Quando a Associação dos Vicentinos começou a ajudar, melhorou muito. Lembro-me que todo sábado passava gente pedindo. Na época de frutas, muita gente vinha aqui em casa pedi as frutas do quintal. Até as pessoas da sociedade roubavam as frutas daqui. Coisas de criança, não é [risos]?

A paisagem da cidade foi mudando. Meu irmão Vicente fez cavalaria no exército e aí mamãe comprou um cavalo para ele. Você sabe onde é que o cavalo ficava? Era aqui no quintal. Até ali, logo atrás da fábrica de tecidos, havia um pastinho para as vacas, os bichos. Hoje é o bairro Colina. Lá se buscava lenha... Agora é cheio de boas casas por lá.

\section{$* * *$}

O surgimento dessa cidade... Ah, não sei. Mas será que é a história da onça? Vejo assim: um lugar pequeno demais, um cerrado. Dizem que apareceu essa onça. Não conheci a primeira capelinha da qual se fala que um homem teria erguido por ter sido salvo dessa onça. Mas me lembro das igrejas antigas e das reconstruções da Matriz.

Aqui era tudo cerrado até bem pouco tempo atrás. Um ermo só. Nós buscávamos muito pequi por aqui. Ali, depois do atual cemitério. Fico imaginando uma onça e um homem muito doido fugindo dela [risos]. Essa era a lenda! Mas vou lhe contar, em detalhes, como 
aprendi esta história. O Coronel Marques, donatário da sesmaria que ao deparar-se com uma onça no meio do cerrado, indefeso e julgando-se perdido, ajoelhou-se e fez uma prece a Nossa Senhora do Carmo. Católico e de muita fé, Marques, pediu à santa que se sua vida fosse salva mandaria construir uma capela em sua honra. A onça não o atacou e ele se retirou são e salvo. Posteriormente, ele voltou e cumpriu a promessa. Construí a capelinha dedicada a Nossa Senhora do Carmo, hoje padroeira da cidade. Sei, Neuber, que aos poucos esta região foi aumentando. Aqui era um lugar de passagem obrigatório dos tropeiros que conduziam as boiadas para o sertão da Bahia. Assim foram surgindo algumas casas em torno da capela e o lugar ficou sendo chamado de Tabuleiro Grande de Nossa Senhora do Carmo.

Durante quarenta e cinco anos Tabuleiro Grande pertenceu a Sete Lagoas. Depois se desmembrou e sua emancipação deu-se em dez de junho de 1912, passando a se chamar de Vila Paraopeba. A partir de 1931 recebeu o nome de Paraopeba, sei que essa palavra de origem indígena que significa "rio do peixe chato", parece-me que há outros sentidos. Dizem que a escolha do nome Paraopeba foi por causa do rio Paraopeba que naquela época, livre de qualquer poluição, era fonte de manutenção dos habitantes que se beneficiavam da pesca, do garimpo e ainda da lavoura nas regiões ribeirinhas. Desde a sua emancipação, nesta cidade já passaram, acho, que mais de vinte prefeitos. Entre 1912 a 1927 os prefeitos eram denominados "Agentes Executivos", felizmente as coisas mudaram.

Lembro do prédio da Prefeitura que não existe mais. Também de uma loja que havia na praça da Matriz, perto da casa do Geraldo Lamindo. Olha, quero lhe contar uma coisa: alguns conhecidos meus em Belo horizonte que me perguntam ainda hoje: "vocês conservam a casa da sua mãe"? Eles nasceram aqui em Paraopeba e depois se mudaram para a capital. Dizem com tristeza: "nós temos um grande arrependimento de termos destruído a casa antiga de nossa família"! Bom, como eu falava, nessa loja funcionava a coletoria federal e ficava na praça da Matriz. Antes de a Lourdes Mascarenhas morrer, tem pouco tempo isso, eu fui visitála. Em sua casa eu avistei um tinteiro antigo, o achei bonito, e me entusiasmei. Eu só não pedi esse tinteiro a ela porque não imaginava que morreria tão rápido. Ela morava perto dessa loja, sabe?

Essa cidade sempre foi poeirenta. Aqui, nessa rua, era chão mesmo. A praça da igreja era toda de chão, poeira e pedra. Onde mora a família Marinho, já existiu uma sorveteria. $\mathrm{O}$ coreto que tem na praça hoje não existia na minha juventude. Quando íamos coroar a Nossa Senhora na igreja matriz, íamos todos na poeira mesmo! Acredito que antigamente fazia mais frio aqui nessa cidade. Mas as coisas vão mudando, não é? 
Uma outra paisagem que mudou foi a onde se construiu a fábrica de tecido. Havia um pasto que foi desapropriado pelo Pedro Barbosa para se construir a Fábrica de tecido - a PISA (Paraopeba Industrial Sociedade Anônima). Isso se deu por volta de 1950. Há nisso até uma história triste. Nesse terreno, sabe? Era do pai da Maria Mingau e foi vendido muito barato! Até dizem que morreu de paixão, eu já lhe contei isso, não foi? Hoje esse terreno está cheio de casas, sei que outros empresários compraram a PISA. Acho que está no terceiro ou quarto dono...

Acho que já lhe contei que essa casa teve escravos, não? As janelas ali no fundo têm uma aparência que nos lembra uma abertura daqueles tempos. Aquele pedaço do fundo da casa [aponta para a janela]. O formato das janelas e portas. Aqui tem mais de quinze cômodos, bem grande. O Sr. Manuel Pinto, sogro do Sr. Avelino Fóscolo escritor e fundador da imprensa desta cidade, morou aqui lá pelos anos de 1850. Acredito que foi por ai. Deve ter tido escravos domésticos. Ah! Sempre gosto de contar isso.

Lembro de ter conhecido o Avelino Fóscolo. Não foi aqui em Paraopeba porque ele já havia se mudado para Belo Horizonte. Eu era mocinha, acho que tinha uns quinze amos, e ele já estava velho. Seu Avelino usava chapéu e bengala pelas ruas da capital. A cabeça bem branquinha, ele tinha uma farmácia no centro da cidade. Acredito que era na Avenida Afonso Pena. E sua casa, se não me falha a memória, era na Rua Cláudio Manoel. Naqueles tempos Belo Horizonte não era como é hoje, era só sossego e calmaria pelas ruas.

Minha tia Araci era muito amiga dele. E também de duas filhas dele, a Adélia e a Cenira. Ele foi importante para essa cidade! Desde os tempos de Tabuleiro Grande. Criou a imprensa por aqui. Casou-se nessa cidade com a D. Mariquinha que era filha de Manuel Pinto Ribeiro. Sabe que o seu Avelino foi dono e morou nessa casa aqui? Eu já lhe disse, não? Meu pai comprou essa casa do seu Avelino. Mamãe tinha tanta estima por ele que o chamava de papai Pinto. As pessoas daqui falam assim: é na rua do casarão da D. Anésia. Quando minha mãe se engravidou de mim, ele morava nessa casa. Mas antes era do seu Manuel, o primeiro farmacêutico daqui, onde morou com sua filha, D. Mariquinha, a primeira professora. Seu Manuel já morava aqui antes de 1850, sabe? O Seu Manuel Pinto morreu com 104 anos, não sei se contei isso? Bem, mas o seu Avelino, além de jornalista foi também escritor e fundou o primeiro teatro da cidade, que já não existe mais. É uma pena, não é? Meu irmão, Wander Moreira, foi jornalista e escreveu sobre o Avelino Fóscolo. Foi um homem importante por aqui! É preciso resgatar esta memória...

Avelino, foi dotado de extraordinária inteligência e grande tino comercial, conseguiu dominar a profissão de farmacêutico, que era a profissão do seu sogro. E de aprendiz tornou- 
se dono de farmácia. A Farmácia Fóscolo funcionou por muito tempo no prédio onde residiu o saudoso Bispo Dom Cirilo de Paula Freitas. Hoje, em seu lugar, fica um Banco e lojas. Fica logo ali em cima, na praça central. Perseverante que era, o idealista Avelino, acalentava o sonho de fundar aqui um jornal. Somente alguém como ele, vivendo em pleno centro de Minas, no sertão inculto do Brasil, com muita dificuldade de transporte, se lançaria nessa aventura. Avelino idealizou e fechou os olhos para quem não acreditava. Gosto de gente assim, Neuber. Depois ele idealizou um pequeno "prelo" manual e encomendou um artesão para construir um de madeira. Soube que adquiriu alguns tipos e em seis de janeiro de $1893 \mathrm{e}$ ditou o primeiro jornal "A Vida". Foi o início do jornalismo em Paraopeba. Li isso a pouco tempo, a minha memória está fresca... sabe? Depois de algum tempo desapareceu "A Vida" e surgiu "O Industrial”, dirigido também por Fóscolo. Ele difundia os ideais dos operários e exercitava os dons literários.

Recordo que me falaram que Avelino Fóscolo era de uma capacidade de trabalho espantosa. Desenvolveu muitas atividades. Atendia aos doentes, receitava e manipulava ele mesmo, as receitas para os doentes. E também ele fazia experiências químicas. Ainda sobrava-lhe tempo para redigir as notas para o jornal e escrever seus romances que publicava em folhetins no seu jornal. Escreveu numerosos romances, entre os quais: A Mulher, $O$ Caboclo, O Mestiço, A Capital cujos exemplares hoje são preciosas raridades bibliográficas. Eu consegui cópias para a biblioteca que lhe falei. Estes livros estão na biblioteca que leva o meu nome, no bairro Nossa Senhora do Carmo. Já me disseram que o seu melhor romance é "O Caboclo" - sua obra-prima. Você se lembra? Foi esse romance que eu the emprestei. O livro "A Capital” tem conteúdo histórico. Avelino assistiu as lutas, avanços e retrocessos que tiveram os componentes da "Comissão Construtora" da nova capital, hoje Belo Horizonte. Os livros do Seu Avelino foram escritos no final do século XIX e início do século XX.

Quando se procura recordar a figura de Avelino Fóscolo e seu papel desempenhado na imprensa de Paraopeba, não se pode esquecer o nome de Manoel Antônio da Silva. Ele foi o continuador da imprensa na cidade. Seu "Neném" como era chamado, lutou para os interesses da comunidade de Paraopeba, com seu insuperável semanário. A querida e saudosa "Gazeta de Paraopeba". Bem, Neuber, contei-lhe uma parte da história do Sr. Avelino. Sabia muita coisa sobre sua vida, mas a gente se esquece. Eu sou apaixonada pela sua vida! Nasci aqui, onde ele morou e foi na mão dele que o papai comprou esta casa. Como já lhe contei esta casa tem memória! Todas esta minúcias eu revivi relendo um artigo que meu irmão, o saudoso jornalista Wander Moreira, que escreveu na Gazeta de Paraopeba em nove de abril de mil 
novecentos e quarenta e oito. É assim, as lembranças vêm e vão... As lembranças dessa casa centenária se mistura com a memória da cidade.

$$
* * *
$$

Comecei a trabalhar em uma livraria em Belo Horizonte. Mas o destino mudou a minha vida. Soube que havia uma tentativa de se construir uma fábrica de tecidos aqui em Paraopeba. Então, o Dr. Pedro Barbosa, que conhecia bem a mamãe, era um dos dirigentes da fábrica de tecidos. Falou assim com a minha mãe: “D. Anésia, quem sabe a Maria Stella gostaria de trabalhar aqui no escritório da fábrica"? Menino, não precisou de falar duas vezes! Aí eu vim para cá. Eu larguei a faculdade em Belo Horizonte, estava no $2^{\circ}$ (segundo) ano de ciências econômicas na UFMG. Lembro que, nessa época, fazia a escrita da livraria Rex de Belo Horizonte. Ela ficava na rua Curitiba, sabe?

Não tive dúvidas! Minha mãe falou assim: "você já está empregada aí”! Eu disse para ela: "mamãe pode deixar, eu quero construir a igreja". Pensava comigo mesma: eu estou com vinte e poucos anos. Vou tentar. Nessa época me intrigava a história da igrejinha do Rosário...

Aos poucos as coisas do destino se concretizavam. Sabe, Neuber, parecia que Nossa Senhora do Rosário estava me trazendo mesmo para Paraopeba. O Silvério, meu futuro marido, estava morando aqui há alguns anos. Sabia que as moças estavam doidas para se casarem com ele? Ele andava por todas as festas... Parecia que ele estava me esperando. Tivemos cinco filhos. Um morreu há três anos. Tem sido uma tristeza! Mas é a vida. Deus levou um tijolinho mas deixou outros: Maria do Rosário, João Lúcio, Silmar Paulo e Susana. Deus levou o Tom. Tenho nove netos e um bisneto.

Depois, me disseram que ele me viu na barraquinha da quermesse e perguntou assim: “que morena bonita é aquela"? Responderam: "aquela ali não dá confiança para ninguém, para nenhum moço daqui”. Não era por causa disso, sabe? Meu ideal era estudar, queria fazer advocacia, era isso!

Mas naquela época eu esqueci tudo! Em quatro meses eu estava noiva. As amigas de Belo Horizonte me aconselharam a não vir para aqui. Achavam que não tinha rapazes para eu namorar. Até que nessa época tinha muito pretendente por aqui. Havia os rapazes do Horto Florestal, da fábrica... Recordo que naquela época havia algumas festas da legião brasileira em algumas casas da cidade. Me lembro que era na casa da Dolores, da Vininha, na casa do Chico Maurício. Aí aconteceu o seguinte: na festa da casa do Chico Maurício, quando tocou a 
primeira música, o Silvério me tirou para dançar. E nós estamos dançando até hoje [risos]! Tivemos cinco filhos, sendo que um morreu recentemente. Ah! Sempre falo disso; já lhe disso isso, mas é meu filho e... Foi uma tristeza só! Mas é a vida, não é? [Os olhos se lacrimejam].

As festas da juventude eram bem diferentes, sabe? As danças eram bem diferentes. Lembro do Silvério, meu marido, conversando com o Padre Herculano que queria fazer um clube de dança aqui. O local escolhido foi o segundo andar do prédio onde era o cinema. Hoje em dia, ninguém pede ao padre coisa desse tipo.

Havia as disputas políticas. Os políticos eram o Dr. Theóphilo, o Padre Augusto, o "Seu Neném” da Gazeta de Paraopeba e o meu tio Quintino. Existia essa liderança. Sei que existiam brigas. Era assim: existiam disputas até para a direção da escola. Uns queriam a minha mãe e outros a dona Corina. No caso dos prefeitos, como já lhe disse teve época que eles eram chamados de "Agentes Executivos". Nesta época eles eram indicados pelos governantes. Não havia eleição direta.

\section{$* * *$}

As festas religiosas eram fervorosas. Para mim, tomou um significado muito importante. Especialmente a festa de Nossa Senhora do Rosário que estou envolvida até hoje. Você conhece a história da Igreja de Nossa Senhora do Rosário dessa cidade? Vou lhe contar...

A história da construção da Igreja de Nossa Senhora do Rosário teve vários episódios. Aqui, antigamente, existiam aqueles senhores, como posso lhe dizer? Há muitos anos atrás havia um farmacêutico aqui e ele era ateu. Segundo me contaram, ele tinha vindo da cidade de Cachoeira dos Macacos, uma cidade aqui dessa região, e foi surpreendido por uma tempestade muito forte. Diante disso, pensou que ia morrer. Então, no meio dessa tempestade, fez uma promessa que afirmava o seguinte: "se eu sobreviver vou ser padre"! Olha, Neuber, nesse instante aconteceu uma coisa, não sei exatamente o que ocorreu. Nesse momento ele teria adormecido...

No outro dia, em volta do seu cavalo estava seco e ele estava no chão. Não havia indício de tempestade alguma. Escute, uns falam que ele teve um sonho. Nesse sonho ele se encontrava dentro de uma casinha e tinha uma senhora vestida de branco. Essa senhora dizia assim: "Não vá embora, espera a chuva diminuir". Daí ele veio embora para Paraopeba e melhorou. Foi a partir desse acontecimento que ele decidiu ser padre. 
Passado algum tempo, quando ele já havia se ordenado, ele voltou para cá, em Paraopeba. O nome dele era Sebastião Ribeiro Vianna. Ele era muito bonito, sabe? Havia também uma senhora chamada Virgínia Coati. Essa senhora era daquelas que namorava escondido, você entende? Não sei ao certo como era. Quando ele voltou do seminário, já padre, acho que ela o desejou de novo... Ele se ordenou rápido porque já era instruído. Foi quando aconteceu um fato que marcou a história da cidade.

Em uma de suas missas lá na Igreja de Nossa Senhora do Rosário ele foi provocado por essa moça que eu lhe disse. Antigamente o padre celebrava a missa de costas para os fiéis. Conta-se que quando ele se virava no altar a batina dele encostava-se ao corpo dela, então ele pediu várias vezes para que ela se retirasse daquele lugar e ela não saía. Sei que começou aquele bate-boca. Por fim, o padre Sebastião acabou interditando a igreja. Desde essa época Igreja de Nossa Senhora do Rosário ficou profanada. Ficou fechada por muitos anos. Muita gente antiga lembra desse fato.

Mas a origem da igrejinha do Rosário, a primeira construção é a seguinte.Vou lhe contar. A nossa casa da rua Guarani, em Belo Horizonte, era grande. Recebíamos parentes e amigos paraopebenses. Fui com Mariinha visitar o Sr. José Maia, na rua Suassuí. Ela contoulhe um caso e lembrou-se que seu pai, o Sr. Veríssimo, foi o construtor da primeira igrejinha do Rosário de Paraopeba, cuja benção se realizou no dia 17 de maio de 1908, sendo padrinhos da capelinha o Sr. Maximiano Matelo e D. Madalena Correia Mascarenhas, e do sino o Sr. Joaquim Venâncio Diniz (Quincão) e senhorita Verônica Moreira. Pra você ver existem muitas histórias...

Pois bem como lhe falava, depois da profanação, os objetos da igreja foram sendo retirados de lá. O sino foi para a capela de Dom Cirilo, que não existe mais. Outras coisas para a Matriz. As pessoas tinham medo de passar por lá. Me lembro que quando eu ia buscar lenha no pastinho, passava em frente dessa igreja. Recordo que ela tinha vidros coloridos nas janelas. Eu ficava encantada ao ver o reflexo dessas vidraças...

Com todo esse acontecimento o padre Sebastião foi para outro lugar. Mas há um fato que se relaciona com esse. Um outro padre, chamado Mata Machado, estava em outra região, em Gouveia - MG. Soube que o padre Mata Machado sonhou com o padre Sebastião. Foi assim: enquanto fazia a sesta do almoço, o padre Mata Machado ouviu o sino soar três vezes e nesse sonho ouvia também uma voz que dizia: "vá à Paraopeba e na porta de igreja tem uma árvore, você faz um chá dessa árvore e ficará bom"! O padre Mata Machado sonhou três vezes com o padre Sebastião falando isso. [Aponta para a parede com o quadro da igreja do Rosário, onde há uma pequena árvore em frente da capela] 
Daí pegou o ônibus e veio para Paraopeba. Chegou todo empoeirado. Desceu do ônibus em frente à igreja Matriz de Nossa Senhora do Carmo. Lá encontrou a Chiquinha Marinho ela estava arrumando o altar da matriz de Nossa Senhora do Carmo quando entrou o padre e parou defronte à imagem de Nossa Senhora do Rosário. Ela perguntou o que o padre desejava. Ele contou o caso para ela, o caso da Igreja de Nossa Senhora do Rosário. A história se desenrolou desse modo: juntaram o padre Mata Machado, a Mariinha e a Chiquinha Marinho e foram ver o estado da igreja do Rosário. Chegando lá, viram que estava tudo destruído. Puro abandono, sabe? Depois decidi comprar trezentos metros de cano para instalar água. Nessa época, por ali era um cerrado só. Hoje está cheio de casas... Voltando à história: então o padre disse: "vocês precisam arrumar essa igreja, porque com a igreja assim profanada a cidade não vai para frente"! Eu lhe contava do chá, não é? Quando os três chegaram em frente da igreja viram que não havia mais a igrejinha nem a famosa árvore para o padre fazer o chá e curar de sua doença. Apenas o terreno limpo e vazio, roçado pela prefeitura. E o padre, admirado e triste exclamou: "Você não sabe a quizila (azar) que dá para o lugar quando cai uma igreja! Precisam mandar reconstruí-la”. Sei que em 1955 ela foi abençoada, mas ele disse isso por volta de 1951.

Há quanto tempo isso se passou, não é? Sei que a igreja caiu toda, ficou em ruínas. Ficava lá sem ninguém fazer nada. Sei que essa história aconteceu no início do século XX, mas não tem muito tempo que o padre Sebastião morreu. Acredito que esses acontecimentos se deram lá pelos anos de 1917, 1918, ou um pouco mais.

Mas aconteceu o seguinte: a Mariinha e o padre Mata Machado se encontraram comigo e me revelou algo que me marcou até hoje. Estavam querendo reconstruir a Igreja de Nossa Senhora do Rosário. Perguntei quanto ficaria para colocá-la de novo em atividade. Me impressionou toda esta história. Daí perguntei ao Sr. José Maria quanto custaria reconstruir a igreja. Ele me disse que ficaria em torno de Cr\$30.000,00. Então pensei que se cada paraopebense desse Cr\$100,00 não seria difícil levantar este dinheiro. Todos os presentes concordaram e acharam a idéia ótima. Decidi sair pela cidade e pedir ajuda para reconstrução da igreja. Durante a campanha houve muitos lances interessantes. Fazia muitas rifas com os objetos doados, organizava barraquinhas nos períodos das minhas férias, a procissão de caminhões de areia ao rio Paraopeba. Escute só. Ano passado, por ocasião da festa do Rosário, aproximou-se de mim um rapaz e disse: “Olá D. Maristela, eu era menino e me lembro da procissão de areia...", Me lembro, que decorreram mais de três anos e a construção, incluindo o altar que foi doado pela firma Ferreira Gonçalves e tudo que ganhamos importou em Cr\$174.000,00 até 31 de agosto de 1954. A imagem da santa foi doada por José Teodoro 
Barbosa. Nesta época, visitava Paraopeba, como se fosse um milagre, a imagem de Nossa Senhora de Fátima, no dia quatorze de agosto de 1954, que em belíssima procissão com Lâmpadas coloridas foi até ao novo templo, a capela do Rosário. Lá, assistimos emocionados a Sua Excelência D. João de Souza Lima, vigário geral da diocese de Diamantina, auxiliado pelo padre Herculano Pimenta benzerem a nova igrejinha, erguida no mesmo local da primeira. Padre Herculano pronunciou eloqüente sermão, entregando-a aos paraopebenses. Foi uma noite inesquecível e emocionante.

Nessa época, como havia lhe falado, estava em Belo Horizonte. Imediatamente escrevi para mamãe falando do meu desejo. Sei que começamos a mobilizar a cidade. O Sr. Neném, editor da Gazeta de Paraopeba, se dispôs a ajudar. O Jair Silva, filho do Sr. Neném, escreveu um artigo e o veiculou na Gazeta. Acho que ele contou esse episódio em sua crônica que se chamava "Oropa, França e Bahia” do jornal "O Estado de Minas”. Daí comecei a trabalhar. Cheguei em Paraopeba num domingo. Fui em todas as casas! Só apenas uma pessoa negou o dinheiro. Foi tudo publicado na Gazeta de Paraopeba. Está tudo documentado, sabe?

Fazíamos rifas, escrevia para as pessoas conhecidas pedindo ajuda. Visitei cidades, lembro de ter ido à Cachoeira dos Macacos, onde o padre Sebastião nasceu. Ah! Esta história vai e volta. Você está percebendo, não está? Mas essa história é muito forte na minha cabeça, faz parte da minha vida e da cidade também, não? Vamos continuar... Fui a Curvelo também e aos poucos conseguimos juntar o dinheiro necessário para a reconstrução da igreja. Daí, a cidade de Paraopeba começou a progredir! Era no início da década de cinqüenta. Inaugurouse a fábrica de tecidos - PISA; veio o asfalto da rodovia. Essa rodovia passaria em Cordisburgo, mas foi desviada para cá; veio também o Horto Florestal, a comarca, uma fábrica de arroz. Paraopeba começou a se desenvolver. Sabe, a arrecadação dos donativos está publicado na "Gazeta de Paraopeba". Hoje quando penso pelo motivo que mobilizou a fazer tudo isso, digo a você: primeiro, herdei da minha mãe uma devoção muito forte à Nossa Senhora do Rosário. Segundo, o padre Sebastião era meu primo bem próximo. Terceiro, seria ótimo para minha terra, pois Paraopeba estava mesmo paralisada. A igrejinha do Rosário fez parte da vida de minha mãe. Zelou-a durante vinte anos como se fosse sua filha. Era sem dúvida a maior divulgadora da devoção à Virgem do Rosário. Ela é também a menina dos meus olhos.

Vou lhe contar a minha história com a festa de Nossa Senhora do Rosário. Acredito que a festa do Congado começou no final do século XIX. Você se lembra do Sérgio Côco? Ele era do Congado, um dos primeiros congadeiros. Ele morreu com mais de cem anos, talvez 
o congado tenha começado no início do século XX. O fato é que ele tem muito tempo por aqui.

Dessa forma, acredito que o congado faz parte da tradição desta cidade. Se alguém acha que ele não faz parte da tradição daqui. Ah! Ele tem que fazer. O Congado não pode morrer. Antigamente não se dava muito valor ao congado. $O$ povo não gostava do congado. Eu tinha uma tia que falava assim: "Maristela, como você gosta disso? Aqueles pretos dançando...". Sempre pensei, e afirmo isso: "sou louca por congado". Eu adorava essa festa desde criança. Mesmo quando me mudei para Belo Horizonte, eu tinha dezessete ou dezoito anos, eu via os congados passando na Avenida Paraná. Eu saia correndo para ver. Batia uma caixa, um tambor, e eu ficava doidinha! A minha devoção foi sempre desde pequena. Minha devoção foi herdada da minha mãe. Ele falava sempre do rosário. Isso foi crescendo, crescendo em mim.

Quando mocinha eu não participava porque eu morava em Sete Lagoas. Estava estudando lá. E naquela época ônibus era muito difícil. Os carros também. Mesmo assim, a minha admiração era forte. Há tempos atrás era apenas um congado, hoje em dia dou comida para sete, oito grupos de congado.

Gosto de lembrar da primeira capela do rosário. Era muito bonita! Veja só, [retira o quadro da parede]. Ela foi construída pelo Sr. Veríssimo nesse mesmo lugar onde fizemos a reconstrução. A data exata eu não sei, acho que foi na primeira década do século XX. Há uma lembrança muito viva para mim. Era quando passávamos para ir ao pastinho que ficava logo depois dela... Eu ficava admirando os vitrais que existia em suas janelas laterais. O sol batia nos vitrais coloridos, era muito bonito! Sei também que depois da profanação dessa capela as pessoas tinham medo de passar ao lado dela. Era jovem ainda... Eu já lhe contei isso, não?

Quando pensei que podia reconstruir a igrejinha do rosário eu desejava fazer uma igualzinho à que foi profanada. Lembrava dos vitrais ao sol, sua beleza... Mas o padre Herculano pediu que não fizesse uma igreja igual à antiga. Aceitei seu pedido. Resolvi essa questão pedindo a um engenheiro recém formado que trabalhava comigo. Ele se dispôs a fazer a planta da igreja.

Gostaria de mostrar para você. Veja essa árvore aqui na frente da igreja [aponta para o quadro], ela faz parte do sonho do padre Mata Machado. Como já lhe contei, o padre Mata Machado sonhou três vezes com o padre Sebastião pedindo que ele tomasse o chá dessa árvore para se curar. Olha só, essa igreja ficava no cerrado. Só havia a casa do Sr. Licurgo que era parente dessa Virgínia Coati que lhe falei. Ela foi a causa da profanação da primeira igreja do Rosário. 
Gostaria de afirmar, novamente, para você: “o congado é cultura!”. Ele surgiu com nossos irmãos escravos. Foram eles que fundaram o congado. Criaram os instrumentos musicais: berimbau, os tambores... Daí começaram a cantar, cantar e cantar.

As lendas sobre o congado são variadas e belas. Uma delas conta que Nossa Senhora apareceu no mar. Os brancos foram lá, cantaram e dançaram tentando aproximação com a santa. Eles tentaram com oferendas, mas também não conseguiram. Aí quando foram os negros, cantando e dançando, ela veio. Começaram as festas! As histórias do congado são tantas...

Não tem muito tempo, soube de uma história que foi publicada no Estado de Minas. Essa reportagem falava de um incêndio em uma casa. Nessa casa havia na parede uma imagem de Nossa Senhora do Rosário. E ela não pegou fogo. Havia nesse quadro uma imagem que eu aprecio muito: trata-se das imagens de São Domingos e Santa Catarina que me faz lembrar as histórias dos mouros e cristãos.

Havia muito preconceito porque era coisa de negro. Nas festas do alto da cidade as pessoas daqui do centro não freqüentavam. Ainda tem preconceito, mas está mudando. Mas os congadeiros dançam com tanta fé que fico encantada! Até na velhice elas continuam dançando. Sabe aquela escola do bairro Dom Bosco chamada Américo Vaz? O Américo Vaz era do congado, sei que passou mal depois da festa do congado, não resistiu e morreu. Ele cantava e dançava de qualquer jeito: doente, velho, com sua farda, ao sol quente...

Sempre fico emocionada com as festas! Conhece aquele grupo de congado que tem penacho? Adoro vê-los. Quando eles passam aqui na porta de casa, fico muito emocionada! Existem vários grupos de congado: Paraopeba, Cordisburgo, Inhaúma, Pontinha. Também os grupos do lado de cá: Abaeté, Divinópolis. Esses são de outro modo. Eles têm uma cadência de ritmo que me emociona. Me lembro da festa de trinta anos de casada. Fiquei extasiada! Eu me casei na igreja do Rosário e jamais de esquecerei. Eu também fui festeira e me vesti de rainha do Congo. Foi lindo!

Depois da minha família, são as festas do Rosário e Paraopeba. Eu vivo para essas festas! Até quando Deus me der saúde e vida eu vou continuar [se emociona e chora]. Adoro minhas festas! Se não fosse minha fé, depois da morte do meu filho, eu não daria conta. Nossa Senhora é tudo! Não daria conta de viver. Minha fé em Nossa Senhora do Rosário é uma coisa surpreendente.

Existe uma música que sempre cantei. Ela é bonita e me acompanha. Escute, é mais ou menos assim: 
"O beija-flor toma conta do jardim

E pedi Nossa Senhora para cuidar bem de mim

Santa Maria, cheira

cheira a flor de rosa, de laranjeira [pausa]

(...)

Do Rosário [esqueci]

Deus é mais, Deus é mais, Deus é mais

Deus me dê saúde e força

Alegria e muita paz".

Essa cantiga tem muitos versos. Ontem mesmo cantei essa música para muitas pessoas.[Gesticula com as mãos]

Veja só, como o tempo passa! Só a igreja que eu reconstruir já fez cinqüenta e cinco anos. Só parei com as festas quando morei fora. Não teve jeito. Depois a associação dos vicentinos reiniciou as festas. Mandaram o convite para mim. E depois fui, novamente, movimentando as festas do congado. E estou até hoje. Há muitos anos oferecemos aqui em nossa casa a refeição (almoço, lanche antes e depois da missa) para os grupos de congado que participaram da festa. São uns sete grupos de congado e mais de quatrocentas pessoas. Tudo sob as sombras das mangueiras que cobrem o quintal da nossa casa. Toda a família participa: filhos, noras, genros, netos, sobrinhos, amigos e convidados. É uma delícia, fé e alegria.

A minha fé em Nossa Senhora do Rosário é tão grande que ela guia o meu caminho. Se eu for contar tudo que ela faz por mim e minha família não haverá papel suficiente. Há seis anos, fomos festeiros novamente. Meu marido e eu comemorávamos cinqüenta anos de casados. A igrejinha também fazia cinqüenta anos. Como o Silvério não dava conta de participar de todas as solenidades, o Tom, meu filho que Deus levou, foi meu companheiro em tudo. Foi uma festa maravilhosa. Há dois anos atrás fui coroada Rainha Perpétua da festa de Nossa Senhora do Rosário. Recebi coroa e bastão. Foi tudo lindo!

É uma luta constante, muito trabalho. Mas isso está em uma das histórias sobre Nossa Senhora do Rosário. São Domingos, que aparece ao lado da Santa, apareceu com o Rosário. Ele teve notícias que os cristãos haviam vencido a guerra contra os mouros. E a Santa Catarina foi a dominicana que fundou a primeira irmandade. Como podemos ver, tem sempre muita dificuldade. Mas fui aprendendo com as dificuldades da vida a superar cada obstáculo. Como lhe disse, peguei a devoção de minha mãe. Isso é a fé! A fé no rosário. Já distribui mais 
de três mil terços. Vou continuar distribuindo os terços. A Nossa Senhora é muito importante. O congado também.

Dou muito valor a isso. Para mim não tem essa coisa de que por ser preto não pode. Sei que é festa de negro, de gente simples. Acho que agora é tradição. Até em Belo Horizonte, que é lugar grande, essa festa está inserida na cidade. Aqui em Paraopeba também. Desde quando era Tabuleiro Grande, Vila Paraopeba e hoje Paraopeba. Agora, graças a Deus, tem valor. Congado é fé e cultura! É nisso que eu acredito.

\section{$* * *$}

Acho que deu para você perceber. A minha religião sempre foi católica. Sou muito católica desde criança. Quando morei em Sete Lagoas com minhas tias, a tia Edite fazia parte de muitas pastorais na igreja e seguia os seus passos: fazia retiros no carnaval, jejuava na quaresma, fazia adoração. Isto tudo marcou muito a minha vida, graças a Deus. Aqui em Paraopeba, anos atrás não havia nenhuma igreja evangélica. Hoje em dia, tem várias igrejas evangélicas, na minha época não havia. Peguei a devoção de mamãe e continuo até quando Deus quiser. Faço com gosto essas festas de Nossa Senhora do Rosário. Em todos os meses da festa estou aqui para ver os dançantes do congado.

Lembro-me que anos atrás vinham muitas missões para Paraopeba. Elas movimentavam as pessoas: sua fé, sua devoção. Estou completando sessenta e cinco anos de apostolado de oração. Isso foi herança da minha mãe. Lembro-me da mamãe ensinando-me a assistir a missas. Ela ia passando pela rua e chamando as pessoas para assistirem e participarem das missas. Eu apenas estou continuando...

\section{$* * *$}

A cidade foi mudando e essas mudanças vão continuar. São coisas da vida, não é? Uma diferença bem marcante da cidade de antes e de hoje são as formas das pessoas dançarem. Na minha época as pessoas dançavam bem mais comportadas. Hoje em dia Paraopeba está bem diferente. Cresceu muito, têm muitas casas bonitas, ruas largas e asfaltadas e diversas praças. Tudo vai se modificando e modernizando. Acho que essa casa 
aqui ainda permanece como antigamente. Como eu lhe disse, ela permanece igual à época do sogro do Sr. Avelino Fóscolo, lá pelo início do século XIX.

Apesar disso tudo, a Nossa Senhora do Rosário veio em minhas mãos sem eu nunca pensar em construir uma igreja. Estou falando muito de Nossa Senhora do Rosário mas, assim como a minha mãe, gosto também do Sagrado Coração de Jesus. Há sessenta anos sou associada do Apostolado da Oração (herança da minha mãe assim como o caderno de orações que herdei dela, eu já lhe falei, não?). E há doze anos sou presidente, na Igreja de Santo Antônio, em Belo Horizonte. Há trinta anos sou adoradora do Santíssimo Sacramento na Catedral da Boa Viagem, também em Belo Horizonte. E agora moro a cem metros da Catedral Como estou feliz! A minha fé é que me sustenta. Apesar das mudanças, isso permaneceu. Quero viver mais, mas estou cansada.

Gosto muito de ajudar, principalmente as causas de Paraopeba. Sou muito entrosada com meus conterrâneos. Eles me dão muitas coisas: roupas, sapatos, móveis, livros para eu levar os pobres, grupos escolares, hospitais. Certa vez, levei muitos livros e a Celina que toma da Capela do Divino teve a feliz idéia de fazer uma biblioteca. E os congados foram logo dizendo: "a biblioteca se chamará Maria Stella Rates". Fiquei muito alegre, captei muitos livros em Belo Horizonte, móveis e está lá até com computador, TV, som. A biblioteca tem sido muito útil ao bairro Nossa Senhora do Carmo. Louvado seja Deus! Casei-me na igrejinha, batizei alguns filhos e netos lá, e enquanto Deus me der vida e saúde, estarei aqui para ajudar nas festas do Rosário. Vivo para minha família, para as festas do Rosário e Paraopeba

Achei essa viagem ao passado espetacular. Só que eu falo muito depressa, não é [risos]? Penso em muitas coisas [silêncio]. Quero que você saiba, rapaz, que é bom demais contar a história da minha cidade que eu amo [lágrimas, um choro discreto]. Não moro aqui em Paraopeba, nessa casa centenária, porque meus filhos e netos todos moram em Belo Horizonte. Mas sempre que posso, estou aqui, principalmente na festa do Rosário! Não posso faltar. Com a perda de meu filho recentemente, meus outros filhos não me deixam mais ficar sozinha. Eles sempre estão juntos de mim e do pai deles. Com a partida do Tom para o Reino de Deus, tudo isto é que me dá forças para viver. O terço é meu companheiro, já distribui durante as festas do Rosário por volta de três mil terços, como lhe falei, e vou continuar. Por mim, eu morava aqui com toda a minha família. Mas no momento não posso. Ah! Como foi importante contar a minha história e a da cidade. São muitas lembranças.... É a história da cidade que se mistura com a minha. É isso, precisamos superar os obstáculos que a vida nos 
proporciona. Só tenho que louvar e agradecer a Deus o dom da vida. E continuar cantando e contando:

“Oh Mãe, Virgem do Rosário

Aceitai louvores

Destes filhos Teus

Amar-Te queremos na terra

E sempre cantar

Teu nome no Céu".

$* * *$ 


\subsection{Anexo 02 - Imagens}

IMAGEM 20: A rua Direita e o sobrado do poeta

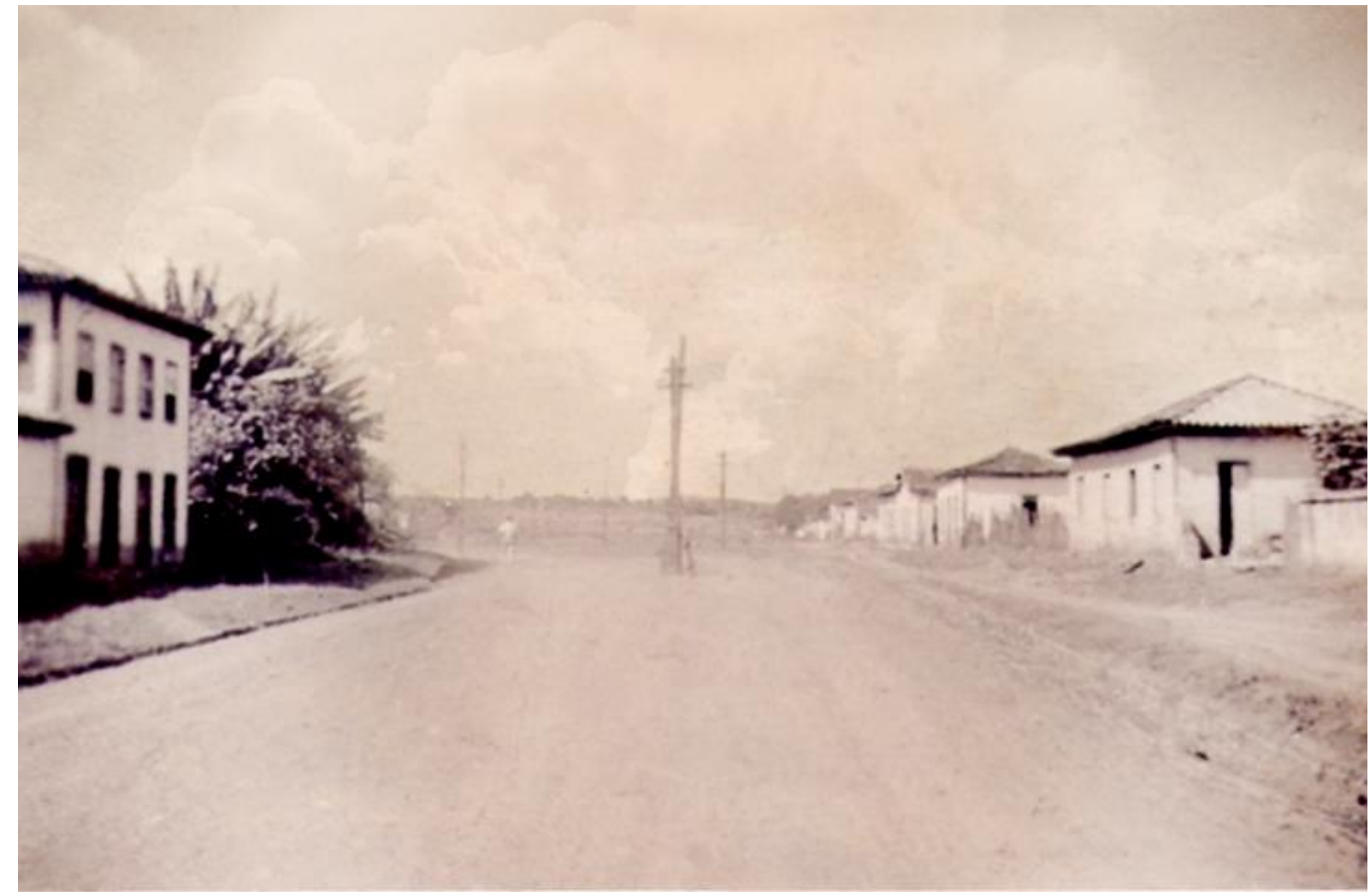

Fonte: Arquivo particular

IMAGEM 21: A banda de música "Lira do Espeírito Santo". No centro, mestre Cazuza

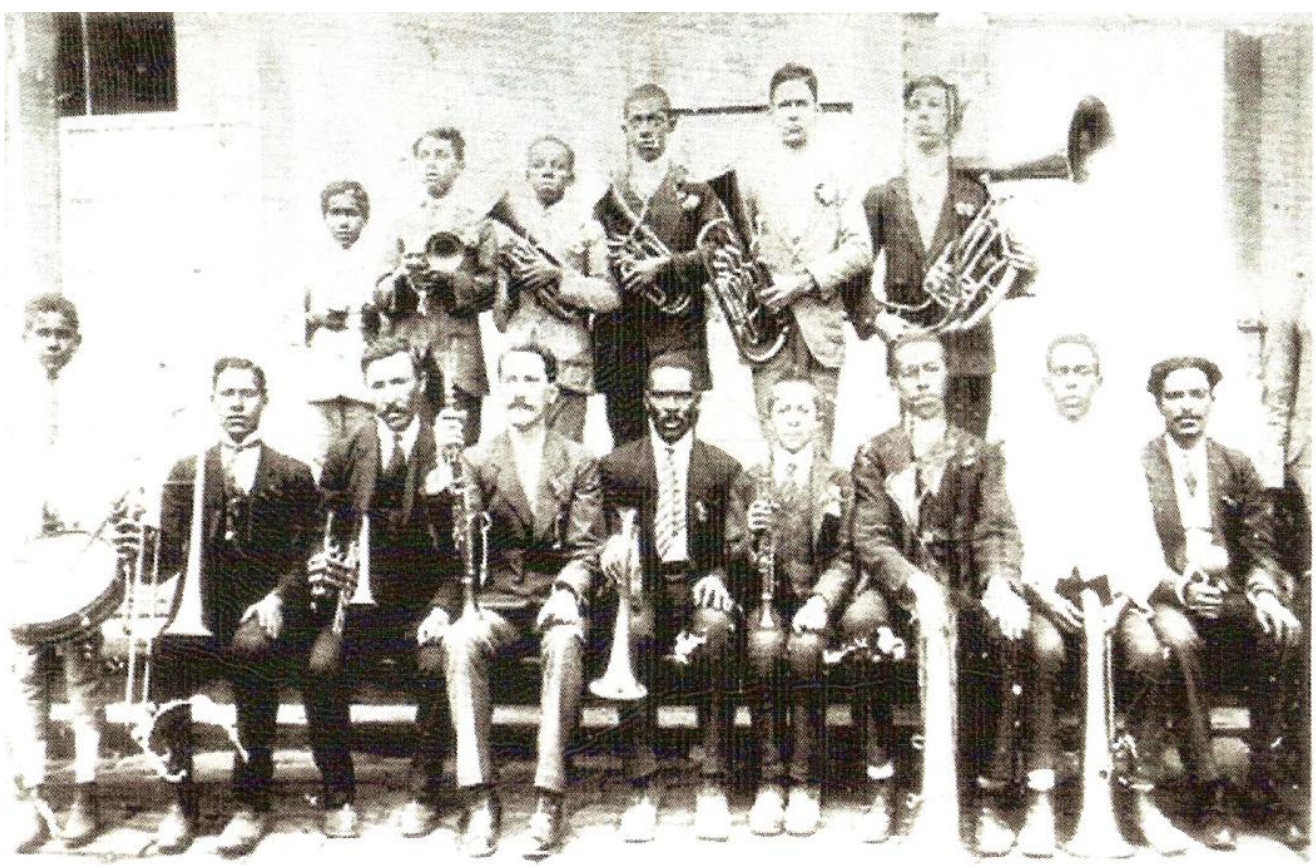

Fonte: Arquivo particular 
IMAGEM 22: As ruas e os becos da cidade

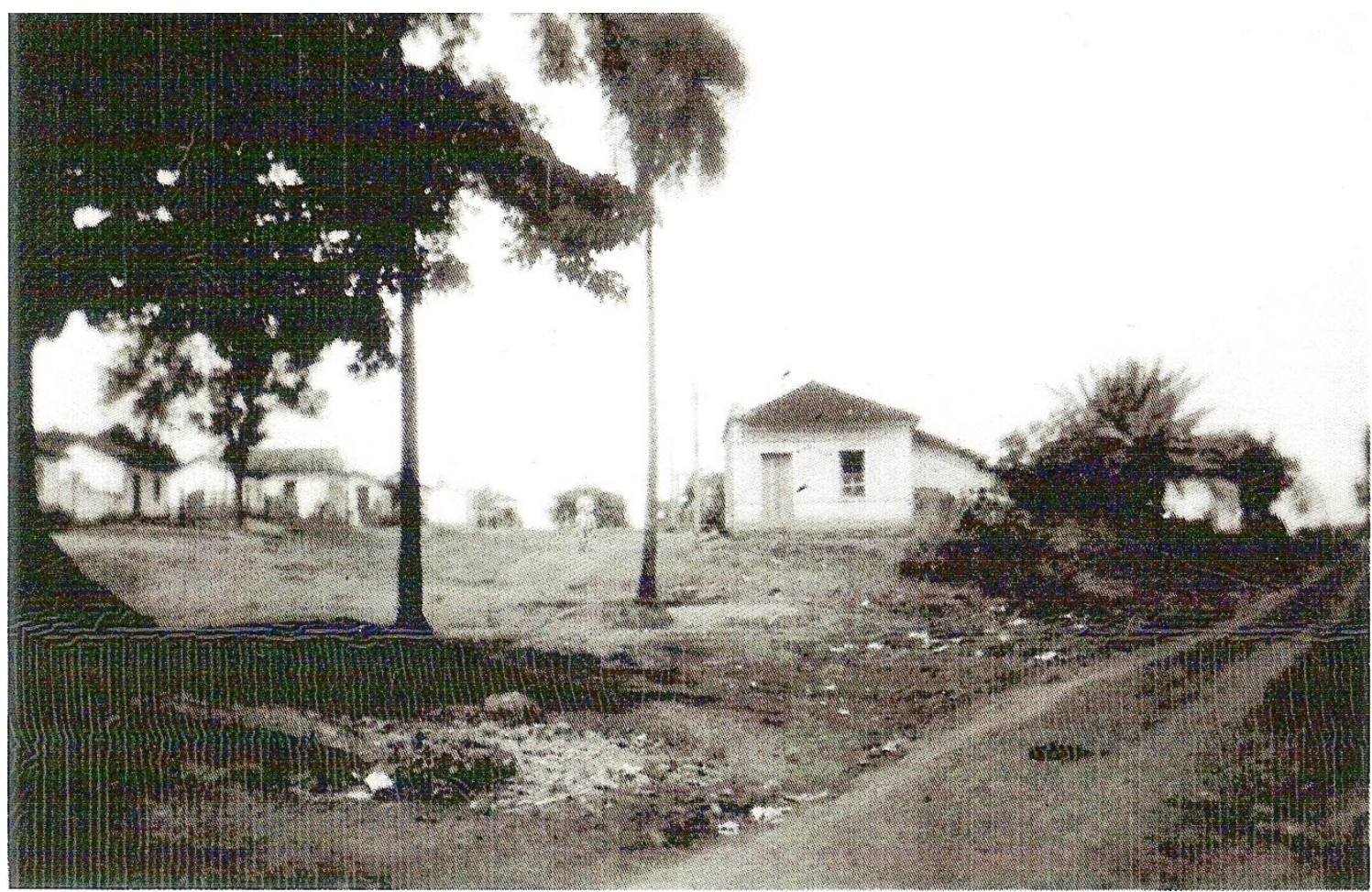

Fonte: Arquivo particular

IMAGEM 23: O primeiro posto de saúde

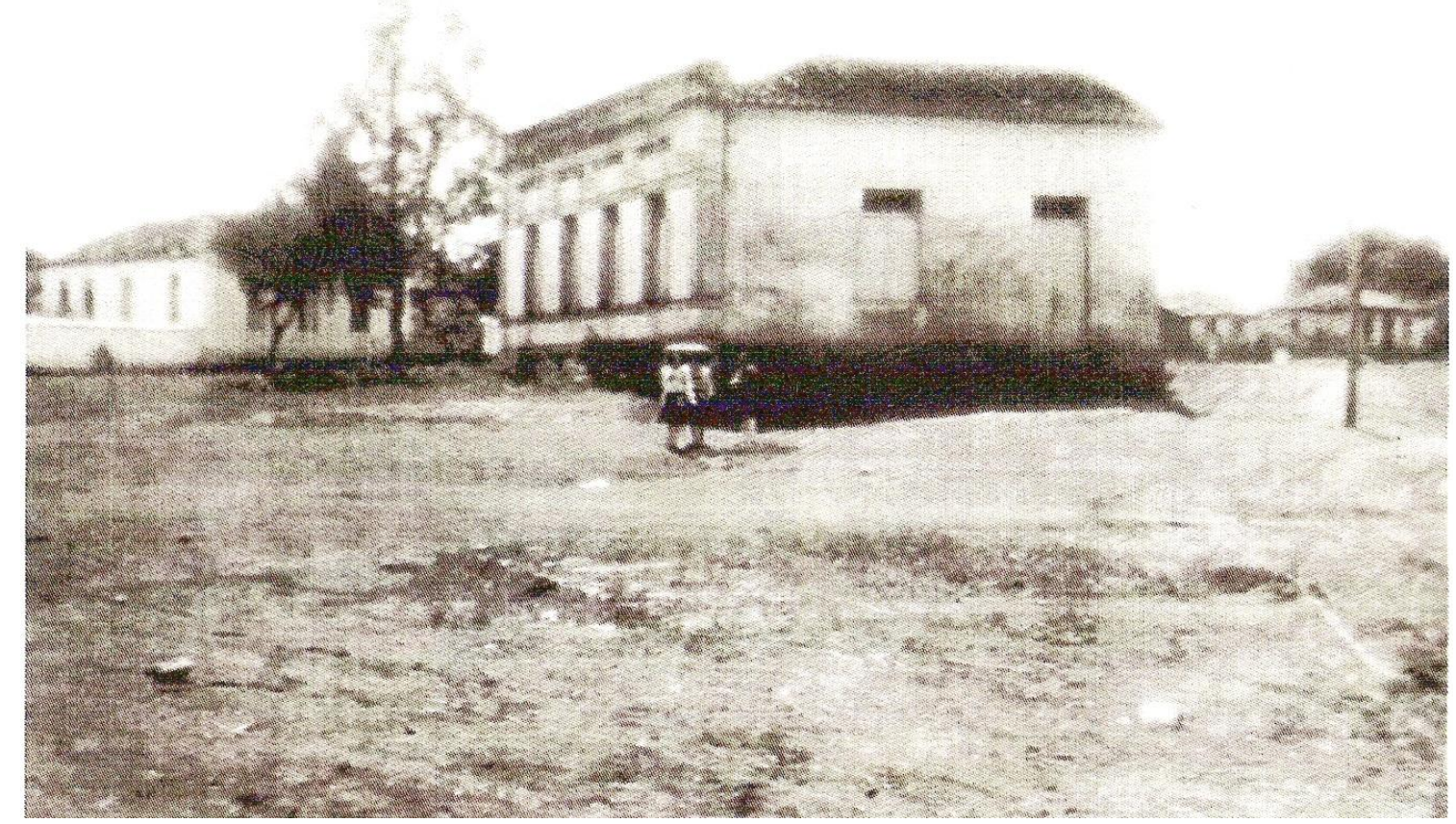

Fonte: Arquivo particular 
IMAGEM 24: O memorialista Sr. Antônio de terno branco, e seu sobrinho, na juventude

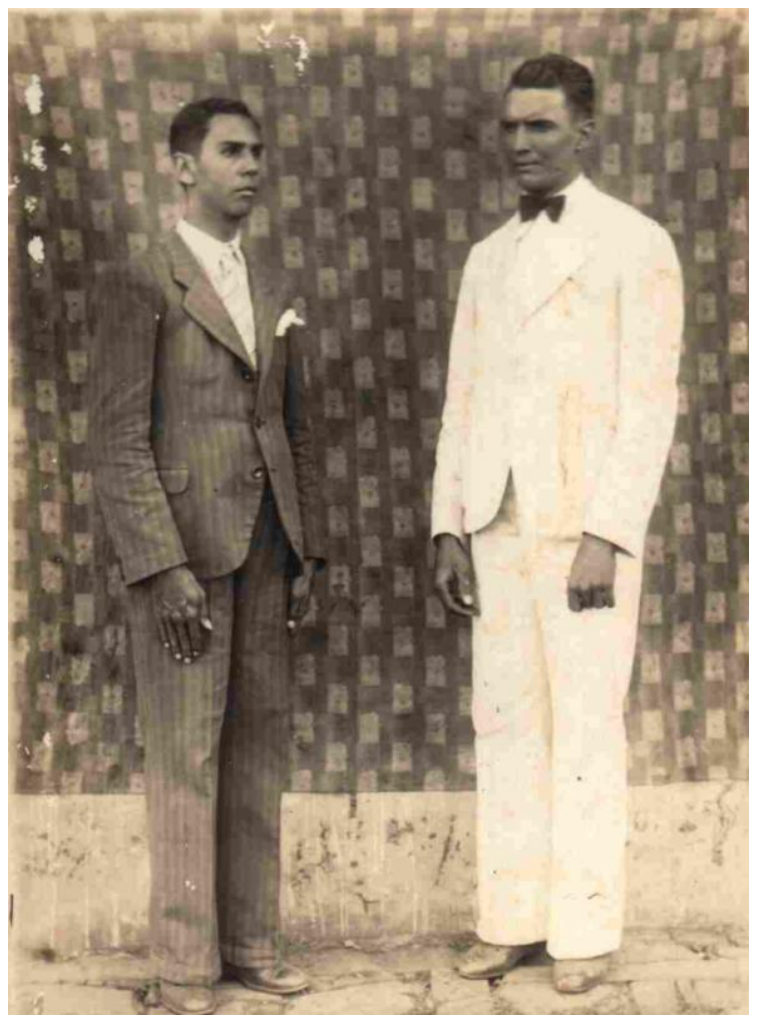

Fonte: Arquivo particular

IMAGEM 25: O memorialista Sr. Antônio em seu aniversário de 100 anos

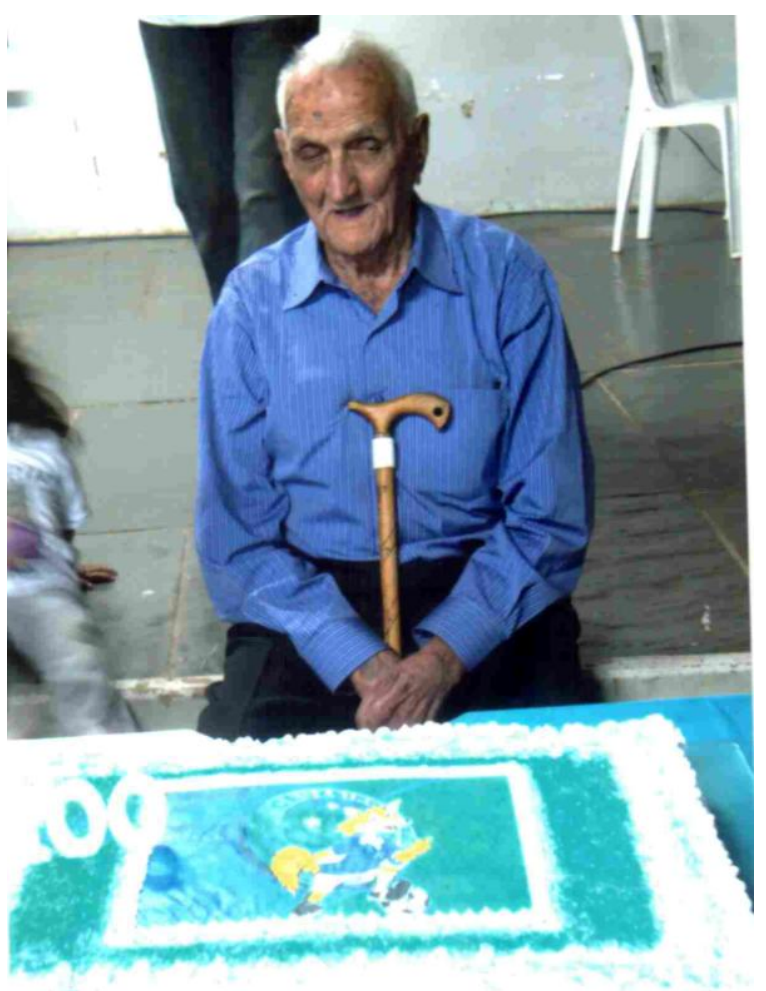


Fonte: Arquivo particular

IMAGEM 26: $\mathrm{O}$ memorialista Sr. José e seu irmão mais velho descobrindo a rua...

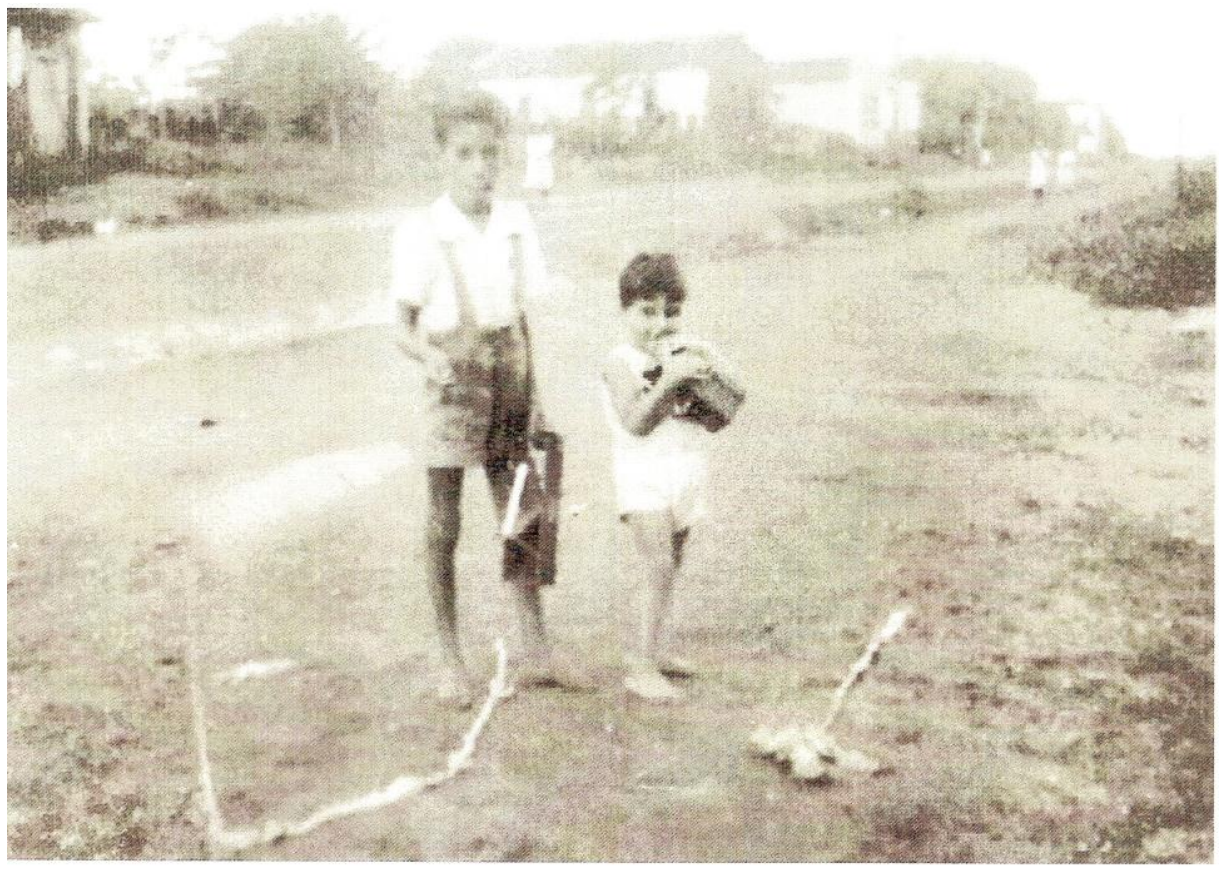

Fonte: Arquivo particular

IMAGEM 27: Os dois memorialistas: O Sr. José e D. Dometilde - "a titia"

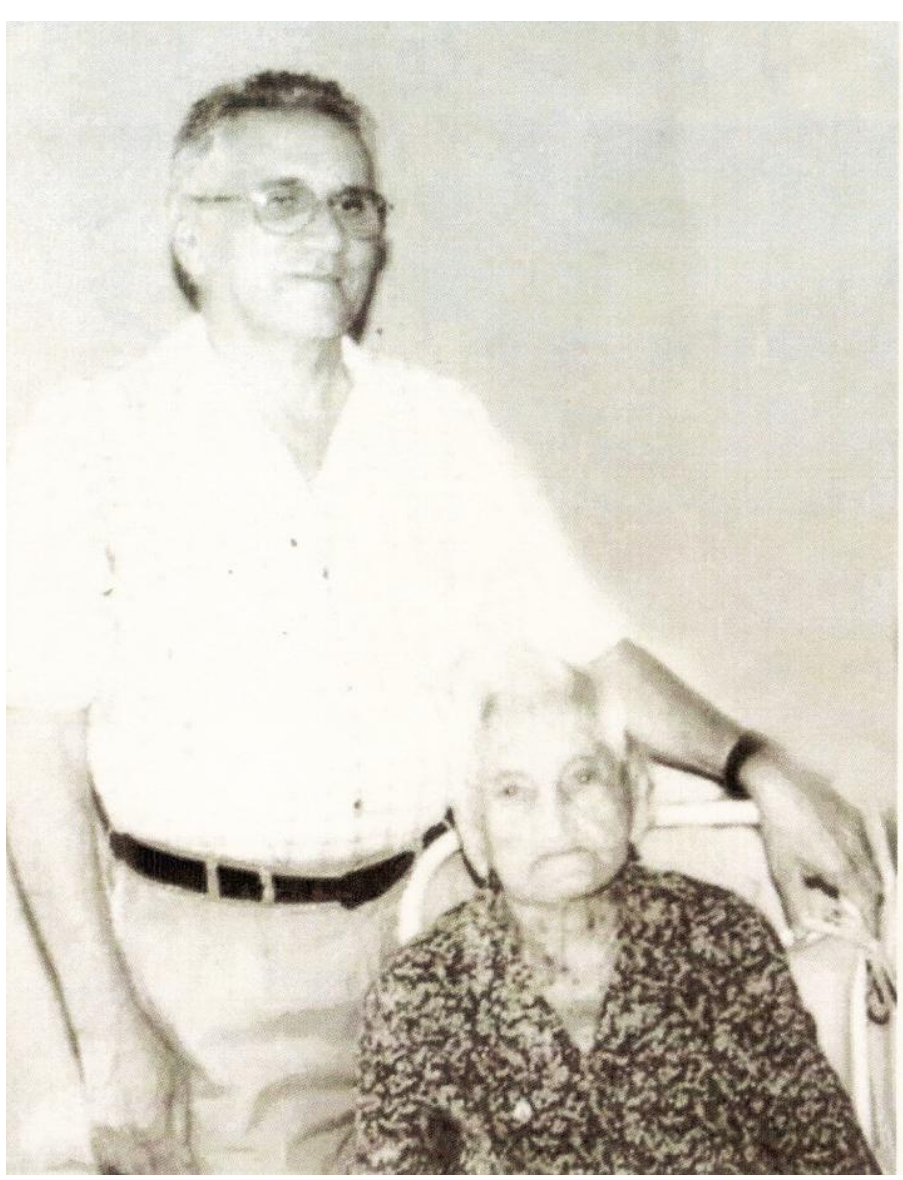

Fonte: Arquivo particular 
IMAGEM 28: O grupo escolar "Afonso Pena"

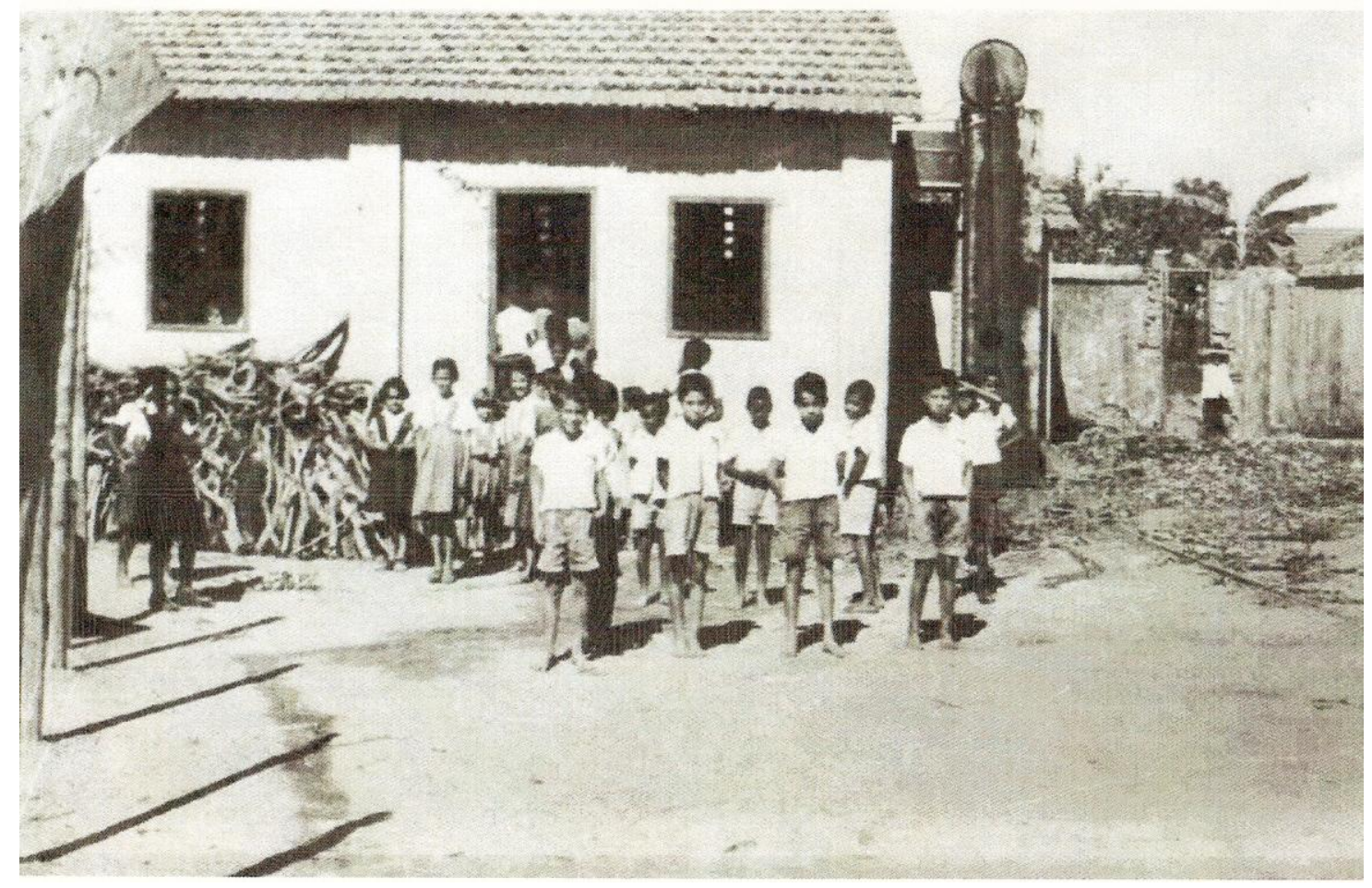

Fonte: Arquivo da escola Conselheiro Afonso Pena

\section{IMAGEM 29: A celebração no grupo escolar Afonso Pena}

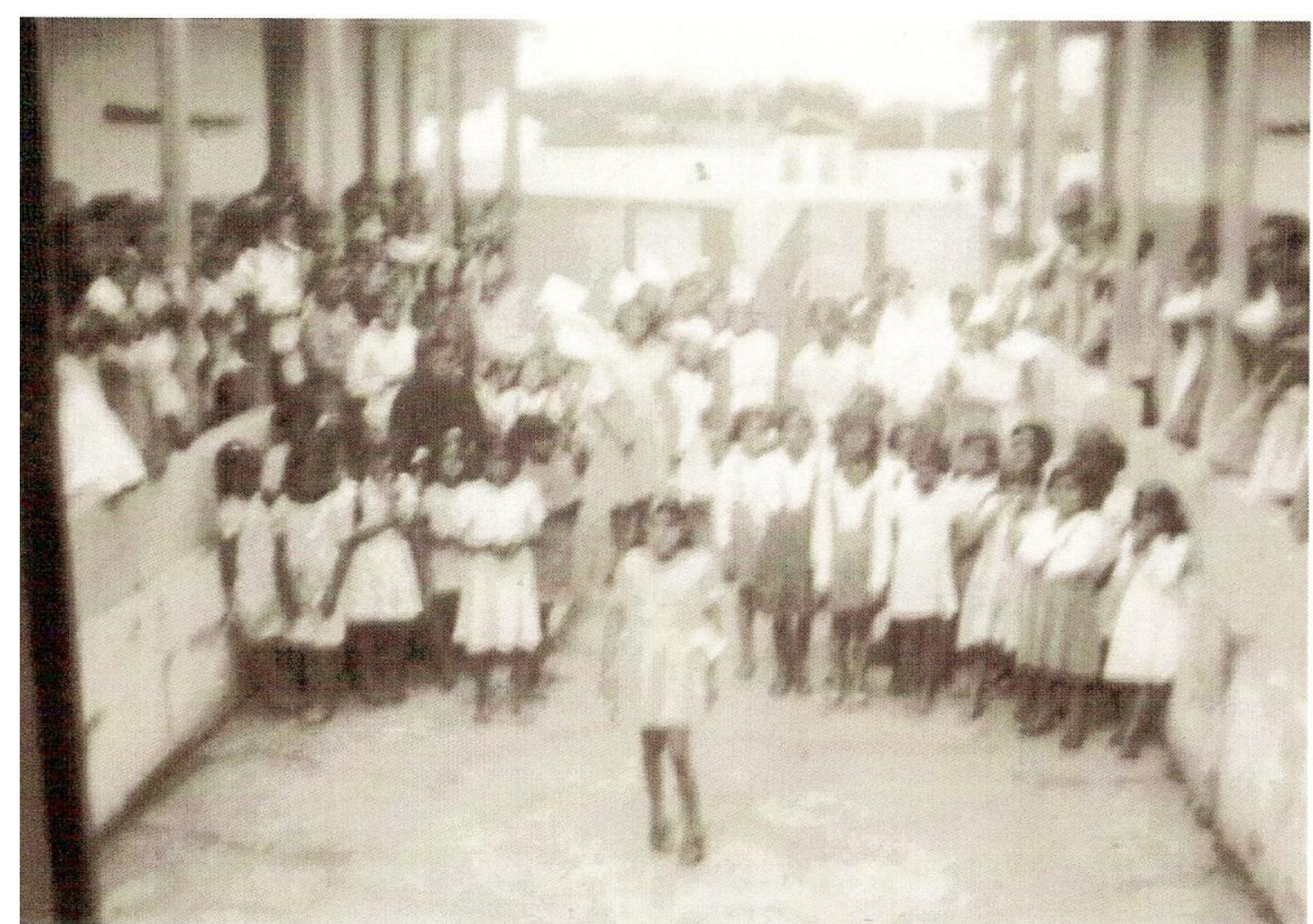

Fonte: Arquivo da escola Conselheiro Afonso Pena 
IMAGEM 30: Os bailados realizados na cidade

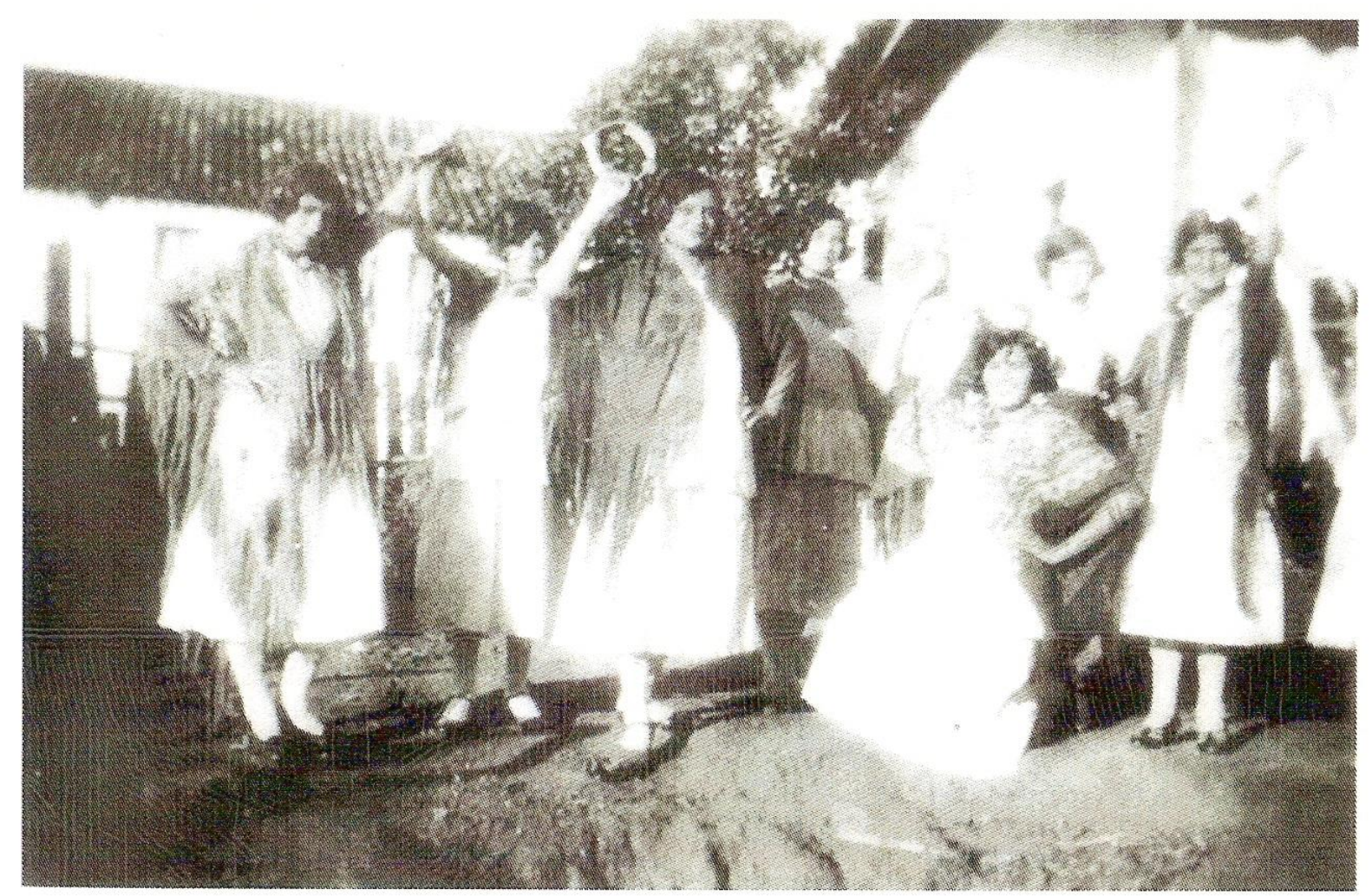

Fonte: Arquivo particular

\section{IMAGEM 31: Os bailados realizados na cidade}

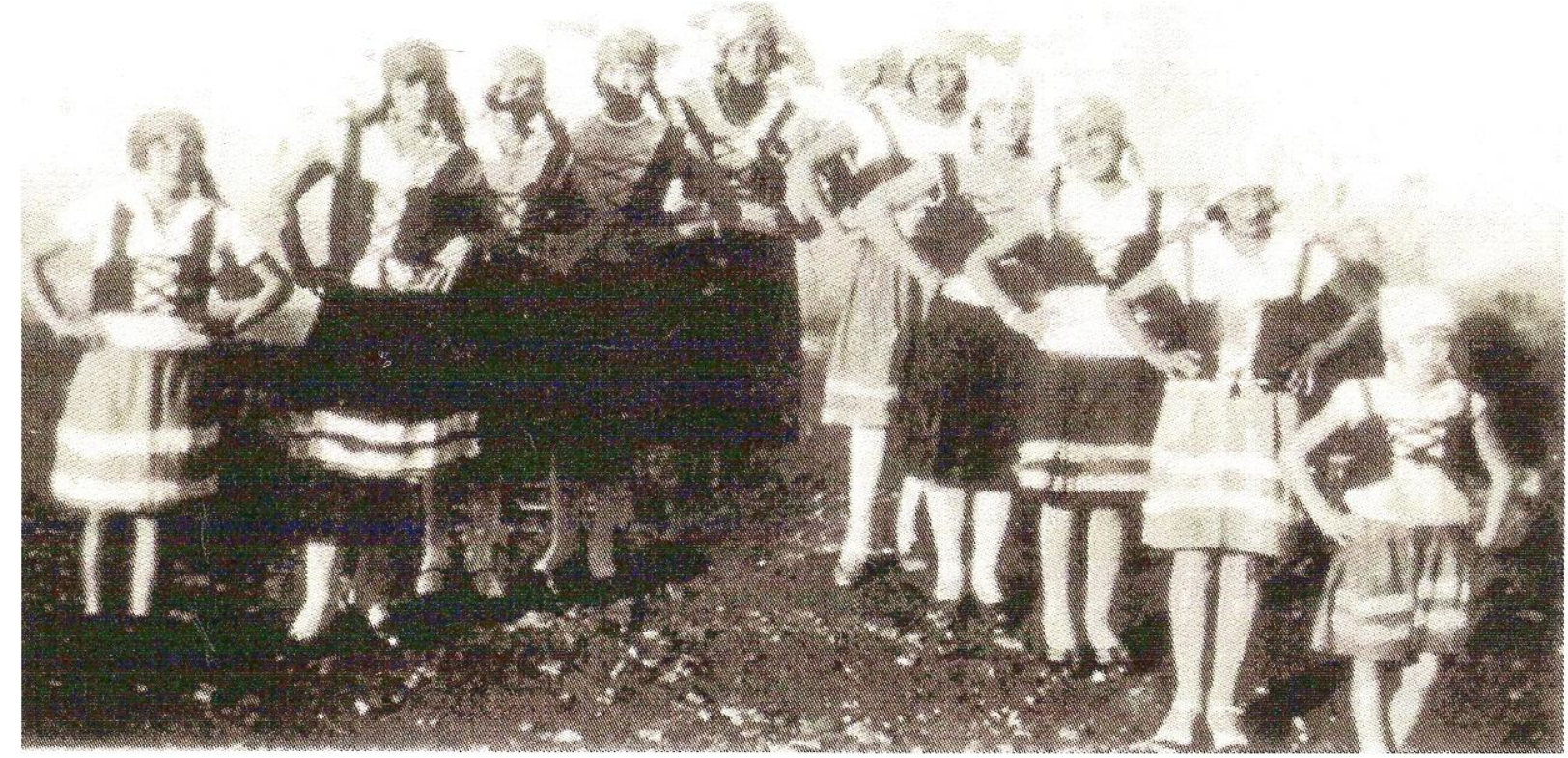

Fonte: Arquivo particular 
IMAGEM 32: O objeto biográfico: o caderno de oração da memorialista D. Maria Stella

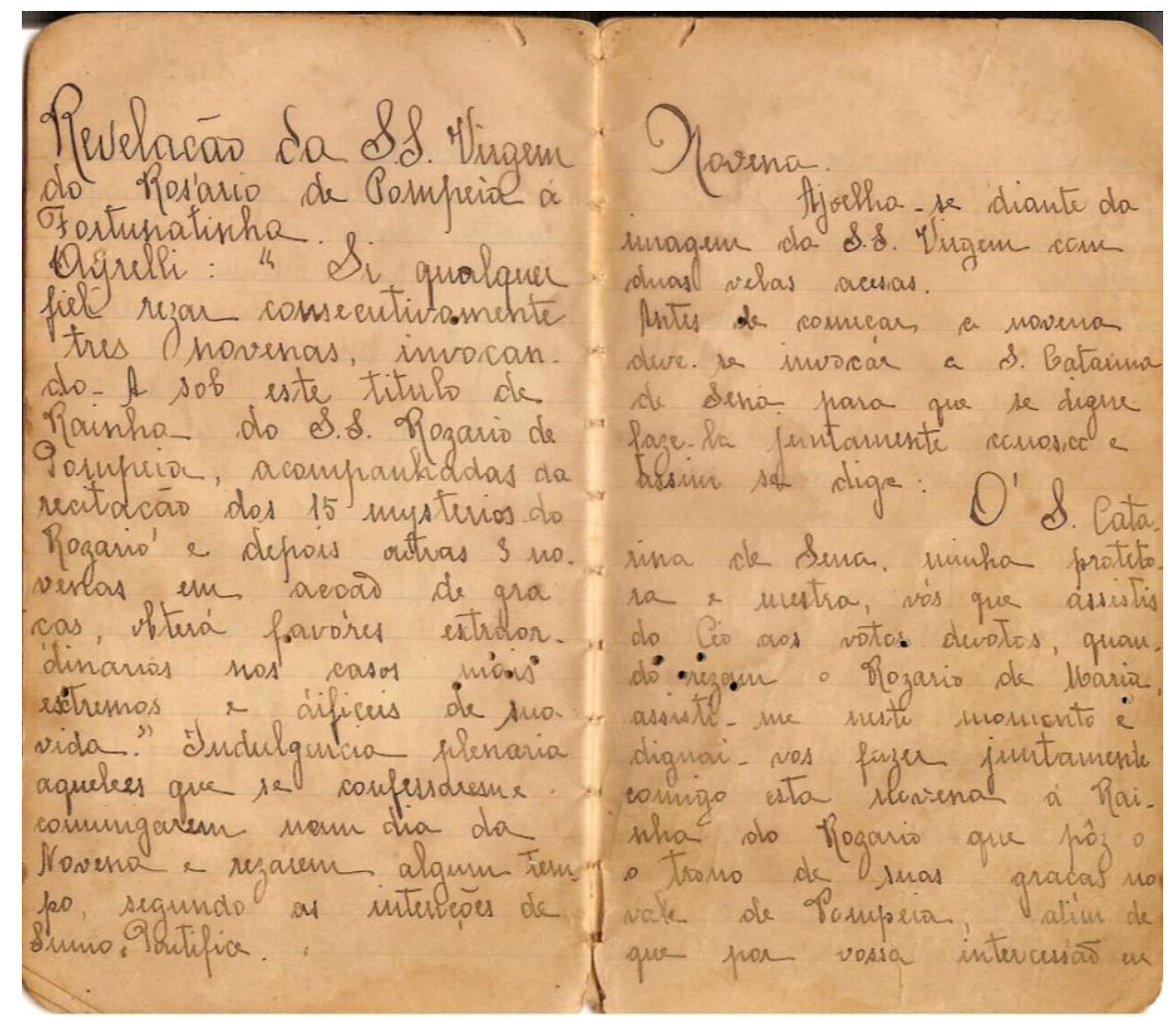

Fonte: Arquivo particular

\section{IMAGEM 33: A memorialista D. Maria Stella herdou da mãe o caderno de oração}

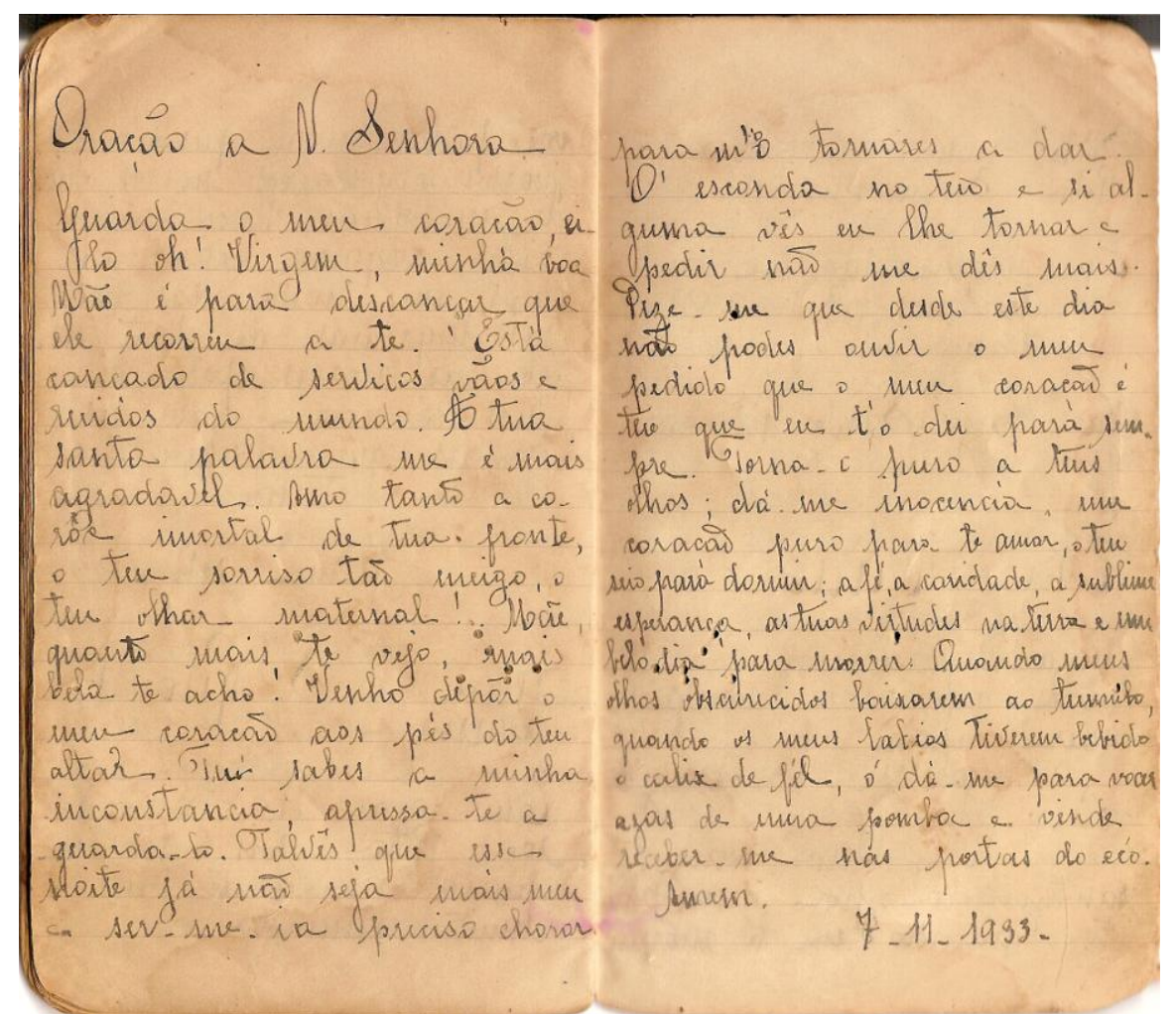

Fonte: Arquivo particular 
IMAGEM 34: A memorialista D. Maria Stella e o marido na reinauguração da igreja do Rosário

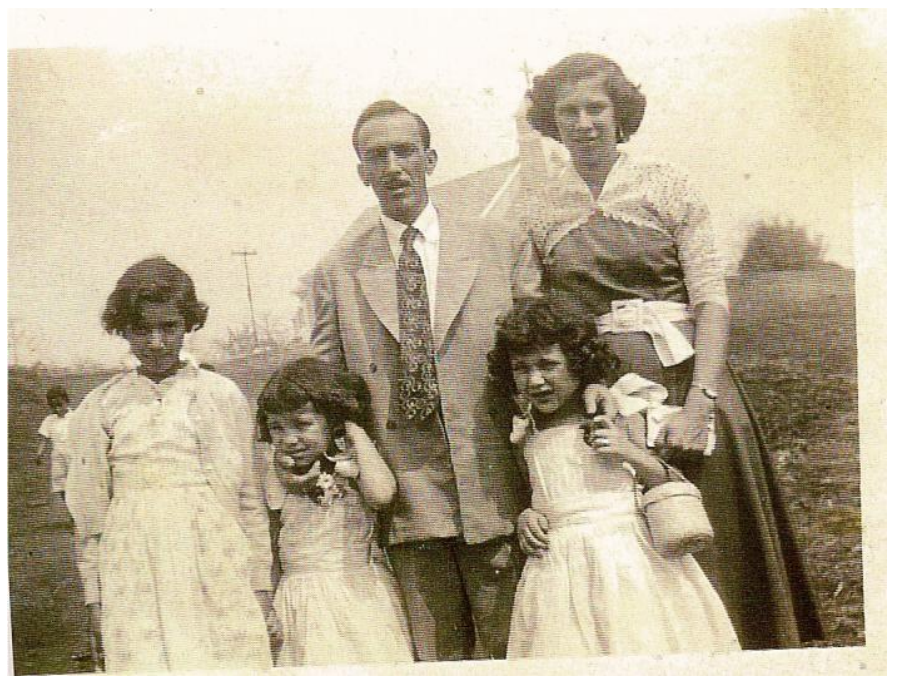

Fonte: Arquivo particular

IMAGEM 35: Campanha em prol da recosntrução da igreja do Rosário

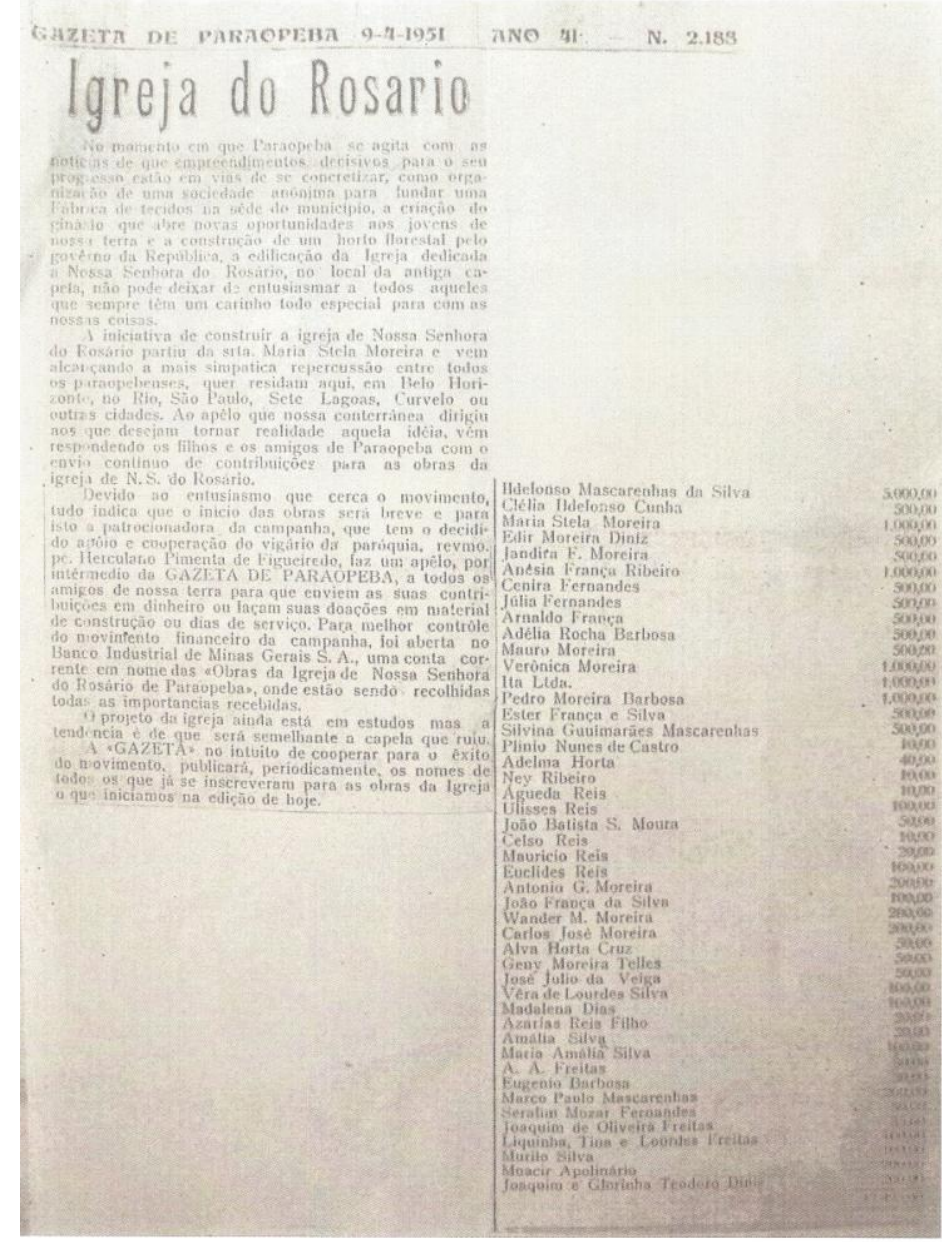

Fonte: Gazeta de Paraopeba - 1951 
IMAGEM 36: A igreja do Rosário reconstruída em quatro ângulos
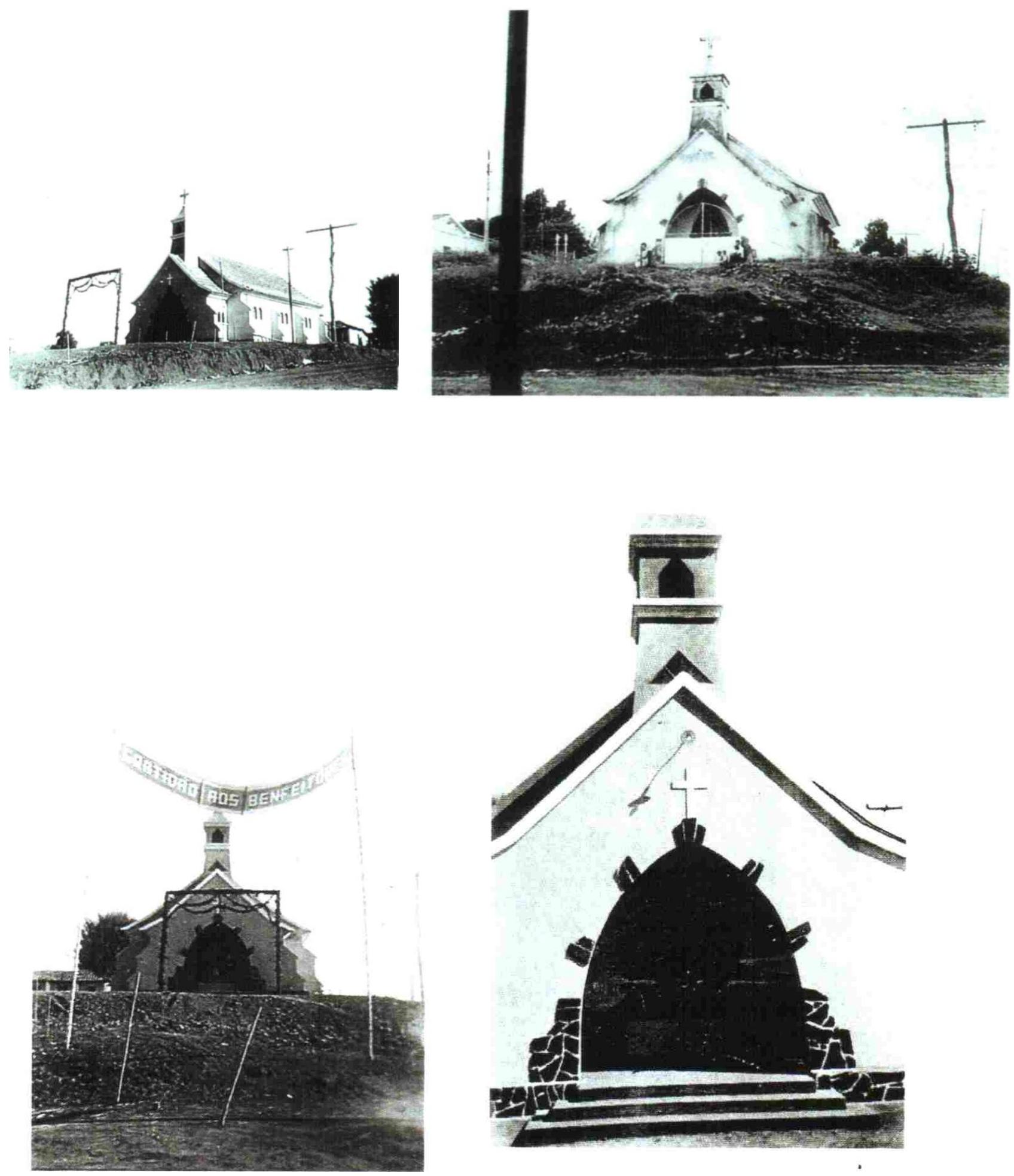

Fonte: Arquivo particular 
IMAGEM 37: Planta da nova Igreja do Rosário

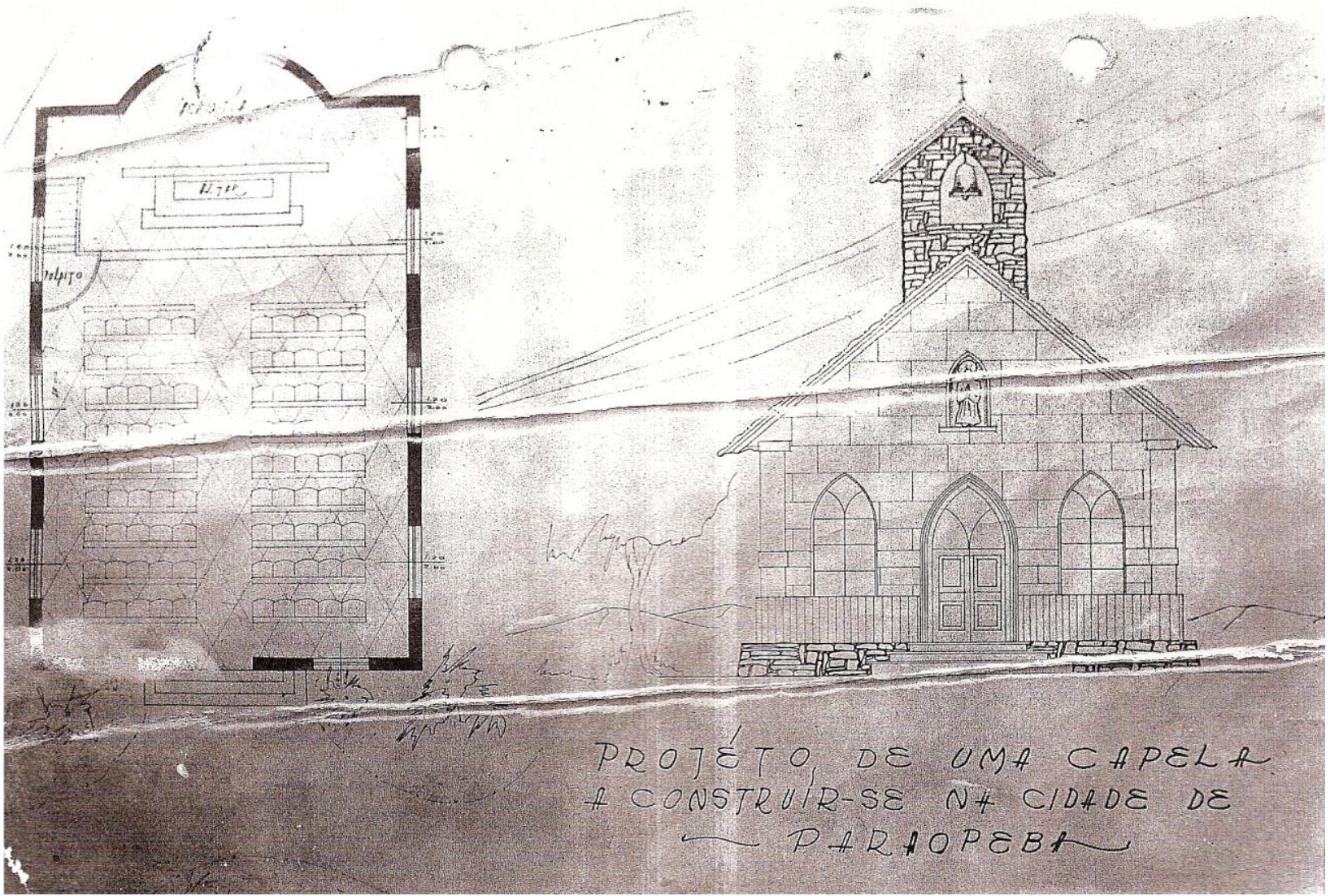

Fonte: Arquivo particular

IMAGEM 38: Coroação dos reis do congado durante a missa de reinauguração da Igreja do Rosário - 14/08/1954

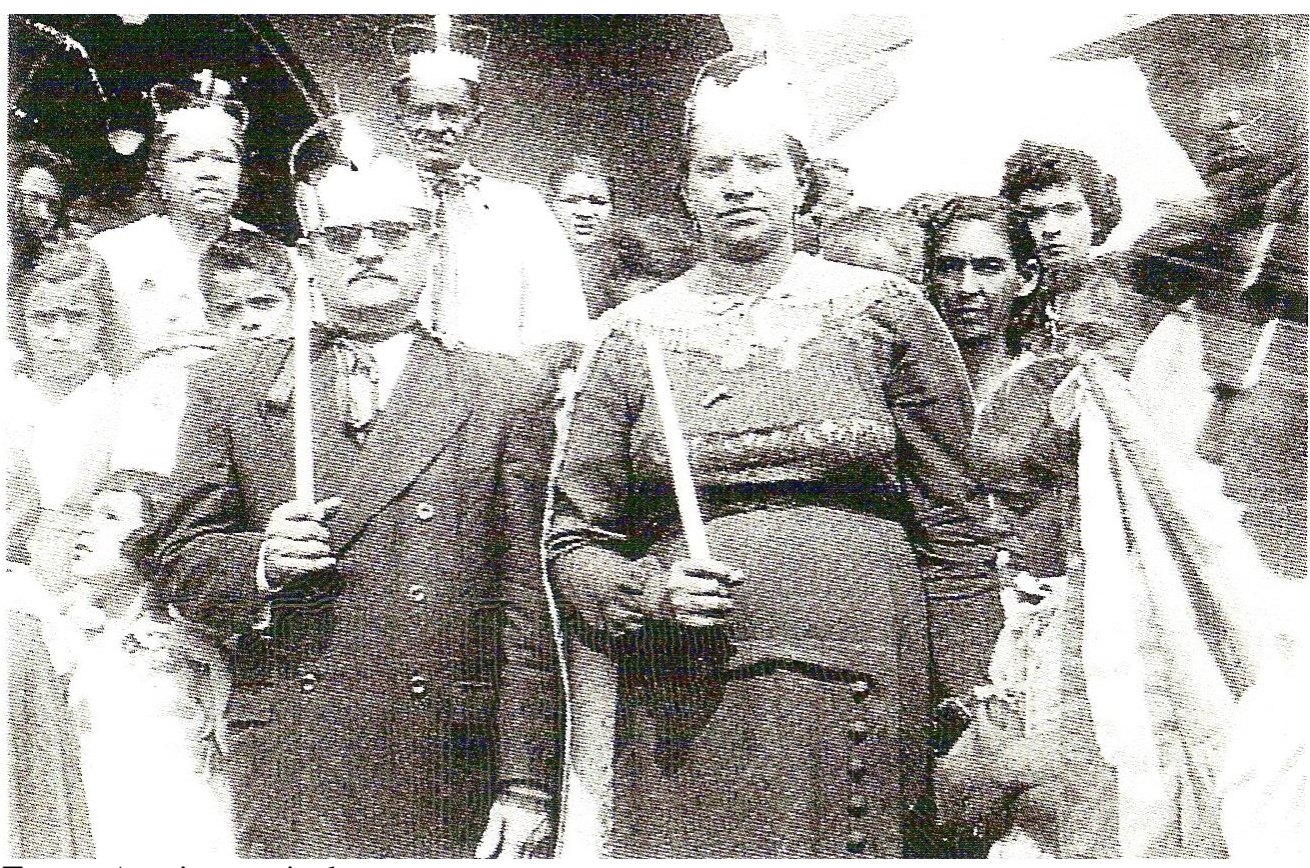

Fonte: Arquivo particular 
IMAGEM 39: Os dançamtes durante a festa do Rosário - 1954

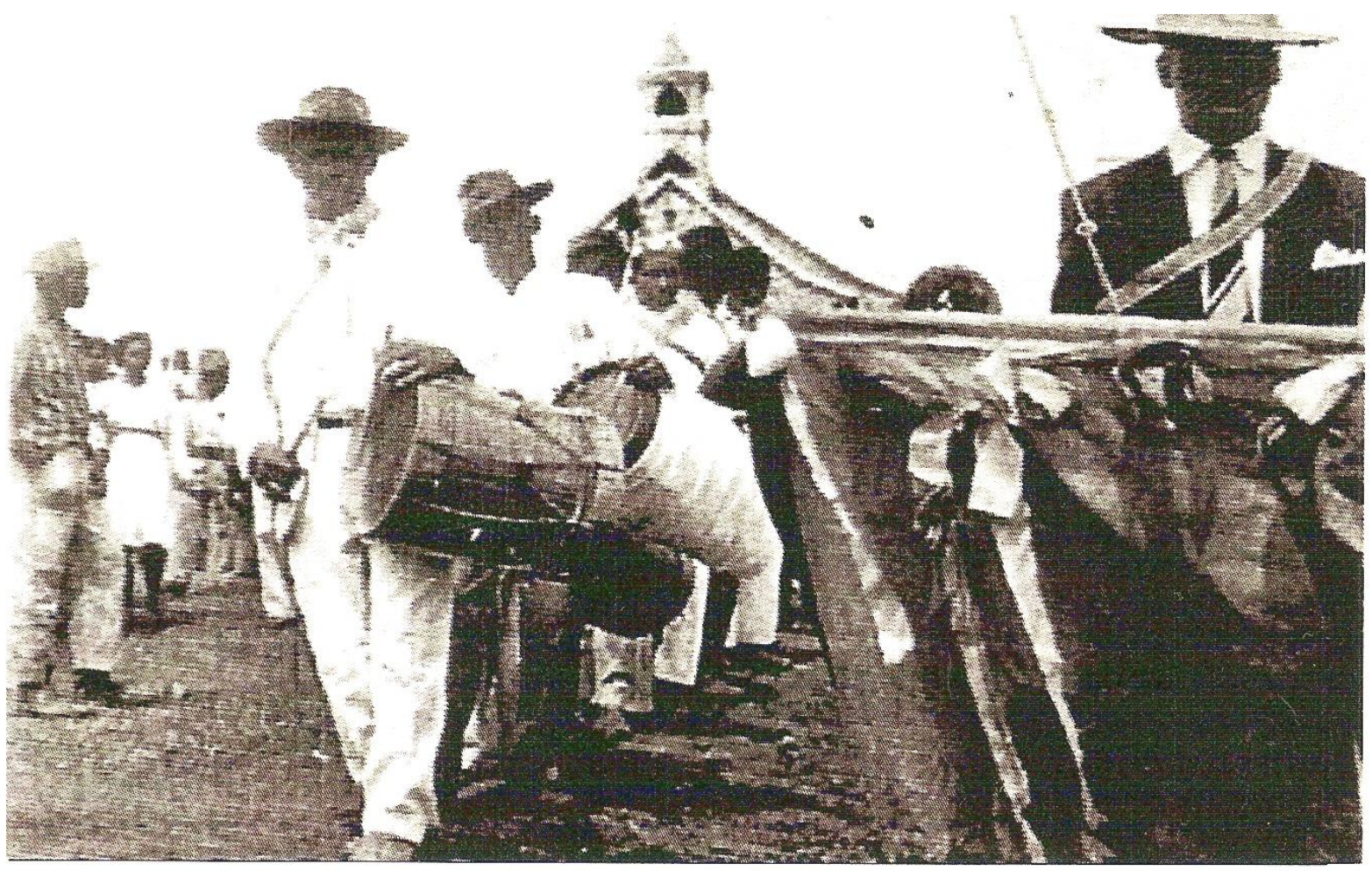

Fonte: Arquivo particular

IMAGEM 40: Procissão religiosa na Praça da Matriz

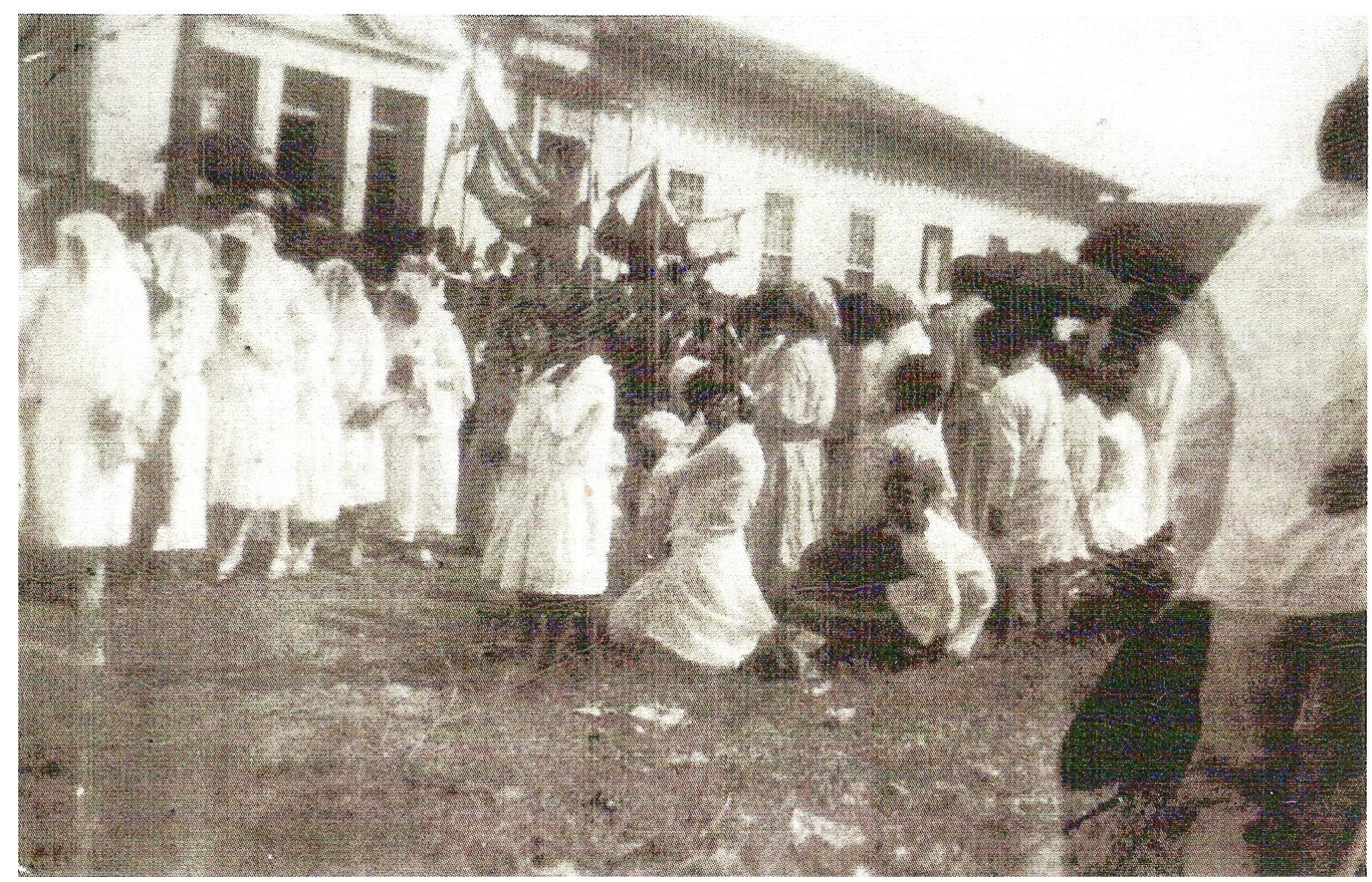

Fonte: Arquivo particular 
IMAGEM 41: Festejo para arrecadação de fundos para financiar a campanha brasileira na II Guerra Mundial

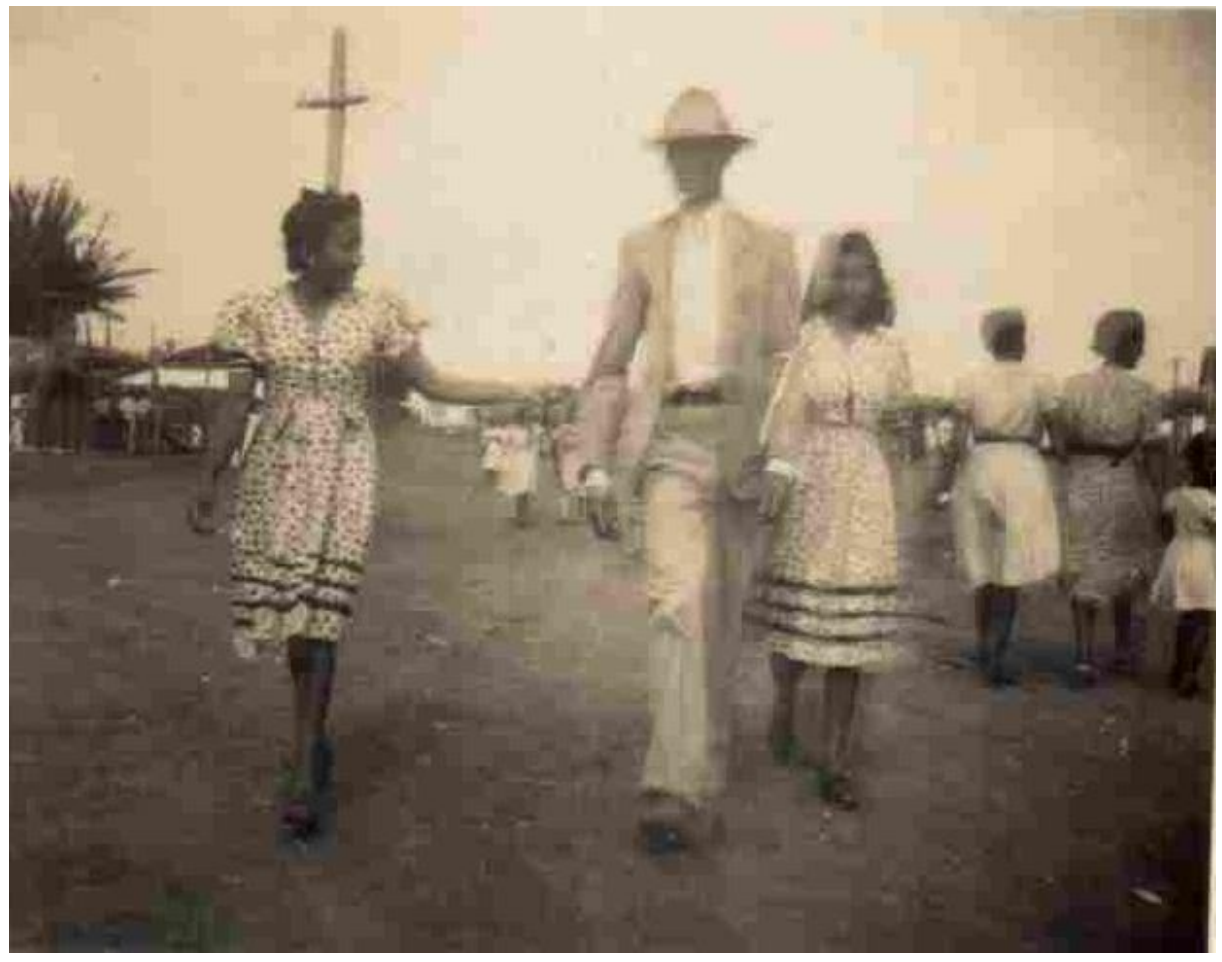

Fonte: Arquivo particular

IMAGEM 42: Festa da cavalhada - década de 1950

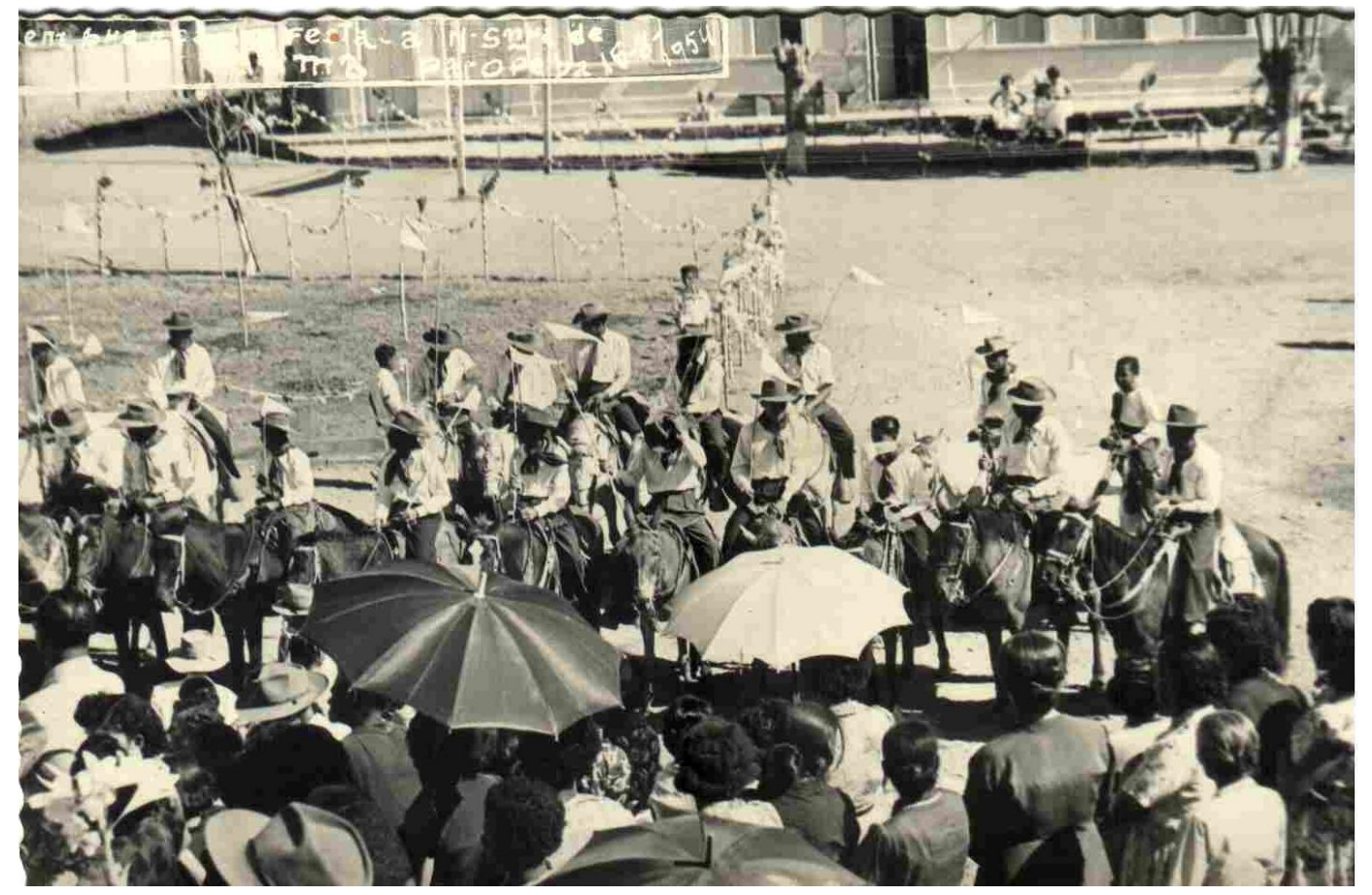

Fonte: Arquivo particular 
IMAGEM 43: Festa na Praça da Matriz

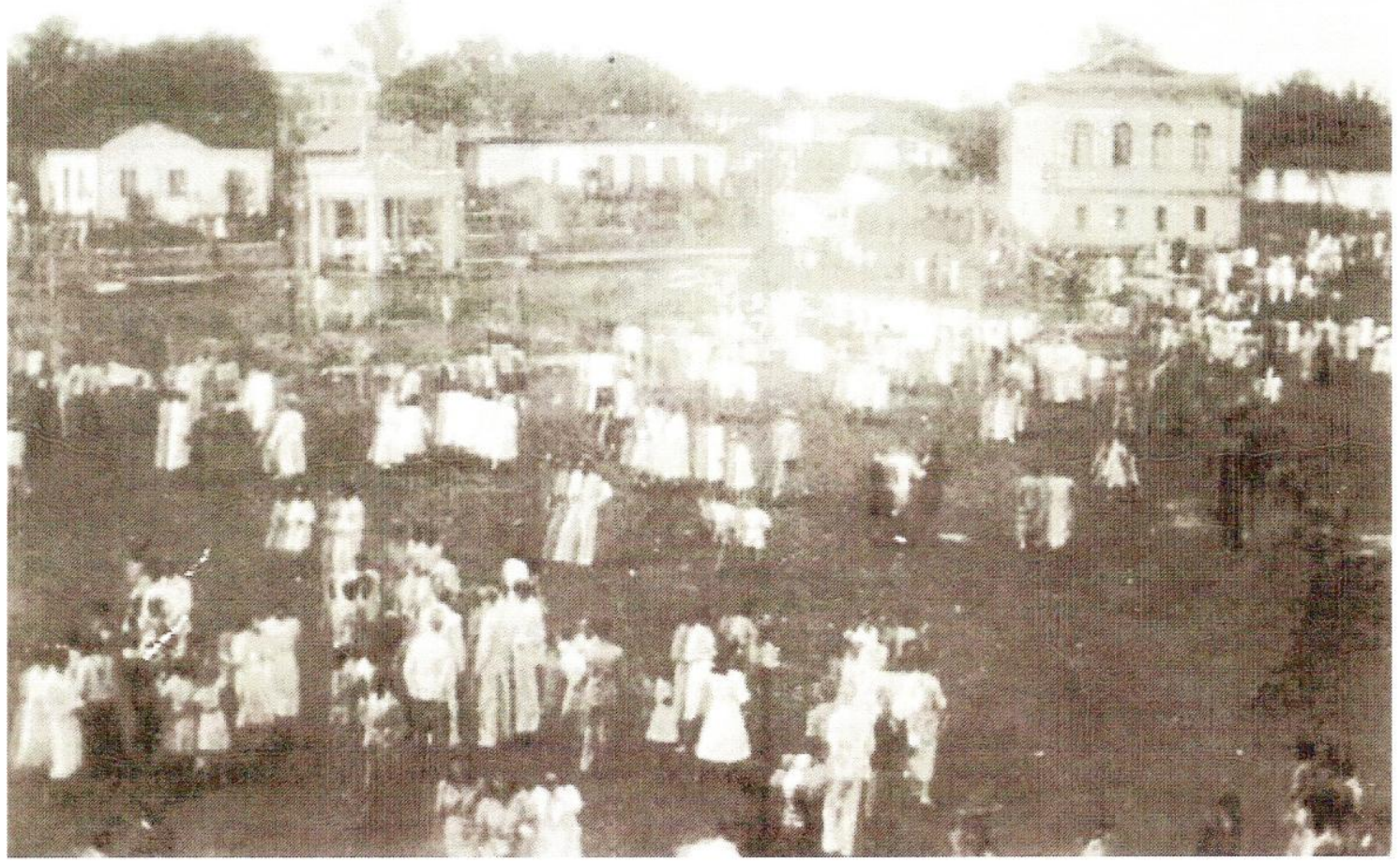

Fonte: Arquivo particular

IMAGEM 44: A memorialista D. Geralda na juventude

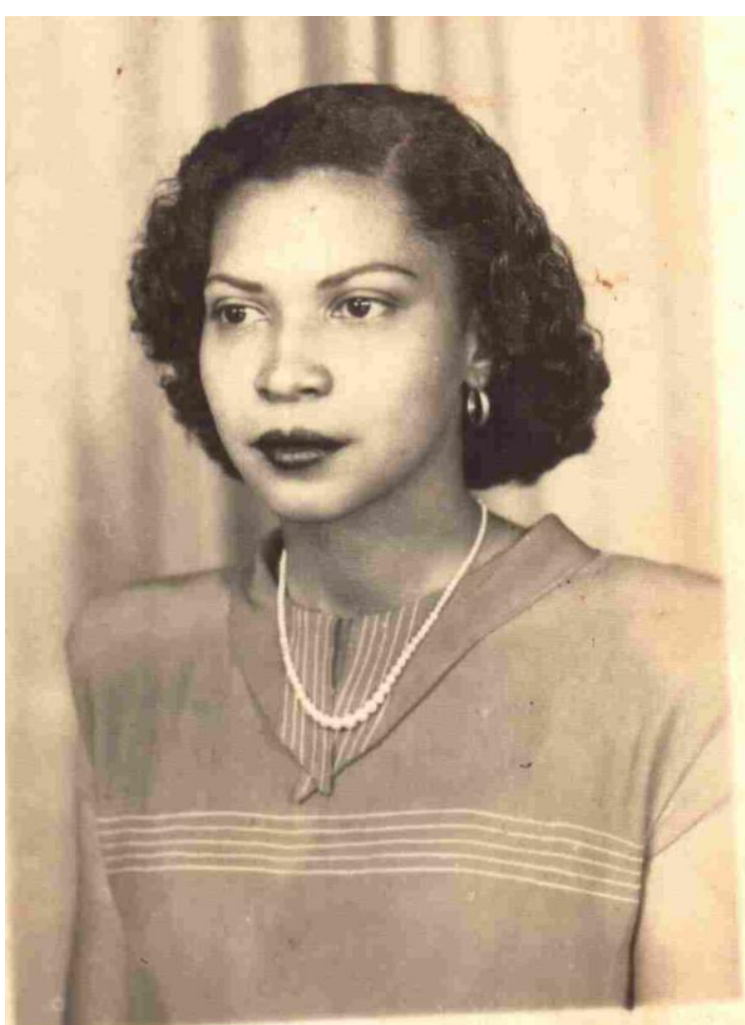

Fonte: Arquivo particular 
IMAGEM 45: Os meios de transporte da cidade

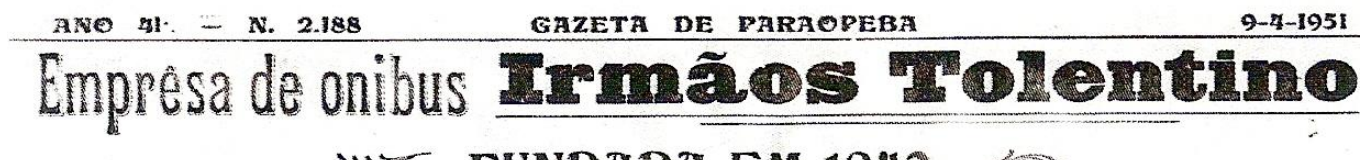
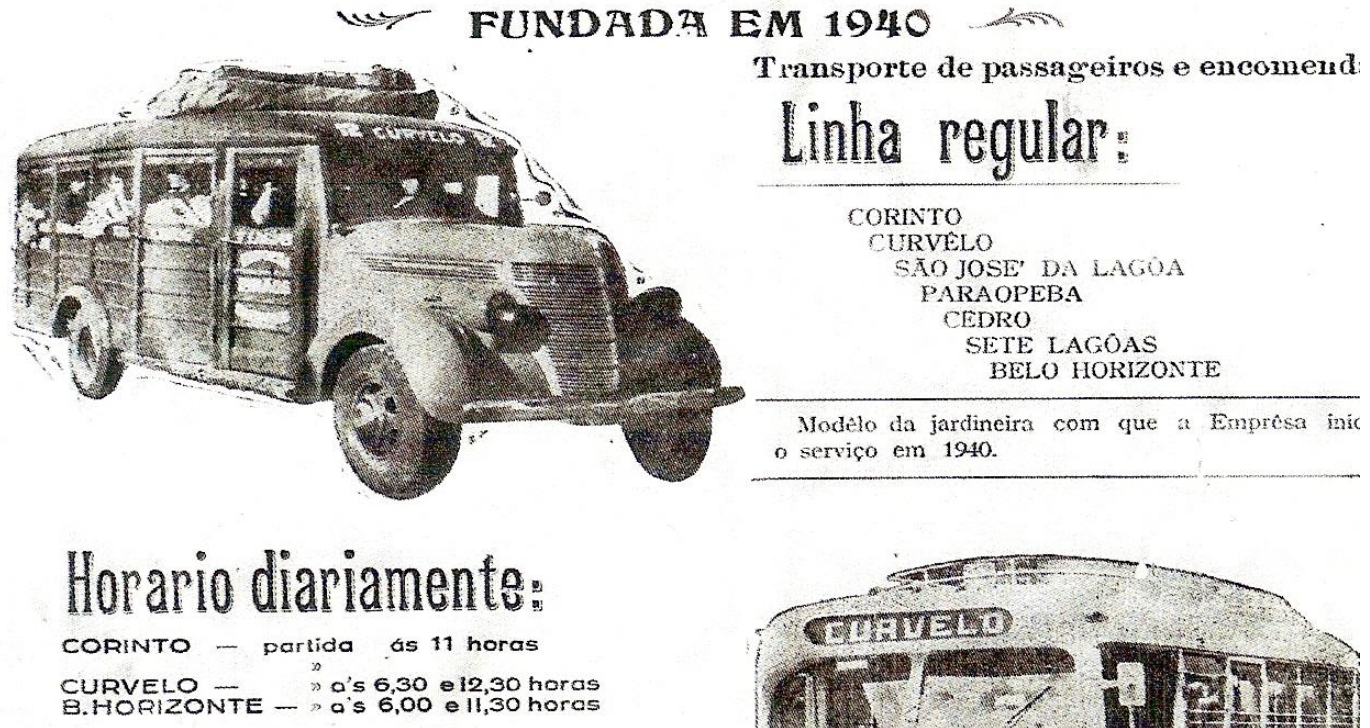

Fonte: Gazeta de Paraopeba

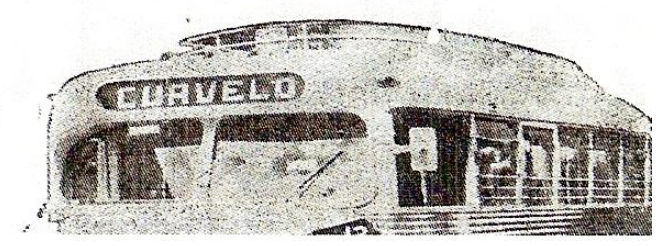

IMAGEM 46: A jardineira do motorista Setembrino

PROPREDADE DE:

IRMIAOS TOLENTINO

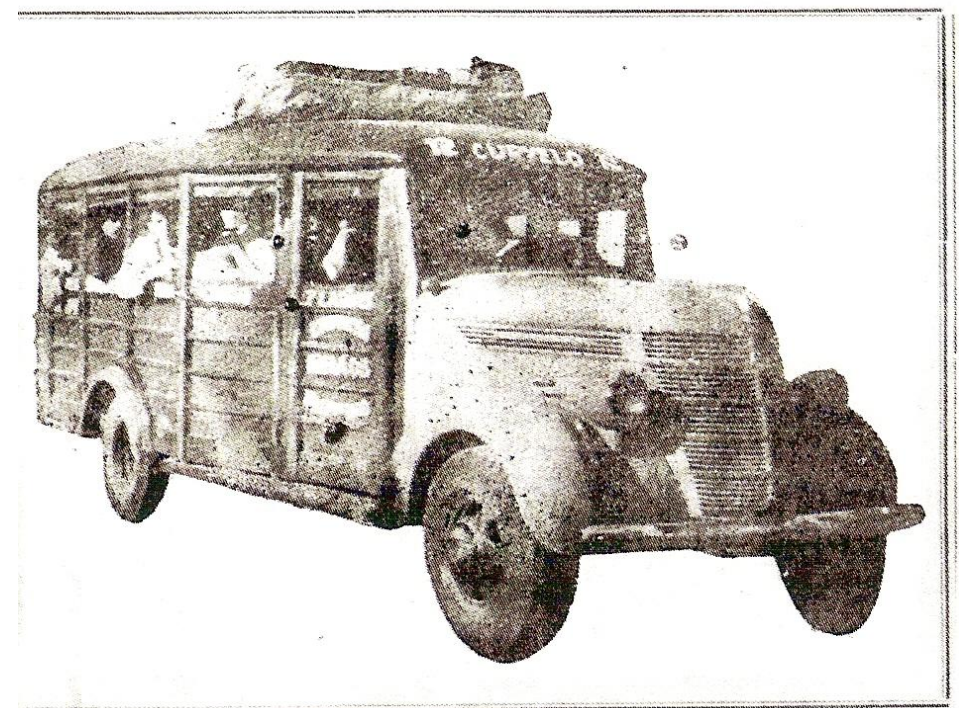

1940 JARDINEIRA USADA PELA EMPRESA. NO INICIO DO SERVICO DE TRANSPORTE COLETIVO ESTABELECIDO NAOUELA EPOCA, NA ZONA CENTRONORTE DO ESTADO.

Fonte: Gazeta de Paraopeba 
IMAGEM 47: A praça do prédio da Gazeta e ao lado, à direita, o prédio do cinema por volta de 1970

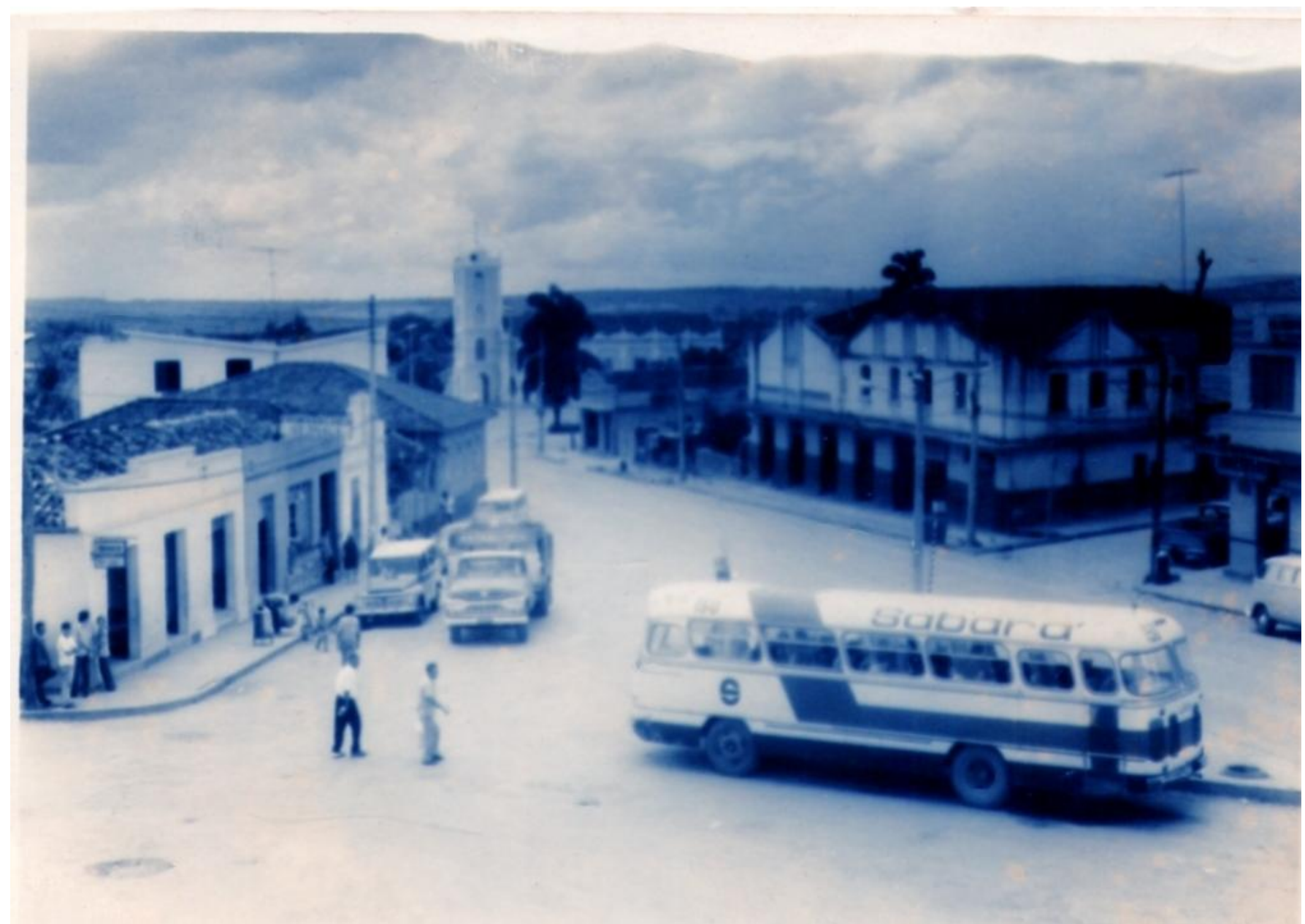

Fonte: Arquivo particular 


\section{Capítulo IV}

\section{A cidade lembrada}

Hoje, mudou de nome, mudaram. Todos os nomes eles vão alterando. É em senhas. São Romão todo não se chamou de primeiro Vila Risonha? O Cedro e o Bagre não perderam o ser? O TabuleiroGrande? Como é que podem remover uns nomes assim? O senhor concorda? Nome de lugar onde alguém já nasceu devia de estar sagrado. (ROSA, 1983, p. 58).

Cidade acaba com o sertão. Acaba? (ROSA, 1983, p. 183).

Sertão: é dentro da gente. (ROSA, 1983, p. 325). 
Este capítulo busca consolidar e interpretar questões já apontadas ao longo da pesquisa. O convívio com aspectos subjetivos e sociais permite que os moradores lancem luz à história individual e a da cidade. Por isso, neste capítulo, teremos a oportunidade de vislumbrar as possíveis correlações das lembranças.

Um dos objetivos deste capítulo é apontar que as memórias subjetivas e sociais são particulares e, ao mesmo tempo, partilhadas. Perceber os pontos obscuros das memórias, seus entraves e soluções, além da conexão estabelecida com os espaços urbanos. Assim, a cidade surge através de cada lembrança dos memorialistas. Poderemos contemplar a passagem do tempo das histórias de vida; conhecermos as gerações anteriores e conhecer hábitos e regras da cidade sem esquecermos, também, do lado pitoresco da comunidade. De forma que os vários itens desmembrados façam ressaltar as peculiaridades subjetivas e sociais reveladas pelas lembranças. Diante disso, este capítulo nos convida a conhecer a memória individual e social da cidade de Paraopeba.

\subsection{As matrizes da memória: tempo, memória, sociedade}

As histórias de vida não são lembranças estáveis. Percebemos que os memorialistas compartilham com os ouvintes suas trajetórias de vida. Relatam seus fracassos e limites, mas, também, através das lembranças e da compreensão, uma tentativa de resolução dos

problemas. É um convite ao diálogo, no qual os narradores nos permitem conhecer sua subjetividade e a comunidade na qual se criaram. Tanto o individual quanto o social transparecem nesse compartilhamento. Assim, os memorialistas relatam: "Nasci aqui em Paraopeba, mas na zona rural", "a única escola da cidade era o Afonso Pena", demarca o Sr. Antônio; a D. Geralda: "Nasci aqui mesmo em Paraopeba. [...] A cidade era bem diferente". Tais relatos, aos poucos, vão nos introduzindo em suas biografias e nos espaços da cidade.

As lembranças vão e vêm, oscilando entre o tempo presente e as evocações do passado. Procurando, cada morador, à sua maneira, unir as recordações aos quadros do espaço e do tempo. Podemos dizer que, por exemplo, a vida familiar de D. Maria Stella está intimamente relacionada à festa de Nossa Senhora do Rosário. Já D. Geralda, o universo de suas memórias está impregnado do ambiente familiar, o espaço e o cotidiano da casa onde nasceu e vive até 
hoje. O quadro espaço-temporal do Sr. José apresenta uma ambiência na palavra escrita relatada em jornais da cidade, onde ele explora as estórias peculiares ouvidas ao longo de sua vida. O Sr. Antônio, com uma memória fabulosa, deixa transparecer os vários espaços da cidade por onde transitou: a roça, a família, a fábrica. As lembranças, deste memorialista nos fazem acreditar que foram moldadas com as mãos.

Desde a antiguidade, a memória fora problematizada. Na tradição grega, há uma história lendária do poeta Simônides de Ceos que se torna esclarecedora acerca das propriedades da memória (apresentamos em detalhes esta história no capítulo "A memória”). Segundo ela, dois princípios regiam a faculdade de conservar o passado: as imagens evocadas e de que forma estas podem ser organizadas. Embora esta seja uma narrativa mítica, sua mensagem parece válida até nossos dias. Assim, as formas de cada narrador contar suas lembranças e encadear seu conteúdo delineiam também sua autobiografia.

\subsubsection{A importância social da memória}

Uma lembrança evocada no momento presente desempenha uma função social. Sendo as lembranças, muitas vezes, evocadas de forma bruta, elas precisam ser trabalhadas pelo espírito para ganhar uma textura apresentável. As imagens evocadas do passado são confrontadas com as do presente e, aos poucos, ganham contornos mais nítidos e se relacionam às experiências do presente. Daí a memória estar vinculada aos contextos sociais, haja vista que "uma memória coletiva se desenvolve a partir de laços de convivências familiares, escolares, profissionais" (BOSI, 2006, p. 408).

Há inúmeras facetas que compõem o mundo social. Às vezes, as lembranças despretensiosas; de outro, os elementos sociais e históricos, os modos e maneiras de amar, se convertem em elementos importantes para a compreensão do mundo. Por isso, as lembranças de um velho podem esclarecer e vivificar laços sociais, apontando sentidos e se humanizando, através das próprias memórias que se relacionam a atitudes e comportamentos do mundo presente.

A partir do trabalho da memória, os narradores conseguem resgatar conteúdos importantes da história individual e da cidade. As lembranças evocadas ganham contornos reveladores, na medida em que, ao evocar as imagens, os memorialistas conseguem atualizar e confrontar 
suas lembranças e o espaço da comunidade. Através dessa operação, conseguimos perceber e compreender o presente sem desprezar o legado do passado.

As lembranças dos narradores não têm a exatidão matemática, posto que precisam do apoio social e afetivo para sustentá-las. Isso se deve ao fato de que as lembranças não são apenas individuais, mas também das famílias, das comunidades em que nascemos e da cidade onde transitamos. Passando de geração para geração, as lembranças sofrem atualizações ao longo do tempo: "Somos de nossas recordações, apenas uma testemunha" (BOSI, 2006, p. 407). Até mesmo pelo fato de necessitarmos do outro para validá-la e aprofundá-la.

Dessa forma é que os narradores testemunham o nascimento da cidade de Paraopeba. Como informa o Sr. José, "consta que essa região era uma sesmaria de um coronel chamado Marques. Ele era católico e devoto de Nossa Senhora do Carmo. A lenda conta que ele veio caçar por essas terras e foi pego de surpresa por uma onça”. D. Maria Stella também lembra da lenda: "O surgimento desta cidade... Ah, não sei. Mas será que é a história da onça? Vejo assim: um lugar pequeno demais, um cerrado. Dizem que apareceu essa onça”.

As recordações surgem não como expressão da memória individual, mas como índices de significação edificados por outros. O passado surge de uma transmissão transcorrida ao longo dos anos. Testemunhas de um evento ocorrido em um tempo que os narradores não experimentaram, entretanto são capazes de comungar com os ouvintes e de lhes transmitir o que sabem. Tais lembranças entram na vida dos narradores e, de maneira própria, são reelaboradas ao longo do tempo. Para depois, serem transmitidas.

\subsection{O tempo das lembranças: o tempo vivido e a experiência}

As palavras que transmitem uma experiência podem ser compartilhadas, pois elas têm continuidade. Tais palavras atravessam o tempo e dialogam com a comunidade e gerações futuras. Walter Benjamin se indaga sobre a transmissão das experiências: "O que foi feito de tudo isso? Quem encontra ainda pessoas que saibam contar histórias como elas devem ser contadas? Moribundos dizem hoje palavras tão duráveis que possam ser transmitidas como um anel, de geração em geração?” (BENJAMIN, 1994, p. 114). 
Este contexto, apontado pelo filósofo, nos remete à proximidade dos efeitos da guerra. Ele se preocupava com o esfacelamento eminente das relações com a tradição e com a experiência. Sabia que os soldados ao regressarem da guerra não conseguiam transmitir às pessoas próximas aquilo que haviam vivenciado. A situação da guerra, constatava o filósofo, tornaram as pessoas mais pobres, em transmitir as experiências aos outros. Mas estes limites da transmissão da experiência, causados pelas guerras, não se restringiria somente a este fenômeno bárbaro. Posteriormente, Benjamin indica também a perda da experiência no campo da cultura de massa. A guerra, não obstante, causaria mudanças violentas no domínio da vida cotidiana, da arte, das relações privadas e sociais. Enfim, além do exemplo da guerra, a exacerbação da técnica demonstrarão a miséria com a qual o homem do século XX enfrentará. O outro fator que nos interessa mostrar agora será a perda da experiência no mundo contemporâneo. Visto que acreditamos que a perda da experiência estaria ligada também com as dificuldades das pessoas se relacionar com o tempo no mundo contemporâneo.

Mas qual é a origem da noção de experiência utilizado por Benjamin? Para Gagnebin, o conceito de experiência vem da palavra alemã Erfahrung, possui o radical fahr de fahren e que significa: percorrer, atravessar uma região durante uma viagem. Pensando o contexto aplicado ao texto este vocábulo nos remete a uma temporalidade comum a várias gerações. Aquilo que pode ser transmitido através da tradição; um conhecimento vivido de maneira coletiva sendo transmitido aos outros (GAGNEBAN, 2007, p. 57).

Esta referência, resgatada através da etimologia alemã, corrobora a intenção de Benjamin em refletir a transmissão de práticas comuns que são simbolicamente compartilhadas; e que no mundo atual se perdera. Os conhecimentos de pai para filho, de geração para geração, em menor ou maior proporção, foram deixando de ser relevante para a formação pessoal e social. Esta prática, pouco comum em nossa época mobilizava o aprimoramento de quem transmite o conhecimento e também para quem apreende o ensinamento. Pois, a experiência, não se faz passivamente. Ao contrário, a experiência, acarreta o trabalho na formação e prática dos indivíduos em uma dada tradição.

No ensaio, Experiência e pobreza, Benjamin mostra com clareza a decadência da experiência no mundo da cultura de massa. Demonstra o empobrecimento do valor simbólico e por conseqüência as dificuldades das pessoas em reger as suas vidas e o que herdaram. Isso se deve ao fato, do conhecimento ser dominado pela técnica; cujo eixo central é a perda do saber 
oriundo da tradição. Dessa forma, a experiência, não teria espaço para se reatualizar. Por isso, o homem moderno não consegue dar e receber conselhos. Os valores, por extensão, comunitário não são compartilhados nem transmitidos.

Os argumentos de Benjamin apontam para dois campos da perda da experiência: o domínio psíquico e espacial. O primeiro, a perda da experiência, se revela pelos valores individuais e privados substituem a crença coletiva. $\mathrm{O}$ anonimato do comportamento da burguesia, as relações sociais são pautadas na história de si mesmo em detrimento a história comum ou social. Cada vez mais as relações interpessoais perdem para o isolamento e o egoísmo generalizado. Poderíamos constatar, a partir de Benjamin, um grande cultivo do narcisismo. Este domínio psíquico, a experiência se converte em vivência (Erbelenis). Para Benjamin, vivência é a modalidade de conhecimento em que é experimentado na privacidade e solidão e não compartilhado pelos membros da comunidade. O segundo, o domínio espacial, é uma decorrência do primeiro. Trata-se de valorizar a arquitetura do interior. Nesta perspectiva, a casa, por exemplo, será refúgio do mundo inóspito e anônimo do exterior. Daí se privilegiar os móveis, tapetes, fotografias, pinturas que se voltam para a intimidade; se afastando, assim, do espaço público.

O que gostaríamos de apontar é que a perda da experiência terá graves conseqüências. Uma delas será a dificuldade das pessoas, no mundo contemporâneo, em se sentirem relacionadas ao meio em que vivem. $\mathrm{O}$ espaço social se enfraquece. Nisso, como conseqüência, reside um diagnóstico triste: a dimensão ética se torna secundária. Já que os atos dos indivíduos não conseguem fazer laços comunitários, ou o fazem de maneira parcial e egocêntrica. Com a perda da experiência, o lastro da tradição se rarefaz. Trazendo com esta perspectiva a falta de ação no meio social. Seja nas organizações comunitárias ou lutas que visem o bem comum. Se não pudermos aprender com àqueles que nos antecederam como poderemos prosseguir? Talvez, pudéssemos responder na esteira de Benjamin, que uma das maneiras será ouvir a voz coletiva que nos permita criar estratégia que nos permitissem remodelar o presente . E, assim, criar e abrir caminhos para o futuro. Esta proposta, ao longo de nossa pesquisa, se revestirá em um dos eixos onde gravita a experiência dos idosos. As vozes dos idosos demonstram uma outra lógica temporal e por conseqüência dialogam com o passado. Eles se expressam através do tempo vivido, colhido da experiência. 
Tentaremos prosseguir e aprofundar e questão do tempo e experiência. Em $O$ narrador, Benjamin também reflete sobre o descrédito da experiência na modernidade. Embora seja um ensaio que remeta, à primeira vista, à crítica literária; ao abordar a narrativa do escritor russo Nikolai Leskov. Efetivamente, este texto, trata também das drásticas mudanças na temporalidade do indivíduo e da sociedade. Aponta a técnica e sua preponderância nas relações com a natureza e com os homens. O filósofo acusa a técnica de responsável por desencadear uma nova forma de miséria e do empobrecimento das relações interpessoais. Seria a técnica, nesse percurso, a base dessa conjuntura; já que esse fenômeno corroboraria a afirmação de que "as ações da experiência estão em baixa" (BENJAMIN, 1994, p.198).

Qual é o empobrecimento das sociedades? Neste raciocínio, é o enfraquecimento da experiência como pertencente à memória da comunidade. Porque esta forma de saber não é da competência da técnica da ciência. Ao contrário, a estabilização e a perpetuação dos poderes favorecidos por e pelas formas de transmissão atuais apontam para a queda da a experiência. Percebemos claramente, por exemplo, nas sociedades autoritárias a queda da experiência, pois estas sociedades que têm como mote a segregação e opressão; eliminando a liberdade e a expressão da experiência. O sentidos da experiência se realiza na coletividade como diz Benjamin, ao se referir aos contos de Leskov. Por isso, a experiência, é capaz de receber dos antepassados os conhecimentos próprios de cada grupo e transmití-los aos outros. E assim incorporar narrativas que vêm de geração em geração e de regiões distantes. Para Walter Benjamin, a falta de da experiência como veículo de transmissão dos conhecimentos do passado colocaria as sociedades atuais em situações preocupantes. Na medida em que os individuais ficariam disponíveis para aceitar as coisas se refletí-las. E com isso, os indivíduos são incapazes de compreender e criticar, nas sociedades contemporâneas, e ficam deslumbrados com novidades que se apresentam nas culturas massificadas.

Deste modo, a experiência, gradativamente, foi perdendo espaço para o que Benjamin chamou de vivência. Se por um lado a experiência alicerça o indivíduo a uma temporalidade que o liga a comunidade; a vivência remete ao tempo insípido e repetitivo. Produzindo, assim, reações imediatistas, sensações e afetos superficiais. Não é à toa o grande número de pessoas que na atualidade são deprimidas e ansiosas, incapazes de fazer do próprio tempo algo intenso e pertencente à própria vida. Desta forma surge um tempo "espremido" pela rapidez e pobre de experiência. Uma temporalidade, marcada pela vivência, não modifica substancialmente os cidadãos e asfixia a subjetividade. Pois neste contexto o tempo perde o caráter humano e 
social e passa ser mera mecanização da vida. No sentido dado por Benjamin, a vivência não promove as relações dos indivíduos com a memória coletiva, e assim aponta para o isolamento. Ao contrário "a experiência que passa de pessoa a pessoa é a fonte que recorrem todos os narradores" (BENJAMIN, 1994, p.198). Isso as pessoas, nas sociedades marcadas pela vivência, não conhecem.

Os ensaios $O$ narrador e Experiência e pobreza são textos que revelam os impasses da modernidade. Em $O$ narrador, Benjamin revela o desaparecimento da figura do narrador tradicional. Demonstra a diferença entre a reminiscência e rememoração na condução da narrativa (demonstramos anteriormente a diferença - no capítulo "A memória"). O fato é que ambos desenvolvem a problemática da perda da experiência no mundo moderno. Acentuando, assim, com graves conseqüências para a contemporaneidade: fetichização da técnica, a vivência da temporalidade atual, a desagregação do referencial simbólico coletivo, a tradição deixa de ser manancial para gerações futuras.

Exploremos mais um pouco este ensaio revelador. Em $O$ narrador, Benjamin enuncia uma espécie de barbárie atual. Trata-se da impossibilidade da voz narrativa em intercambiar experiências. Uma flagrante desagregação é perceber de que as narrativas populares estão de alguma forma impedida de transmitir conhecimentos. Os conhecimentos de boca em boca, de pai para filho são emudecidos na atualidade. São as histórias que criam o espaço simbólico entre grupos e a cidade. Durante a nossa pesquisa, percebemos em graus variados como os idosos transmitem suas experiências. O Sr. José afirma: "Essa e outras histórias permanecem na inconsciente coletivo. Assim, para mim essas histórias que narro não têm intenção de ser uma peça literária. Servem para distrair. O Ser humano é sempre o mesmo! Gosta de ouvir e contar histórias”. De alguma forma, os idosos mantém a transmissão dos conhecimentos e experiência da cidade. Verdadeiros narradores, os quatro idosos, conseguiram revelar a tradição da cidade em nasceram. Entretanto, Benjamin afirma que os narradores estão em extinção:

Por mais familiar que seja seu nome, o narrador não está de fato presente entre nós, em sua atualidade viva. Ele é algo de distante, e que se distância ainda mais [...] Ou melhor, esses traços aparecem, como um rosto humano ou um corpo de animal aparecem num rochedo, para um observador localizado numa distancia apropriada e num ângulo favorável. Uma distância de que a arte de narrar está em 
vias de extinção. São cada vez mais raras as pessoas que sabem narrar devidamente. (BENJAMIN, 1994, p. 97).

Não obstante, acreditamos que nossa pesquisa, consegue apontar uma possibilidade da transmissão da experiência. Pelas lembranças dos idosos pesquisados a experiência foi paulatinamente transmitida. Mas, o ensaísta procura responder o significado da arte de narrar uma história. Ele é enfático ao afirmar que narrar é a "faculdade de intercambiar experiências" (BENAJMIN, 1994, p.198). Por isso, afirmamos ainda há poucos: os idosos pesquisados puderam intercambiar as experiências. A D. Maria Stella a profissão de fé, a religião como forma de relacionar e dar sentido ao mundo. A D. Geralda a memória da casa, a experiência de aprender o ofício de costureira; o Sr. Antônio a experiência e arte do ofício de carpinteiro, o conhecimento e a transformação da cidade; o Sr. José, através do magistério e da escrita contar a história dos habitantes, costumes, em conexão com a comunidade. Por isso percebemos que narrar é sinônimo da transmissão de experiências, como aponta Benjamin.

Na figura do narrador, desenvolvido na obra do escritor russo Nikolai Leskov, se torna claro para nós no sentido de exemplificarmos a nossa intenção em relacionar o narrador com os idosos pesquisados. Há na narrativa de Leskov o viajante, o religioso, o artesão, o camponês. Todos de maneira própria resguardam a experiência frente ao esquecimento. Estes narradores divulgam os conhecimentos e sabedoria adquiridos ao longo dos tempos. Os narradores são conhecedores das histórias e tradições do seu povo. Esta característica é muito esclarecedora, pois o mundo contemporâneo exige um tempo veloz e sem amparo das experiências. A temporalidade dos narradores é a do tempo transmitido oralmente, burilado ao longo das gerações e que revelam a tradição na qual se formou. Sendo assim, o conhecimento, transmitido pelo narrador, se revela útil à comunidade. Esclarece o ensaísta: "Essa utilidade pode consistir seja num ensinamento moral, seja numa sugestão prática, seja num provérbio ou numa de vida - de qualquer maneira, o narrador é um homem que sabe dar conselhos". (BENJAMIN, 1994, p. 200).

O tempo carregado da experiência do vivido é capaz, através dos relatos dos idosos, imprimir a marca pessoal e social. Mas, de que forma a vivência se apresenta em nosso cotidiano? Benjamin se refere ao conjunto de atividades laborativas. Trata-se das relações sociais e econômicas das sociedades contemporâneas. Talvez por isso, as sociedades atuais, o tempo, assumiu uma categoria particular e tantas vezes se expressando de forma danosa às pessoas e 
a comunidade. Assim, o tempo se apresenta como um valor enorme: "Não posso perder tempo", “o tempo é dinheiro", ou "Eu estou sem tempo para...”. Expressões populares que remetem a uma suposta valorização do tempo. Entretanto, quando examinamos detidamente, esse tempo reverenciado pelas sociedades de massa, percebemos o contrário. Ou seja, a desvalorização do tempo como expressão da vida cotidiana, e sem experiência.

Por isso, o tempo assumiu, nas sociedades contemporâneas, valores capitalistas. Ele se expressa como ganho e acúmulo. É desta forma que o tempo perdeu a dimensão de criação, de experiência. Acreditamos que, ao contrário, os idosos desta pesquisa apontam para outra lógica de se conceber e viver o tempo. Para os idosos, como demonstramos através das narrativas, o tempo não é percebido pela lógica do capital, do acúmulo, da automatização. Tão diferente do tempo concebido nas sociedades atuais. Embora eles estejam e façam parte destas sociedades, os idosos conseguem "viver o tempo" de maneira a aprender e ensinar as gerações futuras. Não expressando o tempo como dinheiro, os idosos valorizam o aprendizado, a tradição local. O fato é que os idosos funcionariam como "pequenas ilhas" de resistências frente à massificação atual.

Em Experiência e pobreza, Benjamin interroga: "Pois qual o valor de todo o nosso patrimônio cultural, se a experiência não mais o vincula a nós?” (BENAJMIN, 1994, p. 113). O que percebemos é que a cultura, em sentido amplo, se desvanece diante das sociedades massificadas. Onde tudo se torna rápido e superficial e sem solo onde possa germinar algo que dure mais do que poucas horas. Desta forma, de que maneira se poderá transmitir alguma coisa para as gerações futuras? Se não há algo que perdure, que possa ser burilado pelo tempo e transmitido para às gerações futuras seria impossível a experiência. O fascínio pelo "novo" no mundo da indústria cultural; fazem com que as pessoas vivam sob a criação de heróis que espiam as mazelas sociais. Tudo isso são ingredientes para o declínio dos narradores. Já que matéria prima do narrador é o tempo vivido. O que percebemos, junto com Benjamin, é que nas sociedades massificadas "surge assim uma nova barbárie" (BENJAMIN, 1994, p. 115). Barbárie essa que atropela a ética e a convivência entre os cidadãos.

A experiência, na concepção benjaminiana inclui o sentido do vivido. Pois a experiência, nada mais é do que o conjunto de ações e palavras que formam um saber que é passível de transmissão. Diferentemente da vivência que se caracteriza pela imediatez, a experiência, potencializa o conhecimento adquirido pelo narrador junto à comunidade. Benjamin afirma 
que o conhecimento adquirido através da experiência se enriquece na medida em que o saber gerado dessa experiência é compartilhado com os outros. Ao contrário, do conhecimento advindo das culturas de massa que promove o individualismo e o saber solitário. Ou mesmo um saber que é veiculado pela mídia, com o pretexto de ser público e social, mas que no fundo uniformiza e superficializa tudo o que toca. Isso se dá, simplesmente, porque não é um conhecimento experienciado, mas ditado por grupo de poder monetário que deseja apenas vender e ter lucro.

A reflexão de Benjamin, em $O$ narrador, sobre o tempo foi percebida por ele nas sociedades pré-modernas. Afirma, assim, que nestas sociedades, o tempo era experienciado coletivamente. O tempo não era vivido individualmente como as sociedades contemporâneas insistem em afirmar; desejando nos mostrar, nesta perspectiva, que não haveria outra modalidade temporal. Nas sociedades pré-modernas, como observa Benjamin, o fluxo temporal levava consigo, os conhecimentos adquiridos ao longo das épocas. Era importante, para os membros do grupo ser guardião das experiências da comunidade. Transmití-las para os mais jovens. O tempo se configurava a partir do aprendizado, das ações vividas pela comunidade. Um tempo vivido junto aos outros e com os outros.

Podemos pensar, com Benjamin, em formas de temporalidades diferentes da expressão do tempo das sociedades capitalistas. As atividades, por exemplo, da casa, o tempo que rege a agricultura, o artesanato. Estas tarefas são referências para demonstrarmos outra expressão temporal e a interação com as próprias práticas. Tais atividades são apreendidas através das experiências. Um fazer que, ao contrário do automatismo, liberam ou mantém o psiquismo livre para o devaneio e para o lúdico. Mesmo as lembranças podem vir à consciência mais facilmente. Por isso, as atividades como a artesanal, por exemplo, permitem que cada um imprima em seu ofício sua experiência de vida. Desta forma, o narrador alheio às repetições das sociedades massificadas pode transmitir o conhecimento às gerações futuras.

A transmissão da experiência compreende uma temporalidade que vai na contramão das sociedades atuais. O devaneio, o onírico, o lúdico são ingredientes importantes para compreender o tempo do narrador. Todas estas atividades alargam e incrementam o estado associativo, porque libera o indivíduo para experiência de aprender, ensinar, ouvir e transmitir. Os idosos nos mostram isso quando as atividades manuais os fizeram transmissores de conhecimento da profissão, de si mesmo e da cidade. Além de serem 
narradores, nos ensinaram as relações com o trabalho: o marceneiro, a costureira, a escritor. Todos eles são detentores do saber do próprio trabalho e da cidade.

A tradição, para Benjamin, deve ser percebida como um lugar ordenado na qual as relações humanas são ordenadas no presente. Demonstrando, assim, como o narrador é fruto da tradição. Isso se deve ao fato de que cada narrador imprime o caráter da experiência na vida ao ressignificar a sociedade. Ao contrário do mundo globalizado baseado na vivência, o narrador é aquele que não perde o fio condutor da tradição. $\mathrm{O}$ mundo capitalista, segundo o filósofo, deixou o mundo sem base, desconectado das pessoas cuja temporalidade desvanece a cada minuto.

O sucesso do tempo linear trouxe algumas conseqüências. Dentre elas, o tempo presente tornou-se saturado com o excesso de atividades sem vínculo com a sociedade. Provendo relações interpessoais efêmeras e sem afeto. O tempo racionalizado do mundo contemporâneo necessita para sobreviver economizar o tempo: o ritmo frenético e o utilitarismo com os quais os indivíduos têm que suportar. $\mathrm{O}$ tempo individualizado ao máximo provoca um fenômeno recorrente nas sociedades contemporâneas: a depressão. Embora não tematizaremos as relações do tempo com as doenças mentais, fica clara a conseqüência em se viver em um mundo onde o tempo não é vivido mas capitalizado como moeda de troca. Por isso, como expressa o sociólogo o tempo sem vínculo com a tradição e, por conseguinte, com a experiência se tornou um "tempo presente que se comprimiu" (GUREVITCH, 1979, p. 279). [tradução livre]. ${ }^{11}$

As narrativas orais, foco da nossa pesquisa, se transformam em matéria substancial da tradição. Pois as narrativas fazem transparecer a experiência em sentido pleno: conhecimento individual que se liga às representações sociais. Daí a comunicação entre presente e o passado ser o veículo ativo dos conhecimentos referenciados pelas narrativas. Especialmente os narradores orais presentes em grande parte das culturas. $\mathrm{O}$ que nos faz compreender a constituição das experiências: a construção de uma temporalidade viva, enraizada na consciência histórica e social. Assim, o presente, o passado e futuro e intercambiam nas experiências dos narradores.

\footnotetext{
${ }^{11}$ Trata-se da frase em espanhol: “(...) el tiempo presente se comprimió (...).
} 
Para a nossa reflexão será importante falar um pouco sobre o narrador escolhido por Benjamin. Quem é Nikolai Leskov? O próprio Benjamin esclarece: "Leskov é o escritor mais profundamente enraizado no povo e o mais inteiramente livre de influências estrangeiras" (BENJAMIN, 1994, p. 214). Talvez isso seja a atração que este escritor russo suscitou o interesse do filósofo. As narrativas de Leskov estão próximas do saber popular. Elas fazem parte da tradição local e preservam os aspectos da imaginação e dos tipos populares. Tais personagens têm o encanto dos contos de fadas e partilham os costumes em formas de experiências. São tipos que revelam aspectos próprios da língua, a coloquialidade, as expressões da região onde nasceu a narrativa (demos exemplos de Leskov sobre sua narrativa, ver capítulo “A memória”). Desta forma, resguardando e transmitindo formas particulares de compreender e transmitir conhecimentos. O próprio Benjamin sempre se interessou pelas narrativas ficcionais como tradutor de Proust e também como narrador ficcional em jornais da época, onde aborda essas características (ver na bibliografia: Rastelli Raconte...).

A literatura de Leskov, aponta Benjamin, se pautava pela sabedoria. Ela se ancorava nos aspectos artesanais e contemplativos da vida espiritual. Benjamin explicita este aspecto na figura do justo. Tal personagem se apresenta "geral como um homem simples e ativo, que se transformam santo com a maior naturalidade" (BENJAMIN, 1994, p. 200). Ao misturar aspectos sagrados e profanos, a obra de Leskov adquire liberdade criadora. Afinal, esta perspectiva narrativa está presente em vários contos populares, presentes em muitas sociedades. Não é de se espantar a escolha de Benjamin em exemplificar com as narrativas de Leskov. Pois, as vozes narrativas de Leskov dizem respeito aos anseios e sentimentos da comunidade. Além de fornecer conselhos e ensinar aos ouvintes dos contos experiências profundas da alma humana. Podemos perceber esta característica nas narrativas das "Histórias" do Sr. José ao revelar as crenças e façanhas das pessoas da cidade. Narrativas de aspectos fabulosos e de conselhos. E também o Sr. Antônio, em vários momentos da narrativa, descrevendo as impressões e experiências da própria vida.

A tradição expressa na obra de Leskov, afirma Benjamin, é um grande depositário de significado e ensinamentos. O passado é evocado dar testemunho de segredos e indagações sobre sentimentos e impasses da condição humana. Assim, no momento presente da narrativa, o passado é resgatado e o futuro vislumbrado. O gesto potencializa um campo de sociabilidade na qual os sujeitos se reconhecem enquanto indivíduos sociais. E ao mesmo 
tempo são atravessados pelas confluências de conhecimentos e atitudes que foram forjadas antes e que seguirão adiante. Isso se deve ao fato do narrador:

(...) recorrer ao acervo de toda uma vida (uma vida que não inclui apenas a própria experiência, mas em grande parte a experiência alheia. O narrador assimila a sua substância mais íntima aquilo que sabe por ouvir dizer). O seu dom é poder contar sua vida; sua dignidade é poder contá-la inteira. O narrador é o homem que poderia deixar a luz tênue de sua narração consumir completamente a mecha de sua vida. (BENJAMIN, 1994, p. 221).

As histórias, casos e eventos narrados não eram simplesmente ouvidos. Certamente, através do narrador, estas histórias eram seguidas como ensinamento precioso. Na época em que o narrador era figura importante na comunidade, os conselhos constituíam lição de vida e moldava as condutas e afinavam os pensamentos. Diferentemente de hoje em dia em que dar conselhos significa, muitas vezes, invasão de privacidade. Por isso, o tempo da narração não distingue os mitos de um lado e do outro os ensinamentos da coletividade; nem a expressão oral dos conceitos, como se percebe atualmente. Para o narrador, quando se fala, a experiência se presentifica ao narrar se transmitem verdade e ação.

A narração, desta forma potencializa as lembranças. Tal afirmativa corrobora nossa pesquisa. Em sua desordem aparente, as lembranças vão ganhando contornos mais nítidos e criam "conceitos". Neste caminho, o narrador, seja padre, orador, poeta, ou os idosos todos modulam, a seu modo, a expressão oral. Sem se ancorar em tempo abstrato, o narrador, e em extensão os idosos dessa pesquisa, lembram do tempo passado dando a esse tempo consistência. Nesse sentido, narrar é expressão de grande liberdade, sem a barreira econômica ou escolar. Talvez por isso, os narradores ao se apropriar do passado, criem uma aura mágica e encantatória. O tempo, neste contexto, se estica e desdobra; buscando sentido além dos fatos concretos. Os narradores abrem-se para o mundo e o transforma através das palavras e ações.O Sr. José através das lembranças da "titia" e das suas próprias lembranças relatam, por exemplo, a historia do mestre Furriel que ocorreu no "tempo da fumaça" como se referiu ao tempo deste acontecimento. Segundo o narrador lá pelos idos anos do séuclo XIX. Afirma ainda o Sr. José que este evento e as suas narrativas são "histórias que nascem do espírito daqueles tempos". Assim remodelando as lembranças da "titia" aliadas à sua imaginação, o Sr. José. imprime em suas narrativas orais e escritas o poder da ação em conecção com a comunidade. 
Através de nossa reflexão, deveremos fazer algumas considerações. O narrador oral expressa um tempo vivido levando em conta alguns aspectos. Primeiro, através da narrativa oral, a experiência é transmitida. Além dos conhecimentos pessoais, os conhecimentos da comunidade são veiculados. A presença dos afetos são marcadores efetivos neste tipo de narrativa; pois os afetos são capazes de reelaborar os conteúdos anímicos dos narradores. Segundo o narrador, ao expressar as próprias lembranças, promove conhecimentos produzidos no passado. Dessa forma, o passado se apresenta flexível, desdobrável; e com isso produzindo elementos de preservação e, ao mesmo tempo, novas interpretações.

Por fim, acreditamos que a narrativa oral é uma atitude frente à massificação das sociedades contemporâneas. De que forma isso se apresenta? Pela compreensão de que há outra forma de viver e desfrutar do tempo na atualidade. Os idosos pesquisados, por exemplo, dão testemunho desta perspectiva. Ao contrário da mecanização do tempo pelo excesso da técnica, os narradores, são capazes de transmitir a experiência para gerações futuras. Eles podem mobilizar conhecimentos subjetivos e sociais; potencializam e dão significados aos conhecimentos do grupo, da comunidade. Este tipo de saber escapa a padronização das sociedades de massas. Em conseqüência assistimos ao crescimento das sociedades "sem alma"; que têm dificuldade de se colocarem frente ao outro sem explorá-los. Dizendo com Benjamin, a experiência veiculada pelos narradores da cidade de Paraopeba promove o conhecimento como patrimônio da humanidade.

O sociólogo Gilberto Freyre constatou a influência da península ibérica na consciência do tempo na sociedade brasileira. Embora partindo de outra proposta teórica, Freyre se aproxima dos pressupostos de Walter Benjamin. O tempo ibérico, afirma Freyre, se baseia mais na existência do que nas atividades empresariais. Ao contrário, da sociedade anglo-saxã que cultuava a rapidez, a velocidade, o relógio. Não é á toa que a Revolução Industrial tenha se iniciado na Inglaterra. A sociedade inglesa imprimia, afirma Freyre, na comunidade a lógica do "tempo é dinheiro". Diferente dos portugueses, os ingleses tinham na atividade econômica como base das relações individuais e sociais (FREYRE, 2003).

O gosto pela fruição do tempo sentido, vivido e experienciado pelos portugueses e espanhóis fazia com que eles interagissem com a temporalidade de forma singular. Os ibéricos percebiam e se relacionavam com o tempo através do passado e da tradição. Daí a saudade, ausência que transmite tristeza, mas também esperança, ser a tônica das relações afetiva e 
comunitária. Essa ligação com o tempo, o desprezo pela velocidade e pontualidade acarretavam a concepção dos tempos: presente, passado e futuro como pertencendo a uma única temporalidade. Assim, o tempo das pessoas é sorvido lentamente, aos poucos, num jogo de ausência e presença. Esta perspectiva temporal, para Freyre, estaria na capacidade dos portugueses e espanhóis em estabelecerem contatos com outros povos: ameríndios, africanos por exemplos. Tal contato favoreceria a intimidade que os europeus do norte não tiveram. Dessa forma, as culturas como a brasileira, no âmbito sociológico, seria herdeira desta concepção do tempo: mais plástico menos automatizado. Ao invés de relógios, cronômetros, o tempo é simbolizado pelos sinos da igreja, os rituais das festas populares, as estações do ano para a colheita da lavoura ou a amizade que se constrói na convivência.

Desta forma, a percepção do tempo vivido pelos idosos aqui tratados refletiria a cadência apontada por Gilberto Freyre; e também dá testemunho da experiência refletida por Benjamin. O tempo vivido é uma forma da transmissão da experiência como discutimos anteriormente. A pequena cidade no interior de Minas, retratada pelos memorialistas, expressa esta percepção do tempo. Isso se dá pelos ritmos das festas locais, a igreja, o trabalho a construção das relações pessoais. Um tempo sem o cronômetro, no dizer do sociólogo, sorvido lentamente. Por outro lado, o tempo é integrante da comunidade, da vida social. Exemplos não faltam: D. Geralda, ao ouvir o sino da igreja; D. Maria Stella e as celebrações anuais da festa do Rosário; o tempo da escrita paciente do Sr. José para conseguir fazer com que "a titia" lhe contasse as histórias da cidade. Todos revelam o tempo vinculado à cidade, à tradição local.

É por isso que a psicóloga Ecléa Bosi ao se referir ao sujeito da narrativa não lembra de uma imagem precisa. Também não precisa, ao narrar, o indivíduo entra em contato com vários tempos. Assim "ele evoca, dá voz, faz falar, diz de novo e conteúdo de suas vivências; enquanto evoca, ele está vivendo atualmente e com uma intensidade nova sua experiência". (BOSI, 2003, p. 44). Narrar, então, toma a dimensão resgatadora das experiências com o tempo individual e social. O Sr. Antônio, ao narrar a história da D. Porfíria revela o poder encantatório da narrativa. Revela e reatualiza uma crença muito difundida no interior de Minas e do folclore em geral que é a figura do demônio. Fica entusiamado com o demônio possuindo o corpo da D. Porfíria: "você veja! O que tem nesse mundo... Nunca me esqueci desse acontecimento". Também ao evocar as lembranças da peça teatral na qual interpretou o príncipe. Ele reatualiza e dá voz àquela vivência que o marcou na infância. Já D. Maria Stella 
a vivência da fé e o trabalho com a comunidade a revitaliza e a encoraja para enfrentar as mazelas da vida. Também o tempo vivido de D. Geralda circuncrito basicamente das lembranças do cotidiano de sua casa, dos vizinhos e a rotina de costurar. Sendo assim, o tempo se passa no ritmo lento que se traduz das suas lembranças: os eventos vão e voltam como a respiração, às vezes cansada, que marcam as lembranças da casa e da cidade. Desta forma, a narrativa atualiza novamente as experiências dos memorialistas; proporcionando através das lembranças a possibilidade de viver novamente os eventos. Ao longo das lembranças podemos perceber isso. $\mathrm{E}$ ao longo dos itens abordados aqui poderemos perceber a capacidade de cada narrador "viver novamente" os fatos narrados, os afetos, os eventos da cidade.

Analisemos um pouco mais os narradores desta pesquisa. Percebemos que o tempo relatado pelos memorialistas não é linear. As dimensões do tempo não são estanques nem fixas. As inúmeras lembranças vão se entrelaçando umas nas outras, formando uma massa de imagens e sons que ora são difusas, ora translúcidas. O tempo vivido, carregado de afeto, se apresenta como um momento de eternidade. Como se fosse um "agora", "instante perene" que não segue a cronologia da história oficial. Não há continuidades únicas e lineares como a dos ponteiros dos relógios. A memória dos narradores está cheia de suas experiências pessoais e sociais. Tempo e espaço se tornam inseparáveis, uma vez que criam realidades à parte dos eventos convencionais, pois as lembranças, como um rio, só podem ser vislumbradas diante das margens que as norteiam. Enfim, o que constatamos é que o tempo é a tessitura de nossas vidas.

O que nos chama a atenção nessa divisão do tempo é sua cadência. Na infância, há encanto, o afeto pela qual os sentimentos fazem expandir as situações ao redor: o aprendizado na escola, os amigos, as brincadeiras. As imagens dos pais e das famílias, a proteção do ambiente da casa, a descoberta do mundo extramuros. Aí estão as várias experiências afetivas: é um tempo enorme! Depois a juventude, passagem difícil, pois é o tempo das responsabilidades sociais, do descobrimento de regras comunitárias. O Sr. Antônio atesta: "Apesar de tudo, o trabalho na fábrica não era sacrifício".

Desta forma, a narrativa seria insubstituível para configurar a multiplicidade das experiências humanas. Isto porque, ao contar e relembrar aquilo que não nos é imediato, conseguimos experimentar o tempo. O tempo das vivências cujas dimensões tantas vezes ignoramos. Além 
disso, o tempo vivido através da narrativa nos ajuda a compor um campo social que os documentos oficiais negligenciam. Assim, o que está em jogo não é a noção de verdade única e absoluta; antes, é um exercício constante de compreender a grandeza e a fragilidade da vida humana.

O tempo biográfico dos memorialistas passa e escorrega por entre os dedos. As marcas no rosto, os sulcos que vão se formando diante do relógio da vida. Assim, o tempo individual, ao enfrentar a universalidade dos dias, ajuda a compor a trajetória de cada sujeito humano. Amores tenros e saudosos se refazem diante das horas e do entardecer da experiência vivida. O tempo passou! Essa é uma certeza. Mas também deixou marcas. Por isso, na singularidade da vida dos idosos, advém um tempo marcado no corpo. O tempo do calendário se conjuga com o tempo interior que resiste à implacável passagem das coisas. D. Geralda relata: "Mas depois foi acabando tudo!"

\subsubsection{O tempo social}

Cada grupo possui uma forma de expressar o tempo. O tempo de cada pessoa se aproxima do tempo social. Por isso cada grupo vive o próprio tempo. A família, a escola, por exemplo, demarcam temporalidades próprias; cada grupo possuindo uma extensão temporal e um curso singular.

Assim cada geração possuirá sua modalidade de expressar o tempo, alargando ou afunilando suas marcas. Os comércios, a igreja ou os amigos, por exemplo, darão importância a alguns fatos e a outros não. É dessa forma que as oposições ou resgates de comportamentos se dão na comunidade. As práticas de trabalho poderão se mostrar penosas para uma geração, ou um deleite para outras. Os ritos religiosos podem se revelar satisfatórios para uns e para outros não.

Mas quando ultrapassa a infância, os narradores começam a caminhar mais à vontade. Talvez seja a expressão da independência. $\mathrm{O}$ que nos parece mais difícil para os narradores é o tempo da idade madura. Isso se deve às repetições, à redução dos estímulos individuais e sociais. $\mathrm{O}$ trabalho da memória na velhice demanda o esforço de apontar sentido para as lembranças que 
surgem. Exigindo, dos idosos, uma rapidez que às vezes não conseguem alcançar. Neste momento não há o encantamento da infância. Há limites e perdas.

Podemos pensar que as recordações se aliam a fatos externos a elas. O tempo biográfico confere diálogo com a família, com as ruas e praças da cidade, com a vizinhança e seus costumes. Também com as histórias locais, festas e com as escolas da comunidade. O tempo se localiza nestes espaços sociais. Há o tempo doméstico de D. Geralda e a noção de diferença de costumes: "eu cozinhava toucinho. Mas agora faz mal, não é? E torresmo também! Será porque naquela época não fazia mal? Ah! Mas...”. A casa de D. Maria Stella impregnada de lembranças das brincadeiras de rua e das árvores frutíferas “o quintal aqui era maravilhoso! Aqui na frente tinha uma horta e minha mãe sempre pedia: "vai lá, Maria Stella, pega alface na horta"! Havia uma variedade de hortaliças (...). Olha só, rapaz, tinha no quintal: laranjeiras, mangueiras, jabuticabeiras, como eu me deliciava com jabuticabas, tão negras que às vezes ficavam azuis!”

Nas lembranças do Sr. José as brincadeiras com os vizinhos, a invenção dos brinquedos e a sensação de liberdade: "até sete ou oito anos a gente só brincava... Somente brincava, entendeu? Me lembro das brincadeiras: pegadô, os adultos contavam histórias para a gente, formando a nossa base mental". Percebemos, ainda, nas lembranças do Sr. Antônio o contato com as regras e obrigações desde a primeira infância. $\mathrm{O}$ aprendizado do ofício de lavrador, o amplo contato com a natureza e posteriormente o trabalho como carpinteiro. Era um tempo de trabalho. "A lida diária era na roça. Mas nós transitávamos o tempo todo. Era um ir e vir para lá e para cá constantemente, o tempo todo!”

Já para D. Geralda o tempo da infância revela a escolha do ofício: "fazia de tudo em casa. Depois aprendi a costurar. Eu, desde menina tinha o dom para costurar. Até sem aprender eu já fazia algumas roupas".

Há lembranças cujos elementos representam acontecimentos da biografia pessoal. As memórias ganham contornos próprios e, por conseguinte, o tempo também. São evocações que não estão no calendário, mas têm vida própria, pois são frutos da experiência. Em meio às lembranças do Sr. José há a recordação de um apelido que o marcou por toda vida. E lembrança da professora: "quando ela ficou grávida, pediu minha irmã Lourdes para substituíla. Na minha casa tinha o tratamento carinhoso de me chamar de "coró", "corozinho". Daí ela 
falou isso na escola, aí pegou. Era o segundo ano do grupo. Pegou o apelido e acabou! Até hoje as pessoas me chamam por esse apelido".

D. Maria Stella recorda a devoção de sua mãe por Nossa Senhora do Rosário, que, por sua vez, conferiu sentido para sua vida e para sua fé. "Há uma coisa da minha mãe que me marcou para o resto da vida. Trata-se da sua fé e de sua grande devoção. Ela tinha três devoções: Sagrado Coração de Jesus; Santíssimo Sacramento e Nossa Senhora do Rosário. Lembro sempre da imagem de Nossa Senhora do Rosário ao lado da sua cama. Decidi ficar com a devoção de Nossa Senhora do Rosário, que me marcou ao longo da vida. Até hoje essa devoção é muito forte na minha vida".

O primeiro trabalho, o encontro com o(a) primeiro(a) professor(a), o casamento, a morte são eventos que demarcam cada história de vida. Possui cores próprias e insubstituíveis, marcando e tempo e o dividindo em partes. Daí surgirem às etapas da vida, as transformações e os redirecionamentos de cada percurso. Por isso o tempo tem sentido tão particular.

Por outro lado, a dimensão social nos permite outras formas de estar no mundo. Já não é movida pelas veleidades internas, posto que obedece outro tipo de lógica. A inclusão na escola, o primeiro trabalho e suas regras, o casamento, o calendário das festas da cidade, as atividades políticas nos impele às convenções sociais. A demarcação dos eventos sociais, se por um lado oprime as boas imagens de cada um, como por exemplo, a liberdade da infância. Por outro nos confere o sentido de pertencimento à comunidade, à cidade, ao mundo.

Se pudéssemos conceber uma imagem geométrica para o tempo e o espaço, talvez suas divisões se expressassem assim: o tempo seria uma linha vertical e o espaço uma linha horizontal. O espaço seria identificado pelo deslocamento dos objetos visíveis ao olho. Já o tempo, devido sua abstração, representar-se-ia de outra forma; sem o aspecto "palpável" do espaço. Entretanto, o tempo dos idosos está cheio de vida, pautado por experiências afetivas pelo trabalho, sendo impalpável à distância entre tempo e espaço. Ao narrar, os idosos se convertem em testemunha das gerações nas quais viveram. Através das lembranças, os idosos estabelecem relações entre o tempo individual e o social. 


\subsection{A memória individual: a dimensão do afeto}

Na memória dos idosos há momentos de clareza e momentos difusos. Não deveria ser o contrário porque ela se faz e se refaz constantemente, mesmo na velhice. Diferentemente dos contos populares, onde o herói obedece a um desígnio imperativo rumo ao fim inexorável, a vida dos narradores não se encontra definida. Os contornos, as nuances, lacunas estão presentes. Isso se deve, acreditamos, à dimensão afetiva das lembranças. A cada evocação nos vemos diante de transformações que caracterizam o trabalho da memória. As lembranças são reelaboradas pelo afeto que as sustentam. Com o recuso da imaginação, os idosos, repetem, na tentativa de tornar a narrativa mais verdadeira; a propósito da escritora Issak Dinensen, Hannah Arendt afirma que se narra bem "somente se você consegue imaginar o que aconteceu de alguma maneira, repeti-lo na imaginação, é que você verá as histórias, e somente se você tem paciência de contá-las e recontá-las ("Je me les raconte et reraconte") é que poderá contá-las bem" (ARENDT, 2008, p. 107).

Assim, ao compor o mosaico das lembranças, os memorialistas experimentam novamente os dias vividos. Esse material heterogêneo é composto de lembranças remotas e recentes. Mas daqui e dali, a voz dos memorialistas lança luz àquilo que parece confuso e distante. A partir disso, a vida ganha elementos novos e surpreendentes. Daí a compreensão dos idosos, aliada à percepção, tornar cada lembrança uma descoberta.

As lembranças individuais são uma espécie de estudo de si mesmo. Através delas, cada narrador desenvolve um fecundo método de apreender os valores e eventos que os cercam. As informações colhidas pelos idosos ao longo da vida ensinam aos ouvintes a riqueza da voz humana, pois tais sons são carregados de gestos, afetos e sentidos variados. A vida se revela e as épocas são passadas a limpo.

Estas lembranças examinam, em vários aspectos, a condição humana. A existência de diferentes ângulos de percepção permite ao memorialista construir a própria história. A cronologia pessoal dos narradores nos ensina (ouvintes e leitores) ricas experiências de vida. Porque cada vida possui sua riqueza! Esta riqueza se revela pela experiência que foi burilada ao longo dos tempos. E os idosos são testemunhas desta multiplicidade de eventos. Os anos lhes deram a compreensão dos sentidos do tempo. 
A memória individual está ligada ao afeto. Essa afirmativa, embora óbvia, nos obriga a fazer algumas ponderações. Primeiro, a memória de cada narrador está provavelmente ligada a uma preocupação maior - a necessidade dos homens contarem histórias. Segundo, na medida em que contamos a nossa história usamos elementos alheios às nossas vidas. Há um impulso subjetivo e outro social. Mesmo sendo particular, toda memória estabelece uma conexão direta com a comunidade; a exemplo do sociólogo Halbwachs, que relaciona as lembranças ao grupo e história comuns vivenciados pela comunidade.

Dessa forma, a história de vida apresentada pelos narradores pode se converter em recurso de conhecimento de certos comportamentos pessoais e coletivos. Daí esta estratégia, de relacionar as lembranças individuais e os eventos sociais, serem instrumentos para conhecer: as histórias e os costumes, vontades, vícios, ideologias, paixões e comportamentos da comunidade. Nesse jogo, a cidade se desvela de outra forma. A partir disso, conhecer a si mesmo é também conhecer aos outros.

Constatamos que as lembranças do Sr. Antônio possuem detalhes da vida afetiva e do espaço urbano. Ele se emociona ao falar de lembrança de um episódio de doença ocorrida em sua infância: "esse médico tentou resolver o problema na minha casa, sabe? Me cortou, era sangue voando até o telhado! Eu gritava e minha mãe também. Já, a viagem para Belo Horizonte foi com minha mãe e com meu irmão mais velho". (...) “Além desse lado de minha dor, me recordo com clareza das ruas de Belo Horizonte. As ruas eram de chão e só havia um hospital. Isso em 1913, mais ou menos, eu estava com três anos ou um pouco mais, não é?”. Esta lembrança muito distante no tempo é trazida à luz com intensidade do afeto que a faz perdurar tanto. O Sr. Antônio volta a este evento muitas vezes, aumentando ou retirando detalhes.

As lembranças pessoais, constata Freud, não podem ser "fiéis" ao passado. Isso se deve ao fato de que as lembranças estão conectadas com a vida presente. Que por sua vez, altera a dinâmica do ato de lembrar de cada um, através deslocamentos e associações, própria do sujeito que recorda. Portanto, quando lembramos dos eventos infantis colocamos em órbita aspectos, conflitantes vivenciados em outras épocas. Formando, assim, uma rede de associações de lembranças e esquecimentos que ultrapassa e evento inicial. Deste modo: "tais lembranças não têm emergido, como se diz habitualmente, nestas épocas, sim que têm sido formados nelas, intervindo nestas formações e na relação das lembranças toda uma série de 
motivos muito alheios a um propósito de fidelidade histórica." ${ }^{\text {12 }}$ (FREUD, 1953, p. 222) [tradução livre]. Tal proposta nos revela a dinâmica e a lógica do inconsciente que opera interferindo nas lembranças do sujeito fazendo com que lembre uma e não outra coisa. Acentuando alguns aspectos em detrimento de outros. Nos mostrando, dentre outras coisas, a força e presença do afeto na história de cada indivíduo.

Para D. Maria Stella, é o afeto que a liga à fé, à família e à comunidade; é ele o eixo central de sua vida. Isto porque o amor à comunidade se construiu desde a infância: "depois da minha família, são as festas do Rosário e Paraopeba. Eu vivo para essas festas! Até quando Deus me der saúde e vida eu vou continuar [se emociona e chora]. Adoro minhas festas! Se não fosse minha fé, depois da morte do meu filho, eu não daria conta. Nossa Senhora é tudo! Não daria conta de viver. Minha fé com Nossa Senhora do Rosário é uma coisa surpreendente”.

O filósofo Kierkegaard reflete sobre o amor ágape. Tal expressão do amor, segundo a história, era praticado pelos antigos cristãos. Cada integrante celebrava este amor durante o banquete da eucaristia. $\mathrm{O}$ amor ágape potencializava a caridade, a amizade e a confraternização com os outros. Misturando pobres e ricos e exortando a diferença. O amor cristão, através dos ensinamentos de Jesus Cristo, apregoa o amor pelo diferente. Embora os valores e aspirações sejam, às vezes diferentes dos outros, os memorialistas, podem compartilhar o afeto com a família e a comunidade. $\mathrm{O}$ amor ágape é a possibilidade de ir além da necessidade do amor corporal. Seria uma expressão do amor que celebra a comunhão espiritual, inserindo-os no mundo. Diante disso, amar o próximo como a si mesmo, inclusive o inimigo, pode ser plausível. Assim podemos afirmar que através do amor ágape as pessoas abdicam da morbidez do narcisismo; voltando-se para a partilha com o outro, com o diferente, pois o "próximo é aquele que está mais próximo de ti do que todos os outros, contudo não no sentido de uma predileção" (KIERKEGAARD, 2005, p. 56).

Portanto, o amor ágape transcende os aspectos egocêntricos das relações humanas. Nessa perspectiva, o indivíduo que ama se abre para o infinito. Abre-se para a alteridade, ao espaço da diferença que constitui a essência do ser humano. A partir das expressões do afeto, o

12 Trata-se do trecho do texto de Freud em espanhol: "Tales recuerdos no han emergido, como se dice habitualmente, em estas épocas, sino que han sido formados em ellas, interviendo em esta formación y em la selección de los recuerdos toda uma serie de motivos muy ajenos a um propósito de fidelidad histórica." 
mundo e a cidade se transformam no lugar da liberdade. Condição suprema para a compreensão e a possibilidade de um novo começo.

Na narrativa de D. Geralda a memória oscila e se repete muitas vezes. Procurando um porto seguro, as lembranças precisam continuamente se ancorar, mesmo que seja nas próprias repetições. Aí o afeto se torna fundamental. É através dele que D. Geralda se apóia: a família, a mãe, os gracejos das pessoas, os lugares onde morou adquirem em sua fala a sensação de finitude e afeto. "Ouvia a história de que quando estava passando o enterro do meu pai, com o caixão e tudo, eu estava brincando e cantando na rua. Tinha apenas três anos. Ele trabalhava na Fazenda do Rasgão, como lhe disse, nos carros de boi. Morreu de meningite. Sei que ele morreu novo...". E D. Geralda revela o afeto pela família: "dentro de uma casa sempre tem uma briguinha. Estando junto, alguma coisa acontece, não é? Mas a gente gostava um do outro". D. Maria Stella atesta a emoção pelas festas religiosas: "sempre fico emocionada com as festas! Conhece aquele grupo de congado que tem penachos? Adoro vê-los". Para o Sr. Antônio, o afeto dos irmãos era grande: “eu e meus irmãos combinávamos demais. Todos os irmãos foram criados juntos e sem briga. Imagine só!”. Para o Sr. José a infância era a alegria: "eu me divertia muito!". Desta forma, os narradores constroem as lembranças tendo o afeto como base.

\subsection{Lembranças da família}

O grupo familiar possui lembranças fortes. Não poderia ser diferente. Os primeiros afetos: o pai, a mãe, os irmãos. Mas as recordações não se limitam às pessoas com vínculos de parentesco. Há os vizinhos, amigos que criam raízes afetivas duradouras, pois, através das conversas, algumas aprendizagens vão se construindo e ajudam a instaurar lembranças indeléveis na vida desses integrantes. Uma atmosfera afetiva que permanece no tempo.

Contudo, cada família possui suas características. As relações de autoridade, as regras, o aprendizado do trabalho, os sentimentos. Através do grupo familiar os indivíduos aprendem códigos que irão permitir habitar o mundo: dar nome às coisas, enfrentar as dificuldades da vida. 
Há famílias mais severas, com regras rígidas e austeras. Há outras mais maleáveis e alegres, qualquer que seja a conduta dessa família. É importante acentuar a importância estruturante que a família desempenha na vida das pessoas. Seja para o bem ou para o mal, ou as duas coisas simultaneamente. Os memorialistas preservam uma memória intensa sobre esta época de sua vida. A família será, portanto, o lugar de aprendizagem de si e do mundo.

As famílias dos narradores se enquadram nessa perspectiva. Todos atestam a importância seminal das famílias onde nasceram. A família, para os idosos do interior, nunca se restringem aos pais e irmãos. Há também os tios, avós, primos, amigos e os vizinhos que sempre se fazem presentes. Essa massa de pessoas influencia, cada um à sua maneira, na educação das crianças e na conduta social. Eles são uma enorme quantidade de tipos e personalidades a imprimir marcas na alma de cada um. Desde as virtudes e os ofícios até as manias e medos. A família no interior de Minas possui, constata os idosos, a marca da tradição e dos costumes.

A percepção da criança está envolvida pela vivacidade das imagens familiares. O Sr. Antônio disse que sua infância era assim: "vivi com meus pais na roça. Junto com doze irmãos. Meus pais eram uma maravilha!". Em seguida descreve as relações entre os familiares: "como sendo muito boas". Para o Sr. Antônio a lembrança da infância no espaço familiar era quase paradisíaca: "minha infância foi boa. Em meio aos bichos e plantas".

O perfil psicológico dos pais do Sr. Antônio é muito claro: “meu pai não era culto. Ele aprendeu as coisas na roça. Ele era um homem que sabia tratar todo mundo bem. Tinha prosa boa". Recorda dos hábitos de leitura do pai: "lembro do meu pai lendo romances e jornais. Gostava do romance Iracema de José de Alencar. Lia e fazia comentários. Aprendi a gostar também". A lembrança da mãe é oposta à do pai. O Sr. Antônio afirma que: "minha mãe era mais calada, mais dura. Ela era assim: se tomasse antipatia de alguém, aí acabou". Daí o narrador descreve a alma da mãe e sentencia: "era muito calada, mais fria".

Os vizinhos da roça do Sr. Antônio eram uma extensão de sua família. Eles se irmanavam na alegria e na dor: "meu tio morava pertinho. Era uma relação muito boa com os vizinhos. Um ajudava o outro. Se um sofria, todos sofriam". Para o Sr. José, a família era sinônimo de proteção e de carinho. Havia os vizinhos que ajudavam e acompanhavam na doença, construindo uma forte solidariedade: "Vivi com meus pais até a morte deles. Além de mim, havia mais sete irmãos. Ao todo eram: quatro homens e quatro mulheres". 
Para a menina Maria Stella, a mãe era uma heroína, além de professora exemplar, era uma dama. A educação que recebeu a marcou por toda a vida. "Tenho boas lembranças de minha mãe! Ela era uma pessoa assim: era muito inteligente. Vou lhe contar: por onde ando, não conheci nenhuma pessoa igual a minha mãe. Ela pensava para a frente... Dava muito valor aos estudos". A família do pai fora rica. Morreu quando D. Maria Stella era criança. "Meu pai se chamava Américo e foi fazendeiro a vida toda. Meus avós, pais de meu pai, eram muito ricos". Soube de sua doença e dos cuidados que a mãe lhe dispensara. "Morreu quando eu tinha três anos de idade. Soube que ele morreu do mal de pneumonia, me contaram que ele foi emagrecendo".

A força da família reside no fato de que em "nenhum outro espaço social o lugar do indivíduo é tão fortemente determinado" (BOSI, 2006, p. 425). Em se tratando do interior de Minas, essa premissa ganha nuances próprias. A formação católica muito forte, as regras ora rígidas ora adocicadas pela denguice da convivência. O espaço geográfico por onde as vilas iam surgindo, às vezes no cerrado e sem contato frente a frente com outros, como nas cidades litorâneas. Todos esse fatores nos ajudam a compreender as características das famílias do interior de Minas. $\mathrm{O}$ fato é que a despeito do mito de uma mineiridade (que não iremos tratar aqui) a família para os mineiros e, especificamente para nossos narradores, é muito importante.

Por outro lado, os aspectos subjetivos que sustentam cada família nos certifica que estas imagens estão arraigadas nos indivíduos e em determinados grupos familiares. As primeiras regras de comportamento, as expressões de afeto são apreendidas na família. A figura paterna e materna; o irmão valentão; a irmã prendada; os avós protetores; o tio inteligente; a tia doceira; o irmão predileto; os vizinhos fraternos são todas imagens perenes no imaginário dos narradores.

Para D. Geralda a família era modesta mas deixou boas recordações. "A mãe era carinhosa. Tinha só eu de filha". O pai não chegou a conhecer, mas recorda-se que a "mãe falava que meu pai trabalhava em fazendas dessa região. Em carros de boi, sabe? Entretanto a família era alegre e todos se juntavam para se confraternizarem: “o Neves se juntava com Lauzico para tocar violão". Sendo filha única, os amigos de D. Geralda faziam parte de sua família. 
A peculiaridade da família dos narradores é a permanência. Todos tiveram vizinhos por longos anos, alguns os possuem ainda hoje. Os estreitos laços de afeto e compartilhamento se estenderam para além das cercas dos quintais. Eram eles que auxiliavam na hora as dificuldades e de dor. A presença deles é o testemunho de uma vida. Os cuidados dispensados ao longo dos anos ajudaram a superar as agruras do tempo. O Sr. José confirma que "o ambiente da casa era saudável (...). Meus pais tratavam a gente com muito carinho...”.

\subsection{Os espaços da memória: a cidade}

O espaço nos é dado, o tempo, ao contrário, não. Vivemos o tempo e aí retratamos as experiências. Já o espaço nós herdamos: a casa, a praça, a ambiência do quarto. Capturamos o espaço muitas vezes como prolongamento do nosso corpo. Por isso estabelecemos uma ligação singular com o espaço, pois envolve complexas relações entre o indivíduo e o ambiente.

O espaço da memória experienciado pela criança é ilustrativo. Os quartos, a sala, o quintal, a rua são espaços vivenciados pela criança. As aventuras e fantasias que estes lugares suscitam. O espaço, para os adultos, assume outras formas. Também a escola, o trabalho, as cidades vizinhas redimensionam a noção de espaço. Não ilumina o anterior, apenas o alarga. Pela perspectiva da memória, o espaço potencializa as lembranças. Se na infância, espaço mítico da inocência, se circunscreve na casa da família e proximidades. Já o espaço dos adultos avança por toda a geografia da cidade. Sempre uma cartografia que se reescreve: pelos sonhos, fantasias, lembranças da cidade. O primeiro local de trabalho, as festas comunitárias, o ritual da religião, os prédios, as ruas, dentre outros, vão compondo o espaço da cidade.

O tempo das lembranças não é só individual. É também social. Sendo assim, os narradores não relembram apenas sua época de infância e da família, mas também dos grupos vizinhos, do trabalho, das festas, da cidade. Aos poucos, cada memorialista nos revela as várias particularidades da cidade. Os prédios que não existem mais, as mudanças pelas quais passou a Praça da Matriz, os meios de transporte antigos, as festas dos santos. A cidade, a partir dessas memórias, vai se revelando como um corpo vivo que ora sente nostalgia, ora celebra as conquistas. 
A cidade de Paraopeba é relembrada, primeiro pela lenda em torno de seu surgimento. Embora todos tenham aprendido sobre sua origem nas instituições escolares, vez ou outra afirmam que sua origem se deu quase que como uma fábula. Há aí uma revelação social e cultural característica desta localidade. Por outro lado, as festas da igreja, o teatro, o cinema, os clubes, a imprensa nascida no século XIX, todos compartilhados pelos memorialistas. De repente, a partir das lembranças dos memorialistas, nos tornamos capazes de conhecer uma cidade rica de eventos. Sabemos que a cidade está em seu terceiro nome: primeiro era Tabuleiro Grande, depois Vila Paraopeba e, por último, Paraopeba. Desfilando diante de nós uma profusão de nomes, acontecimentos que pertencem à história da comunidade.

Para D. Geralda, a cidade se faz notar pelo signo das mudanças. A cidade se transformou muito! Apenas faz alusão à história do surgimento dela: “Também tem aquela história da onça, sobre o surgimento da cidade não é?" Entretanto, reconhece as mudanças de nome: "Antigamente se chamava Tabuleiro Grande". Também relembra dos lugares que não existem mais: o teatro, a câmara e a prefeitura, o posto de saúde, e afirma que "a cidade era outra coisa".

D. Maria Stella coloca em dúvida o que aprendeu sobre a origem da cidade. "Ah, não sei. Mas será que é a história da onça? Vejo assim: um lugar pequeno demais, um cerrado. Dizem que apareceu essa onça". Diante da história lendária, reconhece um espaço perdido no sertão de Minas, a cidade era "um ermo só". Até brinca com a história e imagina "um homem doido fugindo da onça". Mas depois D Maria Stella refaz as lembranças e insere as lembranças da origem da cidade ao relato "oficial". O fato é que reconhece a passagem do tempo e as transformações que ocorreram. "Lembro do prédio da prefeitura, que não existe mais". A igrejinha que deu origem à matriz, ela não conheceu. A cidade "sempre foi poeirenta", critica a narradora.

O Sr. José narra o surgimento da cidade com muitos detalhes. Segundo ele, a região onde se localiza a cidade era uma sesmaria e, quando o Coronel Marques veio caçar por este cerrado, se deparou com a onça. Assim, "ele ajoelhou e disse: se for salvo, toda a terra que avistasse no horizonte seria dado à santa”. Além da origem lendária, o Sr. José afirma que haveria um documento na Paróquia de Sabará-MG que faria menção à paróquia daqui - Nossa Senhora do Carmo. As histórias se desdobram. E o Sr. José, bom contador de estórias, afirma que soube de uma possível relação do inconfidente Tiradentes com estas bandas. Segundo ele, 
"Tiradentes teria querido fazer uma estrada daqui de Paraopeba a Paracatu". Percebe as mudanças da cidade, principalmente nos meios de comunicação, que antes eram restritos, além de mencionar os prédios que foram destruídos.

O lugarejo Tabuleiro Grande, segundo o Sr. Antônio, surgiu pela promessa feita a Nossa Senhora do Carmo por um português. Esquece o nome do português, mas relata que ele "estava em cima do pau e prometeu à santa que todo o horizonte à sua frente ele daria para ela". Desde o início, a pequena cidade foi surgindo em torno da capela que pertenceria à santa. "Se fez uma casinha perto da capela, um boteco e assim foi... Daí foi que começou Tabuleiro Grande".

A cidade de Paraopeba surgiu dos caminhos dos tropeiros e do coronel que desbravava a região. As lembranças dos memorialistas confirmam o eixo comum da lenda acerca do surgimento da cidade. Todos fazem referência à história da onça e da promessa feita por um homem para se livrar dela. Uns dão muitos detalhes, como o Sr. José e o Sr. Antônio. D. Geralda apenas faz referência e D. Maria Stella relata em tom de brincadeira essa história. Mas o que é importante ressaltar é o caráter dessa narrativa. Embora com algumas variações, essa história já pertence ao imaginário da memória coletiva da cidade. Através da história oral, a narrativa em torno do surgimento da cidade de Paraopeba vence o tempo e se presentifica nas falas dos idosos. Talvez a afirmação de um historiador possa corroborar as lembranças dos nossos narradores acerca da origem da cidade. Segundo este, "a cidade mineira não tem lugar na altura, só tem no comprimento. Parece um caminho, é uma passagem" (BOSCHI, 1986, p. 33).

\subsubsection{A casa}

Dentre os espaços relatados pelos memorialistas, a casa ocupou um lugar privilegiado. É o espaço do afeto e dos primeiros conhecimentos. Nele reina o afago da família, mas também os medos e privações. Muitas vezes, não é a casa onde nasceu ou cresceu, mas uma em que teve experiências marcantes. A casa sempre será, à percepção do adulto, principalmente dos idosos, o espaço íntimo que protege do mundo "lá fora". Por isso a casa se converte em poderoso elemento de formação na vida de cada um. 
A história dos brasileiros, em sua maioria, está ligada à casa-grande. Não apenas no Nordeste, como estudou Gilberto Freyre, mas em Minas também. O eixo que exprimiria o comportamento do brasileiro, a casa-grande a partir de sua polaridade espacial, revelaria tanto a vida doméstica como as relações de trabalho escravistas, o patriarcado e a predominância do catolicismo. Desvelando uma conduta social com a qual até hoje nos deparamos. Não era o indivíduo, mas a família, representada pela casa-grande, a grande propulsora das relações sociais e econômicas do Brasil. Assim, a casa-grande, a família, era "a unidade produtiva, o capital que desbrava o solo, instala as fazendas, a compra de escravos, bois, ferramentas, a força social que se desdobra em política (...)” (FREYRE, 1963, p. 83).

Foi segundo esse eixo que, em certa medida, a casa se desdobrou em terras mineiras. Sob essa perspectiva sociológica, mas também psicológica. É na casa que se aprendem as regras de convivência, a educação moral, convertendo-se em uma espécie de microcosmos moral e afetivo de suma importância para a formação dos indivíduos. É dessa forma que a primeira infância de D. Maria Stella se revela. A casa velha e secular onde existiam escravos domésticos, vasto quintal de frutas contrapondo com a rua e com a cidade. "Essa casa era igual a uma fazenda. Praticamente não havia vizinhos". Muito velha, a casa é portadora de longa história: "Essa casa deve ter mais de 200 anos. Meu pai a comprou por volta de 1923".

Exercendo particular importância na vida de D. Maria Stella, a casa onde passou sua infância se converte em lugar privilegiado da memória. Memória do aprendizado com a mãe: a confecção dos doces, as regras de etiqueta, o desenvolvimento da devoção a Nossa Senhora do Rosário. O espaço da casa é o de formação espiritual para enfrentar o mundo, uma vez que nessa casa reina absoluta a figura materna que, além de professora, era "musicista e sabia tocar vários instrumentos”. Lembranças caras para D. Maria Stella.

A casa da família de D. Maria Stella possui uma história que caminha em paralelo à da cidade. Essa casa antes pertencia a Manuel Pinto, farmacêutico e sogro de Avelino Fóscolo, criador da imprensa da cidade. De tão velha, essa casa "deve ter tido escravos domésticos". Entretanto, as lembranças não são apenas felizes para D. Maria Stella. A casa a faz relembrar as dificuldades econômicas enfrentadas pela mãe: "Uma vez eu a vi tirando um brinquinho lindo da orelha para vender aos mascates que passavam aqui nessa rua". 
As brincadeiras se desenvolviam na rua, em frente à casa, pois sua enérgica mãe administrava as brincadeiras. O pai era fazendeiro, de origem rica e dono de latifúndios. Mas a casa era também espaço das brincadeiras de coroação da santa, das mangueiras e jabuticabeiras. Um universo lúdico e prazeroso.

A casa é o microcosmo da memorialista. A ambiência do lar reveste tudo de encanto e beleza. Recorda D. Maria Stella: "O jardim era cheio de lírios, minha mãe gostava muito de lírios. Eram brancos e também rosados". Havia também "uma bomba d'água e um cômodo que usávamos para fazer manteiga". Na casa de D. Maria Stella tinha um pequeno pasto e duas vacas. Era uma construção rústica, mas forte, que ainda hoje se mostra firme. Segundo a narradora, esta casa "foi construída de taquara e adobe", e curiosamente não tem nenhum alicerce convencional. É sustentada por "toras de aroeira bem largas".

As lembranças de D. Geralda são de proteção de uma filha única. A casa era modesta, mas cheia de encantos. As primeiras conquistas do mundo... "Nessa casinha aqui no quintal, olha [aponta para a janela]! Existia uma fornalha. Lá eu fiquei cozinhando até quando dei conta". O espaço da casa de D. Geralda revela a simplicidade da rotina. Uma casa regulada pelos afazeres domésticos e o trabalho na roça. A casa desta moradora se alargava até os vizinhos: "Os quintais eram abertos, sem muros. Era apenas um fio de arame farpado até os vizinhos. E ninguém entrava na casa dos outros para roubar".

Porque a casa para D. Geralda era o lugar "em que a gente vivia apenas". Sem luxo e etiqueta, os dias eram passados no plantio da roça: “Era socando arroz no pilão. Tudo era assim!” Nem tudo, apenas a descontração, o movimento das pessoas: "A casa era cheia. As pessoas assentavam nos caixotes" e cantavam ao som do violão. No outro dia, a rotina da casa seguia seu tempo próprio. Sem cardápio, fazia o que tinha para comer. Declara D. Geralda: "Ia até o muro e pegava ora-pro-nóbis ou couve e cozinhava". A vida da casa permanecia inalterável: os dias, meses, anos seguiam sua própria cadência.

Para o Sr. José, o ambiente da casa era de proteção e afeto. A mãe e o pai protetores, que zelavam pelo bem-estar. Sua casa era modesta, mas não faltava nada. As brincadeiras sempre criativas com os amigos da vizinhança. A casa do Sr. José era assim: "Minha casa era muito simples e pobre (...), mas o ambiente da casa era saudável e eu me divertia muito". O narrador revela o sossego que havia na casa e na vizinhança: "Não tinha essa bagunça de vizinho 
incomodar o outro". Os limites tecnológicos eram muitos, pois "era raro uma casa ter um rádio”. Reinava o silêncio, a quietude do ambiente da casa e das proximidades.

A casa do Sr. Antônio era na roça. Embora filho de pais modestos, sua educação revela a grande referência patriarcal. "O pai era enérgico, mas de coração mole, a mãe muito boa, mas guardava mágoa", demarca o memorialista. A família era composta por vários irmãos e muitas lembranças. "Vivi com meus pais na roça, junto com onze irmãos". A roça era um espaço enorme. Além da sua família, o Sr. Antônio lembra-se do vizinho - "meu tio morava pertinho". Permaneceu na casa dos pais até os 30 anos. Apenas se casou em 1945 e sua casa da cidade permanece a mesma até hoje.

Desta forma, a casa da cidade não era apenas moradia. Era referência topográfica. O Sr. Antônio dizia que, para ir a algum lugar da cidade, pedia o nome do dono da casa como referência, pois não havia números nem nomes nas ruas que servissem como referência. "Nós identificávamos o nome da rua pelo nome da pessoa mais velha daquela rua”.

As lembranças da cidade rememorada pelo Sr. Antônio nos confere a possibilidade de apreender aspectos arquitetônicos característicos das construções daquela época. Afirma que a maioria das casas era construída de adobe. As "telhas eram modeladas nas pernas". O barro era colocado "nas coxas para se conseguir o formato das telhas". Os telhados eram feitos de "palha e capim". O piso era de "chão batido".

Tudo era precário, pois a luz das casas era "de velas e lamparinas de querosene”. Compunha, juntos aos habitantes das casas, uma enorme quantidade de animais, já que "os bichos de estimação faziam parte da família. Cachorros e gatos, galinhas e patos". Além dos canteiros de hortaliças - "alface, couve, taioba, tomate bem vermelho". E, para curar as mazelas, “camomila, funcho, alecrim, boldo e tantos outros", fazia parte do quintal da casa.

A casa, na memória do Sr. Antônio, rica em detalhes, nos revela como as moradias eram diferentes. Um universo habitado por pessoas, bichos e plantas. Até os materiais de construção das casas fazem parte da natureza circulante. A casa abrigava a diversidade da vida e experiências sensoriais, embora na precariedade e na pobreza. 
Além das casas dos narradores, havia as moradias da pequena cidade, serpenteando a Praça da Matriz e as ruas de terra vermelha. Pequenos casebres, de adobe e telhado de capim, ao contrário das casas abastadas, eram a maioria na comunidade. Essas casinhas foram aos poucos ocupando espaço no cerrado e distanciando-se da praça principal. Em sua rusticidade, eram uma espécie de mocambos que não se diferenciavam em quase nada das habitações da zona rural propriamente dita:

O mocambo, a palhoça ou tepuja, é que quase não mudou. Apresenta diferenças no Brasil mais de natureza regional, conforme o material empregado na sua construção - folha de buriti, palha de coqueiro, palha de cana, capim, sapé, latas velhas, pedaços mais africanos, em outros mais indígenas. (FREYRE, 2004, p. 347)

A descrição do sociólogo Gilberto Freyre vai ao encontro dos narradores. D. Maria Stella descreve que a cidade não tinha quase casa nenhuma. No entanto, essas casas, em sua simplicidade, revelam, paradoxalmente, grande complexidade. Porque é nesse espaço que começa a formação social, um lugar onde se iniciará todo o ethos do brasileiro, particularmente do mineiro, já que Minas Gerais é um estado de grande extensão territorial e de influências múltiplas: portugueses, negros, índios, católicos em grande quantidade, mas também de cristãos novos (judeus) e outros estrangeiros, comunidades que iam surgindo nos caminhos dos tropeiros. Paraopeba também revela esse roteiro.

Dessa forma, as casas da antiga Paraopeba foram surgindo. A casa-grande, o mocambo, os casebres compunham o modus de ver e de estar na vida. Assim, as casas, esse espaço de formação social e afetivo, revelam os objetos que desenham a história dos indivíduos. Os guarda-roupas, arcas, camas, cadeiras, retratos, cômodas, fogão a lenha, são coisas que adquirem vida própria. Objetos que acompanham afetivamente os memorialistas.

D. Maria Stella guarda com fervor o pequeno caderno de orações herdado da mãe. Se revela um objeto biográfico cuja estima acompanha a história da memorialista. Nele as orações e devoções que a mãe professava e que a filha acabou adotando. "Lembro sempre da imagem de Nossa Senhora do Rosário ao lado da sua cama e dos cadernos de orações". Para o Sr. José, os objetos são os livros que o ajudaram a se formar: "D. Quixote, A divina comédia, etc." Esses objetos preservados em suas casas foram envelhecendo junto com cada um deles. Eles revelam uma escolha, um modo de ver e sentir o mundo. D. Maria Stella remete à sua fé 
inabalável, o Sr. José o aprendizado da leitura e da escrita. Em ambos um exercício de autoconhecimento.

\subsubsection{A rua}

A rua é o espaço de comunicação expresso pelos narradores. É nesse espaço que a experiência de cada um desponta para o mundo. No interior, é quase uma extensão da casa, pois as crianças brincam na rua, os vizinhos trocam informações e compõem um perfil que desenha a cidade. É a partir da rua que também se conhecem os outros, o diferente. E do ponto de vista sociológico, na rua se dá a percepção das raças e as trocas culturais que culminam na celebração da praça.

Na casa de D. Maria Stella existem várias janelas por onde se avista a rua. É lá que brinca com as amigas sob o olhar vigilante da mãe, D. Anésia. Lembra da poeira que exalava da rua e o lamaçal em que esta se tornava nas épocas de chuva. Mas, mesmo assim, no mês de maio, não perdia a coroação de Nossa Senhora. Ia pelas ruas poeirentas até a Praça da Matriz. "Tenho um retrato dessa casa com a rua sem asfalto e calçamento; hoje a rua está asfaltada". Nas lembranças, D. Maria Stella percebe as mudanças das ruas. Elas comunicavam com o mundo e faziam a ligação com os vizinhos - "era ali logo abaixo dessa rua". Mas também era na rua que apreciava outros ofícios: "As mulheres passavam por essa rua com as latas d'água na cabeça ou com feixes de lenha". Afastada dessas imagens que ficaram na memória, declara: "Quando lembro das ruas daquele tempo, sinto muitas saudades!" Pois, para essa memorialista, a rua remete ao conhecimento das pessoas que transitam na cidade, assim como espaço lúdico: "Naquele tempo a gente brincava na rua". Não havia perigo, a rua podia ser considerada uma continuação do ambiente da casa, onde se desfrutava de muitos prazeres: "Ah, éramos livres na rua..."

Nas lembranças da infância do Sr. Antônio, de sua casa na roça, as ruas, ou melhor, os caminhos (picada) representavam a passagem de chegada à cidade. Mas também a rua que dava para o trabalho das plantações. Também havia as ruas que davam para os vizinhos da roça. Eram todos amigos e, quando chegava a época da colheita, íamos pelas pequenas ruelas para pedir ajuda e todos ajudavam. 
Depois, o Sr. Antônio vinha pelas picadas até chegar ao comércio da cidade para fazer a troca de mercadorias: arroz, feijão, milho e outros. Não esquecia o caminho até a chegada na cidade, pois assim a família se mantinha. Havia também o caminho para a escola, toda tarde: "Nós transitávamos o tempo todo. Era um ir e vir para lá e para cá constantemente". Nas lembranças do Sr. Antônio, as ruas da cidade se confundem, muitas vezes, com a geografia da região. "Aqui, tudo era cerrado!"

A rua, para o Sr. José, era o espaço das brincadeiras. Lembra das pedras, das casas dos vizinhos. Naquela época, se podia brincar sem medo. Quase não tinha carros e muito menos perigo. Todos o conheciam. A inocência da infância compartilhada com os amiguinhos da vizinhança: "Rubens, Wanderley, os filhos do Zé Barbeiro, os filhos do Raimundo Castelo". Com aspecto rudimentar, a rua era um convite ao divertimento: "A rua era de chão, cascalho e... de um lado e de outro tinha muitas pedras. Era uma turminha que brincava na rua".

Assim, a rua para o Sr. José era o espaço do lúdico e da criação. Com os amigos, inventava os próprios brinquedos: "Fazíamos carrinhos de lata e brincávamos também de finca. Sabe o que é? É um estilete que arremessávamos na terra". Nas ruas, as brincadeiras se multiplicavam: "bolinhas de gude, o jogo do pião". Desta forma, as ruas eram uma extensão da casa. Na simplicidade das coisas, o Sr. José usufruía desse espaço que oferecia os encantos das descobertas.

As lembranças da rua que cortava a casa de D. Geralda são vívidas. Nota a grande diferença de hoje. Havia poucos vizinhos, os quintais eram grandes e o que os separava era uma exígua cerca de arame. A rua poeirenta, onde passavam os cavalos, era por onde transitavam as pessoas que iam trabalhar na Fazenda do Rasgão. Percebemos que o universo da casa de D. Geralda é seu mundo: vê a si mesma e a cidade a partir da casa e da rua. Tudo se orienta para sua casa e a rua é quase uma extensão. Os pequenos trabalhos que faziam para ajudar a mãe; o primeiro desejo de aprender a costurar observando a avó; os tios que moravam no mesmo quintal; a cozinha, tudo circunscrito na casa. Relata: "Sempre morei por aqui mesmo. Nessa rua havia poucas casas, os quintais eram grandes e não eram fechados com muros. A rua era de chão, poeira..."

Mas sabe dar detalhes das ruas que cruzavam a cidade. A cidade era minúscula! Com poucos passos se trafegava por toda a área urbana. D. Geralda tem a recordação de um acontecimento 
que se passava em sua rua. Sentia uma mistura de nostalgia e medo quando os cavalos passavam na rua balançando os sinos pendurados no pescoço. Relata a lembrança: "Eu fícava deitada e ficava ouvindo o sino batendo no pescoço do cavalo. Sentia muito medo". A rua se tornava o espaço da apreensão e do mistério.

\subsubsection{A escola}

As recordações provenientes da escola são carregadas de afeto e descobertas. Através dessas lembranças, os narradores se aproximam dos moradores da cidade. Os memorialistas conseguem experienciar um mundo fora do ambiente familiar. A escola se converte, assim, em espaço das grandes emoções e diferenças. As regras e valores que servirão para o ingresso na vida comunitária. O conhecimento formalizado. A escola, para os narradores, é um lugar de memória da cidade.

D. Geralda aprendeu a ler e a escrever no Grupo Escolar Conselheiro Afonso Pena. A primeira professora foi D. Margarida Mascarenhas. Acha curioso as crianças de hoje precisarem de uma mochila cheia de material escolar. Em sua época, era apenas um caderno e uma caneta bico-de-pena. Tudo era uma dificuldade! Mas a escola era uma alegria. As cantigas de roda, o bê-á-bá da aprendizagem. Lembra-se das pessoas que passavam na rua a comentar a aprendizagem das crianças em coro. Ouvia-se de longe: "A gente aprendia de forma diferente! As pessoas passavam na rua e ficavam escutando: $b+a=b a$, sabe como? $\mathrm{E}$ depois é que nós formávamos as palavras".

Em sua época, o diretor da escola era o poeta Sabino de Paula Freitas. Era tudo simples, os materiais escolares eram um tinteiro e lousa de pedra. Não havia dinheiro para comprar materiais: "Vendíamos algumas coisas para comprar o tinteiro na venda". Entretanto, a escola possuía encantos e o prazer da aprendizagem.

O Sr. José foi o primeiro aluno de todas as séries. Lembra das professoras e das "levadezas" dos alunos. Seu ingresso na escola foi tardio, por causa da mãe. Ela achava que o filho era muito pequeno para freqüentar a escola. $\mathrm{O}$ espaço escolar foi um universo de conquistas e também do apelido que o acompanha até hoje. Não se esquece da metodologia de ensino, que era ministrado através de cartilhas. Foi alfabetizado pela professora D. Anésia em poucos 
meses. Não se esquece de que o conteúdo das quatro primeiras séries corresponde hoje até a $8^{\mathrm{a}}$ série. Regra de três, juros, porcentagem, tudo isso se aprendia até a $4^{\mathrm{a}}$ série.

Não esquece de seu desempenho escolar: "Na escola eu era bom aluno. Tinha memória e inteligência muito boas. Em todos os quatro anos do grupo escolar, fui o primeiro aluno". Relembra o método de ensino: "A gente aprendia pelo sistema da cartilha. Era assim: a - a - a e o-o-o. Depois ia juntando as sílabas". Para o Sr. José, a escola representava a novidade, o encantamento: "Os colegas que chegavam de fora. Época mais bela da vida".

D. Maria Stella foi aluna da professora D. Anésia, sua mãe, nos quatro anos do Grupo Escolar. Recorda que tinha que se esmerar na aprendizagem e se sair bem nas notas. A escola para D. Maria Stella era um lugar lúdico: as colegas, o uniforme, as brincadeiras. Tudo era uma festa! Aprendeu com a mãe, na casa e na escola, o rigor e a disciplina. Nunca teve dificuldades em aprender. "O meu primeiro dia de aula era uma felicidade! Era bom demais da conta!"

Ao evocar as lembranças da escola, D. Maria Stella, recorda a dedicação da mãe em ensinar. Para que seus alunos não perdessem as aulas em um período de reforma do prédio da escola, D. Anésia, lecionou em sua própria casa. Isso não sai da memória da filha, que continuou a estudar e ser bem-sucedida na escola. "Me lembro quando estavam consertando a sala do grupo, para não ficarmos sem aula, mamãe trouxe a classe toda para estudar aqui em casa. Essa casa virou grupo escolar". A escola, para D. Maria Stella, também está ligada à figura da mãe. A professora D. Anésia foi sua professora durante os quatro anos e também de todos os memorialistas. Exemplo de dedicação e rigor, D. Anésia permaneceu na lembrança de todos.

O grupo escolar Conselheiro Afonso Pena foi a escola de todos os narradores. Representa um lugar de memória da cidade. Foi a primeira escola da cidade e também da região. Mas antes havia outra escola e também professores particulares. Nas palavras do Sr. Antônio, ele foi alfabetizado na roça com professor particular. Só depois foi para a escola Afonso Pena. Recorda da escola na roça e a aprendizagem das primeiras letras e das operações fundamentais de matemática. Mas não aprendia nada de história e geografia. Dizia que, no exame de admissão na escola Afonso Pena, não teve dificuldades em matemática e português, mas das outras disciplinas não conhecia nada. Recorda a conversa da professora com o pai: 
"Seus dois filhos não conhecem nada de história, nada de geografia, nada de geometria. Mas em matemática, ler e escrever, eles dão show".

O Sr. Antônio revela minúcias das escolas e dos sistemas educacionais. Segundo o memorialista, antes da Escola Afonso Pena funcionava uma outra escola improvisada no prédio do posto de saúde. Era por volta da primeira década do século XX. Soubera, também pela sua mãe, onde ela e seu pai tiveram aulas particulares para serem alfabetizados. Essas aulas eram ministradas, no final do século XIX, perto da Praça da Matriz. Também se lembra das pessoas analfabetas da roça. Havia poucos recursos e muitas famílias não se interessavam em educar os filhos. Tudo era difícil! O Sr. Antônio "saía cinco horas da manhã, sete da manhã começavam as aulas. Estudava segunda, terça, quarta e depois voltava na sexta e sábado". Os dias letivos eram diferentes, a folga era na quinta-feira.

Uma lembrança que o acompanhou foram às aulas no sábado do professor e poeta Sabino de Paula Freitas. O memorialista se recorda das palavras em francês e em inglês que ele ensinava. Lembra do seu rigor e cultura. Antes de ser prefeito, o professor Sabino ganhava a vida dando aulas particulares. Separava as turmas para os iniciantes que estavam em processo de alfabetização e os mais avançados. Recorda as frases em francês que aprendeu: "bon jour, mon ami”. Embora morando na roça, o pai fez questão de alfabetizar os filhos. O Sr. Antônio gostava de aprender e estudou até a quarta série.

Quando convocados a lembrar da escola, os narradores reforçam a idéia da escola como espaço importante na formação individual e da cidade. D. Geralda, Sr. Antônio, Sr. José e D. Maria Stella, cujas lembranças escolares atestam a aprendizagem escolar como sendo fundamental em suas vidas. A escola é vista ora de forma lúdica, ora de forma rígida e disciplinar. Contudo, as imagens evocadas são vívidas e intensas.O prédio da escola está muito ligado à história da cidade, autêntico lugar de memória. As lembranças desta escola estão impregnadas na alma de cada um e da história da cidade. 


\subsubsection{O teatro}

O teatro da cidade permanece vivo nas lembranças dos narradores. Ele foi erguido pelo trabalho da comunidade, sob o comando do Sr. Avelino. Além de criador da imprensa, o Sr. Avelino agitou culturalmente a antiga Tabuleiro Grande. Esse teatro, onde após sua demolição ergueu-se um cinema, marcou a infância e a juventude dos moradores mais antigos da cidade. Portanto, o teatro, embora o prédio tenha sido demolido, se manteve presente na lembrança dos memorialistas, uma vez que todos eles registram a participação em espetáculos ali ocorridos.

O Sr. Antônio participou de uma peça nesse teatro. Ele representou o príncipe que se apaixona pela Branca de Neve. "Eu estava com 12 anos quando apresentei a peça". Nas recordações da peça, notamos a empolgação do pequeno ator, que a revive com grande entusiasmo. É capaz de recitar vários trechos da peça: “espelho, existe alguém mais bela do que eu?". Além da peça encenada, o Sr. Antônio começou a namorar a atriz que fez a personagem Branca de Neve - "sei que depois da peça comecei o namoro". O prédio foi demolido no final da década de quarenta, mas o Sr. Antônio recorda: "ele era antigo. Era de madeira... Era teatro e cinema juntos".

Já D. Geralda tem boas recordações dos bailados que assistia no teatro. Era uma alegria para ela, aquele lugar onde apreciava as coisas bonitas. Ela não participava, mas ficava a admirar os espetáculos: "lembro das meninas cantando nos bailados... Eu assistia, mas não participava”. O teatro, construído no início do século XX, por volta de 1904, deu lugar ao cinema. A única coisa que restou foi trechos dos eventos nas lembranças dos habitantes da comunidade.

Para o Sr. José, o teatro, que já não existe mais, representava o lugar da fantasia, principalmente depois da reconstrução do prédio e da inauguração do primeiro cinema da cidade. Lá assistia o cinema mudo, as primeiras películas de sua lembrança: "você sabia que meu pai foi apreciador do cinema mudo? No Cedro também teve cinema mudo...”. O espaço do antigo teatro cedeu lugar ao cinema. "Mas depois teve cinema falado", argumenta o Sr. José. 


\subsubsection{A praça da matriz}

D. Geralda relembra como a praça da Matriz era diferente. A poeira, as casas ao seu redor, os prédios públicos, tudo mudou. Naquela época, para além dessa praça, a cidade começava e terminava no cerrado. "Ali embaixo, na praça da Matriz, onde morava dona Lourdes Mascarenhas, eu tinha medo de ir lá sozinha. Era só mato!”.

O Sr. José lembra do prédio da Prefeitura, do fórum antigo e da cadeia na frente inferior do prédio. Todos foram demolidos. Essa mudança causou tristeza e desolação. Ficavam na parte frontal da praça da matriz: "me lembro do prédio da Prefeitura e da cadeia que funcionava no andar de baixo. Eles foram demolidos".

Também D. Maria Stella, muito devota, menciona em suas lembranças a mudança da praça. Primeiro as mudanças da igreja: a primeira, construída no lugar da capela original, tinha duas torres. Depois a igreja na época do padre Herculano, atualmente, a construção da nova igreja. Recorda que na praça não havia o coreto atual e era muito poeirenta. "Lembro do prédio da Prefeitura que não existe mais. Também de uma loja que havia na Praça da Matriz”.

O Sr. Antônio consegue lembrar, com riqueza de detalhes, da Praça da Matriz. A igreja antiga, a poeira, pois não havia o jardim de palmeiras e nem o coreto que existem hoje. Os prédios demolidos. Lembra de um chafariz que existia na praça onde as pessoas buscavam água. As inúmeras festas e quermesses, bem como as brincadeiras que ali aconteciam. A praça da matriz era o lugar de encontros da comunidade, do comércio e da convivência. "A praça da matriz era grande! Não tinha as palmeiras que tem hoje em dia". A praça da matriz também era lugar de comércio variado: "naquele tempo era venda, armazém, não se chamava loja. Esse armazém tinha de tudo: de seda a toucinho".

Mas a praça da matriz, para o Sr. Antônio, revela uma memória afetiva junto com a geografia da cidade. Parece uma memória do sonho: "no meio da rua tinha um moinho de vento. Era um moinho d'água. Ficava na frente da casa do padre. No meio da praça". Certifica-se da lembrança, reflete e depois retoma: "ele puxa água, como cisterna. Me lembro bem disso porque quase todo domingo eu ia à missa". Assim, a praça da matriz, origem lendária da cidade, espaço onde a comunidade celebra as festas, a fé e também o comércio. Um lugar de trocas, simbólicas e políticas. 
A praça é o lugar de encontro com as diferenças. Ela é o espaço urbano onde se expressa a diversidade. Pessoas de níveis econômicos e culturais diferentes nela se reúnem e se confraternizam: o pobre, o rico, homens e mulheres, a professora e o lavrador, dentre outros. Espaço político por excelência, a praça pública, presentifica a memória da cidade: os prédios da igreja matriz, da prefeitura, da cadeia, os imóveis dos comércios. Assim gravitam na praça, os prédios que representam toda uma época e as festas comunitárias. É na praça que ocorrem os eventos religiosos e socialização.

\subsubsection{O prédio da Gazeta}

Dentre os espaços urbanos da cidade o prédio da Gazeta de Paraopeba é um dos que mais aparecem nas lembranças de nossos memorialistas. Um lugar de memória que está intimamente ligado à história da cidade. Desde do início da imprensa no século XIX até os dias atuais, o prédio da Gazeta , simboliza muitas coisas para cidade: cultura, aprendizado, história dos eventos e as pessoas da comunidade. Embora demolido, se perpetua nas memórias dos idosos e nos jornais que ainda circulam na cidade. O Sr. Antônio recorda-se da oficina do jornal: "eu recordo da gráfica da Gazeta de Paraopeba. Sei que o Sr. Neném, o fundador da Gazeta, começou a trabalhar em uma farmácia que era do Sr. Avelino Fóscolo". As dependências da gráfica "eram muito simples. Tudo era feito à mão porque não tinha energia". O memorialista se lembra que era um bom jornal e o "comprava por 500 réis".

O Sr. José recorda dos últimos anos de vida da Gazeta de Paraopeba, ainda na década de 1950, quando o Sr. Neném, Manuel Antônio da Silva, faleceu. "Nas oficinas da "Gazeta". O jornal era impresso aos sábados, até altas horas, para sair no domingo". A imprensa teve muita importância na cidade de Paraopeba-MG. Dentre as principais podemos revelar a memória escrita através dos vários periódicos produzidos neste prédio e a organização da comunidade a partir dos periódicos. O Sr. José, embora não sendo jornalista, participou dos jornais existentes durante longa data, divulgando suas idéias em uma coluna regular. Devemos também mencionar a farmácia do Sr. Avelino, que era um lugar de memória, mas que os memorialistas não mencionam diretamente. O Sr. Antônio e D. Maria Stela mencionam o prédio da farmácia, mas não o conheceram diretamente. Através de dados escritos conseguimos saber que esta farmácia abrigava também uma biblioteca. Entretanto não podemos fazer mais nenhuma afirmação a partir das lembranças dos narradores. 


\title{
5.6. O gesto e a musicalidade da memória
}

Os ritmos das lembranças não são uniformes, assim como a musicalidade que o acompanha. Na comunidade, as pequenas cantigas populares, são ouvidas e imitadas pelas crianças. Às vezes cantaroladas pela mãe para aliviar o trabalho doméstico, outras vezes aprendidas na escola, ou com os amigos durante certas brincadeiras. O certo é que estas músicas remetem ao universo lúdico e afetivo de cada um, indicando a cadência do tempo interno e externo. As canções populares são meios de formação dos indivíduos desde da infância. Isso se dá através da voz e do prazer que ela transmite.

Pela voz de duas narradoras evocamos antigos costumes da cidade. Assim verificamos na voz de D. Geralda, cujas cantigas de roda, recuperadas pelas lembranças, evocam um passado permeado por afeto e saudade:

\author{
Olha a rolinha doce \\ Doce, doce, doce \\ Embaraçou, doce, doce. \\ Ponha aqui, ponha aqui \\ O seu pezinho \\ Ponha aqui, ponha aqui \\ Bem junto ao meu \\ Já ao tirar o seu pezinho \\ $\mathrm{Na}$ sua graça dá-me eu \\ A rolinha doce, doce \\ Caiu no lago \\ Doce, doce \\ Coloca o nosso amor \\ Doce, doce (...).
}

O ritmo, a cadência das cantigas de roda é recorrente na memória dos idosos. Elas revelam um passado que se faz presente pela musicalidade. D. Geralda, por exemplo, às vezes esquece a letra, mas não o ritmo. Para a narradora, as cantigas de roda revelam o encanto das "brincadeiras sadias", mas também o humor presente nas canções do amigo Mané Serrador:

Ei chuchu, chuchuzinho

Bem temperado, que bom será

Vai pra cozinha

Põe na panela pra temperá (...). 
O estudioso Paul Zumthor nos revela a importância da relação entre a voz e o corpo. Através da performance os cantadores e oradores expressam a condição imediata e inerente ao ato da comunicação. Dessa forma, ao cantarolar as cantigas antigas da comunidade, a narradora reatualiza o ato pelo corpo e pela voz. Este termo, a performance, tem caráter antropológico e se refere "às condições de expressão e da percepção, por outro, performance designa um ato de comunicação e como tal, refere-se a um momento tornado presente" (ZUMTHOR, 2000, p. 59).

A musicalidade de cada pessoa não está separada do mundo. Por um lado guarda o afeto de cada verso, por outro traduz o conhecimento do grupo, da comunidade, da cidade. Por isso uma festa sem música não é festa. E celebrar um ritmo, seja qual for, através do ritmo das palavras formam-se "música". A musicalidade está na infância, mas também nas festas comunitárias. As canções se convertem em uma espécie de identidade de um grupo: uma tradição entoada pelos ritmos e sons. Para D. Maria Stella, a música marca a fé:

\author{
O beija-flor toma conta do jardim \\ E pedi Nossa Senhora para cuidar também de mim \\ Santa Maria, cheira \\ cheira a flor de rosa, de laranjeira [pausa] \\ $(\ldots)$ \\ Do Rosário [esqueci] \\ Deus é mais, Deus é mais, Deus é mais \\ Deus me dê saúde e força \\ Alegria e muita paz".
}

A convergência entre a voz e a musicalidade remete-nos à força propulsora dos costumes e ritmos. Também nos redimensiona à temporalidade uma vez que coloca os cantadores e ouvintes em contato com um plano diferente do cotidiano. Isso se deve ao poder encantatório das palavras cantadas. Além disso, redimensiona as pessoas à sua origem e história coletiva.

D. Maria Stella recorda que certas canções a acompanham por muitos anos: "ontem mesmo cantei essa música para as pessoas”. O ato de lembrar é uma forma de percepção, de presença. E todo corpo, em presença, está em um espaço. Dessa forma, a memorialista "gesticula", movimenta o corpo, procurando no espaço a cadência, um eixo de orientação que deseja imprimir em sua performance. Também, D. Geralda, movimenta o corpo para encontrar o gesto que possa reatualizar o passado. Por isso o cantador "fica se arremexendo" e os meninos 
rindo. A musicalidade das narradoras reatualiza as canções através de suas vozes e de seus gestos e da imitação. Procurando, assim, dar às lembranças os ritmos que as deslocam do passado ao presente.

Há os gestos que os narradores apresentam sem a musicalidade referida. Entretanto, eles estão presentes em muitos momentos da narração. Isto reafirma outras possibilidades e recursos para a memória. As lembranças, além das palavras, são acompanhadas por gestos que expressam situações variadas. D. Maria Stella, em sua casa centenária, localiza as lembranças com gestos que inquirem o espaço doméstico "aponta para a janela na qual avista o jardim"; "localiza os vizinhos"; "aponta a casa ao lado", ou faz uso de certos gestos emocionais: "chora ao lembrar do filho morto". E mesmo a lembrança de sua fé: "retira o quadro da parede".

Já para D. Geralda o gesto, o movimento do corpo no espaço de sua casa são como complemento de suas lembranças. Para reavivar a memória "anda de um lado para o outro até se assentar". Quando as palavras falham, são os gestos que nos ajudam a compreender as lembranças da narradora, assim "aponta para a janela, a casa da vizinha", para se referir ao aprendizado na lousa de pedra "desenha com os dedos no ar". O corpo, para a narradora, é parte integrante da memória - as paradas, o silêncio, os recuos, as repetições integram os signos da memória de D. Geralda.

De modo sutil, Merleau-Ponty fornece-nos elementos para compreender o fenômeno da percepção em relação ao corpo. Para o filósofo, a percepção está no corpo e inseparavelmente dele. O corpo está aberto à vida exterior. Ele é a sede dos significados e sentidos. É o corpo que faz um elo, entre o lugar da comunicação do eu e do universo. Por causa desta relação de imbricação e cumplicidade, corpo e percepção, se entrelaçam entre visão e movimento: "meu corpo, este, se move, meu movimento se desdobra" (MERLEAU-PONTY, 1969, p. 35). Nesta operação o corpo acolhe o olho e capta o mundo; restituindo ao mundo em forma de gesto, de traçado o que percebeu ao seu redor. Assim o corpo não está aqui e percepção lá - ambos se comunicam no ato perceptivo. Para o filósofo, "o enigma reside nisto: em que meu corpo é ao mesmo tempo vidente e visível. Ele, que olha todas as coisas, também pode olhar a si e reconhecer no que está vendo então o outro lado do seu poder vidente" (MERLEAUPONTY, 1969, p. 35). 
O corpo, pela ótica merleau-pontyana, move-se para manipular a coisas. Já que mantém com o mundo à sua volta uma espécie de prolongamento. Assim, o corpo, nesse jogo de olhar e ser visto poderá apurar os sentidos acolhendo, as coisas do mundo, como pertencente ao seu campo perceptivo. Isso esclarece o movimento dos idosos ao perceber e em reconhecer as próprias lembranças. Os corpos dos idosos os ajudam, através dos gestos e movimentos, a prolongar aquilo que viram e perceberam.

Para o Sr. José as palavras são refletidas, degustadas até serem expressas. Daí as pausas e também os risos constantes. Quando narra suas histórias, as mãos acompanham o enredo. O texto é dramatizado com o corpo, talvez por isso o riso, a gargalhada seja tão importante para o Sr. José. É nesse ato, que envolve corpo e voz, que as histórias são contadas. Porque as histórias são "para divertir". É o prazer em narrar as lembranças.

Já as falas e lembranças do Sr. Antônio estão todas cheias de gestos. Em meio à profusão de nomes, referências e detalhes minuciosos, o Sr. Antônio intercala gestos e expressões, onomatopéias e imitações para compor sua memória prodigiosa. $\mathrm{O}$ corpo e os gestos dão maior amplidão às palavras e lembranças. Dessa forma, ao narrar a cirurgia que se submeteu, o sangue jorrando "chuá-chuá - a mão se dirige ao pescoço". No aprendizado do trabalho "faz gestos com a mão, imitando o movimento do tear". Também as brincadeiras na juventude “joga para cima”. Para revelar a indignação com a política "pá, pá, pá - faz gestos com as mãos".

Portanto, nossos memorialistas utilizam o gesto, o corpo e a musicalidade para potencializar as lembranças evocadas. Assim, as lembranças ressurgem, no presente, renovadas, cheias de vida! Elas, de alguma forma, terão provocado no ouvinte o impacto que tem para o narrador. Assim, as palavras, em relação direta com o corpo e o gesto, e expressas pela voz e pela musicalidade trazem para os receptores um passado carregado de sentimentos. $\mathrm{O}$ gesto, o corpo dos memorialistas, dramatiza as lembranças capturando o que está no ambiente.

\subsection{Memória e imagem}

Podemos afirmar que as imagens nos ajudam a compreender o mundo. As histórias também. Entretanto, as imagens nos informam, através das cores e formas, um universo que muitas 
vezes nos parece insondável. A memória sempre está associada a uma ou várias imagens. Às vezes, a memória se traduz por uma imagem que dispensa, ao menos momentaneamente, a narrativa. Ou mesmo, as imagens, são uma forma de narrativa que traduz o mundo com o impacto que dispensa o conceito. Por outro lado, as percepções, são imagens que na história dos indivíduos viria antes narrativa verbal. As lembranças oníricas, por exemplo, muitas vezes dispensam no primeiro momento a enunciação da palavra. Enfim, o queremos afirmar é o caráter importante das imagens na construção da memória.

O caráter imagético da memória pode ser detectado em inúmeros lugares e culturas. As culturas ágrafas, por exemplo, possuem várias imagens moldadas em símbolos que sustentam os rituais e costumes. Os sonhos também possuem relações próximas com as imagens. Até nas sociedades contemporâneas, as imagens se mostram muito presentes e às vezes usadas em excesso pela propaganda e como meio de dominação pela mídia. As cores também possuem uma intimidade com a memória; através delas atribuímos uma realidade palpável e simbólica, uma vez que as cores instituem realidades emocionais com o mundo cuja propriedade tentamos decifrar àquilo que nos escapa.

Por outro lado, a cidade onde moramos física e afetivamente é unificada por uma imagem mental. Os espaços familiares e escolares, por exemplo, estão carregados de imagens e cores particulares; a praça possui uma visão mental caracterizada nas lembranças. Assim, a cidade e nossa relação com ela se estabelecem através das imagens topográficas vivenciadas por cada percebedor.

A tradição ocidental está impregnada da relação entre o olho, o olhar e o conhecimento. Isso vai desde o caráter anatômico (o olho possuiria relação íntima com o cérebro) até as metáforas do olhar com a compreensão de si e do mundo. O crítico Alfredo Bosi atesta que a cultura grega já fazia essa relação. Segundo ele:

O vocábulo eidos, forma ou figura, é termo afim a idea. Em latim, com pouca diferença de sons: video (eu vejo) e idea. E os etimologistas encontram na palavra história (grega e latina) o mesmo étimo $i d$, que está em eidos e em idea. A história é uma visão-pensamento do que aconteceu. (BOSI, 1998, p. 65).

Curiosamente, a linguagem popular, em expressões correntes, está impregnada da relação entre o olhar e o conhecimento, e entre o olhar e o cuidado. Os narradores desta pesquisa 
estabelecem, de forma recorrente, essa ligação. Pois, memória, imagem, conhecimento, percepção possuem forte conexão. O trabalho, por exemplo, está carregado do olhar; pois exige uma atenção plena, que em último caso é um olhar profundo sobre seu ofício. O Sr. Antônio, por exemplo, revela suas ocupações: "Olha, a gente trazia as coisas da fazenda e vendia: arroz, feijão, milho". A expressão "olha" é um convite a perceber os acontecimentos que marcaram a vida do narrador. Para lembrar, seria preciso "ver"! Assim, é como se a memória pudesse ficar mais nítida com esta expressão.

Por um lado, poderíamos afirmar que a imagem é a presença de cor na retina, às vezes com forma e em perspectiva. Por outro lado, essa luz depositada na retina, através da ação psíquica do observante, é traduzida em sentido. Daí a experiência estética e de conhecimento da qual a memória se faz guardiã. Assim, todas as vezes que recordamos, nos tornamos capazes de acionar a "anatomia" das imagens captadas pelo olho e pelo cérebro e, neste mesmo movimento, compreender o mundo através dessa operação. D. Geralda expressa essa potência do olhar ao mencionar que "com a minha vó aprendi de olho, observando ela costurar".

As lembranças de D. Maria Stella estão carregadas de imagens: "Oh! Olhe ali, olha para ali”. Estas expressões não são apenas vícios de linguagem. Implicam associar a percepção, o olhar e a palavra em um único processo. Pois revela experiência estética e de conhecimento: "Olha o que tinha no quintal: jabuticabas (...) e também os lírios brancos e rosados”.

As histórias do Sr. José também estão carregadas de imagens. "A conversão do padre Sebastião e a história do tempo", narrativas que expressam a conexão entre imagem e significado a partir das lembranças. Desta forma, a narrativa seria uma visão e uma reflexão sobre um dado evento. Razão pela qual o Sr. José, ao falar da história da "Casa do Tempo", reflete sobre o tempo: "As pessoas temerosas com a falta d'água começaram a fazer promessas. Ajuntaram baldes de água para jogarem ao pé do cruzeiro (...). Tonico era muito observador (...)”. As imagens sobre o tempo vão aumentando, a tempestade, o dilúvio compõem a história.

Por outro lado, a imagens percebidas dos idosos, não são apenas subjetivas mas expressões objetivas. Os fenômenos e lugares percebidos - casas, ruas, praças, prédios, igrejas - são compreendidas como linguagem nas quais se apreende uma época historicamente vivida. As imagens, dessa forma, possuem e expressam concretamente a formação social da cidade. Isso 
dá concretamente nas narrativas dos idosos. Ou seja, as imagens dos lugares se transformam em experiência percebida. Desta forma, no ato de lembrar e narrar, fazem com que os idosos evoquem os lugares de memória e os relacionem à cidade. É importante notarmos que a imagem no início mental (como falamos acima) se referencia ao espaço da cidade. Até mesmo, a origem lendária da cidade, todos os memorialistas revelam o conteúdo imagético da memória. Assim, quando o coronel estava fugindo da onça, subiu em uma árvore e disse: "tudo que a minha visão alcançar será da santa". Por este caminho, a memória e as imagens, se relacionam intimamente com o espaço urbano. Um exemplo disso é a representação pictórica - desenho em quadros - da origem da cidade feita a partir das narrativas dos memorialistas; localizada no início desta pesquisa.

Desta forma, as imagens contidas nesta pesquisa (o material iconográfico apresentado ao longo da pesquisa) também ajudam a contar a história pessoal e da cidade. Todas as imagens expressam, nesta perspectiva, uma dialética do olhar entre os narradores e o espaço urbano. $\mathrm{O}$ diálogo entre observador das imagens, surgidas das lembranças dos narradores com o espaço da cidade, nos ajudam a perceber os movimentos da história individuais e sociais em relação às épocas passadas. Vemos, por exemplo, o mapa do viajante James Welles onde se localiza a antiga Tabuleiro Grande. A praça da igreja matriz e a capela do Rosário e o processo de reconstrução. A farmácia de Avelino Fóscolo, a sede da Gazeta de Paraopeba; as imagens dos inúmeros periódicos da cidade presentes desde o final do século XIX até os dias atuais e também as casas de Sabino de Paula Freitas e da D Anésia (antiga residência do "Seu Avelino"); além é claro das casas de pessoas anônimas. Podemos perceber também as imagens que retratam as mudanças da paisagem do espaço urbano. Também as imagens das ruas, comécio e sobretudo as pessoas representativas da história da cidade e dos próprios memorialistas estão demonstradas dentre outras, através do material iconográfico, ao longo desta pesquisa.

Além disso, as imagens dos vários jornais da cidade. Estes jornais atravessam e ilustram várias décadas da cidade. Através das imagens dos jornais é possível perceber: as atividades políticas e religiosas, a propaganda do comércio, eventos e festas da cidade. Sem contar as revelações da ciência farmacêutica das épocas passadas - como o coalho Harley - que proporcionou fortuna a Avelino Fóscolo; está retratada pela imprensa local. As imagens dos jornais apresentam também as atividade e publicação dos livros de Fóscolo e de outros 
cidadãos. Portanto, as imagens nos mostram o diálogo em que a iconografia oferece ao leitor elementos para a compreensão da história individual e urbana.

\subsection{A lembrança da religião e do folclore}

A religião católica no interior de Minas Gerais é muito presente. Paraopeba não seria uma exceção. Vemos esta expressão se manifestar de forma clara já na "lenda" fundadora da cidade. A cidadezinha nascera de uma promessa a Nossa Senhora do Carmo. Assim, com a carga da tradição católica, os narradores, expressam sua formação religiosa e sua fé.

A devoção a Nossa Senhora do Carmo consta nas narrativas primitivas da igreja cristã. Tanto que o primeiro templo erguido à Mãe de Deus ocorreu em uma cidade da região de Ática. Os vários nomes dados à Mãe de Deus correntemente se transformaram em distinções atribuídas às colônias de países católicos como a Espanha e Portugal. A primeira referência em Minas da Ordem do Carmo é encontrada em Mariana no ano de 1758. O ensaísta LIMA JUNIOR (2008) revela que o nome Carmo remete ao Monte Carmelo, local onde o Verbo Divino faria as revelações.

O fato é que essa devoção deu nome à Paróquia de Tabuleiro Grande, posteriormente Paraopeba. Demonstra desde o século XVIII costume enraizado na alma da comunidade. A formação do Sr. Antônio sempre esteve ligada à igreja católica. Desde a infância ele saia da roça para assistir a missa na então Vila Paraopeba. A missa era celebrada em latim e o padre se posicionava de costas para os fiéis. "Antes a gente não sabia o conteúdo da missa. Era um tum, tum, tum e a gente não sabia. Era o latim".

Depois, Sr. Antônio ingressou na associação São Vicente de Paulo. Até hoje ele é um confrade. O ensinamento cristão de ajudar aos pobres é um lema em sua vida. Reconhece a importância da religião em sua vida. Por isso ainda freqüenta assiduamente a celebração da missa e também das festas da igreja. A aprendizagem da religião começou na casa dos pais. Depois se casou com uma mulher muito católica e tinha como carisma a caridade.

Igualmente, D. Geralda, fora educada na fé católica. E participava, sempre que podia, das festas da igreja. Embora sua vida não tenha sido vivida tão próxima da igreja como a do Sr. Antônio. Mas a narradora sempre professou a fé e participa das missas. Gostava de ir à igreja 
e às festas dos santos: do Rosário e das quermesses de Nossa Senhora do Carmo. Essas festas eram o pêndulo onde oscilavam a fé e as alegrias mundanas. Eram nelas que se processava o encontro da comunidade, uma espécie de calendário de iniciação à vida coletiva. "A festa ocorria ali na região da Matriz. Não haviam desmanchado a Matriz ainda para reconstruí-la. Era a noite inteira o povo gritando no jogo das bolinhas, nos botequins...", confirma D. Geralda.

Diferentemente dos outros memorialistas, D. Maria Stella dedicou sua vida à devoção a Nossa Senhora do Rosário. Conta que desde criança ficava encantada com os tambores dos negros do congado. Sua mãe, a professora D. Anésia, possuía essa devoção da qual a fillha se tornou herdeira. "Ela tinha três devoções: Sagrado Coração de Jesus; Santíssimo Sacramento e Nossa Senhora do Rosário". As memórias de vida de D. Maria Stella, excetuando sua atividade de filha e de mãe de família, são impregnadas pela fé em Nossa Senhora do Rosário. Desde a época em que organizou a reconstrução da capela de Nossa Senhora do Rosário sua vida se encontra até hoje ligada a essa devoção. Portanto, a vida de D. Maria Stella está enraizada na religião. Desde pequena, quando subia a colina para buscar lenha, passava em frente a antiga igreja do Rosário e lembrava dos "vidros coloridos nas janelas. Eu ficava encantada ao ver o reflexo dessas vidraças...".

Essa igreja permaneceu nas lembranças dos narradores. D. Geralda lembra que "ela tinha um sino, e quando morria alguém, a gente escutava daqui o sino bater". Sua casa fica do outro lado da cidade, mas o som dos sinos ainda repica em sua memória. São, portanto, marcadores do tempo e da fé.

Mas D. Maria Stella sabe da importância de sua devoção a Nossa Senhora do Rosário. Depois da profanação, a igreja entrou em ruínas. Mas com a chegada do padre Mata Machado tomou a fala do sacerdote como desígnio: "vocês precisam arrumar essa igreja, porque com a igreja assim profanada a cidade não vai para frente!". Motivo pelo qual essa memorialista decidiu angariar donativos para a reconstrução da igreja. "fui em todas as casas! Logo depois fazíamos rifas, escrevia para as pessoas conhecidas pedindo ajuda". Sabe que aos poucos fui reconstruindo a capela e a cidade se transformou - "daí a cidade de Paraopeba começou a progredir!”. 
Dessa forma se esboça a tradição da comunidade. Com a fé e o empenho dos cidadãos. Assim, acredito que a festa do Rosário e seu congado "fazem parte da tradição dessa cidade. Se alguém acha que ele não faz parte da tradição daqui, ah! Ele tem que fazer!". Portanto, a narradora reconhece esse evento como vindo de sua fé e que se transpõe e se renova na comunidade, uma vez que se mostram enraizados na cidade.

Os termos "enraizamento" e "desenraizamento", a partir da filósofa Simone Weill, nos auxiliam a compreender as relações dos homens com o mundo. $\mathrm{O}$ enraizamento pressupõe que quando as pessoas estão enraizadas elas participam dos grupos que conservam as heranças das gerações passadas. Isso se dá através de ensinamentos, muitas vezes orais, dos mais velhos: as regras, o trabalho artesanal, as práticas éticas e morais.

Ao transmitir estes conhecimentos, os mais velhos, estariam enfatizando o caráter coletivo da memória. Pois as condições promotoras, pelas quais a comunidade enraíza o homem no meio social, dão vigor às gerações vindouras. Desta forma, esta atitude diante do mundo e dos outros pode ser sentida e percebida de forma palpável: o prédio da cidade preservado, a casa da família, um livro de orações, entre outros. As pessoas enraizadas recebem e transmitem os legados materiais, intelectuais e espirituais às gerações futuras.

A partir dessa perspectiva, as atividades enraizadas não podem ser encaradas como atividades passivas. Ao contrário, estão no seio da cidade, dos grupos, e promovendo a ação transformadora do cotidiano da comunidade. A tradição e o enraizamento se irmanam na tentativa de criar as raízes das pessoas através do trabalho, das festas, das idéias e da memória. Porque o passado não é inerte: “de todas as necessidades da alma humana não há outra mais vital que o passado" (WEIL, 1979, p 418).

“Minha religião sempre foi católica!" Desde moça ouvia a mãe tocar o órgão da igreja e convidar as pessoas para a missa. "Lembro-me que anos atrás vinham muitas missões para Paraopeba. Elas movimentavam as pessoas: sua fé, sua devoção". A religião, para a narradora, é o eixo onde se baseia sua vida. Exercendo as atividades na paróquia, as festas, a fé D. Maria Stella ressalta: “apenas sei que tenho que louvar e agradecer a Deus!", isto porque durante toda vida traçou seu caminho nesta perspectiva. Expressão que parece comungar com a filósofa que teorizou a importância divina na humanidade. Não deveríamos esquecer "que existe uma ordem divina no universo". (WEIL, 1979, p. 398). 
A cultura popular é uma expressão dos indivíduos e da comunidade ao longo dos tempos. Os meios pelos quais se percebe e se apreende a cultura popular são vastos. Acentuaremos alguns, a propósito de nossa pesquisa, somente aqueles que exibem uma conexão com a memória subjetiva e social dos narradores. Certamente o folclore se constitui como relevante expressão da cultura. Decidimos, refletir sobre a religião e o folclore no mesmo item, porque percebemos que os memorialistas os associam em suas lembranças. Por outro lado, a religião no interior de Minas, os aspectos folclóricos estão muitas vezes associados. Principalmente em nossa pesquisa, onde a festa de nossa Senhora do Rosário tem um forte apelo do folclore. Também os aspectos da religiosidade, descrita pelo Sr. José, têm também aspectos da cultura popular na medida em que resgata, em suas "Histórias", a narrativa do divino e do sobrenatural.

O universo folclórico, as narrativas populares estão presentes na vida das comunidades contemporâneas. Estas manifestações são ricas expressões da memória de uma comunidade, pois as narrativas populares não se encontram à parte da comunidade, ao contrário, estão presentes e atuantes em vários níveis da dinâmica social. A função do folclore e das narrativas populares se dá a ver quando estes "vão se acomodando às vicissitudes da vida sócio-cultural que transcende o âmbito estritamente rural, caboclo e rústico" (XIDIER, 1967, p. 9).

A festa do congado é uma forma de teatro popular apresentado nas ruas, cujo jogo cênico é composto por reis, rainhas, a corte, os mordomos, entre outros. Estrutura que nos deixa perceber a presença histórica dos embates entre mouros e cristãos, uma contribuição da cultura hispânica que se juntou ao legado da cultura africana. Do ponto de vista folclórico, o congado ocupa espaço de grande representação na festa de Nossa Senhora do Rosário. Assim, ela é "a festa cristã e os tambores dos negros dão o tom na festa popular" (ARAÚJO, 1973, p. 43).

As festividades do Rosário, trazidas pelos franciscanos no século XVIII, espalharam-se por toda Minas. Ela é a liturgia que rege os pobres e que vara os anos sem cansaço. Ela está em muitas vilas, "sempre branqueado no alto de um morro, tendo à frente um cruzeiro" (LIMA JUNIOR, 2008, p. 95). Além da fé católica, a festa de Nossa Senhora do Rosário dialoga, desde sempre, com elementos do folclore. D. Maria Stella não desconhece esta relação: "ele surgiu com nossos irmãos escravos. Foram eles que fundaram o congado. Criaram os instrumentos musicais: berimbaus, os tambores... Daí começaram a cantar, cantar e cantar". 
Reconhece também o preconceito que sofreu por ser coisa de negro. Mas para a narradora é grande expressão de fé: "os congadeiros dançam com tanta fé que fico encantada".

Recorda que a primeira capela do Rosário de Paraopeba fora construída pelo Sr. Veríssimo onde naquela época era tudo cerrado. Imagem que nunca saiu de sua lembrança. Hoje em dia continua refazendo a festa na cidade. Quando escuta os tambores do congado fica "doidinha". Pois “vive para essas festas. Até quando Deus me der saúde e vida eu vou continuar".

Dessa forma, os elementos da fé católica e do folclore convivem na história de vida da memorialista. A fé no rosário é muito importante: “já distribuir mais de três mil terços". Para a narradora, a tradição do congado está enraizada na sua vida e na cidade. Para D. Maria Stella é compromisso da fé e promoção da comunidade.

Por outro lado, o Sr. José expressa sua ligação com a religião de outra forma. Criado a partir dos preceitos de uma família muito católica, não se sentia bem nessa referência. Havia sido uma criança medrosa devido à punição do inferno. Era piedoso, mas acompanhava com um pouco de insatisfação essa forma de religião. Quando adulto se rebelou com a instituição religiosa. Decidiu buscar novas formas de expressar sua religiosidade: zen-budismo, kardecismo, maçonaria, ocultismo, ioga. Até encontrar Krishnamurti e Carlos Castañeda com os quais se identificou.

Daí, em sua vida, a religião deixar de ser instituída para ser "vivenciada". Prefere o caminho da religiosidade como expressão de autoconhecimento, por isso disse que tudo mais entrou em ruínas. No começo sentia dúvidas, depois a experiência do autoconhecimento apontou um sentido para sua vida. Para o Sr. José a religião assume o caráter de enfrentamento do mistério do mundo; convertendo-se em ação, uma prática, um exercício do transcendente, e "apenas ter a experiência do vazio", declara o Sr. José. O memorialista nos remete à dimensão mística da vida, uma operação da "graça na alma".

Com "plena atenção" o Sr. José refere-se ao estado de puro desprendimento, sem a tirania do ego. Talvez pudéssemos compreender a atenção como uma forma de "oração", uma expressão do amor aos outros, ao mundo. Assim poderíamos compreender, junto com Simone Weil, que: "a extrema atenção é o que constitui no homem a faculdade criadora, e só existe extrema atenção religiosa. A quantidade de gênio criador de uma época é rigorosamente 
proporcional à quantidade de extrema atenção, portanto, de religião autêntica nessa época" (WEIL, 1979, p. 386).

Por isso suas histórias narradas nos jornais em que escreve sempre deixam uma mensagem a esse respeito. A vida cotidiana assumiu, para o memorialista, outras perspectivas. Os eventos sobrenaturais ou transcendentais servem como ensinamento para uma vida mais plena, menos egoísta. As raízes das histórias parecem funcionar como "parábolas" vindas dos sertões de Minas, onde se misturam crendices, absurdos e, sobretudo, transformações.

Dessa forma, o Sr. José concebe a religião como um enfrentamento de um mundo misterioso e belo. A religião, para esse narrador, deve resgatar a dimensão etimológica da palavra: religare. Menos instituída e mais vivenciada, uma religiosidade que procura a superação dos pólos conflitantes como bem e mal, claro e escuro, ou, como ensina a filosofia oriental: o yin e o yang. Uma vida basicamente mística, já que essa perspectiva remete "ao mistério, ao desconhecido". Uma espécie de contemplação, da graça. Por isso a afirmação: "no fim é o vazio". Não como uma falta de conteúdo, mas a transcendência do conflito egóico. A religião promove assim uma união com o diferente, a comunhão o mistério da existência com a alteridade.

\subsection{A memória oral e a escrita}

É óbvia a distância entre a narrativa oral e a escrita, mas também "são inúmeras as ligações entre ambas". (CHARTIER, 2002, p.218). Podemos detectar elementos da cultura oral na escrita, como por exemplo, os escritos que utilizam o folclore, as expressões regionais, entre outras para compor suas narrativas. O fato é que os relatos orais estão também presentes nas publicações impressas e também o contrário. Percebemos também a presença da oralidade nas orações e cantigas lidas em voz alta; e dessa forma expressam a origem da oralidade na cadência da voz. Nesta perspectiva, a oralidade e a escrita dialogam com muita freqüência. Examinemos um pouco mais.

O romance clássico de Cervantes, D. Quixote, espelha essa relação, muitas vezes especular, entre relato oral e escrito. Pois o leitor imaginado por Cervantes deveria entoar várias vezes os tons das palavras para poder captar as múltiplas façanhas dos personagens que conferem 
sentido às narrativas do romance. Assim afirma o narrador: “(...) pois o gosto de ter lido tão pouco se tornava um desgosto de pensar no árduo caminho que se me oferecia para achar o muito que a meu ver faltava de tão saboroso conto". (CERVANTES, 2002, p. 131).

Desse modo, Cervantes já aludia à importância dos vários modos de ler. Uma leitura que não se restringia ao texto escrito, uma vez que era ampliada pelas elaborações do contador que presenciava e experimentava as mudanças do mundo. Percebemos que este romance está na intersecção de múltiplas maneiras de ler, ouvir e escrever: o mundo letrado, o universo da cavalaria, o folclore, dentre outros conteúdos que se desenrolam na narrativa. Por isso, cada forma de contar sofre influências do narrador e do leitor, que alteram sua forma e lhe conferem matizes diversos. Isto porque, a história está sob a tutela do tempo, promove mudanças na compreensão do texto. Cervantes conhecia isto e dizia que mesmo a narrativa "não estando escrita, haveria de estar na memória da gente de sua aldeia e dos lugares circunvizinhos" (CERVANTES, 2002, p.132).

Para estudarmos a complexa relação entre a memória oral e a escrita, gostaríamos de exemplificar com outra obra literária. Guimarães Rosa, autor de Grande sertão: veredas ${ }^{13}$, viveu e conheceu a região onde fizemos nossa pesquisa. A cidade de Cordisburgo é vizinha à Paraopeba. Anteriormente, as duas cidades possuíam a mesma jurisdição. Escritor erudito, Guimarães Rosa, soube utilizar a narrativa oral e transformá-la em elementos narrativos, poéticos e estéticos. Assim, Riobaldo, o narrador do romance, ao colocar no fluxo da narrativa provérbios, cantigas, causos, paródias e reflexões sobre a subjetividade, revela-se, através de sua memória prodigiosa, um narrador oral de grande amplitude. Ao contar, Riobaldo, insere os elementos da narrativa oral no romance. Desenvolvendo assim uma narrativa onde uma coisa puxa a outra, um "causo" desemboca em outro, como na imagem de um rio com múltiplas margens e fronteiras fluidas. Assim e narrador nos esclarece:

A lembrança da vida da gente se guarda em trechos diversos, cada um com seu signo e sentimento, um com os outros acho que nem não se misturam. Contar seguido, alinhavado, só mesmo sendo as coisas de rara importância. De cada vivimento que eu era como se fosse diferente pessoa. Sucedido, desgovernado. Assim eu acho, assim é que eu conto. (ROSA, 1989, p.77).

\footnotetext{
13 Aprofundamos os estudos relativos ao referido tema em nossa dissertação de mestrado que se encontra referenciada nas fontes bibliográficas que sustentam este trabalho.
} 
Obviamente os memorialistas de Paraopeba não são artistas da amplitude de Cervantes e Guimarães Rosa. Entretanto, podemos perceber que o que chamamos de "cultura erudita" e “cultura popular" precisam ser ponderadas. Pensemos, pois, no seguimento que nos interessa aqui: memória oral e escrita. Sabemos que muitas sociedades repassavam seus conhecimentos sem fazer uso da palavra escrita. E mesmo hoje, com o avanço da cultura escrita, a memória oral ainda persiste, por exemplo, nos rituais de casamento e, em certa medida, no tratamento psicanalítico. Visto que, para o psicanalista, a voz e a narrativa do paciente serão importantes na condução da cura.

Do ponto de vista social, as relações entre essas duas instâncias - oral e escrito - são intercambiáveis. Percebemos isso nas práticas, nos pensamentos, nos rituais das pessoas “comuns". Nestas pessoas, as narrativas, são sempre combinações de formas escritas e orais; por exemplo, os ritos religiosos, o folclore. Mas também os narradores da cidade de Paraopeba, em escala menor e diferenciada, nos mostram que a memória de suas vidas e da cidade, apresenta elementos orais e escritos. Ajudando, assim, a dar sentido à pluralidade de certas práticas individuais e sociais.

A memória, seja ela oral ou escrita, é um meio de preservar, transmitir e de conhecer as experiências de cada um e dos outros. Através das lembranças conseguimos, ainda que parcialmente, compreender os que estão distantes de nós, no tempo e no espaço. Por isso, nos tornamos capazes de nos sensibilizar pelos efeitos dos sentimentos e estilos de vida cujas vivências nos são estranhas. E, deste modo, mesmo que obliquamente, nos apoderar de seus valores.

Os memorialistas nos mostram estas relações de várias maneiras. Dentre elas podemos perceber a identificação dos hábitos e valores das gerações a que pertencem. O Sr. José, em suas lembranças, consegue apontar através das histórias publicadas nos jornais a relação do oral com o escrito. Usa o artifício de "titia" como sendo a narradora principal de seus textos. Neles estão as histórias da cidade que intitulou de "sobrenatural". Embora sejam histórias de pessoas "comuns", são escritas por alguém que tem cultura letrada: "eu tinha uma tia chamada D. Mindita, ela era uma contadora de histórias nata. Ela morreu com 104 anos. Titia, é como eu a chamo na minha coluna no jornal, narrava muitas histórias da cidade”. 
Há também elementos do folclore, dos ditados populares, humor, anedotas. A própria estratégia de "aconselhar" ou "passar mensagens" de "transmitir as experiências" está diretamente relacionada com a transmissão da cultura popular por meio de exemplos (embora o narrador afirme não desejar fazer "uma seita" que se coloque como dono da verdade). Ao contar as histórias relatadas pela "titia" e ouvidas por ele, o Sr. José as transforma em texto escrito demonstrando a possibilidade do intercâmbio entre ambas.

Além disso, há na cidade uma enorme quantidade de periódicos que circularam fazem mais de cem anos, cuja profusão corrobora nossas afirmações. Estes periódicos ${ }^{14}$ tinham cunho informativo, mas também anedótico e relatavam situações peculiares da comunidade. Os próprios títulos destes periódicos indicam isso: A urucubaca, O buraco, O alfinete. Assim, numa perspectiva ampla, podemos afirmar que a imprensa na cidade, em funcionamento desde o final do século XIX, contribui para preservar tanto a cultura letrada como a oral em circulação em Paraopeba. Assim, podermos afirmar que uma forma de comunicação dialoga com a outra. O Sr. José afirma que "aqui na cidade existe atividade jornalística há anos, desde o século XIX". Deste modo, este memorialista se coloca como divulgador desta tradição jornalística e também oral.

Mas o que é escrever? Não é tornar o que se vê na natureza uma descrição fiel; cuja finalidade seria fazer com que os leitores acreditassem na similitude perfeita entre forma e conteúdo. Nem é uma operação métrica de certeza e equilíbrio. Talvez, seja exatamente o contrário, pois aquele que busca a "adequação" no ato de escrever possivelmente não terá bons resultados. Pensamos que uma resposta possível para nossa questão seja que escrever é movimentar os signos, explorar as palavras em múltiplos sentidos e significados de forma a "reordenar $e$ reorganizar os símbolos". (CHAUÍ, 2002, p.19).

O Sr. José se aproxima dessa prerrogativa quando afirma que "para as histórias fazer sentido, eu dava o enchimento e escrevia à minha maneira". Dessa forma, o "enchimento" é a capacidade de, na escrita, direcionar o enredo das histórias e, nesse mesmo movimento, preservar o saber e o espírito da narrativa oral. É procurar o "sobrenatural", na expressão do memorialista, e torná-lo compreensível para o leitor. Aqui o leitor se aproxima da noção de ouvinte, já que as narrativas orais se destinam aos ouvintes e estes, como o leitor, podem

\footnotetext{
${ }^{14}$ Os leitores interessados poderão observar exemplos destes periódicos nas iconografias presentes no corpo desta pesquisa.
} 
interpretar as histórias. As histórias não são apenas acontecimentos de Paraopeba, elas "ocorrem em outras regiões. Na verdade, são o espírito de uma época" - conclui o narrador.

Desde jovem o Sr. José lia os clássicos com o objetivo de "conhecer a natureza humana". Sabia que há um parentesco entre as atividades de ler e escrever: "acredito que haja uma relação entre ler e escrever". A leitura "lhe dá munição, argumentos para desenvolver a escrita". O narrador também se posiciona de maneira diferente no cerne das culturas eruditas e populares, mas as histórias escritas pelo Sr. José no jornal se detêm "mais na cultura popular embora a cultura erudita vai atrás". Estas duas facetas da narrativa, oral e escrita, estabelecem intercâmbios. Criam um "campo" onde uma dialoga com a outra.

Por outro lado, nenhuma cultura se forma isoladamente. Ela se dá através da heterogeneidade por meio da qual diversos grupos sociais promovem relações de intercâmbio. Por isso a idéia de "cultura popular" se mostra imprópria. É como se quiséssemos encontrar uma essência, um fim último separado das outras esferas sociais. Pensando assim, "popular" e "erudito" se aplicariam a uma tendência excludente e estanque. É importante, ao contrário, encontrar o diálogo entre as diversidades presentes das sociedades.

Dessa forma, acreditamos que o oral e o escrito devem ser reconsiderados. O que designamos de "oral" muitas vezes encontra ressonância em textos escritos. Imagens, regras, falas se amalgamam nos falantes e ouvintes que, por sua vez, também podem se fazer presentes na escrita. A sobrevivência da memória da cultura popular se liga diretamente à transmissão das expressões orais e dos ensinamentos da comunidade, não excluindo a escrita, mas se apropriando dela. Ou, na ausência dessa escrita, compensá-la com as vozes veiculadas na comunidade. Através da narrativa oral, preserva-se também a memória local.

Há uma constatação óbvia, mas que, todavia pode passar despercebida: trata-se da afirmação de que naturalmente o ser humano é um ouvinte e um falante, não um escritor. A escrita é uma aquisição cultural, tanto que, ainda hoje, certas sociedades vivem sem escrita e nem portanto são consideradas “inferiores”. Na Grécia homérica, por exemplo, através dos poetas cantadores se armazenavam muitas informações e também fazia parte do entretenimento. Como também a Bíblia cuja maioria de suas narrativas possuem origem oral. 
Daí a importância da oralidade. Mas a eficiência na transmissão das informações residia, na antiguidade, pela presença de fatores no mínimo engenhosos, cujo mais estudado é a capacidade rítmica e narrativa dos cantadores orais. A economia da sintaxe, por exemplo, para descrever as ações dos heróis auxiliava a memorização dos oradores. Por isso, sociedades como a grega, com a eficiência do seu alfabeto, conseguiram imprimir seu legado cultural ao ocidente. Nesse ínterim, a oralidade atua como "complemento" das aquisições abstratas da cultura escrita. Daí podermos afirmar que a oralidade e escrita se inscrevem na cultura de forma definitiva.

Walter Ong aborda de forma esclarecedora as relações entre a cultura oral e a escrita, procurando a ressonância que existe entre os elementos orais que subsistem nas culturas letradas. Dessa forma, vale lembrar a importância da memória verbal nas culturas orais. Embora a cultura letrada não prescinda totalmente dessa modalidade de memorização. A faculdade de memorizar se revela, por exemplo, nas transmissões orais presentes na cultura popular. Sobretudo, segundo ONG (1998), através dos contos, advinhas, poesias populares, dentre outros.

Entretanto, Ong, afirma que a memorização verbal das culturas que possuíam escrita era diferente das culturas basicamente orais. A memorização verbal assentada em um texto escrito tem sempre a possibilidade de ser conferida. Mas nas culturas ágrafas a única forma de obter o conteúdo memorizado era através, da repetição literal do texto, realizada pela recitação simultânea das passagens narradas. Assim, as sociedades sem escrita contavam apenas com a memória prodigiosa dos recitadores para transmissão dos conhecimentos.

Uma das características da cultura oral é a tradição heróica elaborada através das gerações. Os indivíduos notáveis são transformados em exemplos para a sociedade, de forma que os feitos notáveis de cada um deles acabam por compor um relato digno de ser memorizado. Assim, indivíduos - Ulisses, Aquiles e Jesus Cristo, por exemplo - pertencem a essa categoria. Também narrativas como as do Chapeuzinho Vermelho, da Gata Borralheira, imprimem de alguma forma esses predicados para a comunidade. Os heróis são depositários de exemplos de virtude e coragem.

Os elementos da cultura popular ganham forte ressonância nas lembranças dos Sr. José, quando o mesmo se apropria da temática da "assombração" para falar do adultério na 
comunidade. Há também em suas narrativas outros exemplos. É o caso do costume de "curar de cobra na sexta-feira da paixão”. Estas narrativas, entre outras, estão na memória social da cidade e ajudam a elaborar e a conformar os elementos culturais do povo. São formas de preservação das culturas populares. Elas são exemplos de virtude que acaba por revelar regras e costumes da cidade, mas que são transmitidos com humor.

Há outra perspectiva da tradição que se revela pertinente e atuante nas lembranças dos narradores. Trata-se da imaginação do povo, passada através do tempo, que tratam dos "costumes populares" como os fenômenos da natureza: a chuva, as estações dos anos, da botânica. E também elementos folclóricos: o lobisomem, as crenças, "visões”, dentre outros, permanecem na cultura da comunidade. Assim, "a tradição, no sentido antropológico, guardaria uma "psicologia popular" que traduziria conhecimentos passados oralmente e transmitidos de geração em geração". (CASCUDO, 1971, p 9). Não queremos esgotar este assunto e nem poderíamos. Porque a "cultura popular" se desdobra em muitos casos e vertentes, impedindo uma leitura unilateral. O diálogo das esferas oral e escrita, denota essa impossibilidade. Na medida em que ao escrever e reescrever determinadas histórias se reinventa a tradição local.

A conversão do padre Sebastião, por exemplo, reverbera nas lembranças dos narradores. As "histórias" do Sr. José, que confessa que esse fato o marcou muito, por isso resolveu escrevêlo. Segundo o memorialista, as "histórias permanecem no inconsciente coletivo". Diz ainda que não se considera literato e que escreve para distrair e para passar aos outros o que acredita. Segundo ele, o ser humano gosta das histórias que formam e dão base mental a cada um..

É neste espírito, apontado pelo Sr. José, do gosto pela fabulação que podemos pensar no legado dos memorialistas. Eles nos contam feitos de gerações anteriores que nos auxiliam a conhecer a comunidade, seus hábitos e costumes. Através da linguagem os narradores têm nos apresentado à manifestação da alma humana: o mito, a advinha, o caso, o ditado. São exemplos de expressões presentes no imaginário oral das comunidades. O Sr. José, através de sua fala e de sua escrita ressalta o elemento lúdico e "educativo" de suas lembranças. Os outros narradores, embora não cultivando a prática da escrita, afirmam o poder da expressão oral. O Sr. Antônio, por exemplo, usa a expressão "uai” várias vezes durante suas lembranças. Tal expressão está presente na comunidade há tempos (como demonstramos esta expressão 
está presente nesta região e na comunicação das pessoas desde o século XIX ) e é utilizada para expressar ou ressaltar certas lembranças. É por isso que detectamos que a palavra escrita e a oral, isso fica claro nas narrativas dos memorialistas, se relacionam para dar sentido aos conteúdos individuais e sociais.

O Sr. José conta uma história que se chamava: O homem que ajudava a morrer, segundo o narrador, quando a pessoa adoecia e ficava agonizando na cama durante muito tempo, era chamado um "homem possuidor de poderes e conhecimentos... Mas sabe o que ele realmente fazia? Sozinho com o enfermo e debulhando o rosário, botava o cotovelo em cima do pescoço da pessoa e o apertava internamente (...). Esse homem matava as pessoas". O narrador dizia que era um fato que ocorria na cidade de Paraopeba. Pelo seu conteúdo trágico e assustador, permaneceu na memória da cidade.

Esse costume não se manifestava apenas em Paraopeba. Parece que ocorria em outras cidades de Minas, mas diferentemente da narrativa do Sr. José, revelava o envolvimento de certas pessoas com a perseguição aos judeus no Estado. Assim atesta o historiador:

\footnotetext{
Afirma-se que quando um judeu disfarçado, ou seja, "marrano", estava para morrer, a fim de evitar que no momento ele se revelasse adepto da lei de Moisés, comprometendo os demais, era logo chamado o "abafador", isto é, um sujeito que tinha por missão estrangular habilmente o doente. Isso permaneceu em nosso costume como os conhecidos personagens que “ajudavam a morrer". (LIMA JUNIOR, 1978, p. 85).
}

Portanto, vemos aí uma a modalidade da narrativa oral que se desloca e se junta a outros elementos.E que por sua vez geram outros comportamentos. Na comunidade onde o Sr. José colheu esta história não há referências a judeus, mas sim a indivíduos com orações poderosas e conhecimentos duvidosos. Era alguém que desfrutava ou que queria algum destaque na comunidade. A narrativa, ou mesmo o fato se desdobrava em outros elementos narrativos, embora o ato de "ajudar a morrer" permaneça nas cidades, em suas memórias orais e escritas.

\subsection{A memória da imprensa}

Com a criação da imprensa local, por Avelino Fóscolo, no final do século XIX, a antiga Tabuleiro Grande nunca mais foi a mesma. Esse fato marcará e memória dos cidadãos e da 
cidade, uma vez que a atividade jornalística está presente até hoje na comunidade. A presença do Sr. Avelino e de seu aprendiz, o "Seu. Neném”, é constante nas falas dos memorialistas. A presença se faz através: das disputas políticas, dos festejos, do pequeno comércio, dos exercícios literários, estão todos presentes, ao longo dos anos, nos diversos periódicos que a cidade produziu.

As máquinas rústicas que imprimiram o primeiro periódico, na história da imprensa mundial, não afastaram ou fizeram diminuir o conhecimento oral. Do ponto de vista histórico, a criação da imprensa trouxe algumas consequiências históricas. Dentre elas, a invenção de Gutenberg, mudou do copista para a oficina; pois já "no final do século $X V$, a reprodução de materiais escritos começou a transferir-se da escrivaninha do copista para a oficina do impressor". (EISENSTEIN, 1998, p. 17). Na pequena Tabuleiro Grande os moradores não dispensavam, como era de se esperar o aprendizado oral, como as pregações dos padres e nem as rezas dos curandeiros pelas publicações impressas. Até as missas celebradas em latim, segundo o Sr. Antônio, não o impedia de ir à celebração. Naquela época, muita gente não sabia ler nem escrever. Mas a imprensa floresceu na cidade. Desde o início da imprensa mundial a transmissão oral não sucumbiu à impressa.

Os periódicos elaborados em Paraopeba, ao que parece, tinham várias facetas. E, ao longo do tempo, foram incorporando outras formas e também objetivos diferentes. No começo, com "Seu Avelino", os jornais eram utilizados para divulgar ideais políticos e libertários, e romances em folhetim. Ele publicava, em forma de folhetim, partes de romances que posteriormente foram publicados como livro. O "Seu Neném" - como era chamado o jornalista Manuel Antônio da Silva - divulgou por mais de 40 anos a Gazeta de Paraopeba, que tratava desde questões políticas, divulgação dos eventos festivos da cidade a propagandas do comércio. Isso só para ficarmos nas figuras emblemáticas da imprensa local, mas ressaltamos que outras existiram. Dentre os jornalistas é possível citar o poeta Sabino de Paula Freitas, com o periódico "A Aliança"; o jornalista e memorialista Agnaldo Edmundo Silva, com o seu "O Divulgador"; e o farmacêutico e, posteriormente, padre Sebastião Ribeiro Vianna, em "Vila Paraopeba" que discutia questões políticas da cidade (todos estão retratados em imagem nesta pesquisa).

Os jornais do final do século XIX publicaram muitos romances em forma de folhetim. Balzac e Eugène Sue foram exemplos franceses. Aqui no Brasil, Machado de Assis se utilizou desta 
forma de divulgação. Assim declara a ensaísta em relação ao folhetim: "Demonstra a forma pela qual os escritores exerciam seu ofício, diferentemente da forma 'séria' impressa em livros". (MEYER, 1996, p.33). O escritor Avelino Fóscolo, em Tabuleiro Grande, publicou muito dos seus romances em folhetim. Os romances retratavam o drama humano em paixões, ódio, vingança e também os ideais políticos se convertiam em ingredientes narrados a "contagotas" nos folhetins. Desde o periódico "A Vida", de 1893 foi o primeiro jornal da cidade, Fóscolo instituiu uma narrativa romanesca, posteriormente utilizada nos livros impressos ${ }^{15}$. Curiosamente, a antiga Tabuleiro Grande teve o primeiro jornal antes de Sete Lagoas da qual pertencia. Sete Lagoas teve seu primeiro periódico em 1895. Essa data também foi do primeiro jornal de Belo Horizonte, O Bello Horizonte, que foi veiculados em 1895 e todos se configuravam como periódicos de vida efêmera.(CASTRO,1997)

Em suas lembranças, o Sr. Antônio afirma: “O 'Seu Neném' fundou a Gazeta e era aprendiz do 'Seu Avelino'. Embora eu não tenha conhecido o 'Seu Avelino', conheci os filhos dele”. O narrador era leitor da Gazeta de Paraopeba e "Seu Neném" era uma pessoa muito conhecida na cidade, era "bondoso e caridoso". Essa memória do Sr. Antônio é acentuada pela de D. Geralda, que diz que o 'Seu Neném' “comprava os jornais dos meninos só para ajudar”. O Sr. Antônio relembra dos conflitos políticos entre o farmacêutico Sebastião e o padre Augusto Horta presentes no jornal, indicando que seria "A Gazeta de Paraopeba"; mas descobrimos que as brigas políticas do farmacêutico Sebastião foram veiculadas no jornal "Vila Paraopeba".

D. Maria Stella afirma que o irmão Wander Moreira formou-se em jornalismo. "Ele falava e conhecia várias línguas. Foi um jornalista respeitado e também escreveu na "Gazeta de Paraopeba". Sabe da importância da imprensa na cidade e relata que Avelino Fóscolo foi importante, ressaltando que "é preciso resgatar essa memória". Revela a memorialista que "o idealista Avelino, acalentava o sonho de fundar aqui um jornal. Somente alguém como ele, vivendo em pleno centro de Minas, no sertão inculto do Brasil, com muita dificuldade de transporte, se lançaria nessa aventura". Desta forma, afirma a narradora “ idealizou um

\footnotetext{
15 É importante mencionar que na cidade circulou, além dos periódicos acima mencionados, vários outros, dentre os quais citamos: $A$ vida, $O$ industrial, Nova Era, Bebé, $O$ crepúsculo, $O$ mosquito, $O$ elephante, $O$ tabuleirense, $O$ leque, $O$ macaco, A faísca, $O$ ensaio, $O$ lidador, $O$ sibelo, $O$ mimo, $O$ operário, $O$ bugary, $O$ bistury, Folha do Cedro, O riso, Villa Paraopeba, A defesa, A urucubaca, Pão d'água, A rua, O alfinete, $O$ então, O divulgador, O gavião, A notícia. Além da Gazeta de Paraopeba que foi editada por mais de quarenta anos.
} 
pequeno "prelo" manual e encomendou um artesão para construir um de madeira. Soube que adquiriu alguns tipos em seis de janeiro de 1893 e editou o primeiro jornal "A Vida".

D. Maria Stella expressa assim a memória dos jornalistas da cidade " não se pode esquecer do nome de Manoel Antônio da Silva, que lutando ao lado do povo e dos interesses de Paraopeba, manteve o semanário insuperável a querida "Gazeta de Paraopeba". A memorialista atesta a importância do jornal para a mobilização e divulgação da reconstrução da igreja. "O Sr. Neném, editor da Gazeta de Paraopeba, se dispôs a ajudar na arrecadação dos donativos. Está publicado na Gazeta de Paraopeba”.

O Sr. José não é jornalista de formação, mas exerce esta atividade na cidade. Resgatando em suas "Histórias" a dimensão oral da memória da comunidade. "Lembro do Sr. Neném, pois era seu barbeiro na juventude". O narrador afirma que lembra do jornal: "Recordo que ia, ainda menino, nas oficinas da Gazeta de Paraopeba. Via as máquinas rústicas e as pessoas trabalhando nelas. O jornal era feito durante a semana e, aos sábados, trabalhava-se até altas horas, para sair no domingo". Permanece ainda em sua memória a atividade do jornalista Manuel da Silva, porque "às vezes, minha coluna faz referência à Gazeta de Paraopeba".

A herança da imprensa de Paraopeba está presente nas lembranças dos narradores, inclusive como exercício, como ofício da palavra. O Sr. José, a partir da década de 1980, fundou o "Repórter de Paraopeba", que acabou, e depois o "Jornal de Paraopeba", que circula há dezoito anos. O memorialista já teve uma coluna chamada "O caminho do meio" no Repórter de Paraopeba. Agora, no Jornal de Paraopeba, a coluna passou a se chamar "Histórias". Tem um objetivo claro: "Vou colocando subliminarmente as minhas crenças e introduzindo algumas visões de mundo em que acredito". Com suas "Histórias" o narrador "descobriu os costumes daqui, aqueles ocorridos antigamente...”.

A imprensa de Paraopeba sobrevive e recria a cidade a partir das lembranças e da palavra escrita. Dialogando com as gerações passadas através das "Histórias", das atividades políticas e da utilidade para a comunidade. Todos os memorialistas fazem referência à imprensa. Ela participou e ainda participa das manifestações subjetivos e sociais. No aspecto subjetivo, como expressão dos ideais literários e políticos; no social, como promotora da tradição local. E como palavra escrita, a imprensa de Paraopeba é expressão do enraizamento na alma dos cidadãos. 


\subsection{A história de uma conversão}

Consta que Sebastião Ribeiro Vianna ${ }^{16}$, nasceu em São Sebastião, Distrito das Almas no município de Curvelo-MG, era filho de Eloy Ribeiro Bhering e Francisca de Freitas Vianna e formado em farmácia pela Universidade de Ouro Preto. Há outra informação que revela que Sebastião Vianna tenha nascido em Cachoeira dos Macacos atual cidade de Cachoeira da Prata-MG. Ordenou-se Padre em 15 de agosto de 1927. Depois da ordenação veio para Cachoeira dos Macacos, onde permaneceu por dois meses ${ }^{17}$. Em seguida veio para Villa Paraopeba onde trabalhou como capelão da fábrica do Cedro. Faleceu no ano de 1949, na cidade de Cachoeira da Prata-MG (antiga Cachoeira dos Macacos), onde está enterrado.

Há um episódio pitoresco e que marcou a história da cidade. Trata-se do confronto do então farmacêutico Sebastião Ribeiro Vianna com o Padre Augusto Horta. Isso ocorreu no ano de 1915. Essa disputa teve como palanque dois periódicos existentes na cidade. O periódico "A Defesa", que tinha como um de seus redatores o padre Augusto Horta e se afirmava como “orgam catholico, defensor dos direitos da religião e do povo". $\mathrm{Na}$ outra ponta, o periódico "Villa Paraopeba", cujo redator-chefe era o farmacêutico Sebastião Ribeiro Vianna. Tal jornal se intitulava "semanário político e comercial".( ver iconografia dos periódicos em anexo)

Durante alguns meses esses jornais serviram como plataforma política e religiosa. De um lado editores católicos, do outro os ateus. O fato é que transparece nos periódicos um intenso debate sobre o direito ou não de se proibir o enterro de cidadãos no cemitério local ${ }^{18}$. Neste momento a expressão "prohibindo as inhumações" se tornou recorrente naquela época nos periódicos A defesa e Villa Paraopeba daquela época.

Conta-se que o farmacêutico ateu ocupava o cargo de $1^{\circ}$ secretário na câmara municipal e fazia oposição ao então vigário da cidade, o padre Augusto Horta que também era dado à atividade política na comunidade. Ao que parece, uma mistura de elementos políticos,

\footnotetext{
${ }^{16}$ Fonte: Gazeta de Paraopeba, edição de 21 de agosto de 1927.

${ }^{17}$ No livro de tombo da Paróquia de Paraopeba-MG conta que a ordenação do padre Sebastião se deu em 1928. Nele encontramos a seguinte afirmação: "Por procissão de janeiro de 1928 foi nomeado coadjunto desta freguesia o Revmo. Irmão Padre Sebastião Ribeiro Vianna ordenado em Diamantina no mez de julho. Sua Revma. Entrou logo no exercício do seu cargo. Graças infinitas agora dadas a N. Senhor".

${ }^{18}$ No livro de tombo da Paróquia de Paraopeba-MG consta a seguinte afirmação: "1916 - constituiu o cemiterio catholico - construido ao lado do civil. Essa entrega foi proveniente de um acordo entre o vigario e a autoridade civil”.
} 
ideológicos, religiosos e até pessoais esquentaram os ânimos da recém criada Villa Paraopeba $^{19}$.

A disputa entre os dois jornais ganhou ares de uma certa "cruzada" no sertão de Minas Gerais. De um lado o partido situacionista representado pelo jornal "A Defesa”, editado pelo padre Augusto Horta e o médico Dr. Theóphilo Nascimento. Do outro lado, o "Villa Paraopeba”, representado pelo farmacêutico ateu Sebastião Ribeiro Vianna e pelo Coronel José Jorge. Assim, no primeiro número do periódico Villa Paraopeba, que veio à luz em 22 de agosto de 1915, o redator-chefe Sebastião Ribeiro Vianna dispara sua queixa:

\begin{abstract}
Accusado por pessoas que exploram a boa fé e a religiosidade do público, o partido situacionista local tinha necessidade de um órgão que viesse aliviar as injustas aleivosias e provar que o acto da Câmara Municipal e do Dr. Delegado de hygiene, prohibindo as inhumações fora do cemitério civil, não era mais que a ractificação da lei $n^{\circ} .12$ de 1893 elaborada pelo saudoso hygienista Dr. João Antônio de Avellar e os distintos sacerdotes Raymundo Vaz de Mello e Pedro Nunes dos Santos. Esses homens viam acima dos pequenos interesses pecunianos o bem estar do povo e reconheciam bem justos os clamores de imprensa local de então contra os males decorrentes das inhumações no cemitério e no tempo tão desastradamente collocados com relação a saude dos habitantes de Taboleiro. (VIANNA, 1915, p.1).
\end{abstract}

Percebemos o tom da narrativa inquisitivo e pomposo. O Jornalista Jair Silva, em uma conferência no ano de 1958, realizada em Paraopeba, já chamava a atenção para as palavras rebuscadas e difíceis do periódico do farmacêutico (SILVA, GAZETA DE PARAOPEBA,1958, n. 8). O fato é que as acusações foram se arrastando. Os dois periódicos ganhavam contornos ora de púlpito, ora de tribuna. Os ateus declaravam que a proibição dos enterros era importante e que a mudança do cemitério necessário, caso contrário colocaria em risco a população, já que o cemitério localizava-se em uma região onde havia muitas cisternas e as pessoas podiam se contaminar.

Segundo o padre Augusto Horta todos que concordassem com as críticas veiculadas no periódico contra "A Defesa" estavam em desacordo o direito canônico, uma vez que se queria proibir enterrar os mortos em um cemitério da igreja. "Eis o nosso caso. A câmara legislou contra o direito canonico prohibindo enterramentos em um cemiterio catholico, sem combinação alguma com a autoridade ecclesiastica que devia ter sido ouvida e consultada antes do nascimento da mencionada prohibição" (HORTA, 1915, p. 4).

\footnotetext{
${ }^{19}$ Pouco mais de dois anos antes a cidade era conhecida pelo nome de Tabuleiro Grande.
} 
As acusações e respostas se arrastaram por meses. Argumentos contra e a favor se revezavam nos jornais. Procurando se alicerçar em bases técnicas, citando higienistas e leis da época, os ateus (eles se declaravam ateus e a comunidade os viam dessa forma) acusavam os católicos de serem manipuladores, pois "o machiavellismo da "Defesa" redunda na revolta de todas as consciências esclarecidas contra a incoherência enequívoca entre seus programas e sua acção". (VIANNA, 1915, p.1). Encontramos no número 7 do periódico Villa Paraopeba uma resposta contundente dos redatores ao padre Augusto Horta. O farmacêutico e o coronel acreditavam que tal padre usava a influência da igreja onde não era sua competência. $\mathrm{O}$ coronel José Jorge assina essa resposta: "O representante da igreja estaria abusando, para suas propagandas eleitoreiras, da eminencia da tribuna sagrada, que só deveria ser destinada a proclamação das verdades históricas do catholicismo, cujas raizes, dulcificadoras dos costumes sociais já se abastaram por isso mesmo pelo universo inteiro". (JORGE, 1915, p.1). Embora assinada por José Jorge, sócio do jornal Villa Paraopeba, foi o então editor Sebastião Ribeiro Vianna que a editou e publicou. O tom da resposta é do farmacêutico Sebastião.

Não sabemos o que se sucedera depois desse ataque. Não há outros periódicos depois dessa data. Apenas Jair Silva, em seu livro de memórias, se referindo ao padre Augusto Horta, declara: "ao contrário do que succedera sempre, o padre perdeu a questão - se refere ao padre Augusto Horta". (SILVA, 1934, p.31). Esse episódio permaneceu na memória da cidade. Os narradores lembram que houve uma disputa e que por isso, após a conversão do Sebastião Ribeiro Vianna, este não cansou de pedir perdão ao padre Augusto Horta. Afirma o Sr. Antônio: "Soube que depois da conversão dele [padre Sebastião], ele pediu perdão ao padre Augusto Horta".

Entretanto, há uma crônica anterior ao embate dos dois periódicos que aponta outras questões. Foi publicada na Gazeta de Paraopeba em janeiro de 1914 e recebeu o título de "Panoramas". Nesta crônica, Sebastião Vianna foi visitar, junto a um amigo, a fazenda Boa Vista. Com tom impressionista pinta com cores fortes a paisagem que presenciara. Avistando o horizonte em que o "observador lá do ponto culminante se vê no centro de um círculo imenso". Essa visão o deixa uma mistura de admiração e de tristeza presente em sua percepção.

Diferentemente do tom ofensivo presente no Villa, esta crônica publicada um ano antes mostra outra faceta de Sebastião. A sua descrição é minuciosa: planícies, montanhas, casinhas 
de cor indefinível, camponeses, o sol rubro, são todas imagens que o farmacêutico vai descrevendo. Mas em um determinado momento, o tom enseja nos leitores uma referência quase mística. Diferentemente do escritor do ano de 1915, cheio de ataques e se definindo como ateu. Assim o crepúsculo evoca imagens e sentimentos: "a força de querer resolver esse mistério, a impressão de quem se embebe na contemplação desse quadro, vai se tornando quase dolorosa, e a montanha começa a se presentificar como um túmulo que encerra despojos queridos... A montanha é espectro e é abismo". (GAZETA DE PARAOPEBA, 1914, p.01).

Entre as imagens descritas, o farmacêutico cronista, observando a fazenda Boa vista e afirma que "a montanha é uma mentira", mesmo afirmando que suas percepções são miragens, ilusões, identifica nos horizontes remotíssimos pontos luminosos, brancos na escuridão das elevações: "são três templos do cotidiano colocados lá bem no alto a refletir a obra do Calvário sobre a área imensa que abrangem”. (GAZETA DE PARAOPEBA, 1914, p.01).

Nessa época, não havia a tribuna do jornal "Villa Paraopeba" e nem sequer a possibilidade de conversão. Entretanto, ousamos pensar, como exercício de comparação, que o ateu e farrista farmacêutico era tocado pela beleza impalpável do crepúsculo. Ali, na narrativa da crônica, havia uma mescla de sentimentos que atestavam a transitoriedade das coisas. Naquele momento, o farmacêutico, os sentimentos antagônicos (ao menos aparentemente) do ateu e do homem de fé se aproximavam. Será que essa crônica indica o germe de uma possível conversão? Não sabemos. Apenas podemos, estando separados no tempo e no espaço, fazer associações aleatórias. Contudo, as imagens indicadas pela percepção do então farmacêutico, são sugestivas e podem apontar para questões subjetivas e indagações como: montanhas, tristeza, templos, calvário...

Tentaremos fazer uma aproximação entre a "conversão" do padre Sebastião Ribeiro Vianna com o apóstolo Paulo, apenas como exercício associativo e introdutório. O fato é que todos os memorialistas citaram o episódio da conversão. Com algumas diferenças e variações entre uma e outra versão, mas o núcleo da narrativa permanece o mesmo. A narrativa bíblica da conversão de Paulo é muito conhecida:

Estando ele em viagem e aproximando-se de Damasco, subitamente uma luz vinda do céu o envolveu de claridade. Caindo por terra, ouviu 
uma voz que lhe dizia: "Saul, Saul, por que me persegues?". Ele perguntou: “Quem és, Senhor?". E a resposta: "Eu sou Jesus, a quem tu estás perseguindo. Mas levanta-te, entra na cidade, e te dirão o que deves fazer". Os homens que com ele viajavam detiveram-se, emudecidos de espanto, ouvindo a voz mas não vendo ninguém. Saulo ergueu-se do chão. Mas embora tivesse os olhos abertos, não via nada. Conduzindo-o então, pela mão, fizeram-no entrar em Damasco. Esteve três dias sem ver, e nada comeu e nem bebeu". ${ }^{20}$ (ATOS, 1990, p.2064).

As imagens evocadas por esse relato estão na memória da tradição cristã ocidental, haja visto que além de textos escritos, há também inúmeras pinturas retratando a conversão de Paulo ${ }^{21}$. A comparação parece inevitável. Os memorialistas dão detalhes do processo de conversão do farmacêutico Sebastião Vianna, vejamos algumas imagens: a luz vinda do céu de Paulo e a luz avistada por Sebastião em meio à tempestade; a ida a Damasco por Paulo montado em um cavalo, o cavalo que Sebastião arreia; Paulo ergue-se do chão, Sebastião adormece no chão; Paulo quando abre os olhos não vê nada, Sebastião ao acordar não vê nenhuma igreja que supunha ter visto. Sem contar que Paulo era letrado e perseguia os cristãos, Sebastião era culto e ateu e combatia o padre da Villa Paraopeba.

Pretendemos com essa aproximação nem exaltar nem menosprezar os relatos. O intuito é a compreensão de um fato que, segundo os narradores, marcou a vida subjetiva e social da comunidade. Os elementos dramáticos parecem estar na biografia do farmacêutico: a vida de boemia, as brigas políticas, a sensibilidade artística, a ligação com a música. Paulo, sendo judeu, aprendeu a ler as escrituras e travou conhecimento com a literatura clássica. Do ponto de vista subjetivo, os exegetas afirmam que Paulo tinha um temperamento passional, Sebastião também, basta ver as defesas inflamadas do seu jornal e os amores com as prostitutas.

Os memorialistas, ao narrar a conversão do padre Sebastião, variam em intensidade e em riqueza de detalhes. D. Geralda, por exemplo, diz que: “A igrejinha do Rosário acabou porque o padre Sebastião excomungou uma mulher". O padre Tião, como retratou a narradora, a excomungou porque quando era "rapazinho quando ela teve envolvimento com ele. Depois se converteu e se regenerou".

\footnotetext{
${ }^{20}$ Há outros relatos da conversão de Paulo que diferem em detalhes, mas que possuem um núcleo comum. Àqueles que se interessam referências importantes podem ser encontradas em At 9, 3-19; 22, 6-16; 26, 12-18.

${ }^{21}$ Ver, por exemplo, as várias manifestações deste tema nas obras do pintor Caravaggio.
} 
D. Geralda afirma, ainda, que "aconteceu um milagre com ele. Não sei se foi em Cachoeira ou em Lagoa da Prata quando aconteceu o tal milagre. Despencou um temporal, uma coisa horrorosa, sabe? Ele estava à cavalo. Não conseguindo andar, pediu à Nossa Senhora, a Deus que o ajudasse. Na mesma hora apareceu uma casinha e ele se abrigou. De repente, quando parou o temporal, ele desamarrou o cavalo e não viu mais casa nenhuma. Foi mais ou menos assim. Então decidiu estudar e se ordenar padre”.

Na narrativa do Sr. Antônio o lugar geográfico muda, mas alguns elementos permanecem como por exemplo a luz, o cavalo. Dentre os narradores, o Sr. Antônio parece ter sido o único que era nascido na época da conversão, já que a disputa política ocorreu em 1915 e o Sr. Antônio nasceu em 1910. Diz que “o episódio aconteceu quando eu era rapazinho”. A experiência se dera assim: "Parece que ele vinha da Pontinha, uma localidade que tem muitos negros aqui da cidade. Avistou uma luz, amarrou o cavalo e foi dormir. Ao acordar, não havia nenhuma capela. Ficou atormentado e se converteu".

Para D. Maria Stella a história adquire outra versão, mas não perde o aspecto sobrenatural da narrativa. Segundo ela os fatos ocorreram assim: "há muitos anos atrás havia um farmacêutico aqui e ele era ateu. Segundo me contaram, ele tinha vindo da cidade de Cachoeira dos Macacos, uma cidade aqui dessa região, e foi surpreendido por uma tempestade muito forte. Diante disso, pensou que ia morrer. Então, no meio dessa tempestade, fez uma promessa que afirmava o seguinte: "se eu sobreviver vou ser padre"!". Curiosamente, em sua narrativa, D. Maria Stella inclui o elemento da promessa, algo incomum para um ateu.

Entretanto, ao acordar, o farmacêutico Sebastião não encontrou nenhum sinal de chuva. $\mathrm{Na}$ outra versão de D. Maria Stella ele teria tido um sonho. Neste sonho havia uma senhora vestida de branco que o ordenava: "não vá embora, espere a chuva diminuir". As duas versões o impeliu a mudar de vida e a se tornar padre. A imagem do sonho se mistura a outra narrativa que também se assemelha a um sonho: um sonho dentro de outro sonho!

Mas o narrador Sr. José foi o que mais se entusiasmou com a conversão do padre Sebastião. Tanto que a escreveu em sua coluna "Histórias" no jornal "Repórter de Paraopeba" ( ver a imagem da narrativa - impressa nesta pesquisa). A narrativa do Sr. José é rica em detalhes, talvez porque nela esteja o conteúdo da transformação espiritual que acredita e aprecia. Então 
o Sr. José nos disse que o farmacêutico teria que fazer um atendimento na roça e “inesperadamente, se perdeu em uma tempestade. Ficou sem rumo, desnorteado. Diante dessa situação seu cavalo se agitara. Foi então que Sebastião avistou uma luz no meio da escuridão. A luz cambiante vinha de uma capela!". Sabe que ao acordar não havia nenhuma capela aí,Sr. José afirma: "aquilo tudo o abalou profundamente e Sebastião diante disso, se converteu".

Para o memorialista o abalo foi crucial para a transformação. Foi um encontro com outra realidade. Sendo contador de histórias, o Sr. José descobriu certos desdobramentos dessa narrativa. O importante a se ressaltar é que o mesmo conteúdo da conversão em todas elas, mesmo algumas sendo umas mais elaboradas que outras. Talvez seja esta a razão pela qual todos os memorialistas reconheçam esse evento como importante para a cidade.

Diante disso, a psicologia social de Salomon Asch reflete sobre os fatos sociais como sendo resultantes de interações psicológicas de experiências entre os seres humanos. Temos que perceber que o espectro das atividades humanas é enorme. O caráter de reciprocidade da ação social, remete ao psicólogo em seu trabalho, o compromisso e a tarefa de aprender as experiências boas ou más dos outros em sua complexidade e diversidade. E daí, procurar compreeender o fenêmeno psicológico em relação à comunidade que o rodeia.

Dessa forma, a interação psicológica permanece altamente complexa, pois os afetos, a dinâmica ambiental das experiências alheias obedece a uma lógica própria e às vezes inusitada. Entretanto, a observação apurada dos eventos realizados pelos outros pode nos transmitir valores e crenças que nos possibilitaria deter informações de coisas vividas pelo grupo social. Por isso podemos "alcançar, através dos outros, uma compreensão de situações que não entendemos; obter informações a respeito de assuntos que não sentimos diretamente". (ASCH, 1969, p.139).

Daí podermos, ainda que a complexidade seja sua base, averiguar a interpretação das representações sociais entre indivíduos e grupo. Acontecimentos de ordens variadas: física, subjetiva, social, podem produzir atos de cunho psicológico. Assim, seguindo a reflexão do psicólogo social Solomon Asch o campo interpessoal engendraria a participação do indivíduo com a comunidade em experiências diversas, pois a importância em perceber um determinado evento que inclua a nós e os outros é de fundamental importância. Isso deverá ser "a primeira 
exigência para a formação de um campo social, de uma relação de grupo no nível psicológico". (ASCH, 1969, p.14).

Mas é importante acentuar, nesse percurso, que os pontos de vista não devem se perder. A interpretação dos pontos de vista não é um mero somatório das partes nas quais o indivíduo se perde no meio, mas sim, um relacionamento estrutural onde o espaço vivido pelo grupo resguarda os atos singulares retendo a perspectiva de cada um. Promovendo um campo psicológico que possa ser compartilhado mutuamente. Sendo assim, a esfera da ação, exigindo um mínimo de trocas, passa a promover o diálogo entre as peculiaridades psicológicas e o meio ambiente onde ela se desenrola. A conversão do padre Sebastião ilustra bem essa prerrogativa.

Depois da conversão de padre Sebastião ele retornou à cidade para trabalhar na comunidade, tornando-se um padre atuante e piedoso. Assim o Sr. Antônio lembra de suas missas: "Me recordo das missas dele. Assisti algumas. Ele era um padre virtuoso. As pessoas comentavam assim: “Que padre se tornou o Sebastião, hein?” ele tomou uma chicotada lá de cima [aponta para o céu].”.

Trabalhou como capelão na fábrica do Cedro, também celebrou em Villa Paraopeba e ajudou seu antigo rival, o Padre Augusto Horta. O Sr. Antônio afirma que ele chegou a morar com o padre Augusto que, arrependido, reconsiderava sua vida: "pedia perdão sempre ao Padre Augusto". Encontramos no livro do tombo o seguinte: "deixou esta freguesia nos últimos dias de agosto de 1935 o Revmo. Padre Sebastião Ribeiro Vianna; (...) largos serviços prestados reverendíssima e esta paróquia (...)” (LIVRO DO TOMBO, 1935, p. 4).

Os narradores não souberam ao certo o que aconteceu depois de sua partida. O certo é que depois de uma vida agitada e a posterior conversão, o padre Sebastião pediu, através do sonho do padre Mata Machado, que a comunidade reerguesse a capela do Rosário que ele amaldiçoara. D. Maria Stella conta que o padre Mata Machado "numa destas ocasiões, teve um sonho, com seu colega e amigo padre Sebastião Vianna, que lhe pediu para ir a Paraopeba, onde existia, abandonada, a capela do Rosário (...)". O fato é que o padre Sebastião permanece no imaginário da cidade. Seja através das peripécias políticas, do talento musical ou da transformação a partir da conversão. A igreja do Rosário está intimamente ligada à história da sua conversão; pois quando reerguida pela organização de D. Maria Stella e da 
comunidade permanece junto a cidade como lugar de memória. Mas também como exemplo de como o homem, a partir da experiência, pode se transformar interiormente dando outro sentido à existência. E ao mesmo tempo dando testemunho à comunidade.

\subsection{A memória política}

A memória política se expressa, muitas vezes, através dos juízos de valores, das atitudes ideológicas apreendidas no decorrer da história de cada um. É assim que cada evocação do presente, feita pelos narradores, traz à tona preconceitos e vivências da convenção social. As lembranças políticas não estão apenas ligadas diretamente a fatores econômicos, mas a elementos da vivência concreta.

Se a memória da infância tem sabores e imagens inusitadas, a memória política esbarra à experiência cotidiana de cada narrador. A zona intermediária entre o sonho e a vigília das evocações infantis e afetivas muda-se drasticamente nas memórias políticas. Isso se deve ao fato de os sujeitos serem, muitas vezes, influenciados por certas vivências menos aprazíveis: as injustiças políticas, as transformações sociais advindas dos partidos políticos ou da ausência desses partidos. Tudo isso parece, para os narradores, como fatos viscerais porque são vivenciados, experimentados.

É assim que o Sr. Antônio narra como na cidade se vivenciava a política. Não havia luta de partidos como hoje. Escolhia-se algumas pessoas na cidade para exercer os postos de comando: prefeito, vereadores, delegado: "naquela época havia um interventor do município. $\mathrm{Na}$ cidade daqueles tempos arranjavam-se os companheiros de governo. Era assim: o governador escolhia algumas pessoas de confiança no município e o interventor, junto com essas pessoas, ficava de prontidão".

D. Geralda relembra as lutas da família Mascarenhas com o padre Augusto e a oposição. A família de empresários e latifundiários da região detinha também o poder político. Eles obrigavam os operários a votar em seu partido. Era uma completa ausência de democracia! Assim ela relata: “A política da cidade era muito diferente. Era a época dos coronéis. Lembro 
que na fábrica os operários eram obrigados a votar nos candidatos dos patrões. Se alguém não votava, mandava embora. Eram despedidos. (...) Eram os Mascarenhas”.

Por sua vez, o Sr. Antônio constata que os políticos que defendiam o povo acabavam morrendo ou sendo assassinados. Foi assim com Juscelino, Tancredo Neves. Esses teriam ajudado os mais pobres. "São os de gravata branca, uai! Esses que acabam com eles, os homens do povo. São esses mesmos - os políticos, os politicão. Esses oficiais... Você não lembra do Juscelino? Foi tudo tramado!".

A memória da política do presidente Getúlio Vargas é viva para o Sr. Antônio. Remete à melhoria dos direitos dos trabalhadores. Embora não haja na pequena cidade as estruturas sindicais que caracterizam a organização dos trabalhadores. Talvez por escassez de outras empresas, os trabalhadores se submetessem as exigências dos patrões - confirmam os memorialistas Sr. Antônio e D. Maria Stella. Ainda assim o Sr. Antônio reconhece os direitos dos trabalhadores advindo do governo de Getúlio Vargas. Trabalhador da roça mas também da fábrica vivenciou duas modalidades de vínculo trabalhista. O primeiro mais livre e sem a opressão industrial, o segundo com carteira assinada e caracterizada por outras obrigações e limites. De modo que esses memorialistas conseguem perceber claramente a diferença da política trabalhista e a relação com a comunidade.

Por outro lado, o Sr. José afirma que a política na época de sua juventude era bem diferente. As pessoas não tinham interesse por política. Acredita o narrador que é pelo fato de os vereadores não serem remunerados como hoje. Havia as brigas políticas entre os rivais, mas não nas proporções de hoje. Para o Sr. José, era uma política de interesses próprios e não coletivos. "A juventude não engajava na política. Havia atividades políticas, mas não eram nem a décima parte que é hoje. (...) $\mathrm{O}$ vereador não ganhava um tostão. Só aqueles que estavam em uma posição estabelecida, que possuíam interesses próprios”.

A memória política expressa, em sua maioria, a herança da política mineira vinda dos coronéis e dos latifundiários. A política se revelava através da lutas de famílias, operários e lavradores formavam um campo de desigualdades. Por isso a afirmação do Sr. Antônio ressaltando a ação política de Vargas para os trabalhadores como uma atitude de encantamento e agradecimento. "A aposentadoria veio com o Vargas, o presidente. Foi ele 
que criou essa lei. Pois eu votei nele! O primeiro voto meu foi para ele! Ele foi o homem do povo, o homem do povão!".

Os narradores D. Geralda e Sr. Antônio retratam a vida política entre a família Mascarenhas, que criou a Fábrica do Cedro, e seus opositores. Uma disputa habitual que aconteceu durante anos. D. Maria Stella se limita a declarar: "havia as disputas políticas". Os opositores aos Mascarenhas foram o médico Dr. Theóphilo Nascimento e o padre Augusto Horta, entre outros.

O campo da memória política possui uma complexidade que muitas vezes os narradores não têm consciência. A família e o meio social delineiam a opção política de cada um. Daí um grande número de pessoas se expressarem através de estereótipos, impedindo uma leitura crítica dos meandros ideológicos dos partidos e de suas respectivas atitudes políticas. Pois é o "gesso do estereótipo que perpetua lembranças enquanto a imobiliza e resume" (BOSI, 2003, p. 113).

Os aspectos da memória como: a infância, a família, as escolas, os bairros, entre outros, encerram limites que muitos narradores desconhecem. Sendo assim, as lembranças podem estreitar as percepções de cada um, com força suficiente para reproduzir, através de várias gerações, condutas e comportamentos artificiais. Por isso a política parece inexistir para alguns, que fingem simplesmente desconhecê-la. Dessa forma podemos afirmar que devemos passar da rapidez da opinião ao conhecimento. A opinião seria expressão massificada e ausência de reflexão, gerando apatia, alienação dos assuntos políticos. Ao contrário, o conhecimento tem o poder da transformação. A atitude reflexiva não é isolamento; é diálogo entre as forças que movem a sociedade. Assim, a psicóloga social pode afirmar que na "relação com o objeto que nos faz passar da opinião para o conhecimento" (BOSI, 2003, p. 121). Enfim, a opinião tem pressa. Não repousa para a reflexão. Porque o exercício do pensar requer a dialética entre o sujeito e o objeto, para depois devolvê-lo ao mundo.

A tradição possui vários sentidos. Mas dentre estes, o significado da tradição como atitude política organizadora do passado parece-nos relevante. Pois este é o sentido que os narradores da cidade de Paraopeba atestam com suas lembranças. À medida que as lembranças, povoadas de nomes e eventos, são evocadas, percebemos que a memória do passado não é simplesmente uma forma de nostalgia. O passado está lá em seu aspecto bruto e literal. 
Entretanto, a partir do sentido tradição ele pode ser revigorado no presente. A tradição não só ordena o passado cronológica e sistematicamente, ela ajuda os narradores a "separar $o$ positivo do negativo, o ortodoxo do herético, o que é obrigatório e relevante dentre a massa de opiniões e dados irrelevantes ou simplesmente interessantes". (ARENDT, 2008, p.215).

Dentro desta perspectiva, a tradição no sentido da filósofa Hannah Arendt, aponta para uma atitude política diante do mundo. Ao ordenar o passado para melhor compreender o presente, ela nos alerta para a necessidade da convivência com a "pluralidade de indivíduos e povos e uma pluralidade de posições para tornar possível a realidade e assegurar a sua continuidade". (ARENDT, 2008, p. 237). Essa forma de estar no mundo, implicaria em atestar que a tradição não é algo estático em algum lugar do passado, mas uma ação política como apontado por Arendt - no cotidiano dos indivíduos. O mundo, segundo esta proposição, não perderia seu contato com os conhecimentos do passado, pois essa é a base, a seiva onde as pessoas retirarão, no presente suas ações transformadoras.

Arendt nos alerta ainda para a relação entre a política e o mundo. O mundo, para a pensadora, não é natural e nem criado por Deus, como poderia afirmar os teólogos. O mundo está ligado à pluralidade humana que permite às gerações a convivência com as outras, apresentando aos sujeitos a riqueza de habitar o mundo. Assim, o mundo, embora não negue a subjetividade, é sempre público. Portanto, por meio da ação, o mundo se realiza em plenitude através da política. Esta entendida amplamente como as condições necessárias para que, homens e mulheres, em sua pluralidade consigam exercer a liberdade.

\subsection{A memória do trabalho}

As narrativas dos memorialistas evocam aspectos importantes do trabalho pessoal e da comunidade. Há os trabalhos da casa, da oficina, da fábrica e também o burocrático. Constatamos que os narradores expressam seu ofício com as mãos, como por exemplo, a costureira, o carpinteiro, o professor e cronista, as preces à nossa Senhora do Rosário, o ofício doméstico. Mas o trabalho na história da cidade sempre foi limitado. 
Os narradores apontam basicamente duas formas de trabalho: o manual e o intelectual. Os trabalhadores manuais são o Sr. Antônio - lavrador e marceneiro - e a D. Geralda, costureira. O Sr. José realiza o intelectual: professor e escritor das "Histórias", um jornalista, embora não se identifique como tal. A D. Maria Stella exerceu o trabalho de contadora e dona de casa. Se pudéssemos classificá-los, diríamos que ela exerceu trabalho intelectual como contadora no escritório da (PISA) e manual como dona de casa.

Entretanto, através dos memorialistas, certificamos que o predomínio dos trabalhos da roça realizado na comunidade não impediu que a indústria florescesse na cidade. A fábrica de tecidos Cedro e Cachoeira existe desde 1872 na comunidade do Cedro e desde 1950 em Paraopeba. Ambas mudaram a paisagem do trabalho na cidade e região. Surgiu uma classe de trabalhadores antes inexistente: os operários. Além desses campos de trabalho haviam os comerciantes, os latifundiários e, em menor escala, os trabalhadores burocráticos.

O universo doméstico relatado por D. Geralda penetra no cotidiano de uma casa. A cozinha movida pelo fogão à lenha, a pequena horta, a colheita de ora-pro-nóbis na cerca do quintal, a aprendizagem do ofício de costureira. Foi no interior da casa que o olhar de D. Geralda vigiava a avó costurando. Nesse ambiente começou o afeto por esse trabalho que a acompanhará por toda a vida. Entre as brincadeiras de menina, as obrigações das tarefas da casa, a costureira ia se construindo. Tudo sem imposição. Mas com desejo de fazer as roupinhas das bonecas a profissão se delineava. "Eu costurava desde menina. Mas era tudo "pros coco", sabe? Olhava minha vó costurando e fui fazendo".

No cotidiano da casa, mas de forma diferente, Sr. Antônio, aprendeu a profissão de carpinteiro. O exercício cotidiano de olhar, medir, serrar, encaixar as peças demarcava o ritual de aprendizagem com o irmão mais velho. Oscilando entre o trabalho de lavrador e o de carpinteiro, Sr. Antônio, construía seu ofício. Ora plantava feijão e milho, ora consertava o telhado e fazia o moinho d'água. Junto ao mestre, o irmão, as mãos eram treinadas e esse ofício o acompanhará pelo resto da vida. Inclusive quando fora empregado na fábrica de tecidos, onde trabalharia até a aposentadoria.

O ofício de carpinteiro se desenvolveria para o de marceneiro. Segundo Sr. Antônio, esse último mais elaborado. O fato é que a aprendizagem dessa profissão relacionava-se diretamente com a intimidade das atividades familiares. $\mathrm{O}$ movimento de um repercutia no 
outro, tanto pela aprendizagem propriamente dita - o fazer, a "mão na massa" -, quanto à temporalidade e à necessidade do grupo familiar. $\mathrm{O}$ trabalho, assim, consistia em elaborar as necessidades de sobrevivência e não o lucro ou séries de objetos confeccionados.

Por isso, Sr. Antônio compara o seu trabalho a uma atividade artística. Expressão refletida nas proporções e beleza dos objetos feitos, bem como em seu caráter único. Era necessário perceber como se corta a madeira, suas propriedades. Depois, encaixá-la acertadamente. Tudo sob a direção e aprovação do irmão. Ele aprendia o ofício pela tutela do afeto. "Aprendi o trabalho de carpinteiro com meu irmão mais velho. Trabalhava com ele na roça construindo engenho, casa, porteira. Me lembro como tinha paciência em me ensinar:[ o irmão dizia] "risca assim a madeira, corta assim..." Eu estava longe de sua capacidade. Ele era um mestre. Quando não trabalhava com meu irmão, cuidava da roça. Ia moer cana e fazia açúcar e farinha".

Ao executar um trabalho manual, o artesão, explora e focaliza com habilidade a relação da mão com a cabeça. O trabalho artesanal estabelece um diálogo constante entre a destreza das mãos e a atividade mental. Por exemplo, no carpinteiro, no escritor, no tocador de viola existem essa relação entre a mão e a atividade mental. Talvez, esse exercício aponte para o trabalho como experiência compartilhada, já que o artesão, busca uma relação entre seu ofício e o outro. O que é produzido por suas mãos, no fim das contas, está dirigido a outro, a uma comunidade, com o produto final e aprendizado.

Por isso, Richard Sennett defende a idéia de que o trabalho manual se manifesta como forma de pensar. Em vários momentos da história o Artífice fora menosprezado por parte da sociedade. Contrariamente, o trabalho feito com as mãos possibilita o exercício do espírito, de forma que as pessoas governem melhor a si mesmas. Ao se deparar com o mundo, o artífice, provocado pelo mundo material é desafiado a transformar estas resistências em produtos transformados. Assim, o engenheiro, o marceneiro, por exemplo, deverá trabalhar "com as mãos" os materiais que manuseia para transformá-los. Com "mãos inteligentes, treinadas, pensantes, os trabalhadores manuais exercitam com perícia a realidade tangível pelas mãos que modelam e transformam. Daí poder dar ao trabalhador a dimensão imaginativa do seu ofício" (SENNETT, 2009, p. 25). 
Na cidade de Paraopeba o trabalho na fábrica de tecidos (PISA) mudou a relação com o trabalho. Na época da fábrica havia os horários rígidos, o cartão de ponto. Também as intrigas e invejas dos colegas que eram instigados a competir, declara o Sr. Antônio. O ofício de marceneiro (agora não é mais carpinteiro) estava ligado aos chefes e às exigências da direção da fábrica. Também presenciara as injustiças. Foi em um momento de indignação, no qual Sr. Antônio reivindicava os direitos do colega injustiçado. "Então tive a primeira decepção no serviço. Esse companheiro era da turma dos pedreiros da fábrica. Ele foi impedido de marcar o cartão porque chegou um minuto atrasado (...). Reclamei, pois soube de um outro operário que chegou dois minutos atrasado e conseguiu entrar para trabalhar. Aí fiquei indignado!”.

O trabalho na fábrica adquire características ausentes na roça e na estrutura de trabalho familiar vivenciada por Sr. Antônio. Lembremos o conceito de racionalização desenvolvido por Simone Weil. Trata-se de um conjunto de métodos, artifícios, normas que a organização industrial imprime aos operários, tendo como um dos objetivos obter maior rapidez e produtividade do trabalhador. Sem liberdade, inclusive de criação, os operários agem de forma a realizarem serviços compulsórios. Dessa forma, os operários, sem voz e singularidade, aparecem como mais uma engrenagem da fábrica. Desenraizados, homens e mulheres, alheios ao seu ofício desconhecem o produto do seu trabalho.

O Sr. Antônio, em sua biografia, admira seu trabalho. Entretanto, nota uma grande diferença em ser marceneiro em casa, junto à família, e dentro da fábrica. Seu trabalho passa a estar condicionado às normas da fábrica. Segundo ele, não é "livre" como na roça. Percebe também as injustiças e a vigilância no seu trabalho e em seus companheiros. Há em suas lembranças o encanto de aprender seu ofício na roça, junto ao irmão. Porém, na fábrica, embora afirme ter gostado de trabalhar, não esconde a preferência do trabalho em família e na roça. Reconhecendo a liberdade que perdera ao ingressar na fábrica.

O trabalho é uma grande expressão do ser humano no mundo. Através dele a humanidade conseguiu se exprimir e se tornou capaz de dar sentido às coisas à sua volta. Entretanto, na era moderna $^{22}$, o mundo ocidental, ao instrumentalizar as coisas, conseguiu rebaixá-los à categoria de meios e fins. Assim, o homo faber, promoveu a perda do valor intrínseco delas e sua ausência de significados.

\footnotetext{
${ }^{22}$ Em A condição humana, Hannah Arendt desenvolve um amplo estudo sobre os aspectos do trabalho na sociedade contemporânea.
} 
Uma transformação aconteceu na esfera do trabalho. Antigamente a mudança da obra em trabalho se dava na medida em que as atividades eram tidas como servis. Porque elas possuíam relevância apenas para aplacar as necessidades vitais. O trabalho ganhou, assim, uma dimensão relevante na esfera pública com o aparecimento de uma sociedade de massas. Mas a relevância não se localiza nos trabalhadores, pois estes serviram mais para a engrenagem capitalista. O trabalho perdendo, assim, a dimensão criativa e emancipadora.

Na era moderna o homo faber passou a ser considerado um exemplo crítico das características que rege as atividades em torno do processo de fabricação de mercadorias. Imbuído de um utilitarismo sistemático, o homo faber pergunta-se com freqüência o "para quê" de seu ofício. Por isso, ao industrializar as coisas, rebaixando-as às categorias de meios e fins, o homo faber provoca a perda do valor intrínseco dos objetos que constrói. Através do pensamento de Arendt apreendemos que há uma relação entre a inteligência com a habilidade, ou seja, o pensamento se integra ao processo do trabalho para introduzir o "primeiro passo" - uma metodologia para a fabricação dos objetos. Perdendo a dimensão da ação na relação entre trabalhador e seu produto, o homem moderno, se esquece que a ação está na base da política. O trabalho, e não o mero "fazer" exige a ação, a pluralidade do mundo. Assim, a filósofa, seguindo o pensamento de Marx, revela a degradação do homem na sociedade manufatureira, "que julga os homens não como pessoas, mas como produtores, segundo a qualidade de seus produtos" (AREDNT, 1991, p.176). Nesse contexto, é visível a conseqüência para o trabalhador é amedrontadora, e prefigura "o funcionamento mais eficaz da máquina, para depois desvalorizar todas as coisas, transformando-as em bens de consumo" (ARENDT, 1991, p. 176).

O nascimento da indústria têxtil é relatado pelos memorialistas. Primeiro a Fábrica do Cedro no século XIX e depois a fábrica de Paraopeba (PISA). Desde 1872, quando a fábrica do Cedro foi inaugurada pela família Mascarenhas, até o início da década de 1950 quando a fábrica de Paraopeba foi inaugurada; constatamos que existe uma repetição do modo das relações operário e patrão. Assim nos informa os dados colhidos.

A fábrica do Cedro foi a primeira deste segmento em Minas Gerais. Desde então as formas de trabalho na comunidade de Tabuleiro Grande mudaram muito. Antes era uma pequena cidade que vivia basicamente das rendas de alguns latifúndios (exemplo: a fazenda do rasgão relatada pelo Sr. Antônio) pequena roças e modestos comércios. Assim relata o historiador: 
O que é interessante é que o regulamento [na fábrica do Cedro], no fundo, era a transposição da relação de trabalho das fazendas escravistas, para o trabalho assalariado na indústria. $\mathrm{O}$ senhor rural, a que pertenciam todas as decisões, foi substituído pelo gerente; o feitor pelo mestre geral, permanecendo a crença de que o operário, tal qual o escravo, só produziria sob severa vigilância. $O$ castigo físico foi substituído pela multa e a segurança do emprego dependia exclusivamente do bom comportamento. (VAZ, 1990, p. 53).

Essa lógica ainda vigorará no século XX. A família Mascarenhas era de origem de latifundiários. O pai dos fundadores da fábrica do Cedro (Antônio, Bernardo e Caetano - o chamado $\mathrm{ABC}$ ) antes e durante, a criação da fabrica do Cedro, sua atividade de dono de fazenda escravagista, fora também comerciante e uma espécie de banqueiro. Uma vez que emprestava dinheiro à comunidade.

O tratamento dado aos operários era duro. O trabalho na fábrica do Cedro reproduzia a lógica escravista e também a organização industrial inglesa. Influência que se deve ao fato de Bernardo Mascarenhas ter visitado a Inglaterra e os Estados Unidos para se informação das estratégias de administração de uma fábrica. Lá, como aqui no Brasil (também no interior de Minas) as condições de trabalho eram de grande subjugação: "as condições de trabalho eram penosas, a começar pelo horário, que ia das 6 da manhã às 6 da tarde, de segunda a sábado, com pequenas pausas para café e almoço. Os prédios eram mal iluminados e os acidentes de trabalho freqüentes, em vista da inexistência de segurança" (VAZ, 1990, p. 53).

A fábrica de tecidos de Paraopeba data do início da década de 1950, distante da inauguração da fábrica do Cedro em quase cem anos. As duas fábricas revelam algumas semelhanças, embora as condições socioeconômicas e o momento histórico sejam bem diferentes. Através dos memorialistas, conseguimos constatar as condições de trabalho muito precárias que existiam na PISA. D. Maria Stella, embora não fosse operária (era secretária), convivia com eles e participou dos momentos iniciais da produção de tecido desta fábrica. "Comecei a trabalhar nesta fábrica na década de 1950, logo após o início dela”. Sobre as condições de trabalho, afirma: "uma situação que eu achava um absurdo. A admissão na fábrica se fazia da seguinte forma: as pessoas trabalhavam quatro meses até seis meses sem ganhar nada. Diziam que era para os operários terem experiência. Eu achava aquilo uma injustiça!”. A memorialista reconhece que as pessoas "não conheciam nem a carteira de trabalho" e que a experiência da fábrica do Cedro "não servia de exemplo para os operários da PISA". Para D. 
Maria Stella: “o patrão era bravo e o operário tinha que obedecer (...) ficava um zum, zum, zum - mas tinha que suportar".

O Sr. Antônio conhece as negociações da fundação da PISA. O médico da cidade, Dr. Guilherme e o Olavo decidiram construir uma fábrica. "Eles falavam que era para dar serviço para a rapaziada. Daí combinaram em levantar o capital". O narrador lembra da empolgação do pai quando da visita do Dr. Guilherme e do Olavo: "eu estou velho, mas os meus filhos podem trabalhar! Decidimos, as pessoas lá de casa, a ser acionistas da fábrica. (...) Vendemos vacas e sacos do plantio para sermos acionistas".

Segundo Sr. Antônio, o Dr. Guilherme tinha o hospital para cuidar, e o Olavo tinha experiência em trabalhar em fazendas. "Daí apareceu! Foi o Dr. Pedro, que era filho daqui, mas morava em Belo Horizonte. Na verdade, era uma raposa, um raposão...”. No final de mais de 20 anos de funcionamento a fábrica PISA entrou em decadência e faliu. D. Maria Stella recebeu suas ações porque saíra da fábrica, mas "muita gente ficou sem nenhum tostão!”. O Sr. Antônio e seus irmãos acionistas não receberam nenhum dinheiro. “Tenho hoje 99 anos e até agora nada”. Depois a PISA foi vendida para a fábrica do Cedro.

Mas o Sr. Antônio consegue perceber a diferença do seu trabalho na roça e depois na fábrica. “A forma de trabalho também se modificou! Na fábrica era uma roda d'água, não é? Na roça não. Não fazia o trabalho agora, podia fazer depois, daqui um ano! Amanhã..." O memorialista atesta a obrigação e o ritmo temporal que existe na fábrica: "fazia o serviço de acordo com a necessidade do serviço lá. O bom era isso! A gente não tinha de pensar em mais nada. Não era esse tipo de obrigação que havia na fábrica. Eu tinha de ficar bem atento com o tempo". Assim demonstra o memorialista as diferenças entre o trabalho na roça e as atividades que desempenhava na fábrica.

A racionalização do trabalho operário caracteriza-se por um forte controle da produção realizada pelos patrões. "Essa postura implica em obter do trabalho dos operários o máximo de produção no mínimo de tempo. Acarretando nos operários angústia, insatisfação, sofrimento. O objetivo da racionalização do trabalho é a obtenção de lucros pelos patrões". (WEIL, 1979, p.111-127). Esta conduta do trabalho está presente nas lembranças dos narradores. 
O trabalho do Sr. José expressa um contentamento no ensino. Professor a vida toda, desenvolveu, através da escrita, o mesmo modelo de ensinar. Antes, trabalhava como ajudante de barbeiro junto ao pai. Contudo, foi como professor que se identificou, tanto que, mesmo aposentado, expressa seu ensino nas crônicas que escreve para o "Jornal de Paraopeba”. Com a ajuda de sua informante, a "titia" decidiu escrever as histórias antigas da comunidade. "Minha profissão sempre foi de professor". Desta formas, as "Histórias" se convertem em mecanismo de ensino.

O trabalho com a escrita, encarado por ele como diversão, retrata não só as curiosidades dos fatos pitorescos da cidade na sua concepção de mundo. Assim, o ofício de escrever encerra uma proposta de ensino: oferecer aos leitores outra forma de perceber a si mesmo e o mundo. Sabemos que escrever, para o narrador, não é apenas uma "forma de entretenimento", mas um ofício rigoroso pois expressa o contínuo trabalho com a palavra, uma depuração da linguagem. Contar histórias é um trabalho fundamental, pois, através dessas histórias, a comunidade revive e transforma seu legado. Por isso, o ofício de "contar histórias" é tão importante. Se esse exercício, para o Sr. José, não tem pretensão literária e sim passar a sua visão das coisas e do mundo, ela é também o elo que liga as histórias de outras pessoas e épocas. Por fim, é a memória da cidade, já que o narrador não conta apenas uma história de si mesmo, mas, sobretudo, com e através dos outros.

O trabalho para os operários, relatado pelos memorialistas, expressa o desenraizamento. Este, por sua vez, desarticula a tradição e faz com que os indivíduos se distanciem de si e dos outros. As relações intersubjetivas se enfraquecem e também os vínculos sociais. A filósofa Simone Weil pensou o desenraizamento nos operários das linhas de montagem das indústrias de década de 1930. Mas podemos pensá-lo na perspectiva de que o desenraizamento repercute até nossos dias. Através da falta de comunicação entre as pessoas de gerações diferentes, no trabalho alienado, na cultura de massas e no isolamento emocional e afetivo.

O passado relatado pelos memorialistas carrega dimensões do vivido. Sua força é libertadora e transformadora. Nos trabalhos de carpinteiro e marceneiro realizados pelo Sr. Antônio, nas costuras de D. Geralda, no trabalho com a fé em forma de promoção da comunidade de D. Maria Stella, na escrita do Sr. José, pois a arte de narrar coordena muitos elementos: a voz, a mão, o olhar, o corpo, o espírito e também os sentimentos. É como se ao narrar, os 
memorialistas potencializassem a palavra em sua ação transformadora, compartilhando emoção e conhecimentos e, sobretudo, inserindo-os na teia social da cidade.

Nos exemplos de trabalho exercidos e percebidos pelos memorialistas, a memória vem acompanhada de prazer e realização, pois o trabalho é a forma pela qual os indivíduos se enraízam subjetiva e socialmente. Podemos afirmar com a psicóloga social que "a memória do trabalho é o sentido, é a justificação de toda uma biografia" (BOSI, 1994, p. 481). Assim, Sr. Antônio ressalta a dignidade erigida pela memória de seu ofício: "tenho a aposentadoria que é pouca, mas é com dignidade que ganhei esse dinheiro. Aprendi desde a infância. Na roça era desta forma! Nós dividíamos o que tínhamos, não era essa ganância". Por isso o trabalho se revela como veículo de sentido para toda uma vida. Quaisquer que seja o ofício, é o que confirmam os memorialistas.

\subsection{Palavras que curam}

A palavra, desde a antiguidade, possui um caráter importante na dinâmica social e cultural. Mas não é só através das artes literárias e teatrais que o valor e poder das palavras se expressam. No âmbito da "psicoterapia”, através da cura verbal, os médicos da época clássica ocidental já utilizavam a palavra como forma de amenizar o sofrimento das pessoas. Desde Platão e Aristóteles, passando pelo famoso médico Hipócrates, notamos a utilização da palavra como forma de cura. Assim, as "belas palavras", eficazmente sugestivas possibilitavam a ordenação na alma dos enfermos de suas crenças, impulsos, sentimentos e pensamentos, pois através desse artifício produzirira na alma a sophrosyne. Que para o ensaísta seria a "bela, harmoniosa e justa ordenação de todos os ingredientes da vida anímica"(ENTRALGO, 1897, P.271). Assim completa, tal ordenação da alma "produz efeitos somáticos benéficos (...)" (ENTRALGO, 1987, P.271). ${ }^{23}$ [ Tradução livre]

Em outro contexto, contudo relevante para nossas análises, o capítulo XVI do ensaio $O$ narrador, de Walter Benjamin, aponta a cura como uma faculdade importante na narrativa. Através da narrativa oral, os narradores, elaboram estratégias para enfrentar as adversidades. A fonte da narração, para Benjamin, está no seio das camadas mais remotas do povo, como os

\footnotetext{
${ }^{23}$ Trata-se de parte do texto em espanhol cujo original é: “(...) bella, armoniosa y justa ordenación de todos ingredientes de la vida anímica (....)". O outro trecho do texto em espanhol é: "produce efectos somáticos beneficiosos (....)".
} 
artesãos, lavradores, operários. A experiência de cada pessoa é passada de geração em geração procurando organizar as heranças que a tradição transmite.

O mundo contemporâneo não conseguiu extinguir essa prática. Os modos de produção capitalista, expressos no individualismo e nos meios de comunicação de massa, não conseguiram eliminar tal prática. A narrativa, todavia, desencadeia o processo da transmissão do conhecimento baseado na relação mestre e aprendiz. Assim, ao narrar a experiência da dor e do medo, por exemplo, deixa de ter o aspecto de vivência solitária e passa a ser compartilhada com a comunidade. Talvez por isso, a narrativa oral seja tão importante para abranger camadas sociais periféricas, e persiste ainda na atualidade como prática de conhecimento e de sociabilidade.

O modelo narrativo, ensina Benjamin, é o narrador dos contos de fada. Presente em todas as sociedades, os contos orais oferecem aos ouvintes meios de enfrentar as forças obscuras do “interior" de cada um. Por isso, os narradores trafegam com facilidade em situações perigosas, indo dos céus aos infernos rapidamente. Os narradores, afirma o ensaísta, "se movem para cima e para baixo nos degraus de sua experiência, como numa escada". (BENJAMIN, 1994, p. 215).

Ao reconstruir, através dos alicerces da memória, os contadores mobilizam conhecimentos para a "cura" dos ouvintes. Prática antiga que se perde na noite dos tempos, mas que ainda sobrevive. Através delas se ensinam às fórmulas para se sair dos infortúnios. Essas narrativas "nos revela as primeiras medidas tomadas pela humanidade para libertar-se do pesadelo mítico." (BENJAMIN,1994, p.215). Pois os contos de fadas desdobrados em dois pólos - a astúcia e a arrogância - liberta os homens das forças que os subjugam.

O Sr. Antônio narra uma história que presenciou. $\mathrm{O}$ memorialista constata o poder curativo das palavras do padre. Notou que uma vizinha ficou doente e resolveu ajudá-la. Procurou o padre para abençoar àquela sofredora e diante de vários imprevistos, revela: "alguma coisa estava impedindo a ida do padre". Quando chegou com o padre, a D. Porfíria "ficou transfigurada e nervosa”. O padre pediu que o narrador saísse e começou a fazer as orações. Quando acabou, o padre estava perplexo: "era o demônio que estava aqui. E consegui que ela me confessasse e depois morreu. As palavras devem ter curado a D. Porfíria". Afirma o narrador. 
Reconhecemos o fator libertador na narrativa apresentada pelo Sr. José em suas "Histórias". Não só há elementos do folclore - ditados, enigmas - como a apropriação do fio narrativo dos contos de fada: "Titia disse...". Sempre uma história que puxa a outra, expressas em linhas infinitas de condensações e deslocamentos. Não há uma “adequação" de uma lógica tradicional, mas um raciocínio calcado na fronteira, da vigília e do sonho.

Assim, a conversão do padre Sebastião se desdobra nas "Histórias" do Sr. José: "Depois de muitos anos desse episódio um homem estava para morrer. Era o irmão da mulher que afrontou o padre Sebastião. Durante o escândalo esse homem tentou matar o padre, mas não conseguiu. Sebastião já se encontrava doente, estava para morrer também. Esse homem quis se redimir do pecado e das afrontas ao padre". Uma história vai puxando outra, multiplicando os sentimentos e expectativas.

A "cura" não é um fim absoluto onde se pretende chegar. Mas um processo cujo movimento encerra uma espécie de libertação da dor e do infortúnio. O próprio memorialista, Sr. José, reconhece que a faculdade de narrar sempre existiu. Embasando a necessidade de contar e recontar para compreender o que nos aflige. Talvez a "cura" esteja no percurso escolhido pelo memorialista para narrar um feito, um ensinamento. No entanto, cabe ao ouvinte "elaborar" o que escutou usando os conteúdos de suas experiências pessoais e coletivas. Assim, a cura pela narrativa, não é o efeito de uma idiossincrasia individual, mas da cumplicidade, da compaixão da própria dor com a dos outros. Através das palavras, a narrativa dialetiza o sofrimento.

A função curativa das histórias se apresenta, pois, aos ouvintes como bálsamo. Quando a voz do narrador embala a criança, acaba por embalar e acariciar também o sofrimento. Desperta o gosto pela vida, elucida os enigmas. Também constatamos este efeito nos adultos, nos depoimentos biográficos, na narrativa como forma de dar sentido ao mundo através da memória.

Por que deveríamos contar histórias? Pela via da memória as mazelas da vida são trazidas à luz para nossa compreensão. Assim, como a criança doente é curada pela voz da mãe, do mago das fábulas; o adulto, ao narrar sua vida, inicia-se no processo de cura. Dessa forma, o sofrimento narrado mobiliza o poder curativo das palavras (em outro contexto, Freud, ao criar a psicanálise reconhecia a cura pela palavra). O fluxo narrativo mobiliza a rigidez do mutismo 
do corpo e do espírito em sofrimento. "através da memória, as fantasias do narrador são dissecadas na multiplicidade das palavras". (GAGNEBIN, 1985, p.11).

Contar as histórias de si mesmo e do mundo se reveste em uma necessidade. Estar imobilizado e incapaz de narrar impede o narrador e a comunidade de alcançar a compreensão salvadora. As lembranças retesadas se transformam sofrimentos incapazes de mudar. Recordar nos coloca junto a um fio que liga vários tempos, possibilitando ao narrador e ao ouvinte adquirir saúde para o corpo e para a alma. Portanto, contar histórias faz com que aqueles que as narram, e também aos ouvintes, mirem no prazer da vida. Há, aí, um efeito libertador.

A cura através das palavras, como mencionamos acima, remete-nos a um tempo remoto. Seja um tempo da cultura e sociedade, seja um tempo da história individual. Pois, na perspectiva do ensaísta Walter Benjamin, a experiência transmuta o ser e o mundo (abordamos anteriormente o conceito de experiência). Embora estejamos numa sociedade movida pela tecnologia, - os narradores orais, psicólogos, psicanalistas por exemplo - proporcionam um ambiente de cura pela palavra. Isso se deve ao fato, das palavras mobilizarem sentimentos, desejos com os quais não temos consciência.

Walter Benjamin, por exemplo, em dois ensaios: Infância em Berlim e Imagens do Pensamento (1997) revelam essa proposta. Ensaios de conotação autobiográfica referem aos poderes curativos das palavras. No primeiro ensaio Benjamin, na parte chamada A Febre o narrador se vê acolhido pelos cuidados da mãe. Através desses cuidados e das palavras da mãe, as dores se dissipavam. Pois o doente se apetecia em ouvir as histórias. Assim entre a dor e corpo febril as histórias iam apaziguando a doença:

\footnotetext{
A dor era um dique só no começo oferecia resistência à narrativa, mais tarde, quando esta se robustecia, ele era minado e lançado ao precipício do esquecimento. Carícias abriam o leito dessa corrente. Eu as amava, pois da mão de minha mãe já gotejavam histórias que, logo, em abundância, emanariam de sua boca. (BENJAMIN, 1997, p. 109).
}

O ensaísta reconhece que as histórias como os contos de fadas possuíam potencial curativo. O segundo ensaio, na parte Conto e Cura afirma Benjamin que desde o início da descrição da doença ao médico, o paciente, já estaria no processo curativo: "daí vem a pergunta se a narração não formaria o clima propício e a condição mais favorável de muitas curas, e 
mesmo se não seriam todas as doenças curáveis se apenas se deixassem flutuar para bem longe - até a foz-nas correnteza da narração". (BENJAMIN, 1997, p.269).

Através desta atividade milenar, de narrar e ouvir, homens e mulheres conseguem compreender o mundo interno e externo. Movimento que se perde no tempo! Dessa fora, podemos compreender a dor como a interrupção do fluxo narrativo. Ao contar e ouvir histórias, o paciente por exemplo, é capaz de compreender e superar sua dor. Já que os elementos conflitantes das narrativas, oferecem subsídios para a superação dos conflitos e dores. Isso se deve, acreditamos, que as narrativas são constituídas de metáforas, símbolos e significados cujo enredo, conseguem mobilizar forças e "desbloquear" a correnteza da narrativa. Deste modo, Benjamin nos alerta para o potencial curativo das palavras. Hoje tão desprezadas pela sociedade de massa e de consumo. Tal sociedade da técnica, ao preconizar o individualismo como de ser e estar no mundo, impediria que a dor se expresse socialmente e encontrasse sentido e expressão. Pois a experiência da dor é ao mesmo tempo única e compartilhada.

É importante salientar as forças que mobilizaram os memorialistas que escapam ao texto escrito e também oral. Trata-se do efeito causado pelas palavras ao longo das entrevistas. Sr. Antônio, por exemplo, ao se deparar com o pesquisador fora dos encontros marcados dizia assim: "Escute Neuber, pensei naquilo que falei com você outro dia - por favor retire nome daquela pessoa. Acho que não deveria mencionar o nome dela nessa situação...”. A D. Maria Stella telefonava para certificar do que havia dito: "Olha, Neuber descobrir outras coisas que falarei com você depois... Eu li isso em meus arquivos sobre a cidade...”. De modo que o fator "terapêutico" das narrativas de expressavam de várias formas. Mobilizando nos narradores afetos e lembranças variadas; fazendo com a memória dos narradores trabalhassem além das entrevistas propiramente ditas.

Nos textos transcritos das entrevistas fica claro o valor e a intensidade das palavras e das lembranças.Declara Sr. José: “escute, Neuber, contar essas histórias mexeu com meus arquivos, minha memória. Então tive que consultar meus arquivos. Mas tem muita coisa... De modo geral é uma recapitulação". Em meio a uma vida simples, D. Geralda reconhece que: "era uma vida difícil, mas divertida". Mas na singeleza do cotidiano de uma casa, costurando e recebendo os amigos e familiares, a narradora declara: "A gente lembra, a saudade... 
Esquece também, não é? Eu me sentia bem. Era uma vida boa que a gente levava. Mas depois foi acabando tudo.Daqui de casa só restou eu. Mas é assim mesmo, é a vida!”.

Para D. Maria Stella "achei essa viagem ao passado espetacular. (...) Quero que você saiba, rapaz, que é bom demais contar a história da minha cidade que eu amo". Para essa narradora sua história está ligada à da cidade: "é a memória da cidade que se mistura com a minha". Além disso, tecer a sua biografia é um compromisso com a fé "apenas sei que tenho que louvar e agradecer a Deus". Narrar se converteria em expressão da fé.

O Sr. Antônio nos diz do poder e da dificuldade que emerge de cada ato de recordação. "Sabe de uma coisa? Tem coisa que a gente não esquece. Tanto as boas quanto as ruins. Por exemplo, a lembrança da roça, da escola... As ruins são lembrar daquela cirurgia que lhe contei. (...) Contar o que a gente lembra é assim mesmo: tem coisa que é fácil lembrar, outras são difíceis". E diante de tantas coisas que vivenciou, o narrador conclui: "É isso, estou satisfeito com a vida".

\subsection{Entre a cidade real e a lembrada}

Em Interpretações dos sonhos, Freud propõe pelos menos duas afirmações. A primeira afirmação atesta que os sonhos possuiriam um sentido aparentemente absurdo. A segunda diz que os sonhos são realizações do desejo. Nisso, haveria uma implicação importante: o sonho são produções do sonhador e portanto, através do relato dos sonhos, se conheceria os sentidos subjacentes ao evento onírico. Assim, a interpretação do sonho, segundo Freud, possibilitaria revelar o sentido oculto que estaria por trás do sonhador. Neste caminho, os sonhos, como expressões do desejo do sonhador, serviriam para poupar o sujeito ameaças dos desejos reprimidos contidos nos enredos dos sonhos.

Partindo dessa premissa, elaborada por Freud, em Interpretação dos Sonhos, somos levados a afirmar que tal atividade de interpretar é via para se chegar aos conteúdos inconscientes. Em decorrência disso, a importância do sonho para psicanálise reside não na concepção do sonho stricto sensu mas em seu relato. É através do relato dos sonhadores que perceberíamos os artifícios e implicações do desejo do sujeito do sonho. Por isso, para psicanálise, o sentido do sonho não se esgotaria em uma única interpretação. Pois, o sonhador, ao relatar o sonho 
sobrepõe elementos da narrativa da sua vida pessoal e do mundo da vigília. Podendo, dessa forma, elaborar pensamentos, imagens latentes aos conteúdos manifestos nos sonhos; às vezes conteúdos inteiramente diferentes entre si.

Freud compreendeu que o aparelho psíquico se formava a partir de um sistema de forças. E por sua vez, este conflito de forças é que determinaria o sentido. Neste aspecto ficaria claro, a partir de Interpretação dos Sonhos, que a operação fundamental da dinâmica psíquica é o recalcamento. Assim, no sistema Pcs/Cs o recalcamento designaria uma atividade específica cuja base consiste em afastar no inconsciente as representações ligadas à pulsão. Portanto, neste modelo, o recalcamento se expressa na possibilidade de se evitar as lembranças penosas. E uma das atividades da dinâmica psíquica, afirma Freud, é "retorno" dos conteúdos operados pelo recalcamento sob forma de sintomas, sonhos, atos falhos, dentre outros. É por isso que a afirmação freudiana é tão contundente: "a interpretação dos sonhos é a via real que leva ao conhecimento das atividades inconsciente da mente" (FREUD, 2001, p. 647).

Depois do recalcamento há a cisão do aparelho psíquico em dois grandes sistemas: o préconsciente-consciente e o inconsciente. Há, portanto, três fases distintas do recalcamento: o recalcamento originário, o secundário e o retorno do recalcado. Este último nos chama atenção para a compreensão das lembranças surgidas nas narrativas dos idosos pesquisados. E de como estas lembranças se apresentaram, ao longo da história da cidade e na memória da comunidade. O que nos importa frisar é que a dinâmica do sistema psíquico acarretam efeitos importantes na linguagem, como o deslocamento e condensação. Esta operação, segundo Freud, nunca é isenta de conflito.

Quando Freud refletiu sobre os sonhos, há um século atrás, concebia os conteúdos oníricos como uma realização alucinatória do desejo. Entretanto, ao longo de mais de um século os teóricos da psicanálise foram ampliando a compreensão dos sonhos; e dando outras interpretações ao sonho. Para o psicanalista René Käes, por exemplo, “o sonho é um trabalho de figuração, de dramatização e de simbolização dos distúrbios que se produzem nas fronteiras intrapsíquicas e intersubjetivas” (KÄES, 2005, p. 166). Percebemos, então, que a partir da perspectiva de Käes o sonho não seria algo apenas interno, mas em relação ao grupo.

Este pesquisador, através do conceito de "intermediário", lança luzes nas modalidades de organização e funcionamento psíquico; nas relações e determinações dos discursos no campo 
grupal e social. De forma a mostrar o aparelho psíquico como sendo constituído entre pessoas; podendo desta forma mostrar os fenômenos pelos quais ocorreriam às transmissões dos elementos psíquicos entre gerações. E criando, assim, uma rede de espaço intersubjetivo. Mas, o que é transmitido entre gerações? Käes, afirma que a transmissão não se daria apenas na continuidade da vida psíquica, seguindo uma ordem previsível. A transmissão se dá através, de alianças inconscientes. Portanto, a vida psíquica continua através das gerações, mas realizadas através das:

Rupturas, as falas, os hiatos não pensados e impensáveis, o nivelamento dos objetos de pensamentos, os efeitos da pulsão de morte. São essas configurações de objetos e de seus vínculos intersubjetivos que são transportados, projetados, depositados, difratados nos outros, em mais de um outro: formam a matéria e o processo de transmissão. (KÄES, 2005, p.129).

Seguindo a premissa da transmissibilidade e do espaço da vida psíquica, Käes nos aponta outra forma de compreender os sonhos. Para Freud, o sonho possuía o efeito do retorno do recalcado para o indivíduo que sonha. René Käes formula a hipótese do espaço onírico como o lugar partilhado pelo grupo. Três hipóteses sustentariam esta afirmação. A primeira, o espaço onírico do grupo se dá na re-presentação das formações inconscientes dos sujeitos ao se depararem com outros membros do grupo. Isso se daria pela ressonância fantasmática e indentificatória dos sujeitos do grupo. A segunda hipótese, esclarece Käes, é afirmação da polifonia dos sonhos. Este possuiria várias "escrituras", mobilizando aspectos enunciativos que constituem os encontros do grupo. Despertando uma sucessão de elementos associativos. A terceira hipótese é o surgimento do intermediário (conceito que designa mediação, transformação por lado e por outro à descontinuidade e ruptura) nas produções do sonho do grupo. Transformando, assim, os conteúdos e restituindo-os ao grupo. Käes nomeia esse processo como "fábrica do sonho". (KÄES, 2005, p. 155-166).

A expressão polifonia dos sonhos foi retirada, por Käes, do lingüista russo Bakhtin. Este pensador preconizava, dentre outras coisas, que a linguagem é expressão vocal que envolveria uma relação do eu com outros indivíduos. A linguagem, neste contexto, é palavra viva; rica de nuances e veiculada entre pessoas reais. E não algo abstrato e descontextualizado. Sendo assim, a linguagem deverá, na perspectiva de Bakhtin, ser considerada em toda complexidade. Ou seja, perceber a linguagem, nos aspectos étnicos, morais, estéticos e sociais contidos nos discurso e expressos nos diálogos. Bakhtin afirmava que o escritor Dostoievski havia criado o 
"romance polifônico", na medida, que narrativa desse escritor era tributária não de uma voz, mas de várias vozes.

Isso dito, a Polifonia dos sonhos, é a hipótese lançada pelo psicanalista, em compreender os espaços oníricos do grupo. Os processos inconscientes que transfiguram de um sujeito ao outro, a transmissão de pensamento de um ao outro sem que os indivíduos envolvidos saibam. Portanto, o espaço criado pelo sonho não teria apenas a "voz" do sonhador mas outras vozes que o atravessam e que ajudam a compreender o sentido daquelas imagens; que por sua vez dialogam com o outro. Assim, a compreensão sobre os sonhos deverá se ater nos aspectos pelos quais as vozes dialogam com os espaços intrasubjetivo e intersubjetivo. Neste sentido, a noção de voz apresentada por Bakhtin é apreendida por Käes para configurar o espaço onírico como sendo constituído por várias vozes. Esta perspectiva amplia a possibilidade de compreender as imagens e pensamento dos sonhos que estavam latentes no grupo.

Acreditamos que esta proposta advinda das descobertas freudiana e que, aliadas às leituras de Käes servirão para interpretarmos as lembranças dos memorialistas pesquisados. Na medida em que os sonhos não serão percebidos apenas como pertencentes aos indivíduos mas ao grupo. Para Käes, os conteúdos dos sonhos criam espaços partilhados e comuns aos integrantes do grupo. Desta forma o sonho potencializa as conexões entre as pessoas ao abrir os conteúdos oníricos à historicidade e a vida social. O sonho, nesta perspectiva, abre à compreensão da constituição da vida comunitária com seus desejos, hiatos, contradições. Alargando, assim, as fronteiras entre o indivíduo e a sociedade. Demonstrando, também as relações entre as organizações intrapsíquica e os conteúdos formados através dos vínculos intersubjetivos.

Talvez possamos também pensar a história da cidade de Paraopeba pela perspectiva do mito fundador. A palavra mythos, em sentido etimológico, diz da narração pública e lendária dos feitos de uma comunidade. Os gregos já percebiam isso. No decorrer da história esta palavra foi adquirindo várias acepções. Para antropologia, por exemplo, a narrativa mítica se refere às tensões, conflitos e contradições que de certa forma não encontrou solução na atualidade. Sendo assim, o mito, se repete, por causa dessas tensões que não foram resolvidas no momento presente. 
Quando nos referimos ao, mito fundador, estamos nos referindo aos conteúdos míticos que colocaria à comunidade em contacto com o passado, no sentido de origem. É como se o passado, livre da fixidez, se fizesse presente recorrentemente. De certa forma há uma correlação com à psicanálise, no que diz respeito ao impulso à repetição de algo imaginário. Essa perspectiva, é para nós importante, na medida que ao nos referirmos ao nascimento da cidade percebemos algo que se repete. Portanto, podemos dizer que: "um mito fundador é aquele que não cessa de encontrar novos meios para exprimir-se, novas linguagens, novos valores e idéias de tal modo que, quanto mais parece ser outra coisa, tanto mais é a repetição de si mesmo" (CHAUÍ, 2000, p. 9).

A fundação, no sentido de toda fundatio, se refere a algo que ocorreu a um momento passado imaginário. Isto é importante para nossa reflexão, pois, através das narrativas dos idosos pesquisados constatamos reiteradas vezes relatam o surgimento imaginário da cidade. Então, por esse caminho, percebemos um instante onde surgiu, se deu início. E que se mantém vivo e presente no desenrolar do tempo. Sabemos quando em mito fundador, referimos a algo que permanece, reverbera no presente e lhe dá sentido e significação. Enfim o mito oferece, elementos "além", da história e cria uma manancial de representação da realidade; ecoando, formando e organizando a comunidade. Quando afirmamos o "além" da história desejamos indicar que a explicação histórica não basta ou mesmo não teria provas documental para falar desse "início" da cidade. Falamos, portanto, da noção de fundação para explicar o surgimento da cidade, porque emana da comunidade e ao mesmo tempo faz com que a própria comunidade se crie e se invente.

A lenda, expressa pelos narradores pesquisados, exemplifica o mito fundador. Todos memorialistas narraram um homem que no século XVIII (aproximadamente) fora atacado por uma onça e através da promessa feita à santa, foi erguida uma capela. A partir daí a comunidade foi crescendo ao redor da igreja. Funda-se aí, a partir do milagre alcançado, a cidade. Curiosamente, o coronel era o "diferente", o "vindo de fora" das cercanias da cidade. Depois outros chegarão à cidade vindo de outros lugares: viajante James Wells: Avelino Fóscolo, o criador da imprensa na cidade; o poeta e educador Sabino de Paula Freitas: o jornalista Manuel Antônio da Silva. Constatamos que este evento se repete ao longo da história da cidade. Pessoas vindas de outros lugares, em certa medida desconhecidos, mas que acabaram marcando os memorialistas em suas narrativas. 
A própria conversão do padre Sebastião Vianna, tão marcante na memória da cidade, ilustra bem isso. Vindo de fora da cidade, o padre Sebastião, desempenhou papel forte na história da cidade. Esta conversão (comentada anteriormente) possui elementos religiosos, míticos e reproduzem os efeitos do ponto de vista da psicanálise, por exemplo, o recalcamento dos conteúdos inconsciente presente nas narrativas dos memorialistas: algo que se repete e que ao mesmo tempo tenta explicar e dar sentido à comunidade. Digamos que o padre Sebastião, por exemplo, expressaria os elementos que vêm "de fora", de outro lugar (físico e da fantasia); dos elementos que possuem o impulso à repetição, algo advindo do imaginário. Que foi introduzido ao longo do tempo e que fazem parte do contexto social e cultural da cidade.

Deste modo, percebemos nas narrativas dos idosos, e constatamos os estes conteúdos imaginários reverberam na comunidade através das lembranças dos memorialistas. Tais efeitos, hipoteticamente, do recalcamento obedeceria à lógica do inconsciente. Ou seja, não necessariamente conteúdos atrelado aos documentos históricos mas que, no entanto, estão presentes e se fazem sentir no contexto das relações pessoais, culturais e sociais. Pois este mecanismo do mito fundador alimenta-se das representações produzidas pelo momento da fundação e as atualiza para inserí-las na história. Esta estratégia de ação do mito fundador se repete indefinidamente. Todos os aspectos do mito fundador: aspectos da psicanálise, da antropologia, da religião e folclore se misturam na formação do imaginário dos memorialistas.

A construção do mito se dá pelas elaborações da elaboração religiosa cristã e condensado na figura do coronel Marques e sua devoção e fé à Nossa Senhora do Carmo; elementos da história da ocupação dos lugarejos do interior de Minas Gerais; pelo exotismo da mata e seus animais; e aspectos subjetivos da construção da identidade do interior de Minas Gerais e seu apego à terra e costumes. Acreditamos que estes componentes, comporiam o mito fundador da comunidade da cidade de Paraopeba, apresentados pelos narradores pesquisados. Ao nosso ver, o mito fundador em questão foi construído sob a perspectiva: das operações da fé na imagem de Nossa Senhora do Carmo, da Natureza selvagem do interior, da figura do estado ou do poder na personagem do Coronel Marques, da cidade construída a partir da fé e das adversidades, enfim a história sendo movida por forças "transcendentais" ou inconscientes fora da margem e atuação dos homens. Desta forma, a partir das narrativas dos idosos houve, podemos falar em alguns desdobramentos. Vejamos, por exemplo, a capela onde surgiu a cidade foi sendo reconstruída ao longo das épocas, a reconstrução da capela do Rosário pela iniciativa da memorialista D. Maria Stella. A farmácia de Seu Avelino onde ele criava os 
elixires, jornais e livros. Os lugares de memória se misturam aos conteúdos inconscientes e são reavivados pelas lembranças dos narradores. Portanto através das lembranças dos idosos percebemos que a transmissão dos conteúdos psíquicos se repetem, e assim, seguindo o raciocínio de Käes, podemos afirmar junto com este psicanalista que tais elementos “deslocase ou transfere-se de sujeito para outro, entre eles ou por meio deles, ou em vínculos de um conjunto (...)" (KÄES, 2005, p. 134).

Por outro lado e de certa forma complementar a essa hipótese haveria também outra forma de se ler os efeitos do mito e do sonho. Para a sociologia, o mito, o sonho se inscreve no âmbito das sociedades "tradicionais" ou primitivos e também entre nós. Pela perspectiva sociológica, o sonho é parte integrante da estrutura social. Assim, o sociólogo Bastide, afirma que: “ $O$ sonho está preso nas redes da organização social e há uma unidade real entre as duas metades do homem, bem como entre o mundo dos mitos ou do sagrado, ao qual o sonho está unido, e o mundo social, no qual o indivíduo vive e, estado de vigília” (BASTIDE, 1978, p. 147)

É assim que podemos compreender, por exemplo, o sonho relatado pela memorialista D. Maria Stella. Trata-se do sonho que teve o padre José Mata Machado com seu colega padre Sebastião Vianna que o pediu para ir à Paraopeba e colher folhas da árvore que existia em frente da porta principal da capela do Rosário. O padre Sebastião havia profanado esta igreja (este relato foi contado pelos memorialistas anteriormente). Com a possibilidade de curar seu infortúnio o padre Mata Machado viajou até Paraopeba. Assim começava o início da reconstrução da capela do Rosário, que se tornou um lugar de memória dos moradores e objeto de fé da D. Maria Stella. Constatamos os elementos sociais e psíquicos presentes no sonho do padre em consonância os ideais de fé dos cidadãos da comunidade de Paraopeba. Relembremos, a narrativa onírica, feita pela memorialista, D. Maria Stella: padre Mata Machado, "teve um sonho, com seu colega e amigo padre Sebastião Viana, que lhe pediu para ir à Paraopeba, onde existia, abandonada, a capela do Rosário e apanhasse uma folha da árvore que existia em frente a sua porta principal. Fizesse um chá desta folha que este curaria sua doença.Qual foi a surpresa dos três [o padre e os amigos paraopebenses], quando chegando ao local, viram que não havia mais a igrejinha nem famosa árvore. Apenas o terreno limpo e vazio, roçado pela Prefeitura. E o padre, admirado e triste exclamou: - " vocês não sabem a quizila (azar) que dá para o lugar quando cai uma igreja! Precisam mandar reconstruí-la". 
Seguindo a hipótese em compreender o sonho pela perspectiva da psicanálise (aqui usando os conceitos e Freud e Käes) tentaremos lançar luz neste sonho narrado pela memorialista. Käes retoma os conceitos de negatividade vindos de Freud e esse conceito poderá ser útil para desenvolvermos nosso raciocínio. O conceito de negativo não tem conotação de juízo de valor, Freud, já o havia empregado como metáfora da fotografia, opondo a neurose à perversão. Entretanto, Käes emprega o Negativo em três modalidades a saber:

Uma negatividade de obrigação, que corresponde à necessidade da psique de produzir o Negativo a fim de efetuar seu trabalho de ligação: uma negatividade relativa, que situa o negativo em relação a um possível; uma negatividade radical, que coincide com a categoria do impossível, em outras palavras, daquilo que não está no espaço psíquico. (KÄES, 2005, p. 98).

O que precisamos frisa no momento é que a negatividade é princípio de trabalho da psique e que portanto, seria um dos meios pelo qual o sujeito ou grupo lida com os conteúdos inconscientes. Pois, segundo Käes, a negatividade de obrigação, por exemplo, teria a necessidade em efetuar as operações de "rejeição, de negação, de recusa, de desmentido/retratação, de renúncia e apagamento" (KÄES, 2005, p. 89) com o objetivo de preservar a organização psíquica. Pensando assim, nossa hipótese seria àquela que o sonho apresentado pela memorialista revelaria uma ressonância dos conteúdos do sonho, apresentado pelo padre, no contexto da negatividade. Mas de que forma isso se daria? Acreditamos que o sonho do padre foi uma expressão de uma aliança do inconsciente funcionando como organizador social e psíquico.

Alguns efeitos desse sonho acentuariam essa hipótese. Primeiro, a vida marcante do padre Sebastião na cidade, era um ateu que se converteu. Depois desempenhou o trabalho na comunidade como evangelizador, teve o episódio com a prostituta e a profanação da igreja do Rosário. E os vários desdobramentos na comunidade e a presença dele no imaginário dos memorialistas. O sonho do colega o recomendando a voltar na cidade para a cura pelo chá da árvore em frente da igreja. Em seguida, D Maria Stella, fervorosa católica, se comoveu pela destruição da igreja e como já era devota a Nossa Senhora do Rosário resolveu reconstruí-la com ajuda da comunidade. E segundo a narrativa da memorialista depois da reconstrução da igreja do Rosário a cidade se desenvolveu: chegou o progresso na cidade: "a construção da PISA (fábrica de tecido), o Horto Florestal, entre outras coisas". Parece-nos, seguindo essa hipótese, que através do sonho do padre, foram mobilizadas forças inconscientes e a partir delas novas formas de organizações sociais foram surgindo. Enfim, no contexto da 
negatividade, os conteúdos não-ditos dos cidadãos, foram organizados para preservar um interesse maior da própria comunidade: a reconstrução da igreja do Rosário, a organização da cidade para um fim comum.

Desta forma, seguindo Käes, que utilizou a metáfora do lingüista de Bakhtin para falar dos sonhos, para o psicanalista, a polifonia dos sonhos, se caracterizaria em dois níveis. Primeiro, a organização do sonho como polifonia interna, já que no relato haveria várias vozes. $\mathrm{O}$ segundo nível, importante para nossa hipótese revela que a: "produção do sonho num espaço psíquico onde há correspondência e interpenetração dos espaços oníricos de vários sonhadores, onde os sonhadores se fazem presentes e se fazem escutar por outros sonhadores, por vários ouvintes, internos e externos" (KÄES, 2005, p. 289). Essa afirmação vai de encontro ao que pensamos, pois, ao sonhar com o colega padre, este sonhador em seu espaço onírico aproximou aos conteúdos imaginários dos cidadãos de Paraopeba. Fazendo que o desejo dos outros tivesse ressonância ao seu sonho. As vozes do padre falecido foi ouvida pelo colega e se fez presente nas vozes dos cidadãos. Assim, poderemos afirmar com o psicanalista: "o sonho é uma polifonia de várias "escrituras" do sonho, que tem como fonte uma série de enunciados e de enunciações constituídos na véspera, que é trabalho por e numa multiplicidade de espaços, de tempos, de sentidos e de vozes". (KÄES, 2005, p.289).

Ao seguirmos este raciocínio percebemos que a cidade surge como cidade real, onírica e lembrada. O fato dos idosos pesquisados relatarem o mesmo evento com detalhes e intensidades diferentes não excluem as consonâncias. Ao contrário, afirma por um lado a individualidade das lembranças mas também o seu espaço comum. Pela psicanálise vemos o retorno do recalcado, as fantasias e o espaço dos sonhos. Pela sociologia a organização social. Acreditamos que tais vertentes de interpretação visam ampliar a compreensão dos conteúdos psíquicos e sociais. Pois, tanto o sonho quanto as lembranças sofrem as influências dos desejos, individuais e sociais. Nesta perspectiva a cidade surge múltipla e viva.

Desta forma, a cidade evocada pelos memorialistas apresenta várias imagens. Ricas em detalhes, as lembranças sugerem, a partir das primeiras impressões da infância, passando pela idade adulta até a velhice. É uma memória povoada de cores, sentimentos, nomes de pessoas e lugares da cidade. Assim, com o passar dos anos, as lembranças rompem os limites individuais e partilha com o grupo as perdas e os sucessos. 
Diante das evocações apresentadas podemos perguntar: é a cidade que habita os narradores ou são eles que moram nela? Há alguns momentos em que a cidade adquire contornos muito pessoais, já em outros a cidade é um objeto diante das percepções. O ensaísta Sério Paulo Rouanet tenta responder a uma questão análoga ao refletir sobre a obra do filósofo Walter Benjamin.

Na obra célebre, As passagens, Walter Benjamin examina a Paris do século XIX percorrendo suas ruas e becos, lojas e jardins com o desejo de compreendê-la. Com a figura do flanêur, aquele passante ocioso que se presta às impressões do momento e desfruta o espaço da cidade como quem procura aquilo que o olhar convencional não pode ver nem entender, Benjamin percebe que a atitude desta flanerie emerge como conseqüência de um tempo desaparecido. Desta forma cada rua e esquina, conduz ao observador, a um passado diferente do olhar convencional. Isto porque, a Paris "é a terra prometida do flanêur, a paisagem construída de pura vida" (BENJAMIN, 2006, p. 462).

Nesse périplo pela cidade, o flanêur descobre os detalhes da vida cotidiana. Ele experimenta as sensações e impressões do passado, faz correlações, se abriga nos prédios, vaga pelas ruas, se inquieta com a multidão. Sem um modelo prévio, ele faz estudos, vivencia a morada do coletivo, observa o mercado. Já que, para o flaneur, é importante perseguir a cidade em seus meandros e detalhes; ampliando a partir dos fragmentos o conhecimento do todo (tratamos em detalhes essa temática no capítulo "A memória").

Entretanto, os memorialistas aqui tratados não seriam o modelo para esta flanerie. A pequena cidade do interior não pode ser comparada a uma metrópole européia. Mas talvez haja um ponto de contato entre essa atitude descrita por Benjamin e a percepção dos narradores. Para Benjamin, em As passagens, reflete diretamente a consciência onírica do coletivo no século XIX, e a cidade como esse espaço de recordação e evocação, onde o homem "habita uma cidade real e é habitado por uma cidade de sonho" (ROUANET, 1992, p. 67).

Assim, seguindo a teoria de Freud, podemos perceber que o que se manifesta no sonho é um trabalho, um exercício do desejo. O sonho se apossa dos elementos da vida cotidiana "real" e do desejo. Dessa forma, haveria uma relação dialética entre a realidade "onírica" e a objetiva e "real". O flanêur, por sua vez, ilustra o possível diálogo entre estas instâncias: os dois níveis da realidade: a onírica e a objetiva. Obviamente, as pessoas habitam a cidade do ponto de 
vista real e concreto. Entretanto, o indivíduo é habitado pela dimensão do desejo, do sonho, da imaginação. Estes elementos que fazem parte da dimensão noturna dos seres humanos. A cidade, como entidade concreta é composta por ruas, praças; por outro lado, a cidade está sujeita à dinâmica do inconsciente em seus hiatos e rupturas. Os habitantes sonham, desejam e se lembram de si mesmos e dos eventos e espaços urbanos.

Aqui, essa correlação pode nos ajudar a compreender as lembranças dos narradores. Uma cidade não é apenas uma entidade física, a toponímia urbana: casas, ruas, praças. Mas também as lembranças que se tem dessa cidade. As lembranças não possuem, à priori, uma exatidão rígida. Antes, as lembranças oscilam entre os lugares reais e entre os afetos que as sustentam. Por isso, cada memorialista é único. As lembranças dos idosos possuem um mapa com características próprias, mas que ao mesmo tempo se entrelaçam com as evocações dos outros e do grupo.

Desta forma, a cidade dos memorialistas é real, concreta e ao mesmo tempo onírica, lembrada. Curiosamente o nascimento da cidade de Paraopeba (antiga Tabuleiro Grande) se sustenta numa dimensão "lendária". O surgimento dessa cidade, cuja história foi transmitida de geração em geração, é perpassado por um ato de fé ou visão proferida por um certo coronel Marques. Atacado por uma onça salvara-se graças à fé em nossa Senhora do Carmo. Assim, a capela surgiu em meio ao sertão, bem como as casinhas ao seu redor. Todos os detalhes lembrados e narrados pelos memorialistas.

A pequena cidade do sertão mineiro não poderia ser a Paris do século XIX, uma metrópole européia. Mas ao lembrar, os memorialistas, evocando sua toponímia, pessoas e evento, dialogam com a atitude característica da flanerie benjaminiana. Os detalhes das ruas, a profusão de nomes, a praça, os eventos, as emoções e afetos tornam peculiares as lembranças da cidade. Nesse sentido, o trabalho das Passagens se irmana com o trabalho das lembranças. A dialética entre o que se vê e o que se sente, criando uma lógica própria de fazer correspondência. Assim, a cidade surge com cores próprias, a cada memória evocada. Constatamos que vivido e o sonhado se ancoram nas lembranças dos idosos, razão pela qual a cidade vibra de história.

Cada narrador confere um tom a essa cidade. Para o Sr. Antônio, na infância, a cidade era um cerrado, com bichos e plantas, na idade adulta muito trabalho e na velhice a constatação de 
melhoria nas condições de vida da cidade. A cidade cheia de detalhes, mas em permanente movimento de mudança: na percepção e no espaço urbano.

Para o Sr. José a cidade de sua infância remete à brincadeiras, divertimentos e ao prazer. Na idade adulta aventuras e na velhice a transformação e projeto espiritual. Por suas palavras as "Histórias" da cidade são contadas, revelando desde tipos folclóricos, até certas visões de mundo amplamente complexas. Uma cidade inventada e recriada pela palavra.

Para D. Geralda, a cidade da infância era simples como sua vida. Na idade adulta o universo de suas ações permanece atrelado ao da casa, do ofício de costureira. A cidade é vista de dentro de seu lar. Na velhice o que se amplia é a visão de certa complexidade nas dinâmicas de habitar e de se apossar da cidade "atual".

Para D. Maria Stella na infância a casa era o microcosmo onde reinava a proteção e os ensinamentos maternos. Nesta época o que a preocupa são o aprendizado da fé e o trabalho comunitário. $\mathrm{Na}$ idade adulta aumenta o compromisso com as festas religiosas e o adensamento dos trabalhos em torno da transmissão da fé católica. A cidade vista pelo olhar da construção do ritual e das celebrações religiosas. Na velhice, a coroação e o exercício da fé religiosa como forma de enraizar a tradição à qual se liga.

A cidade para os narradores é, portanto, empírica e lembrada. E é exatamente a oscilação entre estes pólos que movimenta suas memórias. O trabalho de despertar para as lembranças, chama os narradores, ao exercício constante de rememorar. Os eventos nunca possuem uma única perspectiva, como, por exemplo, a narrativa lendária da origem da cidade, pois cada narrador, através das lembranças, evocam experiências íntimas para transformá-las em narrativas. A imaginação, dispositivo anímico por natureza, completa as "lacunas" de cada lembrança. Assim poderemos afirmar, que habitar uma cidade é apreendê-la física e imaginativamente. A cidade, contudo, necessita dos cidadãos para torná-la habitável, da mesma forma que os cidadãos precisam da cidade para se tornar humanos. 


\subsection{Anexo 03 - Imagens}

IMAGEM 48: O Aprimeira igreja, demolida na década de 1920

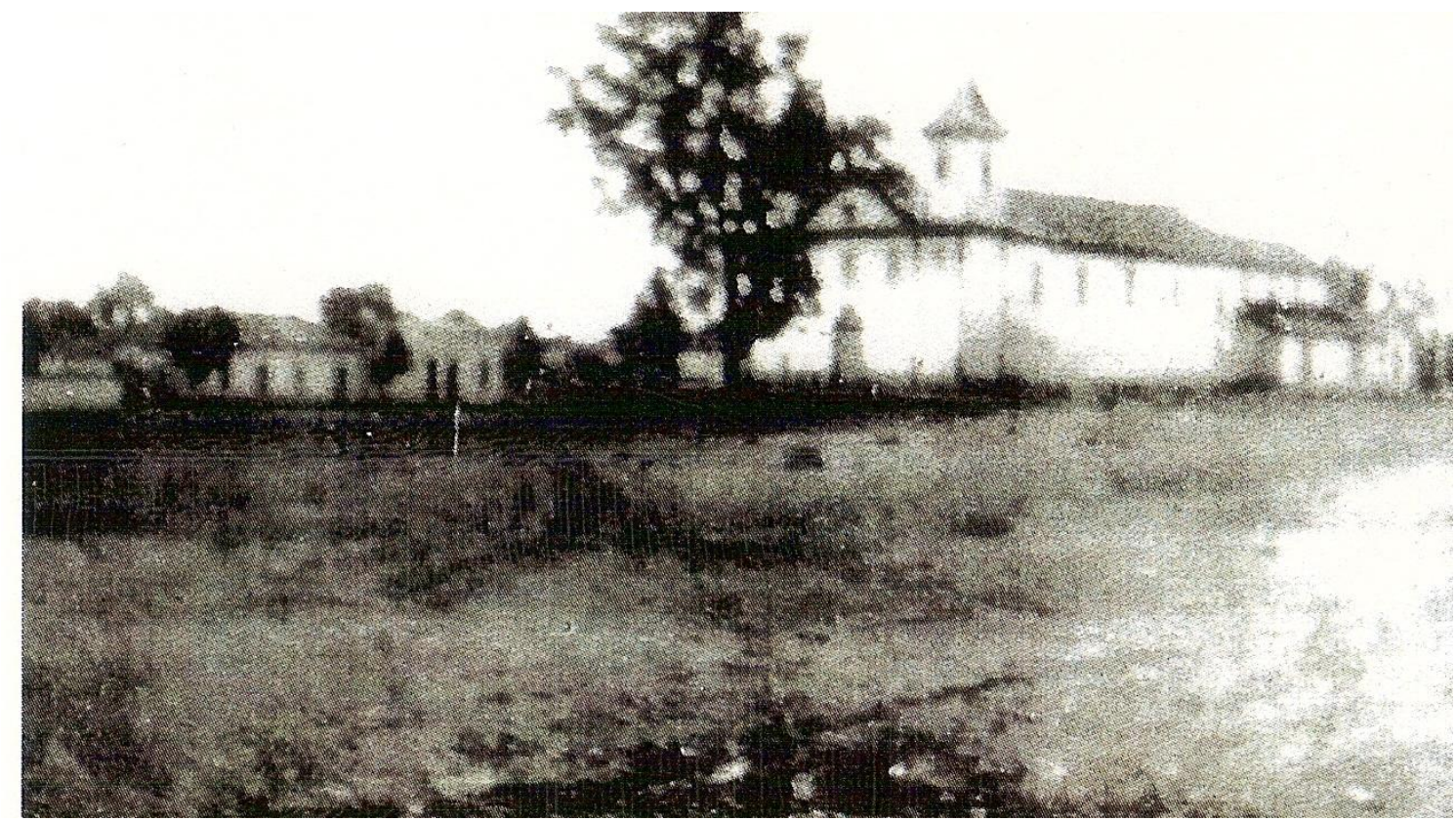

Fonte: Arquivo particular

IMAGEM 49: Igreja erguida após a demolição da primeira

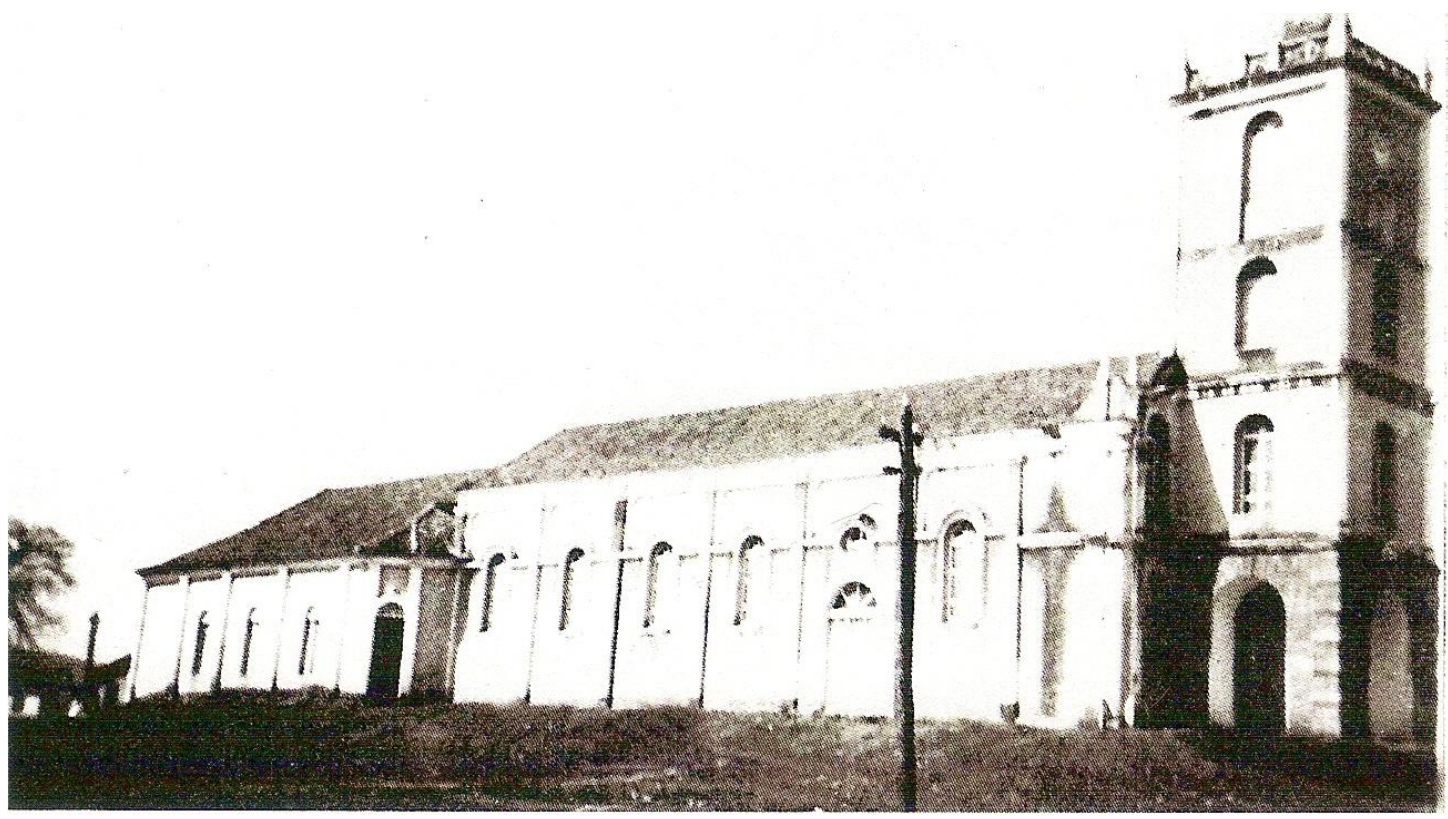

Fonte: Arquivo particular 
IMAGEM 50: Antiga igreja do Rosário - 1908

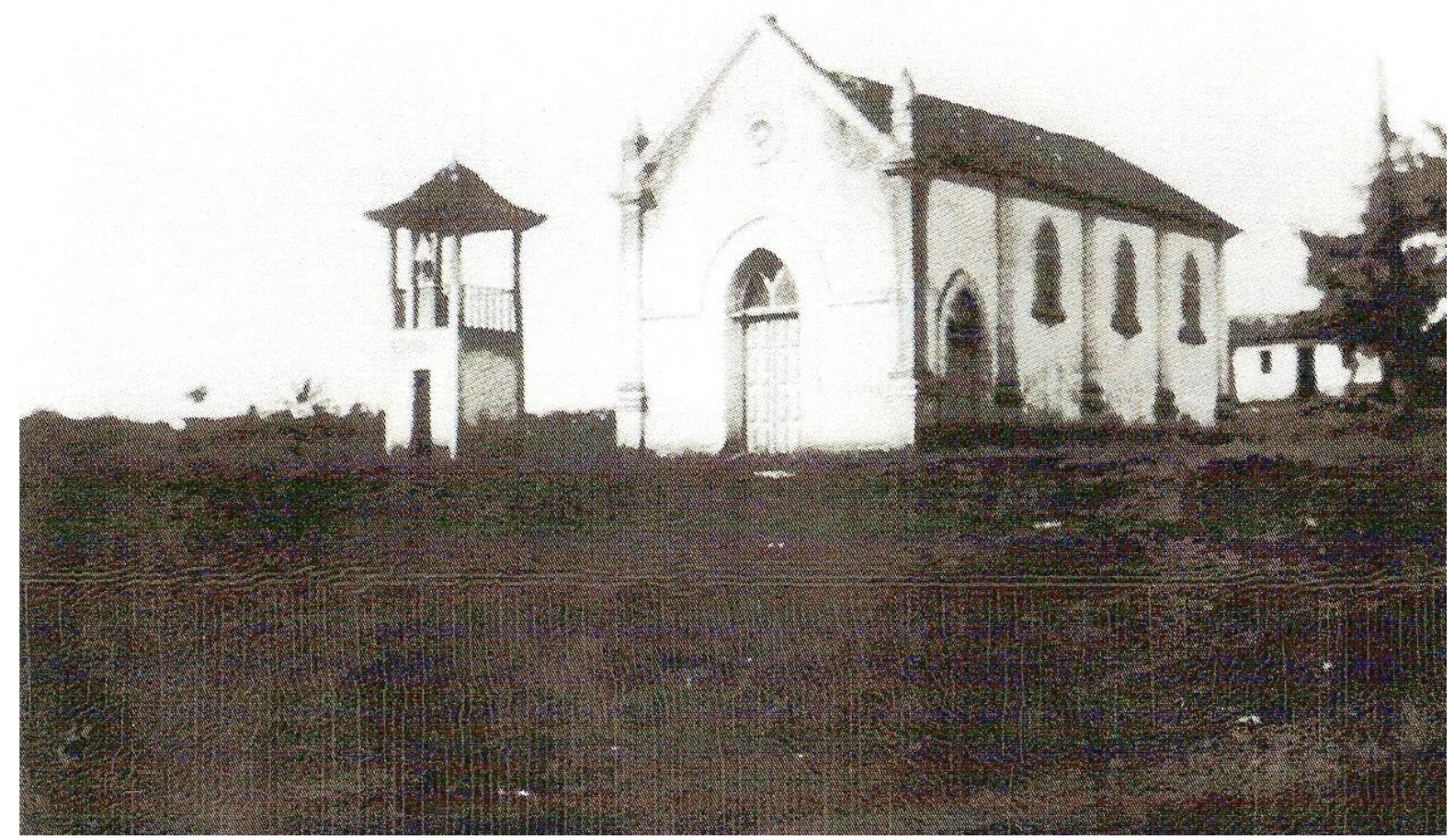

Fonte: Arquivo particular

IMAGEM 51: Outro ângulo da primeira igreja do Rosário

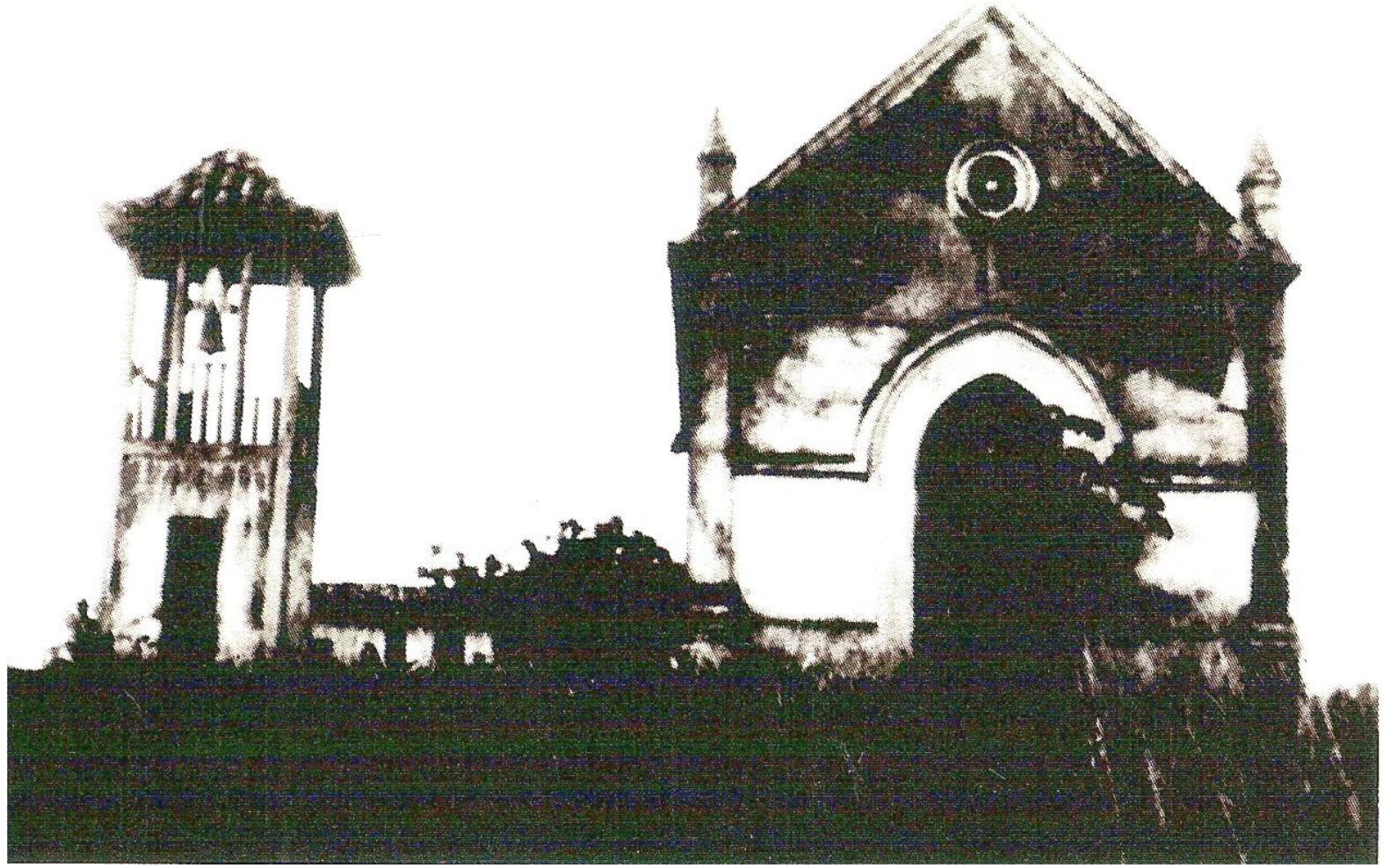

Fonte: Arquivo particular 
IMAGEM 52: A capela do Bispo D. Cirilo

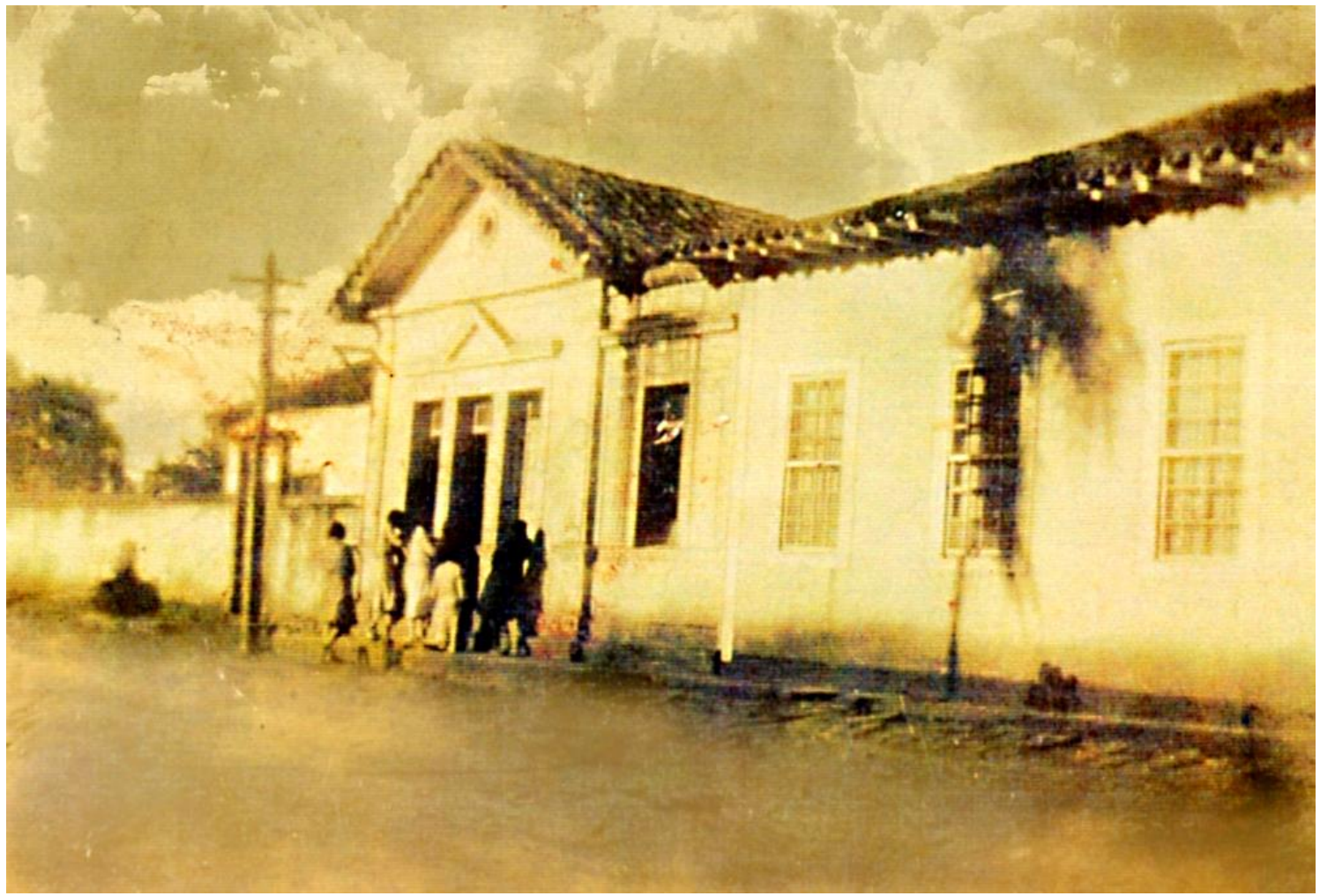

Fonte: Arquivo particular

IMAGEM 53: A farmácia do "seu Avelino", à esquerda da capela

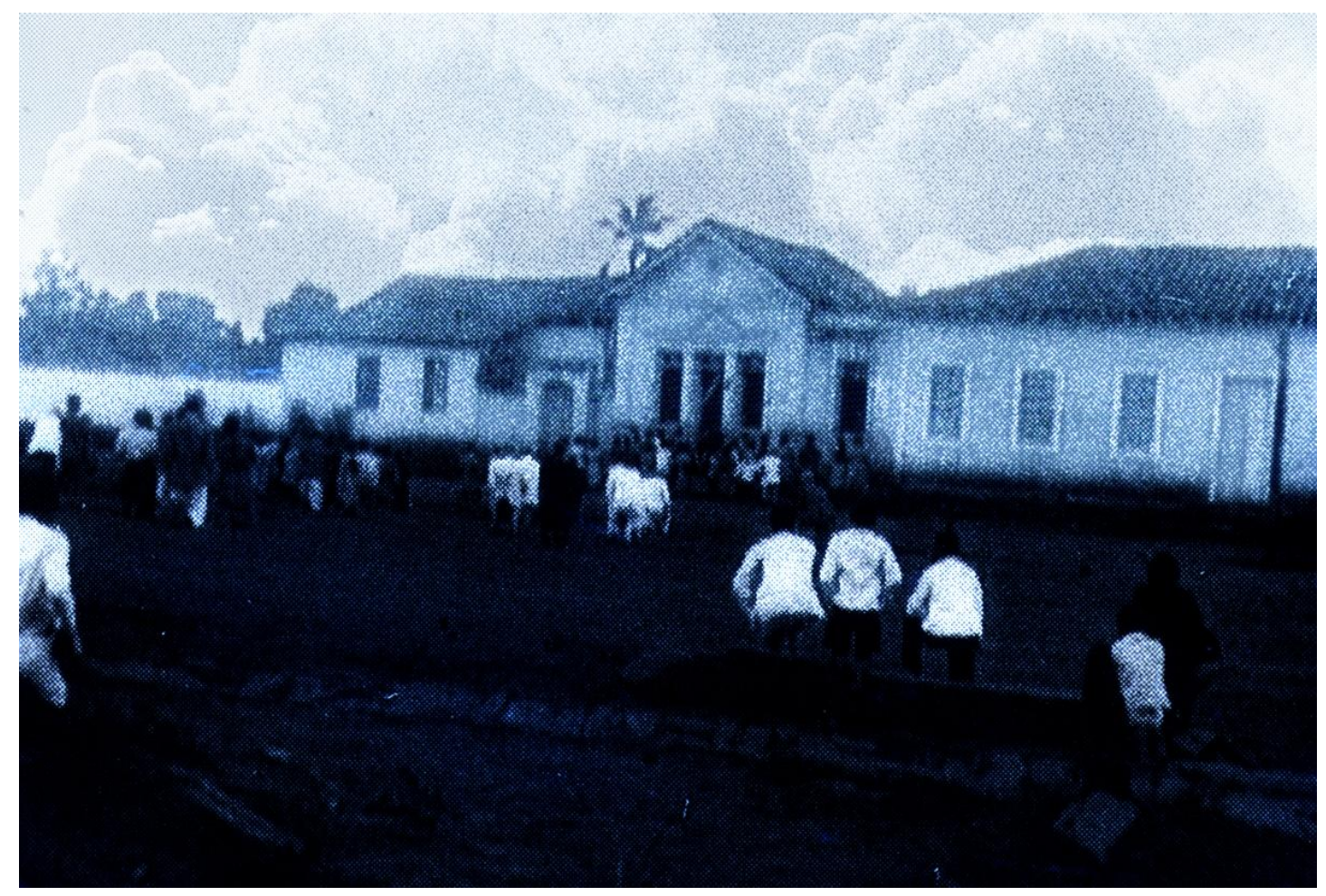

Fonte: Arquivo particular 
IMAGEM 54: Casa centenária: pertenceu ao "Seu Avelino", à professora D. Anésia e à memorialista D. Maria Stella

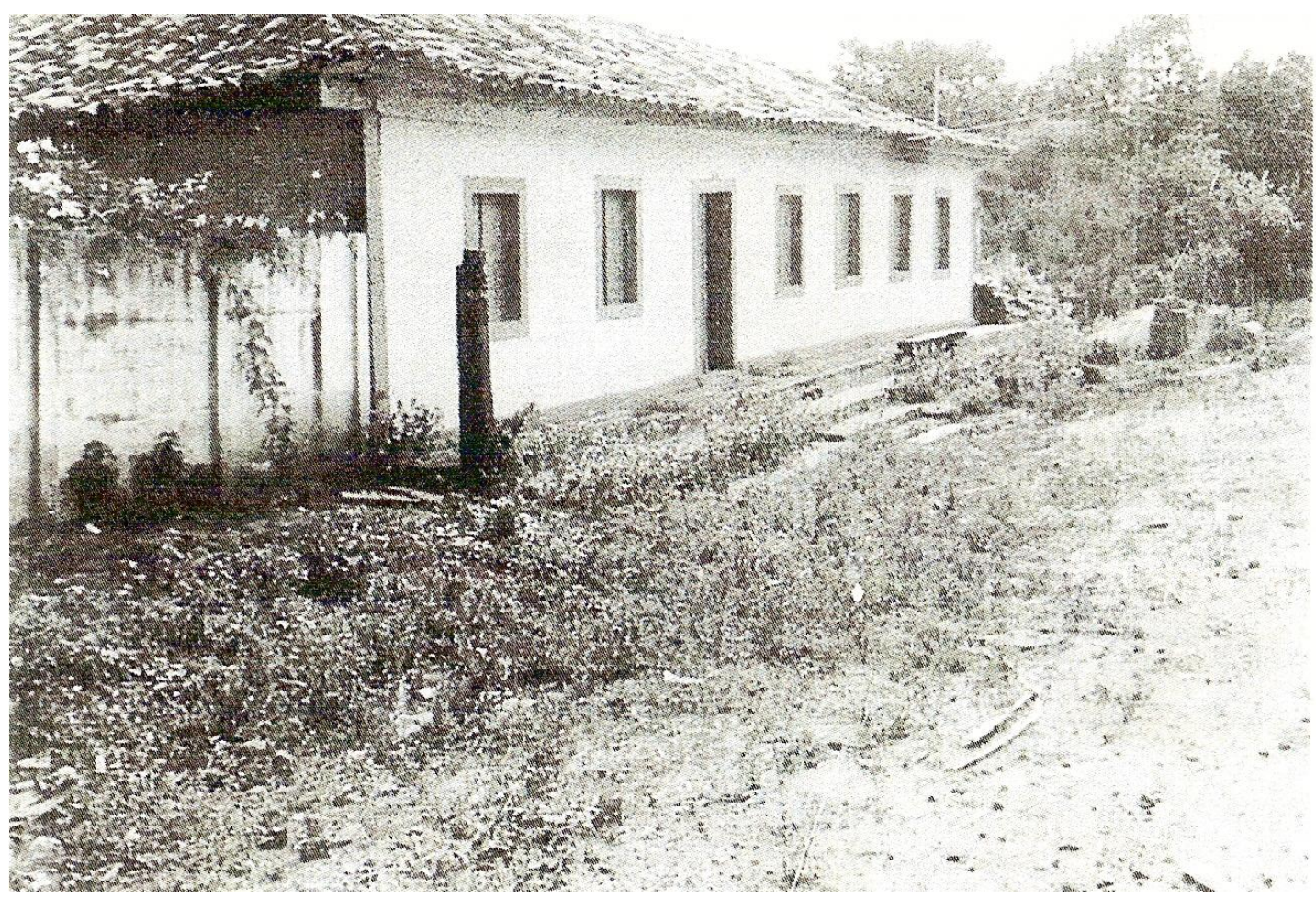

Fonte: Arquivo particular

\section{IMAGEM 55: O prédio da Gazeta}

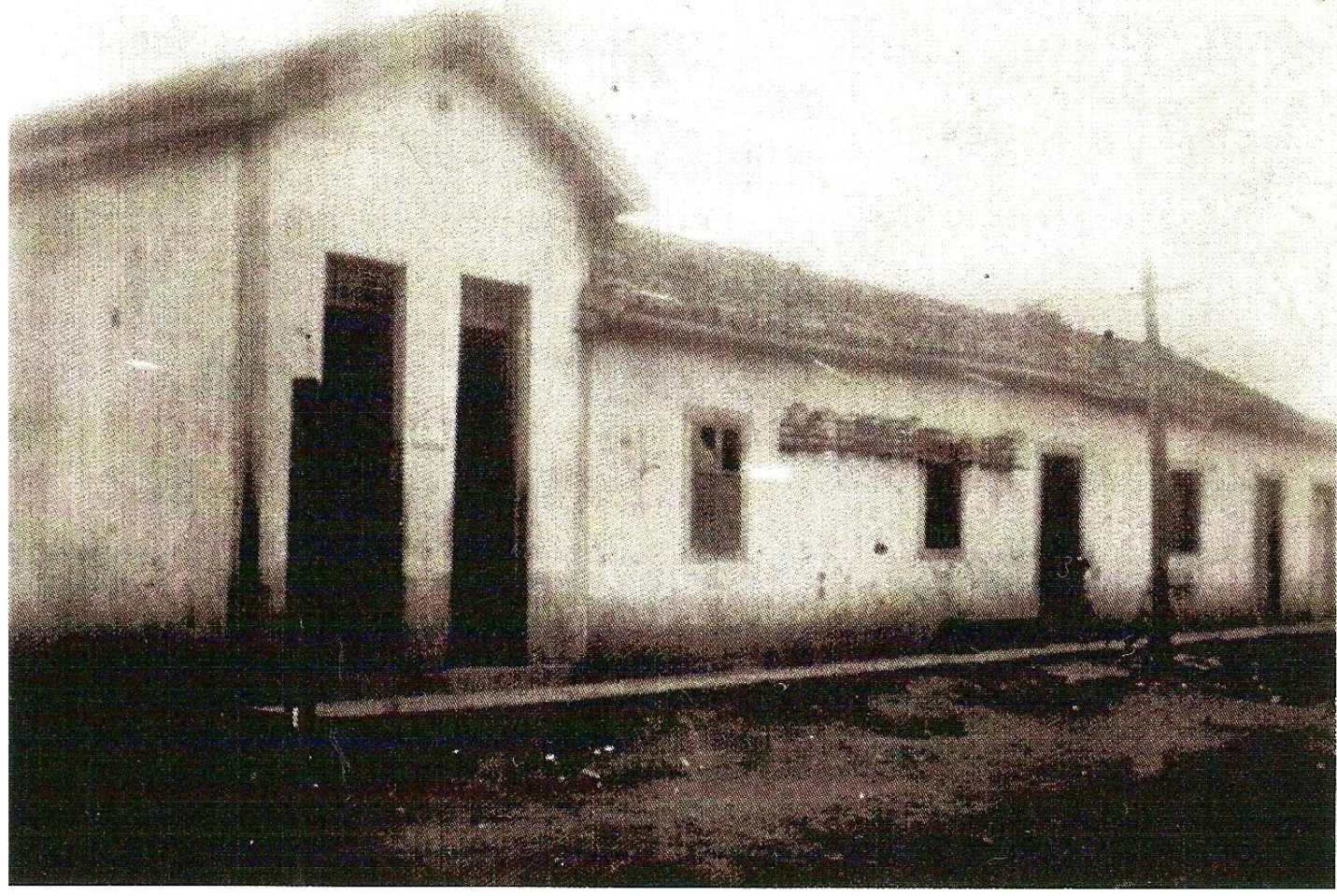

Fonte: Arquivo particular 
IMAGEM 56: A escola Afonso Pena logo após sua inauguração

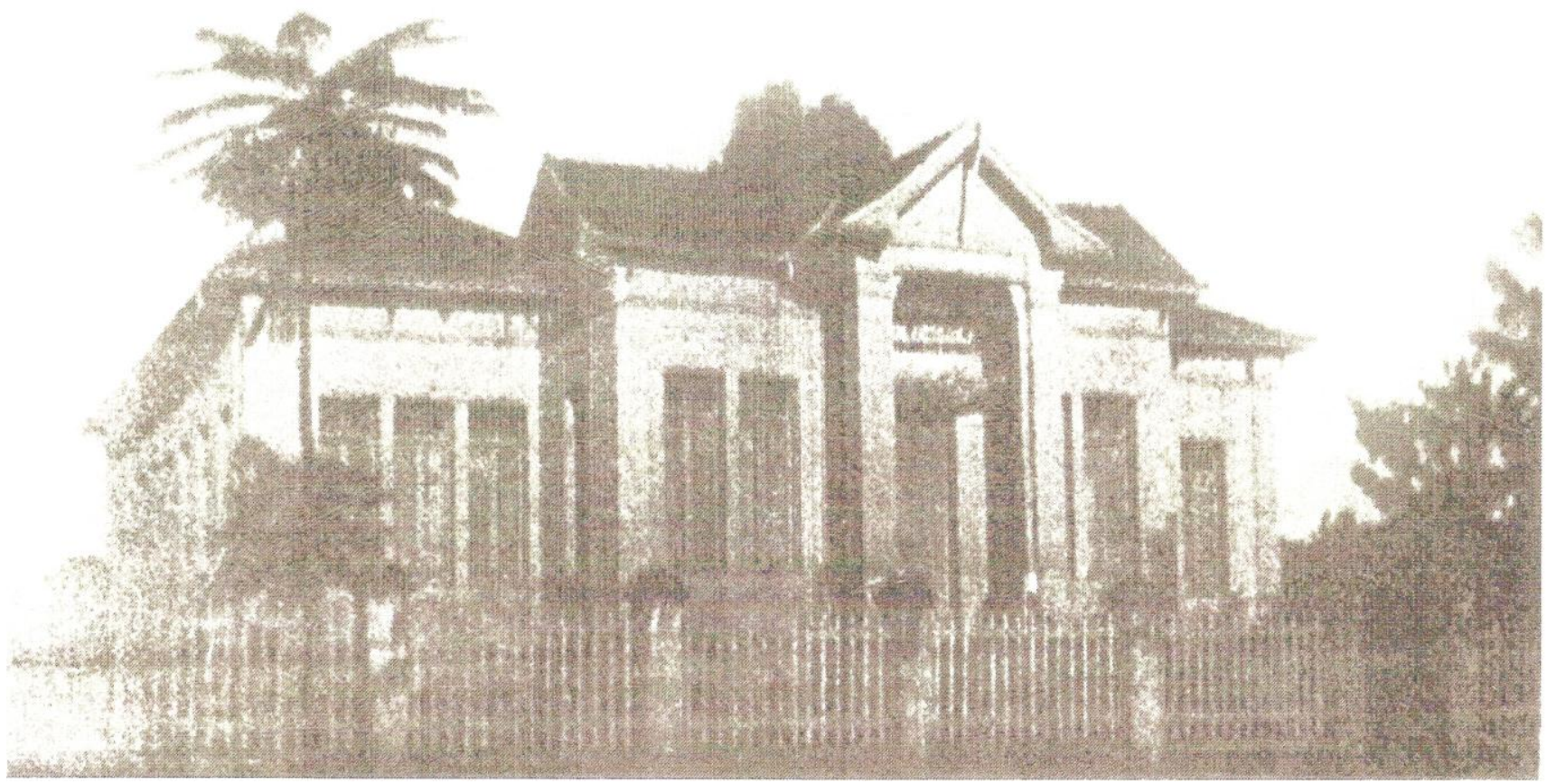

Fonte: Arquivo particular

IMAGEM 57: A escola Conselheiro Afonso Pena

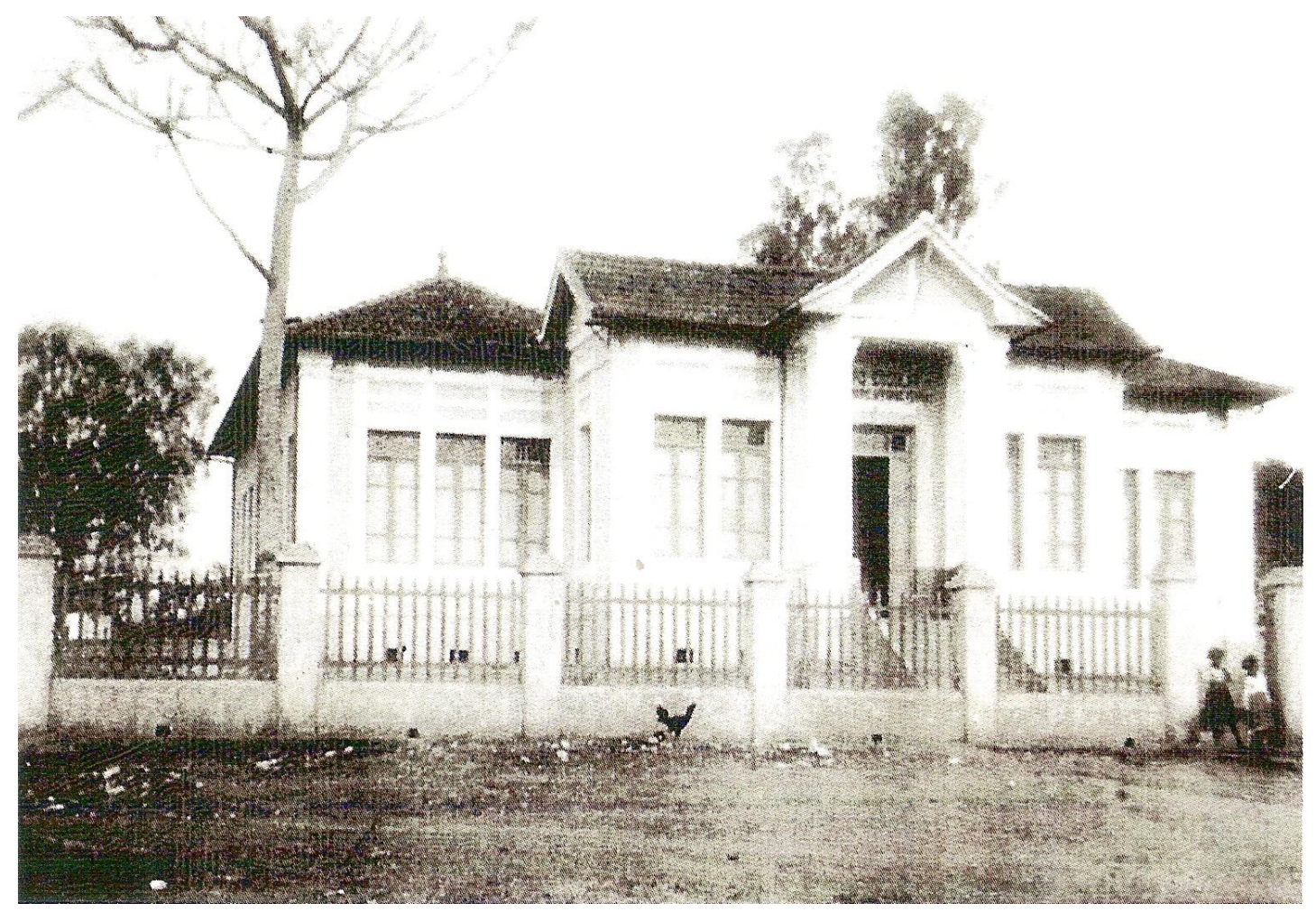

Fonte: Arquivo particular 
IMAGEM 58: A venda da Praça da Matriz

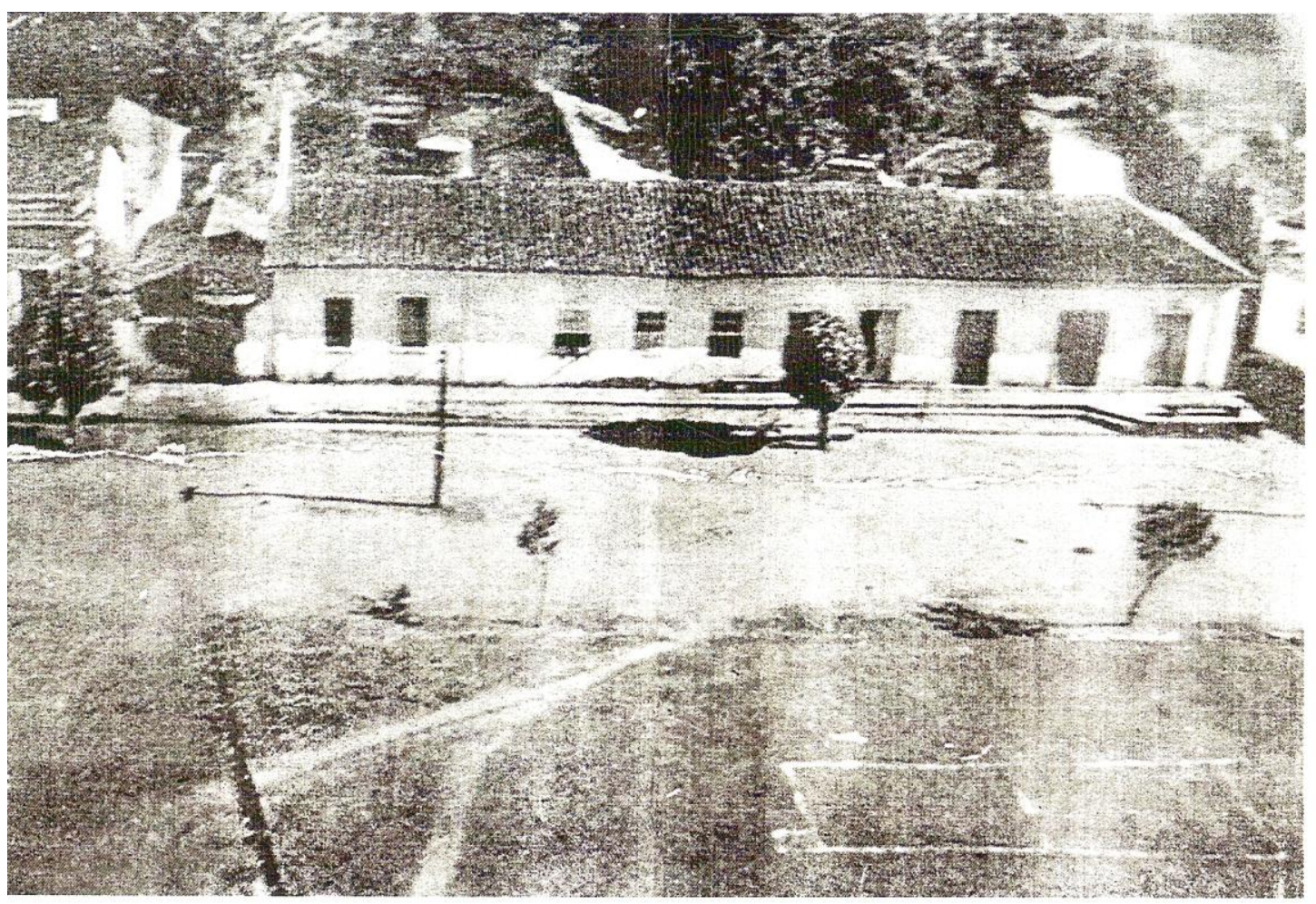

Fonte: Arquivo particular

\section{IMAGEM 59: $O$ teatro - início do século XX}

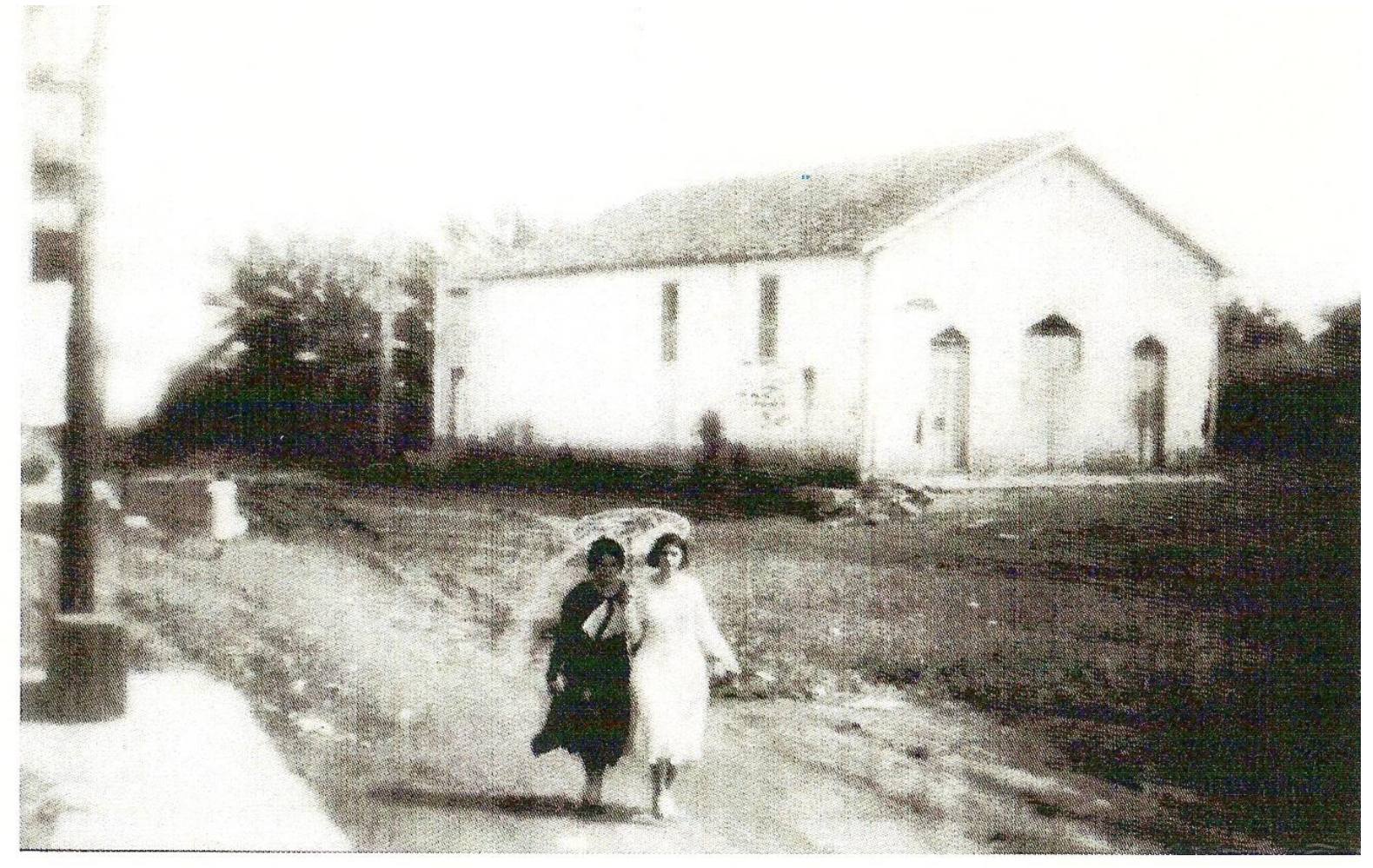

Fonte: Arquivo particular 
IMAGEM 60: $O$ teatro visto por outro ângulo

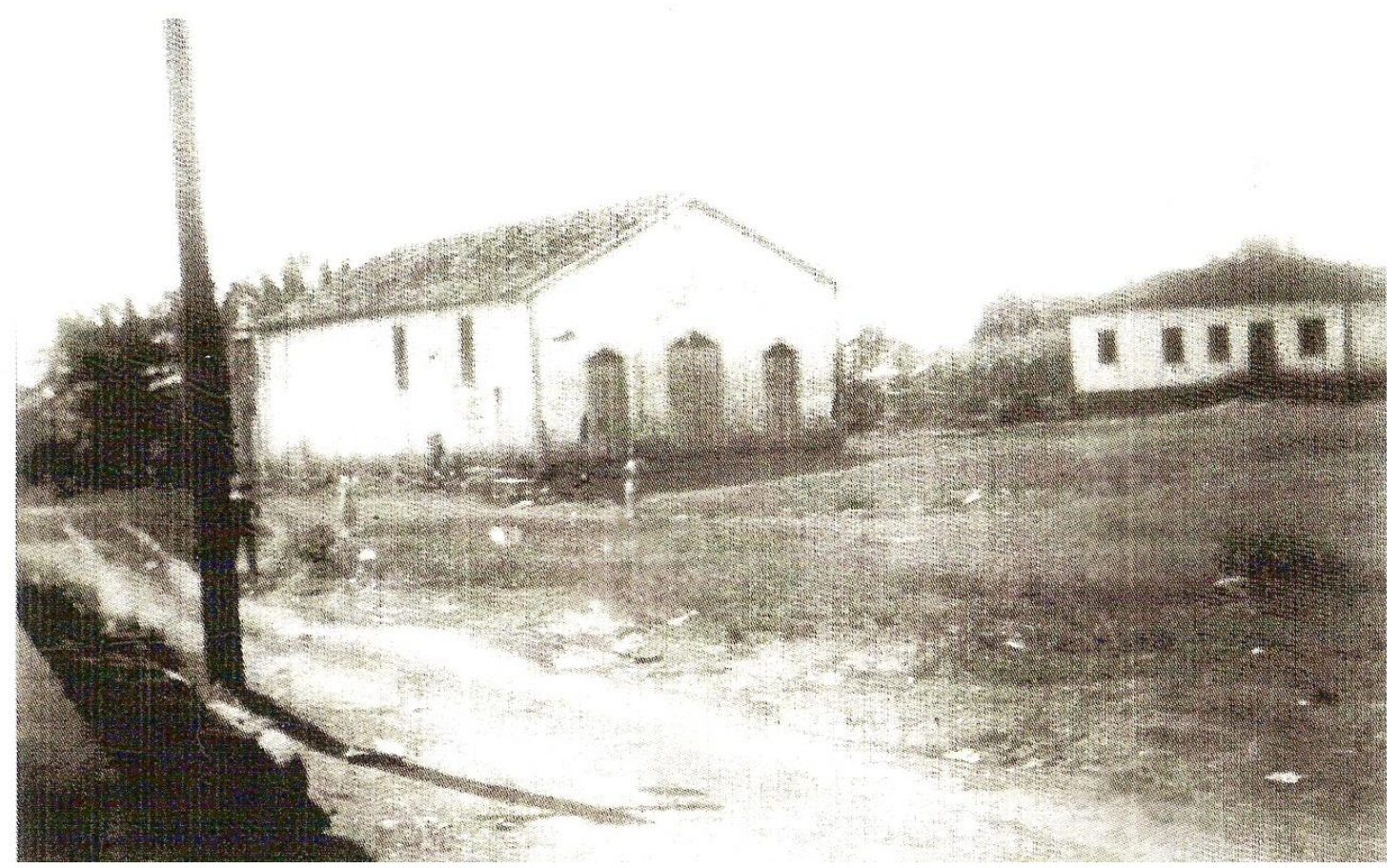

Fonte: Arquivo particular

IMAGEM 61: O teatro em ruínas - década de 1940

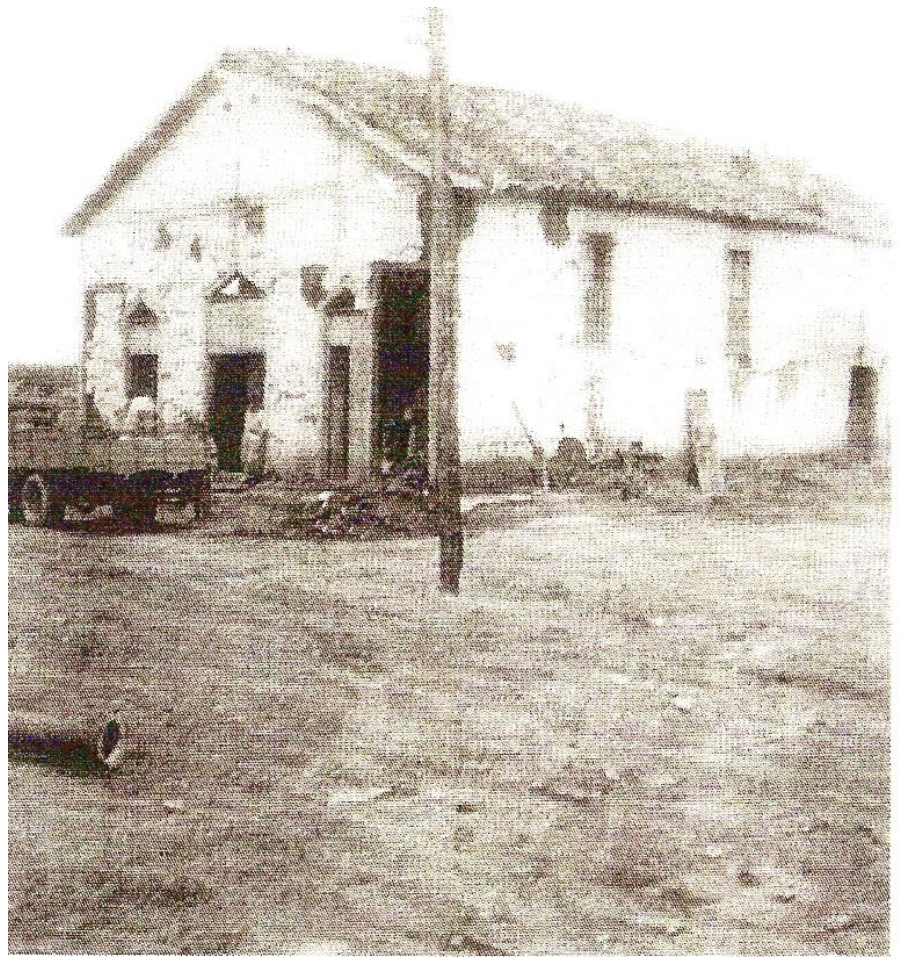

Fonte: Arquivo particular 
IMAGEM 62: A peça de teatro - 1904

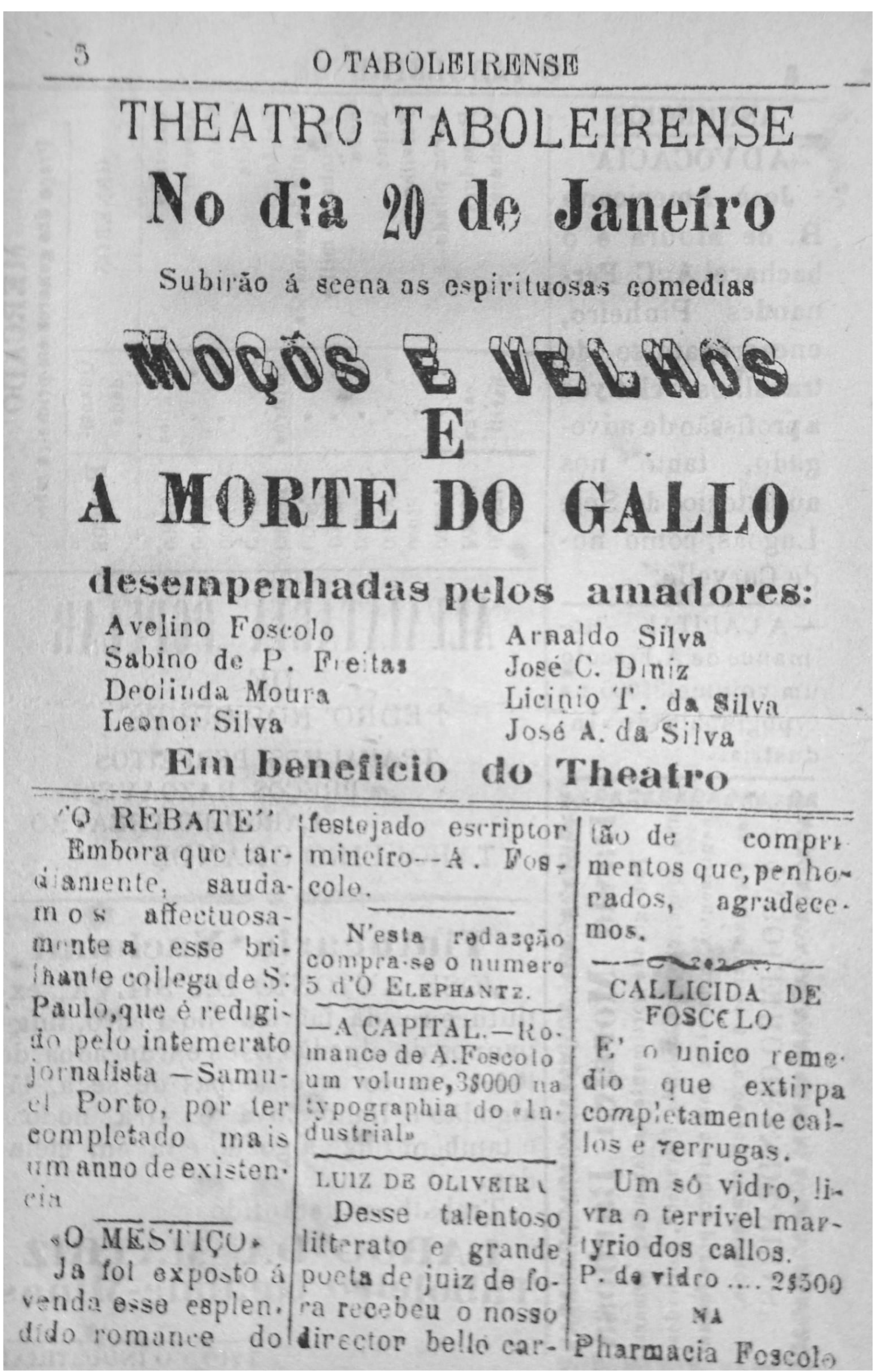

Fonte: Jornal O taboleirensse - Museu Têxtil Décio Magalhães Mascarenhas/Caetanópolis-MG 
IMAGEM 63: O prímeiro número do jornal Gazeta de Paraopeba - 1915

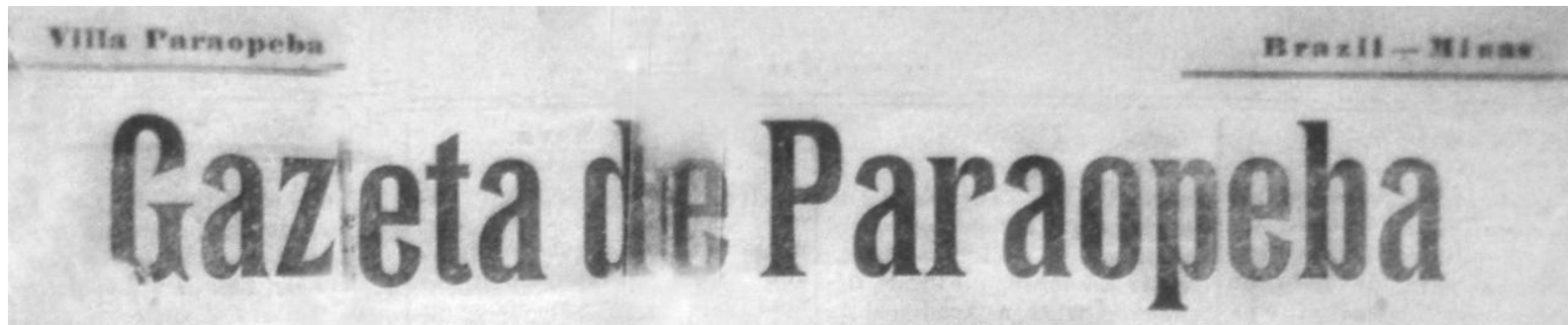

LITTERAM, FTHCIOSA E HUYORISTICA

ReDscras - MANOEL

Grpsare -J. EDULNDO JUNIOR

\begin{tabular}{|c|c|c|}
\hline $3 \mathrm{~d} / 3 \mathrm{~J}$ & o de 18 & Numero \\
\hline 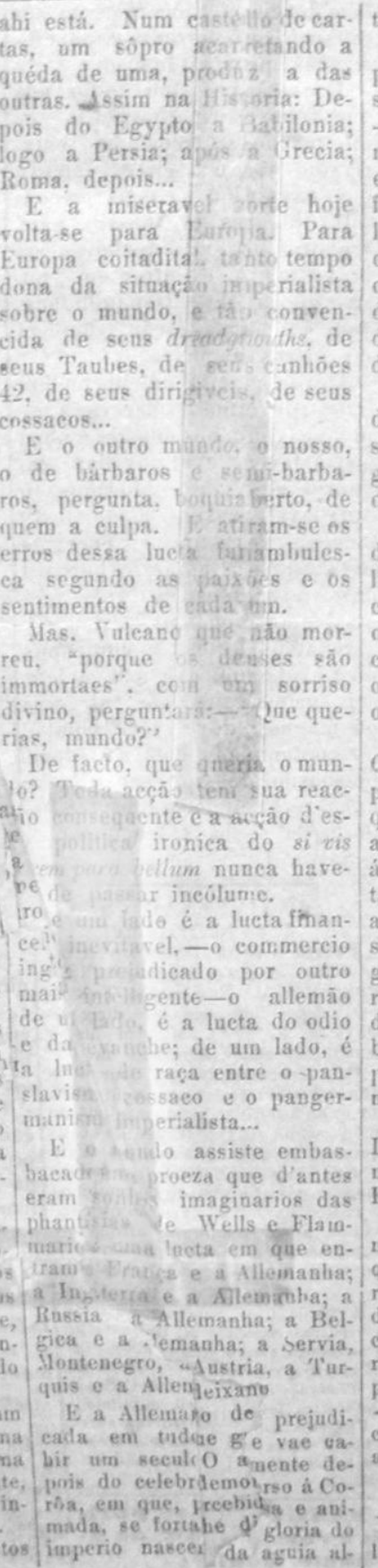 & 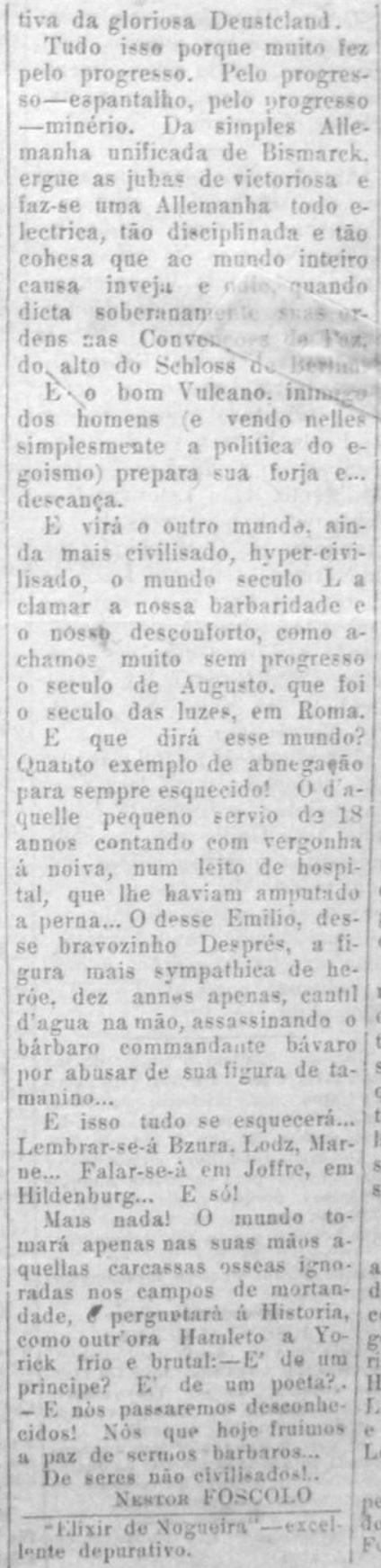 & 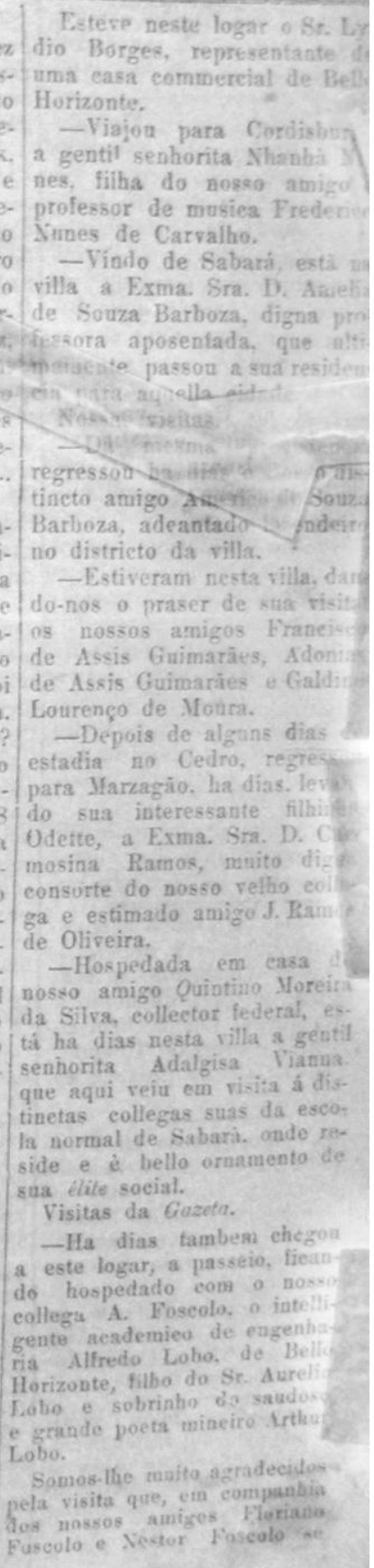 \\
\hline
\end{tabular}

Fonte: Arquivo da biblioteca municipal Agnaldo Edmundo 
IMAGEM 64: O último ano do jornal Gazeta de Paraopeba - 1955

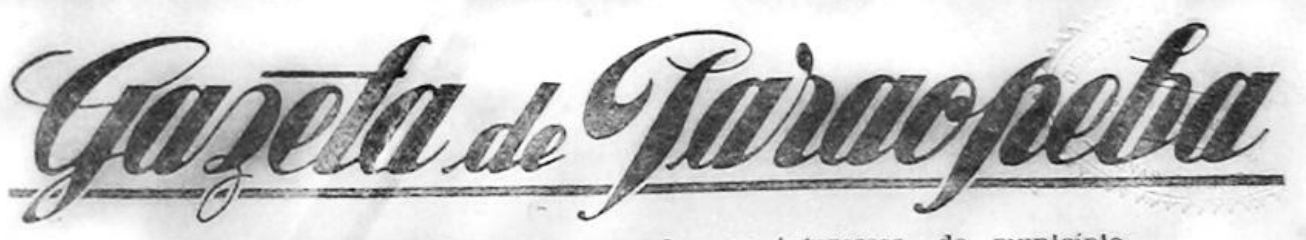

Semanario independente, consagrado aos interesses do municiplo

Proprietario e diretor: Manuel Antonio da Silva

Publica-se aos domingos

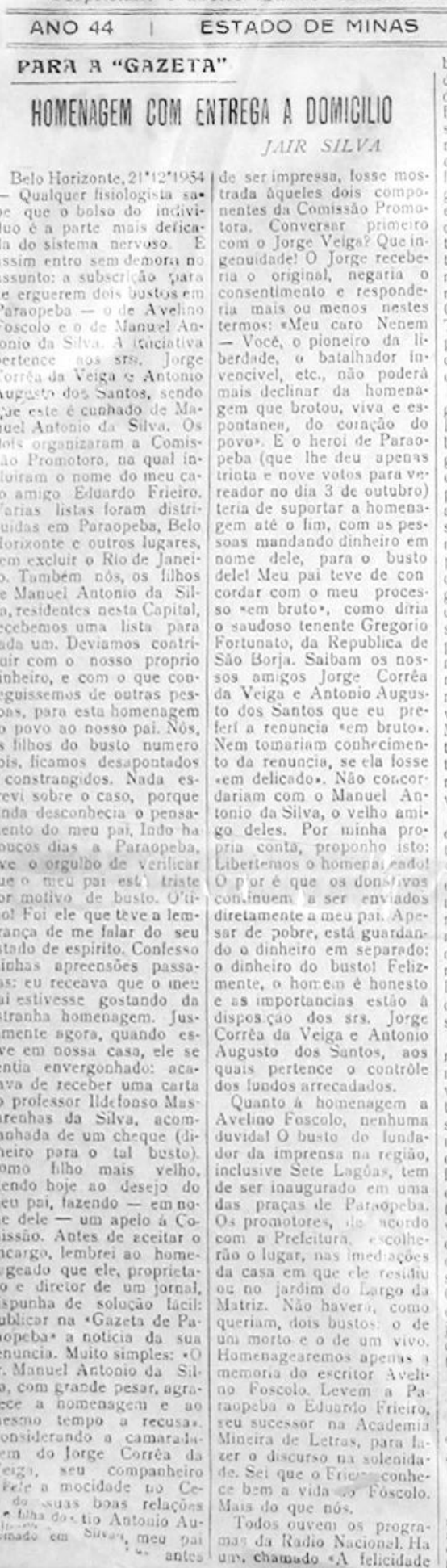

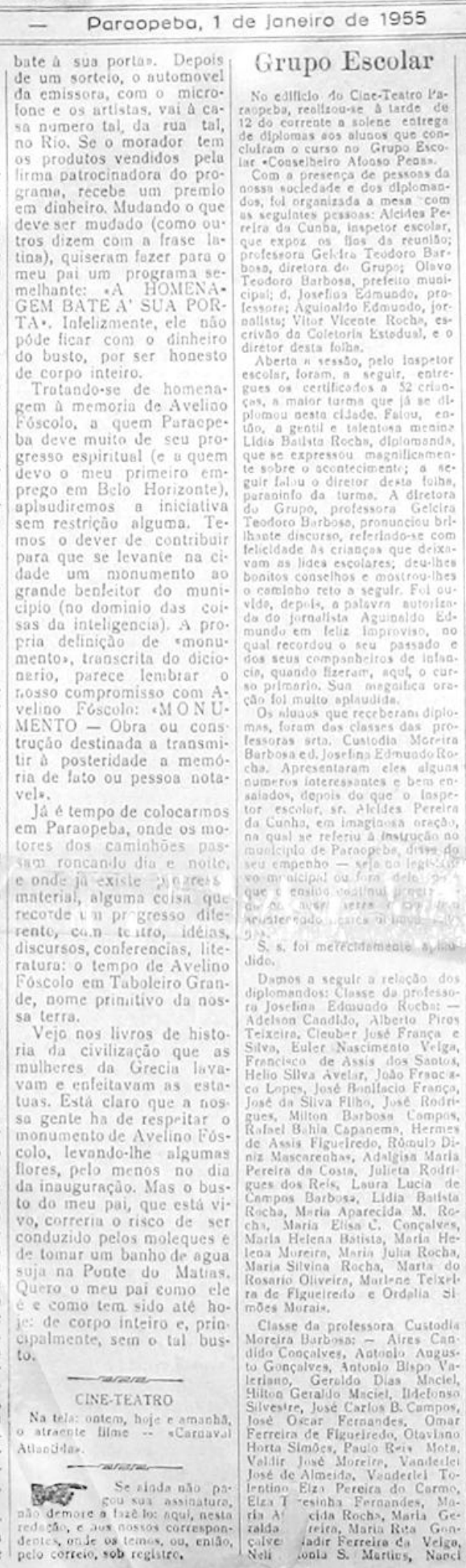
NUM. 2.382

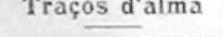

F. de A

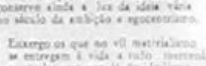

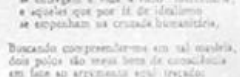

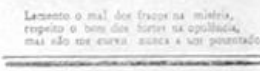

VLAJANTES

Treser M. Mortira - Esteve en-

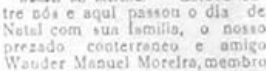
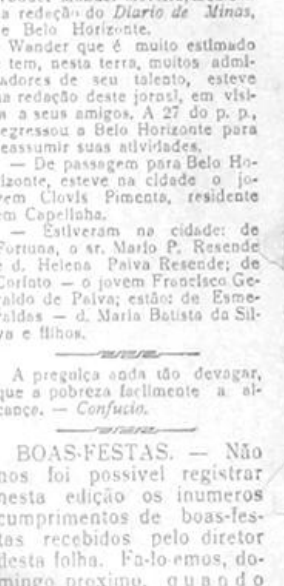

Fonte: Arquivo da biblioteca municipal Agnaldo Edmundo 
IMAGEM 65: O padre Sebastião Ribeiro Vianna. Abaixo, carta do padre aos familiares quando estudava em Roma - 1925
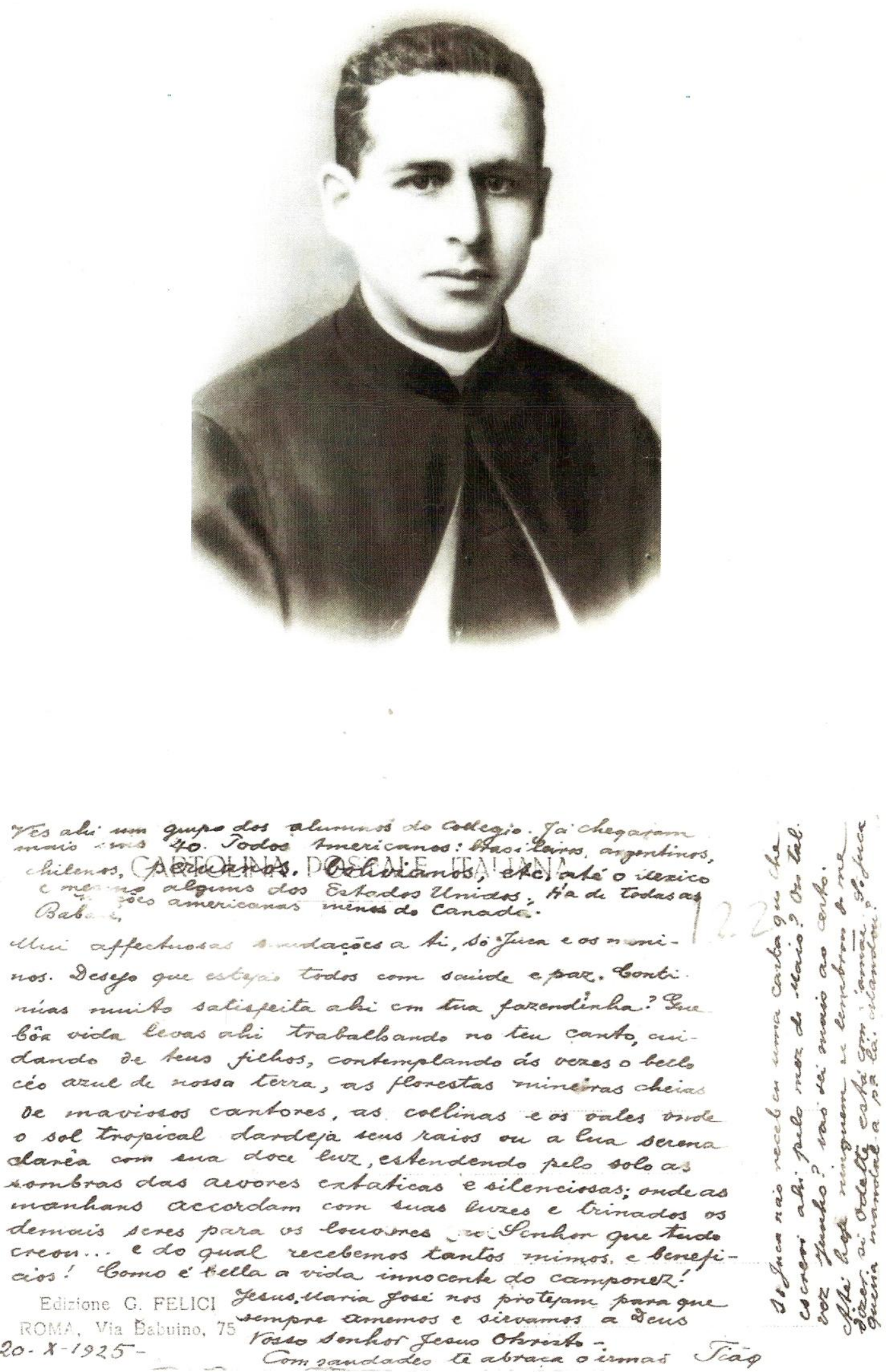

Fonte: Arquivo particular 
IMAGEM 66: A conversão do padre Sebastião narrada no jornal Estado de Minas 1952

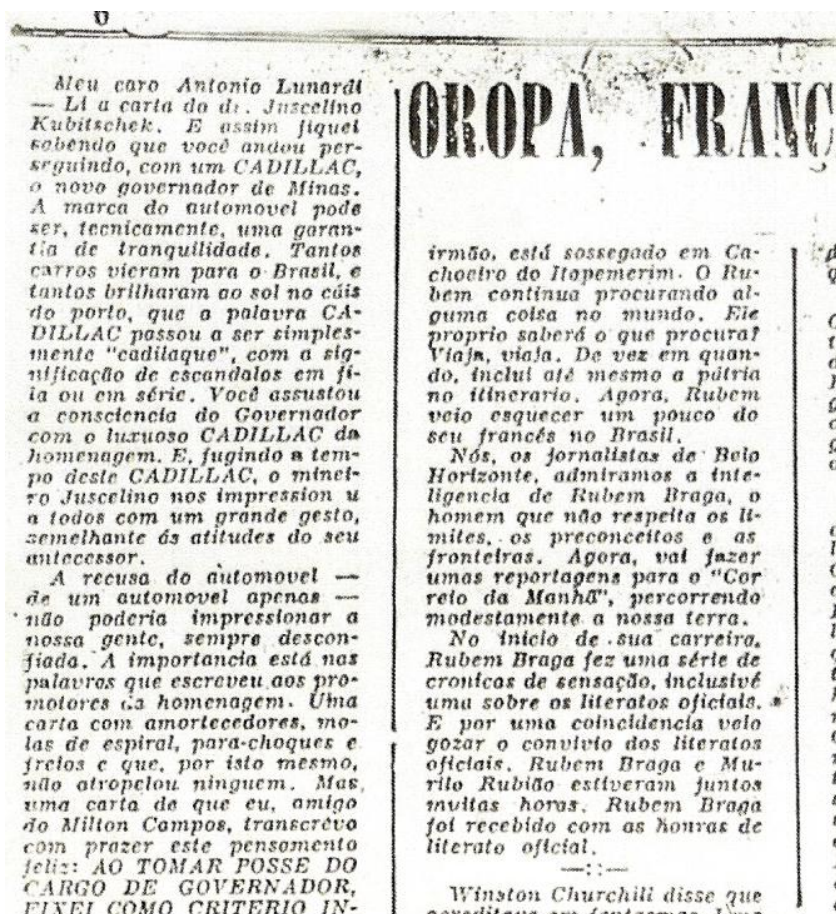
FIXEI COMO CRITERIO INTATIAVEL ESQUIVAR-ME DRANCAS, EMBORA SAIBA QUE REPRESENTAM UMA DEAIONSTRACAO DE AMI ZIADE, COMO NO CASO ERI
APRECO, OU UMA DEFERPRECIA OU HOMENAGES A' PESSOA DO GOVERNA"DOR".

Assim falone o governador Juscelino Kubilschek. Hssim teria falado o ex-governador mendos dizia gos, que nas fa"Nho tenho lugar para por este bonito bezerro.que o se11hor me oferece. Aqui mesmo sle fica muito bem". E delicasentes $\mathrm{em}$ poder dos ofertancos.

Noo ha nada mais dificil do que estabelccer a linha difuzendo as declarasoes que jez, o sr. Juscclino Kubitscr.c. tomou bem claro o seu pro pósito: o governador näo accitará presentes. Esta providendas 0 de terriveis batalkas coin a consciencia.

Em relaffio aos guernado. res que oceitavam presentes, a carta do sr. Juscelino Kubiesche é uma carapuça. $E$, para os

Guarde a CADILLAC, meu caro Antonto Lunardi. O 55 . Iuscelino Kubitschek o aceltari. quando terminar o go. Werno. Ná fique de CADIL In C, como um capeta, distrain do e atercino dos nossos ho-
mens publicos. Fm todo o caso, parabensi porque voce. coin o tal CADILLAC, deu a Juscctino ama grande opor-

$$
-::-
$$

Q sranic Rubem Braga es teve nesta capital. Quando era jequeno, escrevia na imprenate belo Horizonte, Fol cres inendo, e ao mesmo So, 0 poeta Neuton Braga, seu
Orinston churchitis disse paie acreditava em fantasmas. Lina
senhora perguntou se ele th nha visto olgum. $E$ churchill csclareceu: "Nso, porque os verdadeiros fantasmas sdo aqueles que "gente noo ve". referia aos fantasmas propria mente ditos. Entre nos. por cxemplo, "fontasma" sibnifieas muiher mutlo bonita, daquelas que um homem casado legat-
mente nan pode ver. Vocé fot mente nato pode ver. Voce fol ao Rior Vin algum fantasma com um fantasma. o que sque acontece sertte cmaşa. Per. de a palavra. Dit bobagens.
Enfim. fracasso. de todos os modos. Ainda sao poucos os que conseguem ver $u \mathrm{im}$ f que conseguem ver $1 \mathrm{im}$. de pelejar muito com os me sicos, Toscanini deirou col raiva o lugar do ensaio: - Aonde vai, maestrot questra.

Toscaninf foi envelhecendo $e$ como se a velhice näo bas tasse, quebrou a perna. Agora, pode permanecer mutio tenipo ple permanect mutito tentpo perguntas:

-Aonde val, arquestro? Os grandes chefes, musicos ou administradotes, nao se es. quefam dislo: um dia $e$ do
muestro e outro, da orquestra. $-::$

O sr. Getullo Vargas ofere. ceu ao povo carioca uma festa. Túo grande, realmente, que te. ve de ser feita no Eatadio do Maracana. De acordo com notictirio dos fornais, o $s \mathrm{r}$. Getulio Vargas detzou a prafa de esportes logo depois do primeiro tempo do jogo Vasco America. A. muttidá tinha vis* to seu jogo pessoal. $E$ o joso
de conjunto nodo the interessa. Trypue Lie fol a Čllte,
que corresponde a uma bisitn
Dizem que tim dia, depols - Vou buscar outro maes.
ESIALSTADO DE MINAD -

a Virgtnia cofin exuatra na la ta (embora nito ehovesse

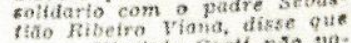
a sra. Virginfa coatt nator entrada om tar atgum, Em resumo, todes reaa ram en publico, tom trementdo Ato de Falta de Coridade. Considerou-se a lore fa do Ro. surio profanada, Tenho no neu arquivo de paraopeloens cxliado uma fotografia da ve tha igrejo, toda cercarla de me to, e com una arvore que it porta pincipal. Qtando at motrer estiver corporeamen to no Ciu mostraret a foto. arafin da igrefa do Rosario Nosso Senhor.

Em ves de arrangat dinhelre para o projeto da fabrica de Maria stela sforeira teve idétia de construit, no mesno lugar, a tgreja so Rosario. padre Sebastito Ribeiro Viana morreu. Mas a sra. Virginfa Coati esta viva. E o celebrante, qualguer que seja. ainda terd recelo da sra. Mis. ginta Coati, que continua de Alem disto, a popularao de paranpela tem fiminuia, em vez de aumentar, 7 odos vas, Matris en cula torre o padte Herctiano Pimenta instalos Clto-falantes. Estive ha pouce tempo em Pareopeba. E conclui que a padre Hercutoria co de acordar os fets a os in. fieis todas as mudrugados. nova igreja do Rosario catara sua destruigar ainda exista. va. $E$ toiles conhecent a his. torio.

Vai ser instalada uma fabri ca de tecidos no Cedro. Em homenagem aos velhos $\mathrm{Mase}$. brtea. A inicintiva pertence a Gulherne Mascarenhas Dale. e a outros brotinhos da industria: Pedro Moreira Barbosa. de fato milionário, e Olavo Teodoro Barbosa.

$0 \mathrm{dr}$. Pedro Alovelra Bar. bosa esta convocondo os parapebenses para uma explicagoo $\mathrm{cm}$ linguagem financeira. telejone para ele e o dinheiro do pobre serfí convertido em deita una coleta entre os pobres, para que cstes ndo se quando os pobres ficarem mais pobres e os ricos mais ricos. A praposito: a senhorita Maria Stela Moreira está com a ideia de construfr nova igreja do Rosario no mesmo lugar em que o povo de Paraopeba dono, at $\xi^{\circ}$ desmoronanento

findl. falecido padre Sebastido Ribeiro Viana estava celebran. do missa e perder a paciencia con lima das devotos, Virgtnia Coall, ajoethada sempro Junto do altar. O padre de
terminou, em voz alta. qua a mulher se ofastasse. E cla. publicamente houve uma série de outros escandalos en torno do escandalo principal. Em vex de consolar a vitima, a verda deira villma, isio $\delta$, a sra. Vir niram-5e em tarno do clero de Paraopeba, o fornalista Agulnatdo Edmundo, em dis.
curso violento, declarou gue para que se csquecan de 37. tantas vezes lembrado por cle o sr. Cofe Fitho matimentro fita do Cafe. Pessoas que se queixam ao vice-prestdente da Republica! O sr. Cale Fi tho estif ficando muito imporseu cartaz. Talvez as providencios fó tenham começado. Ha dias, a Agencia Nacional distributu ans fornats tima fo$4 \mathrm{~m} \mathrm{em}$ audiencta. no Palacio Rio Negro. en Petropolis. o st Cafe Filho, vice-presidente com o chefe do governo, a fim de comunicar a $s$ excía. as suas atividades deside que assumin o alto posto para o qual. fóra investido pelos resultados das urnas em is de outubro ui. trmo. o vice-presidente da Repubica palestrou longamen te com o ar. Getulio Varzas, apresentando a foto da Agencia Nacional um aspecto da audiencia". A legenda e a foCafe Filho saindo da sua fila parn entrar de novo na fila do sr. vice-presidente da RemuBlica!

$$
-::-
$$

Falando agora como escritor falecido. Kumberto de Cannpos tem atacado os colegas vivos. Is estes coniegam a defondiano encrever violenen-az: Mariano eacreven violenen
tigo contra o autor tigo contra o autor orm on, tullo Vargas acabard com a Logralia com eata legenda: da Republica, que so avistor

Fonte: Arquivo particular 
IMAGEM 67: A conversão do padre Sebastião na visão do memorialista Sr. José Década de 1980

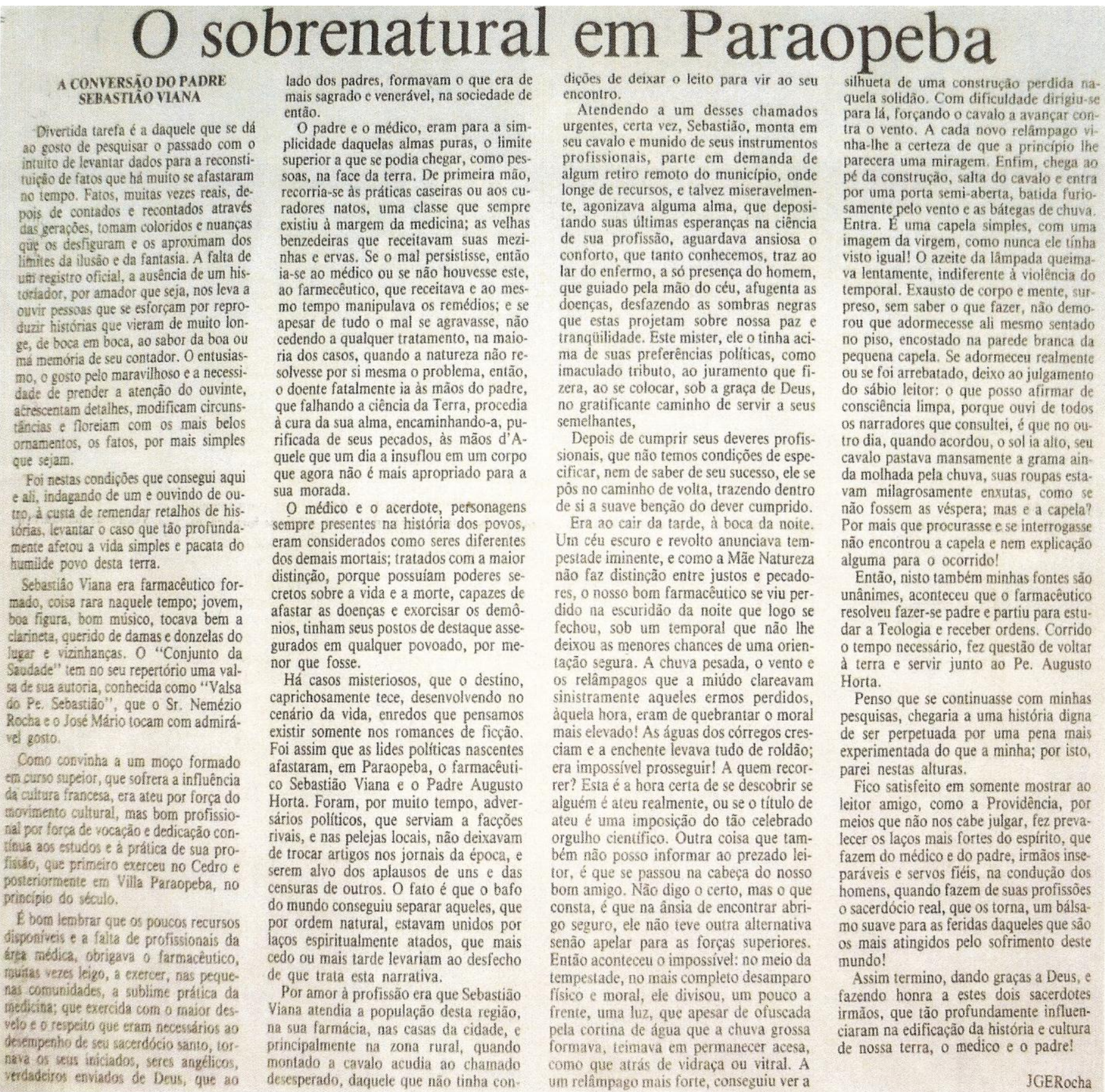

Fonte: Arquivo particular 
IMAGEM 68: Padre Augusto Horta em 1916

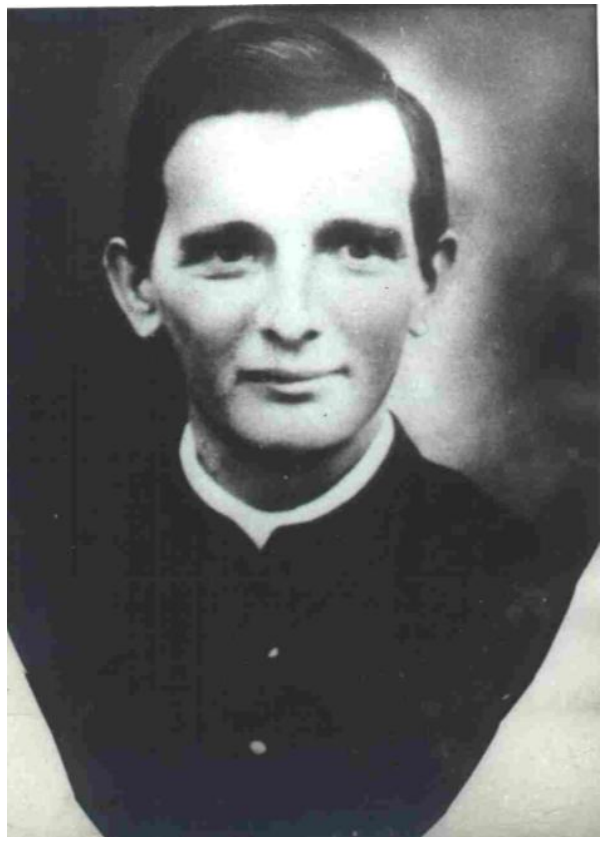

Fonte: Arquivo particular

IMAGEM 69: Cortejo fúnebre do Padre Augusto Horta - início da década de 1940

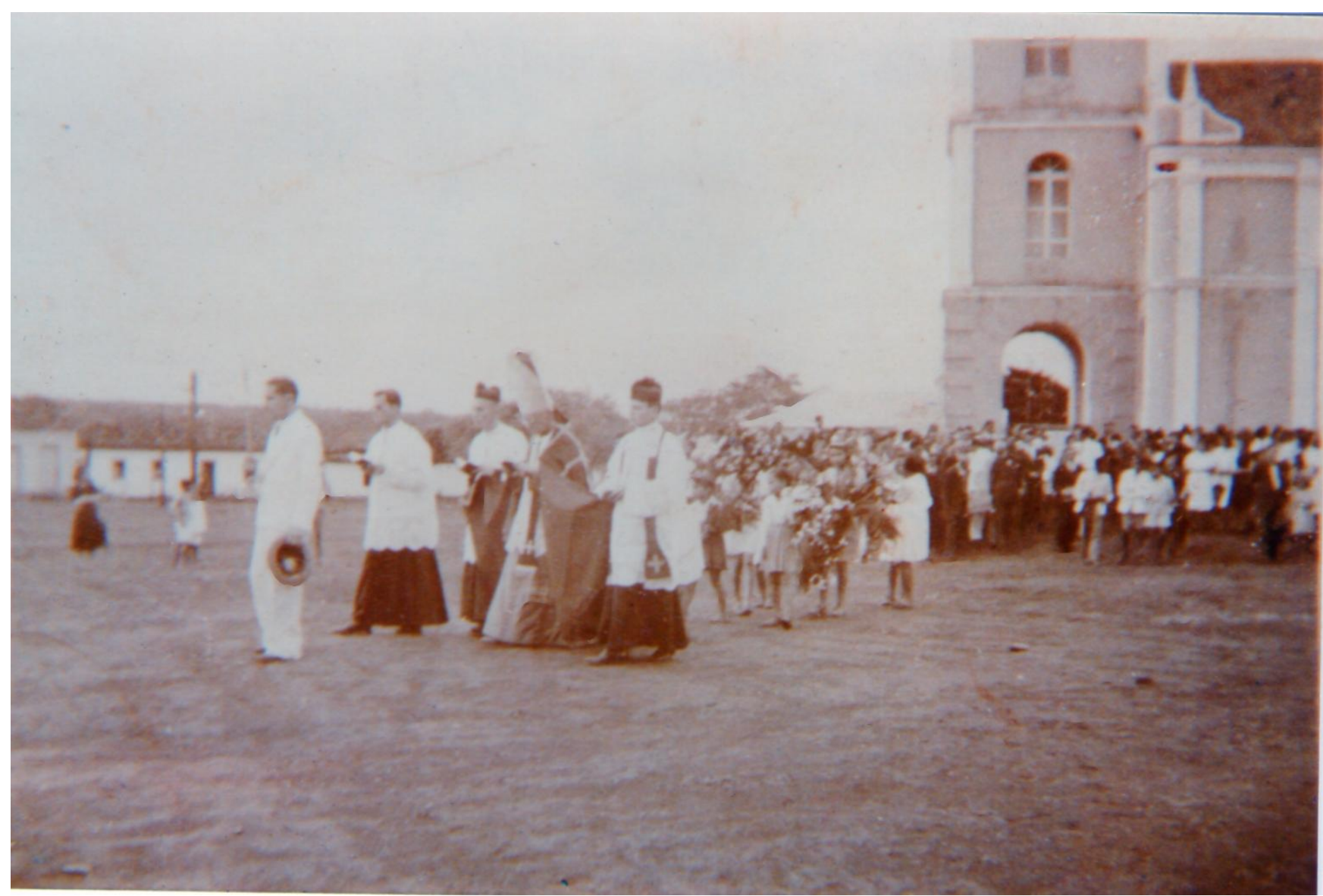

Fonte: Arquivo particular 
IMAGEM 70: A fábrica do Cedro - século XIX, por volta de 1880

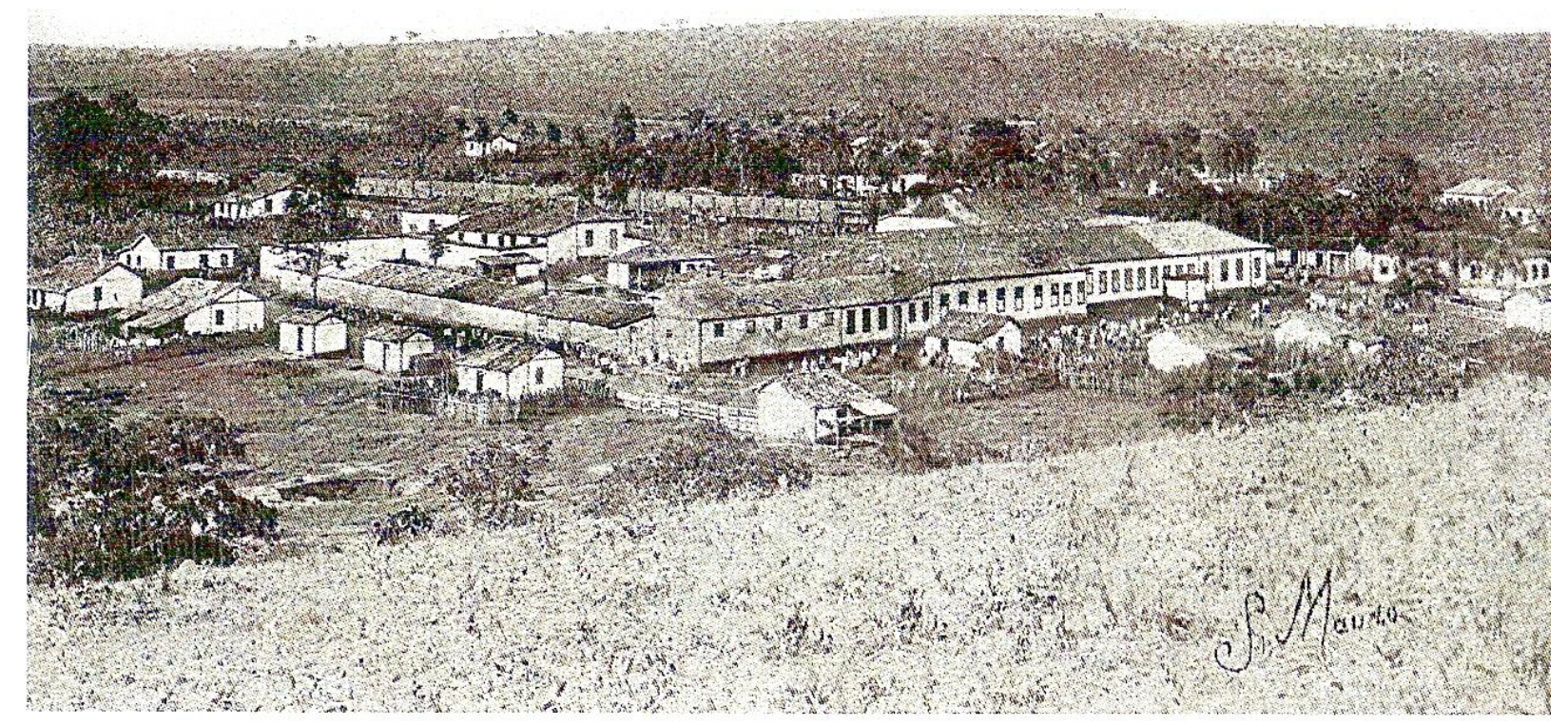

Fonte: Arquivo do Museu Têxtil Décio Mascarenhas

IMAGEM 71: A fábrica de Paraopeba - PISA por volta da década de 1950

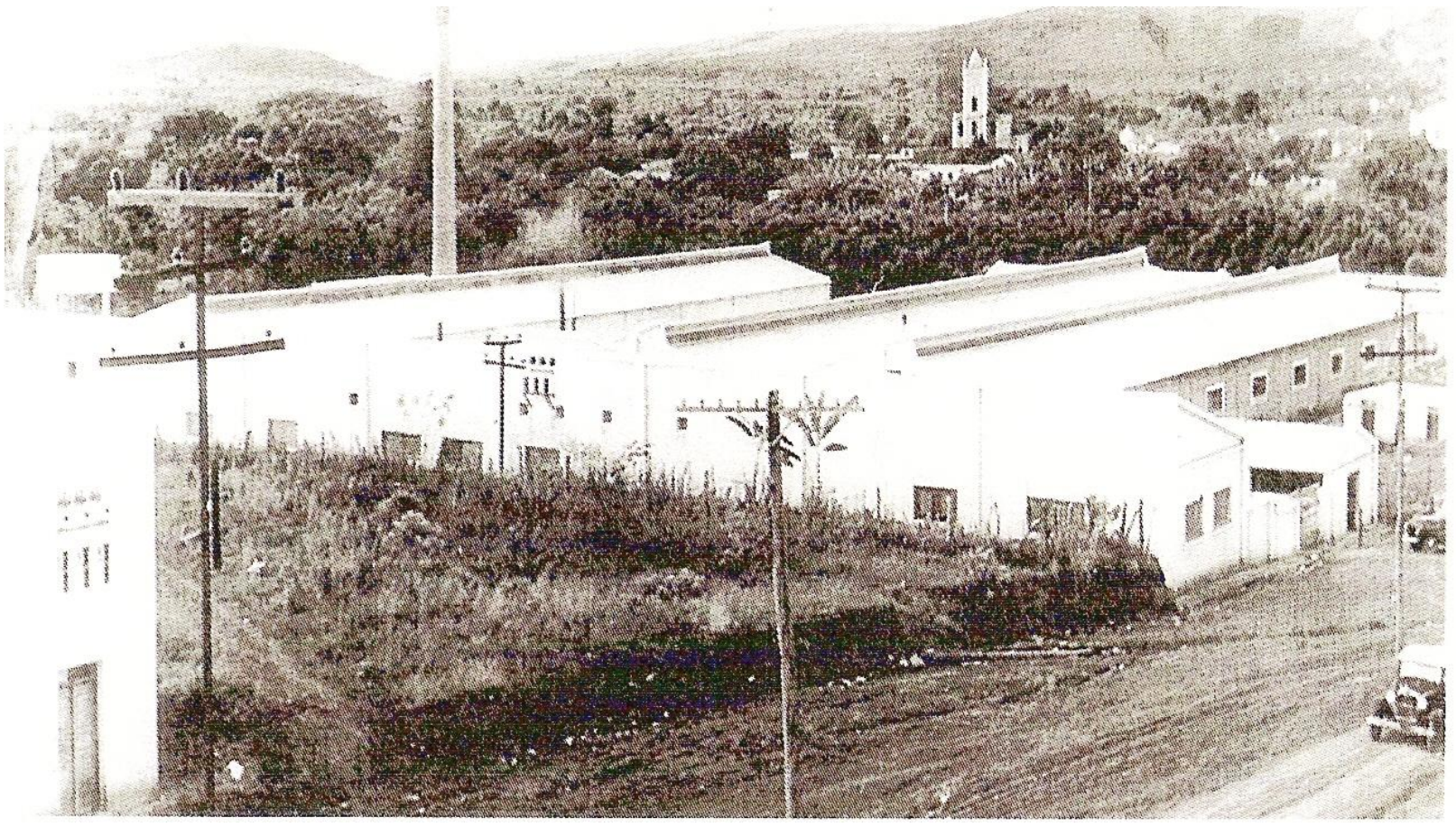

Fonte: Arquivo particular 
IMAGEM 72: Cartaz comemorativo da fábrica de Paraopeba - PISA

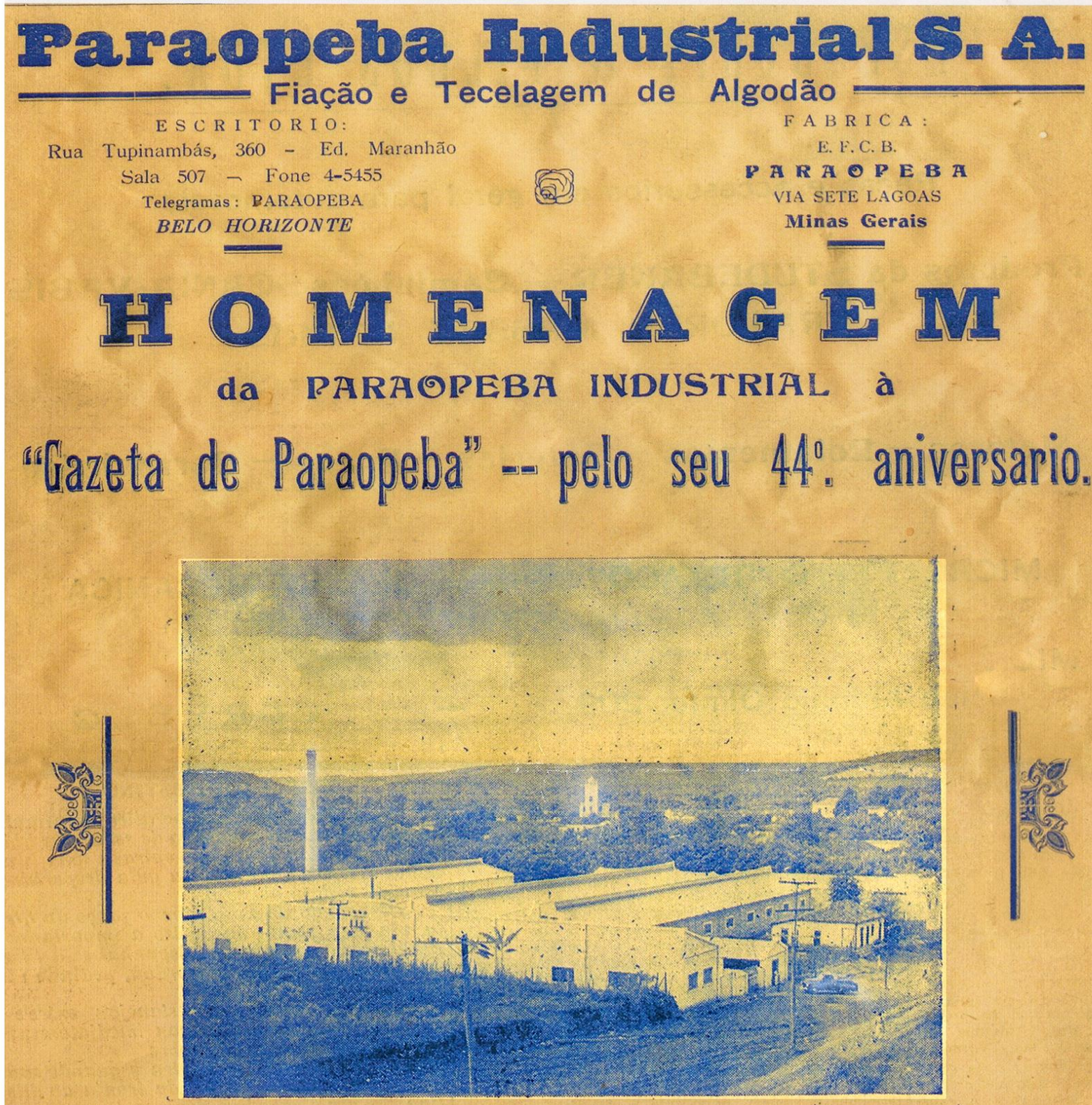

Fundada em maio de 1951. -:- Instalada em janeiro de 1953.

\section{Capital: $16.800 .000,00$}

\section{DIRETORIA :}

Diretor-Comercial: Dr. Pedro Moreira Barbosa

Diretor-Técnico : Dr. Luiz. Antônio Gonzaga

Diretor-Presidente : 1)r. Guilherme Mascarenhas Dale

Gerente: Olavo Teodoro Barbosa

Fonte: Arquivo da biblioteca municipal Agnaldo Edmundo - Paraopeba 
IMAGEM 73: Três momentos do primeiro carregamento de tecido da produção da fábrica de Paraopeba
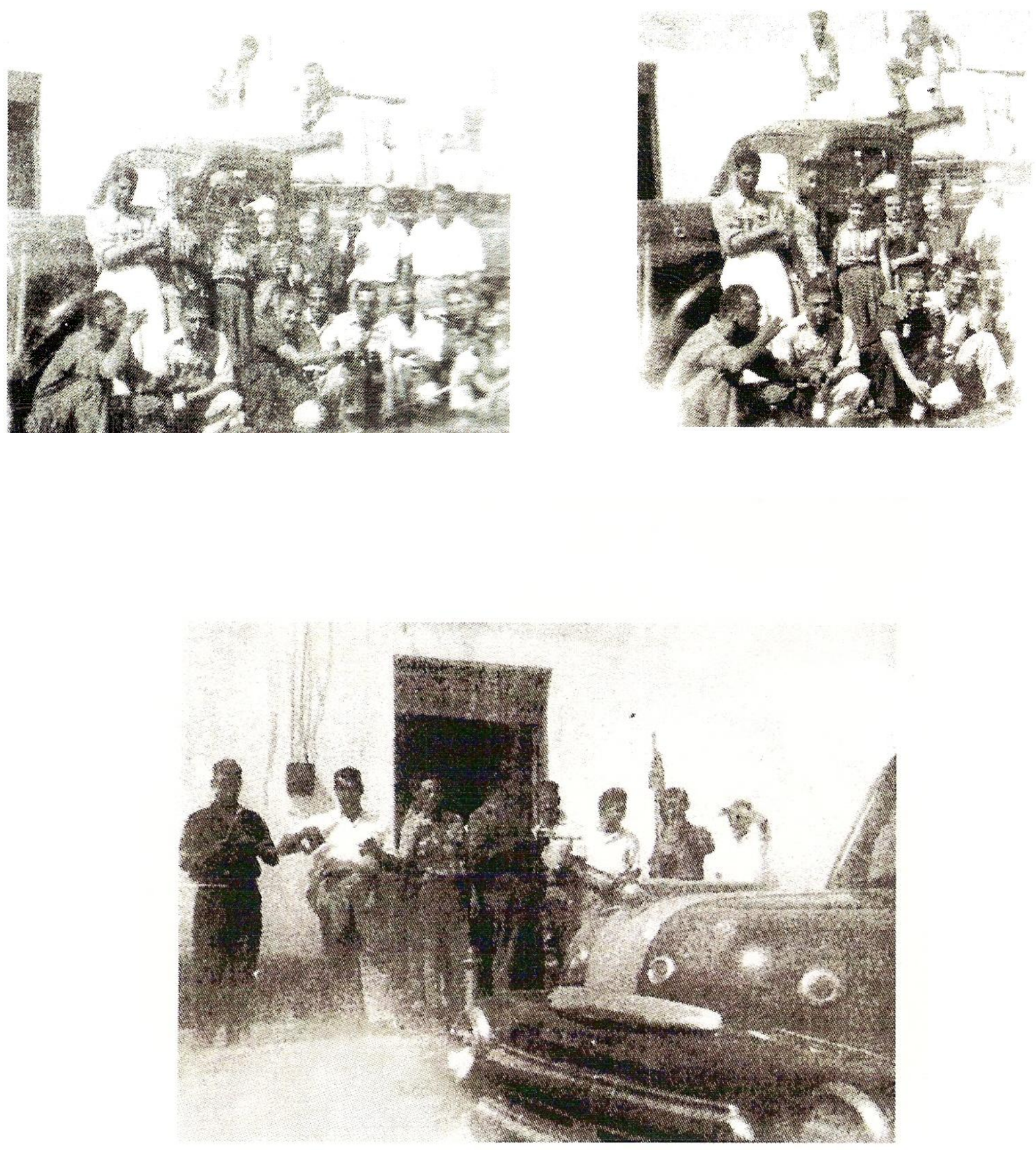

Fonte: Arquivo particular 
IMAGEM 74: Regulamento interno para uso dos banheiros da fabríca do Cedro - 1915
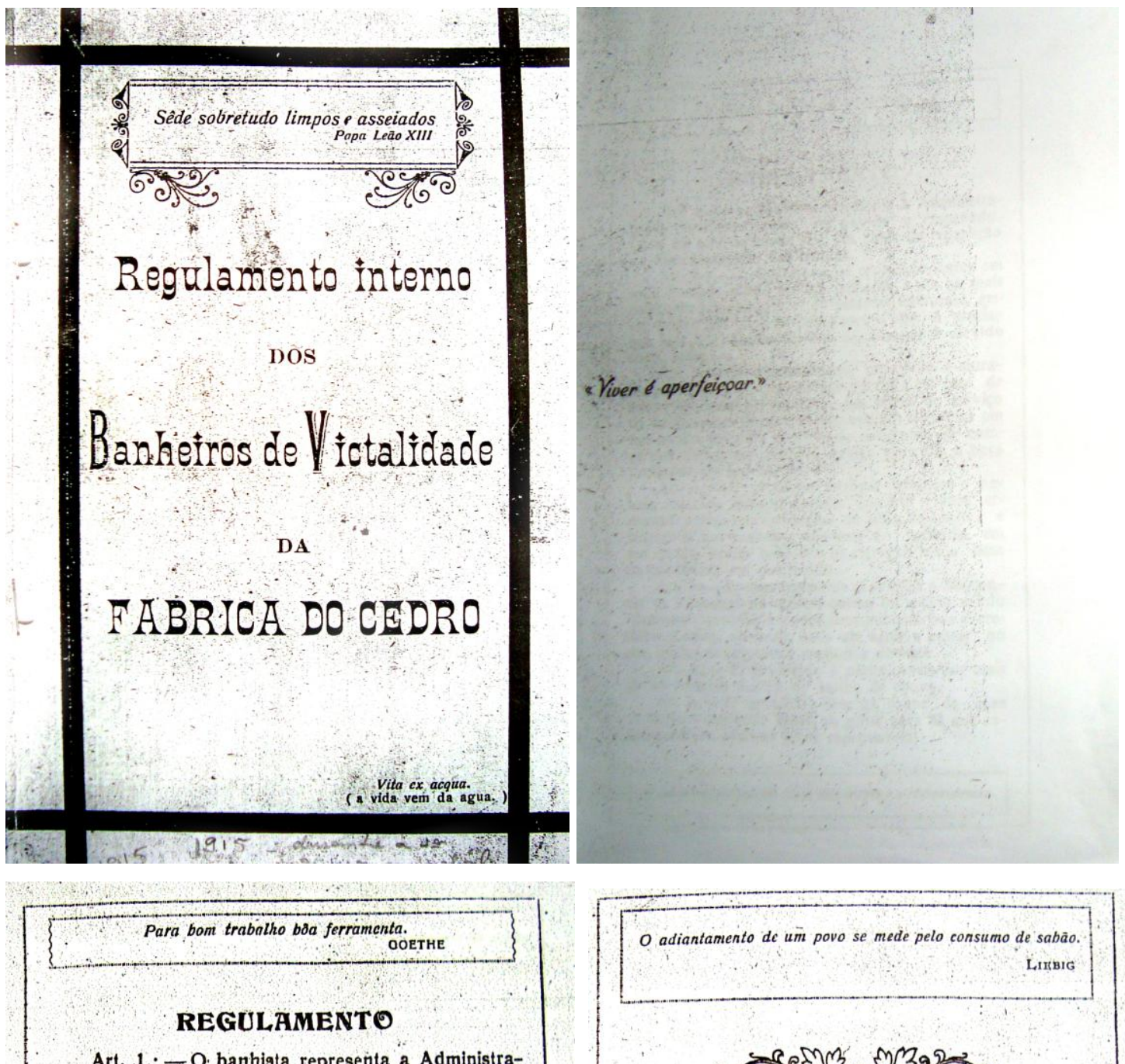

Art. 1. - O banhigta representa a Administracão e como esta deverá ser ouvido e respeitado. Cada dia será auxiliado por um chefe de repartição no funccionamento dos banhos.

Art. 2.- - E' expressamente prohibido, como em todo dominio d'esta fabrica, offender a um ou mais companheiros com gestos ou palavias immoraes, gritos dentro dos banhos como fóra d'elle; é preciso que haja bôa harmonia, bôa combinaçã̃o e devido trato social.

Art. $3 \cdot-E^{\prime}$ expressamente prohibido a entrada e permanencia de qualquer operario na casa de banho sob qualquer pretexto, nas horas de serviço da fabrica e nas horas que não estejam indicadas em sell cartao devendo e convindo entretanto ali com parecer depois do apito do servico e no dia e hora parecer depois do apito do

Art: 4.- - E' prohibido estragar pertences e mo. veis, sujar ou rabiscar paredes, quebrar vidros, arrombar portas, correr dentro da casa de banhos e frequentar um banheiro differente do indicado em seu cartão, sendo cobrados os estragos feitos além da peralidade em que incidir.

Art. 5.- $-\mathrm{E}^{\prime}$ expressamente probibida a frequencia de 2 pessoas no mesmo banho ou latrina; sendo igualmente prohibido andar descomposto nos corredores e salas, devendo cada um sahir e entrar no seu banho devidamente vestido e decente.

Art $6 .-E^{\prime}$ prohibido a permanencia por mais de 15 minutos dentro do banho de chuva.

Art 7.- - E' prohibido ficar ao redor da casa de banhos tentando olhar ou gritar para os que esta dentro e praticar actos reprovaveis.

O trabalho com calculo faz a vidd alegre e a independencia.

$O$ adiantamento de um povo se mede pelo consumo de sabâo. LinBig

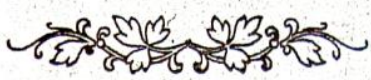

A Administração da Fabrica do Cedro, com o fim de proporcionar todo vigor e salubridade a seus operarios, e, ao miesmo tempo, facultar-ihes meio de aperfeiçoar-se e vạlorisar-se, crea o

\section{SERVIÇO DE BANHOS}

Todo operario de procedimentó regular e que não soffra de males infecto-contagiosos, tem direito a um banho semanal. Para isto será matriculado, recebendo um cartão de ingresso que the marcara hora precisa e lugar do banho adequado as suas condiçōes.

Entregando este melhoramento a seus dignos auxiliares e operarios, espera a Administraçăo que todos concorram para a conservaçāo moral e material desta instituiçāo, cousa aliás facil de conseguir de um pessoal de bons costumes e amante do progresso, como é o pessoal do Cedro.

Que sejam colhidos os grandes effeitos salutares e sociaes que é justo esperar d'esta instituiçẫo, são os đesejos e votos sinceros da Administraçåo.

A sã consciencia faz o somno sereno e sem remorsos. 


\section{Saber d diffieil, fazer ef facil.
sOCRATES \\ PRECEITOS}

1. - $\mathrm{O}$ banho em temperatura natural, o qua năo deve ser demorado, estimula todo o corpo e, roubando-lhe calor, já sem utilidade refresca salutarmente as pessoas que reagem bem.

2. - O banho morno tambem chamado neutro ou indifferente é o mais aconselhado e, de 26 a 30 graus centigrados acalma, desaltera, descança o organismo.

3.- - Qualquer dos banhos acima faz o asseio da pelle, retirando as impurezas que de continuo cahem sobre ella. Estas impurezas são ora lançadas pelo cxterior e são as poeiras, gazes e todos maus conlactos; ora lançadas pelo interior do corpo e que sao, alem dos apontados nos "Conselhos para uma vida feliz" mais as que $3.000,000$ de exgottintios (que sao os póros) lancam diariamente na pelle de cada pessoa na quantidade cerća de 1 a 2 kilos da immundicies que nao retiradas azedam e då um cheiro desagradavel e as feridas perceptiveis ou não, que prejudicam o bom funccionamento da pelle, o qual é da maior importancia para vida.

4.- - O banho, pois, cura certas molestias, atalina muilas outras, perfectibilisa as pessors sadias que delle faz uso e constitue prazer deleitavel para pessoas perfeitas, como para todo vivente sobre quem Deus faz cahir a chuva benefica do Ceu.

5.'- Antes do bantio, que não deve ser usado com estomago cheio, deve-se limpar os entre dentes com palito ou fio de linha, escoval-os e á bocca, com saba commum e gargarejar, enxaguar a garcanta com agua desinfectante ou purai cortar as ganta com agua desinfectante ou pura; cortar as unhâs dọs pés e das mãos, aparar a barba (se a tiver) e uma vez por mez aparar o cabello.

\section{Corpo sâo espirito sâo.}

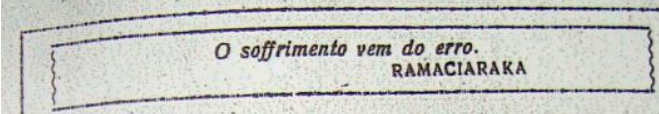

6.- - Os banhos de chuva, neutros ou frios, de6er tomados de 2 jactos, sendo o primeiro ra. vem serega pido toda força com bom sabão, fazendo a massa. gem energica da pelle e musculos. Em seguida to gem energica jacto para enxaguar a fundo, sem deirar nenhum sabão na pelle.

7. - Após o banho é indispensavel usar roupa 7. Após a balle na reabsorva os venenos limpa para que a pelle na roupa suja.

perigosos que contem discutem os sabios a vantagem

8.- - Ainda hoje discutem os sabios a vant

\section{PENALIDADES}

Além das penas em que encorram perante sua conincia do ceito social, os desrespeitadores do regimento inciceilo social, os des Administracão e a juizo desta.

dministração e a juizo desta.

Penalidade Maxima:-Desligamento e expulsão do seio do corpo de operarios, como indign manecer n'elle.

Penalidade Media:-Prohibição, por tempo indeestas penalidaterminado de frequentar os banhos. depois de ouvido des serão applicadas pelo Gerente, depois estiver no o banhista ou o chefe de repartição qu banho ou testemunhas.

Penalidade Minima (Correctiva) A ser applicada pelo banhista:- Prohibição de frequentar os banho até dous mezes

Estas penas serão applicadas em vista do davor da praticado. Haverá multas que reverterão a banhista. igreja local por delictos menores a juizo

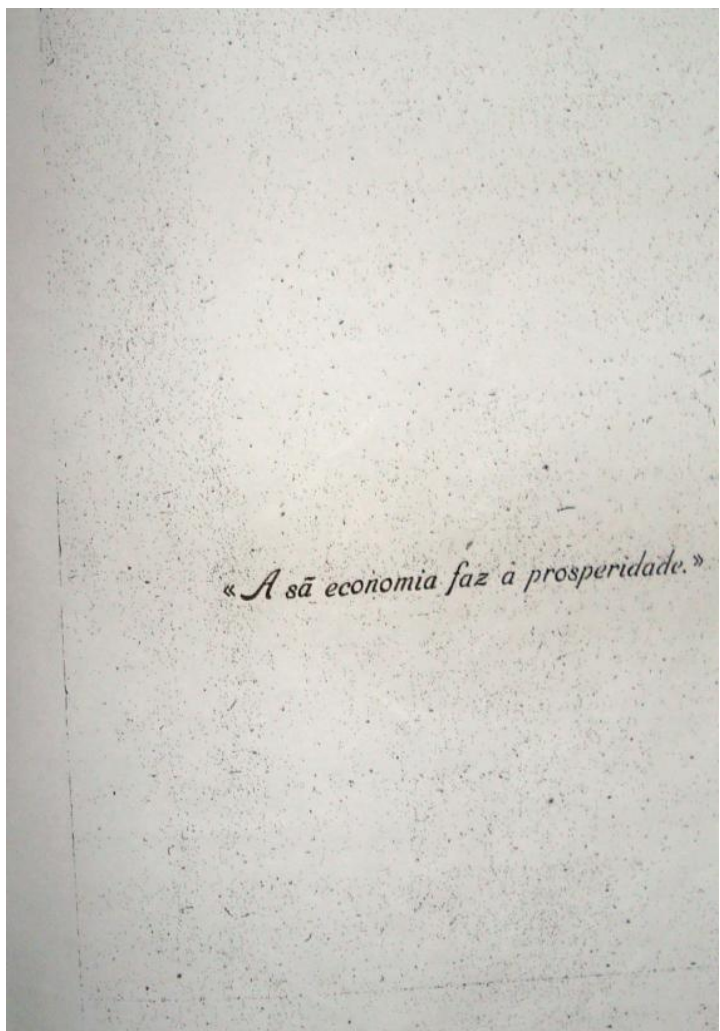

Fonte: Arquivo do Museu Têxtil Décio Magalhães Mascarenhas/Caetanópolis-MG 
IMAGEM 75: Igreja Matriz na década de 1980

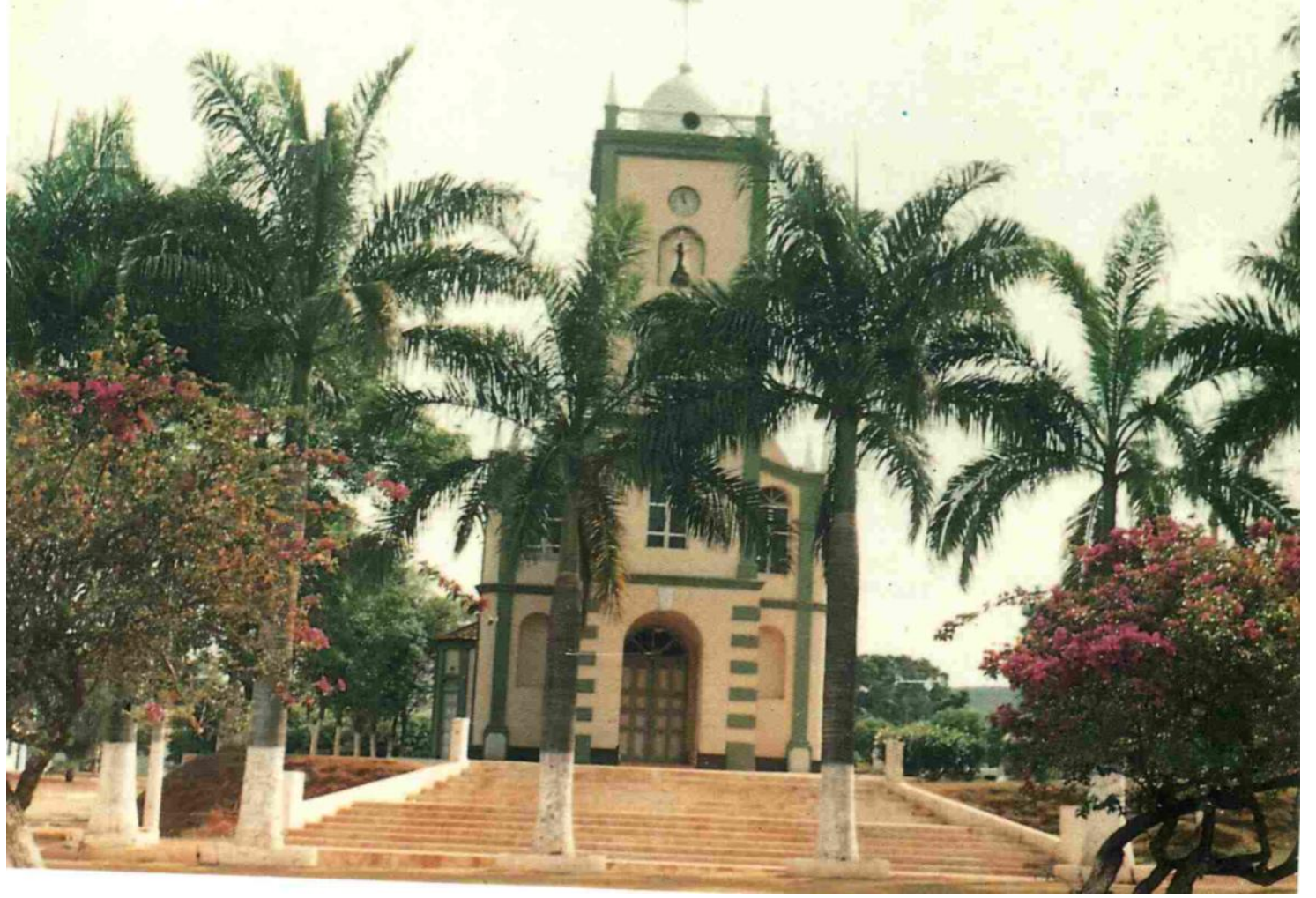

Fonte: Arquivo particular

IMAGEM 76: Vista aérea da cidade na década de 1980

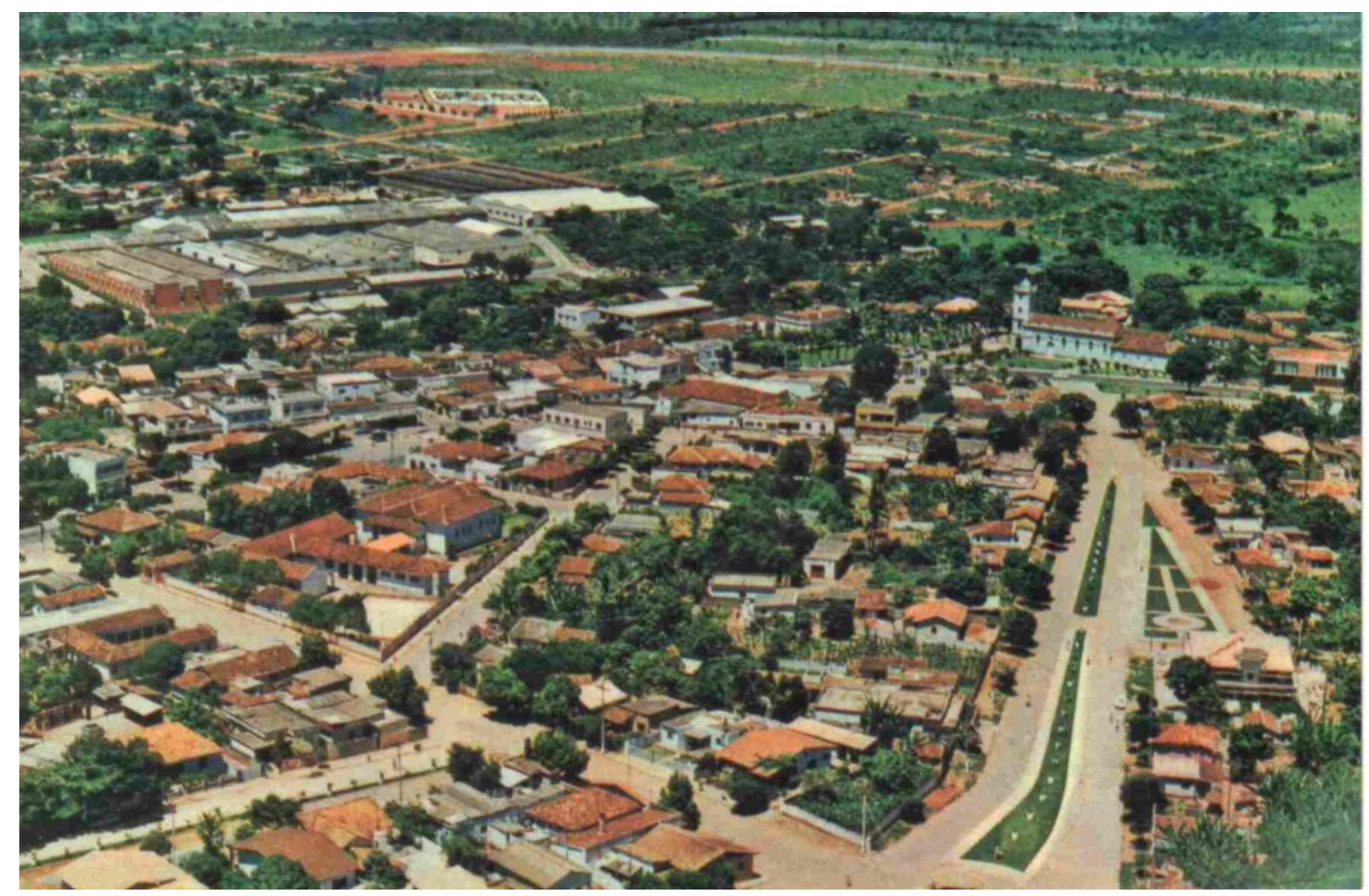

Fonte: Arquivo particular 
IMAGEM 77: Antiga rua Direita, atualmente Avenida Getúlio Vargas

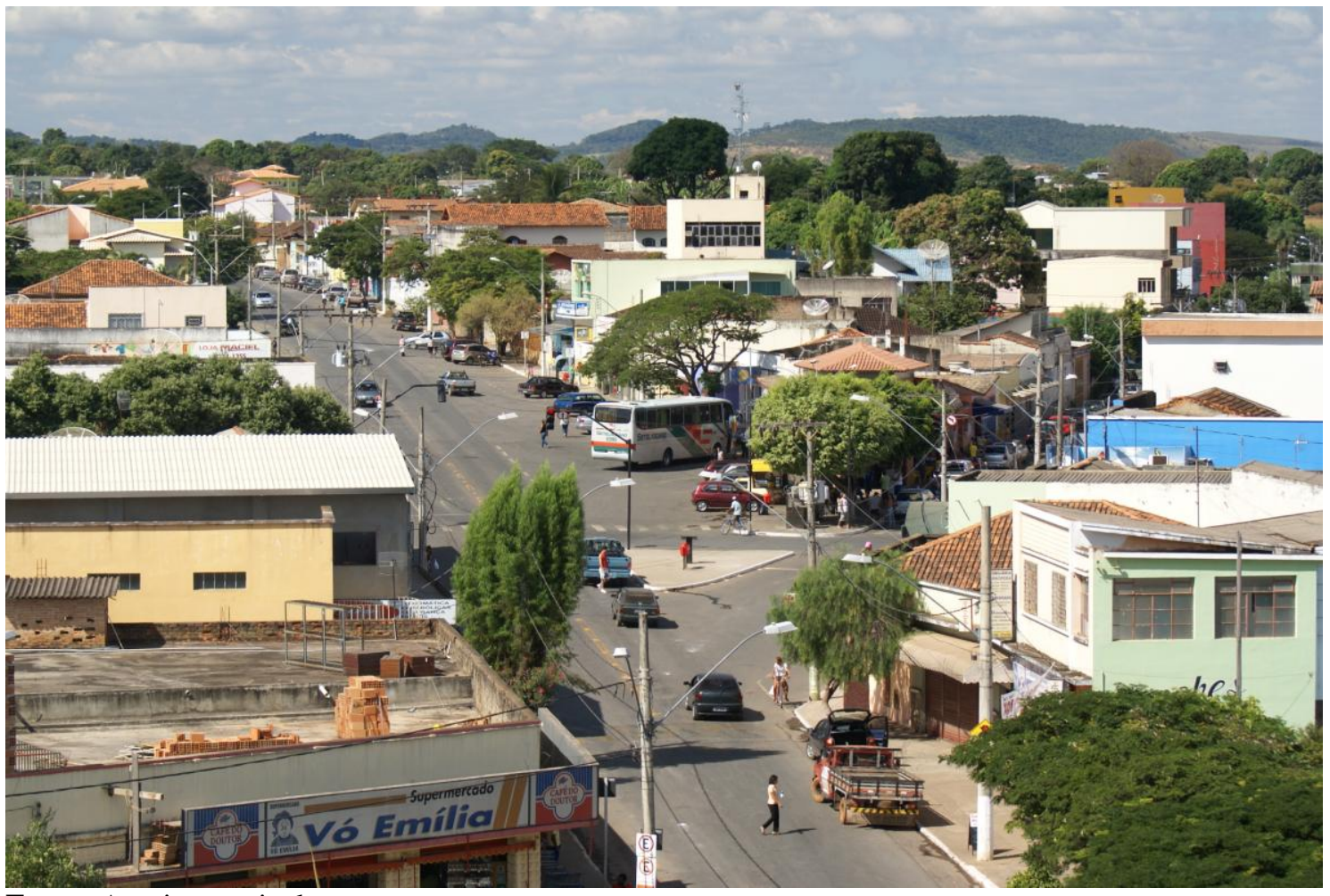

Fonte: Arquivo particular

IMAGEM 78: Vista da torre da igreja Matriz por volta de 2005

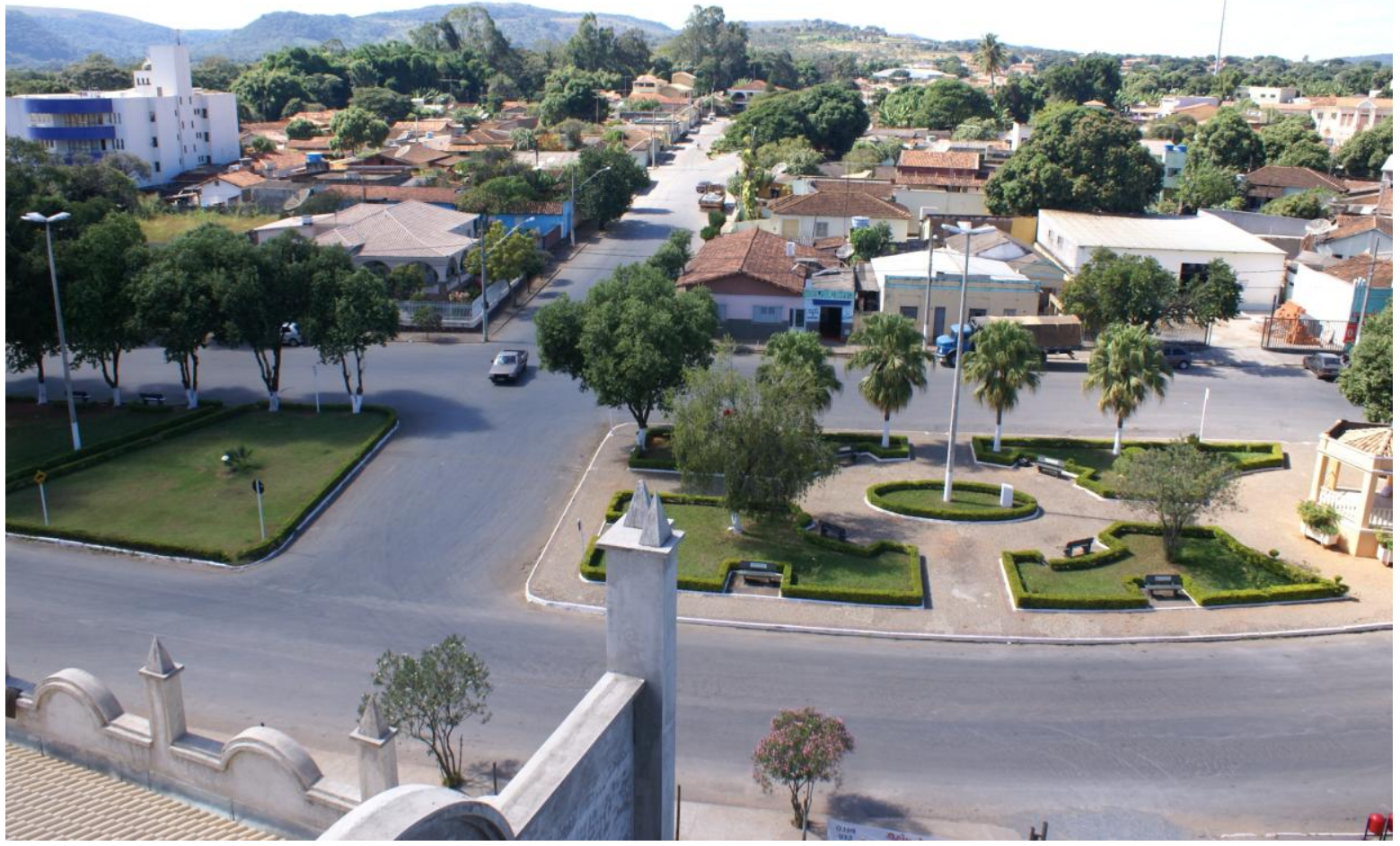

Fonte: Arquivo particular 
IMAGEM 79: Vista aérea da cidade a partir da serra da Fazenda do Rasgão

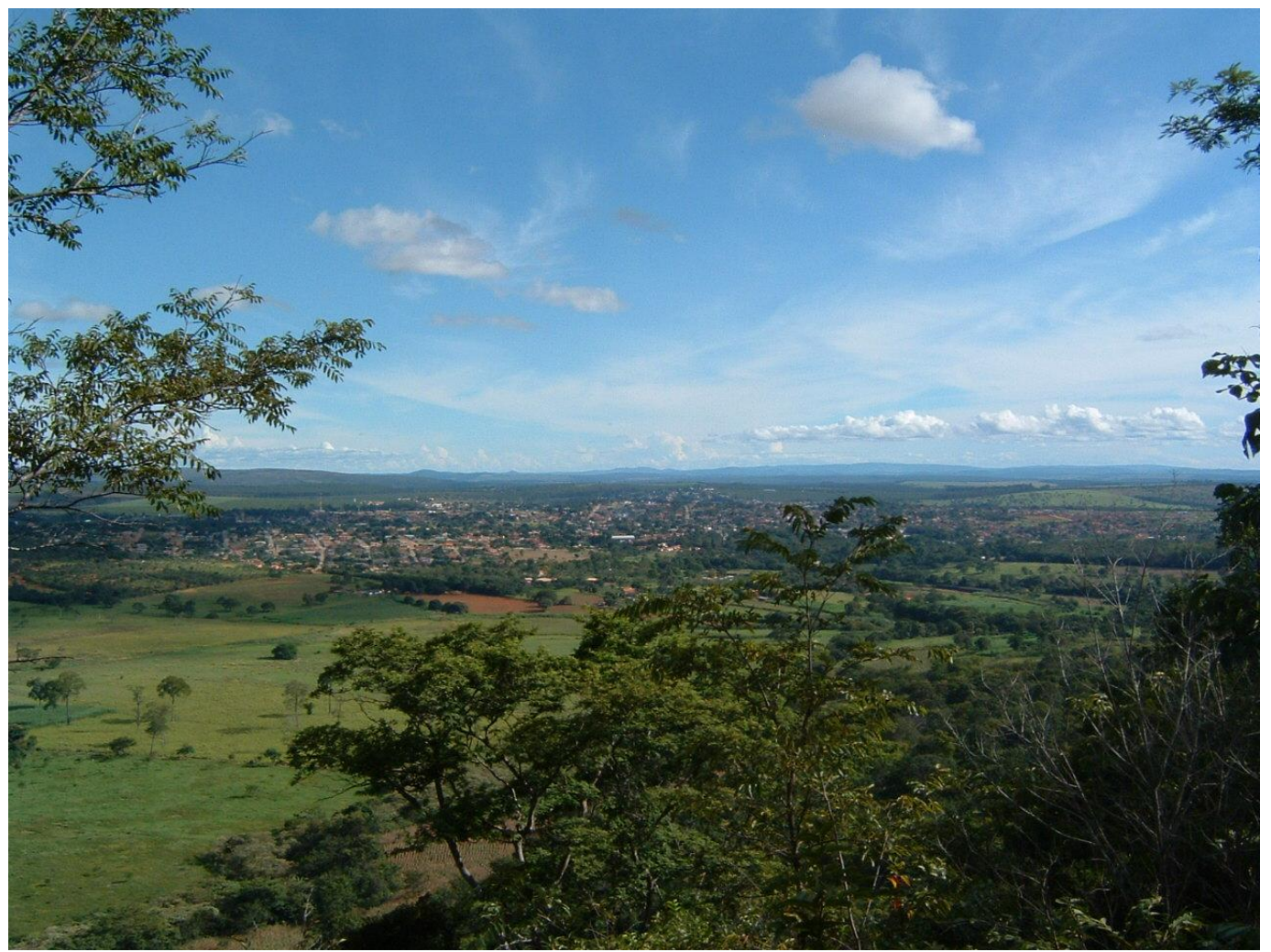

Fonte: Arquivo particular

IMAGEM 80: Outro ângulo da vista aérea da cidade a partir da serra da Fazenda do Rasgão

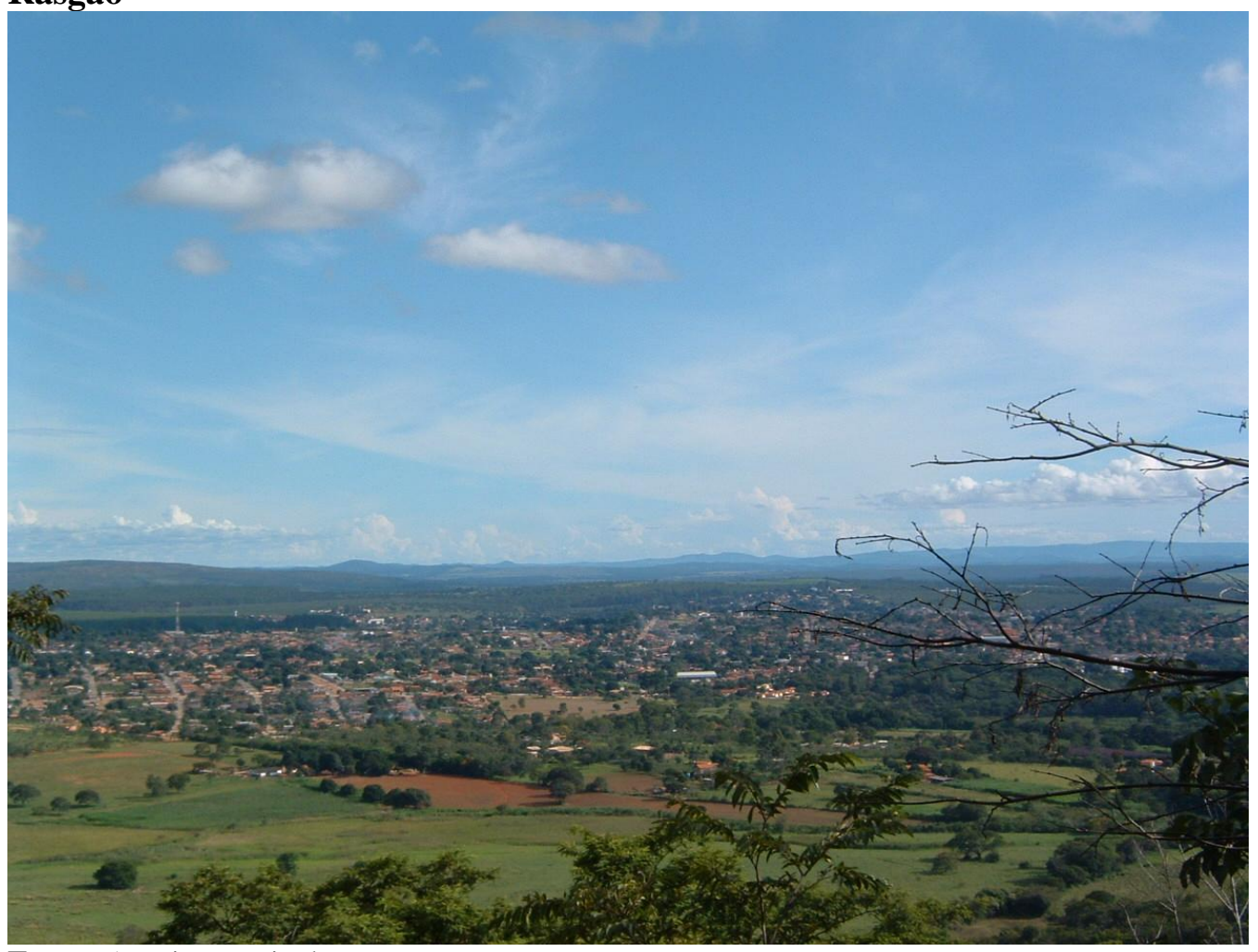

Fonte: Arquivo particular 
IMAGEM 81: Vista aérea da cidade na atualidade

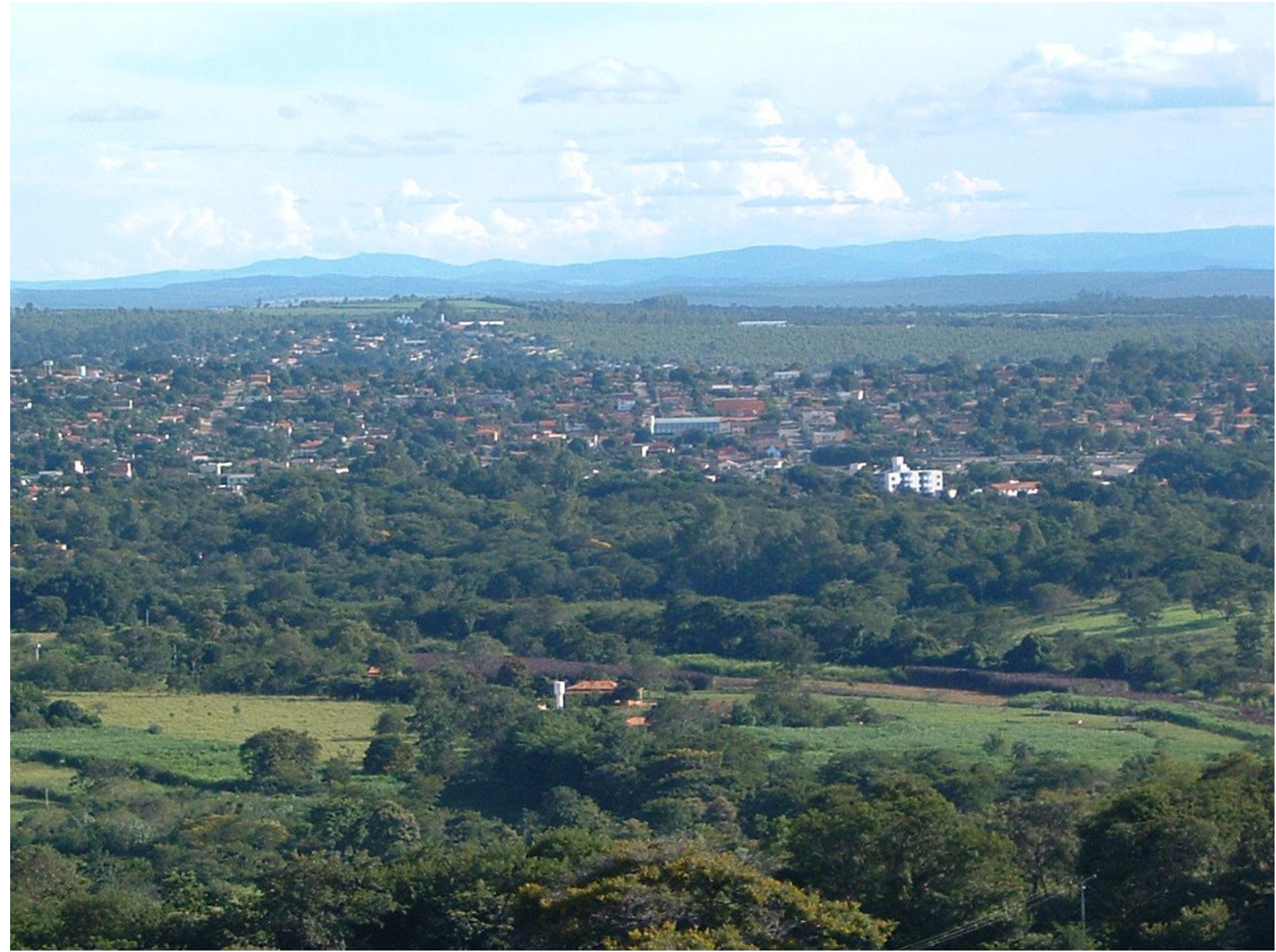

Fonte: Arquivo particular 


\section{Considerações finais}

O tempo vai e vem e depois voa

Como o rio torto se curva P'ra garantir o dito e bendito Assim a memória do velho refaz o rito.

Anônimo ${ }^{24}$

\footnotetext{
${ }^{24}$ Estes versos foram recitados pelo memorialista Sr. José
} 
Para elucidar o problema da memória, tentamos abordá-lo numa perspectiva subjetiva e social em conexão com outras fontes de conhecimento dentre elas: a história, a filosofia. Além disso, procuramos, através da história oral, conhecer as lembranças dos idosos no que se refere à cidade de Paraopeba-MG. O tema da memória subjetiva e social possui várias formas de abordá-la, assim como o tema da cidade. Entretanto, ao propormos estudar a memória em interface com a cidade, acreditamos ter constado algumas coisas. Dentre elas, a memória dos idosos como fonte de conhecimento subjetivo e social.

Dessa forma, conseguimos perceber que as lembranças dos idosos da cidade de Paraopeba contribuem para o conhecimento da história da cidade. Os aspectos da educação, do trabalho, da formação familiar, da religiosidade local, bem como também do urbanismo ficaram evidentes nos depoimentos dos narradores. Por outro lado, a memória também possui sua dimensão subjetiva, já que estas lembranças evocadas pelos idosos passam pelo crivo do afeto e das experiências de cada um.

A premissa de que a memória social se baseia também na memória do grupo e da comunidade pareceu-nos relevante. Por isso é que os fragmentos da memória subjetiva se conectam com a memória da cidade, embora cada morador seja único e cada lembrança tenha suas particularidades. Assim, os mesmos eventos se repetem ao longo das décadas, deixando marcas que fazem com que todos se reconheçam neles. Se, por um lado, a memória subjetiva é irredutível a outras lembranças, por outro, esta mesma memória se comunica com as demais; dando coerência e sentido.

Halbwachs, em Les cadres sociaux de la mémoire, obra concebida no ano de 1925, coloca em evidência o fato de que a memória - diferentemente de Bergson - é um fenômeno coletivo. Para Halbwachs, o ato de lembrar consiste em uma aproximação ou mesmo identificação entre elementos pertencentes à memória individual com eventos da memória coletiva. Para tanto, uma das afirmações pertinentes desta obra deste sociólogo é a crença de que a memória só poderia ser refletida a partir do sentido das convenções sociais; como, por exemplo, a análise dos grupos religiosos. Isto o pesquisador denominou de quadros sociais da memória; Halbwachs afirmava que "isto não é uma simples metáfora."25 (HALBWACHS, 1952, p. 146). [Tradução livre]

\footnotetext{
${ }^{25}$ Trata-se da frase em francês: “Ce n'est pás lá une simple métaphore”.
} 
Posteriormente, em A memória coletiva, Halbwachs não tratará a memória como uma simples identificação, como abordara em Les cadres sociaux de la mémoire. Trata-se agora de perceber a memória como um jogo de intenções, de ir e vir, e não de caminhar para uma única direção. Dessa forma, o indivíduo está presente e participa de muitos grupos sociais (familiar, religioso, etc.), o que nos demanda pensar que a memória se realiza no cruzamento entre duas memórias coletivas. Portanto, a memória de cada pessoa se desvela a partir das relações estabelecidas entre várias memórias coletivas. Daí podermos afirmar que o indivíduo não lembra por si mesmo, mas em relação aos outros. Portanto para se lembrar de algo necessitará da memória coletiva e das interações entre os indivíduos. Assim, para que a dinâmica da memória se revele, o sociólogo afirma:

Se a memória atinge então regiões do passado inegavelmente distantes, conforme as partes do corpo social que se considera, não é porque uns têm mais lembranças do que os outros: mas as duas partes do grupo organizam seu pensamento em torno de centros de interesses que não são mais completamente os mesmos. (HALBWACHS, 1990, p. 124)

Chegamos, pois, a uma referência importante para nossa pesquisa: a noção de espaço da memória. Na última parte de A memória coletiva ao autor mostrou a relevância da linguagem e do tempo; pois o espaço, primordialmente em nossa pesquisa, é o lugar de sentido, de significação. Por isso a casa, a rua, a praça, as igrejas, o teatro se convertem em memórias espacializadas. É a estrutura de uma cidade. E por outro lado, o espaço social, é a condição necessária para que os grupos criem a coesão e memórias coletivas que possam durar. Assim, os idosos pesquisados revelaram em suas lembranças a coesão das imagens e dos sentidos atribuídos às lembranças pessoais e sociais. Daí as lembranças espacializadas se acoplarem numa temporalidade subjetiva. Desta forma o espaço social se identifica com o grupo social, revelando um quadro por onde as lembranças se encontram. Possibilitando pontos de contacto de gerações diferentes entre si e com o espaço urbano como um todo. Cumpre-nos observar que o adjetivo coletiva para alguns é sinônimo de social (ver JEDLOWSKI, NAMER apud SÁ, 2005). Consideramos, ao longo de nossa pesquisa, como sinônimas; lembrando sempre o caráter de construção da memória na relação do sujeito ao meio social.

A vida subjetiva possui características próprias. Ela nos remete a alegrias, medos, sofrimentos, perdas e até a transformações. Diante destes episódios vivenciados pelos narradores cada história de vida traça sua própria trajetória, revelando-se na educação familiar, nos contatos, no aprendizado da escola, na escolha da profissão, na vida amorosa, 
enfim, na visão de mundo. Dessa forma, a vida anímica de cada narrador é uma experiência de mundo em que cada um, à sua maneira, imprime uma marca na vida interna e social.

Além disso, constatamos que as lembranças dos narradores esclareceram a história social da cidade. Através de suas lembranças, os memorialistas, expressam um conhecimento para as gerações futuras. Talvez por isso pudemos apreender a dinâmica de uma cidade através dos ensinamentos dos idosos. Os fatos sociais são percebidos pelos idosos de maneira própria, mas não desvinculados do meio social.

Pudemos com isso conhecer uma cidade que já não existe mais. A começar pelos aspectos urbanísticos: a praça da matriz em várias fases, as ruas que mudaram de nome, as casas que se transformaram ao longo dos anos ou mesmo aquelas que já não existem mais. A memória espacial revelando a história da cidade. Conhecemos também os movimentos das pessoas na cidade: as festas religiosas, as lutas políticas, as relações de trabalho. Dessa forma, a cidade é percebida pelos olhares de quem presenciou as transformações; por isso são lembranças afetivas e não fria, distante como os dados estatísticos. A cidade é revelada aos poucos, cada lembrança lança luz a uma época e evento. As descobertas vão se dando ao longo do diálogo. Os memorialistas se dão conta disso, os ouvintes também e, por extensão, os leitores. Razão pela qual podemos conhecer, através das lembranças dos idosos, a cidade e as gerações passadas.

Mediante nossa pesquisa conseguimos averiguar alguns tópicos: a memória subjetiva tem uma correlação com a memória social; através da história oral, os idosos pesquisados; estabeleceram relações entre a memória subjetiva e social: as lembranças individuais se interconectam à memória do grupo, da comunidade. Nesse aspecto, vale salientar que os idosos se valeram das referências da memória espacial para estabelecerem os vínculos entre a memória individual e a social. Assim, a cidade aparece como um espaço comum entre os idosos: as casas, a escola, o ambiente de trabalho, a praça, o teatro, dentre outras referências ecoam nas lembranças deles. Exemplificamos, ao longo do capítulo "A cidade lembrada", o enunciado acima. Deste modo, os lugares da cidade se conectam com o espaço urbano.

De fato, isso corrobora a afirmação e os estudos da psicóloga social Ecléa Bosi. Esta pesquisadora abordou tais questões em sua obra Memória e Sociedade, onde trabalhou as lembranças dos idosos da cidade de São Paulo. Também o sociólogo francês Maurice 
Halbwachs, que abordamos acima, ofereceu grandes contribuições para a compreensão da memória coletiva afirmando que a memória individual se assentaria na memória do grupo.

A pesquisa de Ecléa Bosi, em Memória e sociedade: lembranças dos velhos, realizada com idosos da cidade de São Paulo é exemplar. Estudo do qual fomos influenciados e somos devedores no que se refere à ambiência da memória individual e às correlações ao social. Esta psicóloga social utilizou conceitos advindos de outros campos de pesquisa: história, sociologia, filosofia dentre outros em seu trabalho. E nos possibilitou compreender a memória subjetiva e social, apontando também para a dimensão urbana da memória. Entretanto, nossa pesquisa foi realizada em outro espaço urbano e momento histórico e com idosos possuidores de outras vivências. Dando à nossa pesquisa, e esta foi nossa intenção, outro perfil e descobertas.

Tal pesquisa, ainda que paradigmática, nos fez estabelecer outras relações. Isto, portanto, não é uma falha da pesquisa da professora Ecléa Bosi. Ao contrário, aponta para a irredutibilidade das memórias individuais por um lado; e por outro para a constituição das memórias no cerne dos contextos sociais. Isto ocorre porque as histórias de vida não são algo estagnado ou empoeirado, nem localizadas em cômodos escuros e separados do meio. Por isso apreendemos com esta pesquisa que "a pedra de toque é a leitura crítica, a interpretação fiel, a busca do significado que transcende aquela biografia: é o nosso trabalho, e muito belo seria dizer, a nossa luta" (BOSI, 2003, p. 69).

Nesse ínterim, o que é comum entre as duas pesquisas torna-se singular, já que a história de vida tem uma especificidade e cada cidade possui sua própria história. Assim, uma cidade do interior de Minas Gerais possui uma trajetória muito diferente da cidade de São Paulo. Esta última presente na pesquisa de Ecléa Bosi. A cidade de Paraopeba-MG nos exigiu uma postura que contemplasse a singularidade dos depoimentos dos memorialistas pesquisados. Sendo assim, as referências teóricas seguiram perspectivas próprias, como, por exemplo, a religiosidade, o folclore, a narrativa literária.

Para tanto, este trabalho demonstrou, através do relato oral e da pesquisa em jornais, em fotografias dentre outros, as relações dos memorialistas com a história da cidade. O universo da cidade, afetivo e histórico, desenhou, a partir do relato da comunidade, uma postura ética, um destino próprio. Isto nos fez reconhecer elementos espaciais da memória, a saber: a casa, a 
rua, a origem "lendária" da cidade. Esta estratégia possibilitou que a cidade fosse revelada pelos memorialistas através de seu espaço "interior" e "real". Além disso, e, sobretudo, o legado do conhecimento que os idosos deixam às gerações futuras. Assim, o grupo de idosos pesquisados conseguiu dar sentido às lembranças subjetivas e da cidade, acentuando a força da tradição e do enraizamento expressos nas lembranças dos narradores, e propondo a necessidade de preservá-la. A cidade de Paraopeba aos poucos foi sendo ressignificada, recriada pelos memorialistas.

A estratégia do filósofo Walter Benjamin para o entendimento dos eventos passados não se baseava numa nostalgia. Também não pretendia entender o passado pela perspectiva da história convencional. Para este filósofo os fragmentos da história são relevantes para compreensão do passado e, conseqüentemente, do presente. Esta estratégia foi relevante para nossa pesquisa. Os fragmentos das lembranças dos idosos nos conduziram a uma nova compreensão da história da comunidade e da cidade de Paraopeba.

Partindo das narrativas orais dos idosos, procuramos relacioná-las com outros documentos. Então comparamos as fontes iconográficas, periódicos, livros, para que pudéssemos lançar luzes às histórias contadas pelos narradores. Assim, como as propostas de Walter Benjamin não invalidam a história oficial, procuramos averiguar os "cacos" das memórias, os fragmentos das narrativas dos idosos e fazê-las dialogar com as histórias relatadas nos documentos existentes na cidade. Acreditamos, assim, que com estes objetivos conseguimos demonstrar, ao menos em parte, em nossa pesquisa.

A história para Walter Benjamin está baseada na descontinuidade, na ruptura. Sendo assim, a história não poderia ser a dos vencedores. Ao contrário, toma partido dos vencidos, àqueles que sob os pontos de vista dos vencedores e do status estabelecido não mencionam. Com essa perspectiva, o filósofo, alimenta a possibilidade de trazer à tona os conteúdos esquecidos e desprezados pelo poder. Sendo assim, essa história com aspectos visivelmente socialistas é um objeto em construção; uma história cujo tempo impregnado está de "agoras". Com esta proposta poder tencionar o tempo presente a se comunicar com os diversos passados.

Esta proposta revolucionária nos guiou com o grupo dos idosos pesquisados. Este grupo de idosos, muitas vezes relegado à margem da sociedade, pôde dar testemunho de um passado cheio de sentido. Se a história, na perspectiva benjaminiana, visa outra leitura dela mesma, 
aqui ela foi retratada sagazmente. Acreditamos que os memorialistas puderam trazer ao momento presente "vários passados": o aprendizado na escola e no trabalho, as práticas políticas, dentre outros. Assim, o conhecimento em pequenos fragmentos das lembranças dos idosos retrataram a vida única dos narradores e a cidade com a qual se relacionam há décadas.

Desta forma, o tempo individual trouxe a percepção de um tempo peculiar à cidade. $\mathrm{O}$ continuum da história apontado por Benjamin foi implodido, na medida em as lembranças em fragmentos dos idosos resgatou "outra" memória social. Ao menos contribuiu para outro entendimento da história da comunidade pesquisada. $\mathrm{O}$ que ajudou a erigir uma pequena história da cidade através das lembranças e das experiências desse grupo de idosos.

Por ocasião da nossa pesquisa documental (jornais, livros, imagens), constatamos várias formas de narrativas da cidade de Paraopeba. Essa pesquisa nos apontou um campo enorme de referências. Algumas narrativas feitas por jornalistas, romancista e poeta demarcaram um ponto que marcou a história da cidade. Trata-se das memórias pessoais e sua relação com a literatura. Estas narrativas foram expressas em: romance, poesias, memórias de viagens, crônicas. Esta profusão de textos escritos presente na cidade e na imprensa local chamou a atenção para a memória expressa pela via literária (aqui entendida de maneira abrangente). Já que nosso objetivo não era a teoria literária, mas absorver e "fazer falar" as obras literárias como expressão individual e coletiva da história da cidade.

Nesse caminho, convém lembrar que os narradores, a despeito de suas formações culturais, expressaram-se a partir de "textos" orais, mas codificado em escrita. Com exceção do Sr. José, que mantém a prática da escrita nos jornais da cidade; a literatura, pois, pareceu-nos um campo vasto de interlocuções: ao nos provocar com metáforas subjetivas e da cidade. Por isso incluímos no capítulo II (“A cidade”) - vários narradores: o viajante, o romancista Avelino Fóscolo, entre outros. Essa iniciativa se pautou na idéia de que o "texto literário" também se converte em fonte de memória pessoal e comunitária. Embora não se reduzisse a isso.

Daí a relevância de termos em mente a importância da linguagem, seja ela oral ou escrita. Pois ela não é apenas comunicação coloquial, é também morada do Ser. Por isso, acreditamos que, a linguagem, em sua diversidade de expressões e idiomas não é apenas léxico e estrutura linguística. E nem somente regras gramaticais: ela é, antes de mais nada, a expressão de ruídos, silêncios, desejos expressos pelos falantes. Por onde se abre um vasto campo de 
possibilidades. Assim, através da dialética, a linguagem humana, transita entre as convenções lingüísticas e a vastidão dos signos. Por isso, cada falante inserido no campo do diálogo, oscila entre limites e a liberdade da criação. Desta forma, a linguagem, pelo ensino de Merleau-Ponty, nos possui e é possuída por nós (MERLEAU-PONTY, 2006).

O diálogo estabelecido entre o pesquisador e os entrevistados foi fundamental para a revelação das lembranças pessoais e da cidade. Compreendemos que o diálogo referido por Merleau-Ponty nos deu a oportunidade de construir a pesquisa da memória individual e social. Os detalhes íntimos, a topografia da cidade, iam surgindo na medida em que a ressonância entre os dois (pesquisador e entrevistados) foram se construindo. Ficou comprovado, nesta pesquisa, que o tipo de estratégia preconizado por uma atitude dicotômica na qual são separados, o sujeito e o objeto, não se sustentaria. Acreditamos que isso se deve ao fato de que as histórias de vida, expressas nesta tese, estariam também baseadas na amizade e na construção mútua do conhecimento.

Sob o aspecto da teoria de campo, observamos a mobilidade das lembranças dos idosos, possibilidade concretizada por meio do "espaço de vida" descrito por Kurt Lewin. Tal aspecto se define como a totalidade dos fatos, dos eventos e sua faculdade de revelarem e mesmo apontarem os comportamentos dos indivíduos. Tomando como base o contexto e o meio nos quais os indivíduos pesquisados se encontravam. Por isso, a noção estanque de presente, passado, futuro não se fez notar. A noção de campo nos permitiu, ainda, compreender os memorialistas de forma mais abrangente. Não procuramos perceber os idosos isoladamente, em dimensões temporais separadas, uma vez que neste contexto, seguimos a proposta do psicólogo Kurt Lewin, que diz que através do campo: "o indivíduo não vê apenas sua situação presente, tem certas expectativas, desejos, medos, devaneios em relação ao futuro. Sua maneira de ver seu próprio passado e o resto do mundo físico e social mesmo sendo errada, constitui o seu nível de realidade do passado (LEWIN, 1965, p. 61).

Desta forma Lewin, ao incluir a noção espacial das ações humanas presentes no campo psicológico, nos apontou para a diversidade e abrangência das lembranças dos idosos. Percebemos a mobilidade, o tempo subjetivo em relação ao contexto social, pois o "espaço e vida" foi considerado em seu movimento. Assim, os idosos foram percebidos no meio ambiente, condição que nos permitiu formar um campo psicológico no qual compreendêssemos a coexistência e a interdependência dos eventos e fatos. Os narradores, ao 
compor o espaço de vida, davam vazão a conteúdos subjetivos e sociais. Além disso, as regiões do campo estabelecidas entre os idosos e o meio criaram uma atmosfera de intercâmbio.

Por isso nossa pesquisa se pautou pela proposta de perceber as múltiplas formas de captar as palavras: oral, escrita, coloquial e "artística". O caminho traçado pelos narradores (os depoimentos orais e escritos) nos ajudou a compreender a trajetória individual (desejos, sonhos, etc.) e da história da cidade. Tanto que a cidade, além de seus aspectos memorialísticos e urbanísticos, foi revelada como "texto". Assim, ao propor a percepção da cidade como signos, convidamos o leitor a entender o espaço urbano como metáforas, nomes, semiologias: "neste esforço de abordagem semântica da cidade, devemos tentar compreender o jogo dos signos, compreender que qualquer cidade é uma estrutura, mas que nunca se deve tentar, mas que nunca se deve querer preencher essa estrutura" (BARTHES, 2001, p. 231).

$\mathrm{Na}$ pesquisa, de Kevin Lynch, sobre a construção da imagem de três cidades norteamericanas encontramos elementos esclarecedores. O urbanista se detém nas cidades de Boston, Jersey City e Los Angeles para compor e averiguar o conceito de imaginabilidade. Usou dois métodos básicos: uma entrevista com os cidadãos e um exame da imagem ambiental suscitada em campo por observadores. Aparentemente simples, a entrevista era realizada em escritórios e era solicitado, aos entrevistados, que desenhassem um mapa da cidade. E depois, era feita uma descrição detalhada das partes da cidade retida na memória.

Um dos resultados obtidos foi à constatação de que a paisagem urbana possui um papel social. As respostas declaradas pelos narradores remetiam as lembranças e símbolos comuns que unem o grupo. Recurso que permitia a comunicação entre si dos membros do grupo. Lynch também encontrou unidades no espaço urbano: caminhos, bairros, pontos de referências. Embora reconhecendo a cidade como mutável e polivalente, o urbanista, aponta em suas conclusões para as características de organização o conteúdo poético e simbólico das cidades, uma vez que a expressividade das imagens evocadas na pesquisa potencializa os significados e associações. Assim, declara o urbanista: "esse sentido de lugar realça todas as atividades humanas que aí se desenvolvem e estimula o depósito de um traço de memória" (LYNCH, 1997, p. 134). 
Graças às conexões variadas, os idosos de nossa pesquisa, freqüentemente identificaram os "lugares memória" da cidade de Paraopeba. Lugares surgidos de lembranças que se aproximam daquelas provenientes das entrevistas de Kevin Lynch. Entretanto, os objetivos eram diferentes em cada uma das pesquisas. Mas os idosos pesquisados conseguiram organizar a cidade através das lembranças. Deste modo, apontam eixos comuns na paisagem da cidade: a praça, casas, a geografia urbana, construindo assim um mapa afetivo e urbanístico da cidade onde nasceram. Paraopeba, assim, surge através das lembranças como um lugar que não existe mais, embora sendo a mesma cidade. Isso se deu porque alguns lugares da cidade foram destruídos. Mas, entretanto, outros permanecem e servem como lugares de memória da cidade. Dentre eles estão a igreja matriz, a escola Afonso Pena, a igreja do Rosário, a casa da D. Anésia e Avelino Fóscolo.

Outro elemento a se destacar, nas memórias dos idosos, foi a referência à linguagem escrita. Consideramos que esta experiência foi muito fecunda. Pois percebemos que ora a palavra oral se coaduna com a escrita, ora não. Isto nos parece pertinente porque a memória individual não é uniforme, move-se em vários planos. Encontramos desvios, condensações, esquecimentos. Freud já alertara para os atos falhos, os esquecimentos presentes nas narrativas dos seus pacientes. No processo psicanalítico o trabalho da memória é primordial, visto que através dele o sujeito se depara com os mecanismos inconscientes da história subjetiva.

Entretanto, o esquecimento não reside apenas em regiões ligadas à subjetividade individual. A tradição, tal qual apresentada por Paul Zumhtor, indica outras formas de atuação para este mecanismo. A literatura oral possui zonas de conflitos, pela qual cria espaços, impasses; que ao interagir com outros conteúdos e tempo histórico pode desaparecer. No entanto, o esquecimento, também pode exibir uma face positiva, esclarece Zumthor. Como por exemplo nos heróis das narrativas orais que ao longo dos anos adquire outras feições, podendo até mesmo desaparecer em determinada época, para depois, ser recuperado em outro momento. Em um jogo constante de presença e ausência, entre lembranças e esquecimento. Pensemos aqui nas narrativas do Sr. José que nos foram apresentadas nesta pesquisa. Heróis que pertencem à cultura popular e que se inscrevem nas crônicas e nas narrativas locais. Assim, memória e esquecimento, são faces de uma mesma moeda, cujo objetivo é tornar o movimento das representações sociais mais eficaz. Baseando-nos, pois, em um processo ininterrupto da cultura e da tradição; nos capacitamos a clarear os caminhos com os quais os elementos da história da cidade vão e voltam. Tal estratégia foi mobilizada pelas lembranças 
dos memorialistas que dão movimento aos conhecimentos e costumes da vida anímica e da cidade.

Neste estudo sobre a memória subjetiva e social fez-se necessário que levássemos em conta os conteúdos religiosos e folclóricos das narrativas, uma vez que tais conteúdos se referem diretamente às atividades que balizam as vidas individuais e sociais da cidade. $\mathrm{O}$ folclore, dialogando com a literatura escrita e oral, bem como com a fé religiosa nos forneceu um retrato substancial das relações subjetivas e sociais da comunidade. Embora este não seja o enfoque primordial da pesquisa, ele se revelou pertencente à vida dos memorialistas. Participando da vida interior e dos eventos da cidade. Por isso, recorremos a Câmara Cascudo (CASCUDO, 1974) - por exemplo, que afirma que o folclore está cravado no cerne da personalidade e na vida social do povo. Desta forma, os elementos da natureza como o vento, o ar e a água assumem corporeidade em práticas curativas e também no processo de compreensão dos fenômenos da natureza; conferindo, assim, um corpo "sobrenatural" aos eventos cotidianos da comunidade.

Voltados sobre si mesmos ou sobre a comunidade, os memorialistas possuem ritmos e rotinas próprios. Os homens e mulheres das cidades do interior aparecem no vasto território do país. Estão ainda, embora haja meios de comunicação modernos, submetidos às crenças e condições sociais que favoreçam a manifestação do sobrenatural. Assim, o folclore se vê misturado à religião oficial. Por isso reina, no imaginário dos idosos, um universo mágico, invocações divinas que são transmitidas pelas gerações anteriores.

Constatamos que o folclore está presente e vivo na vida anímica e da cidade pesquisada. Daí podermos falar que o folclore se estabelece como uma forma de enraizamento, visto que está na base da visão pessoal e da comunidade estudada. Traduz e dá sentido às relações afetivas do grupo. Por isso as histórias orais e escritas estabelecem laço coeso na cosmovisão dos narradores. Os narradores, assim, procuram ordenar as coisas e eventos, fatos e situações. São tentativas, reveladas pelos memorialistas, em conferir sentido aos sentimentos e anseios das pessoas, especialmente no que tange aos medos, angústias, prazeres e aspectos lúdicos da convivência.

Podemos afirmar que o trabalho da memória foi realizado por ambos: idosos e pesquisador. Ao estabelecerem uma espécie de laço no momento da construção do diálogo, as lembranças 
evocadas, se ligavam umas às outras, criando um lastro rico de associações. As memórias mais remotas, os detalhes (às vezes percebidos pelos idosos como desprezíveis), a vida familiar e escolar, as relações de trabalho, os desejos, a cidade em suas relações dinâmicas de evento e de desejo; iam formando o corpo de uma memória maior. As lembranças subjetivas e os acontecimentos da cidade lançavam luz um ao outro.

Sendo uma pesquisa de caráter qualitativo, não nos interessamos pelas regras estatísticas. Isso, acreditamos, não se apresenta como uma falha, mas uma estratégia de pesquisa. Essa pesquisa nos levou a vislumbrar aquilo que outros pensadores especialmente Ecléa Bosi, Hannah Arendt, Simone Weil, Walter Benjamin e Maurice Halbwachs: que a memória possui uma dimensão subjetiva e outra social. Obviamente, cada um à sua maneira e em caminhos teóricos próprios.

Sabemos que há muito por fazer, seja através do trabalho do psicólogo social que deve tentar compreender as relações da memória individual com a social; seja tentando dar voz aos idosos como forma de restituir-lhes a dignidade e os direitos. Neste sentido, as constatações aqui presentes abrem um campo enorme de pesquisa e intervenção, uma vez que as memórias narradas pelos idosos, nos impelem a uma tomada de posição política. Posição respaldada por uma ética que se baseia na relação com alteridade e com a multiplicidade de atos e de visões de mundo.

Nesse ínterim, a constatação acima apresentada nos remete à noção política de Hannah Arendt. Esta pensadora nos convida a compreender o mundo e a agir sobre ele, levando em conta, a convivência com as diferenças e com a pluralidade dos grupos humanos. Portanto, é uma posição aberta às transformações das cidades, já que estas se constituem como palco por excelência, onde as mudanças podem e devem ocorrer. As lembranças dos idosos nos ajudam a fomentar essas mudanças. Acreditamos que nossa pesquisa nos revelou isso. Através das lembranças poderemos criar estratégias para as mudanças na cidade. O campo da utopia se abre como uma espécie de lema para uma ação refletida e eficaz. Isto se daria na medida em que, ao dar valor às vozes dos idosos, poderemos perceber os pontos que necessitam de mudanças. Assim as relações familiares e de trabalho, por exemplo, podem ser repensadas através das experiências dos idosos, aliada ao conhecimento do psicólogo social que pode ajudar a criar estratégias de transformações da cidade, e do mundo. 
Muito há por fazer, seja com relação aos aspectos subjetivos da memória, seja com relação à sua característica social. Entretanto, sabemos dos limites desta pesquisa. Sabíamos desde o início que o campo era interminável. Por um lado a memória é sinônimo da experiência humana no mundo, já que é através dela que o homem se reconhece como tal e pode se relacionar com os outros semelhantes. Por outro lado, a memória é algo inacabado e em constantes transformações. Aliada a isso, existe a temática da cidade que também é vasta. Contudo, essa pesquisa é vertigem e deslumbramento, porque se a vastidão do tema nos casou vertigem também nos encantou e constamos à importância das descobertas. Desta forma, acreditamos que, o psicólogo social, deve trabalhar muito para dar dignidade aos idosos, sobretudo conferindo-lhe voz e abrindo perspectivas para ações efetivas em relações a políticas públicas em favor dos idosos.

Depois de atestar as carências, não deveremos nos eximir dos compromissos sociais. É preciso conhecer a vida dos idosos de perto, tocar e ser tocado por suas lembranças. Elas nos ajudam a conhecer as gerações que nos precederam, bem como a tradição e o enraizamento que elas testemunham. Assim, conseguiremos compreender seus comportamentos e ter uma nova e melhor inserção no mundo. Nos fragmentos das memórias individuais dos idosos adquirimos a capacidade de descobrir o elo que liga o todo às suas partes e vice-versa. Compreendendo melhor a realidade através das lembranças dos idosos, vislumbramos outra possibilidade de restaurar o mundo, a cidade. Tornar o passado cintilante aos olhos do presente.

Diante do exposto, como situar nossa pesquisa no conjunto dessas análises? Estamos conscientes dos limites de nosso trabalho, entretanto as experiências trazidas pelas lembranças dos idosos têm muitos significados. A importância de suas histórias, o conhecimento adquirido ao longo da vida deu-nos a oportunidade, através do diálogo, de apreender a dinâmica da memória subjetiva e social.

É por isso que, reconhecendo as múltiplas faces do tema exposto, podemos perguntar: qual o lugar dos idosos no mundo contemporâneo? Simone de Beauvoir, em A velhice, analisa em vários ângulos esta problemática. Encara a vida dos idosos sem rodeios. Sua análise lúcida traça um panorama da velhice desde a etnologia, passando pela psicologia, medicina, economia dentre outras ciências. Olha a vida dos idosos através da exterioridade, esta necessária à observação científica. Com isto, a ensaísta revela, no decorrer do texto, o drama 
dos idosos, suas angústias, medos, e o descaso social. Neste sentido, em certo momento do texto afirma:

Para que a velhice não seja uma irrisória paródia de nossa existência anterior, só há uma solução - é continuar a perseguir o fim que dê um sentido à nossa vida: dedicação aos indivíduos, à coletividade, às causas, trabalho social ou política, intelectual, criador. (BEAUVOIR, 1990, p. 661.).

É reconhecer a humanidade que existe nos idosos. A dignidade de serem seres humanos. Aqui no Brasil estão sendo desenvolvidas experiências para melhor gestão da problemática relativa aos idosos. Estes trabalhos reconhecem os preconceitos que se dirigem a eles e procuram compreender a realidade do envelhecimento no Brasil. Além de, ao mesmo tempo, sugerir a implementação de estratégias de intervenção social para a melhoria da vida dos idosos. (VON SIMSON; NERI; CACHIONI, 2003).

O nosso estudo não abordou diretamente as estratégias de intervenção para os idosos. Fizemos referência às intervenções como políticas públicas. Contudo, a realidade dos idosos aparece de forma a exigir algumas reflexões. Os quatros idosos pesquisados não sofreram as mazelas descritas em vários estudos: abandono, violência física, dentre outros. Todos têm o amparo da família, ou o dinheiro da aposentadoria. Expressam o descompasso entre a vida e a tecnologia em expansão, a ansiedade e os limites do corpo que lhes causam desconforto. Também o revelam o afastamento das amizades, o excesso de consumo. E, sobretudo, a proximidade da morte. Talvez porque o mundo da tecnologia entre em conflito com a vida de uma cidade do interior, com o tempo e os costumes próprios. Obviamente, no decorrer dos anos, as coisas e hábitos foram moldando a personalidade. Como observadores, os idosos, reconhecem as conquistas da vida moderna, mas também se estranham com a rapidez das mudanças. Atestam, assim, uma vida enraizada na tradição e costumes da cidade cujo trabalho, religião, família, lhes deram e dão sentido à existência.

Norberto Bobbio, em O tempo da memória: da senectude, faz um balanço de sua trajetória de filósofo e jurista. Viveu o terror da guerra e dos grandes dramas sociais do século XX. Este homem teve uma vida consagrada aos temas da política e do Direito. Em certa altura afirma que uma sociedade organizada precisa do Direito e do poder, duas faces de uma mesma moeda, pois a sociedade sem o direito é impotente e o poder sem o controle correria o risco do 
despotismo. O diálogo entre as duas faces desta moeda baliza (ou deveria balizar) os comportamentos éticos diante do mundo.

Entretanto, o jurista declara a importância das lembranças para a velhice. Ao se debruçar sobre as lembranças, Bobbio afirma a necessidade da imaginação. Assim, o filósofo pode com o recurso da imaginação refugiar em si mesmo e reconstruir a identidade. Tarefa que caberia a todos os idosos! O balanço da vida e a reflexão que o tempo impõe, imprime a cada um a tarefa de escavar sua própria história. Mas, esse ato é um poço sem fundo porque o tempo reveste as recordações da certeza das flutuações ininterruptas das coisas e dos eventos. Então, o jurista recomenda: "nada de parar. Devemos continuar a escavar! Cada vulto, gesto, palavra ou canção, que parecia perdido para sempre, uma vez reencontrado, nos ajuda a sobreviver" (BOBBIO, 1997, p. 55).

Diante da capacidade humana de superar os conflitos é necessário o enfrentamento constante. A cada dia os empecilhos se mostram visíveis. Com o passar dos anos o tempo histórico e aquele tempo carregado de afeto nos revelam a empresa difícil que é o desenrolar da vida. As lembranças, como rio, correm sem parar. Esta marca da existência das quais todos somos subjugados e impelidos a enfrentar o mundo é um exercício perene do qual, os idosos, dão testemunho. O conhecimento humano se move para o futuro, mas nunca deve se esquecer do legado do passado. Assim, devemos compreender, junto à pensadora a importância da natalidade e da importância do recomeço, de que a "faculdade inerente à ação como perene advertência de que os homens, embora devam morrer, não nascem para morrer, mas para começar" (ARENDT, 1991, p. 258).

Sendo assim, ao fim de todas estas páginas, além do universo particular de cada uma dos memorialistas, uma nova cidade se descortinou. Oscilando entre a cidade concreta e a lembrada, pudemos recompor junto com os narradores, uma atmosfera cheia de vida e de intensidade. Tivemos acesso a um legado que nos precedeu, mas que, em paralelo a isto, nos impulsiona para o futuro. A profusão de nomes e detalhes nos mostrou a riqueza que desconhecíamos. A cidade, a partir das lembranças dos idosos, aos poucos, foi sendo revelada e doada aos outros. 


\section{Referências bibliográficas}

\subsection{Bibliografia Geral}

1.AGOSTINHO, Santo. Confissões. 9. ed. Petrópolis: Vozes, 1987. (Pensamento humano).

2.ALBERTI, Verena. Manual de história oral. Rio de Janeiro: FGV, 2004.

3.ALBERTI, Verena. Ouvir contar: textos em história oral. Rio de Janeiro: FGV, 2004.

4.ALBERTI, Verena. Tradição oral e história oral: proximidades e fronteira. Revista da associação brasileira de história oral, v.8, n.1, jan./jun. 2005, p.11-28.

5.AMIEL, Anne. Le vocabulaire de Hannah Arendt. Paris: Ellipses, 2007. (Vocabulaire de...).

6.ANDRADE, Carlos Drummond de. Poesia completa. Rio de Janeiro: Nova Aguillar, 1977.

7.ANJOS, Cyro. A menina do sobrado. 2. ed. Rio de Janeiro: José Olympio ; Brasília: INL, 1979.

8.ANTOINE, Jean-Phillippe. The art of memory and its relation to the unconscious. Comparative civilizations review, n.18, 1988, p.1-21.

9.ARANTES, Antônio Augusto. Produzindo o passado: estratégias de construção do patrimônio cultural. São Paulo: Brasiliense : Secretaria de Estado de Cultura, 1984.

10. ARAÚJO, Alceu Maynard. Cultura popular brasileira. 2. ed. São Paulo: Melhoramentos, 1973.

11. ARENDT, Hannah. Homens e tempos sombrios. São Paulo: Companhia das Letras, 2008.

12. ARENDT, Hannah. A condição humana. 5. ed. Rio de Janeiro: Forense Universitária, 1991.

13. ARENDT, Hannah. A dignidade da política: ensaios e conferências. Rio de Janeiro: Relume-Dumará,1993.

14. ARENDT, Hannah. A promessa da política. Rio de Janeiro: Difel, 2008.

15. ARENDT, Hannah. Entre o passado e o futuro. São Paulo: Perspectiva, 2005. (Debates; 64). 
16. ARENDT, Hannah. O que é político. Rio de Janeiro: Bertrand Brasil, 2007.

17. ARENDT, Hannah. O que resta? Resta a língua: uma conversa com Günter Gaus. In: Compreender: formação, exílio e totalitarismo - ensaios 1930-1945. São Paulo: Companhia das Letras; Belo Horizonte: UFMG, 2008.

18. ARGAN, Giulio Carlo. História da arte como história da cidade. São Paulo: Martins Fontes, 2005.

19. ARISTÓTELES. Da lembrança e da rememoração. Trad., notas e com. de Cláudio Willian Veloso. Cadernos de história de filosofia da ciência, Unicamp, série 3, v.2, jan./dez. 2002, p.8-154.

20. ASCH, Solomon E. Psicologia social. São Paulo: Companhia Editora Nacional, 1966.

21. AUGÉ, Marc. Le liuex de memóire du point de vue de l'ethnologue. Gradhiva, n.6, 1989, p.3-12.

22. BADDELEY, Alan. Working memory. Science, v.255, n.5044, 1992, p.556-559.

23. BARBARAS, Renaud. O invisível da visão. In: NOVAES, Adauto (Org.). Muito além do espetáculo. São Paulo: SESC, 2005, p.64-79.

24. BARROS, José D'Assunção. Cidade e história. Petrópolis: Vozes, 2007.

25. BARTHES, Roland. Semiologia e urbanismo. In: A aventura semiológica. São Paulo: Martins Fontes, 2001. (Coleção tópicos).

26. BARTLETT, Frederic C. Remembering: a study in experimental and social psychology. Cambridge: Cambridge University Press, 1932.

27. BASTIDE, Roger. Sociologia do sonho. In: $O$ sonho $e$ as sociedades humanas. In: CALLOIS, Roger; GRUNEBAUM, G. E. Van (Orgs.). Rio de Janeiro, Francisco Alves, 1978. 28. BEHAR, Lisa Block de. La literatura entre el registro y el recurdo. In: CONGRESSO DA ASSOCIAÇÃO BRASILIERA DE LITERATURA COMPARADA, 2. Belo Horizonte, 1991. Anais do II congresso da associação brasileira de literatura comparada. Belo Horizonte, 1991, v.1, p.96-113. 
29. BENJAMIN, Walter. Experiência e pobreza. In: Magia e técnica, arte e política: ensaios sobre literatura e história da cultura.7 ed. São Paulo: Brasiliense, 1994, p.114-119. (Obras escolhidas; 1 )

30. BENJAMIN, Walter. A imagem de Proust. In: Magia e técnica, arte e política: ensaios sobre literatura e história da cultura. 7. ed. São Paulo: Brasiliense, 1994, p.36-49. (Obras escolhidas; 1).

31. BENJAMIN, Walter. O narrador: observações sobre a obra de Nicolai Leskov. In: Magia e técnica, arte e política: ensaios sobre literatura e história da cultura. 7. ed. São Paulo: Brasiliense, 1994, p.197-211. (Obras escolhidas; 1).

32. BENJAMIN, Walter. O narrador: observações sobre a obra de Nikolai Leskov. In: BENJAMIN, Walter. [et al]. Textos escolhidos. São Paulo: Abril Cultural, 1980, p.57-74. (Os pensadores).

33. BENJAMIN, Walter. Passagens. Belo Horizonte: UFMG ; São Paulo: Imprensa Oficial do Estado, 2006.

34. BENJAMIN, Walter. Rastelli raconte et autres récits. Paris: Éditions du Seuil, 1987.

35. BENJAMIN, Walter. Rua de mão única. 5 ed. São Paulo: Brasiliense, 1997. (Obras escolhidas; 2).

36. BENJAMIN, Walter. Sobre o conceito de história. In: Magia e técnica, arte e política: ensaios sobre literatura e história da cultura. 7. ed. São Paulo: Brasiliense, 1994, p.222-232. (Obras escolhidas; 1 ).

37. BENJAMIN,Walter. Pequena história da fotografia. In: Magia e técnica, arte e política: ensaios sobre literatura e história da cultura. 7 ed. São Paulo:Brasiliense, 1994.p91107.(Obras escolhidas; 1$)$.

38. BERGER, Peter; LUCKMANN, Thomas. A construção social da realidade: tratado de sociologia do conhecimento. Petrópolis: Vozes, 1974. (Antropologia; 5).

39. BERGSON, Henri. Matéria e memória: ensaios sobre a relação do corpo com o espírito. São Paulo: Martins Fontes, 1990.

40. BEZERRA, Paulo. A narrativa como sortilégio. In: Lady Macbeth do Distrito de Mtzenski, Nikolai Leskov (Posfácio). São Paulo, ed.34, p.84-90. 
41. BÍBLIA DE JERUSALÉM. São Paulo: Paulinas, 1992.

42. BINSWANGER, Ludwig. Le revê et l'existence. Trad.de l'allemand par Jacqueline Verdeaus. Introduction et notes de Michel Foucault. Éditions Desclee de Bruwer, 1954.

43. BOBBIO, Norberto. O tempo da memória: de senectute e outros escritos autobiográficos. Rio de Janeiro: Campus, 1997.

44. BOLLE, Willi. A cidade como escrita. In: Fisiognomia da metrópole moderna: representação da história em Walter Benjamin. 2. ed. São Paulo: Edusp, 2000, p.271-312.

45. BOLLE, Willi. Cidade e memória. In: Fisiognomia da metrópole moderna: representação da história em Walter Benjamin. 2. ed. São Paulo: Edusp, 2000, p.313-363.

46. BORGES, Jorge Luis. Funes, o memorioso. In: Ficções. Porto Alegre: Globo, 1998, p.539-546. (Obras Completas; 1).

47. BORNHEIM, Gerd. O conceito de tradição. In: Cultura brasileira: tradição contradição. Rio de Janeiro: Jorge Zahar / FUNARTE, 1987, p.13-29.

48. BOSCHI, Caio César. Os leigos e o poder. São Paulo: Ática, 1986.

49. BOSI, Alfredo. Fenomenologia do olhar. In: NOVAES, Adauto (Org.). O olhar. São Paulo: Companhia das Letras, 1998, p.65-87.

50. BOSI, Alfredo. História concisa da literatura brasileira. São Paulo: Cultrix, 1994.

51. BOSI, Alfredo. O ser e o tempo da poesia. São Paulo: Cultrix, 1983.

52. BOSI, Alfredo. O tempo e os tempos. In: NOVAES, Adauto (Org.). Tempo e história. São Paulo: Companhia das Letras / Secretaria Municipal de Cultura, 1992, p.19-32.

53. BOSI, Ecléa. Cultura de massa e cultura popular: leitura de operárias. Petrópolis: Vozes, 1981.

54. BOSI, Ecléa. Memória e sociedade: lembrança de velhos. 4. ed. São Paulo: Companhia das Letras, 1994.

55. BOSI, Ecléa. O tempo vivo da memória: ensaios de psicologia social. 2 ed. São Paulo: Ateliê, 2003. 
56. BOURDIEU, Pierre. Compreender. In: A miséria do mundo. Petrópolis: Vozes, 2003, p.693-737.

57. BOUVOIR, Simone. A velhice. Rio de Janeiro: Nova Fronteira, 1990.

58. BRIOSCHI, Lucila Reis; TRIGO, Maria Helena Bueno. Relatos de vida em ciências sociais: considerações metodológicas. Ciência e cultura, 39(7): 631-637.

59. BROCHMEIER, Jeans. Remembering and forgetting: narrative as cultural memory. Culture \& Psychology, v.8 (1), p.15-43, 2002.

60. BUCK-MORSS, Susan. Dialética do olhar: Walter Benjamin e o projeto das Passagens. Trad. Ana Luiza de Andrade. Belo Horizonte-MG ed. UFMG; Chapecó, SC. Ed. Universitária Argos, 2002.

61. BULGELSKY, Richard B. Mnemonics. In: International encyclopedia of psychiatry, psychology, psychoanalysis and neurology. New York: Aesculapius Publishers, 1977, p.245250, v.7.

62. BURKE, Peter. História como memória social. In: Variedades de história cultural. Rio de Janeiro: Civilização Brasileira, 2000, p.67-89.

63. CALVINO, Ítalo. As cidades invisíveis. São Paulo: Companhia das Letras, 1990.

64. CANDAU, Joel. Antropologie de la memóire. Paris : Armand Colin, 2005.

65. CANDIDO, Antonio. Limites da biografia. Remate de males, Campinas: Departamento de teoria literária da UNICAMP, 1999, p.63-65. (Número especial: Antonio Candido).

66. CANDIDO, Antonio. Literatura e sociedade. 8. ed. São Paulo: Publifolha, 2000. (Grandes nomes do pensamento brasileiro).

67. CANDIDO, Antonio. O discurso e a cidade. 3. ed. Rio de Janeiro: Ouro sobre azul, 2004.

68. CANDIDO, Antonio. Os parceiros do Rio Bonito: estudos sobre o caipira paulista e a transformação dos seus meios de vida. São Paulo: Duas Cidades, 1975.

69. CANDIDO, Antonio. Perenidade da biografia. Remate de males, Campinas: Departamento de teoria literária da UNICAMP, 1999, p.67-69. (Número especial: Antonio Candido). 
70. CARDOSO, Ciro Flamarion S. Iconografia e história. Resgate: revista interdisciplinar de cultura. Campinas: UNICAMP, v.1, 1990, p.09-17.

71. CARRUTHERS, Mary J. The book of memory: a study of memory in medieval culture. Cambridge: Cambridge University Press, 1990.

72. CASCUDO, Câmara. Folclore do Brasil. Rio de Janeiro: Fundo de cultura, 1967.

73. CASCUDO, Câmara. Tradição, ciência do povo. Perspectiva: São Paulo, 1971.

74. CASCUDO, Luís da Câmara. Literatura oral. Rio de Janeiro: Jose Olympio, 1952. (Documentos Brasileiros; 63).

75. CASTRO, Maria Ceres Pimenta Spínola ... et al. Folhas do Tempo: imprensa e cotidiano em Belo horizonte, 1895-1926. Belo Horizonte: UFMG. Associação Mineira de Imprensa, Prefeitura Municipal de Belo Horizonte, 1997.

76. CHARTIER, Roger. A história ou a leitura do tempo. Belo Horizonte: Autêntica, 2009.

77. CHARTIER, Roger. Cultura popular: revisitando um conceito historiográfico. Estudos históricos, Rio de Janeiro, v.8, n.16, 1995, p.179-192.

78. CHARTIER, Roger. Do palco à página: publicar teatro e ler romances na época moderna (séculos XVI-XVIII). Rio de Janeiro: Casa da Palavra, 2002.

79. CHARTIER, Roger. Os desafios da escrita. São Paulo: UNESP, 2002.

80. CHARTIER, Roger. Textos, impressão, leituras. In: HUNT, Lynn. A nova história cultural. 2. ed. São Paulo: Martins Fontes, 2001, p.211-238. (O homem e a história).

81. CHARTIER, Roger. Une histoire de la culture écrite: culture écrite et littérature à l'âge moderne. Annales HSS, jui./oct. 2001, n.4-5, p.783-802.

82. CHAUÍ, Marilena. A destruição da subjetividade na filosofia contemporânea. Jornal de psicanálise, 1976,n . 21, São Paulo, parte 2, p.63-69.

83. CHAUÍ, Marilena. A destruição da subjetividade na filosofia contemporânea. Jornal de Psicanálise, 1976,n. 20, São Paulo, parte 1, p. 29-36.

84. CHAUÍ, Marilena. Brasil: mito fundador e sociedade autoritária. São Paulo: Fundação Perseu Abramo, 2000. 
85. CHAUÍ, Marilena. Experiência do pensamento: ensaios sobre a obra de Merleau-Ponty. São Paulo: Martins Fontes, 2002.

86. CHAUÍ, Marilena. Notas sobre cultura popular. Arte em revista, São Paulo, ano 2, n.3, mar. 1980, p.15-21.

87. COSTA, Joaquim Ribeiro. Paraopeba. In: Toponímia de Minas Gerais: com estudo histórico da divisão territorial e administrativa. Belo Horizonte: BDMG Cultural, 1997, p.323-324.

88. COULANGES, Fustel de. A cidade antiga; estudos sobre o culto, o direito e as instituições da Grécia e de Roma. São Paulo: Humus, 1975.

89. DAMERGIAN, Sueli. O inconsciente na interação humana. Psicologia USP, São Paulo, 2(1/2), p.65-76, 1991.

90. DAMERGIAN, Sueli. Para além da barbárie civilizatória: o amor e a ética humanista. São Paulo: Casa do Psicólogo, 2009.

91. DARTIGUES, André. O que é a fenomenologia? Rio de Janeiro: Livraria Eldorado, 1973.

92. DELLE DONNE, Marcella. Teoria sobre a cidade. Lisboa: Edições 70, 1990.

93. DUARTE, Regina Horta. A imagem rebelde: a trajetória libertária de Avelino Fóscolo. Campinas: UNICAMP, 1991.

94. DUCHARME, Raymond; FRAISSE, Paul. Etude genetique de la memorisation de mots et images. Canad. J. Psychol ./ Rev. Cand. Psychol. 19(3), 1965, p.253-261.

95. DUPONT, Jean-Claude. Mémoire et héritage scientifique de William James. Archives de philodophie, t.69, cahier 3, 2006, p.443-460.

96. ECO, Umberto. Como se faz uma tese. 18. ed. São Paulo: Perspectiva, 2002 (Estudos; 85).

97. ECO, Umberto. Sobre la dificultad de construir un ars oblivionalis. Revista de occidente. Madrid: Ediciones el arquero, 1989, p.9-28.

98. EISENSTEIN, Elizabeth L. A revolução da cultura impressa: os primórdios da Europa Moderna. São Paulo: Ática, 1998. (Múltiplas escrituras).

99. ENTRALGO, Pedro Laín. La curación por la palabra en la antiguedad clássica. Barcelona: Anthropos, 1987. 
100.FARR, Robert M. As raízes da psicologia social moderna. Petrópolis: Vozes, 2004.

101.FENTRESS, James e WICKHAN, Chris. Memória social - novas perspectivas sobre o passado. Lisboa , editorial Teorema LDA, 1992.

102.FERNANDES, Maria Inês Assumpção. Fragmentos da pessoa sobre a cidade: os sentidos do morar. In: Negatividade e vínculo: a mestiçagem como ideologia. São Paulo: Casa do psicólogo, 2009.

103.FERREIRA, Jerusa Pires. Armadilhas da memória e outros ensaios. Cotia: Ateliê, 2003.

104.FLÒRES, César. La memóire. Paris: Presse Universitaires de France, 1972.

105.FÓSCOLO, Avelino. O caboclo. Belo Horizonte: Imprensa Oficial do Estado de Minas Gerais, 1902.

106.FRANK, Joseph. Uma palavra sobre Leskov. In: Pelo prisma russo: ensaios sobre literatura e cultura. São Paulo, ed. USP, 1992, p. 247-250.

107.FREITAS, Sabino de Paula. O poeta, a casuarina e o vento. Belo Horizonte: Vega, 1977.

108.FREITAS, Victor Figueira. Vale do alto Paraopeba. Revista do instituto histórico e geográfico de Minas Gerais, Belo Horizonte, v.10, 1963, p.301-304.

109.FREUD, Sigmund. A interpretação dos sonhos. Rio de Janeiro: Imago, 2001.

110.FREUD, Sigmund. Creación poética y fantasia. Buenos Aires: Santiago Rueda, 1954, p.47-57. (Obras completas de Sigmund Freud; 18).

111.FREUD, Sigmund. El sueño y la telepatia .In: El malestar en la cultura - sobre los sueños, miscelânea.Buenos Aires: Santiago Rueda, 1955, p.158-163.(Obras completas de Sigmund Freud; 19)

112.FREUD, Sigmund. Los recuerdos encubridores. In: El análise profano. Buenos Aires: Santiago Rueda, 1953,p. 205-222.(Obras completas de Sigmund Freud, 12)

113.FREUD, Sigmund. Psicopatologia de la vida cotidiana: olvidos, equivocaciones, torpezas, superticiones, errores. Buenos Aires: Santiago Rueda, 1952. (Obras completas de Sigmund Freud; 1).

114.FREUD, Sigmund. Recuerdo, repetición e elaboración. In: El porvenir de una ilusión. Buenos Aires: Santiago Rueda, 1953, p.139-146. (Obras completas de Sigmund Freud; 14). 
115.FREUD, Sigmund. Totem y Tabu. Buenos Aires: Santiago Rueda, 1953,p7-166.(Obras completas de Sigmund Freud.;8)

116.FREUD. Sigmund. Psicologia de las masas y análisis del yo. Buenos Aires: Santiago Rueda, 1953. (Obras completas de Sigmund Freud; 9)

117.FREYRE, Gilberto. Em torno do conceito hispânico ou ibérico de tempo. In: Palavras repatriadas. Brasília: Ed. UNB ; São Paulo: Imprensa Oficial do Estado, 2003, p.265-283.

118.FREYRE, Gilberto. Oh de casa!: em torno da casa brasileira e de suas projeções sobre um tipo nacional de homem. Recife: Instituto Joaquim Nabuco de pesquisas sociais, 1979. (Estudos e pesquisas ; 13).

119.FREYRE, Gilberto. Sobrados e mucambos: decadência do patriarcado e desenvolvimento do urbano. 15. ed. São Paulo: Global, 2004.

120.FRIEIRO, Eduardo. Feijão, angu e couve: ensaio sobre a comida dos mineiros. Belo Horizonte: Itatiaia ; São Paulo: EDUSP, 1972.

121.FRIEIRO, Eduardo. O romancista Avelino Fóscolo. In: A Capital. Belo Horizonte: Itatiaia : Imprensa Oficial, 1979, p.11-52

122.FROCHTENGARTEN, Fernando. A memória oral no mundo contemporâneo. Estudos Avançados, São Paulo, 19 (55), 2005, p.367-376.

123.FROCHTENGARTEN, Fernando. Memórias de vida, memórias de guerra: um estudo psicossocial sobre o desenraizamento. São Paulo: Perspectiva : FAPESP, 2005. (Estudos; 222).

124.GAGNEBIN, Jeanne Marie. História e narração em Walter Benjamin. São Paulo: Perspectiva, 2007. (Estudos; 142).

125.GAGNEBIN, Jeanne Marie. Narrar e curar. Folha de S.Paulo. São Paulo, 1 de set. 1985. Folhetim, p.01.

126.GAGNEBIN, Jeanne Marie. O que significa elaborar o passado? In: lembrar escrever esquecer. São Paulo: 34, 2006, p.97-105.

127.GARCIA-ROZA, Luiz. Psicologia estrutural em Kurt Lewin. Petrópolis: Vozes, 1974.

128.GEERTZ, Clifford. A interpretação das culturas. Rio de Janeiro: LTC, 1989. 
129.GINZBURG, Carlo. Mitos, emblemas, sinais: morfologia e história. São Paulo: Companhia das Letras, 1989.

130.GONÇALVES FILHO, José Moura. A memória da casa e a memória dos outros. Travessia: revista do migrante. Ano XI, n.32, set./dez. 1998, p.17-24.

131.GONÇALVES FILHO, José Moura. Olhar e memória. In: NOVAES, Adauto (Org.). $O$ olhar. São Paulo: Companhia das Letras, 2006, p.95-124.

132.GONÇALVES FILHO, José Moura. Problemas de método em psicologia social: algumas notas sobre a humilhação política e o pesquisador participante. In: BOCK, A. (Org.). Psicologia e compromisso social. São Paulo: Cortez, 2003, p.193-239.

133.GONÇALVES, Sônia Maria. Declaração. Belo Horizonte: Arquivo Público Mineiro, 2000. (Declara conter no Livro SC - 234, p.172v, 173 e 173v do APM, que Manoel Araújo Morgado solicitou ao representante da Comarca de Sabará aquisição da Sesmaria do Cedro e da fazenda chamada O Pagabem).

134.GRAMSCI, Antonio. Observações sobre o folclore. In: Literatura e vida nacional. 3. ed. São Paulo: Civilização Brasileira, 1986, p.183-190.

135.GUREVITCH, A. Y. El tiempo como problema de historia cultural. In: Las culturas y el tiempo.Paris:UNESCO, 1979(Hermeneia;16)

136.HALBWACHS, Maurice. A memória coletiva. São Paulo: Centauro, 2006.

137.HALBWACHS, Maurice. A memória coletiva. São Paulo: Vértice / Revista dos Tribunais, 1990. (Biblioteca Vértice de sociologia e política).

138.HALBWACHS, Maurice. Les cadres sociaux de la memóire. Paris: Presse Universitaires de France, 1952.

139.HAVELOCK, Eric. A equação oralidade - cultura escrita: uma fórmula para a mente moderna. In: OLSON, David; TORRANCE, Nancy. (Orgs.). Cultura escrita e oralidade. São Paulo: Ática, 1995, p.17-34. (Múltiplas escrituras).

140.HELLER, Agnes. O cotidiano e a história. São Paulo: Paz e Terra, 2008.

141.HILLMAN, James. Cidade e alma. São Paul: Studio Nobel, 1993. (Cidade aberta). 
142.HOBSBAWN, Eric; RANGER, Terence (Org.). Introdução: a invenção das tradições. In: A invenção das tradições. 4 .ed. Rio de Janeiro: Paz e Terra, p.9-23.

143.HUTTON, Patrick. H. The art of memory reconceived: from rhetoric to psychoanalysis. Journal of de history of ideas. v.XLVIII, n.3, july/sept. p.371-390.

144.IZQUIERDO, Ivan. Memória. Estudos Avançados, São Paulo, 13 (6), 1989, p.89-112.

145.JACOBS, Jane. Morte e vida de grandes cidades. São Paulo: Martins Fontes, 2000.

146.JAISSON, Marie. Temps et espace chez Maurice Halbwachs (1925-1945). Revue d'histoire des sciences humaines, n.1, 1999/1, p.163-178.

147.JAMES, William. Memory. In: Psychology: the briefer course. New York: Harper \& Brothers, 1961, p.154-168.

148.JAMES, William. Memory. In: The principles of psychology. Harvard: Harvard University Press, 1983, p.605-649.

149.JAMES, William. The perception of time. In: The principles of psychology. Harvard: Harvard University Press, 1983, p.571-604.

150.JANET, Pierre. L'évolution de le memóire et de la notion du temps. Paris: Chahine, 1928.

151.JEUDY, Henri-Pierre. A crítica da estética urbana. In: Espelho das cidades. Rio de Janeiro: Cada da Palavra, 2005, p.79-154.

152.JEUDY, Henri-Pierre. Memórias do social. Rio de Janeiro: Forense Universitária, 1990.

153.JODELET, Denise (Org.). As representações sociais. Rio de Janeiro: UERJ, 2001.

154.JODELET. Denise. Place de l'experience vécue dans le processus de formation des representations sociales. In: Les savoirs $d u$ quotidian: transmissions, apropriations, representation. Rennes: Presses Universitaires de Rennes, 2006, p.235-255.

155.JOLLES, André. Formas simples: legenda, saga, mito, adivinha, ditado, caso memorável, conto, chiste. São Paulo: Cultrix, 1976.

156.JOSEF, Bella. O resgate da memória na literatura contemporânea. In: CONGRESSO DA ASSOCIAÇÃO BRASILIERA DE LITERATURA COMPARADA, 2. Belo Horizonte, 1991. Anais do II congresso da associação brasileira de literatura comparada. Belo Horizonte, 1991, v.1, p.454-460. 
157.KÄES, René. A polifonia dos sonhos. São Paulo: Idéias e Letras, 2004.

158.KÄES, René. Os espaços comuns e partilhados: transmissão e negatividade. (Org) FERNANDES, Maria Inês Assumpção. São Paulo: Casa do Psicólogo, 2005.

159.KIERKEGAARD, Soren A. As obras do amor. Algumas considerações cristãs em forma de discursos.Petrópolis- RJ, editora Vozes, 2005.

160.KOFFKA, Kurt. Princípios de psicologia da gestalt. São Paulo: Cultrix / USP, 1975.

161.KONDER, Leandro. Walter Benjamin: o marxismo da melancolia. 3. ed. Rio de Janeiro: Civilização Brasileira, 1999.

162.KRAMER, Lloyd S. Literatura, crítica e imaginação histórica: o desafio literário de Hayden White e Dominick LaCapra. In: HUNT, Lynn. A nova história cultural. 2. ed. São Paulo: Martins Fontes, 2001, p.131-173. (O homem e a história).

163.LACHMANN, Renate. Cultural memory and the role of literature. European review, v.12, n.2, 2004, p.165-178.

164.LARSEN, Svend Erik. La culture urbaine: mémoire manquée ou mémoire reconstruite? In: CONGRESSO DA ASSOCIAÇÃO BRASILIERA DE LITERATURA COMPARADA, 2. Belo Horizonte, 1991. Anais do II congresso da associação brasileira de literatura comparada. Belo Horizonte, 1991, v.1, p.163-171.

165.LE GOFF, Jacques (Org.). A história nova. 5. ed. São Paulo: Martins Fontes, 2005.

166.LE GOFF, Jacques. História e memória. 5. ed. Campinas: UNICAMP, 2003.

167.LELOUP, Yves. Les villes du Minas Gerais. Paris: C. N. R. S.: Institut des Hautes Etudes de L'Amérique Latine, 1970.

168.LEROI-GOURHAN, André. O gesto e a palavra. Lisboa: Edições 70, 1987, 2 v.

169.LESKOV, Nikolai. Apenas um retrato de mulher e amores de Luíba. Trad. SCHNEIDER, Otto. São Paulo: Melhoramentos, 1986.

170.LESKOV, Nikolai. Lady Macbeth do distrito de Mtzensk. São Paulo: 34, 2009.

171.LEWIN, Kurt. Princípios de psicologia topológica. São Paulo: Cultrix / USP, 1973.

172.LEWIN, Kurt. Teoria de campo em ciência social. São Paulo: Pioneira, 1965. 
173.LEXICON: dicionário teológico enciclopédico. São Paulo: Loyola, 2003.

174.LIMA JUNIOR, Augusto de. A capitania de Minas Gerais. Belo Horizonte ; São Paulo: EDUSP, 1978.

175.LIMA JUNIOR, Augusto de. História de Nossa Senhora em Minas Gerais: origens das principais invocações. Belo Horizonte: Autêntica : PUC Minas, 2008. (História de Minas Gerais).

176.LIMA, Rogério; FERNANDES, Ronaldo Costa (Orgs.). $O$ imaginário e a cidade. Brasília: UNB ; São Paulo: Imprensa Oficial do Estado, 2000.

177.LOVISOLO, Hugo. A memória e a formação dos homens. Estudos históricos, Rio de Janeiro, v.2, n.3, 1989, p.16-28.

178.LOWENTHAL, David. Como conhecemos o passado. Proj. História, São Paulo, (17), nov. 1998 , p.63-181.

179.LÖWY, Michael. Walter Benjamin, aviso de incêndio: uma leitura das teses "Sobre o conceito de história”. São Paulo: Boitempo, 2005.

180.LUND, Peter Wilhelm. Memórias scientificas. Belo Horizonte: Apollo, 1935. (Biblioteca mineira de cultura).

181.LURIA, Alexander Romanovich. A mente e a memória: um pequeno livro sobre uma vasta memória. 2. ed. São Paulo: Martins Fontes, 2006.

182.LYNCH, Kevin. A imagem da cidade. São Paulo: Martins Fontes, 1997.

183.MAISONNEUVE, Jean. A psicologia social. São Paulo: Martins Fontes, 1988.

184.MALARD, Letícia. Hoje tem espetáculo: Avelino Fóscolo e seu romance. Belo Horizonte: UFMG, 1987.

185.MANGUEL, Alberto. A cidade das palavras: as histórias que contamos para saber quem somos. São Paulo: Companhia das Letras, 2008.

186.MANGUEL, Alberto. Lendo imagens: uma história de amor e ódio. São Paulo: Companhia das Letras, 2001.

187.MANGUEL, Alberto. O livro da memória. In: Uma história da leitura. São Paulo: Companhia das Letras, 1997, 73-83. 
188.MARX, Karl. Primeiro manuscrito. In: FRONM, Erich. Conceito marxista do homem. Rio de Janeiro: Jorge Zahar, 1972, p,89-102.

189.MARX, Karl; ENGELS, Friedrisch. A ideologia alemã. 3. ed. São Paulo: Martins Fontes, 2007.

190.MASCARENHAS, Geraldo Magalhães. Centenário da fábrica do Cedro: histórico 1872/1972. Caetanópolis: Cia de Fiação e Tecido Cedro e Cachoeira, s.d.

191.MEIRY, José Carlos Sebe Bon. Definindo história oral e memória. Cadernos CERU, n.5, série 02, 1994, p.52-60.

192.MEIRY, José Carlos Sebe Bon; HOLANDA, Fabíola. História oral: como fazer, como pensar. São Paulo: Contexto, 2007.

193.MENESES, Adélia Bezerra de. Memória e ficção I (Aristóteles, Freud e a memória). In: Do poder da palavra: ensaios de literatura e psicanálise. São Paulo: Duas Cidades, 1995, p.131-141.

194.MENESES, Adélia Bezerra de. Memória e ficção II (Memória: matéria de mímese). In: Do poder da palavra: ensaios de literatura e psicanálise. São Paulo: Duas Cidades, 1995, p.143-160.

195.MENESES, Ulpiano T. Bezerra de. A história, cativa da memória?: para um mapeamento da memória no campo das ciências sociais. Rev. Hist. Bras., São Paulo, 34:9-24, 1992.

196.MERLEAU-PONTY, Maurice. A percepção do outro e o diálogo. In: A prosa do mundo. São Paulo: Cosac \& Naify, 2002, p.163-180.

197.MERLEAU-PONTY, Maurice. Fenomenologia da percepção. 3. ed. São Paulo: Martins Fontes, 2006.

198.MERLEAU-PONTY, Maurice. O olho e o espírito. Rio de Janeiro: Grifo, 1969.

199.MERLEAU-PONTY, Maurice. O olho e o espírito. São Paulo: Cosac \& Naify, 2005.

200.MERLEAU-PONTY, Maurice. $O$ primado da percepção e suas conseqüências filosóficas. Campinas: Papirus, 1990.

201.MERLEAU-PONTY, Maurice. O visível e o invisível. São Paulo: Perspectiva, 2007. 
202.MERVANT, Jacques. Mémoire et désir: deux observations de Freud. Bulletin de psychologie. Paris, n.389, tome XLII, 1988-1989, p.386-394.

203.MERVANT, Jacques. Psychologie de la reminiscence. Bulletin de psychologie. Paris, n.389, tome XLII, 1988-1989, p.282-288.

204.MERVANT, Jacques. Un modéle rhétorique de l'oubli. Bulletin de psychologie. Paris, n.389, tome XLII, 1988-1989, p.370-373.

205.MEYER, Marlyse. Folhetim: uma história. Companhia das Letras, 1996.

206.MIRANDA, Danilo Santos de (Org.). História e cultura: a importância da memória na formação cultural humana. São Paulo: SESC, 2007.

207.MORAES, Eduardo Jardim de; BIGNOTO, Newton. (Orgs.). Hannah Arendt: diálogos, reflexões, memórias. Belo Horizonte: UFMG, 2001. (Humanitas).

208.MORAES, Fernanda Borges de. De arraiais, vilas e caminhos: a rede urbana da Minas coloniais. In: RESENDE, Maria Efigênia Lage de; VILLALTA, Luiz Carlos (Orgs.). As minas setecentistas. Belo Horizonte: Autêntica ; Companhia do Tempo, 2005, p.55-85, v.1. (História de Minas Gerais).

209.MORIN, Violette. L'objet biographique. Communications. Paris, École pratique des hautes étude, v.13, p.131-139, 1969.

210. MOSCOVICI, Serge. Sobre a subjetividade social. In : Memória, imaginário e representações sociais. Trad. ULUP, Lilian - coordenação : SÁ, Celso Pereira de, Rio de Janeiro : Museu da Reública, 2005. p. 11-62.

211.MUNFORD, Lewis. A cidade na história: suas origens, desenvolvimento e perspectivas. 2. ed. São Paulo: Martins Fontes, 1982.

212.MURPHY-O'CONNOR, Jerome. Jesus e Paulo: vidas paralelas. São Paulo: Paulinas, 2008.

213.NASCIMENTO, Neuber Fernandes. Memória do fluxo: voz e escuta em Grande sertão: veredas. 2005. 148f. Dissertação (Mestrado em Letras) - Faculdades de Letras, Universidade Federal de Minas Gerais, Belo Horizonte, 2005.

214.NAVA, Pedro. Balão cativo. São Paulo: Ateliê, 2000. (Memória; 2). 
215.NORA, Pierre. Entre memória e história: a problemática dos lugares. Proj. História, São Paulo, (10), dez. 1993, p.7-28.

216.NUNES, Benedito. O tempo da narrativa. São Paulo: Ática, 2000.

217.ONG, Walter J. Oralidade e cultura escrita: a tecnologia da palavra. Campinas: Papirus, 1998.

218.PEREIRA, Lígia Maria Leite. Relatos orais em ciências sociais: limites e potencial. Anal. \& Conj., Belo Horizonte, v.6, n.03, set./dez, 1991, p.109-127.

219.PESAVENTO, Sandra. Cidades visíveis, cidades sensíveis, cidades imaginárias. Revista brasileira de história, v.27, n.53, jun. de 2007, p.11-23.

220.PIGLIA, Ricardo. Memoria y tradición. In: CONGRESSO DA ASSOCIAÇÃO BRASILIERA DE LITERATURA COMPARADA, 2. Belo Horizonte, 1991. Anais do II congresso da associação brasileira de literatura comparada. Belo Horizonte, 1991, v.1, p.6066.

221.POEL, Frei Francisco van der. Cronologia da devoção de Nossa Senhora do Rosário entre os bantos, nos séculos XV-XVII, na África, em Portugal e no Brasil. Revista do instituto histórico e geográfico de Minas Gerais, Belo Horizonte, v.XXIII, 22 de abr. 2000, p.61-74. (Edição comemorativa do $\mathrm{V}$ centenário do descobrimento do Brasil e da colonização portuguesa).

222.POLLAK, Michel. Memória e identidade social. Estudos históricos, Rio de Janeiro, v.5, n.10, 1992, p.200-212.

223.POLLAK, Michel. Memória, esquecimento, silêncio. Estudos históricos, Rio de Janeiro, v.2, n.3, 1989, p.3-15.

224.POMIAN, Krzysztof. Evento. In: Enciclopédia Einaudi. Porto: Imprensa Nacional/Casa da Moeda, 1987, p.214-235. v.29. (Tempo/Temporalidade).

225.POMIAN, Krzysztof. História e ficção. Proj. História, São Paulo, (26), jun. 2003, p.1145 .

226.POMIAN, Krzysztof. Tempo/temporalidade. In: Enciclopédia Einaudi. Porto: Imprensa Nacional/Casa da Moeda, 1987, p.11-91. v.29. (Tempo/Temporalidade). 
227.PORTELLI, Alessandro. O que faz a história oral diferente. Proj. História, São Paulo, (14), fev. 1997, p.25-39.

228.PSICOLOGIA USP, São Paulo, v.4, n.1/2, 1993. (Dossiê: Memória).

229.RENGER, Friedrich E. Primórdios da cartografia das Minas Gerais (1585-1735): dos mitos aos fatos. In: RESENDE, Maria Efigênia Lage de; VILLALTA, Luiz Carlos (Orgs.). As minas setecentistas. Belo Horizonte: Autêntica ; Companhia do Tempo, 2005, p.103-126, v.1. (História de Minas Gerais).

230.RESENDE, Maria Efigênia Lage de. Itinerários e interditos na territorialização da Geraes. In: RESENDE, Maria Efigênia Lage de; VILLALTA, Luiz Carlos (Orgs.). As minas setecentistas. Belo Horizonte: Autêntica ; Companhia do Tempo, 2005, p.25-53, v.1. (História de Minas Gerais).

231.RETÓRICA a Hêrenio. Trad. e introdução de Ana Paula Celestino Faria e Adriana Seabra. São Paulo: Hedra, 2005.

232.REVISTA USP, São Paulo, v.30, jun./ago. 1996. (Dossiê: Brasil dos Viajantes).

233.RIBEIRO, Darcy. O Brasil caboclo. In: O povo brasileiro: a formação e o sentido do Brasil. São Paulo: Companhia das Letras, 1995, p.307-338.

234.RIBEIRO, Darcy. O Brasil caipira. In: O povo brasileiro: a formação e o sentido do Brasil. São Paulo: Companhia das Letras, 1995, p.364-407.

235.RIBEIRO, Darcy. O Brasil sertanejo. In: O povo brasileiro: a formação e o sentido do Brasil. São Paulo: Companhia das Letras, 1995, p.339- 363.

236.RICOEUR, Paul [et al]. Las culturas y el tiempo. Paris: UNESCO, 1979 (Hermeneia; 16).

237. RICOEUR, Paul. El tiempo contado. Revista de occidente. Madrid: Ediciones el arquero, 1987, p.41-64.

238.RICOEUR, Paul. La memóire, l'histoire, l'oubli. Paris: Seuil, 2000.

239.RICOEUR, Paul. Tempo e narrativa. Campinas: Papirus, 1995, 3 v.

240.ROSA, João Guimarães. Grande sertão: veredas. 19. ed. 3. reimp. Rio de Janeiro: Nova Fronteira, 2001. 
241.ROSA, João Guimarães. Grande sertão: veredas. São Paulo: Abril Cultural, 1983.

242.ROSENFIELD, Israel. A invenção da memória: uma nova visão do cérebro. Rio de Janeiro: Nova Fronteira, 1994.

243.ROSSI, Paolo. Il passato, la memoria, l'obli: otto saggi di storia delle idee. Bologna: Il Mulino, 2001.

244.ROUANET, Sérgio Paulo. É a cidade que habita os homens ou são eles que moram nela? Revista USP, n.15, set./nov, 1992, p.49-72. (Dossiê Walter Benjamin).

245.SÁ, Celso Pereira de. As memórias da memória social. In: Memória, imaginário e representações sociais. Rio de Janeiro: Museu da República, 2005, p.63-86

246.SAAVEDRA, Miguel de Cervantes. O engenhoso fidalgo D. Quixote de La Mancha. São Paulo: 34, 2002, v.1.

247.SACKS, Oliver. O homem que confundiu sua mulher com um chapéu e outras histórias clínicas. São Paulo: Companhia das letras, 1997.

248.SANTOS, Myrian Sepúlveda dos. Memória coletiva e teoria social. São Paulo: AnnaBlume, 2003.

249.SCARPELLI, Marli Fantini. Na era do testemunho. In: Via Atlântica - Publicação da área de estudos comparados de língua portuguesa ,n.13/2008- FFLECH-USP,p.73-98.

250.SENNETT, Richard. Carne e pedra. Rio de Janeiro: Record, 2008. (BestBolso).

251.SENNETT, Richard. O artífice. 2. ed. Rio de Janeiro: Record, 2009.

252.SILVA, Franklin Leopoldo e. Bérgson, Proust: tensões do tempo. In: NOVAES, Adauto (Org.). Tempo e história. São Paulo: Companhia das Letras / Secretaria Municipal de Cultura, 1992, p.141-153.

253.SILVA, Franklin Leopoldo e. Bérgson: intuição e discurso filosófico. São Paulo: Loyola, 1994. (Filosofia; 31).

254.SILVA, Jair. Buena - dicha. Belo Horizonte: Imprensa Oficial do Estado de Minas Gerais, 1934.

255.SILVA, Jair. Dia do município. Gazeta de Paraopeba. Paraopeba, ano.XXXIV, 09 de jan. 1944, p.02. 
256.SILVA, Jair. Oropa, França e Paraopeba. Estado de Minas. Belo Horizonte, ano.44, 20 de jun. 1954.

257.SILVA, Jair. Oropa, França eBahia. Estado de Minas. Belo Horizonte, ano.41, 25 de fev. 1951.

258.SODRÉ, Olga. Contribuição da fenomenologia hermenêutica para a psicologia social. Psicologia USP, São Paulo, 15(3), 2004, p.55-80.

259.TADIÉ, Jean-Yves; TADIÉ, Marc. Le sens de la memóire. Paris: Gallimard, 1999.

260.TASSARA, Eda Terezinha Oliveira; DAMERGIAN, Sueli. Para um novo humanismo: contribuições da psicologia social. Estudos avançados USP, São Paulo, 10(28), 1996, p.291315.

261.THOMPSON, Alistair. Recompondo a memória: questões sobre a relação entre a história oral e a memória. Proj. História, São Paulo, (15), abr. 1997, p.51-85.

262.THOMPSON, Paul. A voz do passado: história oral. Rio de Janeiro: Paz e Terra, 1992.

263.THOMPSON, Paul. História oral e contemporaneidade. História oral: revista da associação brasileira de história oral, n.5, jun. De 2002, p.9-28.

264.THOMPSON, Paul. Histórias de vida como patrimônio da humanidade. In: WORCMAN, Karen; PEREIRA, Jesus Vásquez (Coords.). História falada: memória, rede e mudança social. São Paulo: SESC-SP : Museu da Pessoa : Imprensa Oficial, 2006, p.16-43.

265.VAZ, Alisson Mascarenhas. Bernardo Mascarenhas: desarrumando e arrumando - um homem de negócio do século XIX. Belo Horizonte: Cia de Fiação e Tecido Cedro e Cachoeira, 2005.

266.VAZ, Alisson Mascarenhas. Cia Cedro e Cachoeira: história de uma empresa familiar 1883/1987. Belo Horizonte: Cedro e Cachoeira, 1990.

267.VEYNE, Paul. Como se escreve a história. Trad. Maria Auxiliadora Kneipp. 4 ed. Brasília: Editora da Universidade d Brasília, 2008, p.017-235

268.VIDAL, Diana Gonçalves. De Heródoto ao gravador: histórias da história oral. Resgate: revista interdisciplinar de cultura. Campinas: UNICAMP, v.1, 1990, p.77-82. 
269.VON SINSON, Olga Rodrigues de Moraes (Org.). Experimentos com histórias de vida. São Paulo: Vértice, 1988.

270.VON SINSON, Olga Rodrigues de Moraes (Org.). Os desafios contemporâneos da história oral. Campinas: CMU, 1997.

271.VON SINSON, Olga Rodrigues de Moraes; NERI, Anita Liberalesso; CACHIONI, Meire (Orgs.). As múltiplas faces da velhice no Brasil. Campinas: Alinea, 2003.

272.VYGOTSKY, L. S. A formação social da mente: o desenvolvimento dos processos psicológicos superiores. São Paulo: Martins Fontes, 1984.

273.WEIL, Simone. A condição operária e outros estudos sobre a opressão. Seleção e apresentação de Ecléa Bosi. Rio de Janeiro: Paz e Terra, 1979.

274.WEIL, Simone. O enraizamento. Bauru: EDUSC, 2001.

275.WEINRICH, Harald. Lete: arte e crítica do esquecimento. Rio de Janeiro: Civilização Brasileira, 2001.

276.WELLS, James W. Explorando e viajando três mil milhas através do Brasil: do Rio de Janeiro ao Maranhão. Belo Horizonte: Fundação João Pinheiro : Centros de estudos históricos e culturais, $1995,2 \mathrm{v}$.

277.WILLIAMS, Raymond. O campo e a cidade: na história e na literatura. São Paulo: Companhia das Letras, 1989.

278.WORCMAN, Karen; PEREIRA, Jesus Vásquez (Coords.). História falada: memória, rede e mudança social. São Paulo: SESC-SP : Museu da Pessoa : Imprensa Oficial, 2006.

279.XIDIEH, Oswaldo Elias. Narrativas pias populares. São Paulo: Instituto de Estudos Brasileiros, 1967.

280.XIDIEH, Oswaldo Elias. Semana santa cabocla. São Paulo: Instituto de Estudos Brasileiros, 1972.

281. YATES, Frances. A arte da memória. Campinas: Unicamp, 2007.

282.YATES, Frances. The art of memory. Chicago: Chicago University Press, 1992.

283.ZUMTHOR, Paul. A letra e a voz: a "literatura" medieval. São Paulo: Companhia das Letras, 1993. 
284.ZUMTHOR, Paul. Introdução à poesia oral. São Paulo: HUCITEC, 1997.

285.ZUMTHOR, Paul. Performance, recepção, leitura. São Paulo: EDUC, 2000.

286.ZUMTHOR, Paul. Permanência da voz. O correio da UNESCO, outubro, 1985, ano 13, n.10, Brasil, p.4-8.

287.ZUMTHOR, Paul. Poesia, tradição e esquecimento. Folha de São Paulo. São Paulo, 17 dez. 1988. Folhetim, p. G2-G5.

288.ZUMTHOR, Paul. Tradição e esquecimento. São Paulo: Hucitec, 1997.

\subsection{Bibliografia de periódicos consultados em Paraopeba}

1. A DEFESA. Paraopeba, n.01, 28 de ago. 1915.

2. ESTADO DE MINAS. Belo Horizonte, ano 44, n.

3. GAZETA DE PARAOPEBA. Paraopeba, ano XLI, n.2.200, 01 de jul. 1951.

4. GAZETA DE PARAOPEBA. Paraopeba, ano XLI, n.2.208, 26 de ago. 1951.

5. GAZETA DE PARAOPEBA. Paraopeba, ano XLI, n.2.210, 09 de set. 1951.

6. GAZETA DE PARAOPEBA. Paraopeba, ano XLIV, n.2.344, 09 de abr. 1954.

7. GAZETA DE PARAOPEBA. Paraopeba, ano XLIV, n.2.362, 15 de ago. 1954.

8. GAZETA DE PARAOPEBA. Paraopeba, ano XLV, n.2.396, 09 de abr. 1955.

9. GAZETA DE PARAOPEBA. Paraopeba, ano XLVIII, 01 de jun. 1958.

10. GAZETA DE PARAOPEBA. Paraopeba, ano XLVIII, 03 de ago. 1958.

11. GAZETA DE PARAOPEBA. Paraopeba, ano XLVIII, 06 de jul. 1958.

12. GAZETA DE PARAOPEBA. Paraopeba, ano XLVIII, 08 de jun. 1958.

13. GAZETA DE PARAOPEBA. Paraopeba, ano XLVIII, 10 de ago. 1958.

14. GAZETA DE PARAOPEBA. Paraopeba, ano XLVIII, 13 de jul. 1958.

15. GAZETA DE PARAOPEBA. Paraopeba, ano XLVIII, 15 de jun. 1958.

16. GAZETA DE PARAOPEBA. Paraopeba, ano XLVIII, 17 de ago. 1958.

17. GAZETA DE PARAOPEBA. Paraopeba, ano XLVIII, 18 de maio 1958.

18. GAZETA DE PARAOPEBA. Paraopeba, ano XLVIII, 20 de jul. 1958.

19. GAZETA DE PARAOPEBA. Paraopeba, ano XLVIII, 22 de jun. 1958.

20. GAZETA DE PARAOPEBA. Paraopeba, ano XLVIII, 25 de maio 1958.

21. GAZETA DE PARAOPEBA. Paraopeba, ano XLVIII, 26 de jun. 1958. 
22. GAZETA DE PARAOPEBA. Paraopeba, ano XLVIII, 27 de jul. 1958.

23. GAZETA DE PARAOPEBA. Paraopeba, ano XVII, 02 de out. 1927.

24. GAZETA DE PARAOPEBA. Paraopeba, ano XVII, 21 de ago. 1927.

25. GAZETA DE PARAOPEBA. Paraopeba, ano XVII, n.943, 9 de abr. 1927.

26. GAZETA DE PARAOPEBA. Paraopeba, ano XXV, 22 de set. 1935.

27. GAZETA DE PARAOPEBA. Paraopeba, ano XXV, 6 de out. 1935.

28. GAZETA DE PARAOPEBA. Paraopeba, ano XXVI, 09 de abr. 1936.

29. GAZETA DE PARAOPEBA. Paraopeba, ano XXXIV, n.1846, 10 de set. 1944.

30. GAZETA DE PARAOPEBA. Paraopeba, ano XXXIV, n.1854, 05 de nov. 1944.

31. GAZETA DE PARAOPEBA. Paraopeba, ano XXXVI, 01 de junho de 1947.

32. GAZETA DE PARAOPEBA. Paraopeba, ano XXXIX, 13 de fev. 1949.

33. GAZETA DE PARAOPEBA. Paraopeba, ano XXXIX, 24 de jul. 1949.

34. GAZETA DE PARAOPEBA. Paraopeba, ano XXXV, 04 de fev. 1945.

35. GAZETA DE PARAOPEBA. Paraopeba, ano XXXVIII, n.2.032, 09 de abr. 1948.

36. JORNAL DE PARAOPEBA. Paraopeba, ago. 1992.

37. MINAS GERAIS. Belo Horizonte, Imprensa Oficial, 1926.

38. VILLA PARAOPEBA. Paraopeba, 09 de ago. 1931.

39. VILLA PARAOPEBA. Paraopeba, ano 1, n.1, 22 de ago. 1915.

40. VILLA PARAOPEBA. Paraopeba, ano 1, n.3, 05 de set. 1915.

41. VILLA PARAOPEBA. Paraopeba, ano 1, n.5, 19 de set. 1915.

42. VILLA PARAOPEBA. Paraopeba, ano 1, n.6, 26 de set. 1915.

43. VILLA PARAOPEBA. Paraopeba, ano 1, n.7, 03 de out. 1915. 


\section{Anexos}

\subsection{ANEXO 04: Roteiro da entrevista semi-estruturada}

\section{I - A infância - O tempo da infância}

A. A casa

1) Onde o sr. (a sra.) nasceu?

2) Como era a casa do sr. (a sra.)?

B. A família

3) Com quem o sr. (a sra.) morava? O que o sr. (a sra.) lembra deles?

4) Quantos irmãos o sr. (sra.) tinha?

C. A rua e os vizinhos

5) O senhor (a sra.) se lembra da rua, dos vizinhos? Quem eram seus vizinhos?

6) O sr.(a sra.) era próximos dos vizinhos? Como era a relação?

D. O trabalho

7) Os seus pais trabalhavam em que?

8) Seus pais trabalhavam em casa? O sr. (a sra.) lembra dos seus pais trabalhando?

9) O sr. (a sra.) lembra se,aqui nessa cidade, quais eram os trabalhos mais comuns?

E. A escola

10) O sr. (a sra.) estudou em qual escola?

11) Até quando o sr. (a sra.) freqüentou a escola?

12) O que o sr.(a sra.) lembra dos seus primeiros dias na escola?

13) Como era a primeira professora?

14) Como era a convivência entre as crianças? E a relação com os professores?

F. As casas

15) O sr. (a sra.) se lembra como eram as casas da cidade?

G. A cidade

16) O sr. (a sra.) sabe como a cidade de Paraopeba surgiu?

17) O sr. (a sra.) se lembra de algum prédio que já não existe? 
18) Como eram as praças, as ruas da cidade?

\section{II - O tempo da maturidade.}

H. A cidade e os eventos

19) Qual a profissão do sr. (a sra.)?

20) O sr. (a sra.) se recorda de como era a cidade na sua juventude?

21) Como eram as atividades política da cidade?

I. A cidade e as festas

22) O sr. (a sra.) freqüentava as festas da cidade?

23) Quais eram as festas?

J. A cidade e a religião

24) O sr. (a sra.) se formou em qual religião?

25) De que forma a religião marcou o sr. (a sra.)?

26) O sr. (a sra.) participava das festas religiosas? Quais?

\section{III - O tempo e a cidade: a narrativa}

27) O sr. (a sra.) poderia contar a diferença entre a cidade de antigamente e a cidade de agora?

28) O sr. (a sra.) poderia falar sobre esta experiência de contar sua história e da cidade? 


\subsection{ANEXO 05: Termos de consentimento livre e esclarecido}

Você está sendo convidado a participar, como voluntário, de uma pesquisa. Após ser esclarecido(a) sobre as informações a seguir, no caso de aceitar fazer parte do estudo, assine ao final deste documento, que está em duas vias. Uma delas é sua e a outra é do pesquisador responsável. Em caso de recusa você não será penalizado(a) de forma alguma.

\section{INFORMAÇÕES SOBRE A PESQUISA:}

Título do projeto: A cidade lembrada: um estudo sobre a memória subjetiva e social

Pesquisador responsável: Neuber Fernandes Nascimento

Telefone para contato (inclusive para ligações a cobrar): (31) 3714-1214

1. Será realizada uma entrevista como parte da pesquisa de doutorado intitulada A cidade lembrada: um estudo sobre a memória subjetiva e social, sob orientação da Profa. Dra. Sueli Damergian e tem como objetivo conhecer a memória da cidade de Paraopeba.

2. O objetivo dessa entrevista é estritamente acadêmico e para fins didáticos, não havendo nenhuma outra finalidade oculta.

3. A entrevista deverá durar por volta de 60 (sessenta) minutos, dependendo da sua disponibilidade. Haverá gravação em fita cassete, que ficarão sob guarda do pesquisador.

4. Vale salientar que a participação é voluntária e a entrevista pode ser interrompida a qualquer momento. Além disso, o sigilo será garantido e sua identidade não será revelada sob nenhuma hipótese.

5. O material coletado na pesquisa poderá ser utilizado em uma futura publicação em livro e/ou periódico científico, mas, novamente reforça-se o sigilo, pois em nenhum momento sua identidade será revelada.

6. A pesquisa não trará nenhum risco para você e nem oferecerá alguma vantagem financeira.

Neuber Fernandes Nascimento - Pesquisador Executor

Aluno de Pós-Graduação em Psicologia Social

Instituto de Psicologia da Universidade de São Paulo - USP

\section{Consentimento da participação da pessoa como sujeito}

$\mathrm{Eu}$, abaixo assinado, concordo em participar do estudo A cidade lembrada: um estudo sobre a memória subjetiva e social, como sujeito. Fui devidamente informado e esclarecido pelo pesquisador Neuber Fernandes Nascimento sobre a pesquisa, os procedimentos nela envolvidos, assim como os possíveis riscos e benefícios decorrentes de minha participação. Paraopeba, / / . 


\section{TERMO DE CONSENTIMENTO LIVRE E ESCLARECIDO}

Você está sendo convidado a participar, como voluntário, de uma pesquisa. Após ser esclarecido(a) sobre as informações a seguir, no caso de aceitar fazer parte do estudo, assine ao final deste documento, que está em duas vias. Uma delas é sua e a outra é do pesquisador responsável. Em caso de recusa você não será penalizado(a) de forma alguma.

\section{INFORMAÇÕES SOBRE A PESQUISA:}

Título do projeto: $A$ cidade lembrada: um estudo sobre a memória subjetiva e social

Pesquisador responsável: Neuber Fernandes Nascimento

Telefone para contato (inclusive para ligações a cobrar): (31) 3714-1214

1. Será realizada uma entrevista como parte da pesquisa de doutorado intitulada $A$ cidade lembrada: um estudo sobre a memória subjetiva e social, sob orientação da Profa. Dra. Sueli Damergian e tem como objetivo conhecer a memória da cidade de Paraopeba.

2. O objetivo dessa entrevista é estritamente acadêmico e para fins didáticos, não havendo nenhuma outra finalidade oculta.

3. A entrevista deverá durar por volta de 60 (sessenta) minutos, dependendo da sua disponibilidade. Haverá gravação em fita cassete, que ficarão sob guarda do pesquisador.

4. Vale salientar que a participação é voluntária e a entrevista pode ser interrompida a qualquer momento. Além disso, o sigilo será garantido e sua identidade não será revelada sob nenhuma hipótese.

5. O material coletado na pesquisa poderá ser utilizado em uma futura publicação em livro e/ou periódico científico, mas, novamente reforça-se o sigilo, pois em nenhum momento sua identidade será revelada.

6. A pesquisa não trará nenhum risco para você e nem oferecerá alguma vantagem financeira.

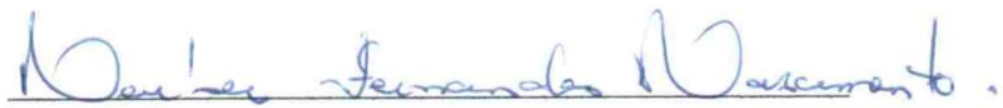

Neuber Fernandes Nascimento - Pesquisador Executor

Aluno de Pós-Graduação em Psicologia Social

Instituto de Psicologia da Universidade de São Paulo - USP

\section{Consentimento da participação da pessoa como sujeito}

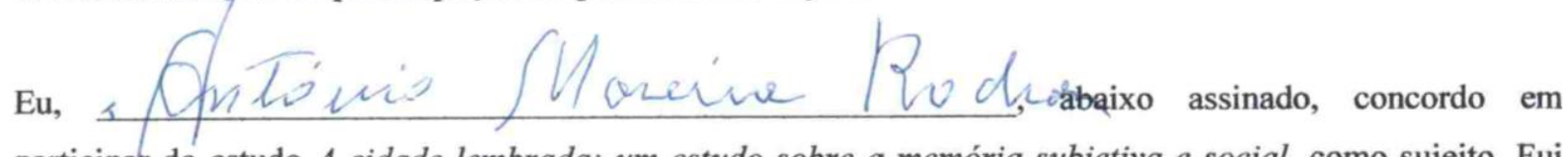
participar do estudo $A$ cidade lembrada: um estudo sobre a memória subjetiva e social, como sujeito. Fui devidamente informado e esclarecido pelo pesquisador Neuber Fernandes Nascimento sobre a pesquisa, os procedimentos nela envolvidos, assim como os possíveis riscos e benefícios decorrentes de minha participação. Paraopeba, 0 / 0 / / O9. 


\section{TERMO DE CONSENTIMENTO LIVRE E ESCLARECIDO}

Você está sendo convidado a participar, como voluntário, de uma pesquisa. Após ser esclarecido(a) sobre as informaç̃̃es a seguir, no caso de aceitar fazer parte do estudo, assine ao final deste documento, que está em duas vias. Uma delas é sua e a outra é do pesquisador responsável. Em caso de recusa você não será penalizado(a) de forma alguma.

\section{INFORMAÇÕES SOBRE A PESQUISA:}

Título do projeto: A cidade lembrada: um estudo sobre a memória subjetiva e social

Pesquisador responsável: Neuber Fernandes Nascimento

Telefone para contato (inclusive para ligações a cobrar): (31) 3714-1214

1. Será realizada uma entrevista como parte da pesquisa de doutorado intitulada $A$ cidade lembrada: um estudo sobre a memória subjetiva e social, sob orientação da Profa. Dra. Sueli Damergian e tem como objetivo conhecer a memória da cidade de Paraopeba.

2. O objetivo dessa entrevista é estritamente acadêmico e para fins didáticos, não havendo nenhuma outra finalidade oculta.

3. A entrevista deverá durar por volta de 60 (sessenta) minutos, dependendo da sua disponibilidade. Haverá gravação em fita cassete, que ficarão sob guarda do pesquisador.

4. Vale salientar que a participação é voluntária e a entrevista pode ser interrompida a qualquer momento. Além disso, o sigilo será garantido e sua identidade não será revelada sob nenhuma hipótese.

5. O material coletado na pesquisa poderá ser utilizado em uma futura publicação em livro e/ou periódico científico, mas, novamente reforça-se o sigilo, pois em nenhum momento sua identidade será revelada.

6. A pesquisa não trará nenhum risco para você e nem oferecerá alguma vantagem financeira.

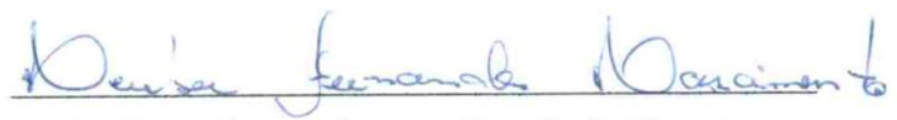

Neuber Fernandes Nascimento - Pesquisador Executor

Aluno de Pós-Graduação em Psicologia Social

Instituto de Psicologia da Universidade de São Paulo - USP

\section{Consentimento da participação da pessoa como sujeito}

Eu, Jose fevaldo Edmund are abaixo assinado, concordo em participar do estudo A cidade lembrada: um estudo sobre a memória subjetiva e social, como sujeito. Fui devidamente informado e esclarecido pelo pesquisador Neuber Fernandes Nascimento sobre a pesquisa, os procedimentos nela envolvidos, assim como os possíveis riscos e beneficios decorrentes de minha participação. Paraopeba, " /12 108. 


\section{TERMO DE CONSENTIMENTO LIVRE E ESCLARECIDO}

Você está sendo convidado a participar, como voluntário, de uma pesquisa. Após ser esclarecido(a) sobre as informações a seguir, no caso de aceitar fazer parte do estudo, assine ao final deste documento, que está em duas vias. Uma delas é sua e a outra é do pesquisador responsável. Em caso de recusa você não será penalizado(a) de forma alguma.

\section{INFORMAÇÕES SOBRE A PESQUISA:}

Título do projeto: A cidade lembrada: um estudo sobre a memória subjetiva e social

\section{Pesquisador responsável: Neuber Fernandes Nascimento}

Telefone para contato (inclusive para ligações a cobrar): (31) 3714-1214

1. Será realizada uma entrevista como parte da pesquisa de doutorado intitulada $A$ cidade lembrada: um estudo sobre a memória subjetiva e social, sob orientação da Profa. Dra. Sueli Damergian e tem como objetivo conhecer a memória da cidade de Paraopeba.

2. O objetivo dessa entrevista é estritamente acadêmico e para fins didáticos, não havendo nenhuma outra finalidade oculta.

3. A entrevista deverá durar por volta de 60 (sessenta) minutos, dependendo da sua disponibilidade. Haverá gravação em fita cassete, que ficarão sob guarda do pesquisador.

4. Vale salientar que a participação é voluntária e a entrevista pode ser interrompida a qualquer momento. Além disso, o sigilo será garantido e sua identidade não será revelada sob nenhuma hipótese.

5. O material coletado na pesquisa poderá ser utilizado em uma futura publicação em livro e/ou periódico científico, mas, novamente reforça-se o sigilo, pois em nenhum momento sua identidade será revelada.

6. A pesquisa não trará nenhum risco para você e nem oferecerá alguma vantagem financeira.

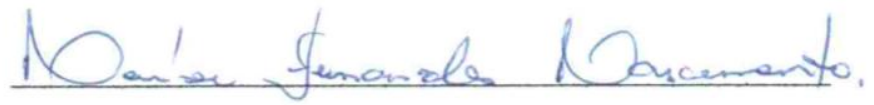

Neuber Fernandes Nascimento - Pesquisador Executor

Aluno de Pós-Graduação em Psicologia Social

Instituto de Psicologia da Universidade de São Paulo - USP

\section{Consentimento da participação da pessoa como sujeito}

Eu, Geralda maría fraufo, abaixo assinado, concordo em participar do estudo A cidade lembrada: um estudo sobre a membria subjetiva e social, como sujeito. Fui devidamente informado e esclarecido pelo pesquisador Neuber Fernandes Nascimento sobre a pesquisa, os procedimentos nela envolvidos, assim como os possíveis riscos e benefícios decorrentes de minha participação. Paraopeba, 09/01/09. 


\section{TERMO DE CONSENTIMENTO LIVRE E ESCLARECIDO}

Você está sendo convidado a participar, como voluntário, de uma pesquisa. Após ser esclarecido(a) sobre as informações a seguir, no caso de aceitar fazer parte do estudo, assine ao final deste documento, que está em duas vias. Uma delas é sua e a outra é do pesquisador responsável. Em caso de recusa você não será penalizado(a) de forma alguma.

\section{INFORMAÇÕES SOBRE A PESQUISA:}

Título do projeto: $A$ cidade lembrada: um estudo sobre a memória subjetiva e social

Pesquisador responsável: Neuber Fernandes Nascimento

Telefone para contato (inclusive para ligações a cobrar): (31) 3714-1214

1. Será realizada uma entrevista como parte da pesquisa de doutorado intitulada $A$ cidade lembrada: um estudo sobre a memória subjetiva e social, sob orientação da Profa. Dra. Sueli Damergian e tem como objetivo conhecer a memória da cidade de Paraopeba.

2. O objetivo dessa entrevista é estritamente acadêmico e para fins didáticos, não havendo nenhuma outra finalidade oculta.

3. A entrevista deverá durar por volta de 60 (sessenta) minutos, dependendo da sua disponibilidade. Haverá gravação em fita cassete, que ficarão sob guarda do pesquisador.

4. Vale salientar que a participação é voluntária e a entrevista pode ser interrompida a qualquer momento. Além disso, o sigilo será garantido e sua identidade não será revelada sob nenhuma hipótese.

5. O material coletado na pesquisa poderá ser utilizado em uma futura publicação em livro e/ou periódico científico, mas, novamente reforça-se o sigilo, pois em nenhum momento sua identidade será revelada.

6. A pesquisa não trará nenhum risco para você e nem oferecerá alguma vantagem financeira.

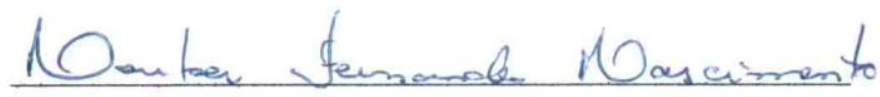

Neuber Fernandes Nascimento - Pesquisador Executor

Aluno de Pós-Graduação em Psicologia Social

Instituto de Psicologia da Universidade de São Paulo - USP

\section{Consentimento da participação da pessoa como sujeito}

Eu, Marra Stella worena Rates, abaixo assinado, concordo em participar do estudo A cidade lembrada: um estudo sobre a memória subjetiva e social, como sujeito. Fui devidamente informado e esclarecido pelo pesquisador Neuber Fernandes Nascimento sobre a pesquisa, os procedimentos nela envolvidos, assim como os possíveis riscos e benefícios decorrentes de minha participação. Paraopeba, $14 / 06 / 09$. 


\subsection{ANEXO 06: Os periódicos da cidade}

\section{IMAGEM 82: O Industrial}

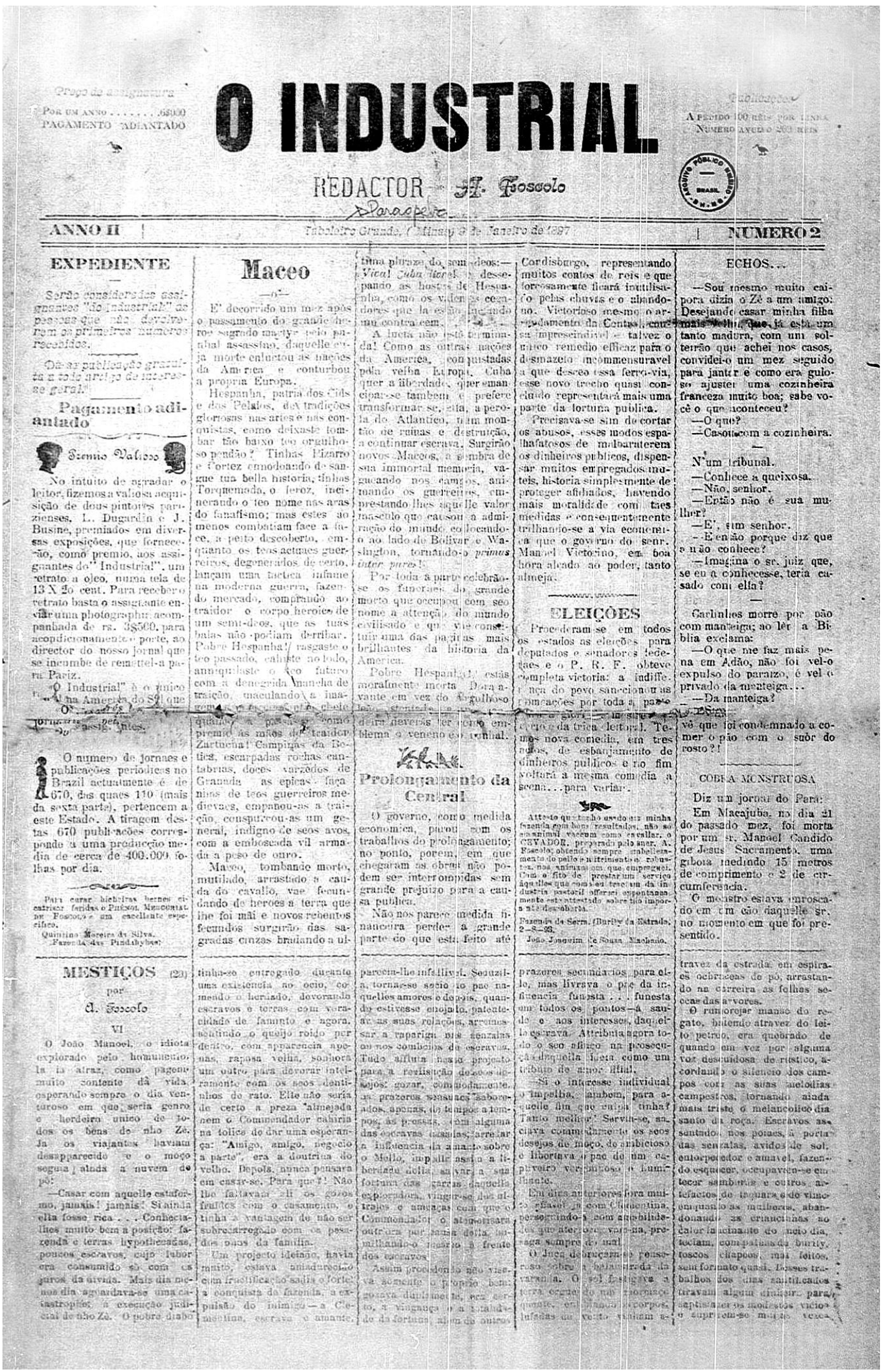




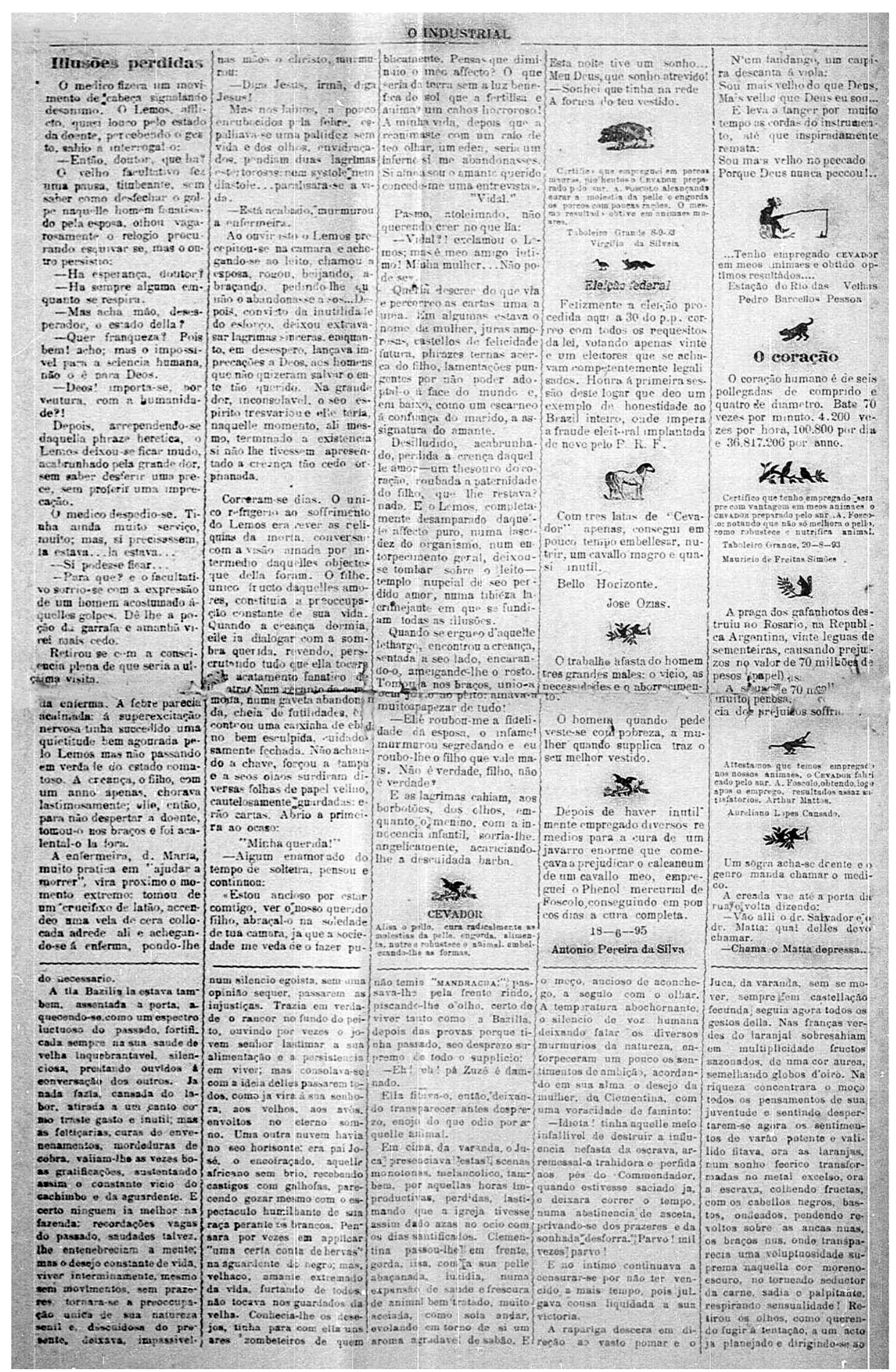




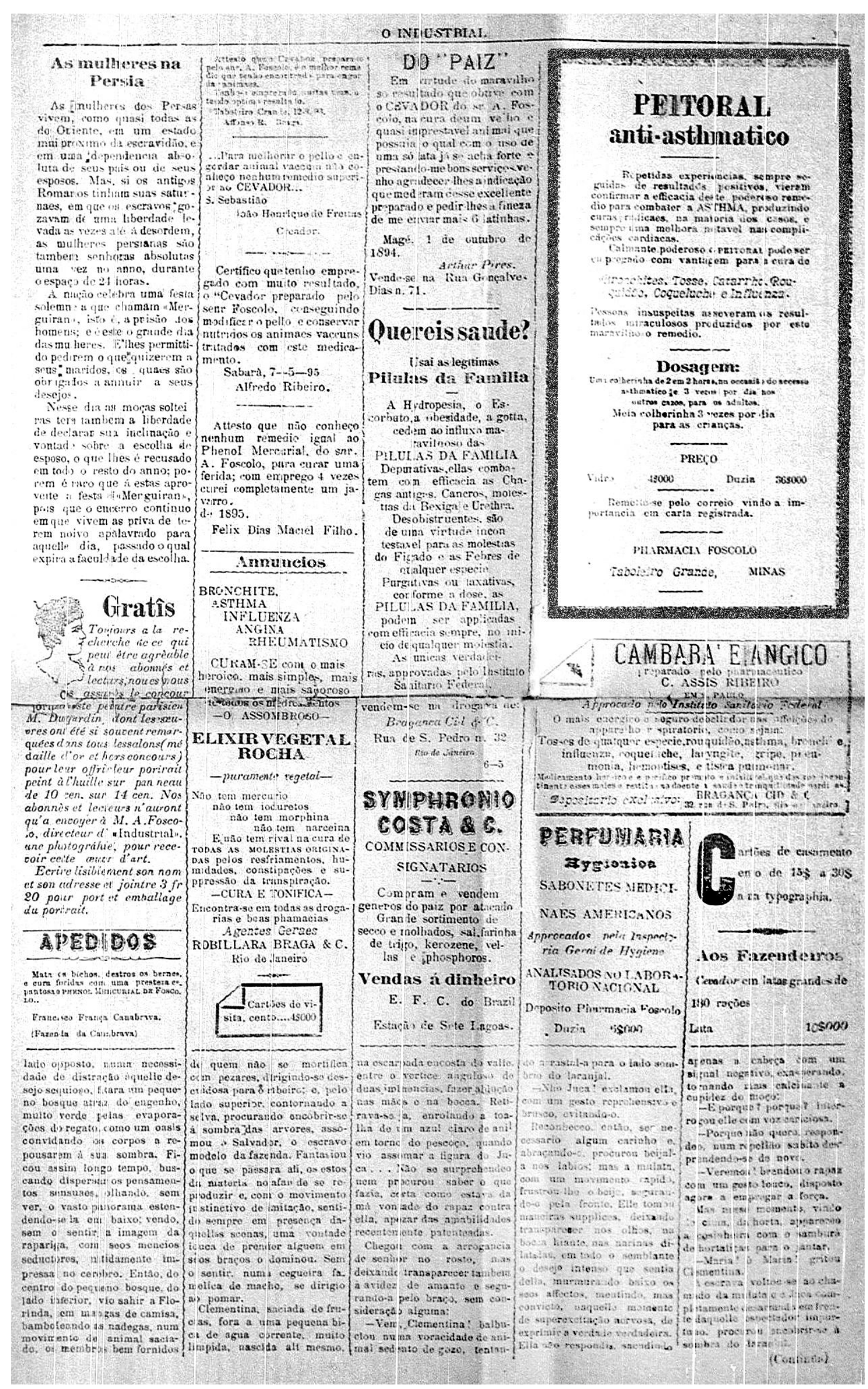




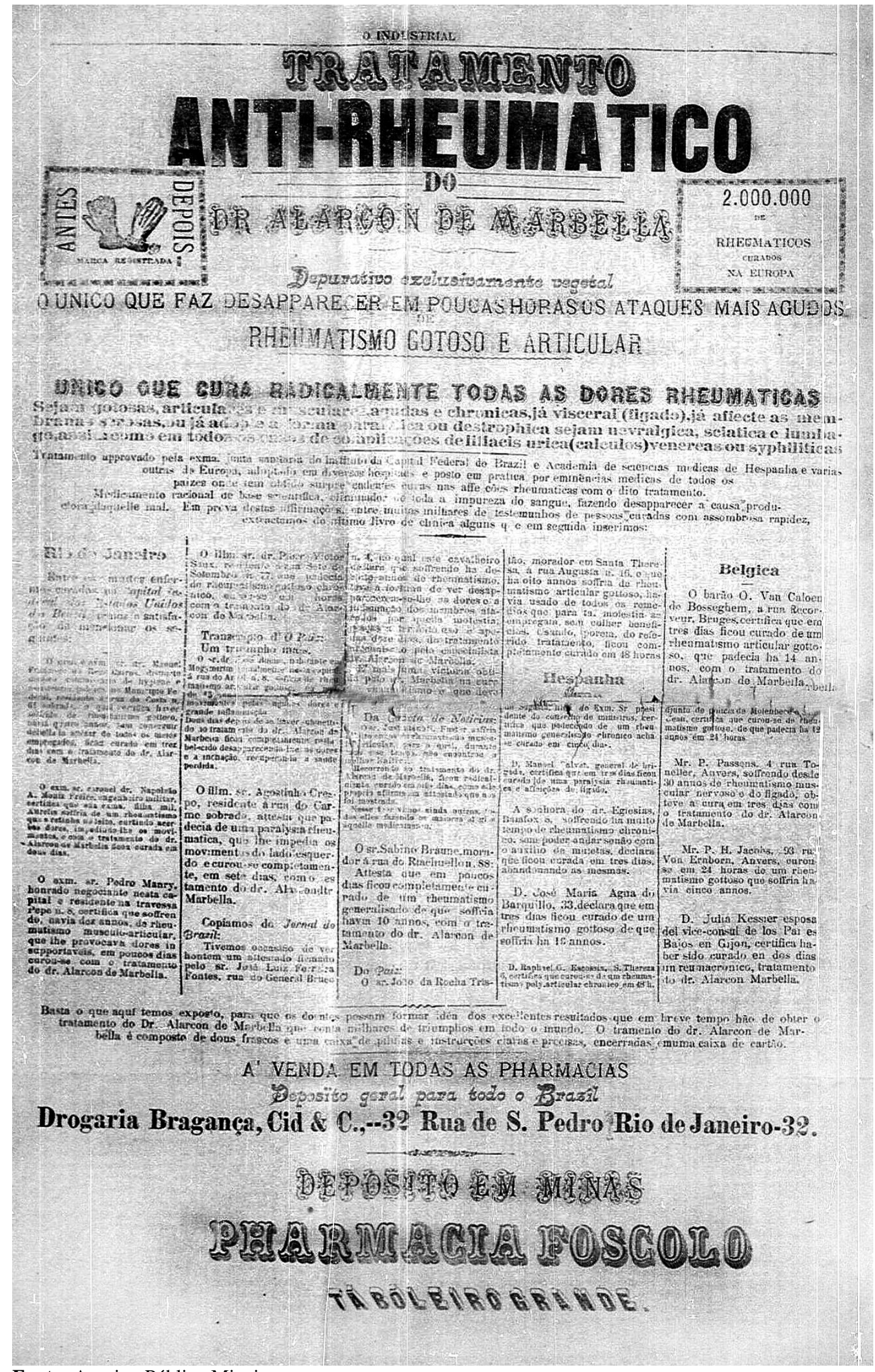

Fonte: Arquivo Público Mineiro 


\section{IMAGEM 83: O Bébé}
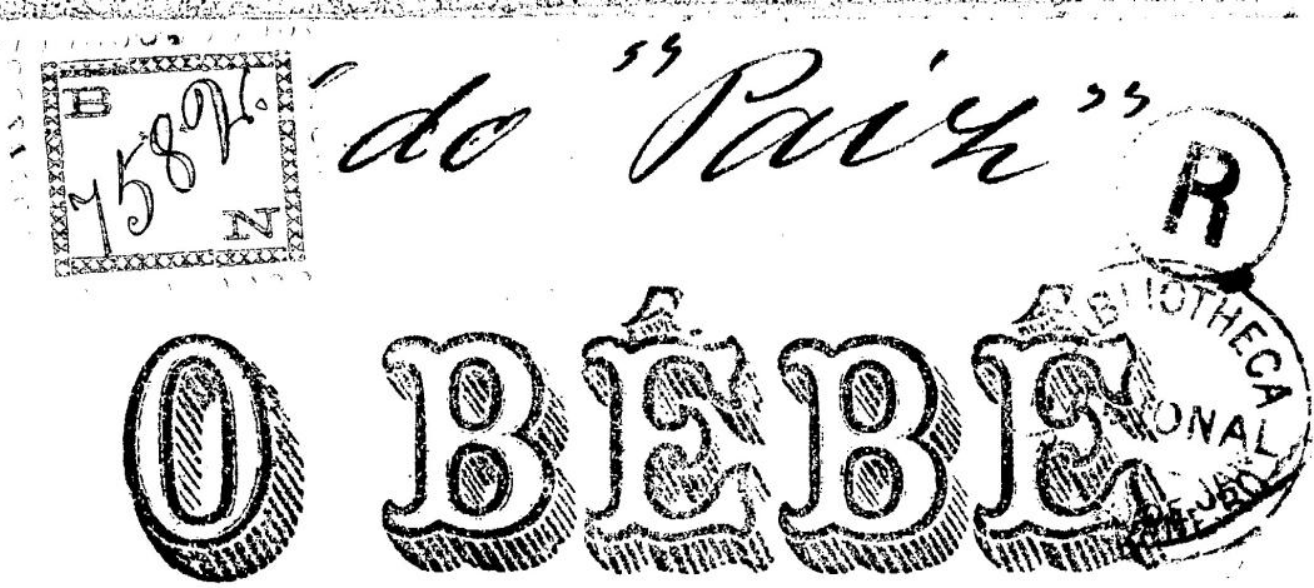

Sropriciarios

M. A. DA SILA E J. R. DE OLiteira

Anno 1 LSTADODE MINAS T Num. 1 Taboleino Grante, 5 de Junho de 1897

$\mathbb{O}$ CBolé Jos estorcos que pa1.1 1 s5o tem boa ron-

Aprosenta-so hoje tader de prosurar ao publico benoromo, manter a nota alegro, interessante e rocreativa. zinho humilile sonsageiro do nossas obscuras ideias:

Como a plantinia

N'esta quadra in- em humido e escuro fantil, qual c a nos- subterraneo, dirigo sa, fallecem-nos não os frageis rebentos só a precisa instru- para a lenda fracaç̧ão, mas tambem mente illuminada os dotes intellectu- pelos raios solares, aes que são o apana- assim tambem $" 0$ gio de todos os que Bebén pequenino e labutam nas lides da fraco,procurará com imprensa; todavia, suas debeis forças, "O Bébé» fará todos alcançar algum ca- 


\section{IMAGEM 84: O Elephante}

EE. UU. DO BRAZIL TABOLEIROGRAÑE MINAS GERAES

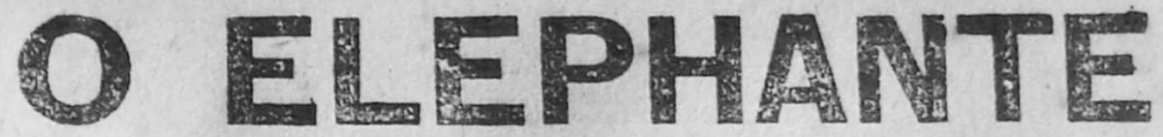

LITTERARIO, NOTICIOSO E HUMORISTICO

Director-MANOEL A. DA SILVA.

ANNO-I DOMINGO, 22 DE NOVEMBRO DE $1903\{$ NE-XI

15 DE NOVEABPOO

Foin'estadata.la jusiamente 14 an. nos, que se procla. mou a republica Brazileira.Caso vira gem nos anncies da historia; a trauzição da monarchia para a tepublica: foz .se, sem derramar-se u. ra a gotta de sangtie. Benjamim Constant e Deodoro, es he.róes d'esse dia glorioso; ja pagaram à natureza o tribuio natural que the der viam; mas of seus nomes, caminharão sempte atravez da historia como dous fachos Iuminosus: como duas ostrellas brilhantes de primeira grandeza,que implantaram para sempre a democra. cia n'este colosso qus se chama Brazil o a quem Deus fadou paraser uma das maiores nações do mundo:

Que sous filhos

procurem sempre e- das que amam since leval-o e engrande- romente esta lerra Gel-o, são os votos a bençoada

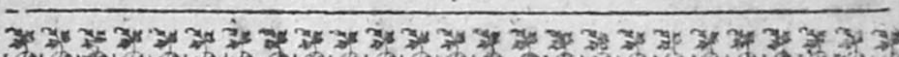
से

\section{IPagina da caracãa}

( A elvina Tamos)

"Ah! cono são lugubres as vózes de uma alma apaixonada, sob a dolorosa impressão da desventural

murier do dia, quando a noute vem começando a distender preguiçó. samente as suis ne. gras e mysteriosas azas sobie a face escabrosa da ter:a; uma tristeza immensa; um pezar estra nho; indetinivel, me invade a alma... Nium desfallecimento indescriptivel; $s 10$. to que vou deixar de existir, e que jama. is os meus olhos fitarảo timidos e compassivos os da quella que tão meigamente despertou o meu coração, tornando 0 eseravo submisso do s encana tos de sua peregrina e fascinadora bolle. $\mathrm{za}$ !

A's vezes, alla noute, no delirio da insomnia, debruço. me an parapeito da janella do ineu quar. to; unico confidente o testemunha das minhas dores e dos meus sentimentos recondiros; e penso corn suprema me. laricholia sobre a diversidade desta mundo de illusōes onde tudo que hoje parece vigoroso inabalavel, amanha succumbindo-se, sopulta-se nas bramas espessas do passa.

Fonte: Arquivo do Museu Têxtil Décio Mascarenhas 
IMAGEM 85: O Ensaio

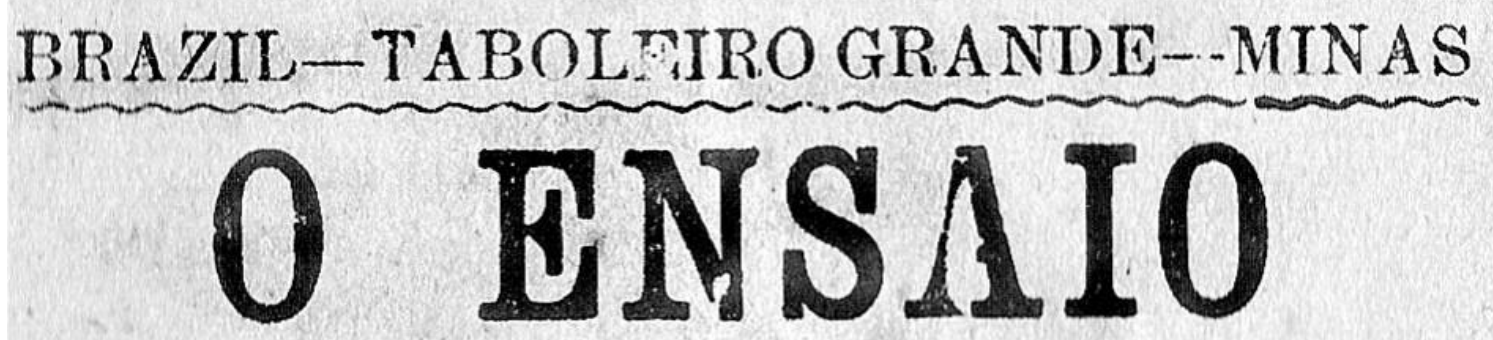

PUBLICAÇÃU SEMANAL

Amno I I 24 de Setembro de 1905 | N. 3 - OENSAO, midade que lhe mina. va aes poucos a ex Por 6 mezes...1\$000 istencia, por corto se

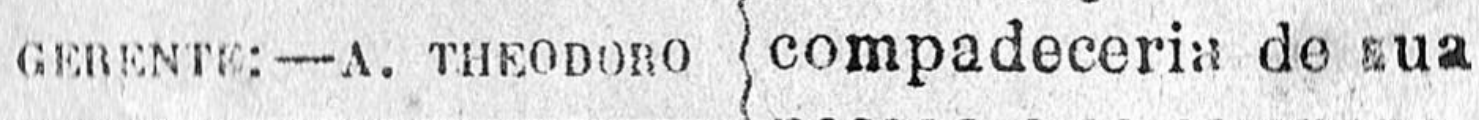
Maria Nascimento pesscia e so compenod. Maria Nascimento traria de quo tudo são Após onze annos de illusões nesta vida. at $x 6 z$ scffrimento, $E$ afinal teve que cesupportado com a re- der á lei fatal-aquel. signação propria das la quo cum tanta paalmas bòas, succum- ciencia e resignação biu a 19 do corrento supportou até ao ula exm.asmr.a D. Maria timo alento de vida, a Nascimento, digna terrivel molestia quo conscrte do sni. A. a levou ao tumulo. Nascimento Junior.

Quem a visse no Cumadres visinhas leito da dòr resistin- brigam como as galdo a cruél enfer. linhas. 
IMAGEM 86: O Taboleirense

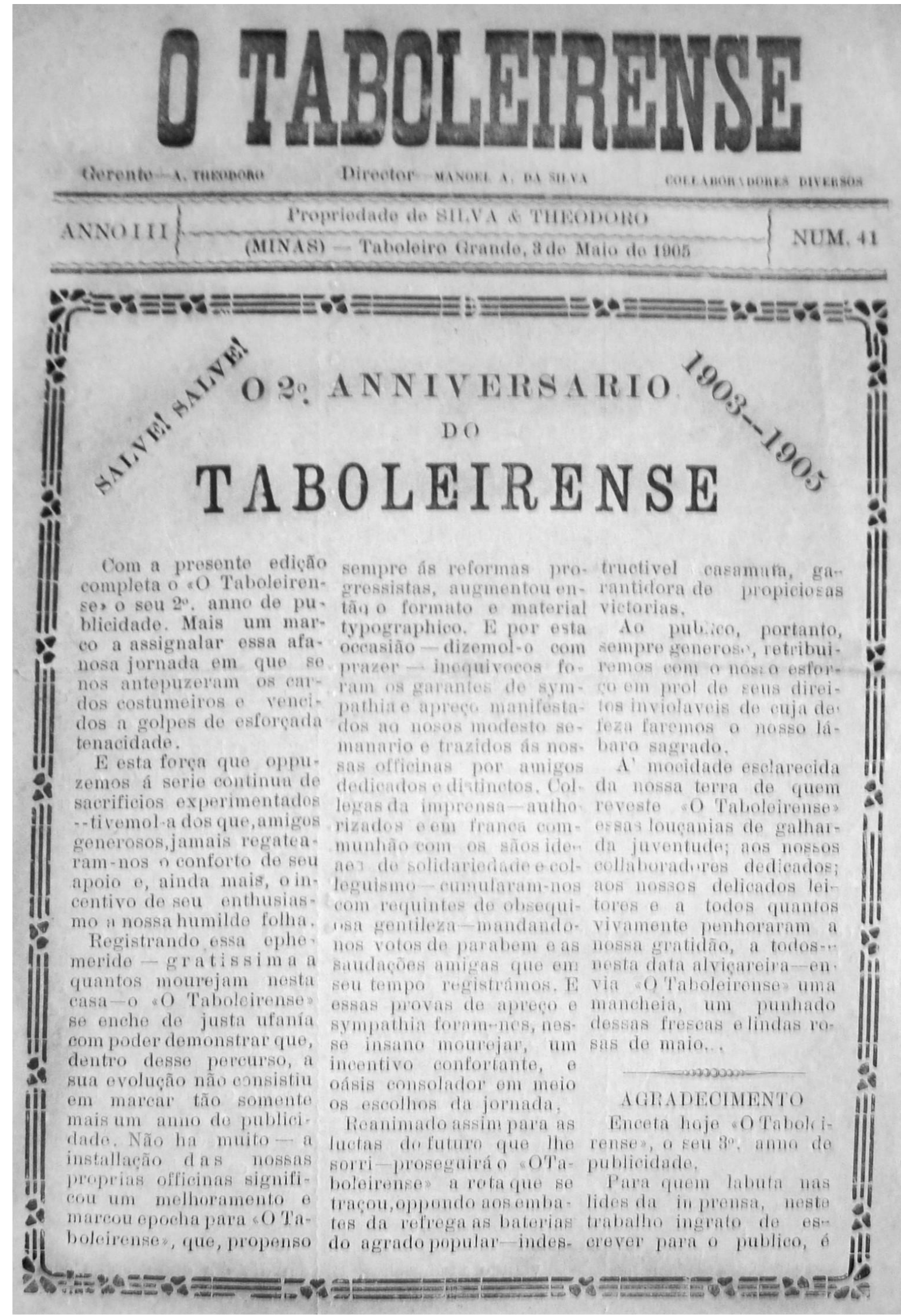

Fonte: Arquivo do Museu Têxtil Décio Mascarenhas 
IMAGEM 87: O Operário

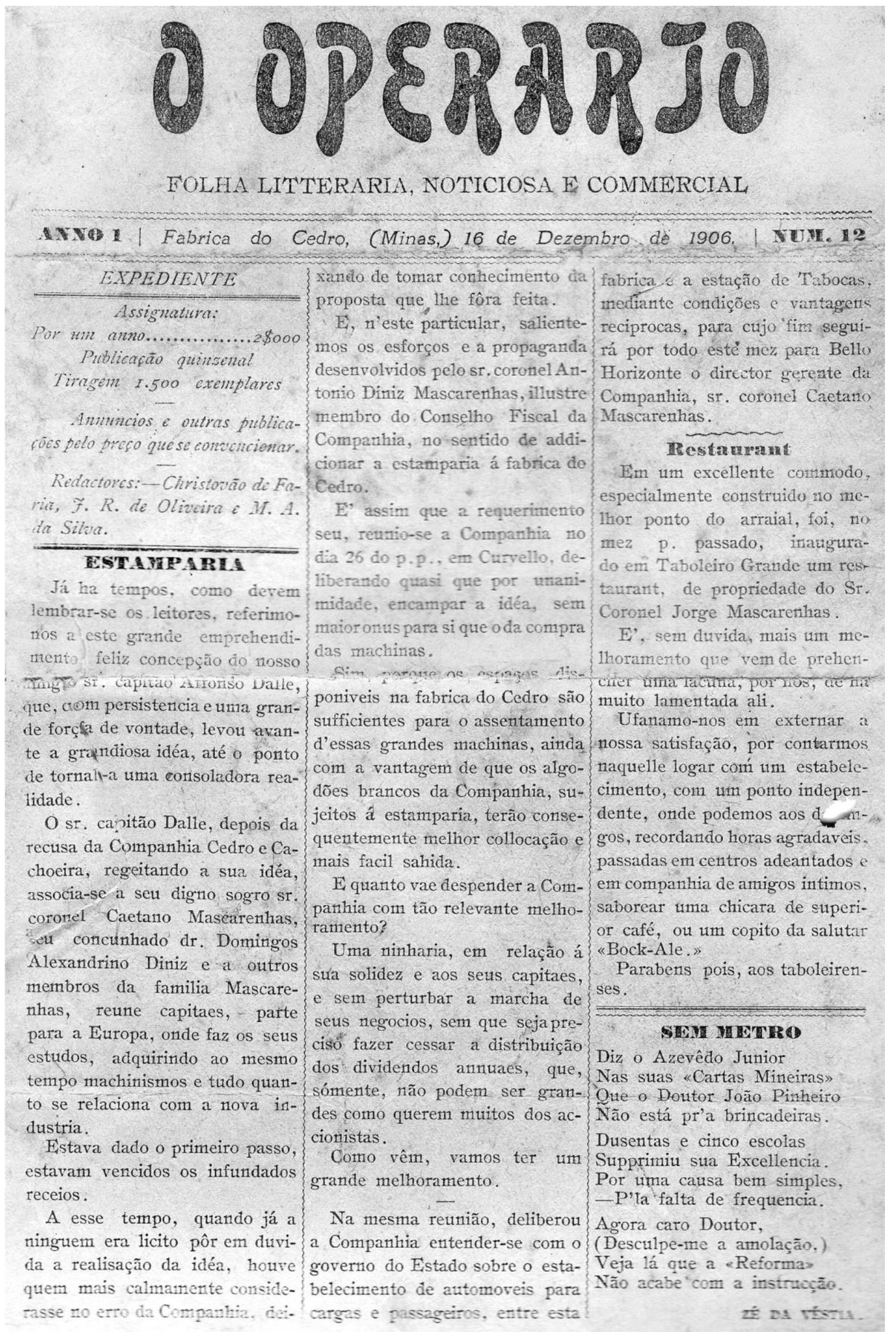

Fonte: Arquivo particular 
IMAGEM 88: O Bogari

ANNO I - NUM. 3

BRASIL - MINAS

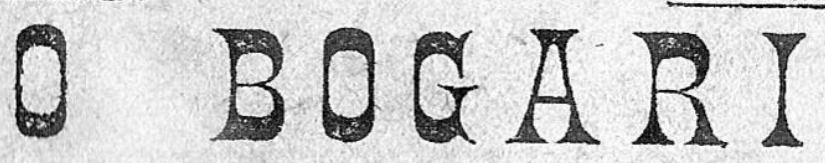

FOIMA IITHERARIA, NOTICIOSA F IMPARCIAL,

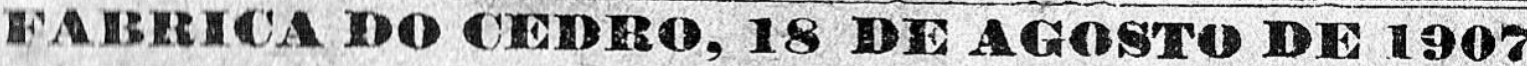

\section{«O BOGARI»}

Reapparece hoje a nossa foTha, que, desde Maio tem a sua publicação interrompida.

Motivos diversos determinaram a sua ñ̂์ circulação durante esse tempo, o que bastante nos contrariou, Mas, no nosso meio, of difticil mesmo, sentio impossivel, manter-se um jornal, com publicaçto regular, porque as difficuldader com que sempre tem de arear uma empresa for. nalistica, por modesta que seja, ndo valeu para superal-as-a bó vontade e os esfofços de seus directores.

Hoje, reauimados, voltamos ao nosso humilde logar e espexamos poder feguir desassonbradamente em busca do ideal que nos aleuta e que é o objecto de nossas aspiraçbes,

\section{"O OPERARIO}

Com o seu numero 24 , de 4 do corrente desappareceu da arena este nosso collega local. Com pesar registramos esse facto.

\section{THEATRO}

A 9 do corrente foram levadas á scena, no theatro provisorio deste logar, quatro comedias, pelo grupo dramatico 'Club Primavéra,' aqui organisado ha pouco.

A nova aggremiação á cuja estréa animadora tivemos a satisfaçấo do assistir, por gentil e delicado couvite que nos fó dirigido, muito promette para o futuro, realmente,

Tomaram parto na representaçâo, os Surs. Antouio $\Lambda$. dos Santos, M. Mourío, Aristeu Ramos, Casemiro Msteves, Oscar Baptista, José d. Patrocinio, Luiz Teixeira, Raymundo Leite, Candido Nery e as Senhoritas Risoleta, Mulata, Preta e Emilia .

Ao "Club Primavéra" e á sua distincta e talentosa directora Exm? Snr? D. Maria E. M. 


\section{IMAGEM 89: O Mimo}

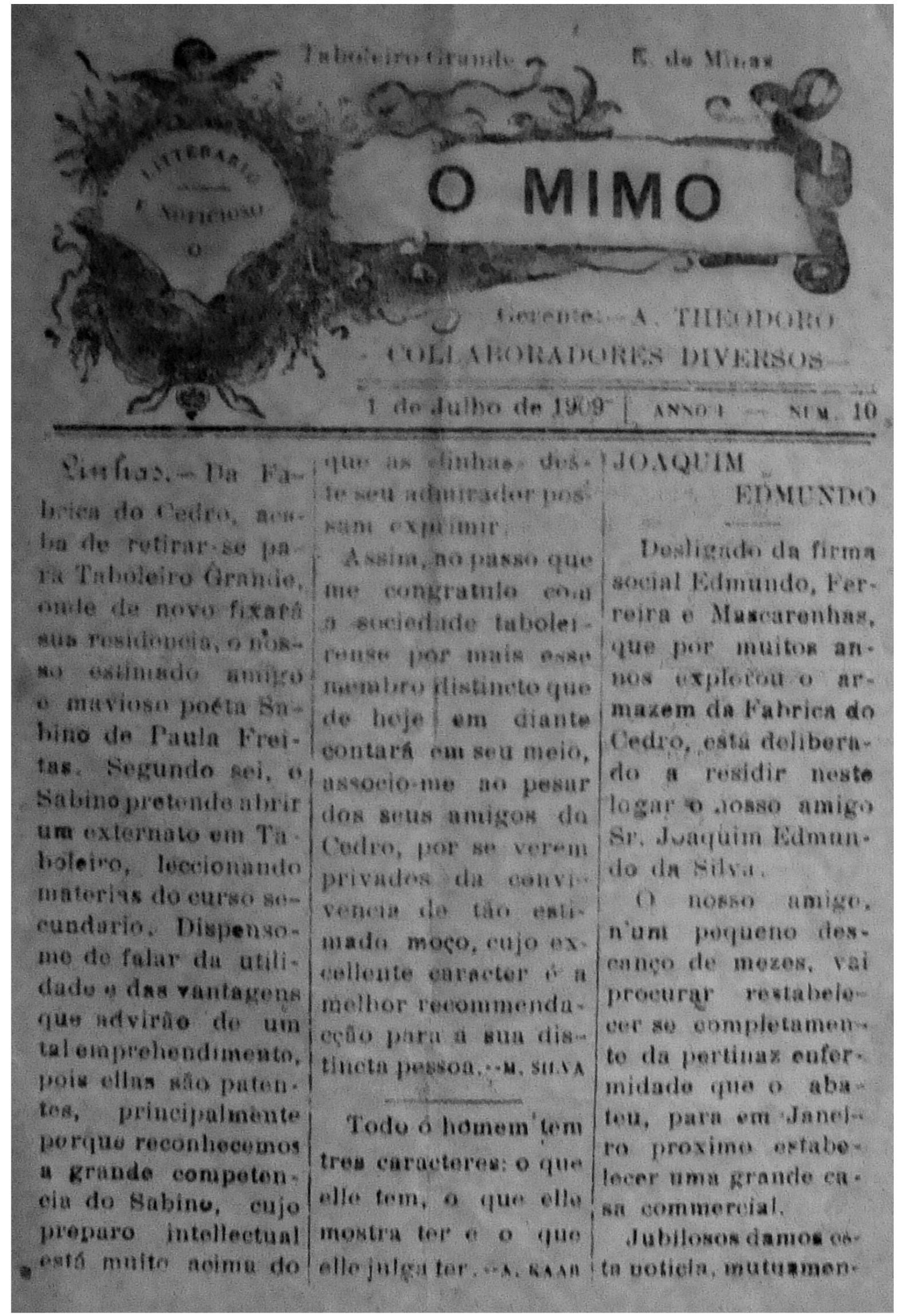

Fonte: Arquivo do Museu Têxtil Décio Mascarenhas 


\section{IMAGEM 90: Folha do Cedro}

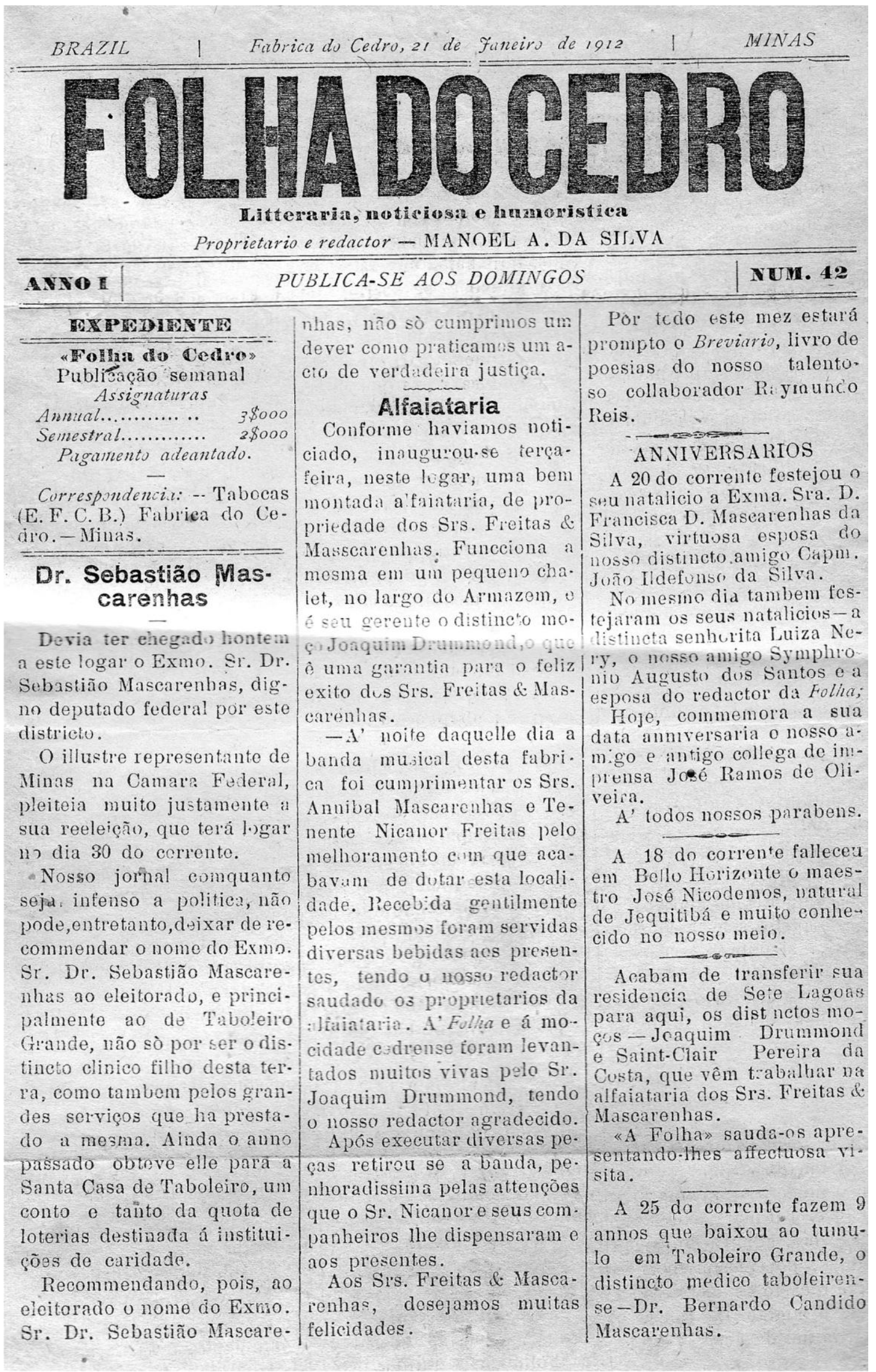

Fonte: Arquivo particular 


\section{IMAGEM 91: A Urucubaca}

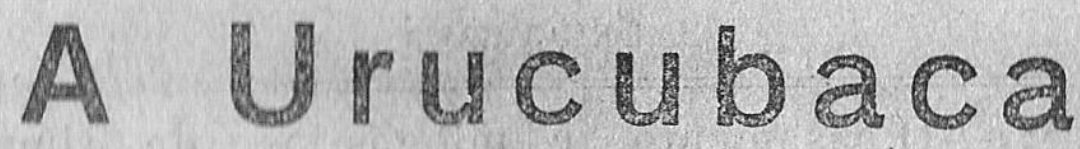

SEMANARIO CRITICO, SATYRICD II IMUMORISTIDO

Propriedade de uma associação

mez mi | Villa Paraopeba,5 de Setembro de 1915 | N. 9

EXPEDIENTE

*A. Uneracetaloacean

Gerente--

Antonio Placido Ribeiro ABSIGNA'UURA

Mensal .$\$ 200$

Correspondencia: - TABOCASL. F. C. do Brazil-Minas.

\section{Chronica}

Pediu-nos um nosso amigo para fuclamarmos nesta secçĭo, de quem de direito sobre o máu cheiro que de vez em yuaudo tresanda por todos os angulos da villi, de. rivado das cevas, couros expostos para seccar e sabão podre, o que constitue um serio perigo para a saude publica.

Cremos que o 110 sso amigo perdeu o seu tempo, encarfersindo nos de tal appello, pois que a nossa «A Urucubaca" não é jornal "hygieni. co" e portanto nada conseguirá a respeito.

Entre nós ainda não houve barulho maior du que o oriundo da questão de hygiene; entretanto dos logares que co. nhecemos é este o mais esquecido da liygiene e onde existe grande numero de cevas, de latrinas seccas etc., - que "muitos" julgam una felicidade para a villa, uma verdadeira demonstração de seu progresso.

Em torio o caso, como temos bom desejo de servir ao arnigo a que nos referimos, endereçamos o seu pedido ao "Dr. Izidro Vianna," actual delegado hygienista, para S. S. providenciar do modo que julgar peor e mais inconveniente. E' só a que podemos fazer e não achamos inuito.

\section{Canixaza}

Gơna moses. - O retrato do Barulho não está máu, mas elle nos disse que esse negocio de indigestão d historia. 


\section{IMAGEM 92: A Defesa}

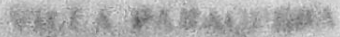
A DEFESA

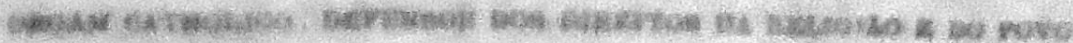

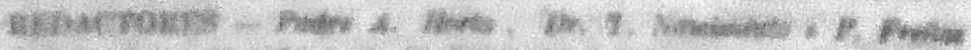

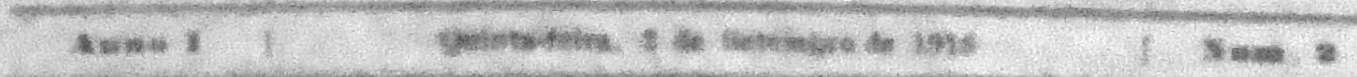

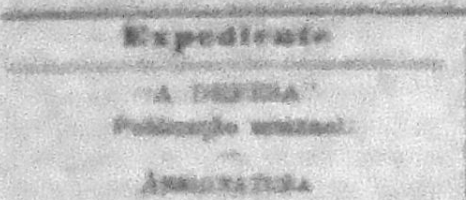

Secueding

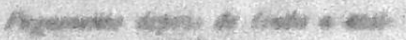
chiserat

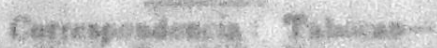

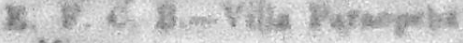
Mitnatis:

\section{Religino e polities}

ก

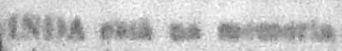

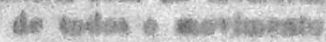

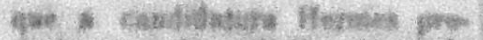

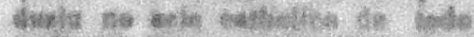

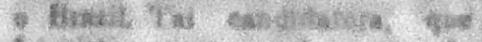

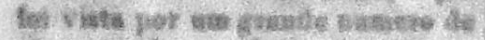

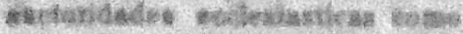

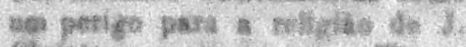

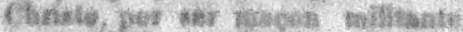

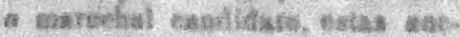

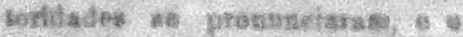

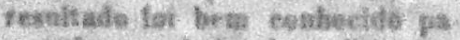

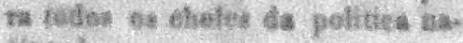
Utobsh.

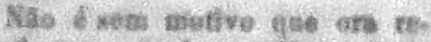

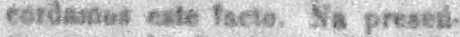

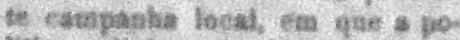
lifica relighosa in bute contra a poltion prulage on elril, tres ex nsacses adrencarion whrodngids Ast res drbect te alguar quas te whens sathoticae, que a politica

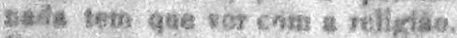

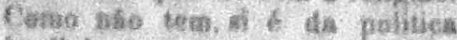
irrally losa gase nescert as maivera

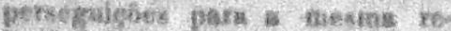

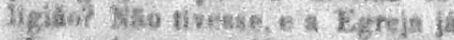
usto trethe se masilontado a resa pelisa, pelis sen lentrines e und verind representanite, gete esiabelece penas espicitistes -serexas,

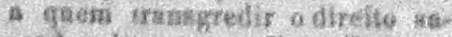
grates do solo is a Pastaril Colinetive dos Arechis pis of hibo

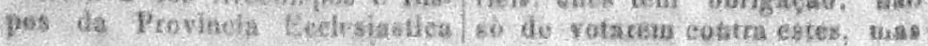

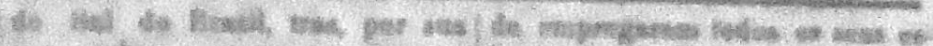

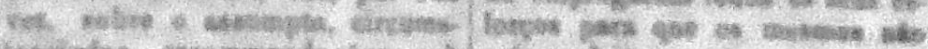

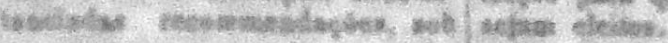

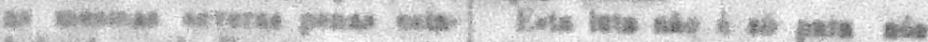

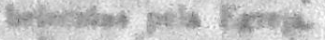

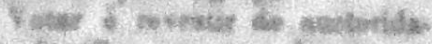

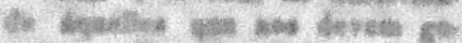

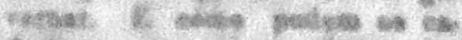

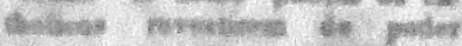

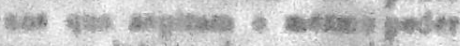

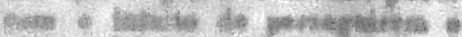

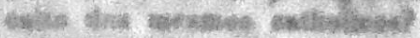

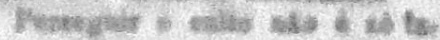

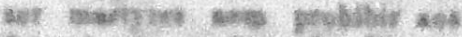

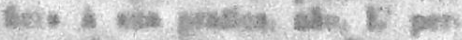

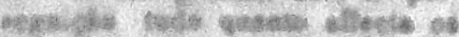

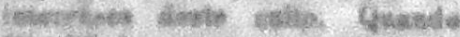

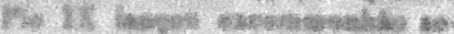

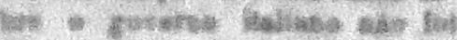

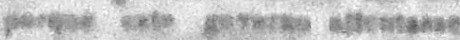

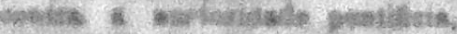

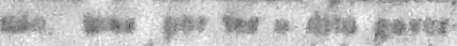

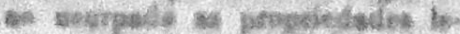

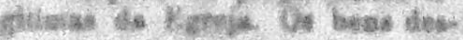

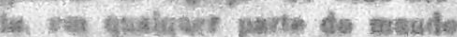

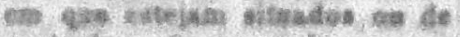

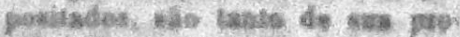

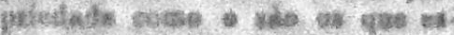

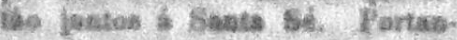

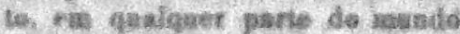

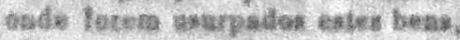
bilo exectnmangados us anerpadd be, enve perackaidores lia Rigre:

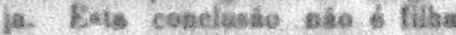

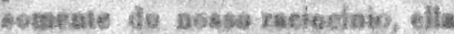
resa expreasa no Dirato Kecle atasion.

Pelo gen se ve, as que na pre.

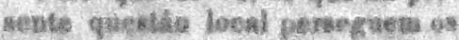

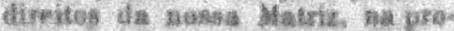
hibighe $d v$ eemiteris fatholics.

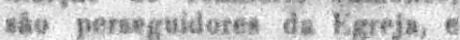
por isea nato poden receber voLos dos fleig disstat, oenatituioduthe sactoridades. Inso serí ar mar isinigros fontra a religháe, sera costrati graviseima ezlpo whe eom Dens

Nive É dis una nato votar nos ad-

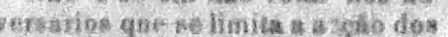

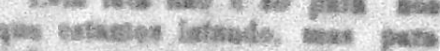

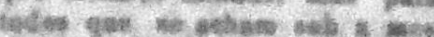

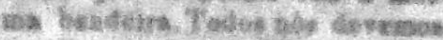

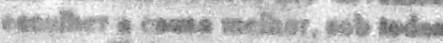

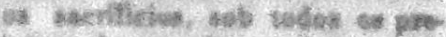

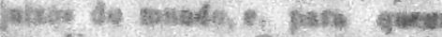
toth 16.3 enests wither of a de

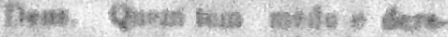
ja kraigr cota o partite lovia h

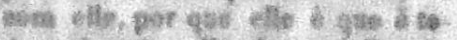

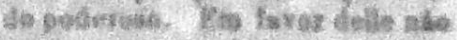

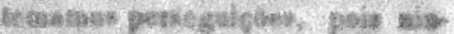

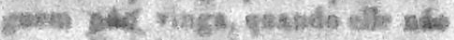

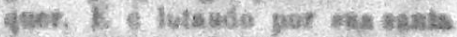

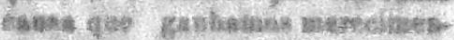
15. 4 moterstu Jukcas diete eav vels

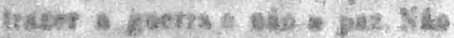

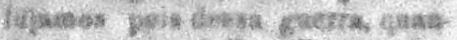

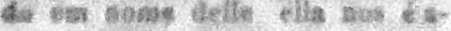
youstusts.

Aryextles ase ve dipendio catho

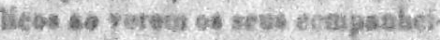

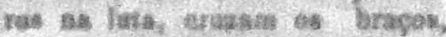

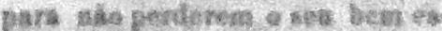

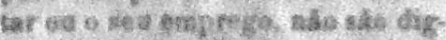

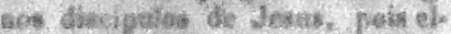

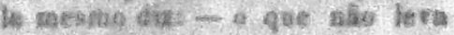

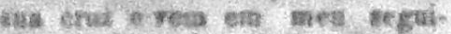

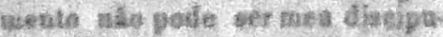
fo. - Xus, gue ark arrontanies lant to odio e perneguldito pars cum-

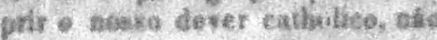
nevarecone pos venturs is poess bans tetar e as naknas callveat

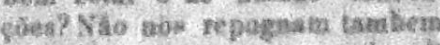
os baldoes fine se nas atiran? Stas, ruas vale intumailo per a gadile que dus salvot, Partante. a despeita da tadid peraiscirewoe na lata, enahura os eeptras que tambern vo dizen cathelicon nos conteriplem cors in mabs firo indiflerenca; errobora tantos ontros cheras "de risligiosidede" sem reHgida, denonsiven a noesa panes de politiva e logem deta vu se collogaems tha piarte adsersaria exabora finatonevic antros que tated 
IMAGEM 93: Villa Paraopeba

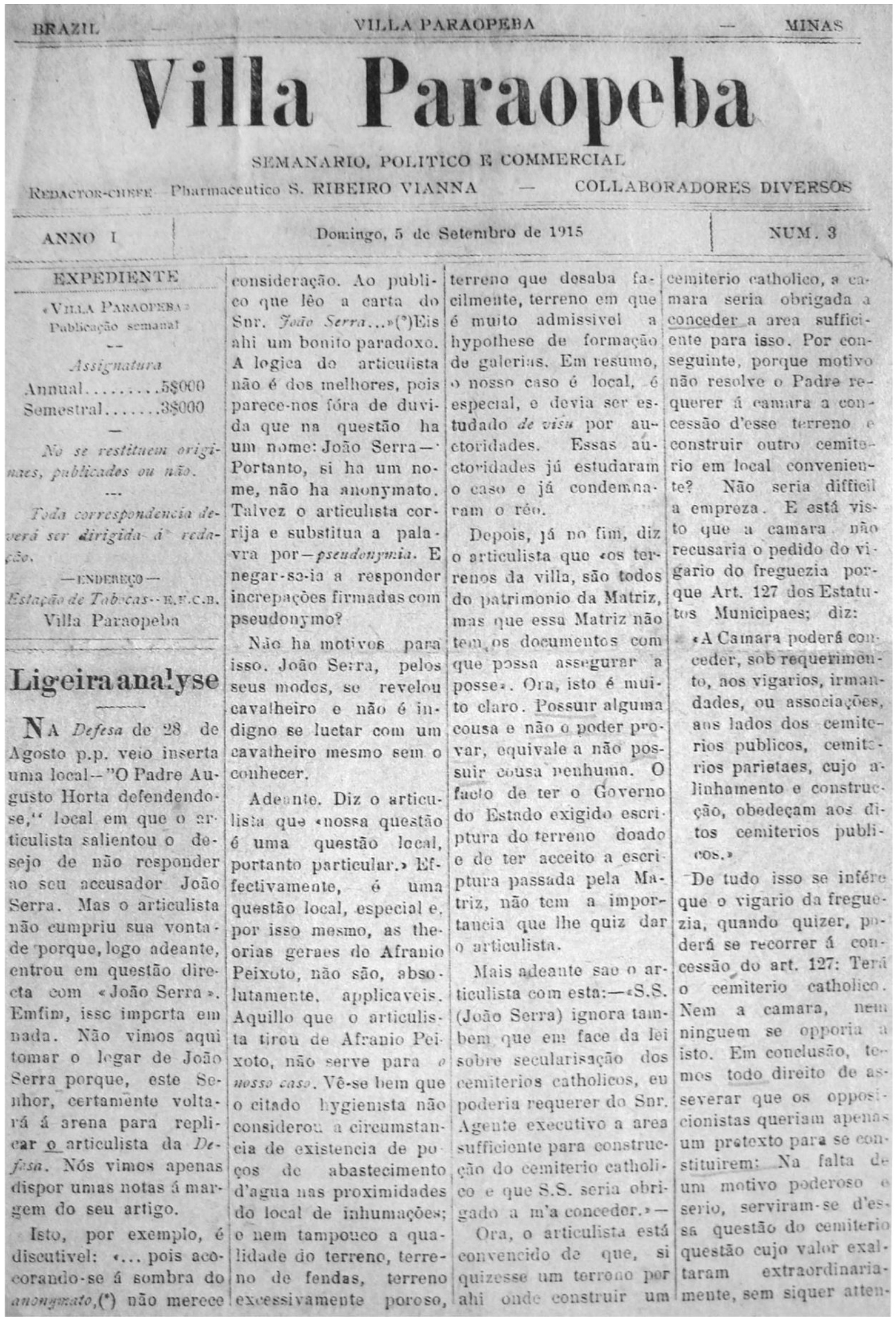

Fonte: Arquivo particular 


\section{IMAGEM 94: A Rua}

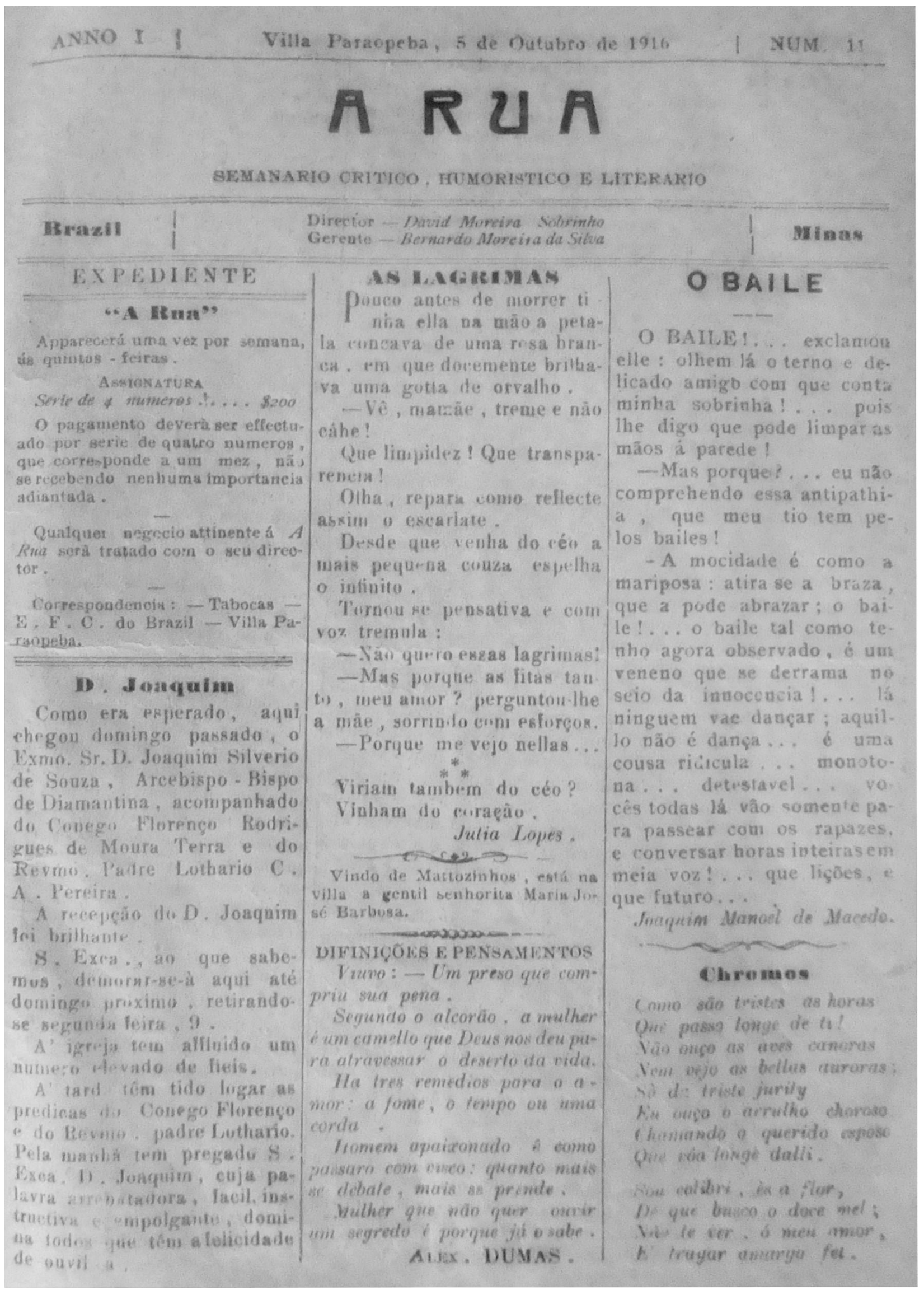

Fonte: Arquivo do Museu Têxtil Décio Mascarenhas 
IMAGEM 95: O Alfinete

\section{O ALFINETE}

HEBDOMADARIO DE CRITICA E* HUMORISMO

Director:-D. Moreira Sobrinho

Pubblicação semanal

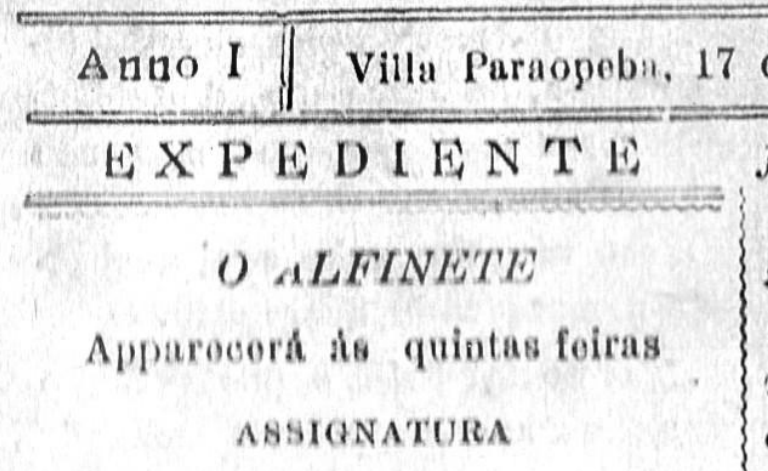

Sorib do 4 numeros.... $\$ 300$

Corrospondencia:-TAFOCAS - E. F. Gontral do Brazil-VILLA PA. RAOPEBA.

\section{De binoculo}

A Gizota lo Paraopoba que já conta quasi oito annss de publicasito ininterrilyta, sendo que no primeiro semestre de 1918 appareceu diariamente, com toda pontualidade, vae, segundo somos informados, suspender a sua publicação.

$A$ alta no preço do papel de impressão leva-a a esta medida.

Mruitu gente ouve falar quie o papal esti caro, mas não se dá ao trabalho de indagar se é real essa aflirmativa, e qual o precio verda. deiro desse aitigo. O que é certo é que o ullimo adquirido custou mais de 20 reis, por uma fotha no formato da "Gazeta". Assim, vamos ficar privados des. se jornal que tem cooperado pelo engrandecimento desta terra, e cuja manutenção ha exigido do seu redactor e proprietario os maiores sacrificios, sendo entre nós não muitos os que the prestam o seu auxilio. Ha um numero elevido de leitores da folha rejerida que julgam na. turalmente inutil a sua existencia, porque ñão a amparam.

E' possivel que após o seu de. sipparecimento, os que pensam des. te modo, ventam a comprehender que um jornal, em qualquer tocalidade é um elemento util e ao mesmo tempo indispensavel.

Veiu afinal a tabella approvada pelo Commissariado de Alimentcȩão e já está ella publicada. Não sabemos é se jà está em execução; pensamos que sim, não obstante haver constado que os preços es. pecificados não agradaram. Os srs. commerciantes devem ter em vistci que, se o preço de alguns dos gemeros da referida tabella, não offerecem margun a lucros esies lucros sercão, entretanto, abtida ent 
IMAGEM 96: O Divulgador

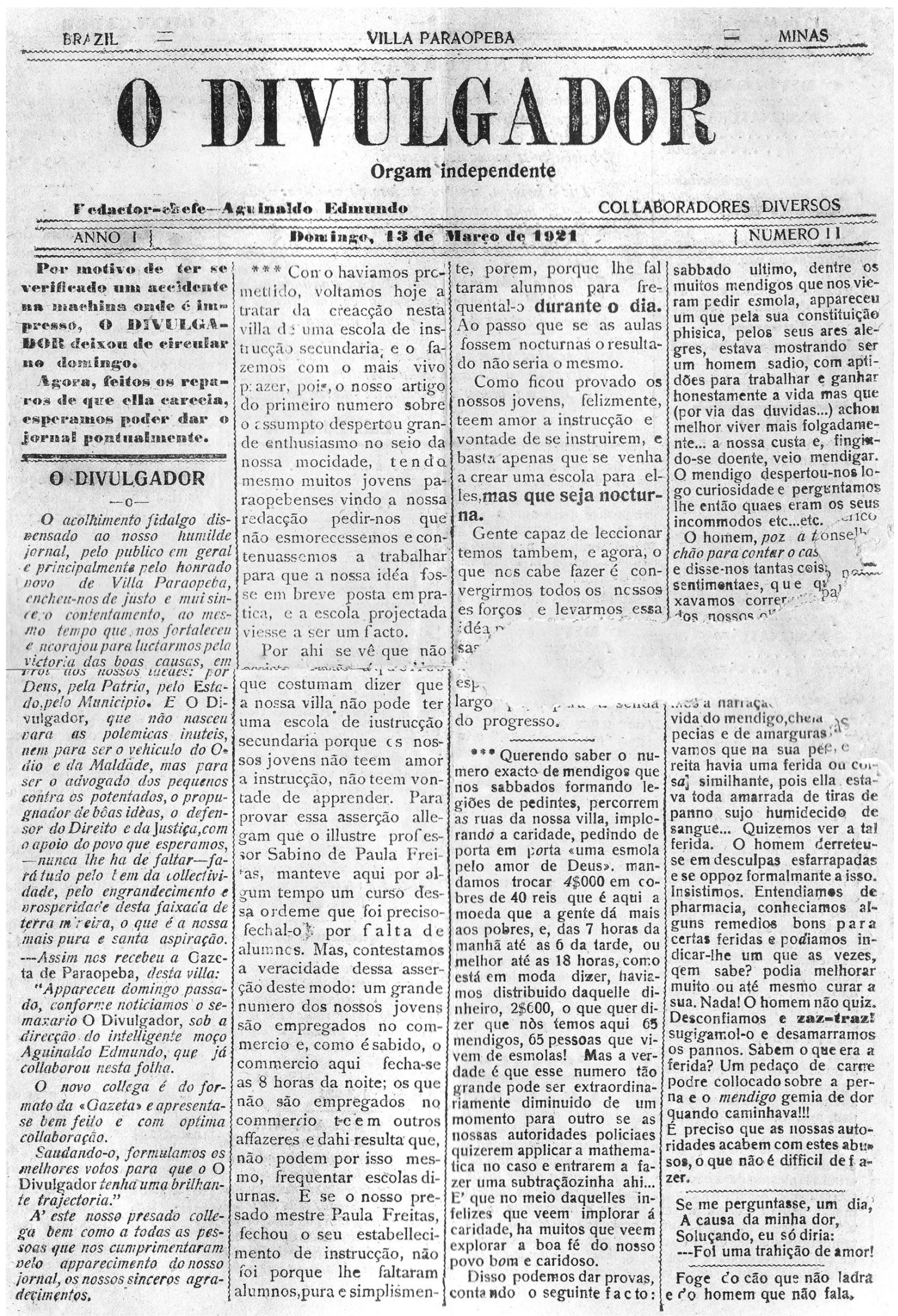

Fonte: Arquivo particular 


\section{IMAGEM 97: O Gavião}

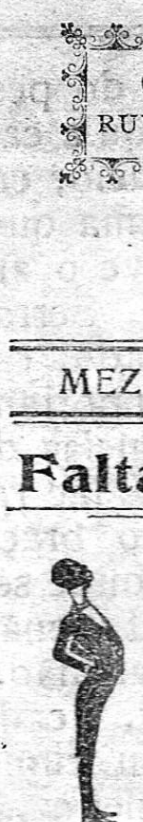

TPPENTE:

UX B. DA SILVA

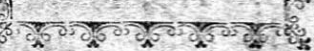
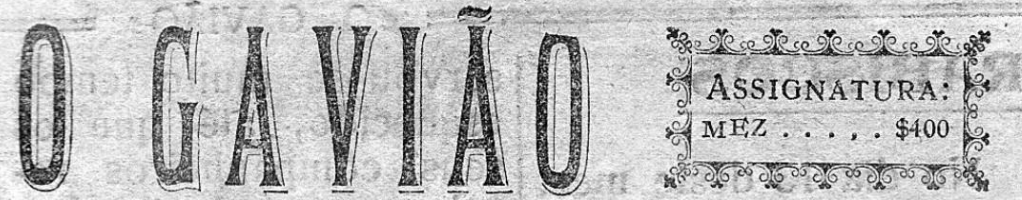

\section{ORGAM CRITICO, HUMORISTICO E LITERARIO}

\begin{tabular}{l|l|l|l|l|l} 
MEZ V Villa Paraopeba, 21 de Agosto de 1924 & NUM 17
\end{tabular}

Falta de cortezia \}jeca, forte e minusculo, diz:

O episodio que -Uai, mocinho, vanvou contar é veri- cê dance a outra varsa; dico, e passou-se essa não, porque essa na roça, em um porea é minha.

balle para que fui convidado.

- Começado o bai-

le, dono da casa distyehira as moças na sala, emquanto a rapaziada, Touca para dançar a qua drilha, se mantinha á por. tzde entrada, esperando ordem para avançar.

Entra o primeiro matuto e dirige-se para a sua escolhida, mui acanhado. home?

-Não sió.

- Apois então cotuque os meu braço.

Vem o outro e pergunta a mesma coisa á escolhida e se obtem resposta affimativa, com a sua cortezia rude:

- Pois se vancê não tem par, misture os baxềro.

Nisto, um dos rapazes sem par, divisa um bom para elle, e chega-se muito respaitoso, pedindo a honra, quando um

\section{K. Pitão Kollares}

\section{TOU}

Uma egua puxa da moenda. İ nha Ornelia que ainda é dura No trabalho de fazenda, Garapa vum tacho apura.

A um canto o Juca Veutura

Vae apromptando a encommenda Que lhe fez, de rapadura,

Jumto a uma gamella suja Orde 1111 b́f garo babiria

Vè-se um negrinho pellaio.

Que é um prodigio de gafeira, A pedir numa berreira:

"Nlia mãe, eu quero mellado !"

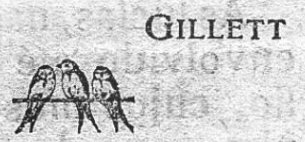

O casamento é um laço que a mulher arma ao ho. men e o homem a muther, no qual cahem os dois.

O peccado inicial

Veiu de Eva e Pae Adão: Do peecado original

Surgiu a reproducção.

O diplomata é como o peixe. Que faz um ou outro? Nada...

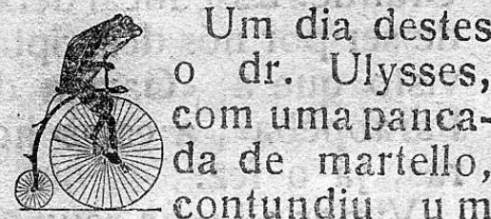
dedo da mão. Com receio de que o mesmo viesse a azangar (palavras delle), á noite, embebeu uma plasta de algodão em lintura de iodo a $20 \%$ e collocou-a no referido dedo doloroso. 0 resultado não se fez esperar: caustico é mesmo para queimar-durante toda noite gemeu, mas gemeu muito, não da machucadura, mas do curativo que foi devéras feroz.

No outro dia, com os olhos a arder por năo os haver pregado durante toda noite, respondeu a um amigo que the perguntou sobre 0 - seu estado, que a dôr que soffreu foi peor do que a das mulheres num parto; disse isso, é verdade, mas não garantiu... e nem podia fazel-o. 20thilt: $=3$ in

«Ainda não comprehendi porque se pede a mão da moça quando se quer toda a moça.»

Fonte: Arquivo particular 
Carvalho Almeida - Mryss - Villa Paragdeba

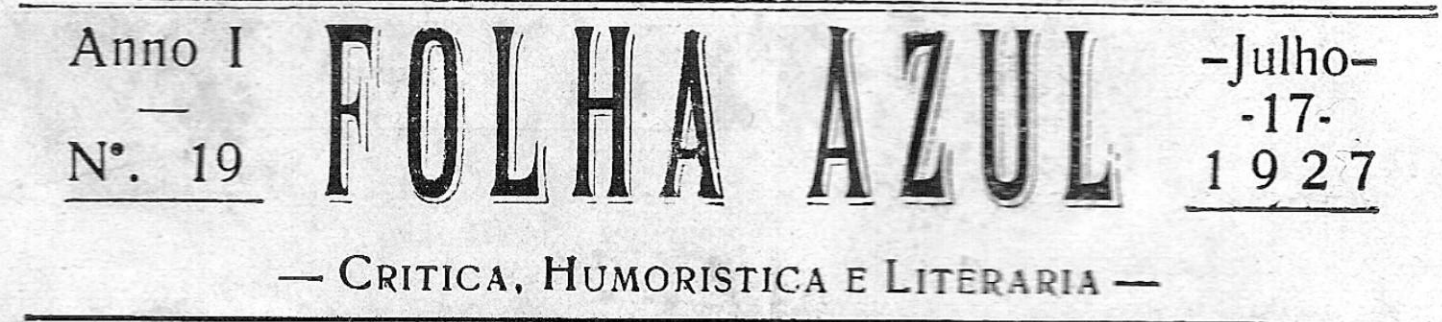

Gerente-MANOEL MOREIRA DINIZ WNignatura „- MEASAL : 500 réis

\section{Saias curtas}

A predilecção da mulher pela perna nùa não existiria se ella conhecesse melhor a psychologia amorosa do homem. O maior prazer que uma mulher pode dar-nos não é o de vel-a, nem mesmo é o de possuil-a, - é o perturbado: prazer de advinhala. A saia de baião, á Benoiton, o vestido de cauda á 1880 -que nos permittiam advinhar, eram mil vezes mais voluptuosos do que a facilima, desastrada e democratica saia curta de hoje.

Nada ha, em amor, que tanto appeleça como aquillo que muito se esconde; nâo sei se foi Brantêm que disse isto; mas, se não foi elle sou eu. A verdade é que o habito da nudez está estragando todas as delicadas emoções que nos podia dar a mulher. Os nossos avòs romanticos caiam em extase diante dim tornozello fíno calçado de sêda côr de rosa; nós, hoje, voltamos a cara e nem damos por isso. A Eva que passa na rua já não é a «appetecida», é a desencantada. Não suggere o pensamento amorosc, provoca o commentario grosseíro. Aquelle respeito su- persticioso que em nós produza grande dame, a esenhora», na mais nobre accepção da palavra, desappareceu. Diante duma cre. atura de pernas á amostra, seja ella a mais virtuosa mulher do murdo, é impossivel o sentimento da veneração-um pouco antigo, mas enternecedor! A saia compridá é inadaptavel ás condições da vida moderna. Pois bem; façamol-a subir até deixar de ser incommoda, mas não tan. to que deixe tambem de ser dis. creta...

\section{JULIO DANTAS}

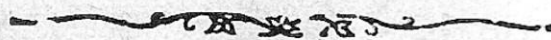

\section{NA BERLINIA ...

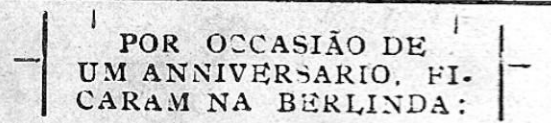

José do Dino, por ser o mais intelligente. Aristoteles, por estar le amores novos.

Euclydes, por estar sempre bancando ofirGerson, por ter lindus cabellos. [me. Lauro, por ser o mais sympathico.

Jusé Santos, por ser quasi noivo.

Neca Nascimento, por dansar bem.

Gumercindo, nor ser $u$ mais sério.

Americo B. Filho, por ser o mals querido.

Chiquinha, por ser a mais loura.

Quiquita, por ser a mais meiga.

Helena, por ser a mais sincera.

Maria Raymunda, pot ser a mais graciosa. Phinóca, por ter os cabellos pretos.

Anyde Campello, por ser a mais risonha. Custodia Barbosa, por ser a mais retratuida. Po!ycena, por ser a mais siugela.

Maria Witta, por ser a mais indifferente. F, $\in$ u, por ser admiradora da "Folha szal'?. 
IMAGEM 99: A Alliança

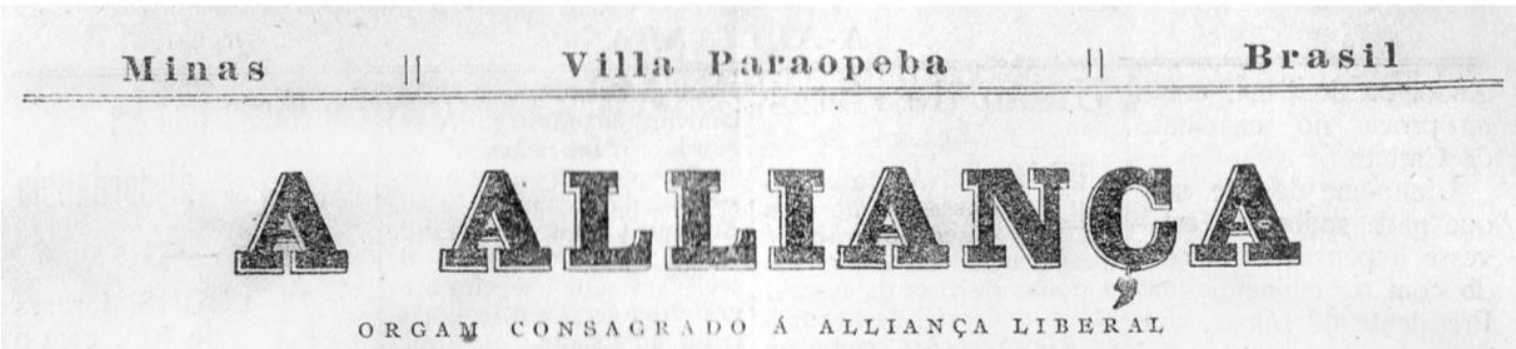

Redactor:- Sabino de Paula Freitas

Gerente: = David Moreira Sobrinho

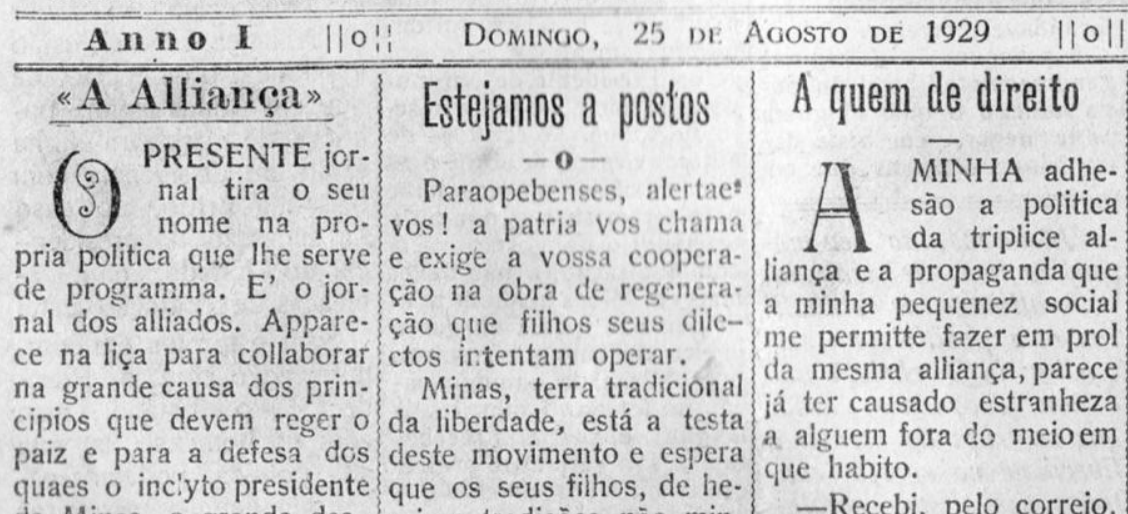
de Minas, o grande des- roicas tradiçồes, nào mincendente dos Andradas, tam os seus gloriosos anque hopra os seus ante- tepassados.

passados, se fez o forte $A$ arma requerida na general.

Formando nas suas fileiras, este orgam ouvirá 3s suas ordens e transtores, com os quaes con. tam os alliados e todos os partidos democraticos do paiz, para o bello canto de victoria.

Leitores, o momento pelitico da patria reclama a vossa actividade. Si vós quizerdes ter direito, si quizerdes ser ouvido na justiça das vossas reclamaçồes de cidadàos que sois, levantae-vos agora e ponde de promptidầo. $\mathrm{O}$ momento é azado. $\mathrm{O}$ grito do sonhado ideal par tiu de Minas. E' mister que todas as forças liber. tadoras se congreguem num esforço unico, e que nós mineiros nos formemos em torno do nosso chefe Antonio Carlos.

\section{A immobilidade politica} A immóntifica com ella e 10 momento actial é um com a Parahyba do Normal que precisa ser com- te cuja uniảo de vistas batido, como symptoma com os dois primeircs esdoentio nas fibras organi- tados faz lembrar o seu cas da naçào.

heroismo dos tempcs co-

Eis que com o grito de loniaes, e afinal com to. Minas a patria se desper- das as forças libertadoras ta. Ponhamo-nos de pé. do paiz, pretende dar um que justificasse a sua ines-
-Recebi, pelo correio, um exemplar do «Globo», diario que se publica na capital federal, devidamen-

te cintado, a mim dirigido. Nào sendo eu assignante desse jornal e nào tendo o mesmo adherido á poliprocurei nas paginas do referido jornal o signal perada visita. Nào me foi difficil encontrar, pois o artigo que me veio destinado estava fechado por traços vermelhos. Vinha na secçào ineditorial e tinha por epigraphe, «A consciencia religiosa dos Mineiros», e era uma transcripçấo do Paiz.

E' conhecido por todos os que leem o conteudo do referido artigo que a golpe de exterminio na oligarchia até então reinante e fundar o reino da democracia que ha quarenta annos foi proclama. do no Brasil como o unico capaz de satisfazer a aspiraçào dos brasileiros. Paraopebenses, ouvi a um „candidato que apezar voz do grande Antonio de nầo ser catholico nelle Carios, acompanhae-o si se pode confiar e até mequercis o bem da vossa recer o catholicismo, do patria. A' qualificaçâo e que querer um outro que depois ás urnas e tereis nâo sendo tambem catho-
cumpriło o vosso dever.

Fonte: Arquivo particular 


\section{IMAGEM 100: O Buraco}

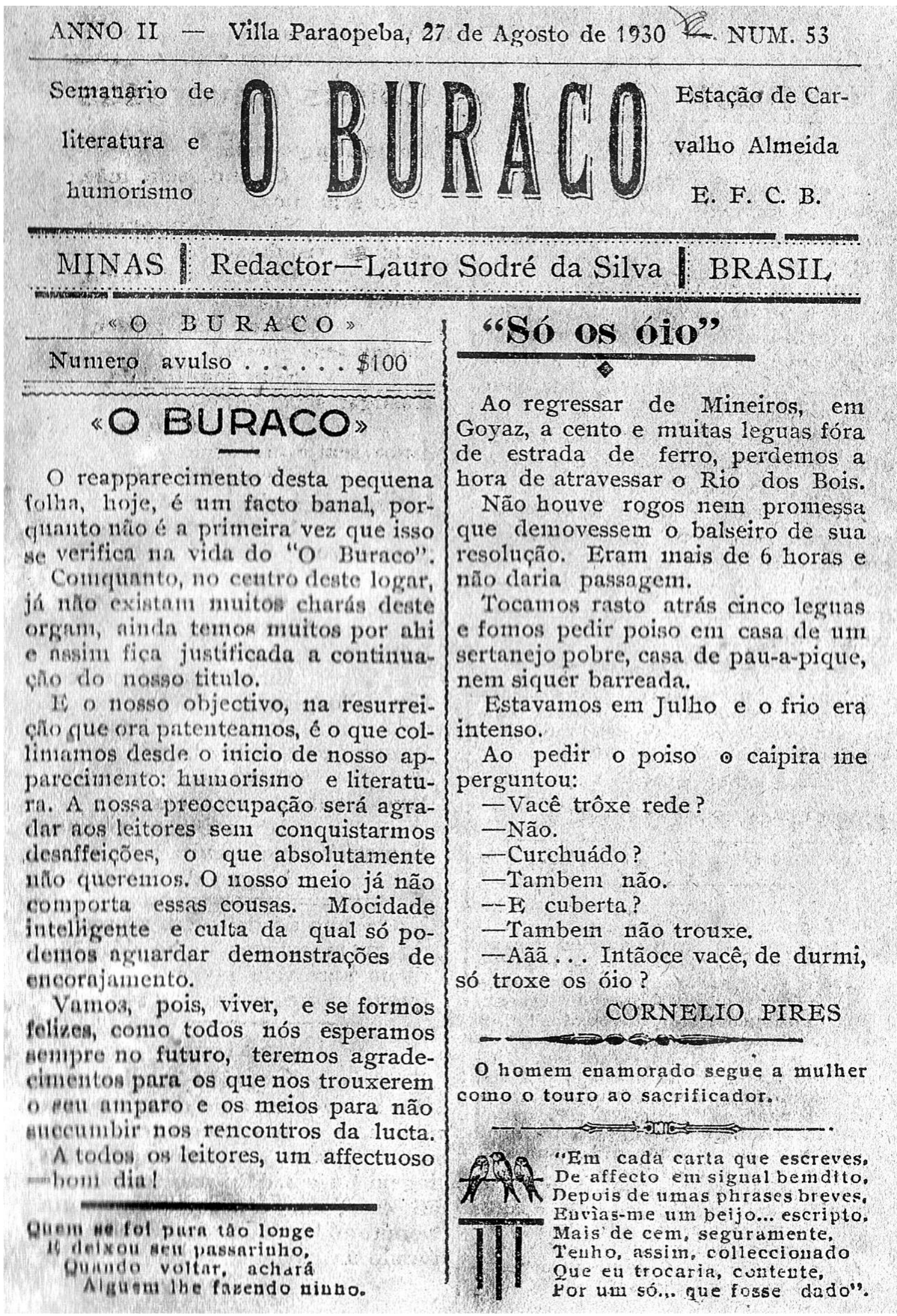

Fonte: Arquivo particular 


\section{IMAGEM 101: A Miséria}

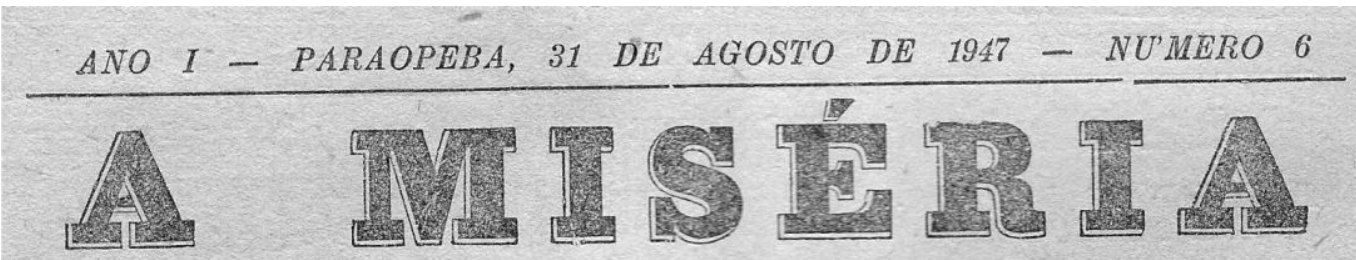

O'RGÃO DE CRITICA, HUMORISMO ELITERATURA

\section{Carreĩn Soltapla Esse, sim!..}

Foi um grito de angustia, arrepiando a calma noturna ou foi talvez 0 tetrico gemido dos ventos?

Foi um lamento de tristeza vartido de uma alma solitaria, ou a convulsão da densa folhagem espalhada pelo vendaval?

Não foi por certo a chuva, varrendo as ramadas. Nem tão pouco o alucinado sibilar dos ventos, assobiando lugubres historias nos ouvidos das folhas inedrosas.

Tambem o som cavo das bátegas furiosas martelan do de rijo a terra sêca, não se ergue assim envolto na tristeza, repassado de infinita angustia...

Foi um grito que se ermen e ficou boiando na chuva que caia e as rajaforam levando a todos o recantos.

Sim, foi um grito que se alteou, quando a tempestade desfigurava a feição do universo e lagrimas ardentes escorriam pelo semblante entristecido de uma figura solitaria, solitaria e triste como a propria noite embuçada na chuva...

\section{ANONIMO.}

\section{$\longrightarrow 0$}

Na semana passada eu tive prejuizo e não tive. Explico: durante 0 tempo que meu pai permane ceu aqui, (foram poucas horas) não pude ver a minha menina, mas tive a alegria de estar junto dele: Logo tive prejuizo

\section{E'VERDADE} Consta que à noite de domingo passado, no Cedro; proximo ao buteco do José Grosso, houve um bate-boca e, logo depois um bate-pau, que atingitu o azarento que mora com o mesmo José Grosso. O outro untou cebo nas canelas e virou fumaç.
Só queru un dia, desolado, vin seu ideal mais puro derrubado só quem a Desventura jáa sentiu, santily-a sem jamais ter blasfemado quen corhere a Dor, algumas vezes, o desespero e o Sofrimento mudio, só quem fugiu da Yida mulíos mêses, e áastor-se da Vida e assin de tudo, e guen yoltou depois de novo à Vida purificado em sua proprla Dor! - só esse póde, de alna comovida, amar a vida con imenso amorl. LUIZ OTAVIO cosesesser.

De ajudante a mestre

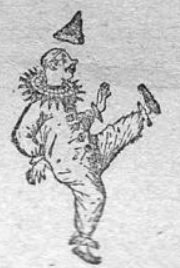

O Clovis está, agora, trabalhan do como ajudante de pedreiro d o Raimundo Marinho, atessado em apren-

aprender mesmo já contratou com o Gercino o feitio de uma fornalha para sabão.

Agenciador de serviços para o Clovis, nesta zona: José Marinho.

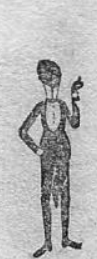

\section{FUTURO BIGAMO}

O José do Argemiro, com o arrojo de namoro em que está, serà, futuramente, um bigamo, pois quer casar com uma pequena daqui e dá esperança a outra do Cedro. Não se falando em algumas avulsas que estão anotadas no seu caderno e às quais ele corresponde com um sorriso e uma promessa, dizem que ainda lá para os lados da Lontra ele está muito cotado.

O José, segundo opínião de um seu amigo que admira a sua atividade, é de opinião que ele deve deixar o emprego para ficar o dia inteiro namorado. Que falta de absurdo!

\section{A \&l lisisitian social}

Falar da vida alheia, é bom, mas, da nossa - deixemos disso. - J. FELICIO.

\section{NATALICIOS}

Fez anos ontem o José ex-do Odilon, rapaz desempenado, que gosta muito das moças e é valente de verdade.

- Tambem fez anos, outra vez, ontem, o José do Argemiro que ontem, o José do Argemiro que
foi nuito cumprimentado pelas suas pequenas daqui e do Cedro, por cartas. Estas foram abertas e lidas em presença do Juvenal que babou de inveja e pediu ao aniversariante para ensinar-lhe a tatica de se fazer querido dos mocos. O José afirmou que não pode ensinar, pois ele pagou papode ensinar, pois um macumbeiro ra aprender a um ma

da Barra da Inhauma. do Doraci Lopes, ex-continuo da Prefeitura e hoje auxiliar da casa comercial Leonel Mota, e tambem irmão do Cristiano. 0 aniversariante que apanha passariresariane engorda suinos, prome-

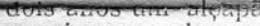
Está perdoado pela falta.

\section{ITINERANTES}

Viajou ontem para o Cedro e regressou ontem mesmo, o sr. Vicente Lacerda, noivo firme al e manteigueiro aqui.

- Em sua companhia viajou tambem para o mesmo lugar, pela ultima vez, o Noel do Mato, que não é mais candidato a pedreiro e aquí está muito ocupado à rua Benedito Valadares.

- Viajando clandestinamente no caminhão do Adolfo Corrêa, esteve ha dias em Cordisburgo o Dionisio Catita, companheiro folgado do José do Argemiro.

$$
\text { crearewos }
$$

\section{(c) $R \mathbb{R} \| \mathbb{D} \mathbb{D}$}

De onde vens? Do eterno dia.

Quera te conduz? A bollanęa.

Que procuras? A desgraça.

Que tu levas? A esperanca.

Quem te envia? 0 Ser Supremo.

onde vais? A todo o mundo.

Quem socorres? Não escolho.

Quem te espera? 0 mal profundo.

Quem te maldiz? 0 usurásio.

Quem te ignora? 0 egoista.

Quem te sorri? A miséria.

E quem te implora? A desdita.

Quem te singe? A luz ceieste.

Quem te deu? Fol outra laz.

Ouem te suia? 0 bem eterno.

E a boa mão nos conduz.

Não cobices a mulher feia do proximo.

Fonte: Arquivo particular 